\section{UMass Amhert}

\section{Refractique (Lensball World) Photography Innovation \& Excellence Scholarship}

Subjects: About Us Refractique We specialize in lensball education via our digital course Globalize with over 2.5 hours of dedicated refraction photography video learning content directly downloadable through our website. We also distribute the $80 \mathrm{~mm}$ and $60 \mathrm{~mm}$ via our beautiful packages on Amazon Purpose: We provide a premium offering and pride ourselves on our products - enjoying this fun creative photography ourselves initially before enabling others to learn more about this wonderful hobby

Eligibility: studying an Arts Degree (or relevant photography course)

Level of Study: Postgraduate

Type: Scholarship

Value: US\$2,000 (occurs on a twice yearly basis with a US $\$ 1,000$ per scholarship eligible)

Frequency: Annual

Country of Study: Any country

Application Procedure: 1. Prepare a refraction photography submission and send to support@refractique.com. 2. The submission must be for a minimum of 10 quality refraction related photos, with a maximum of 20 photos. You are also required to write a minimum of 500 words to describe the photos, what they mean to you and what kind of photographic techniques you used to obtain the results/outcome in the photos. You may also like to write more generically about refraction photography - what are the benefits, how to take great photos and how you use refraction accessories including the lensball. The judge will award the scholarships based on the standard of the photos as well as the written text

Closing Date: 30 January and 30 June of each year Funding: Private
Additional Information: For further information, refer the website link. lensballs.com/pages/social-support

\section{For further information contact:}

Email: support@refractique.com

\section{Union College}

\section{Union College Board of Trustees Scholarship}

Purpose: This scholarship is worth full tuition

Eligibility: 1. Must attend a college or university in the state of Nebraska. 2. Must be an incoming freshman. 3. Must enroll full time. 4. Must have a grade point average of 3.9 or higher (or a GED score of 750 or higher). 5. Must have an ACT score of 32 or higher OR an SAT score of 1,500 or higher

Level of Study: Graduate

Type: Scholarship

Value: US $\$ 21,250$

Length of Study: Varies. addition of years is possible

Frequency: Annual

Country of Study: Any country

Application Procedure: 1. Admissions information is available on the Union College website by clicking on the 'Admissions Policy' link. Admissions applications are available in online and PDF formats. 2. In addition to a completed application, each student must submit an official high school transcript and ACT/SAT scores. 3. Students whose first language is not English must also submit TOEFL (Test of English as a Foreign Language) scores. 4. Admissions applications are available in online and PDF formats. In addition to a completed application, each student must submit an official high school transcript and ACT/SAT scores 
Closing Date: 1 April

Funding: Private

\section{For further information contact:}

3800 S. 48th St., Lincoln, NE 68506-4386, United States of America

Tel: (1) 4024862600

Email: enroll@ucollege.edu

\section{United Nations Educational, Scientific and Cultural Organization (UNESCO)}

7 place de Fontenoy, F-75352 Paris, France

\author{
Tel: $\quad$ (33) 145681000 ext. 81507 \\ Fax: (33) 145675503 \\ Contact: $\quad$ Ms F Abu-Shady, Director, Equipment \& \\ Fellowships Division
}

As early as 1951, a programme to promote and develop youth exchange for educational purposes has existed in UNESCO. The Organization continued its action under the Fellowships Programme to respond to the needs of Member States in the field of human resources development and capacity building. This programme has up to date enabled more than 52,000 fellows from around the world to study in different countries contributing to intellectual solidarity, international cooperation and mutual understanding.

\section{United Nationals Educational Scientific Cultural Organization Individual Fellowships}

Subjects: Food science and production, architectural restoration, interpretation and translation, business studies, education and teacher training, fine and applied arts, law, natural sciences, social and behavioural science, and mathematics

Purpose: To provide opportunities to further primarily higher education or research generally abroad, and to acquire international experience in fields of study for which appropriate facilities are not available in the country of origin

Eligibility: Open to nationals of UNESCO member states and associate members

Level of Study: Doctorate, Postdoctorate, Postgraduate, Professional development

Type: Fellowship
Value: Monthly allowance usually based on UN stipend scale, plus travel, tuition, books and small equipment costs Length of Study: No more than 9 months Frequency: Dependent on funds available Country of Study: Other

Application Procedure: Application through national authorities specially designated by UNESCO member states (usually National Commission for UNESCO or appropriate Ministry). Direct applications will not be considered.

\section{United Nations Educational, Scientific and Cultural Organization(UNESCO)/International Sustainable Energy DelSEDC Co-Sponsored Fellowships Programme}

Subjects: Energy and sustainable development; ecological management of energy resources; renewable energy; sustainable and renewable energy power generation

Purpose: To enhance the capacity-building and human resources development in the area of sustainable and renewable energy sources in developing countries and countries in transition

Eligibility: Holder of at least a BSc degree or BA in Economics; proficient in English language; not more than 35 years of age

Length of Study: This is a four weeks fellowship programme Country of Study: Any country

Application Procedure: All applications should be endorsed by the National Commission for UNESCO and must be duly completed in English or French

Closing Date: 3 April

Contributor: UNESCO/ISEDC

Additional Information: For more details, please visit the website www.opportunitiesforafricans.com/unesco-isedcco-sponsored-fellowships-programme-2018-fully-funded-tomoscow-russia/

For further information contact:

Email: info@oppurtunitydesk.org

\section{United Nations International School of Hanoi}

G9 Ciputra Lac Long Quan Road, Tay Ho District, Vietnam

Tel: $\quad$ (84) 437581551

Email:_info@unishanoi.org

Website: www.unishanoi.org 
United Nations International School of Hanoi's mission is to encourage students to be independent, lifelong learners who strive for excellence and become responsible stewards of our global society and natural environment, achieved within a supportive community that values diversity and through a programme reflecting the ideals and principles of the United Nations.

\section{United Nations International School (UNIS) Hanoi Scholarship Programme for Vietnamese Students in Vietnam}

Subjects: Scholarship is offered for IB programme. The IB programme is designed to be challenging in all areas with students required to take six different subjects across a broad range of academic disciplines, in addition to Theory of Knowledge, an extended essay and CAS (Community Action Service) involvement

Purpose: Students may apply to the UNIS Hanoi Scholarship Programme for entry to Grade 8, Grade 9 and Grade 10. The students will graduate with the International Baccalaureate Diploma

Eligibility: The Students applying for the Scholarship Programme at UNIS Hanoi must hold or be eligible to hold a Vietnamese passport and should have permanent residence no more than one hour of transport from UNIS Hanoi. Applicants are required to provide a copy of Household registration book. Graduate from Grade 12 at UNIS Hanoi before their 20th Birthday. Vietnamese students are eligible to apply for this scholarship. For detailed information, please visit website Type: Scholarship

Value: The UNIS Hanoi Scholarship Programme gives the opportunity for students to enter UNIS Hanoi with a full $(100 \%)$ fee waiver until graduation

Country of Study: Vietnam

Application Procedure: Applicants should use the Application Checklist in the Application Package to ensure they have a complete application. All applicants are strongly encouraged to submit applications well before deadline. Completed applications with supporting documents and a recent passport style photo should be handed in to the school at the main gate addressed

Closing Date: 31 December

Contributor: United Nations International School of Hanoi

Additional Information: Shortlist finalists are invited to UNIS Hanoi for interview and testing in the week of May 20th

\section{For further information contact:}

Email: scholarships@unishanoi.org

\section{United States Center for Advanced Holocaust Studies}

United States Holocaust Memorial Museum, 100 Raoul Wallenberg Place South West, Washington, DC 20024-2126, United States of America

$\begin{array}{ll}\text { Tel: } & \text { (1) } 2024880400 \text { / } 2023147802 \\ \text { Fax: } & \text { (1) } 2024799726 \\ \text { Email: } & \text { vscholars@ushmm.org } \\ \text { Website: } & \text { www.ushmm.org } \\ \text { Contact: } & \text { Ms Jo-Ellyn Decker, Program Coordinator }\end{array}$

The United States Holocaust Memorial Museum is the United State's national institution for the documentation, study and interpretation of Holocaust history, and serves as the country's memorial to the millions of people murdered during the Holocaust. The Center for Advanced Holocaust Studies fosters research in Holocaust and genocide studies.

\section{Joyce and Arthur Schechter Fellowship}

Subjects: Linguistics, cultural studies, and related subjects Purpose: To provide for a Scholar to be in residence at the Museum for a period of six weeks to three months to conduct research using the vast resources of the Museum

Eligibility: Applicants must hold a $\mathrm{PhD}$ or be an advanced $\mathrm{PhD}$ candidate (ABD) by the application deadline. Those candidates with equivalent professional or terminal degrees or recognised professional standing may also apply

Type: Fellowship

Value: A stipend of US $\$ 5,000$ to cover housing, living, and international or domestic travel expenses. The Joyce and Arthur Schechter Fellow will also be provided with office space, postage, and access to a computer, telephone, facsimile machine, and photocopier. Cost sharing by the applicants home institution is welcome

Frequency: Annual

Country of Study: United States of America

Application Procedure: Applicants must submit a completed application form and supporting material for fellowship consideration. To request an application form or additional information please contact Renee Taft, Director, Visiting Scholars Program, at the Center for Advanced Holocaust Studies

Closing Date: 31 October

Funding: Private

Additional Information: The Schechter Fellow is encouraged to participate in the Museum's broad array of scholarly and other programmes 


\section{For further information contact:}
Tel:
(1) 2023140378
Fax: (1) 2024799726
Email:_rtaft@ushmm.org
Contact: Ms Renee Taft, Visiting Scholar Programme Director

\section{United States Center for Advanced Holocaust Studies Dissertation Award}

Subjects: Holocaust and genocide studies

Purpose: To encourage the work of exceptional new scholars in the area of the holocaust and genocide studies. The fellowship also provides an opportunity for a new $\mathrm{PhD}$ to work at the Center on a conversion of the dissertation into a monograph or on a new post dissertation holocaust related research topic Eligibility: Open to all $\mathrm{PhD}$ candidates completing their dissertations after January 1st 1998 and before the application deadline

Level of Study: Postdoctorate

Type: Award

Value: A stipend of up to US $\$ 15,000$ for residence at the Center. The museum will also provide office space, postage, and access to a computer, telephone, facsimile machine, and photocopier

Length of Study: 1 semester or more

Frequency: Annual

Study Establishment: United States Center for Advanced Holocaust Studies

Country of Study: United States of America

Application Procedure: Applicants must contact Renee Taft, Director, Visiting Scholars Programme, or Betsy Anthony, Programme Assistant, Visiting Scholar Programme for more information and application forms. Dissertations should be nominated by the author's university department chair and accompanied by a letter of acceptance for the degree and a 250 word abstract of the dissertation's subject matter. Three copies of the dissertation should be submitted. A statement must be included giving the United States Holocaust Memorial Museum permission to produce the dissertation for copying purposes

Closing Date: 15 March

Funding: Private

Additional Information: The Center's historian, Fellows in residence, and publications staff will be available to assist the successful applicant

\section{For further information contact:}

Tel: $\quad$ (1) 2023140378

Fax: (1) 2024799726

Email: rtaft@ushmm.org

Contact: Ms Renee Taft, Visiting Scholar Programme Director

\section{United States Commission on International Religious Freedom (USCIRF)}

732 N. Capitol Street, N.W., Suite A714, Washington, DC 20401, United States of America

$\begin{array}{ll}\text { Tel: } & \text { (1) } 2025233240 \\ \text { Fax: } & \text { (1) } 2025235020 \\ \text { Email: } & \text { communications@uscirf.gov } \\ \text { Website: } & \text { www.uscirf.gov }\end{array}$

United States Commission on International Religious Freedom is an independent, bipartisan United States of America federal government commission, the first of its kind in the world, that monitors the universal right to freedom of religion or belief abroad. USCIRF reviews the facts and circumstances of religious freedom violations and makes policy recommendations to the President, the Secretary of State, and Congress. USCIRF Commissioners are appointed by the President and the Congressional leadership of both political parties.

\section{United States of America Commission on International Religious Freedom Internships}

Subjects: USCIRF offers Administrative, Communications, Government Relations, Office of Legal Counsel, Policy: Legal Research and Policy: Regional Policy Analysis

Eligibility: Currently enroled undergraduates (sophomores, juniors and seniors) and graduate students (including JD and LLM candidates) with minimum 2.5 GPA are eligible for internships with USCIRF. Students of United States of America can apply (or otherwise authorized to intern with the United States of America government). For detailed information, visit website

Type: Internship

Value: All United States Commission on International Religious Freedom (USCIRF) internships are paid; however, course credit may be available

Country of Study: United States of America

Application Procedure: The mode of applying is via email, fax, or mail (applicants should specify the internship and semester they are applying for in their cover letter and the subject line of an emailed application). Policy Department: Regional Policy Analysis Intern should specify what region they are applying for in their cover letter and the subject line of an emailed application. Application requirements: cover letter explaining qualifications and why one would like to intern at USCIRF; resume; $3-5$ page writing sample; $2-3$ letters of reference 
Closing Date: 20 July (Fall semester: September to December), 1 November (Spring semester: January to May), 1 April (Summer Semester: June to August)

Contributor: United States of America Commission on International Religious Freedom (USCIRF)

Additional Information: Internships can be full-time or part-time for a minimum of 8 weeks. Internships are available year-round, and applications are accepted on a rolling basis

\section{For further information contact:}

Email: internship@uscirf.gov

\section{United States Institute of Peace (USIP)}

2301 Constitution Avenue, NW, Washington, DC 20037, United States of America

\section{Tel: $\quad$ (1) 2024571700 \\ Fax: $\quad$ (1) 2024296063 \\ Email: grant_program@usip.org \\ Website: www.usip.org \\ Contact: Ms Cornelia Hoggart, Senior Programme \\ Assistant}

The United States Institute of Peace (USIP) is mandated by the Congress to promote education and training, research and public information programmes on means to promote international peace and resolve international conflicts without violence. The Institute meets this mandate through an array of programmes, including grants, fellowships, conferences and workshops, library services, publications and other educational activities.

\section{Jennings Randolph Program for International Peace Dissertation Fellowship}

Subjects: A broad range of disciplines and interdisciplinary fields

Purpose: To support dissertations that explore the sources and nature of international conflict, and strategies to prevent or end conflict and to sustain peace

Eligibility: Open to applicants of all nationalities who are enroled in an accredited college or university in the United States of America. Applicants must have completed all requirements for the degree except the dissertation by the commencement of the award

Level of Study: Doctorate

Type: Fellowships
Value: US\$20,000, which may be used to support dissertation writing or field research

Length of Study: 1 year

Frequency: Annual

Study Establishment: The student's home university or site of fieldwork

Country of Study: United States of America

Application Procedure: Applicants must complete a webbased application form, available on the Institute's website

Closing Date: 5 January

Funding: Government

No. of awards given last year: 10

Additional Information: The programme does not support work involving partisan political and policy advocacy or policy making for any government or private organization

\section{For further information contact:}

Tel: $\quad$ (1) 2024293853

Email: jrprogram@usip.org

Contact: Miss Shira Lowinger, Program Coordinator

\section{Jennings Randolph Program for International Peace Senior Fellowships}

Subjects: Preventive diplomacy, ethnic and regional conflicts, peacekeeping and peace operations, peace settlements, postconflict reconstruction and reconciliation, democratization and the rule of law, cross-cultural negotiations, United States of America policy in the 21 st century and related subjects

Purpose: To use the recipient's existing knowledge and skills towards a fruitful endeavour in the international peace and conflict management field, and to help bring the perspectives of this field into the Fellow's own career

Eligibility: Open to outstanding practitioners and scholars from a broad range of backgrounds. The competition is open to citizens of any country who have specific interest and experience in international peace and conflict management. Candidates would typically be senior academics, but applicants who hold at least a Bachelor's degree from a recognized university will also be considered

Type: Fellowship

Value: A stipend, an office with computer and voicemail and a part-time research assistant

Length of Study: Up to 10 months

Frequency: Annual

Study Establishment: USIP

Country of Study: United States of America

No. of awards offered: 136

Application Procedure: Applicants must complete a web-based application form, available on request from the Institute or from the website 
Closing Date: Early January (check with website)

Funding: Government

No. of awards given last year: 10

No. of applicants last year: 136

For further information contact:

Tel: $\quad$ (1) 2024293886

Email: jrprogram@usip.org

Contact: Miss Shira Lowinger, Program Coordinator

\section{United States-India Educational Foundation (USIEF)}

Fulbright House 12 Hailey Road, New Delhi, Delhi 110001, India

Tel: $\quad$ (91) $1123328944 / 48$

Fax: (91) 23329718

Email: info@fulbright-india.org

Website: www.fulbright-india.org

Contact: Programme Officer

The activities of the United States Educational Foundation in India (USEFI) may be broadly categorized as the administration of the Fulbright Exchange Fellowships for Indian and United States of America scholars and professionals, and the provision of educational advising services to help Indian students wishing to pursue higher education in the United States. USEFI also works for the promotion of dialogue among fulbrighters and their communities as an outgrowth of educational exchange.

\section{Fulbright Distinguished Awards in Teaching Program for International Teachers}

Subjects: The Fulbright Distinguished Awards in Teaching Program for international teachers (Fulbright DAI) is sponsored by the Bureau of Educational and Cultural Affairs, United States of America Department of State

Purpose: It is part of the overall Fulbright Program, named in honor of Senator J. William Fulbright, which promotes mutual understanding among people of the United States and other countries

Eligibility: The applicant should: 1 . Be a citizen of India and reside in India at the time of application. 2. Live and teach in the states of Andhra Pradesh, Odisha, Telangana, Karnataka, Kerala, Tamil Nadu, Puducherry, Lakshadweep and the Andaman and Nicobar Islands, Chhattisgarh, Goa, Gujarat,
Madhya Pradesh, Maharashtra, Daman and Diu, and Dadra and Nagar Haveli. 3. Hold at least a bachelor's degree. A teacher training degree is preferred. 4. Be a full-time teacher teaching any subject at any level (primary, middle, secondary or senior secondary). 5. Have completed at least five years of full-time teaching experience at the program start

Level of Study: Graduate

Type: Award

Frequency: Annual

Country of Study: Any country

Application Procedure: 1. Fellows will be selected through a merit-based open competition. After the application deadline, a screening committee will review all eligible applications. 2. Short listed candidates will be interviewed by a committee in New Delhi which will select nominees whose names will be forwarded to Washington, D.C. for further consideration. Nominees will be required to take the iBT TOEFL examination in May. 3. All candidates will be notified of their status in September

Closing Date: 1 March

Funding: Private

\section{For further information contact:}

Email: colin@fulbright.org.nz

Contact: Mr Colin Kennedy

\section{Fulbright Indo-American Environmental Leadership Program}

Subjects: Environmental information systems and reporting, environmental policy and law, environmental education and environmental sciences, technology and testing

Purpose: To provide funding for Indian environment professionals to explore future links between American and Indian organisations with common agendas

Eligibility: Open to all Indian mid-level environment professionals with at least five years of professional experience in the respective field and a Master's or professional degree of at least four years duration. Applicants will preferably be under 50 years of age. Special attention will be given to applicants who can demonstrate involvement in co-operative efforts between academia, research institutions, government, industry and non governmental organisations to make practical contributions to environmental policies and programmes

Level of Study: Postdoctorate, Professional development Type: Internship

Value: Round-trip travel from India to the United States of America, a monthly stipend, professional allowance, settlingin allowance plus health insurance. No allowance or travel is provided for dependants

Length of Study: 4 and 8 weeks 
Frequency: Annual

Study Establishment: Selected Fellows will be placed at environmental public, private, non governmental organisations, academic institutions, research centres or environment related government agencies

Country of Study: United States of America

Application Procedure: Applicants must obtain an application form either in person from USEFI offices or by sending a stamped addressed envelope to the nearest local USEFI office. The envelope should be superscribed USEFI-IAELP. Application forms can also be downloaded from the website or requested via email specifying the relevant fellowship category. Although USEFI does not require applicants to have a letter of affiliation from a United States institution at the time of applying, it encourages all applicants to correspond, in advance, with potential host institutions

Closing Date: 1 August for completed applications and 15 July for application form requests

Additional Information: If the applicant is successful but unable to arrange an affiliation or name an institution in the United States of America with which to be affiliated, USEFI will help secure placement. The programme will combine short-term practical training/internship with opportunities for networking with American counterpart organisations

\section{For further information contact:}

Email: lakshmi@fulbright-india.org

\section{Fulbright-Nehru Master's Fellowships}

Purpose: The Fulbright-Nehru Master's Fellowships are designed for outstanding Indians to pursue a master's degree program at select United States of America colleges and universities in the areas of Arts and Culture Management including Heritage Conservation and Museum Studies; Environmental Science/Studies; Higher Education Administration; International Legal Studies;

Eligibility: In addition to the General Prerequisites, the applicants should: 1. Have completed an equivalent of a United States of America bachelor's degree from a recognized Indian university with at least 55\% marks. Applicants should either possess a four-year bachelor's degree or a completed master's degree, if the bachelor's degree is of less than four years' duration. 2. Have at least three years' full-time (paid) professional work experience relevant to your proposed field of study by the application deadline. 3. Demonstrate experience in leadership and community service. 4. Must not have another degree from a United States of America university or be enrolled in a United States of America degree program Level of Study: Graduate

Type: Fellowship
Frequency: Annual

Country of Study: Any country

Closing Date: 15 June

Funding: Private

For further information contact:

Email: humphrey@usief.org.in

\section{Fulbright-Nehru Postdoctoral Research Fellowships}

Purpose: These fellowships are designed for Indian faculty and researchers who are in the early stages of their research careers in India

Eligibility: 1 . The applicant must have a PhD degree within the past four years. S/he must have obtained $\mathrm{PhD}$ degree between 15 July and 16 July. The applicant is required to upload his/her $\mathrm{PhD}$ degree certificate/provisional $\mathrm{PhD}$ certificate in the online application. 2. the applicant must be published in reputed journals and demonstrate evidence of superior academic and professional achievement. Please upload a recent significant publication (copy of paper/article) in the online application. 3. If applicant is employed, please follow the instructions carefully regarding Letter of Support from Home Institution. If applicable, please obtain the endorsement from the appropriate administrative authority on the FNPostdoc Letter of Support from Home Institution. The employer must indicate that leave will be granted for the fellowship period

Level of Study: Postgraduate

Type: Fellowship

Frequency: Annual

Country of Study: Any country

Application Procedure: These fellowships provide J-1 visa support, a monthly stipend, Accident and Sickness Program for Exchanges per United States of America Government guidelines, round-trip economy class air travel from India to the United States of America, a modest settling-in allowance, and a professional allowance

Closing Date: 15 July

Funding: Private

For further information contact:

Email: postdoc@usief.org.in

\section{United States-India Educational Foundation (USIEF) Fulbright-CII Fellowships for Leadership in Management}

Subjects: Leadership in management 
Purpose: To enable business managers to attend a management programme in the United States

Eligibility: Open to Indian business managers. Age limit, preferably not above 40, Nationality: Indian, Designed for: Mid-level Managers in Indian Industries

Level of Study: Professional development

Type: Fellowship

Value: See website for details

Length of Study: 10 weeks

Frequency: Annual

Study Establishment: Carnegie Mellon University

Country of Study: United States of America

No. of awards offered: 49

Application Procedure: Applicants must complete an application form, available from the CII

Closing Date: 15 February

Funding: Corporation, Foundation

Contributor: USEFI and employers of selected Managers

No. of awards given last year: 8

No. of applicants last year: 49

Additional Information: For further information contact the Confederation of Indian Industry (CII). Please check the website www.usief.org.in/Fulbright-Nehru-CII-FellowshipsLeadership-Management.aspx

\section{For further information contact:}

Confederation of Indian Industry, Mantosh Sondhi Centre, 23, Institutional Area, Lodi Road, New Delhi, Delhi 110003, India

Tel: $\quad$ (91) 246299947 ext. 367

Fax: (91) 24601298,24626149

Email: sudarsan@usief.org.in

Contact: Ms S Rajeshwari, Executive Officer

\section{United States-United Kingdom Fulbright Commission}

188 Kirtling Street, SW8 5BN, London, United Kingdom

Tel: $\quad$ (44) 2074046880

Fax: (44) 2074984023

Email: programmes@fulbright.co.uk

Website: www.fulbright.co.uk

Contact: Mr Michael Scott-Kline, Director

The United States-United Kingdom Fulbright Commission has a programme of awards offered annually to citizens of the United Kingdom and United States of America.

\section{The Fulbright-Edinburgh University Award}

Subjects: All subjects

Purpose: To enable a United States citizen to pursue postgraduate study in the United Kingdom at the University of Bristol

Eligibility: Applicant must be a United States citizen (resident anywhere but the United Kingdom), and a graduating senior, holding a BS/BA degree, master's or doctoral degree candidate, young professional or artist

Level of Study: Doctorate, Graduate, Postgraduate

Type: Award/Grant

Value: Up to $£ 20,000$, limited sickness and accident benefit coverage, as well as participation in a number of Fulbright Scholar events including the Fulbright Forum in January are also included

Frequency: Annual

Study Establishment: University of Edinburgh

Country of Study: United Kingdom

Application Procedure: Please visit the website us. fulbrightonline.org/applynow.html

Closing Date: 18 October

Additional Information: For more information, visit www. ed.ac.uk/studying/postgraduate and us.fulbrightonline.org/ program_country.html?id=112

\section{For further information contact:}

Tel: (44) 1316514221

Email:_Robert.Lawrie@ed.ac.uk

Contact: Ms Lawrie Robert, Head of Scholarships \& Student Finance

\section{Universities Canada}

Tel:

(1) 6135633961 ext. 259

Email: tanaka@univcan.ca

Contact: Gabrielle Leblanc, Program Officer

Universities Canada manages government-funded international partnership programs and more than 130 scholarship programs on behalf of private sector companies.

\section{ConocoPhillips Canada Centennial Scholarship Program}

Subjects: All disciplines are eligible

Purpose: To support young Canadian visionaries who have a drive to make a difference in the future. The scholarship 
programme encourages individuals with academic excellence and demonstrated leadership

Eligibility: Canadian citizens or permanent residents of Canada

Type: Scholarship

Value: Up to $C \$ 5,000$ per year for college studies and up to C\$10,000 per year for university studies

Length of Study: 2 years

Country of Study: Canada

Closing Date: 30 May

Additional Information: For more information, please contact awards@univcan.ca

\section{For further information contact:}

Email: ucawards@ucalgary.ca

\section{Fessenden-Trott Scholarship}

Subjects: All disciplines are eligible

Eligibility: Any Canadian educational institution which is a member, or affiliated to a member of Universities Canada

Type: Scholarship

Value: $\$ 9,000$

Length of Study: 3 years

Country of Study: Canada

Closing Date: 15 June

Additional Information: For more information, please contact awards@univcan.ca

\section{For further information contact:}

Tel: (1) 6135631236

Email: awards@aucc.ca

\section{Multiple Sclerosis Society of Canada Scholarship Programs: John Helou Scholarship}

Subjects: All disciplines are eligible

Purpose: To encourage academic excellence and the pursuit of higher education among students who are directly affected by Multiple Sclerosis

Eligibility: Candidates must be female Canadian citizens or permanent residents

Type: Fellowship

Value: C\$6,250 per academic year

Length of Study: 4 years

Country of Study: Canada

Application Procedure: Applicants must submit their own application electronically through the online platform: www. fwis.fr

Closing Date: 31 March
Additional Information: For additional information, please contact awards@univcan.ca

For further information contact:

Email: lindsay.gulin@mssociety.ca

\section{Tanaka Fund Program}

Purpose: The Tanaka Fund Program provides institutional support for the enhancement of Japanese language study opportunities at Canadian universities. It aspires to promote and help improve Japanese language education, and to support institutional program development

Type: Grant

Value: To be confirmed

Length of Study: To be confirmed

Country of Study: Canada

Additional Information: For further details, please contact tanaka@univcan.ca

\section{For further information contact:}

Email: tanaka@univcan.ca

\section{Universities Federation for Animal Welfare (UFAW)}

The Old School, Brewhouse Hill, AL4 8AN, St Albans, United Kingdom
Tel:
(44) 1582831818
Fax: (44) 1582831414
Email: ufaw@ufaw.org.uk
Website: www.ufaw.org.uk

The Universities Federation for Animal Welfare (UFAW), the international animal welfare science society, is a United Kingdom registered scientific and educational charity that brings together the animal welfare science community, educators, veterinarians and all concerned about animal welfare worldwide in order to achieve advances in the well-being of farm, companion, laboratory and captive wild animals, and for those animals with which we interact in the wild.

\section{Universities Federation for Animal Welfare Student Scholarships}

Subjects: Research that is likely to provide new insight into the subjective mental experiences of animals relevant to their 
welfare and at understanding their needs and preferences, and also applied research aimed at developing practical solutions to animal welfare problems

Purpose: To encourage students to develop their interests in animal welfare and their abilities for animal welfare research

Eligibility: Applications are welcome from individuals studying at universities or colleges in the United Kingdom or an overseas institution at which there is a UFAW University Links representative. Students will usually be undertaking courses in the agricultural, biological, medical, psychological, veterinary or zoological sciences. Applicants need a nominated supervisor to oversee the project

Level of Study: Graduate, Postgraduate

Type: Scholarship

Value: $£ 170$ subsistence and $£ 30$ departmental expenses for each week of study

Length of Study: Funding provided for a maximum of 8 weeks (although project duration may be longer)

Frequency: Annual

Country of Study: Any country

Application Procedure: Applicants must complete a UFAW Animal Welfare Student Scholarship application form available for download from the UFAW website www.ufaw.org.uk Closing Date: 26 February

Funding: Private

Additional Information: Successful applicants must submit a written report to UFAW by November of the year in which the project was undertaken. Please see the website for further details www.ufaw.org.uk

\section{University College Birmingham}

Summer Row, B3 1JB, Birmingham, United Kingdom

Tel: (44) 1216041000

Fax: (44) 1216087100

Email: Registry@bcftcs.ac.uk

Website: www.ucb.ac.uk

Contact: Student Scholarships

\section{Target Recruitment Partial Fee Waiver}

Subjects: Tourism, hospitality and child care

Purpose: To reduce tuition fee for new international students Eligibility: Applicants must refer to the website for details Level of Study: Postgraduate

Type: Scholarships

Value: Up to $£ 1,000$
Length of Study: 1 year

Frequency: Annual

Study Establishment: University College Birmingham

Country of Study: United Kingdom

Closing Date: Check the website

Additional Information: Applications can be considered for entry in Semester 1 (Late September/Early October) or Semester 2 (Late January/Early February). Applications should be made at least 2 months prior to the entry date. No applications are necessary. Partial Fee Waivers will be noted in all offer letters sent to applicants from relevant countries. For more information contact the International Student Office on international

\section{For further information contact:}

Email: international@ucb.ac.uk

\section{University College London}

Gower Street, WC1E 6BT, London, United Kingdom

Tel: $\quad$ (44) 2076792000

Fax: (44) 2076913112

Email: postmaster.ucl.ac.uk

Website: www.ucl.ac.uk

Just 175 years ago, the benefits of a university education in United Kingdom were restricted to men who were members of the Church of United Kingdom; University College London (UCL) was founded to challenge that discrimination. UCL was the first university to be established in United Kingdom after Oxford and Cambridge, providing a progressive alternative to those institutions social exclusivity, religious restrictions and academic constraints. UCL is the largest of over 50 colleges and institutes that make up the federal University of London.

\section{A C Gimson Scholarships in Phonetics and Linguistics}

Subjects: Phonetics and linguistics

Purpose: To financially support $\mathrm{MPhil} / \mathrm{PhD}$ research

Eligibility: United Kingdom, European Union and overseas students are eligible to apply

Level of Study: Doctorate, Postgraduate, Research

Type: Scholarship

Value: $£ 1,000$

Frequency: Annual 
Study Establishment: University College London Country of Study: United Kingdom

Application Procedure: Applicants should write indicating their intention to compete for the bursaries to the department Closing Date: 1 June

\section{For further information contact:}

Tel: $\quad$ (44) 2076794245

Email: n.wilkins@ucl.ac.uk

Contact: Natalie Wilkins

\section{A J Ayer-Sumitomo Corporation Scholarship in Philosophy}

Subjects: Philosophy

Purpose: To financially support MPhil/PhD research

Eligibility: All applicants who are admitted to research programmes in philosophy will automatically be considered for this award

Level of Study: Doctorate, Postgraduate, Research

Type: Scholarship

Value: Up to $£ 800$

Frequency: Annual

Study Establishment: University College London

Country of Study: United Kingdom

Application Procedure: No separate application is required. All who are admitted to research programmes in philosophy will automatically be considered for the scholarship. Any queries should be directed to the department

Additional Information: Decisions regarding this award will be made in September

\section{For further information contact:}

Tel:

$$
\text { (44) } 2076794451
$$

Email: r.madden@ucl.ac.uk

Contact: Dr Rory Madden

\section{Alfred Bader Prize in Organic Chemistry}

Subjects: Organic chemistry

Purpose: To financially support MPhil/PhD research

Eligibility: Applicants must contact the department

Level of Study: Doctorate, Postgraduate, Research

Type: Scholarship

Value: $£ 1,000$

Frequency: Annual

Study Establishment: University College London

Country of Study: United Kingdom

Application Procedure: Applicants must contact the department
Closing Date: 1 May

Additional Information: The award will be announced in October

\section{For further information contact:}

Tel: $\quad$ (44) 2076794650

Fax: (44) 2076797463

Email: m.1.jabore@ucl.ac.uk

Contact: Ms Mary Lau Jabore

\section{Amelia Zollner IPPR/UCL Internship Award}

Purpose: The Amelia Zollner IPPR/UCL Internship Award was founded in 2007 in memory of University College London's (UCL) student Ameial Zollner. IPPR and UCL co-fund an annual, approximately 3-month London-based IPPR internship reserved for a recent UCL graduate - as a stepping stone to working in policy or politics. The internship will normally run from October through December, but can take place at any time of the year

Eligibility: (1) Applicants must be final year UCL students, about to graduate (Bachelors, Masters or Research degree) in any area, interested in and passionate about policy and politics, current affairs and social justice, and the work of IPPR, as well as enthusiastic about political research. (2) Applicants can come from any country, but must be able to work in the United Kingdom (United Kingdom/European Union nationals or holders of valid work permit). (3) Applicants should have some research skills, and need to be committed to the aims of IPPR of wanting to build a fair, more democratic and environmentally sustainable world

Level of Study: Graduate, Postgraduate, Research

Type: Award

Value: $£ 5,000$ or the equivalent of the current IPPR salary for the duration of the internship. Check with website

Length of Study: 3 months

Frequency: Annual

Country of Study: United Kingdom

No. of awards offered: $4-8$

Application Procedure: Applications should be made direct to IPPR and submitted preferably by email to intern@ippr.org

Closing Date: 30 January

No. of applicants last year: $4-8$

Additional Information: Please refer website for further information www.ucl.ac.uk/prospective-students/scholarships/ undergraduate/zollner_ippr_internship

\section{For further information contact:}

Tel: (44) 2074706133

Email: k.simony@ippr.org 


\section{Archibald Richardson Scholarship for Mathematics}

Subjects: Pure mathematics

Purpose: To financially support students to pursue MPhil/ $\mathrm{PhD}$ research

Eligibility: United Kingdom, European Union and overseas applicants are eligible to apply. All applicants who firmly accept a place for MPhil/PhD research in pure Mathematics department will be considered

Level of Study: Doctorate, Postgraduate, Research

Type: Scholarship

Value: UK£3,000

Frequency: Annual

Study Establishment: University College London

Country of Study: United Kingdom

Application Procedure: All applicants who firmly accept a place for $\mathrm{MPhil} / \mathrm{PhD}$ research in pure mathematics will be considered automatically

Closing Date: 15 May

\section{For further information contact:}

Tel: $\quad$ (44) 2076792839

Fax: (44) 2073835519

Email: h.higgins@ucl.ac.uk, s.datta@ucl.ac.uk

Contact: Ms Helen Higgins

\section{Arnold Hugh William Beck Memorial Scholarship}

Subjects: Electronic and Electrical Engineering

Purpose: To financially support research Master's and MPhil/PhD students

Eligibility: Applicants should have applied for a place for graduate study at University College London. A past or current holder of the scholarship may apply again for the scholarship but such applications will be considered in open competition with other applicants. No individual may hold the scholarship for more than three years in total

Level of Study: Doctorate, Postgraduate, Research

Type: Scholarship

Value: $£ 6,500$

Frequency: Annual

Study Establishment: University College London

Country of Study: United Kingdom

Application Procedure: Applicants should send an academic curriculum vitae and a letter of more than 500 words describing their areas of interest in the discipline to the address given below. If the applicant has not applied to UCL, they must complete a graduate application form and enclose it with the scholarship application

Closing Date: 15 August

\section{For further information contact:}

Tel: (44) 2076797306

Email: p.johnson@ee.ucl.ac.uk

Contact: Ms Patricia Johnson, The Graduate Tutor

\section{Bentham Scholarships}

Subjects: Law

Purpose: To financially support prospective LLM students

Eligibility: Applicants must be overseas students from outside the European Union. An applicant must have accepted an offer (either conditional or unconditional) to read for the LLM at UCL to be eligible

Level of Study: Postgraduate

Type: Scholarship

Value: $£ 2,000$

Frequency: Annual

Study Establishment: University College London

Country of Study: United Kingdom

Application Procedure: There is no application procedure. All eligible students will automatically be considered if they have firmly accepted their offer of admission by May 31st

Closing Date: Refer website

Additional Information: The scholarships will be based on academic merit. The faculty will only consider these applicants who have firmly accepted their offer of admission to the LLM by May 31st

\section{For further information contact:}

Tel: $\quad$ (44) 2076791441

Fax: (44) 2072093470

Email: graduatelaw@ucl.ac.uk

Contact: The Graduate Officer

\section{Bioprocessing Graduate Scholarship}

Subjects: Biochemical engineering

Purpose: To financially support study leading to an MPhil/PhD

Eligibility: Open to students resident outside the United Kingdom and pursuing the MSc or MPhil or $\mathrm{PhD}$ research in the department of biomedical engineering

Level of Study: Doctorate, Postgraduate

Type: Scholarship

Value: Up to a maximum of $£ 11,000$ per year. This sum can be set against tuition fees and/or be received as maintenance allowance payable in quarterly installments 
Length of Study: Maximum of 4 calendar years

Frequency: Annual

Study Establishment: University College London

Country of Study: United Kingdom

No. of awards offered: 8

Application Procedure: Applicants must contact the department at the address given below

Closing Date: 15 February

Funding: Trusts

No. of applicants last year: 8

\section{For further information contact:}

Tel: $\quad$ (44) 2076793796

Email: nigelth@ucl.ac.uk

Contact: Dr Paul Dalby

\section{Brain Research Trust Prize}

Subjects: Neurology or clinical neurosciences

Purpose: To financially support MPhil/PhD research students Eligibility: Open to United Kingdom, European Union and overseas students. Overseas fee-paying students should be aware that only home tuition fee (European Union rates) is included in the award

Level of Study: Doctorate, Postgraduate, Research

Type: Studentship

Value: Stipend, tuition fees at United Kingdom/European

Union rate and travel budget

Length of Study: Up to 3 years

Frequency: Annual

Study Establishment: University College London Institute of Neurology

Country of Study: United Kingdom

Application Procedure: Applicants should contact the UCL Institute of Neurology. Please submit full curriculum vitae, references and statement of research interests indicating how these would complement projects on offer

Closing Date: Refer website

Funding: Government, Trusts

Contributor: The Brian Research Trust

\section{For further information contact:}

Cell Signalling Laboratory, Institute of Neurology, UCL, 1 Wakefield Street, WC1N 1PJ, London, United Kingdom

\section{Tel: $\quad$ (44) 2076794031}

Email: phdstudentship@ion.cl.ac.uk

Contact: Dr Jennifer Pocock

\section{British Chevening/University College London (UCL) Israel Alumni/Chaim Herzog Award}

Subjects: All subjects. Preference given to public policy, economics and history

Purpose: To financially support masters study

Eligibility: Candidates will need to return to Israel for at least 3 years after completion. Preference will be given to candidates between 25 and 40; Israeli nations currently living in Israel; applicants who have never studied in the United Kingdom; applicants who are graduates of an Israeli university/ students who obtained 1st degree by summer. Please contact the University for updated information

Level of Study: Postgraduate

Type: Scholarship

Value: Tuition fees, return airfare and living expenses

Frequency: Annual

Study Establishment: University College London

Country of Study: United Kingdom

Closing Date: Refer to website

\section{For further information contact:}

The British Council, PO Box 10304, 3 Shimshom Street, Jerusalem 91102, Israel

Email: scholarships@britishcouncil.org.il

\section{Child Health Research Appeal Trust Studentship}

Subjects: Child health, Medical sciences, Natural sciences, Social and Behavioural sciences

Purpose: To fund graduate students for MPhil/ $\mathrm{PhD}$ research Eligibility: Open to committed individuals wishing to do research in a clinical context, who expect to graduate with a United Kingdom first class or upper second class honours degree or equivalent from abroad

Level of Study: Doctorate, Postgraduate

Type: Studentship

Value: Tuition fees at the United Kingdom/European Union student rate, a stipend equivalent to MRC levels and UK $£ 3,000$ towards research costs

Length of Study: 3 years

Frequency: Annual

Study Establishment: UCL Institute of Child Health

Country of Study: United Kingdom

Application Procedure: Studentships are advertised on the department's vacancy website between November-January each year. Applicants should refer to www.ich.ucl.ac.uk/ich/ humanresources/ for instructions on how to apply

Closing Date: Early January 
Funding: Trusts

No. of awards given last year: Up to 4

For further information contact:

Email: chratapps@ich.ucl.ac.uk

\section{Civil and Environmental Engineering Graduate Scholarship}

Subjects: Civil and environmental engineering Purpose: To financially support MPhil/PhD study

Eligibility: Applicants should hold or except to obtain a First Class (Honours) Degree or equivalent. Applicants should have been offered a place at UCL and should firmly have accepted that offer or be intending to do so. They can be from any country outside the European Union

Level of Study: Doctorate, Postgraduate

Type: Scholarship

Value: UK£5,000 per year

Length of Study: 3 years

Frequency: Annual

Study Establishment: University College London

Country of Study: United Kingdom

Application Procedure: Applicants should write indicating their intention to compete for the scholarship to the department

Closing Date: 31 July

Additional Information: If the applicant has not already applied to UCL, please complete a graduate application form and enclose it with the scholarship application

\section{For further information contact:}

Tel: $\quad$ (44) 2076797994

Fax: (44) 2073800986

Email: m.khraisheh@ucl.ac.uk

Contact: Dr Majeda Khraisheh

\section{Common Wealth Shared Scholarship Scheme (CSSS)}

Subjects: Development and planning

Purpose: To financially help students of high academic ability from developing Commonwealth countries

Eligibility: Candidates must be from a developing Commonwealth country, must not have undertaken studies lasting a year or more or be currently studying in a developed country. They should hold or expect to attain, a United Kingdom First Degree (Bachelor's degree) with at least Upper Second Class (Honours) Degree or equivalent and have accepted an offer of place at the development planning unit
Level of Study: Postgraduate

Type: Scholarship

Value: Tuition fees, maintenance costs, some study expenses and return airfare

Length of Study: 1 year

Frequency: Annual

Study Establishment: University College London

Country of Study: United Kingdom

Application Procedure: Application forms are available from the Development Planning Unit

Closing Date: 31 March

Contributor: Department for International Development (DFID) and UCL

No. of awards given last year: 3

Additional Information: Preference is given to candidates unable to afford the cost of studying abroad by themselves. Candidates are expected to return to their home countries to work or study as soon as the award ends

\section{For further information contact:}

Tel: $\quad$ (44) 2076791111

Fax: (44) 2076791112

Email: dpu@ucl.ac.uk

Contact: The Programme Administrator

\section{Dawes Hicks Postgraduate Scholarships in Philosophy}

Subjects: Philosophy

Purpose: To financially support postgraduate research

Eligibility: United Kingdom, European Union and overseas students are eligible to apply

Level of Study: Postgraduate, Research

Type: Scholarship

Value: Up to $£ 5,000$

Frequency: Annual

Study Establishment: University College London

Country of Study: United Kingdom

Application Procedure: No separate application is required. All who are admitted to research programmes in philosophy will automatically be considered for the scholarship. Any queries should be directed to the department

Closing Date: Check with website

Additional Information: Decisions regarding this award will be made in September

\section{For further information contact:}

Tel: $\quad$ (44) 2076794451

Email: r.madden@ucl.ac.uk

Contact: Dr Rory Madden 


\section{Department of Communities and Local Government (formally Office of the Deputy Prime Minister)}

Subjects: Spatial planning and international planning

Purpose: To financially support full-time study

Eligibility: Open to candidates who take up full time study only with residence restrictions, already holding or offer for the MSC spatial planning or MSC international planning, 2:1 or equivalent (except in exceptional circumstances)

Level of Study: Postgraduate

Type: Bursary

Value: Tuition fees at United Kingdom/European Union rate plus (For United Kingdom/European Union nationals only) along with a monthly stipend of $£ 500$

Length of Study: 1 year

Frequency: Annual

Study Establishment: University College London

Country of Study: United Kingdom

No. of awards offered: 16

Application Procedure: Applications are available from www.esrc.ac.uk (ESRC) and should be sent to the department. Potentially eligible candidates will be contacted by the department

Closing Date: Refer website

Funding: Government

Contributor: Department of Communities and Local Government

No. of awards given last year: 7

No. of applicants last year: 16

For further information contact:

Tel: $\quad$ (44) 2076797501

Email: j.hillmore@ucl.ac.uk

Contact: Judith Hillmore

\section{Edwin Power Scholarship}

Subjects: Applied mathematics

Purpose: To support a graduate student to the Department of Mathematics for Master's study or PhD research in Applied Mathematics

Eligibility: Applicant must be a graduate student admitted to the Department of Mathematics for Master's study or MPhil/ $\mathrm{PhD}$ research in applied mathematics

Level of Study: Postgraduate, Research

Type: Scholarship

Value: $£ 400$, subject to annual renewal based on satisfactory progress

Length of Study: 3 years

Frequency: Annual
Study Establishment: University College London

Country of Study: United Kingdom

Application Procedure: Candidates wishing to apply for the Scholarship must send written notice of their intention to apply for the Scholarship to the Head of the Department of Mathematics at UCL

Closing Date: 15 August

\section{For further information contact:}

Tel: $\quad$ (44) 2076792839

Fax: (44) 2073832839

Email: h.higgins@ucl.ac.uk, s.datta@ucl.ac.uk

Contact: Ms Helen Higgins

\section{Eleanor Grove Scholarships for Women Students}

Subjects: German language and literature

Purpose: To promote and encourage study and proficiency in German

Eligibility: Candidate must be a female student of the college. The scholarship will be awarded to assist a student who is reading for a higher degree, or, in special cases, to enable a BA student to study German abroad. Candidates must have completed at least five terms of study with UCL's Arts and Humanities faculty

Type: Scholarship

Value: $£ 950$

Frequency: Annual

Study Establishment: University College or elsewhere approved by the Faculty of Arts and Humanities

Country of Study: United Kingdom

No. of awards offered: 2

Application Procedure: Contact the Graduate Tutor

Closing Date: 25 May

No. of applicants last year: 2

Additional Information: This scheme is currently under process, please check for the availability of scheme from the college

\section{For further information contact:}

The Graduate Tutor, Department of German, UCL, WC1E 6BT, London, United Kingdom

Email: german@ucl.ac.uk

\section{English Heritage Scholarships}

Subjects: Archaeology: artefact studies, managing archaeological sites, and the technology and analysis of archeological materials 
Purpose: To financially support postgraduate study

Eligibility: Applicants need a minimum of 2 years work experience in British archaeology

Level of Study: Postgraduate

Type: Scholarship

Value: Up to $£ 13,210$

Frequency: Annual

Study Establishment: University College London

Country of Study: United Kingdom

Application Procedure: Applicants must contact the department

Closing Date: Normally mid-July, check the department website

\section{For further information contact:}

Tel: $\quad$ (44) 2076797495

Fax: (44) 2073832572

Email:_k.thomas@ucl.ac.uk

Contact: Professor Ken Thomas

\section{Fielden Research Scholarship}

Subjects: German language and literature

Purpose: To financially support MPhil/PhD study

Eligibility: Applicants must have applied for MPhil/PhD research in German language and literature

Level of Study: Doctorate, Graduate, Postgraduate

Type: Scholarship

Value: $£ 500$

Frequency: Annual

Study Establishment: University College London

Country of Study: United Kingdom

No. of awards offered: 1

Application Procedure: Applicants must contact the department

Closing Date: 25 May

No. of awards given last year: 1

No. of applicants last year: 1

\section{For further information contact:}

School of European Languages, Culture and Society, University College London, Gower Street, WC1E 6BT, London, United Kingdom

Email: joseph.tilley@ucl.ac.uk

Contact: Mr Joe Tilley

\section{Follett Scholarship}

Subjects: Philosophy
Purpose: To financially support MPhil/PhD research

Eligibility: United Kingdom, European Union and overseas students are eligible to apply

Level of Study: Doctorate, Postgraduate, Research

Type: Scholarship

Value: Up to $£ 13,000$ towards fees and/or maintenance

Frequency: Annual

Study Establishment: University College London

Country of Study: United Kingdom

Application Procedure: No separate application is required. Applicants who are admitted to research programmes in philosophy will automatically be considered for the scholarship. Any queries should be directed to the department

For further information contact:

Tel: $\quad$ (44) 2076794451

Fax: (44) 2076793336

Email: r.madden@ucl.ac.uk

Contact: Dr Rory Madden

\section{Franz Sondheimer Bursary Fund}

Subjects: Chemistry

Purpose: To financially support MPhil/PhD research

Eligibility: Preference is given to overseas applicants

Level of Study: Doctorate, Postgraduate, Research

Type: Scholarship

Value: Approx. $£ 2,000$

Study Establishment: University College London

Country of Study: United Kingdom

No. of awards offered: 2

Application Procedure: Applicants must contact the department

Closing Date: 1 May

No. of awards given last year: 1

No. of applicants last year: 2

For further information contact:

Tel: $\quad$ (44) 2076794650

Fax: (44) 2076797463

Email: m.l.jabore@ucl.ac.uk

Contact: Ms Mary Lou Jabore

\section{Gaitskell MSc Scholarship}

Subjects: Economics

Purpose: To financially support full-time Master's study in the Department of Economics 
Eligibility: Open to candidates who have applied for a place for graduate study at UCL and are not already receiving full financial support from other sources for fees and living costs

Level of Study: Postgraduate

Type: Scholarship

Value: $£ 5,000$

Frequency: Annual

Study Establishment: University College London (UCL)

Country of Study: United Kingdom

Application Procedure: Applications not needed. All applicants to the department are automatically considered

For further information contact:

Tel: $\quad$ (44) 2076795861

Fax: (44) 2076162775

Email: d.fauvrelle@ucl.ac.uk

Contact: Ms Daniella Fauvrelle

\section{Gay Clifford Fees Award for Outstanding Women Students}

Subjects: Any Master's programme in either the Faculty of Arts and Humanities or the Faculty of Social and Historical Sciences

Purpose: To financially support postgraduate study

Eligibility: Open to prospective female Master's degree students in the faculties of Arts and Humanities and Social and Historical Sciences with a First Class (Honours) undergraduate degree or equivalent

Level of Study: Postgraduate

Type: Scholarship

Value: $£ 2,500$ (deducted from tuition fees)

Length of Study: 1 year

Frequency: Annual

Study Establishment: University College London

Country of Study: United Kingdom

Application Procedure: Applicants should refer to the website for further information about the application procedures and deadlines

Closing Date: See website

No. of awards given last year: 4

Additional Information: This scholarship is under review. To be notified of any updates follow us on Twitter@ucl_studentfund

\section{For further information contact:}

Tel: $\quad$ (44) $2076792005 / 4167$

Email: studentfunding@ucl.ac.uk

\section{Harold and Olga Fox Overseas Postgraduate Prize Studentship}

Subjects: Biology

Purpose: To provide financial assistance to prospective overseas students intending to pursue a full-time programme of research leading to $\mathrm{MPhil} / \mathrm{PhD}$ degree in the Department of Biology at UCL

Eligibility: Applicants should contact the Department of Biology for full details on eligibility

Level of Study: Postgraduate, Research

Type: Scholarship

Value: $£ 15,000$

Application Procedure: Applicants should contact the Department of Biology for further information

For further information contact:

Email: k.rowlinson@ucl.ac.uk

\section{Health Risk Resources International (HRRI) Scholarship}

Subjects: Risk management

Purpose: To financially support postgraduate study

Eligibility: Applicants must have applied for a place for graduate study at UCL

Level of Study: Postgraduate

Type: Scholarship

Value: United Kingdom/European Union tuition fees

Frequency: Annual

Study Establishment: University College London

Country of Study: United Kingdom

Application Procedure: Applicants should contact the department. If the applicants have not applied to UCL they must complete a graduate application form and enclose it with the scholarship application

Closing Date: Check the website for closing date

For further information contact:

Tel: $\quad$ (44) 2072883366

Fax: (44) 2072883322

Email: m.jacks@chime.ucl.ac.uk

Contact: Ms Marcia Jacks

\section{Ian Karten Charitable Trust Scholarship (Hebrew and Jewish Studies)}

Subjects: Hebrew and Jewish studies

Purpose: To financially support postgraduate study 
Eligibility: Applicants must have applied for a place for graduate study at UCL in the Department of Hebrew and Jewish Studies

Level of Study: Graduate, Postgraduate

Type: Scholarship

Value: $£ 1,000$ each

Frequency: Annual

Study Establishment: University College London

Country of Study: United Kingdom

Application Procedure: Applicants should contact the department. If the applicants have not applied to UCL they must complete a graduate application form and enclose it with the scholarship application

Closing Date: 1 June

Funding: Trusts

For further information contact:
Tel: $\quad$ (44) 2076793028
Fax: (44) 2072091026
Email: n.f.lochery@ucl.ac.uk
Contact: Dr Neil Lochery

\section{Ian Karten Charitable Trust Scholarship (Microbiology)}

Subjects: Clinical tropical microbiology

Purpose: To financially support postgraduate study

Eligibility: Applicants must be United Kingdom nationals aged 30 years or under at the start of their intended academic year of study

Level of Study: Postgraduate

Type: Scholarship

Value: $£ 2,500$

Frequency: Annual

Study Establishment: University College London

Country of Study: United Kingdom

Application Procedure: Applicants should contact the department

For further information contact:

Email: t.mchugh@rfc.ucl.ac.uk

Contact: Dr T D McHugh

\section{Ian Karten Charitable Trust Scholarship (Neuroscience)}

Subjects: Neuroscience

Purpose: To financially support postgraduate study in neuroscience

Eligibility: Applicants must be United Kingdom nationals aged 30 years or under on October 10th in the intended year of entry
Level of Study: Postgraduate

Type: Scholarship

Value: $£ 2,750$

Frequency: Annual

Study Establishment: University College London

Country of Study: United Kingdom

Application Procedure: Applicants must contact the department

Closing Date: Check the website for closing date

\section{For further information contact:}

Department of Anatomy and Developmental Biology, Gower St, Bloomsbury, London, United Kingdom

Tel: $\quad$ (44) 2076797740

Fax: (44) 2076797349

Email: anatpgenquires@anatomy.ucl.ac.uk

Contact: The Teaching Administrator

\section{Institute of Education, University of London Centenary Masters Scholarships}

Purpose: For current and next academic year, IOE is offering Centenary Masters Scholarships for students who plan to work either in their home country, or another, to improve the circumstances of disadvantaged, excluded or underachieving citizens

Eligibility: 1 . Be citizens and residents of a low or middle income country with a GNI not higher than $\$ 8,000$ per capita (as per the World Bank GNI per capita classification tables). 2. Have an offer to study a full time masters degree in London at the UCL Institute of Education (October start). 3. Not have studied or lived in the United Kingdom before

Level of Study: Postdoctorate

Type: Scholarship

Value: $\$ 8,000$

Length of Study: 1 year

Frequency: Annual

Country of Study: Any country

Closing Date: 5 April

Funding: Foundation

For further information contact:

Email: info@canterbury.ac.nz

\section{Jacobsen Scholarship in Philosophy}

Subjects: Philosophy

Purpose: To financially support MPhil/PhD research

Eligibility: Open to United Kingdom, European Union and overseas students 
Level of Study: Doctorate, Postgraduate, Research

Type: Scholarship

Value: Up to $£ 9,500$

Frequency: Annual

Study Establishment: University College London

Country of Study: United Kingdom

Application Procedure: No separate application is required. Applicants who are admitted to research programmes in philosophy will automatically be considered for the scholarship. Any queries should be directed to the department

Additional Information: Decisions regarding this award will be made in September

\section{For further information contact:}

Tel: $\quad$ (44) 2076797115

Email: r.madden@ucl.ac.uk

Contact: Dr Rory Madden

\section{James Joseph Sylvester Scholarship}

Subjects: Mathematics

Purpose: To financially support MPhil/PhD research

Eligibility: United Kingdom, European Union and overseas students are eligible to apply

Level of Study: Doctorate, Postgraduate, Research

Type: Scholarship

Value: Up to $£ 3,000$

Frequency: Annual

Study Establishment: University College London

Country of Study: United Kingdom

Application Procedure: Applicants must contact the department

Closing Date: 15 May

\section{For further information contact:}

Department of Mathematics, University College London, Gower Street, WC1E 6BT, London, United Kingdom

Tel: $\quad$ (44) 2076792839

Fax: (44) 2073835519

Email: h.higgins@ucl.ac.uk, s.datta@ucl.ac.uk

Contact: Ms Helen Higgins

\section{Jevons Memorial Scholarship in Economic Science}

Subjects: Economics

Purpose: To financially support MPhil/PhD study

Eligibility: Candidates must have graduated or be a candidate for graduation in the term in which the award is made. Previous tenure of the scholarship does not debar candidate from competing on a second occasion. Normally the scholar elected must pursue a course of study and research for a higher degree at UCL

Level of Study: Doctorate, Postgraduate

Type: Scholarship

Value: £55

Frequency: Annual

Study Establishment: University College London

Country of Study: United Kingdom

Application Procedure: Applicants should send particulars of the research work they intend to pursue plus an academic curriculum vitae to the department. If the applicant has not applied to UCL, they must complete a graduate application form and enclose it with the scholarship application

Closing Date: 15 May

For further information contact:

Tel: $\quad$ (44) 2076795861

Fax: (44) 2079162775

Email: d.fauvrelle@ucl.ac.uk

Contact: Ms Daniella Fauvrelle

\section{John Carr Scholarship for Students from Africa and the Caribbean}

Subjects: Law

Purpose: To financially support prospective LLM students

Eligibility: Applicants must be overseas students from Africa and the Caribbean. An applicant must have accepted an offer (either conditional or unconditional) to read for the LLM at UCL to be eligible

Level of Study: Postgraduate

Type: Scholarship

Value: $£ 2,000$

Frequency: Annual

Study Establishment: University College London

Country of Study: United Kingdom

Application Procedure: There is no application procedure. All eligible students who have accepted the offer of admission by March 31 st will automatically be considered

Closing Date: 2 March

Additional Information: The scholarships will be based on academic merit. The faculty will only consider those applicants who have firmly accepted their offer of admission to the LLM by May 31st

\section{For further information contact:}

Tel: (44) 2076791441

Fax: (44) 2072093470

Email: graduatelaw@ucl.ac.uk 


\section{John Hawkes Scholarship}

Subjects: Pure mathematics

Purpose: The primary purpose is to support third year study in pure mathematics but a secondary purpose when there is no suitable candidate or candidates for the whole sum available, is to support a graduate research student

Eligibility: United Kingdom, European Union and overseas students are eligible to apply

Level of Study: Doctorate, Postgraduate, Research

Type: Scholarship

Value: Up to $£ 12,000$ per year

Length of Study: 3 years

Frequency: Annual

Study Establishment: University College London

Country of Study: United Kingdom

Application Procedure: Applicants should write to the Head of the Department, indicating their wish to be considered for the scholarship and providing details of their academic achievements to date. Applicants should also include an upto-date curriculum vitae

Closing Date: 1 May

\section{For further information contact:}

Tel: $\quad$ (44) 2076792839

Fax: (44) 2073835519

Email: h.higgins@ucl.ac.uk,s.datta@ucl.ac.uk

Contact: $\quad$ Ms Helen Higgins

\section{John Stuart Mill Scholarship in Philosophy of Mind and Logic}

Subjects: Philosophy

Purpose: To financially support MPhil/PhD research

Eligibility: Open to United Kingdom, European Union and overseas applicants

Level of Study: Doctorate, Postgraduate, Research

Type: Scholarship

Value: Up to $£ 1,400$

Frequency: Annual

Study Establishment: University College London

Country of Study: United Kingdom

Application Procedure: No separate application is required. All who are admitted to research programmes in philosophy will automatically be considered for the scholarship. Any queries should be directed to the department

Additional Information: Decision regarding this award will be made in September

\section{For further information contact:}

Tel: $\quad$ (44) 2076794451

Email: r.madden@ucl.ac.uk

Contact: Dr Rory Madden

\section{Joseph Hume Scholarship}

Subjects: Law

Purpose: To financially support LLM students or MPhil/PhD research

Eligibility: For all LLM or MPhil/PhD research students in the Department of Laws

Level of Study: Doctorate, Postgraduate, Research

Type: Scholarship

Value: $£ 1,600$

Frequency: Annual

Study Establishment: University College London

Country of Study: United Kingdom

Application Procedure: There is no application procedure. All eligible students will automatically be considered

Closing Date: 23 March

Additional Information: Please check the website for further details www.laws.ucl.ac.uk/study/graduate/applying/ funding-scholarships/

For further information contact:

Tel: $\quad$ (44) 2076791441

Fax: (44) 2072093470

Email: graduatelaw@ucl.ac.uk

Contact: The Graduate Officer

\section{Keeling Scholarship}

Subjects: Philosophy

Purpose: To financially support MPhil/PhD research

Eligibility: United Kingdom, European Union and overseas students are eligible to apply

Level of Study: Doctorate, Postgraduate, Research

Type: Scholarship

Value: United Kingdom/European Union tuition fees plus a bursary

Frequency: Annual

Study Establishment: University College London

Country of Study: United Kingdom

Application Procedure: No separate application is required. Applicants who are admitted to research programmes in philosophy will automatically be considered for the scholarship. Any queries should be directed to the department 
Closing Date: Check the website

Additional Information: For more information on eligibility please check www.ucl.ac.uk/philosophy/keeling/scholarship

\section{For further information contact:}

Tel:

$$
\text { (44) } 2076797115
$$

Email: r.madden@ucl.ac.uk

Contact: Dr Rory Madden

\section{Liver Group PhD Studentship}

Subjects: Hepatology

Purpose: To financially support students to pursue MPhil/ $\mathrm{PhD}$ research

Eligibility: Open to United Kingdom and European Union applicants holding a relevant First or Upper Second Class

Level of Study: Doctorate, Postgraduate, Research

Type: Scholarship

Value: Home student fees plus a maintenance allowance (1st year approx. $£ 14,500$ )

Length of Study: 3 years

Frequency: Dependent on funds available

Study Establishment: Royal Free and University College Medical School, UCL-Hampstead campus

Country of Study: United Kingdom

Application Procedure: Applicants should contact the department

Closing Date: Refer website

Funding: Foundation

Contributor: The Liver Group Charity

No. of awards given last year: 1

\section{For further information contact:}

Centre for Hepatology, Department of Medicine (Royal Free Campus), Royal Free and University College Medicine School, Rowland Hill Street, Hampstead, NW3 2PF, London, United Kingdom
Tel:
(44) 2074332854
Fax: (44) 2074332852
Email: c.selden@rfc.ucl.ac.uk
Contact: Dr Clare Selden

\section{Margaret Richardson Scholarship}

Subjects: German

Purpose: To financially support MPhil/PhD study
Eligibility: Open to applicants should have applied for a place for graduate study at UCL and have Upper Second Class Degree or equivalent in German or a related field of study to enable them to do research work in this subject. Previous tenure of the scholarship does not debar a candidate from competing on a second occasion

Level of Study: Doctorate, Graduate, Postgraduate

Type: Scholarship

Value: $£ 5,000$ (may split into two awards of $£ 2,500$ each)

Frequency: Annual

Study Establishment: University College London

Country of Study: United Kingdom

Application Procedure: Applicants should contact the department. If the applicant has not applied to UCL, they must complete a graduate application form and enclose it with the scholarship application. The application must give particulars of the research work which they intend to pursue in the event of the scholarship being awarded to them

Closing Date: 25 May

\section{For further information contact:}

School of European Languages, Culture and Society, University College Gower Street, WC1E 6BT, London, United Kingdom

Email:_joseph.tilley@ucl.ac.uk

Contact: Mr Joe Tilley

\section{Master of the Rolls Scholarship For Commonwealth Students}

Subjects: Law

Purpose: To financially support prospective LLM students

Eligibility: Applicants must be overseas students from the Commonwealth countries. An applicant must have accepted an offer (either conditional or unconditional) to read for the LLM at UCL

Level of Study: Postgraduate

Type: Scholarship

Value: $£ 2,000$

Frequency: Annual

Study Establishment: University College London

Country of Study: United Kingdom

Application Procedure: There is no application procedure. All eligible students who firmly accept the offer of admission by May 31 st will be automatically considered

Closing Date: Check with website

No. of awards given last year: 1 
Additional Information: The scholarships will be based on academic merit. The faculty will only consider those applicants who have firmly accepted their offer of admission to the LLM by May 31 st

\section{For further information contact:}

Tel: $\quad$ (44) 2076791441

Fax: $\quad$ (44) 2072093470

Email: graduatelaw@ucl.ac.uk

Contact: The Graduate Officer

\section{Master's Degree Awards in Archaeology}

Subjects: Archaeology

Purpose: To financially support MA and MSc programmes in the Institute of Archaeology

Eligibility: Open to students on MA and MSc programmes in UCL's institute of archaeology

Level of Study: Postgraduate

Type: Scholarship

Value: Approx. $£ 1,000$

Frequency: Annual

Study Establishment: University College London

Country of Study: United Kingdom

Application Procedure: Applicants must contact the department

Closing Date: Mid-March, check the department website for details

\section{For further information contact:}

Tel: $\quad$ (44) 2076797499

Fax: (44) 2073832572

Email: 1.daniel@ucl.ac.uk

Contact: Lisa Daniel

\section{Master's Degree Awards in Biochemical Engineering}

Subjects: Biochemical engineering

Purpose: To financially support postgraduate study

Eligibility: Open to United Kingdom/European Union resident applicants only

Level of Study: Postgraduate

Type: Scholarship

Value: A full award amounts to $£ 9,000$ plus tuition fees

Frequency: Annual

Study Establishment: University College London

Country of Study: United Kingdom
Application Procedure: Applicants must contact the department at the address given below or the British Council Office in Colombo

Closing Date: 1 July

Additional Information: The scholarships may be partly or fully funded

\section{For further information contact:}

Tel: $\quad$ (44) 2076793796

Email: nigelth@ucl.ac.uk

Contact: Professor Nigel Titchener-Hooker

\section{Member Scholarship in Statistics}

Subjects: Statistics

Purpose: To financially support full-time graduate study and research

Eligibility: Applicants should have graduated from UCL or be a candidate for graduation in the term in which the award is made. United Kingdom, European Union and overseas students are eligible to apply

Level of Study: Postgraduate, Research

Type: Scholarship

Value: $£ 55$

Frequency: Annual

Study Establishment: University College London

Country of Study: United Kingdom

Application Procedure: Applicants should write to the department indicating their intention to compete for the scholarship

\section{For further information contact:}

Tel: $\quad$ (44) 2076791872

Fax: (44) 2073834703

Email: marion@stats.ucl.ac.uk

Contact: Ms Marion Wave

\section{Monica Hulse Scholarship}

Subjects: Mathematics

Purpose: This Scholarship, founded in 2004, is funded from a regular lifetime gift from Dr Paul Hulse, alumnus of UCL, in memory of his mother, Monica Hulse (1934-1999). One scholarship is awarded annually to a prospective graduate student from any country admitted to the Department of Mathematics for full-time Master's study or MPhil/PhD research 
Eligibility: Open to graduate students in the department of mathematics in the first year of their Master's course or Ph-

D. The applicant should not be in receipt of any other special funding

Level of Study: Doctorate, Postgraduate, Research

Type: Scholarship

Value: $£ 1,000$

Frequency: Annual

Country of Study: Any country

Application Procedure: Applicants must send written notice of their intention prior to the start of the academic year along with an academic curriculum vitae

Closing Date: 31 May

Funding: Private

No. of awards given last year: 1

Additional Information: Application link for the following grant is www.ucl.ac.uk/prospective-students/scholarships/ graduate/deptscholarships/mathematics

\section{For further information contact:}

Email: h.higgins@ucl.ac.uk,s.datta@ucl.ac.uk

\section{National Health Service Bursaries}

Subjects: Speech and language sciences

Purpose: To financially support postgraduate study

Eligibility: Open to United Kingdom and European Union applicants only who have applied for a place for graduate study at UCL

Level of Study: Postgraduate

Type: Bursary

Value: United Kingdom/European Union tuition fees. United

Kingdom residents will also normally be eligible for a means tested bursary

Frequency: Annual

Study Establishment: University College London

Country of Study: United Kingdom

Application Procedure: There is no separate bursary application form. Application procedure is an automatic process once an offer of a place has been made

Additional Information: When an offer of a place has been made, the NHS Student Grants unit will contact the applicant directly

\section{For further information contact:}

Tel: $\quad$ (44) 2076794202

Email: n.wilkins@ucl.ac.uk

Contact: Natalie Wilkins

\section{Nederlandse Taalunie Scholarship}

Subjects: Modern Dutch studies (literary translation from Dutch into English option)

Purpose: To financially support postgraduate study

Eligibility: Applicants must have applied for a place for graduate study at UCL

Level of Study: Postgraduate

Type: Scholarship

Value: $£ 2,500$

Frequency: Annual

Study Establishment: University College London

Country of Study: United Kingdom

Application Procedure: Applicants should contact the department. If the applicant has not applied to UCL, they must complete a graduate application form and enclose it with the scholarship application

Closing Date: 15 July

\section{For further information contact:}

Tel: $\quad$ (44) 2076793117

Fax: (44) 2076166985

Email: t.hermans@ucl.ac.uk

Contact: Professor Theo Hermans

\section{Perren Studentship}

Subjects: Astronomy

Purpose: To financially support graduate study and research Eligibility: United Kingdom, European Union and overseas applicants are eligible to apply

Level of Study: Postgraduate, Research

Type: Studentship

Frequency: Every 2 years

Study Establishment: University College London

Country of Study: United Kingdom

Application Procedure: Applicants should provide particulars of their academic record and of the work that they intend to pursue to the department

Closing Date: 15 May

Funding: Trusts

Contributor: Perren Fund

\section{For further information contact:}

Tel: $\quad$ (44) 207679473

Email: lahauestar@ucl.ac.uk

Contact: Professor Ofer Lahau 


\section{R B Hounsfield Scholarship in Traffic Engineering}

Subjects: Traffic engineering

Purpose: To financially support MPhil/PhD research in Traffic Engineering in the Department of Civil and Environmental Engineering

Eligibility: Candidates should hold or expect to obtain a First Class (Honours) Degree or equivalent and should have been offered a place at UCL and have firmly accepted that offer or be intending to do so

Level of Study: Doctorate, Postgraduate, Research

Type: Scholarship

Value: Not less than $£ 120$

Frequency: Dependent on funds available

Study Establishment: University College London

Country of Study: United Kingdom

Application Procedure: Enquiries should be directed to the department

Closing Date: 15 May

Additional Information: If the applicant has not already applied to UCL, please complete a graduate application form and enclose it with the scholarship application

\section{For further information contact:}

Tel: $\quad$ (44) 2076792710

Fax: (44) 2073800986

Email: civeng.admissions@ucl.ac.uk

Contact: Professor R L Mackett

\section{Research Degree Scholarship in Chemical Engineering}

Subjects: Chemical engineering

Purpose: To financially support MPhil/PhD research

Level of Study: Doctorate, Postgraduate, Research

Type: Scholarship

Value: $£ 2,000$

Frequency: Annual

Study Establishment: University College London

Country of Study: United Kingdom

Application Procedure: Applicants must contact the department

Closing Date: Check the website for closing date

\section{For further information contact:}

Tel: $\quad$ (44) 2076793835

Fax: (44) 2073832348

Email: h.mahgerefteh@ucl.ac.uk

Contact: Dr Haroun Mahgerefteh

\section{Research Degree Scholarships in Anthropology}

Subjects: Anthropology

Purpose: To financially support research in the field of anthropology

Eligibility: Please contact the Department of Anthropology

for details

Level of Study: Doctorate, Postgraduate, Research

Type: Scholarship

Value: United Kingdom/European Union tuition fees

Frequency: Annual

Study Establishment: University College London

Country of Study: United Kingdom

No. of awards offered: 12

Application Procedure: Applicants must contact the department

Closing Date: 30 April

No. of awards given last year: 4

No. of applicants last year: 12

For further information contact:

Tel: $\quad$ (44) 2076798622

Fax: (44) 2076798632

Email: ucsapga@ucl.ac.uk

Contact: Ms Diana Goforth

\section{Richard Chattaway Scholarship}

Subjects: History of modern warfare from 1870

Purpose: To financially support MPhil/PhD study

Eligibility: Open to applicants who have applied for a graduate study at University College London (UCL). The scholar selected must pursue research for a higher degree at UCL. Receipt of the scholarship must be acknowledged in any publication or research paper which has benefitted from it

Level of Study: Doctorate, Postgraduate

Type: Scholarship

Value: $£ 2,000$

Frequency: Annual

Study Establishment: University College London

Country of Study: United Kingdom

Application Procedure: Applicants must contact the department. If the applicants have not already applied to UCL they must complete a graduate application form and enclose it with the scholarship application. Applicants must include particulars of the research work they intend to pursue in the event of the scholarship being awarded to them

Closing Date: 15 May 
Funding: Individuals

Contributor: Private donation in honour of Richard Chattaway

No. of awards given last year: 1

\section{For further information contact:}

Email: n.miller@ucl.ac.uk

Contact: Professor Nicola Miller, Head of the Department

\section{Royal National Orthopaedic Hospital Special Trustees Research Training Scholarship}

Subjects: Surgical sciences

Purpose: To give orthopaedic specialists of the future an early exposure to the first-class research culture at Stanmore

Eligibility: Open to students enrolled in the MSc in Surgical Sciences programme undertaking a research project at the Royal National Orthopaedic Hospital/Institute of Orthopaedic and Musculoskeletal Science

Level of Study: Postgraduate

Type: Scholarship

Value: A stipend, tuition and bench fees

Frequency: Annual

Study Establishment: Royal National Orthopaedic Hospital, Stanmore

Country of Study: United Kingdom

Application Procedure: Once students have been accepted by a supervisor, they should contact the R\&D office, Royal National Orthopaedic Hospital. Applicants will be asked to send an outline of the research project and their curriculum vitae. Applicant should contact the department at the address given below

Funding: Private

Contributor: The RNOH Special Trustees and the R\&D Subcommittee

Additional Information: Recipients of the scholarships must present their research findings at a symposium to be held at the RNOH. The R\&D Director and the Non-Executive Director for research will review applications

\section{For further information contact:}

Royal National Orthopaedic Hospital, Brockley Hill, Stanmore, HA7 4LP, Middlesex, United Kingdom

Tel: $\quad$ (44) 2089095752

Email:1philpots@rnoh.nhs.uk

Contact: Dr Liz Philpots, R\&D Manager

\section{Score Africa/Allan \& Nesta Ferguson Charitable Trust Scholarship}

Purpose: To financially assist African nationals to undertake $\mathrm{MSc} / \mathrm{PhD}$ studies at the Centre for International Health and Development (CIHD) at UCL

Eligibility: Applicants should refer to the website for full details on eligibility

Level of Study: Postgraduate

Type: Scholarship

Value: Partial payment towards tuition fees

Frequency: Annual

Application Procedure: Applicants should refer to the website for further information on application procedures, forms and deadlines

\section{For further information contact:}

Email: cihdsc@ich.ucl.ac.uk

\section{Shell Petroleum Development Company Niger Delta Postgraduate Scholarship}

Subjects: MSc chemical process engineering or MSc mechanical engineering or MSc civil engineering

Purpose: To provide opportunities for postgraduate study in the United Kingdom for young students and professionals, who demonstrate both academic excellence and the potential to become leading professionals in the oil and associated industries

Eligibility: The applicant must: (1) have obtained a degree of at least an equivalent standard to a United Kingdom Upper Second Class (Honours Degree); (2) be neither a current nor former employee (who have left employment less than 5 years before) of SPDC, the Royal Dutch Shell Group of Companies or Wider Perspectives Limited, or current employee's relatives; (3) not already have had the chance of studying in the United Kingdom or another developed country; (4) be aged between 21 and 28 years; (5) originate from one of the Niger Delta States in Nigeria, namely Rivers, Delta or Bayelsa and currently reside in Nigeria

Level of Study: Postgraduate

Type: Scholarship

Value: Full tuition fee funding, maintenance allowance, return airfares and arrival allowance

Frequency: Annual

Study Establishment: University College London

Country of Study: United Kingdom

Closing Date: See website for details 


\section{For further information contact:}

Student Funding Office, UCL, Gower Street, WC1E 6BT, London, United Kingdom

Email: studentfunding@ucl.ac.uk

\section{Sir Frederick Pollock Scholarship for Students from North America}

Subjects: LLM

Purpose: To financially support prospective LLM students Eligibility: Applicants must be overseas students from North America. An applicant must have accepted an offer (either conditional or unconditional) to read for the LLM at UCL to be eligible

Level of Study: Postgraduate

Type: Scholarship

Value: $£ 2,000$

Frequency: Annual

Country of Study: United Kingdom

Application Procedure: There is no application procedure. All eligible students will be automatically considered

Closing Date: 2 March

Additional Information: The scholarships will be based on academic merit. The faculty will only consider those applicants who have firmly accepted their offer of admission to the LLM by May 31 st

For further information contact:

Tel: $\quad$ (44) 2076791441

Fax: (44) 2072093470

Email: jane.ha@ucl.ac.uk

Contact: The Graduate Officer

\section{Sir George Jessel Studentship in Mathematics}

Subjects: Mathematics

Purpose: To financially support MPhil/PhD research

Eligibility: Applicants must be graduates of University College London. All applicants who firmly accept a place for MPhil/PhD research in the Mathematics Department will be considered

Level of Study: Doctorate, Postgraduate, Research

Type: Studentship

Value: $£ 1,800$

Frequency: Annual

Study Establishment: University College London

Country of Study: United Kingdom

Application Procedure: Applicants must contact the department
Closing Date: Refer the website

Additional Information: Please refer the website for further details www.ucl.ac.uk/prospective-students/scholarships/ graduate/deptscholarships/mathematics

For further information contact:

Tel: $\quad$ (44) 2076792839

Fax: (44) 2073835519

Email: h.higgins@ucl.ac.uk

Contact: Ms Helen Higgins

\section{Sir James Lighthill Scholarship}

Subjects: Applied mathematics

Purpose: To financially support MPhil/PhD research

Eligibility: United Kingdom, European Union and overseas students are eligible to apply. All applicants who firmly accept a place for MPhil/PhD research in the Mathematics Department will be considered

Level of Study: Doctorate, Postgraduate, Research

Type: Scholarship

Value: $£ 500$ per year

Frequency: Annual

Study Establishment: University College London

Country of Study: United Kingdom

Application Procedure: Applicants must contact the department

Closing Date: Refer website

For further information contact:

Tel: $\quad$ (44) 2076792839

Email:_h.higgins@ucl.ac.uk

Contact: Ms Helen Higgins

\section{Sir John Salmond Scholarship for Students from Australia and New Zealand}

Subjects: Law

Purpose: To financially support prospective LLM students

Eligibility: Applicants must be overseas students from Australia and New Zealand. An applicant must have accepted an offer (either conditional or unconditional) to read for the LLM at UCL to be eligible

Level of Study: Postgraduate

Type: Scholarship

Value: UK£2,000

Frequency: Annual

Study Establishment: University College London

Country of Study: United Kingdom 
Application Procedure: There is no application

Closing Date: Refer website

Additional Information: The scholarships will be based on academic merit. The faculty will only consider these applicants who have firmly accepted their offer of admission to the LLM by May 31st

\section{For further information contact:}

Tel:

$$
\text { (44) } 2076791441
$$

Fax: (44) 2072093470

Email:_jane.ha@ucl.ac.uk

Contact: The Graduate Officer

\section{Sully Scholarship}

Subjects: Psychology

Purpose: To financially support MPhil/PhD research

Eligibility: Open to the most outstanding candidate in the second year of their $\mathrm{PhD}$ research programme

Level of Study: Doctorate, Postgraduate, Research

Type: Scholarship

Value: $£ 2,200$

Frequency: Annual

Study Establishment: University College London

Country of Study: United Kingdom

Application Procedure: There is no separate application and the award is given to an outstanding student who is registered in the department's $\mathrm{PhD}$ programme and is in the second year of study

Closing Date: Refer website

No. of awards given last year: 1

\section{For further information contact:}

Tel: $\quad$ (44) 2076795332

Fax: (44) 2074304276

Email: psychology-pg-enquiries@ucl.ac.uk

Contact: Head of the Department

\section{Teaching Assistantships (Economics)}

Subjects: Economics

Purpose: To financially support MPhil/PhD students

Eligibility: MPhil/PhD students who have successfully completed their 1st year in the department

Level of Study: Doctorate

Type: Assistantship

Value: UK£11,000

Frequency: Annual

Study Establishment: University College London
Country of Study: United Kingdom

Application Procedure: Contact the Department of Economics for details

Closing Date: Refer website

\section{For further information contact:}

Email: d.fauvrelle@ucl.ac.uk

\section{Thames and Hudson Scholarship}

Subjects: Comparative art and archaeology

Purpose: To financially support postgraduate study

Level of Study: Postgraduate

Type: Scholarship

Value: A scholarship up to a maximum value of $£ 15,000$ or up to 4 scholarships totalling that value

Frequency: Annual

Study Establishment: University College London

Country of Study: United Kingdom

Application Procedure: Applicants must contact the department for details

Closing Date: Mid-July, check the department website

\section{For further information contact:}

Tel: $\quad$ (44) 2076797495

Fax: (44) 2073832572

Email: k.thomas@ucl.ac.uk

Contact: Professor Ken Thomas

\section{The George Melhuish Postgraduate Scholarship}

Subjects: Philosophy

Purpose: To financially support postgraduate research

Eligibility: Open to United Kingdom, European Union and overseas applicants

Level of Study: Postgraduate, Research

Type: Scholarship

Value: Up to $£ 3,700$

Frequency: Annual

Study Establishment: University College London

Country of Study: United Kingdom

Application Procedure: No separate application is required. Applicants who are admitted to research programmes in philosophy will automatically be considered for the scholarship. Any queries should be directed to the department

No. of awards given last year: 2

Additional Information: Decision regarding this award will be made in September 
For further information contact:

Tel: $\quad$ (44) 2076794451

Email: r.madden@ucl.ac.uk

Contact: Dr Rory Madden

\section{The Lloyd's Register Scholarship for Marine Engineering and Naval Architecture}

Subjects: Marine engineering and naval architecture

Purpose: To financially support an MSc in marine engineering or naval architecture

Eligibility: Any country students are eligible to apply. All students must apply in writing. Consideration will be given to those with low financial means

Level of Study: Postgraduate

Type: Scholarship

Value: $£ 10,000$

Frequency: Annual

Study Establishment: University College London

Country of Study: United Kingdom

Application Procedure: Applicants should write indicating their interest in being considered for this scholarship to the department

Closing Date: 1 June

Funding: Commercial

Contributor: Lloyd's Register

No. of awards given last year: 1

Additional Information: Only one award is currently available

For further information contact:

Tel: $\quad$ (44) 2076793907

Fax: (44) 2073880180

Email: info@meng.ucl.ac.uk

Contact: The Graduate Tutor

\section{The Professor John Scales Award in Biomedical Engineering}

Subjects: Response of the body to implants or aspects of bioengineering of joint replacement

Purpose: To financially support postgraduate study

Eligibility: Applicants should hold a First or Upper Second Class (Honours) Degree in engineering, material science or biology

Level of Study: Postgraduate

Type: Scholarship

Value: $£ 6,500$
Length of Study: 3 years

Frequency: Every 3 years

Study Establishment: University College London

Country of Study: United Kingdom

Application Procedure: Applicants should send a curriculum vitae along with a covering letter to the address given below

Funding: Private

Additional Information: Overseas students would have to pay their own fees

For further information contact:

Tel: $\quad$ (44) 2089540636

Email: a.bartram@ucl.ac.uk

Contact: Mrs A Bartrum, Secretary to Professor Bluwn

\section{University College London Department Awards for Graduate Students}

Subjects: Phonetics and linguistics

Purpose: To financially support Master's and MPhil/ $\mathrm{PhD}$ programmes

Eligibility: United Kingdom, European Union and overseas students are eligible to apply

Level of Study: Doctorate, Postgraduate

Type: Scholarship

Value: $£ 500$

Frequency: Annual

Study Establishment: University College London

Country of Study: United Kingdom

Application Procedure: Applicants must contact the department

Closing Date: 15 May

For further information contact:

Tel: $\quad$ (44) 2076793262

Fax: (44) 2073834108

Email: $\quad$ s.anyadi@ling.ucl.ac.uk

Contact: Ms Stefanie Anyadi

\section{University College London-AET Undergraduate International Outreach Bursaries}

Eligibility: Applicants must be a national of any African country (including Madagascar), currently living in an African country, and have one or both parents living in an African country, or are orphaned 


\section{For further information contact:}

Email: m.omona@africaeducationaltrust.org

Contact: Ms May Omona

\section{University College of London Hong Kong Alumni Scholarships}

Purpose: To provide financial aid for studies at UCL

Eligibility: (1) Applicants must be holders of Hong Kong Permanent Identity Cards or Chinese citizens who have received full-time education in Hong Kong and/or China for no less than 5 of the 8 years immediately prior to the start of study at UCL. (2) Applicants must hold an offer of admission to full-time undergraduate study at UCL - in any area except Medicine - which they have firmly accepted or intend to do so. (3) Applicants must be self-financing and liable to pay tuition fees at the rate for overseas students. (4) Applicants should be in financial need and unable to fund their planned studies at UCL without financial help

Type: Scholarship

Value: Up to $£ 10,000$ towards tuition fees for a maximum of 4 years

Frequency: Annual

Study Establishment: United College London

Country of Study: United Kingdom

No. of awards offered: 13

Application Procedure: Completed UG HK application form should be submitted along with required documentation as detailed in the form to UCL Scholarships

Closing Date: 10 April

Funding: Foundation

No. of awards given last year: 1

No. of applicants last year: 13

Additional Information: Interviews will be held in Hong Kong and applicants invited for interview will be required to present themselves for interview in Hong Kong at applicants' own expense

\section{For further information contact:}

Tel: $\quad$ (44) 2076790004

Email: studentfunding@ucl.ac.uk

\section{William Blake Trust Bursary}

Subjects: History of British art

Purpose: To financially support postgraduate or MPhil/ $\mathrm{PhD}$ study

Eligibility: Applicants must have applied for a place for graduate study at UCL
Level of Study: Doctorate, Postgraduate

Type: Bursary

Value: $£ 2,000$

Frequency: Annual

Study Establishment: University College London

Country of Study: United Kingdom

Application Procedure: Applicants must contact the department. If the applicants have not already applied to UCL they must complete a graduate application form and enclose it with the scholarship application

Closing Date: 15 May

\section{For further information contact:}

Tel: $\quad$ (44) 2076797546

Fax: (44) 2079165939

Email: d.dethloff@ucl.ac.uk

Contact: Ms D Dethloff

\section{William Moore Gorman Graduate Research Scholarship}

Subjects: Economics

Purpose: To financially support students entering the first year of the MPhil/PhD degree in department of Economics

Eligibility: Open to candidates who have applied for a place for graduate study at University College London

Level of Study: Doctorate, Postgraduate

Type: Scholarship

Value: $£ 16,200$

Length of Study: 1 year

Frequency: Annual

Study Establishment: University College London

Country of Study: United Kingdom

Application Procedure: Students must indicate why they wish to be considered for this scholarship on their admission application form (section 26)

Closing Date: Refer website

No. of awards given last year: 9

Additional Information: The scholarship will be awarded to students who are not already receiving full financial support from other sources for fees and living costs, and will be, awarded on the basis of academic merit

\section{For further information contact:}

Tel: $\quad$ (44) 2076795861

Fax: (44) 2079162775

Email: d.fauvrelle@ucl.ac.uk

Contact: Ms Daniella Fauvrelle 


\section{University Commission for \\ Development Academy of Research and Higher Education Scholarships}

Rue Royale 180, BEL 1000 Brussels, Belgium

Website: www.ares-ac.be/en/cooperation-au-developpem ent/bourses/masters-et-stages-en-belgique

Contact: ARES

\section{Academy of Research and Higher Education Scholarships}

Subjects: Aquaculture, health, food technology, economics, international development, GIS, information technology, agriculture, environment, human rights, microfinance

Level of Study: Postgraduate

Value: The scholarship covers international travel expenses, living allowance, tuition fees, insurance, housing allowance

Country of Study: Any country

Application Procedure: To apply for the scholarship, complete the single form scholarship application and admission to one of the French-speaking universities of Belgium

Closing Date: 9 February

Additional Information: The scholarships are for nationals of: Benin, Bolivia, Burkina Faso, Burundi, Cambodia, Cameroon, Cuba, Ecuador, Ethiopia (only for courses in English), Haiti, Madagascar, Morocco, Niger, Peru, Philippines, DR Congo, Rwanda, Senegal, Vietnam. For more details, please visit official scholarship website: www.ares-ac.be/en/cooperationau-developpement/bourses/masters-et-stages-en-belgique

\section{For further information contact:}

Email: scholarships-cooperation@ares-ac.be

\section{University Institute of European Studies}

Via Maria Vittoria 26, ITA-10123 Turin, Italy

Tel: $\quad$ (39) 118394660

Fax: (39) 118394664

Email: info@iuse.it

Website: www.iuse.it

Contact: Ms Maria Grazia Goiettina, Course Secretariat
The University Institute of European Studies promotes international relations and European integration by organizing academic activities. The Institute has a comprehensive library in international law and economics. Since 1952 the Institute has been a European Documentation Centre (EDC), thus receiving all official publications of European institutions.

\section{LLM in International Trade Law - Contracts and Dispute Resolution - Scholarships}

Subjects: The main objective of the LLM programme (held in English) is providing fundamental tools and competencies needed to deal with the complex reality of international commercial transactions from a European and an international perspective and in particular with respect to: contracts' drafting, interpretation and management of international commercial contracts, international dispute resolution, arbitration and Moot Court

Eligibility: Applicants must have successfully completed a first level university degree of at least 3 years' duration, either in law, economics, political sciences, business administration or equivalent

Level of Study: Postgraduate

Funding: Government, Private, Foundation, Individuals

\section{For further information contact:}

Tel: $\quad$ (39) 116936945

Fax: (39) 116936369

Email: tradelaw@itcilo.org

Contact: Course Secretariat

\section{University of Aarhus}

Nordre Ringgade 1, Bygning 327 3, DNK 8000 Aarhus, Denmark

Tel: $\quad$ (45) 89421111

Fax: (45) 89421540

Email: au@au.dk

Website: www.au.dk

Contact: Faculty of Social Sciences

The University of Aarhus was founded in 1928 as Universitetsundervisningen i Jylland - University Teaching in Jutland in classrooms rented from the Technical College and 
a teaching corps consisting of 1 Professor of philosophy and 4 Readers of Danish, English, German and French. However, today the University has 20,000 students with 5,000 staff.

\section{Doctor of Philosophy Scholarship in Globalisation and International Economics}

Subjects: International economics

Purpose: To enable students to take up research in the related fields

Eligibility: Open to applicants who have a Master's degree or to students who expect to obtain their Master's degree in the near future

Level of Study: Postgraduate, Research

Type: Scholarship

Value: Approx. salary of $€ 2,700$

Length of Study: 3 years

Frequency: Annual

Study Establishment: Aarhus School of Business

Country of Study: Denmark

Application Procedure: Application forms can be downloaded from the Aarhus website. The form should be sent with a curriculum vitae and an outline of a research project including a description of the proposed theory and methods

Closing Date: 19 February

Contributor: Danish Social Science Research Council

\section{For further information contact:}

Tel: (45) $89486482 / 392$

Email: pje@asb.dk

Contact: Peter Jensen, Head of Department

\section{University of Aarhus PhD Scholarships}

Subjects: Psychology

Purpose: To provide financial support and encourage research work

Eligibility: Open to candidates who have obtained a Danish university Master's degree or an examination at an equivalent level

Level of Study: Doctorate

Type: Scholarship

Value: US $\$ 42,000$; US $\$ 44,000$ per year

Length of Study: 3 years

Frequency: Annual

Country of Study: Denmark
Application Procedure: Applicants may download the application form from the website. The completed application form along with project description, plan for the course, budget and copy of degree certificate(s) must be submitted

Closing Date: 16 June

Additional Information: Further information may be obtained from Administrator Henrik Friis Bach, The Faculty of Social Sciences Secretariat, Tel: 89421546

\section{For further information contact:}

Email: socialsciences@au.dk

\section{University of Aberdeen}

University Office, King's College, AB24 3FX, Aberdeen, United Kingdom

Tel:

(44) 1224273506

Fax: (44) 1224272041

Email:_ ptgoff@abdn.ac.uk

Website: www.abdn.ac.uk

Contact: The Postgraduate Registry

The University of Aberdeen is the fifth oldest in the United Kingdom. Aberdeen is an international university serving one of the most dynamic regions of Europe with over 13,000 students and over 3,000 staff, and is at the forefront of teaching and research in medicine and the humanities and sciences.

\section{Aberdeen International Masters Scholarship}

Value: $£ 2,000$ tuition fee discount Country of Study: United Kingdom

Application Procedure: You do not need to apply for this scholarship. Once you have applied and been given a conditional or unconditional offer of admissions for an eligible Masters programme, you will automatically receive an email from the Vice Principal forInternationalisation to advise you that you have been offered the scholarship with instructions on how to accept the scholarship

Additional Information: Students cannot receive a cash alternative for scholarship 


\section{For further information contact:}

Email: admin@scholarship-positions.com

\section{Arts Humanities Research Council Collaborative Doctoral Partnership PhD studentship}

Subjects: Applications are welcome from non-Higher Education Institutions (non-HEIs) Organisations located within the United Kingdom. These can be any type of organisation which has the research capacity to 'host' a doctoral student

Purpose: The Collaborative Doctoral Partnership scheme gives non-higher education institutions with a proven track record in postgraduate research the opportunity to manage PhD students, with a minimum of three studentships per year Eligibility: 1. Applications are welcome from non-Higher Education Institutions (non-HEIs) Organisations located within the United Kingdom. These can be any type of organisation which has the research capacity to 'host' a doctoral student. 2. Smaller non-HEI Organisations may wish to submit a joint application as a consortium. If successful, the consortium would be the Collaborative Doctoral Partner with the AHRC. Organisations applying as a consortium should ensure that there is a clear strategic rationale for holding a single allocation between them

Value: The value for the stipend is $£ 14,777$ per annum plus a $£ 550$ additional stipend payment. In addition, the National Library of Scotland will provide up to $£ 1,000$ per year to contribute towards travel and related research costs

Length of Study: 3 years

Country of Study: Any country

Application Procedure: You could use the website link : www.ahrc-cdp.org. Visit the official link www.ahrc.ac.uk for further inquiry

Closing Date: 13 September

\section{For further information contact:}

Email: Lucie.Connors@ahrc.ukri.org

\section{China Scholarship Council (CSC) Scholarship}

Purpose: The CSC Scholarship is a scholarship programme for Chinese $\mathrm{PhD}$ students, who will take a full $\mathrm{PhD}$ at the University of Aberdeen

Eligibility: 1. To be eligible to apply for this scholarship in China, candidates must submit with their application, a conditional scholarship offer letter from Curtin University. 2. To ensure interested candidates meet the China Scholarship Council application deadline in March each year, Curtin University strongly encourage students submit their online e-application for admissions latest by 31 January of the applying year to avoid missing the deadline. 3. Scholarship Recipients must hold a conditional offer of enrolment subject to the CSC award and also fulfil the entry requirements of Curtin University, including a high level of English language proficiency

Type: Scholarship

Country of Study: Any country

Application Procedure: Applications for the CSC Scholarship should be submitted online at: apply.csc.edu.cn/csc/ main/person/login/index.jsf. Please consult the CSC website for the deadline

Additional Information: If you have any further questions, please contact Catriona Milne, International Officer for China, via email: catriona.milne@abdn.ac.uk

For further information contact:

Email: catriona.milne@abdn.ac.uk

\section{Common Data Access MSc Petroleum Data Management Scholarships}

Purpose: To pursue MSc programme

Value: Each scholarship is valued at $£ 5,000$ for the duration of the MSc Petroleum Data Management degree and will contribute towards the programme tuition fees

Country of Study: Any country

Closing Date: 31 May

For further information contact:

Email: info@cdal.com

\section{Elphinstone PhD Scholarships}

Subjects: Arts and humanities, social sciences, business management, life sciences and medicine natural sciences and physical sciences

Type: Scholarship

Value: Cover tuition fees for the duration of their supervised study

Country of Study: Any country

For further information contact:

Email: infohub@abdn.ac.uk

\section{Principal}

Subjects: Music

Level of Study: Unrestricted 
Type: Scholarship

Study Establishment: University of Aberdeen

Country of Study: United Kingdom

For further information contact:

Email: studentfunding@ed.ac.uk

\section{University of Adelaide}

Graduate School of Management, 3rd Floor Security House, 233 North Terrace, Adelaide, SA 5005, Australia

$\begin{array}{ll}\text { Tel: } & (61) 83035525 \\ \text { Fax: } & (61) 882234782 \\ \text { Email: } & \text { cmchugh@gsm.adelaide.edu.au } \\ \text { Website: } & \text { www.gsm.adelaide.edu.au } \\ \text { Contact: } & \text { MBA Admissions Officer }\end{array}$

\section{Adelaide Postgraduate Coursework Scholarships}

Subjects: All subjects

Eligibility: Open only to the citizens of Australia or permanent residents who have achieved Honours 1 or equivalent

Level of Study: Postgraduate

Type: Scholarship

Value: Covers $50 \%$ of the tuition fee costs

Length of Study: 2 years

Frequency: Annual

Study Establishment: University of Adelaide

Country of Study: Australia

Application Procedure: Applicants must apply directly to the scholarship provider. Check website for further details

Closing Date: Varies

\section{For further information contact:}

Adelaide Graduate Centre, Adelaide University, Adelaide, SA 5005, Australia

Tel: $\quad$ (61) 883134455

Fax: $\quad$ (61) 882233394

Email: adrienne.gorringe@adelaide.edu.au

\section{Adelaide Scholarships International}

Subjects: All subjects

Purpose: To attract high quality overseas postgraduate students to areas of research strength in the University of Adelaide to support its research effort
Eligibility: Open only to the citizens of Australia or permanent residents who have achieved Honours 1 or equivalent

Level of Study: Postgraduate

Type: Scholarships

Value: For Postgraduate Research (Subclass 574) visa holders the award provides compulsory standard Overseas Student Health Cover (OSHC) Worldcare policy for the student and their spouse and dependents (if any) for the standard duration of the student visa. It does not cover the additional 6 month extended student visa period post thesis submission. If the award holder does not hold a subclass 574 visa then he/she is responsible for the cost of health insurance

Length of Study: 2 years (Masters) or 3 years $(\mathrm{PhD})$

Frequency: Annual

Study Establishment: University of Adelaide

Country of Study: Australia

Application Procedure: Candidates must apply directly to the university. Check the website for further details

Closing Date: 30 June and 30 November

Contributor: Adelaide University

\section{For further information contact:}

Email: student.centre@adelaide.edu.au

\section{Arts Start Up Scholarships at University of Adelaide in Australia}

Subjects: Scholarships are awarded within the Faculty of Arts

Purpose: The Faculty of Arts at the University of Adelaide is inviting applications for Arts Start Up Scholarships. The scholarships are available to international students from India, Sri Lanka, Vietnam, Indonesia, Malaysia, United Kingdom and Hong Kong who are seeking entry into a Faculty of Arts postgraduate coursework program

Eligibility: Citizens of India, Sri Lanka, Vietnam, Indonesia, United Kingdom, Malaysia and Hong Kong are eligible to apply. If English is not your first language then you will need to show that your English language skills are at a high enough level to succeed in your studies

Type: Postgraduate scholarships

Value: The scholarship provides a one-off $\mathrm{A} \$ 4,000$ payment for travel and living expenses. The scholarship will be paid to the recipient following confirmation of enrolment after the census date for the semester they commenced in

Study Establishment: Scholarships are awarded within the Faculty of Arts

Country of Study: Australia

Application Procedure: When offered admission to The University of Adelaide, you will need to accept the offer 
within 20 business days. This will automatically be your application for the scholarship

Closing Date: Open

Additional Information: Please check the website for more details scholarship-positions.com/arts-start-scholarshipsuniversity-adelaide-australia/2018/02/06/

\section{For further information contact:}

Email: admin@scholarship-positions.com

\section{Asia Pacific Institute of Information Technology) _IT PhDs in Grid Computing}

Subjects: High performance and grid computing

Purpose: To enable high performance numerical computing on service-oriented architectures

Eligibility: Open only to the citizens of Australia and New Zealand or permanent residents who have achieved Honours 2a or equivalent

Level of Study: Postgraduate

Type: Scholarship

Value: A $\$ 24,650$ per year

Length of Study: 3 years and 6 months

Frequency: Annual

Study Establishment: The Australian National University, The University of Adelaide

Country of Study: Australia

Application Procedure: Check website for further details Closing Date: 21 September

Contributor: Adelaide University and The Australian National University

\section{For further information contact:}

Email: Peter.Strazdins@cs.anu.edu.au

Contact: Peter Strazdins

\section{Australian Building Codes Board Research Scholarship}

Subjects: Building, building surveying, fire engineering, architecture, construction, plumbing, hydraulic design or similar

Purpose: The ABCB runs the Student Research Scholarship Program to encourage undergraduate and postgraduate research in the field of building regulatory reform in Australia, which can contribute to the $\mathrm{ABCB}$ fulfilling its charter

Eligibility: To be eligible for the scholarship, applicants must be students currently undertaking undergraduate or postgraduate studies in building, building surveying, fire engineering, architecture, construction, plumbing, hydraulic design or similar at an Australian educational institution; and research that forms a component of a program or course at an educational institution (e.g. tertiary), such as a research project, thesis or dissertation

Level of Study: Graduate

Type: Scholarship

Value: Up to A\$5,000 one off payment

Length of Study: 1 year

Country of Study: Australia

Application Procedure: To apply for the scholarship, applicants are asked to submit an ABCB Research Scholarship Application Form together with a resume and academic transcript to date to the Research Scholarship Project Officer at abcb.scholarship@abcb.gov.au

Closing Date: Rolling applications

Additional Information: For more information on the Student Research Scholarship Program, please contact the Research Scholarship Project Officer at abcb. scholarship@abcb.gov.au

\section{For further information contact:}

Email: abcb.scholarship@abcb.gov.au

Contact: Research Scholarship Project Officer

\section{Ferry Scholarship - UniSA}

Subjects: Chemistry and physics

Purpose: To promote study and research into the scientific fields of physics and chemistry

Eligibility: Open only to the citizens of Australia below the age of 25 who have achieved Honours 1 or equivalent

Level of Study: Postgraduate

Type: Scholarship

Value: $A \$ 7,500$ per year

Length of Study: 1 year

Frequency: Annual

Study Establishment: Flinders University, The University of Adelaide, University of South Australia

Country of Study: Australia

Application Procedure: Applicants must apply directly to the university. Check the website for further details

Closing Date: 31 March

Funding: Individuals

Contributor: Late Cedric Arnold Seth Ferry

\section{For further information contact:}

Tel: $\quad$ (61) 83023967

Email: jenni.critcher@unisa.edu.au

Contact: Jenni Critcher 


\section{Joint Postgraduate Scholarship Program}

Subjects: High and new technology in agriculture, applied social science and WTO-related areas (e.g. finance), energy sources and environment, engineering, life science and public health, material science and new material, telecommunication and information technology

Eligibility: Open to applicants who are citizens and permanent residents of the People's Republic of China at the time of application; are less than 35 years old at the time of application (this is a CSC eligibility requirement); are a university student completing a master's degree, or enrolled as a first year PhD student, or new graduates from their university at the time of application; agree to return to China upon completion of their studies and/or research; hold an unconditional offer of enrolment at the University of Adelaide, which is subject to the applicant also being successful in applying for a CSC award. They must therefore fulfil the relevant academic entry requirements set by the University of Adelaide for all international scholarship holders, including a high level of English language proficiency; English is the language of instruction at the University of Adelaide and proficiency in speaking, listening to, reading and writing English is essential. The IELTS (International English Language Testing System) is the preferred English language proficiency although TOEFL scores are also accepted. Applicants who have not provided evidence that they have met the university's minimum English Language Proficiency requirements by the closing date are not eligible for a CSC scholarship. CSC applicants are not permitted to undertake Pre-Enrolment English programs as the CSC will not award scholarships to applicants who have not met the university's minimum ELP requirements for direct entry. The Scholarships will give priority to graduates of the Chinese universities listed as "985 Project" Universities. Eligible candidates will be assessed by the University of Melbourne and Karlsruhe Institute of Technology on the basis of their academic transcripts and their research work

Type: Scholarship

Value: Australia

Country of Study: Any country

Application Procedure: The mode of applying is electronically. For detailed information, please visit website

Closing Date: 31 March

Contributor: The China Scholarship Council (CSC) and The University of Adelaide (UA)

Additional Information: The students of China can apply for these scholarships

\section{Scholarships in Plant Cell Physiology}

Subjects: Plant cell physiology
Purpose: To improve the nutritional qualities of crop plants allowing the fortification of animal and human diets without adversely affecting crop plant

Eligibility: Open only to the citizens of Australia who have achieved Honours 1 or equivalent, or Honours $2 \mathrm{a}$ or equivalent

Level of Study: Postgraduate

Type: Scholarship

Value: $A \$ 27,500$ per year

Length of Study: 3 years

Frequency: Annual

Study Establishment: The University of Adelaide

Country of Study: Australia

Application Procedure: Applicants must apply directly to the university. Check website for further details

Closing Date: 31 August

Contributor: Adelaide University

\section{For further information contact:}

Tel: $\quad$ (61) 883038145

Email: matthew.gillam@adelaide.edu.au

Contact: Dr Matthew Gillam

\section{University of Alaska Fairbanks (UAF)}

School of Management PO Box 756080, Fairbanks, AK 99775-6080, United States of America

Tel: $\quad$ (1) 9074746511

Fax: (1) 9074745219

Email: famba@som.uaf.edu

Website: www.uaf.edu/som/mba

Contact: MBA Admissions Officer

\section{Rasmuson Fisheries Research Center Fellowships}

Subjects: The Rasmuson Fisheries Research Center (RFRC) was founded in 1994 by Elmer E. Rasmuson with an endowment to the University of Alaska Fairbanks

Purpose: This fellowship is especially interested in seeing proposals on applied topics aligned with the research priorities and needs of the North Pacific Fishery Management Council [PDF]

Eligibility: 1 . Awards will be made to support excellence in graduate student research. The award is not a Research Assistantship, but a Fellowship in recognition of scholastic excellence. Awards are open to any full-time or 
prospective CFOS graduate student. 2. Research should produce findings with a potential for continued development as a scientific or applied initiative. 3. Projects should be distinctive and make an original contribution to existing knowledge. 4. Projects should have potential economic value to the fishing industry and contribute to long-term benefits for Alaska. 5. Awards may be contingent on receipt of research funding from other sources. The award cannot be used for research expenses. See item \#6, "Current and Pending," under "Format of Proposals" below. 6. Proposals should be submitted by the graduate student with faculty advisor endorsement as described in item $\# 8$ below. 7. Awards are renewable. Master's students can be funded for a maximum of two (2) years and $\mathrm{PhD}$ students for a maximum of three (3) years. Continuation requests require a satisfactory progress report

Level of Study: Postgraduate

Type: Fellowship

Value: Fellowship award of $\$ 35,000$

Frequency: Annual

Country of Study: Any country

Application Procedure: Complete format of proposals are available in the below link. www.uaf.edu/cfos/research/majorresearch-programs/rasmuson-fisheries-resear/rfrc-fellowships/

Closing Date: 25 January

Funding: Private

\section{For further information contact:}

Tel: $\quad$ (1) 9074742619

Email: clsutton3@alaska.edu

\section{University of Alberta}

Faculty of Graduate Studies \& Research, Killam Centre for Advanced Studies, 2-29 Triffo Hall, University of Alberta, Edmonton, AB T6G 2E1, Canada

Tel: $\quad$ (1) 7804923499

Fax: (1) 7804920692

Email: grad.services@ualberta.ca

Website: www.ualberta.ca/gradstudies

Opened in 1908, the University of Alberta has a long tradition of scholarly achievements and commitment to excellence in teaching, research and service to the community. It is one of Canada's five largest research-intensive universities, with an annual research income from external sources of more than $C \$ 3,00,000,000$. It participates in 18 of 21 of the Federal Networks of Centres of Excellence, which link industries, universities and governments in applied research and development.

\section{Canadian Initiatives For Nordic Studies (CINS) Graduate Scholarship}

Subjects: Fine arts, humanities, natural, physical, applied and social sciences and more

Purpose: To provide financial assistance to students who wish to pursue higher studies

Eligibility: Open to Canadian citizens or landed immigrants, who have completed a Bachelor's degree from a Canadian university or college with high scholastic achievement. Applicants must be in residency at the Nordic destination for a minimum of 6 months and provide a written report to CINS no later than 6 months after completing the proposed programme of study

Level of Study: Postgraduate

Type: Scholarship

Value: C $\$ 5,000$

Frequency: Annual

Application Procedure: Applicants should include the following in their application: contact details, citizenship status, social insurance number and date of birth, current academic status with formal transcripts, written acceptance from the host Nordic institution and reference letters

Closing Date: 15 February

Additional Information: Applicants can study at any recognized institution granting earned degrees at the postbaccalaureate level in the applicant's field of study and located in one of the Nordic countries: Denmark, Finland, Iceland, Norway, Sweden, the Faroe Islands and Greenland

\section{For further information contact:}

Tel: $\quad$ (1) 7804923111

Email: chale@ualberta.ca

Contact: Chair of the Board

\section{Izaak Walton Killam Memorial Scholarship}

Purpose: It will be offered to outstanding students registered in, or admissible to, a doctoral program. No restrictions on citizenship

Eligibility: Offered to outstanding students registered in, or admissible to, a doctoral program. No restrictions on citizenship. All fields are eligible for funding. Applicants must have completed at least one year of graduate work (master's or doctoral level) before start of tenure; tenure may begin on May 1st or September 1st. Additional information regarding eligibility criteria can be found in the Applicant 
Instructions document below. Please note that the GPA is calculated over the current graduate program graded course work

Level of Study: Graduate

Type: Scholarship

Value: $\mathrm{C} \$ 35,000$

Length of Study: 2 years

Frequency: Annual

Country of Study: Any country

Application Procedure: Students complete the Izaak Walton Killam Memorial Scholarship application form and submit supporting documents to their department to be considered for both the Izaak Walton Killam Memorial Scholarship and the Dorothy J Killam Memorial Graduate Prizes. A complete Izaak Walton Killam Memorial Scholarship Application includes: For Applicants: Izaak Walton Killam Memorial Scholarship Applicant Instructions 1. Izaak Walton Killam Memorial Scholarship Application Form. 2. Two Letter of Reference to Support Application for Graduate Awards. 3. Transcripts (copies of official transcripts for all post-secondary study are required to support an application. Your home department may have copies in your department file. If your department does not have these transcripts, you are required to submit new transcripts. Unofficial copies of University of Alberta transcripts are acceptable)

Closing Date: 28 February

Funding: Private

\section{For further information contact:}

Killam Centre for Advanced Studies 2-29 Triffo Hall University of Alberta Edmonton, Alberta T6G 2E1, Canada

Email: gswbsite@ualberta.ca

\section{University of Alberta MBA Programme}

Length of Study: 20 months; 72 months

Application Procedure: Applicants must complete and return the form, with two official academic transcripts, Graduate Management Admission Test scores, three letters of recommendation, a two page statement of intent, a detailed curriculum vitae, an application deposit of C\$60 (US\$45), and a TOEFL score (if applicable) of 550+

Closing Date: 30 April (for part-time)

\section{For further information contact:}

Tel: $\quad$ (1) 7804923946

Fax: (1) 7804927825

Email:_mba.programs@ualberta.ca

Contact: MBA Admissions Officer

\section{University of Amsterdam}

The University of Amsterdam is a public university located in Amsterdam, The Netherlands.

\section{Amsterdam Excellence Scholarships (AES)}

Subjects: Master's Programmes offered at the University of Amsterdam

Purpose: The Amsterdam Excellence Scholarships (AES) awards scholarships to exceptionally talented students from outside Europe to pursue eligible Master's Programmes offered at the University of Amsterdam

Eligibility: Non-European Union students from any discipline who graduated in the top $10 \%$ of their class may apply. Selection is on the basis of academic excellence, ambition and the relevance of the selected Master's programme to a student's future career

Level of Study: Postgraduate

Type: Scholarship

Value: $€ 25,000$ per annum

Length of Study: 1 year

Frequency: Annual

Study Establishment: University of Amsterdam

Country of Study: Netherlands

Application Procedure: Applications are made through the Admissions Offices of the Graduate Schools

Closing Date: 15 January or 01 February

Additional Information: For more details, please visit official scholarship website: www.uva.nl/en/education/masters/scholarships-tuition/scholarships-and-loans/amsterdamexcellence-scholarship/amsterdam-excellence-scholarship.html

\section{For further information contact:}

P.O. Box 19268, NLD 1000 GG Amsterdam, The Netherlands

Email: servicedesk-ac@uva.nl

\section{Amsterdam Science Talent Scholarship (ASTS)}

Subjects: Science

Purpose: Scholarship is available for pursuing the masters degree programme at the University of Amsterdam

Eligibility: Non-Dutch talented students from the European Union / European Economic Area can apply

Value: $€ 12,500$ (covering tuition and living expenses)

Length of Study: 2 years

Country of Study: Any country 
Application Procedure: Check the entry requirements of your programme under 'Application and admission'. Overview of Science Master's Programmes. Register in Studielink (on the same page) Submit your application online after receiving your UvA-net ID (this can take up to 48 hours)

Closing Date: 1 March

Additional Information: For more details, please visit the website scholarship-positions.com/fully-funded-science-talentscholarship-university-amsterdam-netherlands

\section{For further information contact:}

Email: master-science@uva.nl

\section{MacGillavry Fellowships}

Subjects: Astronomy, Informatics and Logic, Biological Science and Biomedical Science, Earth Sciences (Physical Geography), Physics, Chemistry, Mathematics, and Statistic

Purpose: These fellowships are available in the field of Biological Science and Biomedical Science, Earth Sciences (Physical Geography), Informatics and Logic, Physics, Chemistry, Astronomy, Mathematics, and Statistics

Eligibility: Eligibility for the Scholarship: 1 . A PhD degree in one of the scientific disciplines of their Faculty. 2. A scientific profile that links to one of the research fields eligible for application. 3. A publication record in international, high quality, peer-reviewed journals. 4. A few years of postdoctoral experience, preferably at the international level. 5. Welldeveloped organizational and communication skills. 6. Affinity for teaching at the undergraduate and graduate level

Level of Study: Postgraduate

Type: Fellowship

Value: The annual salary range for an assistant professor, including annual holiday allowance and the bonus is between $€ 50,755$ and $€ 78,935$ (before tax), depending on experience and past performance

Frequency: Annual

Country of Study: Any country

Application Procedure: To apply for the MacGillavry Fellowship you are invited to use the application form on the MacGillavry website of the Faculty of Science. www. uva.nl/en/faculty/faculty-of-science/macgillavry-fellowship/ macgillavry-fellowship.html

Closing Date: 4 February

Funding: Private

\section{For further information contact:}

Email: servicedesk-icts@uva.nl

\section{University of Auckland}

Private Bag 92019, Auckland 1000, New Zealand

Tel: $\quad$ (64) 93737599

Fax: (64) 93737437

Email: appointments@auckland.ac.nz

Website: www.auckland.ac.nz

Contact: $\quad$ Ms S Codhersides, HR Manager

The University of Auckland is committed to conserving, advancing and disseminating knowledge of the highest standard through teaching by scholars who are among the foremost researchers in New Zealand. The University aims to be of high international standing and to contribute to the advancement of knowledge to its local, national and international communities.

\section{Anne Bellam Scholarship}

Subjects: Music

Purpose: To assist students to further their musical education overseas

Eligibility: The candidate must be under 30 years of age and a citizen of New Zealand, must have completed or will complete in the year of application any degree or diploma in performance or any postgraduate music degree at the University of Auckland

Level of Study: Postgraduate

Type: Scholarship

Value: Up to NZ\$30,000 for study overseas and up to $\$ 10,000$ for study at the University of Auckland

Length of Study: 1 year

Frequency: Annual

Study Establishment: University of Auckland

Country of Study: New Zealand

Application Procedure: The candidate must supply, one week in advance of examination, an outline of his proposed study plans and itinerary

Closing Date: Please check website

Funding: Government

\section{For further information contact:}

Faculty of Creative Arts and Industries, School of Music, University of Auckland, Private Bag 92019, Auckland 1000, New Zealand

Email: scholarships@auckland.ac.nz 


\section{Arthington Davy Scholarship}

Subjects: All subjects

Purpose: To study and research in areas which will significantly contribute to the development of Tonga

Eligibility: The candidate must be a Tongan citizen, born to Tongan parents and possess a first University degree

Level of Study: Research

Type: Scholarship

Value: The Arthington Davy Scholarship may cover the cost of part of the cost of a postgraduate study or research programme

Study Establishment: Trinity College

Country of Study: United Kingdom

Application Procedure: The candidate must submit a complete curriculum vitae and academic record, proof of Tongan origin, details of the intended postgraduate study preferably with a letter of conditional acceptance from the University concerned, full details of tuition fees and living expenses and of finances available from the student's own resources or elsewhere and the names of two academic referees

Closing Date: 30 November (for course commencing in March or April), 31 May (for course commencing in September or October)

Funding: Commercial, Private, Foundation, Individuals

\section{For further information contact:}

Email: hf202@hermes.cam.ac.uk

Contact: Tutor for Advanced Studies

\section{Asian Development Bank Japan Scholarship}

Subjects: Environmental science, development studies, international business and engineering

Eligibility: The candidate must possess a minimum English language requirement for entry into postgraduate study at the University of Auckland. IELTS with an overall score of 6.5 and no band less than 6.0 or a TOEFL paper-based 575 with a TWE of 4.5 or computer-based 233 with a TWE of 4.5

Level of Study: Postgraduate

Type: Scholarship

Value: Tuition fee at the University of Auckland, Airfare from his or her home country to Auckland, New Zealand, Basic cost of living in Auckland, Health and medical insurance in New Zealand, and Airfare from Auckland, New Zealand, to the scholar's home country at the conclusion of his or her course of study

Study Establishment: University of Auckland

Country of Study: New Zealand
Application Procedure: Applications can be filled online Closing Date: 20 July(check with website)

Funding: Government, Private

Contributor: Asian Development Bank and Government of Japan

\section{For further information contact:}

Email: information@adbj.org

\section{Auckland Council Research Scholarship in Urban Economics}

Purpose: The purpose of this scholarship is to encourage and support postgraduate research into urban economics that has particular relevance to local government in New Zealand

Eligibility: 1 . At the time of application candidates must be enrolled or planning to enrol in a postgraduate programme at a New Zealand university (applicants may be enrolled as full time students). 2 . The postgraduate programme must be in the area of urban economics. Universities NZ and Auckland Council reserve the right to determine the eligibility of a particular area of study. 3. A thesis, dissertation, or research report must be a requirement of the postgraduate programme Level of Study: Graduate, Postgraduate

Type: Scholarship

Value: NZ \$3,000 or NZ \$1,500

Frequency: Annual

Country of Study: Any country

Application Procedure: Candidates must complete an application using the Universities NZ scholarships application website universitiesnz.communityforce.com/ Each year Auckland Council may grant one scholarship with an award of NZ $\$ 3,000$. For candidates who are enrolled on a part time basis the value of the award will be NZ\$1,500

Closing Date: 1 February

Funding: Private

Additional Information: Application link to fill the basic information is universitiesnz.communityforce.com/Login. aspx

\section{For further information contact:}

Email: scholarships-cf@universitiesnz.ac.nz

\section{Commonwealth Scholarship}

Subjects: All subjects

Purpose: The scholarships are available to students to be enroled at the University of Auckland for the Degree of 
Doctor of Philosophy; another approved Doctorate or a Master's degree

Eligibility: The candidate must be a citizen of Commonwealth of Nations, including Australian, British and Canadian citizens. The candidate must be tenable for a maximum of 36 months for a $\mathrm{PhD}$ candidate or 21 months for a Master's candidate

Level of Study: Doctorate, Postgraduate

Type: Scholarship

Value: Up to NZ $\$ 25,000$ per year plus health insurance and fees at the domestic rate

Study Establishment: University of Auckland

Country of Study: New Zealand

Application Procedure: The candidate must send the application for UA Commonwealth Scholarships must be made through the appropriate organization in the scholar's home country on the Commonwealth Scholarship application form Closing Date: 31 July

Funding: Government

\section{For further information contact:}

Scholarships Office, Student Administration, The University of Auckland, Private Bag 92019, Auckland Mail Centre, Auckland 1142, New Zealand

Tel: $\quad$ (64) 93737599 ext 87494

Fax: (64) 93082309

Email: scholarships@auckland.ac.nz

\section{Doctoral Scholarships}

Subjects: All subjects

Purpose: To assist and encourage students to pursue doctoral studies at The University of Auckland

Eligibility: The candidate must be a citizen or a permanent resident of New Zealand. New Māori and domestic3 Pacific doctoral applicants with a GPA of 7.50 or above, from their most recent qualifying programme, will be guaranteed a scholarship provided the qualifying programme was completed at a New Zealand university

Level of Study: Doctorate

Type: Scholarship

Value: NZ\$27,900 plus fees, with the possibility of a six-month extension. There will be an annual cost-of-living adjustment to the doctoral stipend

Length of Study: 3 years

Frequency: Annual

Study Establishment: University of Auckland

Country of Study: New Zealand

Application Procedure: The candidate must fill the application form and send it to the Scholarships office. The selection will be made on the basis of merit
Closing Date: Varies (refer to relevant faculty)

Funding: Government

\section{For further information contact:}

Email: c.tuu@auckland.ac.nz

Email: scholarships@auckland.ac.nz

\section{Fulbright Scholarship}

Subjects: All subjects

Purpose: To encourage and facilitate study for approved postgraduate degrees at the University of Auckland by candidates already selected to hold Fulbright Awards

Eligibility: The candidate must be a citizen of the United States of America and intending to take up Fulbright Awards to study in New Zealand and should enrol for a full-time at the University of Auckland for an approved Master's or Doctoral degree

Level of Study: Doctorate, Postgraduate

Type: Scholarship

Value: NZ\$15,000 per year plus research/tuition fees

Frequency: Annual

Study Establishment: University of Auckland

Country of Study: New Zealand

Application Procedure: The candidate must send the completed application form to the Scholarships office

Closing Date: Check with the university

Funding: Government

\section{Hope Selwyn Foundation Scholarship}

Purpose: The HOPE Selwyn Foundation is a registered charitable trust established in 1996 to assist the funding of research and education essential to the health and welfare of older people in New Zealand

Eligibility: 1. The purpose of the scholarships is to support or partially support the salaries of young scientists (the definition of "young" being reasonably flexible) who are in the early stages of their careers. 2. Candidates undertaking a Masters or doctoral thesis will be considered for support. Candidates will normally be working under supervision in a recognised research environment with a senior research leader. 3. HOPE Sewlyn Foundation scholarships may be held with any other bursary or award unless the candidate's other awards preclude this

Level of Study: Postgraduate

Type: Scholarship

Value: NZ \$6,000

Length of Study: 4 years

Frequency: Annual

Country of Study: New Zealand 
Closing Date: 31 October

Funding: Foundation

\section{For further information contact:}

The University of Auckland, Private Bag 92019, Auckland 1142, New Zealand

Email: pc.dasilva@auckland.ac.nz

\section{International College of Auckland PhD Scholarship in Plant Sciences}

Subjects: Plant Science

Purpose: To assist eminent Chinese scholars from nominated areas of China to study plant sciences at the University of Auckland and to promote links between China and New Zealand in the field of plant sciences

Eligibility: The candidate must possess a $\mathrm{PhD}$ in the field of plant science and who has paid the fees, or arranged to pay the fees, for full-time enrolment in the School of Biological Sciences

Level of Study: Postdoctorate

Type: Scholarship

Value: NZ\$20,000 per year. The scholarship's emolument will be paid as a tuition/compulsory fees credit and the balance as a fortnightly stipend

Length of Study: 3 years

Frequency: Annual

Study Establishment: University of Auckland

Country of Study: New Zealand

Application Procedure: The candidate must submit the completed application form along with the curriculum vitae and at least two academic reference letters

Closing Date: 1 October

Funding: Government

Contributor: The International College of Auckland

\section{For further information contact:}

Email: scholarships@auckland.ac.nz

\section{Maori and Pacific Graduate Scholarships (Masters/ Honours/PGDIP)}

Subjects: All subjects

Purpose: To assist and encourage Maori and Pacific students to pursue Masters, Honours and PGDip courses at The University of Auckland

Eligibility: The candidate must be a Maori or Pacific student who are citizens or permanent residents of New Zealand

Level of Study: Graduate, Postgraduate
Type: Scholarship

Value: Up to $\$ 10,000$ plus compulsory fees

Length of Study: 1 year

Frequency: Annual

Study Establishment: University of Auckland

Country of Study: New Zealand

Application Procedure: The candidate must fill up the application form and send it to the Scholarships office. The Selection Committee will assess the application form

Closing Date: Please check website

Funding: Government

\section{Masters/Honours/PGDIP Scholarships}

\section{Subjects: All subjects}

Eligibility: The candidate must be a citizen or a permanent resident of New Zealand. In case of a Master's degree, the candidate must be tenable until the date for completion of the requirements for the degree as specified in the General Regulations - Masters degrees

Level of Study: Graduate, Postgraduate

Type: Scholarship

Value: Up to NZ\$10,000 per year plus compulsory fees

Length of Study: 1 year

Frequency: Annual

Study Establishment: University of Auckland

Country of Study: New Zealand

Application Procedure: The candidate must fill the application form and send it to the Scholarships office. Selection will be made on the basis of merit

Closing Date: 1 November

Funding: Government

\section{New Zealand Agency for International Development Scholarship (NZDS) - Open Category}

Subjects: All subjects

Eligibility: The candidate must possess minimum English language requirements for entry into the University of Auckland postgraduate study. IELTS (International English Language Testing System Certificate) with an overall score of 6.5 and no band less than 6.0 or a TOEFL (Test of English as a Foreign Language) paper based 575 with a TWE of 4.5 or computer based 233

Level of Study: Postgraduate

Type: Scholarship

Value: Tuition, enrollment/orientation fees, return economy fare travel, medical insurance and provision for students to meet course and basic living costs

Study Establishment: University of Auckland

Country of Study: New Zealand 
Application Procedure: Application form can be downloaded from the website

Closing Date: 1 June

Funding: Government

Contributor: New Zealand Agency for International Development and the Ministry of Foreign Affairs

For further information contact:

Tel: (64) 93737599 ext 87556

Fax: (64) 93737405

Email: rfatialofa.patolo@auckland.ac.nz

\section{New Zealand International Doctoral Research (NZIDRS) Scholarship}

Subjects: All subjects

Purpose: To provide financial support for postgraduate students from designated countries seeking doctoral degrees by research in New Zealand universities

Eligibility: The candidate must hold an A' average or equivalent in their studies, meet the requirements for entry into a research-based doctoral degree programme at a New Zealand university

Level of Study: Doctorate, Research

Type: Research scholarship

Value: Living allowance (NZ $\$ 25,000$ per year), a travel allowance (NZ \$2,000), a health insurance allowance (NZ \$500), and a book and thesis allowance (NZ \$800)

Length of Study: 3 years

Study Establishment: University of Auckland

Country of Study: New Zealand

Application Procedure: The candidate must complete the application form in English and attach supporting documents as stipulated in the application form

Closing Date: 16 July

Funding: Government

Contributor: Government of New Zealand

For further information contact:

Tel: $\quad$ (64) 44720788

Fax: (64) 44712828

Email: scholarships@educationnz.org.nz

Contact: Scholarships Manager

\section{Property Institute of New Zealand Postgraduate Scholarship}

Subjects: Real property

Purpose: To promote postgraduate study in the field of real property
Eligibility: The candidate must possess a Master's degree or full-time $\mathrm{PhD}$ candidate and has the paid the fees, or arranged to pay the fees, for study in the Department of Property at Lincoln University, Massey University or The University of Auckland

Level of Study: Doctorate

Type: Scholarship

Value: NZ\$1,500

Length of Study: 1 year

Frequency: Annual

Study Establishment: University of Auckland

Country of Study: New Zealand

Closing Date: 31 March

Funding: Government

Contributor: Property Institute of New Zealand

For further information contact:

Tel: $\quad$ (64) 93737599 ext 87494

Fax: (64) 93082309

Email: scholarships@auckland.ac.nz

\section{Reardon Postgraduate Scholarship in Music}

Subjects: Music

Purpose: To honour and in memory of Daniel Patrick Reardon and Kathleen Mary Reardon

Eligibility: The candidate must possess a degree or diploma with a specialization in Performance in the year of the award Level of Study: Postgraduate

Type: Scholarship

Value: NZ\$4,500

Length of Study: 1 year

Frequency: Annual

Study Establishment: University of Auckland

Country of Study: New Zealand

Closing Date: 30 September

Funding: Government

Contributor: Reardon Memorial Music Trust

\section{Senior Health Research Scholarships}

Subjects: Health

Purpose: To attract health professionals to return to the University to study full-time for a $\mathrm{PhD}$ in a health-related field Eligibility: The candidate must be a citizen or a permanent resident of New Zealand and who have worked for 3 years as a health professional

Level of Study: Doctorate

Value: NZ\$40,000 plus compulsory fees

Length of Study: 3 years 
Frequency: Annual

Study Establishment: University of Auckland

Country of Study: New Zealand

Application Procedure: The candidate must submit an application form and send it to the Scholarships office. Selection shall be made on the basis of merit

Closing Date: 1 November

Funding: Government

\section{The AUT Queen Elizabeth II Diamond Jubilee Doctoral Scholarship}

Purpose: AUT Doctoral Scholarship AUT aims to: Develop an internationally-aware, skilled future leader Establish enduring education and professional linkages

Eligibility: 1 . The scholarship will be awarded annually to a doctoral student who is a citizen, and resident in, one of the following Pacific countries; Cook Islands, Fiji, Kiribati, Nauru, Niue, Papua New Guinea, Samoa, Solomon Islands, Tokelau, Tonga and Vanuatu to carry out doctoral study at AUT University. 2. Applicants must be a citizen and resident of one of the eligible countries. Applicants may not have citizenship or permanent residence status of New Zealand or any other developed country. Applicants who are New Zealand citizens from the Cook Islands, Niue, Tokelau and dual citizens of Samoa are exempt from this requirement; however, they must reside in the Cook Islands, Nuie, Tokelau or Samoa or another eligible country. Preference may be given to those applicants who have also been schooled in an eligible country. 3 . The recipients of this scholarship will have strong academic references plus a strong academic record and/or have demonstrated the potential for quality research. Previous study should include research methodologies papers and an independent research project, including the writing of a report on that research

Level of Study: Postgraduate

Type: Scholarship

Value: NZ\$25,000

Frequency: Annual

Country of Study: Any country

Application Procedure: Application will be via the online scholarship application portal available from the link. It is not possible to submit incomplete scholarship applications through the online application process. In order for the application to be submitted all requested documentation must be included. The following documents or statements must be completed and uploaded in the application portal by the closing date. Incomplete applications will not be forwarded to the selection panel. 1. AUT Queen Elizabeth II Diamond Jubilee Doctoral Scholarship on-line application form. 2. Academic transcript(s) if any previous tertiary study has been completed at a university other than AUT. 3. A certified copy of the applicant's birth certificate or passport. 4. Two referee's reports are required. Applicants must not submit referee's reports directly. Nominated referees will be sent a request directly by the on-line application system. Please advise your referees that they will be receiving an email requesting a reference statement and that this must be submitted by the closing date or your application will be ineligible. If the referee declines to provide a reference before the closing date you will be able to nominate another referee. 5. A two page statement (maximum 1,000 words) outlining the applicant's research proposal using the template provided with the online application form. Please note this must be two pages only (plus one page for references). If a longer document is provided you will be asked to rewrite it. 6 . Written support from the proposed primary supervisor if they have not acted as one of the referees above. 7. A brief C.V. (maximum three pages)

Closing Date: 15 October

Funding: Private

\section{For further information contact:}

55 Wellesley St E, Auckland 1010 New Zealand

Email: scholars@aut.ac.nz

\section{The University of Auckland International Doctoral Fees Bursary}

Subjects: All subjects

Purpose: To assist international students from all countries who wish to pursue doctoral studies

Eligibility: Permanent citizens and residents of Australia and New Zealand are not eligible for the scholarship

Level of Study: Doctorate

Type: Bursary

Value: NZ \$25,000

Frequency: Annual

Study Establishment: University of Auckland

Country of Study: New Zealand

Application Procedure: The application form can be obtained from the Scholarships Office, University of Auckland

Closing Date: 1 August

Funding: Government

\section{University of Auckland International Doctoral Scholarship}

Subjects: All subjects

Purpose: To assist international students from all countries who wish to pursue doctoral studies 
Eligibility: The scholarship is available to international students from all countries who wish to pursue Doctoral studies on a full-time basis. Permanent citizens and residents of Australia and New Zealand are not eligible for the scholarship Level of Study: Doctorate

Type: Scholarship

Value: NZ $\$ 25,000$, in the form of a fortnightly stipend

Frequency: Annual

Study Establishment: University of Auckland

Country of Study: New Zealand

Application Procedure: The application form can be obtained from the Scholarships Office, University of Auckland

Closing Date: Varies

Funding: Government

\section{University of Auckland Business School}

School of Business \& Economics, Private Bag 92019, Auckland, New Zealand

Tel: $\quad$ (64) 93737599

Fax: (64) 93737437

Email:_execpro@auckland.ac.nz

Website: www.business.auckland.ac.nz

Contact: Dr Gary Cayton, Director MBA

\section{Kupe Leadership Scholarships}

Purpose: The Kupe Leadership Programme will involve a three-day Orientation in early March; two two-day workshops held during each mid-semester break; a one-day workshop in the inter-semester break and a concluding day-long workshop in November

Eligibility: The Kupe Leadership alumni will develop a reputation for embodying these values and for contributions they make, nationally and possibly internationally

Level of Study: Postgraduate

Type: Scholarship

Frequency: Annual

Country of Study: Any country

Closing Date: 24 August

Funding: Private

\section{For further information contact:}

The University of Auckland, Private Bag 92019, Auckland, 1142, New Zealand

Tel: (64) 800616263

Email: pc.dasilva@auckland.ac.nz

\section{University of Auckland Executive MBA Programme}

Length of Study: More than 2 years

Application Procedure: Applicants must return a completed form. A deposit of $A \$ 250$ is payable on acceptance. Foreign students may be required to sit a test of English proficiency Closing Date: 3 November (for trimester one), 4 May (for trimester two), 17 August (for trimester three)

\section{For further information contact:}

Business Administration International Students Office, Private Bag 92019, Auckland 1142, New Zealand

Tel: $\quad$ (64) 93737513

Fax: (64) 93737405

Email: international@auckland.ac.nz

Contact: MBA Admissions Officer

\section{University of Bath}

Claverton Down, BA2 7AY, Bath, United Kingdom

Tel: $\quad$ (44) 1225388388

Fax: (44) 1225388388

Website: www.bath.ac.uk

Contact: University of Bath

The University of Bath received its Royal Charter in 1966 and is now firmly established as a top ten United Kingdom university with a reputation for research and teaching excellence.

\section{United Kingdom-India Year of Culture GREAT Postgraduate Scholarships}

Subjects: Scholarships are awarded in the Faculty of Humanities and Social Sciences, Faculty of Engineering and Design and scholarship in the Faculty of Science

Purpose: The University of Bath is currently accepting applications for United Kingdom-India Year of Culture GREAT Scholarships. This scholarship is available to the international fee-paying student from India studying a full-time taught postgraduate masters programme

Eligibility: Indian students are eligible to apply for this scholarship. For most programmes, the requirement for non-native English speakers is 6.5 in the IELTS Academic English test, with no less than 6.0 in any element Type: Postgraduate scholarships 
Value: If you are an international fee-paying student you could be eligible for one of ten United Kingdom-India Year of Culture GREAT Scholarships each worth $£ 5,000$

Study Establishment: Scholarships are awarded in the Faculty of Humanities and Social Sciences, Faculty of Engineering and Design and scholarship in the Faculty of Science

Country of Study: United Kingdom

Application Procedure: If you are eligible for the scholarship scheme we will let you know and invite you to apply. Queries for MSc students should be addressed to msc-mnat-bath.ac.uk and for MBA students to mbaapps-atmanagement.bath.ac.uk

Closing Date: 1 June

Additional Information: For more details please see the website scholarship-positions.com/uk-india-year-ofculture-great-postgraduate-scholarships-university-bath-uk/ $2018 / 01 / 27 /$

\section{For further information contact:}

Email: mbaapps-at-management.bath.ac.uk

\section{University of Bern}

Hochschulstrasse 4, Bern CH 3012, Switzerland

Tel: $\quad$ (41) 316318111

Email: info@imd.unibe.ch

Website: www.unibe.ch/eng/

The University of Bern offers top quality teaching, special recognition in leading-edge disciplines, and a campus environment intimately linked to the social, economic, and political life of the city. The university's comprehensive offering includes 8 faculties and some 160 institutes with 12,500 students. Its academic and research organization prides itself on its interdisciplinarity. The university is actively involved in a wide range of European and worldwide research projects.

\section{Excellence Scholarships for Postgraduate Study}

Subjects: All subjects

Purpose: Scholarship for international students

Eligibility: Applicants must, by end of July, have graduated with at least a Bachelor's degree in the same field of study as the selected Master's programme and must be residing in their home country. The criteria for selection are previous academic excellence and the potential of the candidate

Level of Study: Graduate
Type: Scholarship

Value: CHF 1,600 per month for the entire duration of the course

Frequency: Annual

Application Procedure: Check website for specific details

Closing Date: 21 December

Funding: Commercial

\section{For further information contact:}

Tel: $\quad$ (41) 316318049

Email: claudine.rossi@int.unibe.ch

Contact: Claudine Ross

\section{UniBE International 2021}

Purpose: To support for young researchers and to the university's internationalization

Level of Study: Doctorate, Postgraduate

Length of Study: 3 years

Study Establishment: University of Bern

Country of Study: Switzerland

Application Procedure: Please email your application including any related documents as one pdf to lenka.fehrenba ch@entwicklung.unibe.ch

Closing Date: 17 May

Contributor: Swiss National Fund (SNF)

For further information contact:

Email: sandro.stauffer@uls.unibe.ch

\section{University of Birmingham}

Student funding office, Edgbaston, West Midlands B15 2TT, Birmingham, United Kingdom

Tel: $\quad$ (44) 1214143142

Fax: (44) 1214146637

Email: j.e.bryan@bham.ac.uk

Website: www.as.bham.ac.uk/funding

Contact: Joanne Bryan, Assistant Director of Student Financial Support

The University of Birmingham is a leading research institution, offering a wide range of programmes, high teaching and research standards, and excellent facilities for academic work. 


\section{A Master of Science Business Scholarships}

Subjects: Business

Purpose: Birmingham Business School offers a number of scholarships for students on the MSc Business programmes to reward outstanding academic achievement. The financial support offered is to contribute towards tuition fees. These awards are based on merit and will be selected by a panel of representatives from the Business School

Eligibility: To be eligible for the MSc Business Scholarship you will need to: Have received an offer to study on one of our 1 year eligible MSc programmes and should have submitted a scholarship application, with all requested information attached, by the final deadline

Value: MSc Business Scholarships are usually up to $£ 5,000$ offered against tuition fees. Successful scholars will still need to pay the remainder of the fees

Country of Study: Any country

Closing Date: 1 June

\section{For further information contact:}

Email: msc@business-school.ed.ac.uk

\section{A Master of Science in Robotics Scholarship}

Subjects: MSc Robotics

Purpose: To support students on the MSc Robotics Programme

Eligibility: Students with a place on the MSc Robotics programme

Level of Study: Postgraduate

Type: Scholarship

Value: $£ 5,000$

Length of Study: 1 year

Frequency: Annual

Study Establishment: The University of Birmingham

Country of Study: United Kingdom

Application Procedure: Apply for the MSc Robotics programme and submit your curriculum vitae and a 300-500 words personal statement to professor Jeremy L Wyatt via email at jlw@cs.bham.ac.uk and Dr Michael Mistry at m.n. mistry@bham.ac.uk

Closing Date: May

Funding: Private

Additional Information: For more information, contact the School of Computer Science

\section{For further information contact:}

Email: hello@harbour.space

\section{Abu Dhabi National Oil Company (ADNOC) Scholarship Program}

Subjects: Engineering and physical sciences

Purpose: The Scholarship Department's mission is to educate, train and prepare UAE nationals to take up leading positions in the oil and gas industry, as part of its commitment towards the process of Emiratization of jobs both for ADNOC Headquarters and ADNOC Group of Companies

Eligibility: UAE National

Level of Study: Doctorate, Postgraduate, Research

Type: Equipment grant

Value: Monthly stipend, cash award at the end of the semester based on academic performance, cover tuition fees, computer allowance, travel tickets. 1. Cash Award for Outstanding students. 2. Full Health and Dental Care Coverage

Application Procedure: Application is through the organization's website

Closing Date: Open all year

Additional Information: For more details, please visit the website www.adnocscholar.ae and also contact Doctoral Research Enquiry Service, dr@contacts.bham.ac.uk

\section{For further information contact:}

Email: $\quad$ dr@contacts.bham.ac.uk

Contact: Doctoral Research Enquiry Service

\section{Amelia Earhart Fellowship - Zonta International}

Subjects: Engineering and Physical Sciences

Purpose: The Amelia Earhart Fellowship program helps talented women, pursuing advanced studies in the typically male-dominated fields of aerospace-related sciences and engineering, achieve their educational goals. The Fellowship enables these women to invest in state-of-the-art computers to conduct their research, purchase expensive books and resource materials, and participate in specialized studies around the globe

Eligibility: Women of any nationality pursuing a $\mathrm{PhD} /$ doctoral degree who demonstrate a superior academic record in the field of aerospace-related sciences or aerospacerelated engineering are eligible. Applicants must be registered in a full-time $\mathrm{PhD} /$ doctoral program when funds are received in September and must not graduate before April

Type: Scholarship

Value: The Fellowship of US\$10,000, awarded to 35 Fellows around the globe each year, may be used at any university or college offering accredited postgraduate courses and degrees in these fields

Country of Study: Any country 
Application Procedure: Applications should be sent to the Foundation directly. For more details, please check: www. zonta.org/WhatWeDo/InternationalPrograms/AmeliaEarhart Fellowship.aspx

Closing Date: 15 November

Funding: Trusts

\section{For further information contact:}

Email: zontaintl@zonta.org

\section{Amphlett Scholarship (Theology and Religion)}

Subjects: Theology and Religion. Humanities

Purpose: Donald Amphlett was a Birmingham solicitor who died in 1956 and left his money to establish a trust fund to provide scholarships for Chinese students to study Theology and Religion at the University

Eligibility: This award is only available to Chinese students applying to study for a postgraduate degree programme in Theology and Religion

Type: Scholarship

Value: The Amphlett scholarship pays for tuition and accommodation fees, either in part or in full. Assistance with travel costs to and from the home country may also be given

Frequency: Annual

Country of Study: Any country

Application Procedure: It is recommended that the application should reach the Amphlett Committee a year in advance

Closing Date: Open all year

Funding: Trusts

\section{For further information contact:}

Email: support.team@postgraduatesearch.com

\section{Arthurian Postgraduate Awards}

Subjects: Arts and Law

Purpose: The Eugène Vinaver Trust, in association with the British Branch of the International Arthurian Society and under the terms of the Barron Bequest, offers a number of annual awards for postgraduate research in any field of Arthurian Studies

Eligibility: The awards are open to graduates of any university in the British Isles, including those of the Republic of Ireland

Level of Study: Graduate, Postgraduate

Value: The awards, currently of $£ 1,250$, are intended as a contribution to postgraduate fees. Preference will be given in the making of awards to support for full research degrees. Students who are awarded a grant for the coming year may apply for grants in future years on a basis of parity with those applying for the first time

Frequency: Annual

Country of Study: United Kingdom

Application Procedure: There is no standard application form. Instead, a leaflet is available giving details of information to be supplied by applicants in typed or word-processed form. The leaflet is available in electronic form on the www. internationalarthuriansociety.com/british-branch/view/awards along with further information and contact details

Closing Date: 30 April

Funding: Trusts

\section{For further information contact:}

Email: dr@contacts.bham.ac.uk

\section{Arts and Humanities Research Council Funding through the Midlands3Cities Doctoral Training Partnership}

Subjects: Arts and law, African studies, American and Canadian studies, antiquity, archaeology, classics and ancient history, drama and theatre arts, English language and linguistics, English literature, film and creative writing, heritage, history, history of art, law, modern languages and cultures, music, philosophy, theology and religion, geography, education

Purpose: The AHRC is continuing its very substantial commitment to funding doctoral research through a new round of Doctoral Training Partnerships (DTPs)

Type: Scholarships

Value: $£ 4,121$ per annum

Frequency: Annual

Country of Study: Any country

Application Procedure: Please refer to our application page Closing Date: 14 January

Additional Information: Please refer to the Midlands3Cities Doctoral Training Partnership website

\section{For further information contact:}

Email: m4c@warwick.ac.uk

\section{Association of Dental group (ADG) Postgraduate Bursary}

Subjects: Dentistry

Purpose: The Association of Dental Groups (ADG) offers an award of $£ 5,000$ for postgraduate students to reward the best voluntary scheme to promote $\&$ deliver improvements in oral health 
Eligibility: This award is open to all postgraduate dental students who have an under-graduate dentistry degree who are undertaking a voluntary project that seeks to improve and promote better oral health. The project must be within the United Kingdom and focused on one of two issues of significant concern, namely either improving access for disadvantaged people or building awareness of oral cancers and the need for early diagnosis

Type: Scholarships

Value: The award is composed of $£ 2,500$ as award to the winner and a further $£ 2,500$ to be used to support delivery of a project to improve and promote oral health

Country of Study: Any country

Application Procedure: Apply for this award by completing and submitting an application form, which can be found on the website: www.dentalgroups.co.uk/dentists/postgradapplication.html

Closing Date: 31 December

\section{For further information contact:}

Email: adgdentalawards@gmail.com

\section{Biosciences Studentships}

Subjects: Biological Sciences Purpose: To undertake the full range of personal development training and activities provided within the School and the University Graduate School Eligibility: Applicants should possess, or expect to achieve, at least a good upper second class honours degree or equivalent qualification in an appropriate subject. Evidence of previous research experience, for instance undergraduate project work, is desirable. Qualifications of a suitable standard from every country in the world are accepted for postgraduate entry Level of Study: Doctorate

Type: Research

Value: A number of studentships funded by United Kingdom Research Councils and other major sponsors (e.g. Cancer Research-United Kingdom) are available each year for home and European Union students. Studentships may provide full funding (fees and stipend)

Length of Study: 3 or 4 years

Application Procedure: You can apply through the Biosciences $\mathrm{PhD}$ course page on our Course Finder

Closing Date: Open all year

Additional Information: For more details contact Biosciences Graduate Research School, biosciences-phd@contacts. bham.ac.uk

\section{For further information contact:}

Email: biosciences-phd@contacts.bham.ac.uk

Contact: Biosciences Graduate Research School

\section{Birmingham Business School Doctoral Scholarship}

Subjects: Accounting and finance, economics, management and marketing

Purpose: The scholarship is to recognise and support the highest calibre candidates studying $\mathrm{PhD}$ level

Eligibility: A successful applicant will have a very good undergraduate degree. They should have, or be in the process of completing a masters typically in a business-related subject or economics

Level of Study: Doctorate, Research

Type: Scholarship

Value: Fees only and fees plus generous maintenance scholarships available

Length of Study: 3 years

Study Establishment: The University of Birmingham

Country of Study: United Kingdom

Application Procedure: Application forms can be downloaded from the Business School website. You must hold an offer of a place to study a $\mathrm{PhD}$ and apply before the deadline Closing Date: May

Funding: Private

Contributor: The University of Birmingham

Additional Information: For more information, email to business-pgr-research@contacts.bham.ac.uk

\section{For further information contact:}

Email: business-pgr-research@contacts.bham.ac.uk

\section{Birmingham Law School - Doctoral Scholarships}

Subjects: Law

Purpose: To pursue postgraduate research

Eligibility: These awards are open to students worldwide for full- and part-time, campus-based doctoral research in the College of Arts and Law

Level of Study: Doctorate

Type: Scholarships

Value: $£ 11,000$ support per year towards living expenses for full-time applicants

Length of Study: 3 years

Country of Study: Any country

Application Procedure: These awards are advertised with the College of Arts and Law Doctoral Scholarships - please refer to this page for full application details and application forms

Closing Date: 17 March

Additional Information: For further details, please contact calpg-research@contacts.bham.ac.uk (College of Arts and Law) 


\section{For further information contact:}

Email: calpg-research@contacts.bham.ac.uk

\section{Boehringer Ingelheim Fonds Fellowships}

Subjects: Arts and Law, Engineering and Physical Sciences, Life and Environmental Sciences, Medical and Dental Sciences, Social Sciences

Purpose: The British Lebanese Association (BLA) Scholarship Fund was established in 1985 as part of the BLA's initiative to contribute towards rebuilding national capabilities after a decade of conflict. The Fund has a central part in achieving the aims of the BLA

Eligibility: Applications are restricted to candidates who are Lebanese, Jordanian or Palestinian (including Palestinians inside Israel) and Syrian. Applications for study at universities outside the United Kingdom cannot be considered. Priority is given to candidates permanently living in the Foundation's target countries. The Foundation will, however, consider Syrians residing elsewhere due to current circumstances in Syria Level of Study: Graduate, Postgraduate

Type: Scholarship

Value: Depending on availability of funding, the BLA aims to provide partial funding for two or three scholarships each academic year

Frequency: Dependent on funds available

Country of Study: Any country

Application Procedure: BLA scholarships are currently offered in partnership with the Said Foundation and prospective candidate should go to the www.saidfoundation.org/ scholarship-applications for further information on the programme and to complete the application form online

Closing Date: 30 November

\section{For further information contact:}

Email: secretariat@bifonds.de

\section{Boehringer Ingelheim Fonds PhD Fellowships}

Subjects: Engineering and physical sciences, life and environmental sciences, medical and dental sciences

Purpose: The Boehringer Ingelheim Fonds awards PhD fellowships to outstanding junior scientists who wish to pursue an ambitious $\mathrm{PhD}$ project

Eligibility: The Boehringer Ingelheim Fonds (BIF) awards $\mathrm{PhD}$ fellowships to European citizens working in Europe or overseas, and to non-European citizens pursuing their $\mathrm{PhD}$ project in Europe. Applicants should not be older than 27 years at the respective deadline (1 February, 1 June, 1 October)
Level of Study: Postgraduate

Value: The fellowship comprises a competitive monthly stipend that is initially granted for 2 years and that can be extended for up to another 1 year. Participation in international scientific conferences is also supported. In addition, fellowship holders are offered personal support, seminars to discuss their projects, communication training and alumni meetings, and thus can become part of a worldwide network Country of Study: United Kingdom

Closing Date: Open all year

Funding: Trusts

Additional Information: Please check website for more details: www.bifonds.de/fellowships-grants/phd-fellowships. html

\section{For further information contact:}

Email: secretariat@bifonds.de

\section{Canon Foundation Fellowships}

Subjects: Arts and law, engineering and physical sciences, life and environmental sciences, medical and dental sciences, social sciences

Purpose: To promote international cultural and scientific relations between Europe and Japan

Eligibility: The candidates hold a doctorate or at least a master's degree. They are eligible during the ten-year period following the successful completion of their $\mathrm{PhD}$ or MA degree

Level of Study: Doctorate

Value: From $€ 22,500$ to $€ 27,500$ per year for different periods

Length of Study: 3 months to 1 year

Country of Study: Any country

Application Procedure: Applications should be submitted in full (including the acceptance by the proposed host institute and the research plan) to the Secretariat of the Canon Foundation in Europe well in advance of the deadline. www. canonfoundation.org/register.php

Closing Date: 15 September

Funding: Private

Additional Information: For more details, please check the website www.canonfoundation.org/programmes/researchfellowships/. Also contact dr@contacts.bham.ac.uk (Doctoral Research Enquiry Service)

\section{For further information contact:}

Canon Foundation in Europe, Bovenkerkerweg 59, NLD 1185 XB, Amstelveen, Netherlands 
Tel: (31) 205458934

Email: foundation@canon-europe.com

\section{College of Arts and Law Distance Learning Scholarship(s)}

Subjects: Arts and law, African studies, American and Canadian studies, antiquity, archaeology, classics and ancient history, drama and theatre arts, English language and linguistics, English literature, film and creative writing, heritage, history, history of art, law, modern languages and cultures, music, philosophy, theology and religion

Purpose: To offer a funding opportunity for distance learning students, studying research programmes starting in the academic year

Eligibility: The scholarships are open to prospective or current students undertaking full-time or part-time distance learning research programmes, worldwide

Level of Study: Doctorate, Postgraduate

Value: Up to $£ 3,000$ for full-time home/European Union students and up to $£ 10,000$ for full-time overseas students

Length of Study: 1 year

Country of Study: Any country

Application Procedure: Return the completed application form to calpg-research@contacts.bham.ac.uk

Closing Date: 31 March

Additional Information: If you would like any further information, please email calpg-research@contacts.bham.ac.uk or telephone 01214148442

\section{For further information contact:}

Email: calpg-research@contacts.bham.ac.uk

\section{College of Arts and Law Doctoral Scholarships}

Subjects: Arts and Law, African Studies, American and Canadian Studies, Antiquity, Archaeology, Classics and Ancient History, Drama and Theatre Arts, English Language and Linguistics, English Literature, Film and Creative Writing, Heritage, History, History of Art, Law, Modern Languages and Cultures, Music, Philosophy, Theology and Religion

Level of Study: Doctorate

Type: Scholarship

Value: $£ 11,000$ support per year towards living expenses for full-time applicants, adjusted pro-rata for part-time applicants Length of Study: Three years full-time, or six years part-time Study Establishment: University of Birmingham

Country of Study: Any country

Application Procedure: Applicants who have already applied for AHRC funding through the Midlands3Cities consortium will automatically be considered for one of these
College awards, without submitting a separate application. In order to apply, you must first have completed an application to study. Once you have done so, please complete the funding application form, and return the completed form to calpg-research@contacts.bham.ac.uk. The application must also be supported by two references

Closing Date: 17 March

Contributor: Birmingham Research Institute

Additional Information: For more information please email calpg-research@contacts.bham.ac.uk or telephone 0121 4148442

\section{For further information contact:}

Email: calpg-research@contacts.bham.ac.uk

\section{College of Arts and Law Masters Scholarships}

Subjects: Arts and Law, African Studies, American and Canadian Studies, Antiquity, Archaeology, Classics and Ancient History, Drama and Theatre Arts, English Language and Linguistics, English Literature, Heritage, History, History of Art, Modern Languages and Cultures, Music, Philosophy, Theology and Religion

Purpose: The College of Arts and Law offers a number of home/European Union fees-only scholarships for candidates wishing to study full- and part-time masters-level courses from September 2016. These awards cover tuition fees for all masters-level degrees

Eligibility: These awards are open to United Kingdom/European Union students, studying campus-based masters-level degrees in the College of Arts and Law. International students are also eligible to apply, and will receive a reduction in tuition-fees equivalent to the home/European Union rate if successful

Level of Study: Graduate, Postgraduate

Type: Scholarship

Value: These awards cover one year

Country of Study: Any country

Application Procedure: Please go through the website

Closing Date: 22 April

Funding: Trusts

For further information contact:

Email: calpg-research@contacts.bham.ac.uk

\section{Emslie Horniman Anthropological Scholarship Fund}

Subjects: Antiquity, Archaeology, History, Modern Languages and Cultures 
Purpose: The major aim of the Fund is to encourage postgraduates to pursue fieldwork, and so to develop their careers as Anthropologists and make significant contributions to the discipline

Eligibility: Open to citizens of the United Kingdom, Commonwealth or Irish Republic who are university graduates or who can satisfy the trustees of their suitability for the study proposed. Preference is given to applicants whose proposals include fieldwork outside the United Kingdom. Graduates who already hold a doctorate in anthropology are not eligible. Open to individuals only, as no grants are given to expeditions or teams

Level of Study: Doctorate, Postgraduate

Value: Around $£ 1,000$ - $£ 9,500$

Country of Study: Any country

Application Procedure: Seven copies of each application with supporting references must be submitted. Short-listed candidates will normally be required to attend an interview in London in late-May/early-June

Closing Date: 31 March

Additional Information: Grants to successful candidates will be paid at the start of their fieldwork

\section{For further information contact:}

Email: admin@therai.org.uk

\section{Francis Corder Clayton Scholarship}

Subjects: American and Canadian Studies, Antiquity, Archaeology, Drama and Theatre Arts, English Language and Linguistics, English Literature, History, History of Art, Modern Languages and Cultures, Music, Philosophy, Theology and Religion

Purpose: Open to any full-time postgraduate undertaking a programme in an Arts subject. One award is available each year and will be tenable for one year only

Eligibility: Open to current full-time PG students only.

Taught and research-based programmes

Level of Study: Graduate, Postgraduate

Value: This scholarship will cover the home rate of postgraduate tuition fees. Stipends for living costs may be available in some cases; however, this will be subject to available funding and cannot be guaranteed

Country of Study: United Kingdom

Application Procedure: Applications cannot be made directly for these awards; candidates need to be nominated by their school or department. If you are interested and fit the eligibility criteria, please make an expression of interest to the postgraduate administrator within your school, or your admissions tutor. For more information, please submit a query to Funding, Graduation \& Awards through intranet.birming ham.ac.uk/student/student-hub/homepage.aspx
Closing Date: 13 May

Funding: Trusts

\section{For further information contact:}

Email: sfo@contacts.bham.ac.uk

\section{Funds for Women Graduates Foundation Grants}

Subjects: Arts and Law, Engineering and Physical Sciences, Life and Environmental Sciences, Medical and Dental Sciences, Social Sciences, Education

Purpose: FfWG offers foundation grants to help women graduates with their living expenses (not fees) while registered for study or research at an approved institution of higher education in Great Britain. The criteria are the proven needs of the applicant and their academic calibre

Eligibility: Women graduates from Britain and overseas are eligible to apply. For more information please visit website

Level of Study: Doctorate

Value: The amount of the Foundation Grant will be decided by FfWG

Country of Study: Any country

Application Procedure: Details of how to apply can be found on the Funds for Women Graduates website (www. ffwg.org.uk/)

Closing Date: 22 February

Additional Information: For more details contact Doctoral Research Enquiry Service-dr@contacts.bham.ac.uk

\section{For further information contact:}

Email: grants@ffwg.org.uk

\section{German Historical Institute London PhD Scholarships}

Subjects: Modern Languages and Cultures, International Relations

Eligibility: Applicants from British universities will normally be expected to have completed one year's post-graduate research, and be studying German history or Anglo-German relations

Level of Study: Doctorate, Postgraduate, Research

Type: Award

Value: Various

Length of Study: Up to 6 months

Application Procedure: Please apply online on the GHIL website (www.ghil.ac.uk)

Closing Date: 31 March 


\section{For further information contact:}

Email: prize@ghil.ac.uk

\section{Guest Keen and Nettlefolds PG Scholarship}

Subjects: Chemical Engineering, Civil Engineering, Electronic, Electrical and Systems Engineering, Mechanical Engineering, Metallurgy and Materials Engineering

Eligibility: This scholarship is open to postgraduate engineering students studying on research programmes who have performed well academically. One nomination is made per engineering school

Level of Study: Postdoctorate, Research

Value: $£ 1,000$ towards maintenance

Study Establishment: Any

Country of Study: Any country

Application Procedure: This is an in-year scholarship that will be open for nomination any time. This scholarship is only available to current students by nomination through their School

Closing Date: None. Open all year

Additional Information: For more information please contact Postgraduate Recruitment Team-pg@contacts.bham.ac.uk

\section{For further information contact:}

Email: sfo@contacts.bham.ac.uk

\section{Hudswell International Research Scholarship}

Subjects: Electronic, Electrical and Systems Engineering Purpose: To provide awards in support of research undertaken by members in the fields of electrical, electronic or manufacturing engineering, to assist IET members with research work leading to the award of a doctorate

Eligibility: The research programme must be undertaken outside the applicant's home country. Applicants must be in the first or second year of the research programme. For more information please visit website

Level of Study: Doctorate, Research

Type: Award

Value: $£ 5,000$

Country of Study: Any country

Application Procedure: Please visit the website conferences. theiet.org/achievement/scholarships/postgraduate/index.cfm

Closing Date: 6 April

\section{For further information contact:}

Email: awards@theiet.org

\section{Institution of Mechanical Engineers Postgraduate Research Scholarships}

Subjects: Mechanical Engineering

Eligibility: Students who are normally resident in the United Kingdom, who will commence their postgraduate degree in the next academic session

Level of Study: Doctorate, Research

Value: Full-time up to $£ 6,500$ p.a. Part-time pro rata

Length of Study: Three years

Country of Study: Any country

Application Procedure: For applications forms and information please check the Institution of Mechanical Engineers website (www.imeche.org/careers-education/scholarshipsand-awards/postgraduate-research-scholarships)

Closing Date: 1 August

Contributor: The Institution of Mechanical Engineers

\section{For further information contact:}

Email: dr@contacts.bham.ac.uk

\section{Ironbridge Institute - John Pagett Bursary}

Subjects: Archaeology, History

Eligibility: Applicants must be : Registered (or be registered) for a postgraduate research degree at the University of Birmingham

Type: Scholarship

Value: $£ 3,000$

Frequency: Annual

Country of Study: Any country

Application Procedure: For further details about this scholarship, please visit the website: www.birmingham.ac. uk/schools/historycultures/departments/ironbridge/postgradu ate/funding.aspx

Closing Date: 30 June

\section{For further information contact:}

Email: r.h.white@bham.ac.uk

\section{Lee Kuan Yew Scholarship}

Subjects: Arts and Law, Engineering and Physical Sciences, Life and Environmental Sciences, Medical and Dental Sciences, Social Sciences

Purpose: Lee Kuan Yew Scholarship recipients can pursue either a Masters or PhD programme at a local or overseas university

Eligibility: Applicants should have excellent track record of leadership and service, within or beyond their profession; and 
good academic achievements, for example, a Second Class Upper honors or equivalent degree

Type: Scholarship

Value: Scholarship recipients will receive a one-off sum of $\mathrm{S}$ $\$ 10,000$, and an annual allowance of: $\mathrm{S} \$ 50,000$ for private sector awardees; or $\mathrm{S} \$ 10,000$ for public sector awardees, if they are concurrently sponsored by their organisations

Country of Study: Any country

Application Procedure: he completed document should be sent to applications@psd.gov.sg. The application can be found on the www.pscscholarships.gov.sg/scholarships/ other-scholarships/lee-kuan-yew-scholarship

Closing Date: 18 December

Funding: Trusts

\section{For further information contact:}

Email: june_yeo@psd.gov.sg

\section{Leslie H Paddle Scholarship}

Purpose: To encourage excellence in engineering and technology research, with a preference for electrical, electronic or manufacturing engineering

Eligibility: 1. Postgraduate awards are for members of the Institution of Engineering and Technology and are open to the following categories of IET membership: Student, TMIET, MIET and FIET. Associate and lapsed members are not eligible to apply. 2. Applicants must have been a member of the IET for at least one year by the closing date for applications. 3. Applicants do not need to be professionally registered engineers. However, applicants are expected to satisfy the educational requirements for Registration as either a Chartered or Incorporated Engineer. 4. Applicants need to have started their PhD or EngD research programme by the closing date for applications and achieved at least a 2:1 (or equivalent) in their first degree. MSc courses and MRes degrees are not eligible

Level of Study: Graduate, Postgraduate

Type: Scholarship

Value: One award of $£ 5,000$

Frequency: Annual

Country of Study: Any country

Application Procedure: Applications can be made through the IET website. www.birmingham.ac.uk/postgraduate/ funding/Leslie-H-Paddle-Scholarship.aspx

Closing Date: 5 April

Funding: Private

\section{For further information contact:}

Email: dr@contacts.bham.ac.uk

\section{Leverhulme Trade Charities Trust Postgraduate Bursary}

Subjects: Arts and Law, Engineering and Physical Sciences, Life and Environmental Sciences, Medical and Dental Sciences, Social Sciences

Purpose: Available to students connected with Commercial Travellers, Grocers or Chemists that are experiencing financial difficulty

Eligibility: The Leverhulme Trade Charities Postgraduate Bursaries are designed to provide support for eligible United Kingdom students i.e. those who are (or who are connected with) Commercial Travellers, Grocers or Chemists, in financial need undertaking full-time Postgraduate degree courses at institutions in the United Kingdom, leading to recognised qualifications (e.g. $\mathrm{PhD} / \mathrm{MSc}$ )

Level of Study: Graduate, Postgraduate

Value: The maximum value of any bursary is $£ 5,000$. This amount may be adjusted according to the applicant's personal financial need and to the amount of funds available

Country of Study: United Kingdom

Application Procedure: For further information about eligibility and definitions please visit the website, www. leverhulme-trade.org.uk/postgraduate-bursaries/eligibility

Closing Date: 1 October

Funding: Trusts

\section{For further information contact:}

Email: admin@leverhulme-trade.org.uk

\section{Music Department Scholarships}

\section{Subjects: Music}

Purpose: A number of scholarships, of varying value, are offered by the Music Department to students studying postgraduate programmes in Music (research or taught)

Eligibility: Scholarships are available for United Kingdom, European Union and International students

Level of Study: Graduate, Postgraduate

Type: Scholarship

Value: A wide range of scholarships, of varying value, are offered

Country of Study: Any country

Closing Date: 17 June

Funding: Trusts

\section{For further information contact:}

Email: scrist@emory.edu 


\section{Paul and Yuanbi Ramsay MSc Computer Science Bursary}

Subjects: Computer Science

Purpose: To support outstanding students with priority given to those from a low income background

Eligibility: The bursary will be awarded to Home/European Union Masters students in need of financial assistance and then on academic merit

Level of Study: Postgraduate

Type: Bursary

Value: The home rate of tuition fee

Length of Study: 1 year

Frequency: Annual

Study Establishment: University of Birmingham

Country of Study: United Kingdom

Application Procedure: Full guidance and a downloadable application form for this award will be available from www. intranet.birmingham.ac.uk/awards or the School of Computer Science website from May of the year in which you will start your study

Closing Date: Mid-July

Funding: Private

Contributor: Paul and Yuanbi Ramsay

No. of awards given last year: 2

\section{For further information contact:}

Email:Fga@contacts.bham.ac.uk

\section{Rosgen Family Scholarship}

Purpose: Business

Eligibility: The scholarship holder will be from Central or South America; The scholarship will be allocated on the basis of intellectual excellence and evidence of a commitment to the economic development of Central or South America

Level of Study: Graduate, Postgraduate

Type: Scholarship

Value: The Rosgen Family Scholarship is worth $£ 5,000$ and can either contribute towards the cost of the Birmingham MBA tuition fee or living costs

Frequency: Annual

Country of Study: Any country

Application Procedure: In order to apply to the above scholarship, please submit an expression of interest to Victoria Harold (details below). Once this has been received, an application form will be sent to you. Please complete the application form, including a personal statement relating to the scholarship theme, and an academic essay (essay title provided with application form)

Closing Date: None. Open all year

Funding: Trusts
For further information contact:

Email: mbaadmissions@bham.ac.uk

\section{Santander \& University of Birmingham Scholarship}

Subjects: Arts and Law, Engineering and Physical Sciences, Life and Environmental Sciences, Medical and Dental Sciences, Social Sciences

Eligibility: Applicants must have an excellent academic background obtaining a good 2:1/Upper Second Class or equivalent Bachelors degree as a minimum

Level of Study: Graduate, Postgraduate

Type: Scholarship

Value: $£ 5,000$ towards the cost of tuition fees for a one-year Masters programme

Country of Study: Any country

Closing Date: 31 March

Funding: Trusts

For further information contact:

Email: fga@contacts.bham.ac.uk

\section{School of Chemistry International Students Postgraduate Bursary}

Subjects: Chemistry

Eligibility: To be eligible for this opportunity students must: Be classified as overseas for fees purposes, Be privately funded, Satisfy the University's entry requirements for postgraduate study

Value: The value of the bursary is $£ 4,000$ per annum towards tuition fees

Frequency: Annual

Country of Study: Any country

Application Procedure: Applications should be sent online at the, www.birmingham.ac.uk/postgraduate/courses/applypg/index.aspx

Closing Date: None. Open all year

For further information contact:

Email: chemistry.pgt@ed.ac.uk

\section{Science without Borders Archaeology PhD scholarships}

Subjects: Archaeology

Purpose: The University of Birmingham is delighted to be one of the United Kingdom institutions selected to participate 
in the Science without Borders (Ciência sem Fronteiras) scheme

Eligibility: Science without Borders scholarships are only open to Brazilian students. Students should hold a Masters degree or equivalent. Students must also meet English language requirements: IELTS 6.0 (no less than 6.0 in any band) or TOEFL 93 (no less than 22 in Reading, 21 in Listening, 23 in Speaking, 21 in Writing)

Value: CsF will pay up to $£ 20,000$ towards tuition and bench fees for each Ciência sem Fronteiras PhD student per year of their study in the United Kingdom

Country of Study: Any country

Application Procedure: Students must apply through Universities United Kingdom. Website: sciencewithoutborders. international.ac.uk/

Closing Date: None. Open all year

For further information contact:

Email: iro@bristol.ac.uk

\section{Simon Evans Scholarships}

Subjects: Simon Evans, an alumnus of Birmingham Business School, kindly makes funds available for exceptional students to gain access onto marketing courses

Eligibility: Applicants must be a United Kingdom / European Union national,

Level of Study: Graduate, Postgraduate

Type: Varies

Value: A number of scholarships of $£ 5,000$ towards tuition fees are available

Country of Study: Any country

Application Procedure: Please check the website for more details: www.birmingham.ac.uk/schools/business/depart ments/marketing/courses/simon-evans-scholarships.aspx

Closing Date: 1 August

\section{For further information contact:}

Email: simon.evans@worc.ac.uk

\section{The Annemarie Schimmel Scholarship}

Subjects: Arts and Law, Engineering and Physical Sciences, Life and Environmental Sciences, Medical and Dental Sciences, Social Sciences

Purpose: The Scholarship was established in honour of Professor Annemarie Schimmel to commemorate her great contribution to culture and poetry in Pakistan and her role as a dedicated woman scholar. It offers the opportunity for postgraduate study in the United Kingdom to a woman who is committed to make a genuine contribution to her chosen field on her return to Pakistan

Eligibility: The Schimmel scholars will be chosen for their ability and commitment without discrimination as to religion, caste or creed. Candidates must have either a professional degree or they should have completed sixteen years of education in a relevant discipline

Level of Study: Graduate, Postgraduate

Value: The scholarship is awarded for one academic year for a Master's degree at recognized institutions of higher education in the United Kingdom. Doctoral candidates are not eligible

Country of Study: Any country

Closing Date: 7 June

\section{For further information contact:}

Email: nosheenimian@gmail.com

\section{The Birmingham Eighteenth-Century Centre (BECC-BCECS) British Society for Eighteenth- Century Studies Postgraduate Travel Award}

Purpose: The award is designed to support research in the eighteenth century, making use of the relevant holdings of the Cadbury Research Library

Eligibility: Applicants are also encouraged to take advantage of the rich eighteenth-century resources available in Birmingham more widely, including the Library of Birmingham, Birmingham Museum Trust

Level of Study: Postgraduate

Type: Award

Frequency: Annual

Country of Study: Any country

Application Procedure: Submit a research proposal of 500 words, including an explanation of how the use of Birmingham collections will benefit your research. Candidates will be asked to make few more changes. 1. Provide a written report on the research visit. 2. Write a blogpost of up to 1,000 words for the BECC website. 3. Return to Birmingham in the following academic year to give a presentation about the research, ideally as part of an existing event or seminar series in the University of Birmingham research programme; this later visit will be supported by additional travel expenses

Closing Date: 28 February

Funding: Private

\section{For further information contact:}

Edgbaston B15 2TT, Birmingham, United Kingdom

Email: becc@contacts.bham.ac.uk 


\section{University of Bristol}

Student Funding Office, Senate House (Ground Floor), Tyndall Avenue, BS8 1TH, Bristol, United Kingdom
Tel:
(44) 1179289000
Fax: (44) 1173317873
Email: student-funding@bris.ac.uk
Website: www.bristol.ac.uk
Contact: Ms Penny Rowe, Student Funding Advisor

The University of Bristol is committed to providing highquality teaching and research in all its designated fields.

\section{Global Accounting and Finance Scholarship}

Subjects: The awards can only be used as fee waivers towards the cost of tuition fees

Purpose: The Department of Accounting and Finance is offering eight scholarships worth $£ 5,000$ each to eligible international students studying for a postgraduate qualification in Accounting and Finance

Eligibility: You can apply for a University of Bristol Global Accounting and Finance Scholarship if you: 1. are classed as an overseas student for fee purposes AND. 2. have applied to start one of the qualifying Accounting and Finance MSc programmes at the University of Bristol in September. To be eligible for the University's Postgraduate scholarships, students must: 1 . Be an applicant to any one year, full-time postgraduate programme at the University of Bristol. 2. Start their postgraduate programme in September. 3. Be classed as an overseas student for fee paying purposes. 4. Not already be in receipt of other funding which would equate to more than the full cost of tuition fees alongside a Bristol scholarship

Level of Study: Postgraduate

Type: Scholarship

Value: $£ 5,000$

Frequency: Annual

Country of Study: Any country

Application Procedure: You can submit an application for the Global Accounting and Finance Scholarship using the International Scholarships online application form

Closing Date: 31 March

Funding: Private

\section{For further information contact:}

Tel: (44) 1179289000

Email: funding@bristol.ac.uk

\section{Global Economics Postgraduate Scholarship}

Subjects: Economics

Purpose: The Department of Economics is offering five scholarships worth $£ 5,000$ each to eligible international students studying for a postgraduate qualification in Economics

Eligibility: Kindly check the terms and conditions for the scholarship under the following link, www.bristol.ac.uk/inter national/fees-finance/scholarships/terms-and-conditions/

Level of Study: Graduate, Postgraduate

Type: Scholarship

Value: $£ 5,000$ each

Frequency: Annual

Country of Study: Any country

Application Procedure: There are two rounds of scholarships to avail. Round One Deadline: 31 March. Successful applicants will be informed via email by 26 April. Round Two Deadline: 30 June. Successful applicants will be informed via email by 19 July

Closing Date: 31 March and 30 June

Funding: Private

\section{For further information contact:}

University of Bristol, Senate House, Tyndall Avenue, BS8 1TH, Bristol, United Kingdom

Tel: (64) 1173311223

Email: iro@bristol.ac.uk

\section{International Postgraduate Scholarships - Taught Master's Programmes}

Subjects: All subjects

Purpose: This programme provides plenty of offers for future research postgraduate researchers with access to studentships, supervision from world-class experts and excellent facilities on our $\mathrm{PhD}$ and doctoral programmes

Eligibility: Open to candidates holding an offer for a 1 year taught postgraduate programme at the University of Bristol

Level of Study: Postgraduate

Type: Scholarship (MSc)

Value: $£ 2,000$

Length of Study: 1 year

Frequency: Annual

Study Establishment: University of Bristol

Country of Study: United Kingdom

Application Procedure: Check website for further details

Closing Date: 30 June

Funding: Private 


\section{For further information contact:}

International Recruitment Office, University of Bristol Union, Queens Road, Clifton, Bristol, United Kingdom

Email: iro@bristol.ac.uk

Contact: Penny Rowe, Student Funding Advisor

\section{Phyllis Mary Morris Bursaries}

Purpose: Phyllis Mary Morris née Doidge graduated with a degree in Geography in 1930

Eligibility: You can apply for a Phyllis Mary Morris Bursary if you: 1. are classed as an overseas student for fee purposes AND. 2. have applied to start a qualifying one-year, full-time taught postgraduate programme at the University of Bristol in September

Level of Study: Graduate

Type: Bursary

Value: $£ 2,000$

Frequency: Annual

Country of Study: Any country

Closing Date: 30 June

Funding: Private

\section{For further information contact:}

University of Bristol, Beacon House, Queens Road, BS8 1QU, Bristol, United Kingdom

Tel: (44) 1179289000

Email: graduation-office@bristol.ac.uk

\section{University of British Columbia (UBC)}

2329 West Mall, Vancouver, BC V6T 1Z2, Canada

Tel: $\quad$ (1) 6048222211

Fax: (1) 6048225802

Email:_graduate.awards@ubc.ca

Website: www.ubc.ca

Contact: Ms Jiffin Arboleda, Awards Administrator

The University of British Columbia (UBC) is one of North America's major research universities. The Faculty of Graduate Studies has 6,500 students and is a national leader in interdisciplinary study and research, with 98 departments, 18 interdisciplinary research units, 9 interdisciplinary graduate programmes, 2 graduate residential colleges and 1 scholarly journal.

\section{Izaak Walton Killam Predoctoral Fellowships}

Subjects: All subjects

Purpose: To assist doctoral students with full-time studies and research

Eligibility: Open to students of any nationality, discipline, age or sex. This award is given at the $\mathrm{PhD}$ level only and is strictly based on academic merit. Students must have a First Class standing in their last 2 years of study

Level of Study: Doctorate

Type: Fellowship

Value: $\mathrm{C} \$ 22,000$ per year and $\mathrm{C} \$ 1,500$ travel allowance for the duration of the award

Frequency: Annual

Study Establishment: UBC

Country of Study: Canada

No. of awards offered: 200

Application Procedure: Top ranked students are selected from the University Graduate Fellowship competition. Application forms can be obtained from individual departments, the Faculty of Graduate Studies or the website. Students must submit their applications to the departments, not to the Faculty of Graduate Studies

Closing Date: Each department has its own internal deadline, usually in early Autumn

Funding: Private

No. of awards given last year: 12

No. of applicants last year: 200

\section{For further information contact:}

Email: gsaward@ucalgary.ca

\section{University of British Columbia Graduate Fellowship (UGF)}

Subjects: All subjects

Purpose: To assist graduate students with their studies and research

Eligibility: Open to students of any nationality, discipline, age or sex. This award is strictly based on academic merit, and as a result, applicants must be nominated by their departments based on academic merit. Students must have a First Class standing in their last 2 years of study

Level of Study: Graduate

Type: Fellowship

Value: $C \$ 16,000$ per year for 2-year fellowships, $C \$ 16,000$ for 1-year fellowships, or $\mathrm{C} \$ 8,000$ for 1-year partial fellowships

Frequency: Annual

Study Establishment: UBC

Country of Study: Canada 
No. of awards offered: Approx. 2,500

Application Procedure: Applicants must submit their applications to the UBC department by the department deadline date, not to the Faculty of Graduate Studies. UGF applications are available from the website

Closing Date: Early Autumn

Funding: Government

No. of awards given last year: 460

No. of applicants last year: Approx. 2,500

Additional Information: Please check for internal departmental deadlines

For further information contact:

Email: graduate.awards@ubc.ca

\section{University of California at Los Angeles (UCLA) Center for India and South Asia}

Department of History, 11387 Bunche Hall, Los Angeles, CA 90095-1487, United States of America

\section{Tel: $\quad$ (1) 3102062654}

Email: subrahma@history.ucla.edu

Website: www.international.ucla.edu

Contact: Professor Sanjay Subrahmanyam, Chair of Indian History

The main thrust behind the creation of the UCLA Center for India and South Asia is to raise the profile of South Asia on campus and more generally in southern California. The organization aims at transforming UCLA into one of the leading poles of integrated research activity on India and South Asia in the country.

\section{University of California, Los Angeles (UCLA)Sardar Patel Award}

Subjects: Modern Indian subject (History, social sciences, humanities, education or fine art)

Purpose: To award the best dissertation submitted at any American university on the subject of modern India

Eligibility: Open to candidates who have written their dissertations while being enrolled at any accredited university in the United States

Level of Study: Research

Type: Award

Value: US $\$ 10,000$

Frequency: Annual
Application Procedure: Applicants must submit 2 hard copies of their dissertation, 7 copies of abstract, a copy of their curriculum vitae and a letter from the dissertation supervisor Closing Date: 15 October

For further information contact:

Email: cisa@international.ucla.edu

\section{University of California Berkeley - Haas School}

S440 Student Services Building, Suite 1902, Berkeley, CA 94720-1902, United States of America

Tel: $\quad$ (1) 5106421405

Fax: (1) 5106436659

Website: www.haas.berkeley.edu

Contact: MBA Admissions Officer

\section{Hellman Fellows Fund}

Subjects: Awards may be used for any research-related expense, such as research assistants, equipment, or travel. Up to $5 \%$ of the award money can also be used for childcare and elder-care (dependent) expenses

Purpose: The purpose of the Hellman Fellows Fund is to support substantially the research of promising assistant professors who show capacity for great distinction in their research Eligibility: In determining the allocation of awards, the Chancellor will seek the counsel of a panel of faculty comprised of tenured Hellman Fellows and a member of the Academic Senate Committee on Research, chaired by the Vice Provost for the Faculty. Applications should therefore include an introductory description which is accessible to someone who is not an expert in the given field

Level of Study: Postgraduate

Type: Funding support

Value: Maximum value of up to US\$60,000

Frequency: Annual

Country of Study: Any country

Application Procedure: 1. Applications should be brief, no more than 3 pages, and written with the understanding that they will be reviewed by a panel of faculty from the sciences and humanities that may not include specialists in the field of study. 2. Applications should therefore include an introductory description which is accessible to someone who is not an expert in the given field

Closing Date: May

Funding: Private 


\section{For further information contact:}

Vice Provost for the Faculty, 200 California Hall, MC 1500 Berkeley, CA 94720-1500, United States of America

Tel: (1) 5106426474

Email: yasyavg@berkeley.edu

\section{Western Center for Agricultural Health and Safety}

Purpose: The overarching goal of the WCAHS Small Grant Program is to encourage the development of creative research projects while nurturing researchers - particularly earlycareer researchers - interested in improving agricultural health and safety for the Western United States

Eligibility: 1. Faculty with PI eligibility in the Western region (AZ, CA, HI, NV). 2. PhD students or postdoctoral scholars in the Western region. 3. Applicants from AZ, HI, and NV are encouraged to apply

Level of Study: Graduate

Type: Grant

Value: Graduate students \& postdoctoral scholars may request up to US $\$ 10,000$ Faculty may request up to US\$30,000

Frequency: Annual

Country of Study: Any country

Application Procedure: For further information, check the website aghealth.ucdavis.edu/

Closing Date: 27 July

Funding: Private

Additional Information: aghealth.ucdavis.edu/small-grantprogram

\section{For further information contact:}

Email: aghealth@ucdavis.edu

\section{University of California, Berkeley}

Graduate Services, Graduate Fellowships Office, 318 Sproul Hall \#5900, Berkeley, CA 94720 5900, United States of America

Tel: $\quad$ (1) 5106426000

Fax: $\quad$ (1) 5106426000

Email: gradappt@berkeley.edu

Website: www.berkeley.edu

Founded in the wake of the gold rush by the leaders of the newly established 31st state, the University of California's flagship campus at Berkeley has become one of the preeminent universities in the world. Its early guiding lights, charged with providing education (both 'practical' and 'classical') for the state's people, gradually established a distinguished faculty (with 20 Nobel laureates to date), a stellar research library, and more than 350 academic programs.

\section{Conference Travel Grants}

\section{Subjects: All subjects}

Purpose: To allow students to attend professional conferences Eligibility: Applicants must be registered graduate students in good academic standing. They must be in the final stages of their graduate work and planning to present a paper on their dissertation research at the conference they are attending

Level of Study: Doctorate, Graduate

Type: Grant

Value: Amount of the grant depends upon the location of conference (i.e. up to US\$400 within California; US\$600 elsewhere in North America, including Mexico or Canada; and US $\$ 1,000$ outside North America)

Frequency: Dependent on funds available

Study Establishment: University of California, Berkeley

Country of Study: United States of America

Application Procedure: Applicants must submit an application form and one letter of support from their graduate advisor attesting to the academic merit of the trip. Applications can be obtained from the website

Closing Date: 3 weeks before the date of travel

For further information contact:

Email: aips@pakistanstudies-aips.org

\section{University of California, Los Angeles (UCLA) Center for 17th and 18th Century Studies and the William Andrews Clark Memorial Library}

10745 Dickson Plaza, 310 Royce Hall, Los Angeles, CA 90095 1404, United States of America

Tel: $\quad$ (1) 3102068552

Fax: $\quad$ (1) 3102068577

Email: c1718cs@humnet.ucla.edu

Website: www.c1718cs.ucla.edu/

Contact: Fellowship Co-ordinator

University of California, Los Angeles (UCLA) Center for 17th and 18th century Studies provides a forum for the 
discussion of central issues in the field of early modern studies, facilitates research and publication, supports scholarship and encourages the creation of interdisciplinary, crosscultural programmes that advance the understanding of this important period. The William Andrews Clark Memorial Library, administered by the Center, is known for its collections of rare books and manuscripts concerning 17th and 18th-century Britain and Europe, Oscar Wilde and the 1890 s, the history of printing, and certain aspects of the American West.

\section{Clark-Huntington Joint Bibliographical Fellowship}

Subjects: Early modern literature and history and other areas where the sponsoring libraries have common strengths

Purpose: To support bibliographical research

Level of Study: Postdoctorate, Professional development

Type: Fellowship

Value: US $\$ 5,000$

Length of Study: 2 months

Frequency: Annual

Study Establishment: The Clark Library and the Huntington Library

Country of Study: United States of America

No. of awards offered: 15

Application Procedure: Applicants must submit an application form, a curriculum vitae, a proposal statement, a bibliography and three letters of reference

Closing Date: 1 February

Funding: Private

No. of awards given last year: 1

No. of applicants last year: 15

For further information contact:

Email: ortiz@humnet.ucla.edu

Contact: Fellowship Co-ordinator

\section{University of California, Los Angeles (UCLA) Institute of American Cultures (IAC)}

1237 Murphy Hall, Box 951419, Los Angeles, CA 900951419, United States of America

Tel: $\quad$ (1) 3102062557

Fax: $\quad$ (1) 3108258099
Email: iaccoordinator@gdnet.ucla.edu

Website: www.gdnet.ucla.edu/iacweb/iachome.htm

Contact: Dr N Cherie Francis, Co-ordinator

The UCLA Institute of American Cultures (IAC) is committed to advancing knowledge, strengthening and integrating interdisciplinary research and enriching instruction on African Americans, American Indians, Asian Americans and Chicanos. Since 1969, the IAC has been responsible for developing and expanding graduate studies, research and training in ethnic studies and is a major contributor to the academic and intellectual life of the University.

\section{University of California at Los Angeles Institute of American Culture (IAC) Postdoctoral/Visiting Scholar Fellowships}

Subjects: Arts and humanities, education and teacher training, fine arts, applied arts, law, social sciences and sciences

Purpose: To enable PhD scholars wishing to work in association with the American Indian Studies Center, the BUNCHE Center for African American Studies, the Asian American Studies Center and the Chicano Studies Research Center, to conduct research and publish books or manuscripts relating to ethnic studies and interdisciplinary instruction

Eligibility: Open to citizens of the United States of America and permanent residents

Level of Study: Postdoctorate

Type: Fellowship

Value: US $\$ 29,000$; US $\$ 34,000$ stipend plus health benefits and up to US $\$ 4,000$ in research support

Length of Study: Up to 1 year

Frequency: Annual

Country of Study: United States of America

Application Procedure: Applicants must complete an application form, available from one of the ethnic studies centres, the IAC, or from the website

Closing Date: 31 December

No. of awards given last year: 4

Additional Information: Further information is available on request or from the website

For further information contact:

Tel: (1) 3108257315

Fax: (1) 3102067060

Email: aisc@ucla.edu

Contact: Fellowship Director 


\section{University of Cambridge}

The Old Schools, Trinity Lane, CB2 1TN, Cambridge, United Kingdom

\author{
Tel: $\quad$ (44) 1223337733 \\ Fax: (44) 1223332332 \\ Email: dmh14@cam.ac.uk \\ Website: www.admin.cam.ac.uk \\ Contact: Hugo Hocknell, Student Registry
}

The University of Cambridge is a loose confederation of faculties, colleges and other bodies. The colleges are mainly concerned with the teaching of their undergraduate students through tutorials and supervisions and the academic support of both graduate and undergraduate students, while the University employs professors, readers, lecturers and other teaching and administrative staff who provide the formal teaching in lectures, seminars and practical classes. The University also administers the University Library.

\section{Arthington-Davy Grants for Tongan Students for Postgraduate Study}

Subjects: Awards are made from the Arthington-Davy Fund, generously set up by the late Humphrey Augustus Arthington-Davy, British High Commissioner to the Kingdom of Tonga from 1973 to 1980 , and left by him to be managed by his Cambridge College, Trinity

Eligibility: Eligible applicants must: 1. Hold a first University degree. 2. Have applied for admission, or already received an offer of admission, for a post-graduate study course at any University in the world, and. 3. Be of Tongan origin

Level of Study: Postgraduate

Type: Grant

Value: Graduate Course Fees, and maintenance allowance, less any financial support received from elsewhere

Length of Study: For minimum further period required to complete $\mathrm{PhD}$

Frequency: Annual

Country of Study: Any country

Application Procedure: A completed application form should be sent together with the following: Proof of Tongan origin academic transcripts details of the intended postgraduate study, preferably with a letter of conditional acceptance from the University concerned 1. Clear and precise details of tuition fees, living expenses and finances available from the student's own resources and/or from other institutions. 2. Names and email addresses of two academic referees. 3. CV

Closing Date: 30 November

Funding: Private

Additional Information: www.trin.cam.ac.uk/postgraduate/ graduate-funding-awards/ for more information

\section{For further information contact:}

Email: grad.tutor@trin.cam.ac.uk

\section{Dorothy Hodgkin Postgraduate Award}

Eligibility: Applicants must have already applied for and been accepted for a $\mathrm{PhD}$ place at the University of Cambridge, must be a national of one of the eligible countries (Russia plus all countries on the DAC List of ODA Recipients), must be intending to start their $\mathrm{PhD}$ that coming October and must hold a high-grade qualification, at least the equivalent of a United Kingdom First Class (Honours) Degree, from a prestigious academic institution

Type: Award

Value: Approx. $£ 12,300$ per year (university composition plus college fees and maintenance stipend)

Length of Study: 3 years

Frequency: Annual

Application Procedure: There is no separate application form for this competition

Closing Date: 15 December

Contributor: The United Kingdom Research Councils and Industrial Partners

Additional Information: Each DHPA is jointly sponsored by both a Research Council partner and a private sector company partner. Further details can be found on the Research Councils United Kingdom website

\section{For further information contact:}

Email: kfw20@admin.cam.ac.uk

\section{Evans Fund}

Subjects: All aspects of anthropology and archaeology of South East Asia, especially in relation to Borneo, the Malay Peninsula, Singapore and Thailand

Purpose: To support research

Eligibility: Open to graduates of any university who intend to engage in research in a suitable field

Level of Study: Doctorate, Postdoctorate, Postgraduate

Type: Fellowship

Value: Up to UK£6,000 per year 
Length of Study: 1 or 2 years in the first instance, up to a maximum of 3 years

Frequency: Annual

Study Establishment: The University of Cambridge

Country of Study: Any country

No. of awards offered: 8

Application Procedure: Applicants must obtain an application form from the Secretary, which must be returned together with an outline of the applicant's proposed scheme of travel and research, a curriculum vitae and the names and addresses of two referees

Closing Date: 7 March

Funding: Private

Contributor: Legacy

No. of awards given last year: 5

No. of applicants last year: 8

Additional Information: It is expected that the successful candidate will either be based in Cambridge, or will spend a substantial period of time in Cambridge during or after their period of research

\section{For further information contact:}

Department of Social Anthropology, University of Cambridge, 2 Free School Lane, CB2 3QA, Cambridge, United Kingdom

Tel: $\quad$ (44) 1223334599

Fax: (44) 1223335993

Email: ms127@hermes.cam.ac.uk

Contact: Secretary, Evans Fund Advisory Committee

\section{Fitzwilliam College Charlton Studentships}

Subjects: All subjects

Purpose: Part-cost award for masters students

Eligibility: Fitzwilliam must be the applicant's first choice on university application form, and must have received a conditional offer from the university by the closing date for receipt of applications

Level of Study: Graduate

Type: Scholarship

Value: $£ 3,000$ to $£ 10,000$

Length of Study: 1 year

Frequency: Annual

Study Establishment: Fitzwilliam College

Country of Study: United Kingdom

No. of awards offered: 45

Application Procedure: Apply online at www.fitz.cam.ac. uk/academic/scholarships-prizes/graduate-scholarships

Closing Date: 31 March

Funding: Individuals
Contributor: Fitzwilliam College

No. of awards given last year: 2

No. of applicants last year: 45

Additional Information: Does not include PhD, MBA, MFin or PGCE.

\section{For further information contact:}

c/o graduate officer, Fitzwilliam College, CB3 0DG, Cambridge, United Kingdom

Email: graduate.officer@fitz.cam.ac.uk

\section{Fitzwilliam College Graduate Scholarship}

Subjects: All subjects

Eligibility: Open to candidates who have applied for admission to Cambridge University through the Board of Admission of Graduate Studies and subsequently satisfied the conditions of admission. Preference is given to those studying arts subjects

Level of Study: Postgraduate

Type: Fellowship

Value: $£ 1,250$

Length of Study: A maximum of 3 years. Candidates must reapply annually

Frequency: Annual

Study Establishment: Fitzwilliam College, University of Cambridge

Country of Study: United Kingdom

No. of awards offered: 15

Application Procedure: Applicants must write for details

Closing Date: Early September

Funding: Private

No. of awards given last year: 1

No. of applicants last year: 15

Additional Information: Preference is given to candidates conducting research in an arts subject

For further information contact:

Tel: $\quad$ (44) 1223332035

Fax: (44) 1223332082

Email: grad.scholarships@fitz.cam.ac.uk

Contact: Dr W Alison, Tutor for Graduate Students

\section{Fitzwilliam College Hirst-Player Studentship}

Subjects: Theology

Purpose: To support students who need assistance with payment of fees and who would otherwise be unable to read for a degree in Cambridge 
Eligibility: Open to graduates of any university. The awards are only available to candidates who have applied for admission to the University through the Board of Graduate Studies and subsequently satisfied the conditions of admission made by the Board. Preference is given to those intending to take holy orders in a Christian church

Level of Study: Postgraduate

Type: Studentship

Value: $£ 2,000$ per year. The award is designed to supplement other funds

Length of Study: 1 year

Frequency: Annual

Study Establishment: Fitzwilliam College, University of Cambridge

Country of Study: United Kingdom

Application Procedure: Applicants must complete the application form, available on request. Candidates should also place Fitzwilliam College as first preference on the form

Closing Date: 1 October

Funding: Private

No. of awards given last year: 1

\section{For further information contact:}

Email: grad.scholarships@fitz.cam.ac.uk

Contact: Dr W Alison, Tutor for Graduate Students

\section{Fitzwilliam College J R W Alexander Studentship in Law}

Subjects: Law

Eligibility: Open to graduates from a British university who will have graduated by the time they come into residence

Level of Study: Postgraduate

Type: Studentship

Value: $£ 350$. The award is designed to supplement funding from other sources

Length of Study: 1 year

Frequency: Annual

Study Establishment: Fitzwilliam College, University of Cambridge

Country of Study: United Kingdom

No. of awards offered: 2

Application Procedure: Applicants must have applied for admission to the University through the Board of Graduate Studies and subsequently satisfied the conditions of admission made by the Board. Candidates should also place Fitzwilliam College as their first preference on their application

Closing Date: 25 September

Funding: Private

No. of awards given last year: 1

No. of applicants last year: 2
For further information contact:

Email: graduate.office@fitz.cam.ac.uk

Contact: Dr W Alison, Tutor for Graduate Students

\section{Fitzwilliam College Leathersellers}

Subjects: Physical or biological sciences, mathematics or engineering

Purpose: To support students who wish to undertake research Eligibility: Open to home graduates from any United Kingdom university who have been admitted to a course of research in one of the appropriate faculties

Level of Study: Postgraduate

Type: Scholarship

Value: $£ 2,000$ per year. The award is designed to supplement funding from other sources

Length of Study: 3 years, subject to an annual review

Frequency: Annual

Study Establishment: Fitzwilliam College, University of Cambridge

Country of Study: United Kingdom

No. of awards offered: 6

Application Procedure: Applicants must complete an application form, available on request

Closing Date: 13 June

Funding: Commercial

No. of awards given last year: 1

No. of applicants last year: 6

\section{For further information contact:}

Email: graduate.office@fitz.cam.ac.uk

Contact: Dr W Alison, Tutor for Graduate Students

\section{Fitzwilliam College Research Fellowship}

Subjects: All subjects

Purpose: To enable scholars to carry out a programme of new research

Eligibility: Open to candidates who are carrying out research for a $\mathrm{PhD}$ at any United Kingdom or Irish university, or who have recently (normally defined as less than 1 year before the date of application) completed their course of study for this degree

Level of Study: Doctorate

Type: Fellowship

Value: Varies. Non-stipendiary funding is also offered (candidates are expected to apply for the appropriate grants for the support of their research on their own initiative)

Frequency: Annual 
Study Establishment: Fitzwilliam College, University of Cambridge

Country of Study: United Kingdom

No. of awards offered: 161

Application Procedure: Applicants must write for details

Closing Date: January

No. of awards given last year: 1

No. of applicants last year: 161

Additional Information: Fellowships are awarded for new research only and not to enable candidates to complete their $\mathrm{PhD}$ dissertation

\section{For further information contact:}

Email: jmw65@cam.acuk

Contact: The Master's Secretary

\section{Fitzwilliam College Shipley Studentship}

Subjects: Theology

Purpose: To enable graduates to undertake research

Eligibility: Open to graduates of any university. The awards are only available to candidates who have applied for admission to the University through the Board of Graduate Studies and subsequently satisfied the conditions of admission made by the Board. Candidates should also place Fitzwilliam College as their first preference in their application

Level of Study: Postgraduate

Type: Studentship

Value: $£ 1,250$ per year. The award is designed to supplement other funds

Length of Study: 1 year

Frequency: Annual

Study Establishment: Fitzwilliam College, University of Cambridge

Country of Study: United Kingdom

No. of awards offered: 5

Application Procedure: Applicants must complete an application form, available on request

Closing Date: 1 October

Funding: Private

No. of awards given last year: 1

No. of applicants last year: 5

For further information contact:

Email: graduate.office@fitz.cam.ac.uk

Contact: Dr W Alison, Tutor for Graduate Students

\section{Fitzwilliam College: E D Davies Scholarship}

Subjects: All subjects
Eligibility: Candidates should be already registered for, or applying for, a research degree course, at Fitzwilliam College Level of Study: Graduate

Type: Scholarship

Value: $£ 1,250$ per year

Length of Study: $1-3$ years, yearly re-application required

Frequency: Annual

Country of Study: United Kingdom

No. of awards offered: 25

Application Procedure: Submit online application form

Closing Date: 25 September

No. of awards given last year: 2

No. of applicants last year: 25

For further information contact:

Email: dmh14@cam.ac.uk

\section{Fitzwilliam College: Gibson Scholarship}

Subjects: Theology

Eligibility: Intention to work towards a doctorate in New Testament Studies required

Level of Study: Graduate, Postgraduate

Type: Scholarship

Value: $£ 1,000$ per year

Length of Study: $1-3$ years

Frequency: Annual

Country of Study: United Kingdom

No. of awards offered: 8

Application Procedure: Submit online application form

Closing Date: 25 September

No. of awards given last year: 1

No. of applicants last year: 8

For further information contact:

Email: graduate.office@fitz.cam.ac.uk

\section{Fitzwilliam College: Hirst-Player Scholarship}

Subjects: Theology

Eligibility: Students needing assistance with fees, who would otherwise be unable to study at Cambridge, eligible only. Students having intention to take Holy Orders in a Christian Church preferred. Students must be studying as a member of Fitzwilliam College during the period of the award

Level of Study: Postgraduate

Type: Scholarship

Value: $£ 2,000$ maximum

Length of Study: $1-2$ years

Frequency: Annual 
Country of Study: United Kingdom

Application Procedure: Submit online application form

Closing Date: 25 September

No. of awards given last year: 2

For further information contact:

Email: graduate.office@fitz.cam.ac.uk

\section{Fitzwilliam College: Leathersellers}

Subjects: Engineering

Eligibility: Only home graduates from a British University are eligible. Physical or biological sciences or mathematics students also eligible. Studying as a member of Fitzwilliam College during the period of the award

Level of Study: Doctorate

Type: Scholarship

Value: $£ 3,000$ per year

Length of Study: 1-3 years, subject to the approval of the Tutorial Committee

Frequency: Annual

Country of Study: United Kingdom

No. of awards offered: 8

Application Procedure: Application form available from college graduate admissions office gradadmissions@fitz. cam.ac.uk

Closing Date: 13 June

No. of awards given last year: 1

No. of applicants last year: 8

For further information contact:

Email: dmh14@cam.ac.uk

\section{Fitzwilliam College: Shipley Scholarship}

Subjects: Theology

Eligibility: Applicant must be studying as a member of Fitzwilliam during the period of the award

Level of Study: Graduate, Postgraduate

Type: Scholarship

Value: $£ 1,250$

Length of Study: 1 year

Frequency: Annual

Country of Study: United Kingdom

Application Procedure: Submit online application form

Closing Date: 25 September

No. of awards given last year: 1

For further information contact:

Email: graduate.office@fitz.cam.ac.uk

\section{Fitzwilliam Society JRW Alexander Law Book} Grants

Subjects: Law

Eligibility: All Fitzwilliam students on the LLM degree course are eligible

Level of Study: Postgraduate

Type: Grant

Value: $£ 100$

Length of Study: 1 year

Frequency: Annual

Country of Study: United Kingdom

No. of awards offered: 3

Application Procedure: No application is necessary

No. of awards given last year: 3

No. of applicants last year: 3

For further information contact:

Email: graduate.office@fitz.cam.ac.uk

\section{Fitzwilliam Studentship: Peter Wilson Estates Gazette Scholarships}

Subjects: Land economy

Purpose: Part-cost award

Eligibility: Preference is given to those who name Fitzwilliam as their first choice college on the university application form. One of the awards is prioritised for an applicant who has been an undergraduate member of the college

Level of Study: Graduate

Type: Scholarship

Value: $£ 3,000$

Length of Study: 1 year

Frequency: Annual

Country of Study: Any country

Application Procedure: Submit an online application form at www.fitz.cam.ac.uk/academic/scholarships-prizes/graduatescholarships

Closing Date: 31 March

Funding: Individuals

No. of awards given last year: 4

Additional Information: Any MPhil course offered by the Department of Land Economy at the University of Cambridge

\section{Girton College Graduate Research Scholarship}

Subjects: All subjects covered by Cambridge University Eligibility: A first-class degree is almost always required and election will be conditional on the candidate being granted Graduate Student status by the University of Cambridge. The 
holder must become a member of the college and either be a candidate for a masters or a $\mathrm{PhD}$ degree

Level of Study: Doctorate, Graduate, Postgraduate, MBA

Type: Scholarship

Value: University and college fees and some proportion of maintenance costs

Frequency: Annual

Study Establishment: University of Cambridge

Country of Study: United Kingdom

No. of awards offered: 200

Application Procedure: Application should be made online via www.girton.cam.ac.uk/graduates/research-awards

Closing Date: 28 March

No. of awards given last year: 3

No. of applicants last year: 200

For further information contact:

Email: graduate.office@girton.cam.ac.uk

\section{Girton College Overseas Bursaries}

Subjects: All subjects

Eligibility: A first-class degree is almost always required and election will be conditional on the candidate being granted Graduate Student status by the University of Cambridge. The holder must become a member of the college

Level of Study: Doctorate, Graduate, Postgraduate, MBA

Type: Bursary

Value: $£ 200-£ 1,000$ per year

Frequency: Dependent on funds available

Study Establishment: University of Cambridge

Country of Study: United Kingdom

Application Procedure: Application forms can be downloaded from www.girton.cam.ac.uk/graduates/researchawards or may be obtained from the Graduate Secretary, Girton College, Cambridge, CB3 0JG, United Kingdom (email: graduate.office@girton.cam.ac.uk)

Closing Date: 28 March

For further information contact:

Email: graduate.office@girton.cam.ac.uk

\section{Girton College: Doris Woodall Studentship}

Subjects: Research in economics or an allied subject Eligibility: A first-class degree is almost always required and election will be conditional on the candidate being granted Graduate Student status by the University of Cambridge. The holder must become a member of the college

Level of Study: Doctorate, Graduate, Postgraduate, MBA
Type: Studentship

Value: Between $£ 750$ and $£ 5,000$

Frequency: Annual

Study Establishment: University of Cambridge

Country of Study: United Kingdom

Application Procedure: Application should be made online via www.girton.cam.ac.uk/graduates/research-awards

Closing Date: 28 March

\section{For further information contact:}

Email: graduate.office@girton.cam.ac.uk

\section{Girton College: Ida and Isidore Cohen Research Scholarship}

Subjects: Modern Hebrew studies

Eligibility: Open to students working in modern Hebrew studies. A first-class degree is almost always required and election will be conditional on the candidate being granted Graduate Student status by the University of Cambridge. The holder must become a member of the college

Level of Study: Doctorate, Graduate, Postgraduate

Type: Scholarship

Value: Between $£ 3,000$ and $£ 5,000$

Frequency: Annual

Study Establishment: University of Cambridge

Country of Study: United Kingdom

Application Procedure: Application forms can be downloaded from external link or may be obtained from the Graduate Secretary, Girton College, Cambridge, CB3 0JG, United Kingdom

Closing Date: 28 March

For further information contact:

Email: graduate.office@girton.cam.ac.uk

\section{Girton College: Irene Hallinan Scholarship}

Subjects: All subjects covered by Cambridge University Eligibility: A first-class degree is almost always required and election will be conditional on the candidate being granted Graduate Student status by the University of Cambridge. The holder must become a member of the college and either be a candidate for a masters or a $\mathrm{PhD}$ degree

Level of Study: Doctorate, Graduate, Postgraduate, MBA

Type: Scholarship

Value: Between $£ 3,000$ and $£ 6,000$

Frequency: Annual

Study Establishment: University of Cambridge

Country of Study: United Kingdom 
No. of awards offered: 200

Application Procedure: Application should be made online via www.girton.cam.ac.uk/graduates/research-awards

Closing Date: 28 March

No. of awards given last year: 3

No. of applicants last year: 200

\section{For further information contact:}

Email: graduate.office@girton.cam.ac.uk

\section{Girton College: Maria Luisa de Sanchez Scholarship}

Subjects: All subjects covered by University of Cambridge Eligibility: Applicants must be of Venezuelan nationality. A first-class degree is almost always required and election will be conditional on the candidate being granted Graduate Student status by the University of Cambridge. The holder must become a member of the college

Level of Study: Doctorate, Graduate, Postgraduate, MBA

Type: Scholarship

Value: University and college fees, and some proportion of maintenance costs

Frequency: Annual

Study Establishment: University of Cambridge

Country of Study: United Kingdom

Application Procedure: Application forms can be downloaded from www.girton.cam.ac.uk/graduate/researchawards or may be obtained from the Graduate Secretary, Girton College, Cambridge, CB3 0JG, United Kingdom (email: graduate.office@girton.cam.ac.uk)

Closing Date: 28 March

No. of awards given last year: 1

Additional Information: Eligible to nationals of Venezuela

\section{For further information contact:}

Email: graduate.office@girton.cam.ac.uk

\section{Girton College: Ruth Whaley Scholarship}

Subjects: Anglo-saxon, norse and celtic, archaeology, history of art, architecture, landscape architecture, classics, linguistics, English, modern and medieval languages, history, music philosophy

Eligibility: Open to outstanding students of non-European Union citizenship seeking admission to Girton. It is open to students following arts subjects. A first-class degree is almost always required and election will be conditional on the candidate being granted Graduate Student status by the
University of Cambridge. The holder must become a member of the college

Level of Study: Doctorate, Graduate, Postgraduate

Type: Scholarship

Value: Contribution towards living costs

Frequency: Annual

Study Establishment: University of Cambridge

Country of Study: United Kingdom

Application Procedure: Application forms can be downloaded from www.girton.cam.ac.uk/graduates/research-awards or may be obtained from the Graduate Secretary

Closing Date: 28 March

No. of awards given last year: 1

Additional Information: For further details, please refer to the website www.girton.cam.ac.uk/students/graduatescholarships/

\section{For further information contact:}

Girton College, Huntingdon Rd, Girton, CB3 0JG, Cambridge, United Kingdom

Email: graduate.office@girton.cam.ac.uk

Contact: Graduate Secretary

\section{Girton College: Sidney and Marguerite Cody Studentship}

Purpose: Period of travel and study in continental Europe of up to 12 months and normally of not less than 6 months Eligibility: Open to graduate members of any faculty except English who have completed less than nine terms in residence. A first-class degree is almost always required and election will be conditional on the candidate being granted Graduate Student status by the University of Cambridge. The holder must become a member of the college

Level of Study: Doctorate, Graduate, Postgraduate

Type: Studentship

Value: Up to $£ 3,000$

Frequency: Annual

Study Establishment: University of Cambridge

Country of Study: United Kingdom

Application Procedure: Application should be made online via www.girton.cam.ac.uk/graduates/research-awards

Closing Date: 28 March

No. of awards given last year: 1

\section{For further information contact:}

Email: graduate.office@girton.cam.ac.uk 


\section{Girton College: Stribling Award}

Eligibility: Open to Girton students who are already members of the College, namely undergraduates coming into graduate status or current MPhil students who are going on to a $\mathrm{PhD}$. A first-class degree is almost always required and election will be conditional on the candidate being granted Graduate Student status by the University of Cambridge

Level of Study: Doctorate, Graduate, Postgraduate

Type: Award

Value: $£ 1,000$, normally in addition to a studentship or any other funding for fees and maintenance

Frequency: Annual

Study Establishment: University of Cambridge

Country of Study: United Kingdom

Application Procedure: Application should be made online via www.girton.cam.ac.uk/graduates/research-awards

Closing Date: 28 March

No. of awards given last year: 2

Additional Information: Award only available to Girton College Students

\section{For further information contact:}

Email: graduate.office@girton.cam.ac.uk

\section{Girton College: Travel Grant}

Level of Study: Graduate, Postgraduate

Type: Grant

Value: Contribution to academic travel and

Frequency: Every 2 years

Country of Study: Any country

Application Procedure: Application should be made online via www.girton.cam.ac.uk/graduates/research-awards

Closing Date: 22 April at midnight

Additional Information: Please note this is a strict dead-line, no allowance can be made for late applications or reference letters

\section{For further information contact:}

Email: graduate.office@girton.cam.ac.uk

\section{Gonville and Caius College Gonville Bursary}

Subjects: All subjects offered by the University

Purpose: To help outstanding students from outside the European Union to meet the costs of degree courses at the University of Cambridge
Eligibility: Open to candidates who have been accepted by the College through its normal admissions procedures, and who are classified as overseas students for fees purposes. A statement of financial circumstances is required

Level of Study: Doctorate, Postgraduate

Type: Bursary

Value: Reimbursement of college fees

Length of Study: Up to 3 years, with a possibility of renewal, dependent on satisfactory progress

Frequency: Annual

Study Establishment: Gonville and Caius College, the University of Cambridge

Country of Study: United Kingdom

Application Procedure: Applicants must contact the Admissions Tutor for further information. There are no application forms

Closing Date: Deadlines are the same as for the University's courses

\section{For further information contact:}

Gonville and Caius College, Trinity Street, CB2 1TA, Cambridge, United Kingdom

Tel: $\quad$ (44) 1223332447

Fax: (44) 1223332456

Email: admissions@cai.cam.ac.uk

Contact: Admissions Tutor

\section{Gonville and Caius College Michael Miliffe Scholarship}

Subjects: All subjects

Purpose: To help candidates from underdeveloped countries Eligibility: Open to both undergraduate and graduate students from developing countries who have been admitted through the College's normal admissions procedures

Type: Scholarship

Value: Approx. $£ 5,000$ per year with the possibility of additional support in exceptional cases

Frequency: Annual

Study Establishment: Gonville and Caius College, University of Cambridge

Country of Study: United Kingdom

Application Procedure: Applicants must complete an application form. Please write to the Director at the main address or email fellowships@brown.edu

Closing Date: The same as for the University's courses Additional Information: There are no application forms

\section{For further information contact:}

Contact: Dr P Binski, Tutor for Admissions 


\section{Gonville and Caius College W M Tapp Studentship in Law}

\section{Subjects: Law}

Purpose: To encourage the study of law

Eligibility: Open to candidates who are not already members of the College, but who propose to register as graduate students at the University of Cambridge. Candidates must be under 30 years of age as of October 1st of the studentship year and be graduates or expect to be graduates no later than August of the same year. Preference is given to applicants nominating Gonville and Caius College as their first choice when applying under the Cambridge Intercollegiate Graduate Application Scheme

Level of Study: Doctorate, Postgraduate

Type: Studentship

Value: A stipend similar to that of a state studentship for research, plus fees and certain allowances, a dependent allowance, an allowance for a period of approved postgraduate experience, a travelling contribution for foreign students and a research allowance for research students

Length of Study: 1 year, renewable for up to a maximum of 3 years

Frequency: Annual

Study Establishment: Gonville and Caius College, University of Cambridge

Country of Study: United Kingdom

Application Procedure: Applicants must complete an application form, available from the Admissions Tutor

Closing Date: 15 January

\section{Kings College: Stipendiary Junior Research Fellowships}

Purpose: To support gifted young researchers

Level of Study: Postdoctorate, Research

Type: Fellowship

Value: Permit complete freedom to carry out research within the academic environment of the college

Length of Study: 4 years

Frequency: Annual

Study Establishment: University of Cambridge, King's College

Country of Study: United Kingdom

Closing Date: October

\section{For further information contact:}

King's College, King's Parade, CB2 1ST, Cambridge, United Kingdom
Tel:

Email:

(44) 1223331100

Contact: Dr Keith Carne, Bursary

\section{Lucy Cavendish College: Becker Law Scholarships}

Subjects: Law

Eligibility: Open to women accepted to read for the LLM and MCL by the law Faculty at the University of Cambridge

Level of Study: Postgraduate

Type: Scholarship

Value: At least $£ 1,000$ per year

Length of Study: Up to 3 years, conditional on satisfactory academic progress

Frequency: Annual

Study Establishment: Lucy Cavendish College, University of Cambridge

Country of Study: United Kingdom

Application Procedure: Please contact to the Secretary of the Studentship and Bursary Committee

Closing Date: 30 June

\section{For further information contact:}

Lucy Cavendish College, Lady Margaret Rd, CB3 0BU, Cambridge, United Kingdom

Tel: $\quad$ (44) 1223332190

Fax: (44) 1223332178

Email: st420@cam.ac.uk

Contact: Secretary, Studentship and Bursary Committee

\section{Lucy Cavendish College: Dorothy and Joseph Needham Studentship}

Purpose: For studies in Natural Sciences

Eligibility: Check website or contact organisation for updates Level of Study: Postgraduate

Type: Studentship

Value: $£ 1,000$ per year

Length of Study: Up to 3 years, conditional on satisfactory academic progress

Frequency: Annual

Study Establishment: Lucy Cavendish College, University of Cambridge

Country of Study: United Kingdom

Application Procedure: Please contact to the Secretary of the Studentship and Bursary Committee

Closing Date: 30 June 


\section{Lucy Cavendish College: Enterprise Studentship}

Subjects: For MBA or MPhil in Bioscience Enterprise

Eligibility: Open to women accepted on the MBA course and on the MPhil in Bioscience Enterprise. One is open to any student the other is only available to nationals of United States of America and Canada

Level of Study: Postgraduate, MBA

Type: Studentship

Value: $£ 1,000$ per year

Frequency: Annual

Study Establishment: Lucy Cavendish College, University of Cambridge

Country of Study: United Kingdom

Application Procedure: Please contact to the Secretary of the Studentship and Bursary Committee

Closing Date: 30 June

\section{Lucy Cavendish College: Evelyn Povey Studentship}

Purpose: For postgraduate research in French Studies

Eligibility: A woman accepted to undertake postgraduate research in French or French Studies at the faculty of Medieval and Modern languages at the University of Cambridge

Level of Study: Postgraduate, Research

Type: Studentship

Value: up to $£ 4,500$ per annum

Length of Study: Up to 3 years, conditional on satisfactory academic progress

Frequency: Annual

Study Establishment: Lucy Cavendish College, University of Cambridge

Country of Study: United Kingdom

Application Procedure: Candidates who are accepted by the University of Cambridge and Lucy Cavendish College will automatically be considered, there is no separate form of application

Closing Date: 28 February each year

Funding: Trusts

Lucy Cavendish College: Isaac Newton - Dorothy Emmet Research Fellowships Positions in Arts and Humanities

Subjects: Arts and humanities, law and English

Purpose: To assist research in the arts and humanities, with a preference for law and English

Eligibility: Open to women who hold $\mathrm{PhDs}$ for research in the arts and humanities, with a preference for law and English Level of Study: Postdoctorate
Type: Fellowships

Value: Stipend for each of these Research Fellowships will be $£ 17,111$ per year

Length of Study: The appointments will be for one year in the first instance from October and will be renewable annually Frequency: Annual

Application Procedure: Please contact to the Secretary of the Studentship and Bursary Committee

Closing Date: 31 May

For further information contact:

Email: lcc-admin@lists.cam.ac.uk

Contact: Secretary of the Studentship and Bursary Committee

\section{Lucy Cavendish College: Lord Frederick Cavendish Studentship}

Purpose: For doctoral research in any subject

Eligibility: Open to women accepted to undertake doctoral research in any subject at the University of Cambridge

Level of Study: Postgraduate

Type: Studentship

Value: college fees

Length of Study: Up to 3 years, conditional on satisfactory academic progress

Frequency: Annual

Study Establishment: Lucy Cavendish College, University of Cambridge

Country of Study: United Kingdom

Application Procedure: Please contact to the Secretary of the Studentship and Bursary Committee

Closing Date: 30 June

\section{Lucy Cavendish College: Mastermann-Braithwaite Studentship}

Subjects: Linguistics

Eligibility: A woman accepted to undertake postgraduate research in Linguistics at the University of Cambridge

Level of Study: Postgraduate, Research

Type: Studentship

Value: College fees

Length of Study: Up to 3 years, conditional on satisfactory academic progress

Frequency: Annual

Study Establishment: Lucy Cavendish College, University of Cambridge

Country of Study: United Kingdom 
Application Procedure: Please contact to the Secretary of the Studentship and Bursary Committee

Closing Date: 30 June

\section{Lucy Cavendish College: Research Fellowships}

Subjects: arts and humanities, social sciences or science and engineering

Purpose: To support post-doctoral research

Eligibility: Female, right to work in United Kingdom, holder of $\mathrm{PhD}$ or equivalents

Level of Study: Postdoctorate

Type: Research fellowship

Value: tbc

Length of Study: 3 years

Frequency: Every 3 years

Study Establishment: Lucy Cavendish College, University of Cambridge

Country of Study: As applicable

No. of awards offered: 110

Application Procedure: see notices when advertised

Funding: Private

No. of awards given last year: 1

No. of applicants last year: 110

\section{For further information contact:}

Email: registrar@lucy-cav.cam.ac.uk

Contact: Registrar

\section{Nabil Boustany Scholarships}

Subjects: MBA

Purpose: To enable a Lebanese national to attend the Cambridge MBA on a full scholarship

Eligibility: Open to candidates of all nations although priority given to Lebanese nationals, who have obtained a good Honours Degree from a recognized university and have at least 3 years of full-time, real-world experience. Candidates will need to demonstrate a high intellectual potential, practical common sense and the ability to put ideas into action. They also need to be highly motivated with a strong desire to learn. Applicants will be asked to take the Test of English as a Foreign Language (TOEFL) where applicable and the Graduate Management Admission Test (GMAT)

Level of Study: MBA

Type: Scholarship

Value: $£ 30,000$

Length of Study: 2 years

Frequency: Every 2 years
Study Establishment: Judge Business School, University of Cambridge

Country of Study: United Kingdom

No. of awards offered: 4

Application Procedure: Applicants must email their curriculum vitae to admissions@boustany-foundation.org. Applicants must also be applying for the Cambridge MBA programme

Closing Date: 15 May

Funding: Foundation

Contributor: The Nabil Boustany Foundation

No. of awards given last year: 1

No. of applicants last year: 4

Additional Information: The scholarship recipient is normally required to spend a summer internship, carrying no salary, within a Lebanese organization. Applicants must be accepted into the Cambridge MBA programme

\section{For further information contact:}

1 avenue des Citronniers, 06800 Cagnes-sur-Mer, France

Fax: (44) 7793150556

Email: info@boustany-foundation.org

Contact: Mr M Tamar

\section{Newnham College: Moody-Stuart Scholarships in Turkish Studies}

\section{For further information contact:}

Newnham College, Sidgwick Avenue, CB3 9DF, Cambridge, United Kingdom

Tel: $\quad$ (44) 1223335700

Fax: (44) 1223357898

Email: enquiries@newnham.cam.ac.uk

Contact: Bursar

\section{Osborn Research Studentship}

Subjects: Medieval art, architectural and cultural history Purpose: To support students carrying research or taking advanced courses

Level of Study: Postdoctorate, Postgraduate

Type: Studentship

Value: Up to $£ 12,000$ to match with funds administered centrally by the UCAM

Length of Study: $1-3$ years

Frequency: Every 3 years

Study Establishment: The University of Cambridge

Country of Study: United Kingdom 
Application Procedure: For further details, please check website www.sid.cam.ac.uk/current/postgrads/scholarships Closing Date: 1 April

Funding: Private

Contributor: Sidney Sussex College

\section{For further information contact:}

Email: graduate.funding@admin.cam.ac.uk

\section{Pembroke College: College Research Studentships}

Subjects: All subjects

Eligibility: Preference in awarding these studentships will be given to candidates who intend to register for a $\mathrm{PhD}$ degree at Pembroke. However, candidates registering to study for an MPhil will also be considered for an award if they are intending to carry on to a $\mathrm{PhD}$ after they have finished their MPhil

Level of Study: Postgraduate

Type: Studentship

Value: College/University fees plus a maintenance allowance of $£ 12,000$ per year

Frequency: Annual

Study Establishment: Pembroke College

Country of Study: United Kingdom

Application Procedure: All applicants for any of these awards must apply in the first instance to the Board of Graduate Studies for their University place. Candidates should indicate that they are applying for a Pembroke College award. In making awards preference will be given to those who nominate Pembroke as their college of first choice. All candidates are expected to apply for Research Council funding where appropriate, and for University CHESS funding, if they are eligible. The College will take into account candidates' income from other sources when making awards

Closing Date: 6 January

Additional Information: Applicants should also complete a Pembroke Studentship form. This can be completed online, downloaded or obtained from the Graduate Secretary. The awards are conditional on the selected students being admitted as a registered Graduate Student by the Board of Graduate Studies with effect from October 1st each academic year. Early application is recommended

\section{For further information contact:}

Pembroke College, CB2 1RF, Cambridge, United Kingdom
Tel:
(44) 1223338100
Fax:
(44) 1223338163
Email: tut@pem.cam.ac.uk
Contact: Graduate Secretary

\section{Pembroke College: Graduate Studentships in Arabic and Islamic Studies (including Persian)}

Subjects: Arabic and Islamic studies

Eligibility: Preference in awarding these studentships will be given to candidates who intend to register for a $\mathrm{PhD}$ degree at Pembroke. However, candidates registering to study for an MPhil will also be considered for an award if they are intending to carry on to a $\mathrm{PhD}$ after they have finished their MPhil

Level of Study: Postgraduate

Type: Studentship

Value: Covers University and College fees (at the Home/European Union rate) for three years

Frequency: Annual

Study Establishment: Pembroke College

Country of Study: United Kingdom

Application Procedure: All applicants for any of these awards must apply in the first instance to the Board of Graduate Studies for their University place. Candidates should indicate that they are applying for a Pembroke College award. In making awards preference will be given to those who nominate Pembroke as their college of first choice. All candidates are expected to apply for Research Council funding where appropriate, and for University CHESS funding, if they are eligible. The college will take into account candidates' income from other sources when making awards Closing Date: Please check website

Additional Information: Applicants should also complete a Pembroke Studentship form. This can be completed online, downloaded or obtained from the Graduate Secretary. The awards are conditional on the selected students being admitted as a registered Graduate Student by the Board of Graduate Studies with effect from October 1st each academic year. Early application is recommended.

\section{Pembroke College: MPhil Studentship for Applicants from the Least Developed Countries}

Subjects: All subjects

Purpose: The College is offering this one-year studentship to enable the winner to study for an MPhil degree, or equivalent, at the University of Cambridge

Eligibility: Eligibility is confined to nationals of the fifty 'Least Developed Countries' as defined by the United Nations. The other is for nationals of the fifty 'Least Developed Countries' as defined by the United Nations (check at www.un.org/special-rep/ohrlls/ldc/list), most of which are in Africa or South-East Asia

Level of Study: Postgraduate

Type: Studentship 
Value: University fees at least at the standard rate for Home/European Union students, plus college fees and a maintenance of $£ 10,465$

Frequency: Annual

Study Establishment: Pembroke College, University of Cambridge

Application Procedure: All applicants for any of these awards must apply in the first instance to the Board of Graduate Studies for their University place. Candidates should indicate that they are applying for a Pembroke College award. In making awards preference will be given to those who nominate Pembroke as their College of first choice. All candidates are expected to apply for Research Council funding where appropriate, and for University CHESS funding, if they are eligible. The College will take into account candidates' income from other sources when making awards

Additional Information: Applicants should also complete a Pembroke Studentship form. This can be completed online, downloaded or obtained from the Graduate Secretary. The awards are conditional on the selected students being admitted as a registered Graduate Student by the Board of Graduate Studies with effect from October 1st each academic year. Early application is recommended

\section{Pembroke College: The Bethune-Baker Graduate Studentship in Theology}

Subjects: Arabic and Islamic studies, law, and theology

Eligibility: Open to candidates who intend to register for the $\mathrm{PhD}$ degree at the University of Cambridge

Level of Study: Postgraduate

Type: Studentship

Value: College and university fees for three years

Frequency: Annual

Study Establishment: University of Cambridge

Country of Study: United Kingdom

Application Procedure: All applicants for any of these awards must apply in the first instance to the Board of Graduate Studies for their University place. Candidates should indicate that they are applying for a Pembroke College award. In making awards preference will be given to those who nominate Pembroke as their college of first choice. All candidates are expected to apply for Research Council funding where appropriate, and for University CHESS funding, if they are eligible. The College will take into account candidates' income from other sources when making awards

Closing Date: Please check website

Contributor: HM the Sultan of Oman and of Professor

E.G. Browne
Additional Information: Applicants should also complete a Pembroke Studentship form. This can be completed online, downloaded or obtained from the Graduate Secretary. The awards are conditional on the selected students being admitted as a registered Graduate Student by the Board of Graduate Studies with effect from October 1st each academic year. Early application is recommended

\section{Pembroke College: The Bristol-Myers Squibb Graduate Studentship in the Biomedical Sciences}

Subjects: History, physics and the bio-medical sciences Eligibility: Open to candidates who intend to register for a $\mathrm{PhD}$ degree at the University of Cambridge

Level of Study: Postgraduate

Type: Studentship

Value: The studentship will have a value sufficient to pay college fees for three years

Frequency: Annual

Country of Study: United Kingdom

Application Procedure: All applicants for any of these awards must apply in the first instance to the Board of Graduate Studies for their University place. Candidates should indicate that they are applying for a Pembroke College award. In making awards preference will be given to those who nominate Pembroke as their college of first choice. All candidates are expected to apply for Research Council funding where appropriate, and for University CHESS funding, if they are eligible. The College will take into account candidates' income from other sources when making awards

Closing Date: Please check website

Additional Information: Applicants should also complete a Pembroke Studentship form. This can be completed online, downloaded or obtained from the Graduate Secretary. The awards are conditional on the selected students being admitted as a registered Graduate Student by the Board of Graduate Studies with effect from October 1st each academic year. Early application is recommended

\section{Pembroke College: The Grosvenor-Shilling Bursary in Land Economy}

Subjects: All subjects

Eligibility: Applicants must normally reside in Australia and hold a qualification from an Australian tertiary institution. There is no restriction as to the academic field

Level of Study: Postgraduate

Type: Scholarship

Value: $£ 500$

Frequency: Annual 
Application Procedure: All applicants for any of these awards must apply in the first instance to the Board of Graduate Studies for their University place. Candidates should indicate that they are applying for a Pembroke College award. In making awards preference will be given to those who nominate Pembroke as their college of first choice. All candidates are expected to apply for Research Council funding where appropriate, and for University CHESS funding, if they are eligible. The College will take into account candidates' income from other sources when making awards

Closing Date: Please check website

Additional Information: Applicants should also complete a Pembroke Studentship form. This can be completed online, downloaded or obtained from the Graduate Secretary. The awards are conditional on the selected students being admitted as a registered Graduate Student by the Board of Graduate Studies with effect from October 1st each academic year. Early application is recommended

\section{Pembroke College: The Lander Studentship in the History of Art}

Purpose: The College is very pleased to be able to offer one studentship for an outstanding art historian, supported by the estate of Professor J.R. Lander

Eligibility: Candidates must be applying to study for a $\mathrm{PhD}$ degree in the History of Art at the University of Cambridge, with Pembroke as first-choice college

Level of Study: Postgraduate

Type: Studentship

Value: The studentship will, if necessary, pay university and college fees, at the home rate, plus a maintenance allowance (approx. $£ 10,140$ a year), for a maximum of 3 years

Frequency: Annual

Study Establishment: Pembroke College, University of Cambridge

Country of Study: United Kingdom

Application Procedure: All applicants for any of these awards must apply in the first instance to the Board of Graduate Studies for their University place. Candidates should indicate that they are applying for a Pembroke College award. In making awards preference will be given to those who nominate Pembroke as their College of first choice. All candidates are expected to apply for Research Council funding where appropriate, and for University CHESS funding, if they are eligible. The College will take into account candidates' income from other sources when making awards

Closing Date: 10 January

Additional Information: Applicants should also complete a Pembroke Studentship form. This can be completed online, downloaded or obtained from the Graduate Secretary. The awards are conditional on the selected students being admitted as a registered Graduate Student by the Board of Graduate Studies with effect from October 1st each academic year. Early application is recommended

\section{Pembroke College: The Monica Partridge Studentship}

Subjects: All subjects

Purpose: To offer a graduate studentship for a student from South-East Europe to study at Pembroke

Eligibility: Open to the students of the nationals of Albania, Bosnia and Herzegovina, Bulgaria, Croatia, Greece, Kosovo, Macedonia, Montenegro and Serbia. Applications from students from Romania, Slovenia and Turkey will be considered if there is no suitable candidate from the countries listed above. Preference will be given to fund students studying for a $\mathrm{PhD}$, but MPhil applicants intending to continue to a $\mathrm{PhD}$ will also be considered

Level of Study: Postgraduate

Type: Studentship

Value: The studentship will have a value sufficient to cover college fees $(£ 2,229)$ and maintenance $(£ 10,140)$ for three years for a PhD student or, in the case of an MPhil student, one year

Frequency: Annual

Study Establishment: Pembroke College, University of Cambridge

Country of Study: United Kingdom

Application Procedure: All applicants for any of these awards must apply in the first instance to the Board of Graduate Studies for their University place. Candidates should indicate that they are applying for a Pembroke College award. In making awards preference will be given to those who nominate Pembroke as their college of first choice. All candidates are expected to apply for Research Council funding where appropriate, and for University CHESS funding, if they are eligible. The College will take into account candidates' income from other sources when making awards

Closing Date: 31 January

Additional Information: Applicants should also complete a Pembroke Studentship form. This can be completed online, downloaded or obtained from the Graduate Secretary. The awards are conditional on the selected students being admitted as a registered Graduate Student by the Board of Graduate Studies with effect from October 1st each academic year. Early application is recommended 


\section{Pembroke College: The Nahum Graduate Studentship in Physics}

Subjects: Physics

Eligibility: Preference in awarding these studentships will be given to candidates who intend to register for a $\mathrm{PhD}$ degree at Pembroke. However, candidates registering to study for an MPhil will also be considered for an award if they are intending to carry on to a $\mathrm{PhD}$ after they have finished their MPhil

Level of Study: Postgraduate

Type: Studentship

Value: The studentship will have a value sufficient to pay College fees for three years. Moreover, additional awards, of up to the equivalent of University fees for a Home student $(£ 3,465)$, may be made to individual applicants, depending on need and the availability of funds

Frequency: Annual

Study Establishment: Pembroke College

Country of Study: United Kingdom

Application Procedure: All applicants for any of these awards must apply in the first instance to the Board of Graduate Studies for their University place. Candidates should indicate that they are applying for a Pembroke College award. In making awards preference will be given to those who nominate Pembroke as their college of first choice. All candidates are expected to apply for Research Council funding where appropriate, and for University CHESS funding, if they are eligible. The College will take into account candidates' income from other sources when making awards

Closing Date: 31 January

Additional Information: Applicants should also complete a Pembroke Studentship form. This can be completed online, downloaded or obtained from the Graduate Secretary. The awards are conditional on the selected students being admitted as a registered Graduate Student by the Board of Graduate Studies with effect from October 1st each academic year. Early application is recommended

\section{Pembroke College: The Pembroke Australian Scholarship}

Subjects: All subjects

Eligibility: Applicants must normally reside in Australia and hold a qualification from an Australian tertiary institution. There is no restriction as to the academic field

Level of Study: Postgraduate

Type: Scholarship

Value: $£ 500$
Frequency: Annual

Application Procedure: All applicants for any of these awards must apply in the first instance to the Board of Graduate Studies for their University place. Candidates should indicate that they are applying for a Pembroke College award. In making awards preference will be given to those who nominate Pembroke as their College of first choice. All candidates are expected to apply for Research Council funding where appropriate, and for University CHESS funding, if they are eligible. The College will take into account candidates' income from other sources when making awards

Closing Date: 31 January

Additional Information: Applicants should also complete a Pembroke Studentship form. This can be completed online, downloaded or obtained from the Graduate Secretary. The awards are conditional on the selected students being admitted as a registered Graduate Student by the Board of Graduate Studies with effect from October 1st each academic year. Early application is recommended

\section{Pembroke College: The Thornton Graduate Studentship in History}

Subjects: History

Eligibility: Preference in awarding these studentships will be given to candidates who intend to register for a $\mathrm{PhD}$ degree at Pembroke. However, candidates registering to study for an MPhil will also be considered for an award if they are intending to carry on to a $\mathrm{PhD}$ after they have finished their MPhil

Level of Study: Postgraduate

Type: Studentship

Value: The studentship will have a value sufficient to pay College fees for three years. Moreover, additional awards, of up to the equivalent of University fees for a Home student $(£ 3,465)$, may be made to individual applicants, depending on need and the availability of funds

Frequency: Annual

Study Establishment: Pembroke College

Country of Study: United Kingdom

Application Procedure: All applicants for any of these awards must apply in the first instance to the Board of Graduate Studies for their University place. Candidates should indicate that they are applying for a Pembroke College award. In making awards preference will be given to those who nominate Pembroke as their college of first choice. All candidates are expected to apply for Research Council funding where appropriate, and for University CHESS funding, if they are eligible. The College will take into account candidates' income from other sources when making awards 
Closing Date: 31 January

Additional Information: Applicants should also complete a Pembroke Studentship form. This can be completed online, downloaded or obtained from the Graduate Secretary. The awards are conditional on the selected students being admitted as a registered Graduate Student by the Board of Graduate Studies with effect from October 1st each academic year. Early application is recommended

\section{Pembroke College: The Ziegler Graduate Studentship in Law}

Subjects: Law

Eligibility: Preference in awarding studentships is given to candidates who intend to register for a $\mathrm{PhD}$ degree at Pembroke

Level of Study: Postgraduate

Type: Studentship

Value: Covers university and college fees (at the Home/European Union rate)

Frequency: Annual

Study Establishment: Pembroke College

Country of Study: United Kingdom

Application Procedure: All applicants for any of these awards must apply in the first instance to the Board of Graduate Studies for their University place. Candidates should indicate that they are applying for a Pembroke College award. In making awards preference will be given to those who nominate Pembroke as their college of first choice. All candidates are expected to apply for Research Council funding where appropriate, and for University CHESS funding, if they are eligible. The College will take into account candidates' income from other sources when making awards

Closing Date: 31 January

Additional Information: Applicants should also complete a Pembroke Studentship form. This can be completed online, downloaded or obtained from the Graduate Secretary. The awards are conditional on the selected students being admitted as a registered Graduate Student by the Board of Graduate Studies with effect from October 1 st each academic year. Early application is recommended

\section{Peterhouse: Research Studentships}

Subjects: All subjects

Eligibility: Open to prospective $\mathrm{PhD}$ candidates

Level of Study: Postgraduate

Type: Studentship

Value: varies

Frequency: Annual

Study Establishment: Peterhouse College
Country of Study: United Kingdom

No. of awards offered: 57

Application Procedure: Please contact at graduates@pet. cam.ac.uk for more information

Closing Date: Early January

No. of awards given last year: 5

No. of applicants last year: 57

Additional Information: Number of awards varies from year to year

\section{For further information contact:}

Peterhouse, Trumpington Street, CB2 1RD, Cambridge, United Kingdom

Email: graduates@pet.cam.ac.uk

Contact: Graduate Admissions

\section{Principal's Studentship}

Subjects: Mathematics or humanities

Purpose: To support an MPhil or PhD student

Level of Study: Graduate

Type: Studentship

Value: Approx. Between $£ 3,000$ and $£ 12,000$ per year

Length of Study: $1-3$ years

Frequency: Dependent on funds available

Study Establishment: Newnham College, University of Cambridge

Country of Study: United Kingdom

Closing Date: 3 April

Funding: Private

\section{For further information contact:}

Email: studentfunding@ed.ac.uk

\section{Ramanujan Research Studentship in Mathematics}

Subjects: Mathematics

Purpose: The Ramanujan Studentship is normally awarded for nine months in the first instance, while the student takes the course leading to the MASt in Mathematics

Eligibility: For students from India hoping to do research for a PhD degree in Cambridge. Students of any University or comparable institution in India who have not already begun residence in Cambridge and who hold a First Class Honours degree or its equivalent, or are likely to do so by the time of entry, are eligible to apply

Level of Study: Research

Type: Studentship 
Value: Graduate Course Fees, maintenance allowance (at up to the minimum rate set by the University), and a return ticket from India to the United Kingdom

Length of Study: For minimum duration of the course (can be renewed for further 3 years)

Frequency: Annual

Country of Study: United Kingdom

Closing Date: 18 January

Additional Information: Shortlisted applicants will be invited to submit a full application by 4 February

\section{For further information contact:}

Email: gradfunding-at-trin.cam.ac.uk

\section{Ramanujan Research Studentship in Mathematics at Trinity College, Cambridge}

Subjects: Studentship is awarded in the field of Pure or Applied Mathematics of Cambridge

Purpose: Trinity College, University of Cambridge is offering Ramanujan Research Studentship for students who wish to undertake research in Mathematics. Student should hold a first class honours degree or its equivalent from any university or comparable institution in India

Eligibility: Indian students can apply for this studentship. Applicants from outside the home country will often need to meet specific English language/other language requirements in order to be able to study there

Type: Research

Value: For a student who has no support or only partial support from any other source, the studentship covers: Graduate Course Fees, Maintenance allowance (at up to the minimum rate set by the University), and a Return ticket from India to the United Kingdom. If the Studentship is renewed for the $\mathrm{PhD}$, another return ticket from India to the United Kingdom will be awarded. The applicant may also be considered for a discretionary maintenance allowance for the period between completion of the MASt and commencement of PhD

Study Establishment: Studentship is awarded in the field of Pure or Applied Mathematics of Cambridge

Country of Study: Any country

Application Procedure: Completed Preliminary Application Forms must be returned by post or email

Closing Date: 15 January

Additional Information: For more details please browse the website scholarship-positions.com/ramanujan-researchstudentship-mathematics-trinity-college-cambridge-uk/2015/ $11 / 14 /$

\section{For further information contact:}

Email: gradfunding-at-trin.cam.ac.uk

\section{Robinson College: Lewis Graduate Scholarship}

Purpose: The College expects to award one Lewis Scholarship to a graduate student applying to read for a $\mathrm{PhD}$ degree in the humanities

Eligibility: Open to all applicants who name Robinson College as their college of first choice on the Board of Graduate Studies Application Form for Admissions as a Graduate student, or are prepared to change college if offered the scholarship. The scholarship is conditional on the candidate being offered a place at the University

Level of Study: Postgraduate

Type: Scholarship

Value: varies

Length of Study: The scholarship is tenable for up to 3 years, subject to satisfactory academic progress

Study Establishment: University of Cambridge

Country of Study: United Kingdom

Application Procedure: Applicants should send a curriculum vitae and details of their intended programme of research including no more than one A4 page describing their proposed research project), together with details of other grant applications. Applications must be submitted by post to the Graduate Admissions Tutor

Closing Date: Please check website

Additional Information: Please check website for latest updates

\section{For further information contact:}

Robinson College, Grange Rd, CB3 9AN, Cambridge, United Kingdom

Tel: (44) 1223339100

Fax: (44) 1223351794

Email: graduate-admissions@robinson.cam.ac.uk

Contact: Graduate Admissions Tutor

\section{St John's College Benefactors' Scholarships for Research}

Subjects: All subjects offered by the University

Purpose: To fund candidates for $\mathrm{PhD}$ and MPhil degrees

Eligibility: Open to candidates of any nationality with a First Class (Honours) Degree or equivalent

Level of Study: Postgraduate

Type: Scholarship

Value: $£ 9,000$, plus approved college and university fees, a Scholar's Book Grant of up to $£ 100$ and other expenses

Length of Study: Up to 3 years

Frequency: Annual 
Study Establishment: St John's College, University of Cambridge

Country of Study: United Kingdom

Application Procedure: Applicants must see the Cambridge University Graduate Studies prospectus for particulars

Closing Date: 1 May

No. of awards given last year: 3

For further information contact:

St John's College, St John's Street, CB2 1TP, Cambridge, United Kingdom

Tel: (44) 1223338612

Fax: (44) 1223766419

Email: graduate_admissions@joh.cam.ac.uk

\section{Trinity College: Studentships in Mathematics}

Subjects: Mathematics

Purpose: The Trinity Studentship in Mathematics is a one-year studentship intended for students who wish to undertake research in Mathematics at the University of Cambridge but who are required by the Faculty of Mathematics to take, in the first instance, the course leading to the Master of Advanced Study (MASt)

Eligibility: Eligible candidates must; 1. Have applied for admission, or already received an offer of admission, to the University of Cambridge for the MASt degree. 2. Not yet have been members of the University of Cambridge as an undergraduate or graduate student

Level of Study: Graduate, Postgraduate

Type: Studentship

Value: Graduate Course Fees for the MASt, discretionary maintenance allowance, and return ticket from the country of origin to the United Kingdom for overseas students

Length of Study: 1 year of study

Frequency: Annual

Country of Study: Any country

Closing Date: 22 January

Funding: Private

Additional Information: Please visit the website for more information

\section{Westminster College Lewis and Gibson Scholarship}

\section{Subjects: Theology}

Purpose: To enable Scholars to study for a theology degree at the University of Cambridge as an integral part of his or her training for the ministry of a church in the reformed tradition which has a Presbyterian order

Eligibility: Open to graduates of a recognised university who are members of the United Reformed Church in the United Kingdom or of any church not established by the state which is a member of the World Alliance of Reformed Churches and has a Presbyterian form of government. Applicants must have been recognised by their churches as candidates for the Ministry of Word and Sacrament, but should not yet have been ordained

Level of Study: Postgraduate

Type: Scholarship

Value: One scholarship of $£ 6,000$ or two scholarships of $£ 3,000$ approx

Length of Study: 1 year, renewable for up to 2 further years Study Establishment: The University of Cambridge

Country of Study: United Kingdom

Application Procedure: If it is the intention to study at the postgraduate level, an application should be made at the same time to the Board of Graduate Studies of the university. The Scholar will normally study for one of the following degrees: $\mathrm{BA}$ or MPhil in theology, or $\mathrm{PhD}$. He or she will be a member of both Westminster College and one of the University's constituent colleges

Closing Date: 24 December

Funding: Private

Contributor: A legacy controlled by the United Reformed Church

No. of awards given last year: 2

Additional Information: Scholars from outside the United Reformed Church have usually been theology graduates and have used the scholarship for postgraduate work

\section{For further information contact:}

Westminster College, Madingley Rd, CB3 0AA, Cambridge, United Kingdom

Tel: $\quad$ (44) 1223741084

Fax: (44) 1223300765

Email: jp225@cam.ac.uk

Contact: Reverend John Proctor, Director of Studies

\section{William Wyse Studentship in Social Anthropology}

Subjects: Social anthropology

Purpose: To support study

Eligibility: Open to all students who wish to study for the degree of $\mathrm{PhD}$. The Studentships are open to any person who is admitted to the University of Cambridge by the Board of Graduate Studies and intends to do research in Social 
Anthropology leading to the $\mathrm{PhD}$. Degree, regardless of whether they are liable for fees at the Home or Overseas rate. It is a condition of the Studentships that United Kingdom and European Union students are eligible for ESRC or ViceChancellor's Awards and that overseas students fulfil the eligibility criteria for Cambridge International Scholarships Level of Study: Doctorate

Type: Studentship

Value: Varies

Length of Study: 3 years

Frequency: Annual

Study Establishment: The University of Cambridge

Country of Study: United Kingdom

No. of awards offered: 8

Application Procedure: Applicants should contact the admissions secretary for details

Closing Date: 11 January

Funding: Private

No. of awards given last year: 5 grants

No. of applicants last year: 8

Additional Information: For further details, refer the website link mentioned below. www.socanth.cam.ac.uk/about-us/ funding/william-wyse-funding/william-wyse-studentship

For further information contact:

Email:_enquiries@socanth.cam.ac.uk; graduatesecretary@socanth.cam.ac.uk

Contact: Admissions Secretary

\section{Wood Whistler Prize and Medal}

Subjects: English literature

Purpose: To reward an outstanding student

Level of Study: Graduate

Type: Prize

Value: Approx. $£ 2,500$

Frequency: Annual

Study Establishment: Newnham College, University of Cambridge

Country of Study: United Kingdom

Application Procedure: There is no application form. Names are put forward by the English faculty of the University of Cambridge

Funding: Private

\section{For further information contact:}

Email: tutorial.office@newn.cam.ac.uk

\section{University of Cambridge (Cambridge \\ Commonwealth Trust, Cambridge \\ Overseas Trust, Gates Cambridge \\ Trust, Cambridge European Trust and Associated Trusts)}

Cambridge Trusts, Trinity College, Trinity Street, CB2 1TQ, Cambridge, United Kingdom

Tel: $\quad$ (44) 1223351449

Fax: (44) 1223323322

Email: info@overseastrusts.cam.ac.uk

Website: www.admin.cam.ac.uk

The Cambridge Commonwealth Trust and the Cambridge Overseas Trust (formerly the Chancellor's Fund) were established in 1982 by the University of Cambridge under the Chairmanship of his Royal Highness the Prime of Wales to provide financial assistance for students from overseas who, without help, would be unable to take up their places at Cambridge. Since 1982, the Cambridge Commonwealth Trust has brought 6,600 students from 51 countries to Cambridge, the Cambridge Overseas trust 4,252 students from 76 countries.

\section{British Chevening Cambridge Scholarships for Postgraduate Study (Indonesia)}

Subjects: All subjects

Purpose: To financially support those undertaking postgraduate study

Eligibility: Applicants must be citizens of Indonesia

Level of Study: Postgraduate

Type: Scholarship

Value: The University Composition Fee at the overseas rate, approved college fees, a maintenance allowance sufficient for a single student and a contribution towards return economy airfare

Length of Study: 1 year

Frequency: Annual

Study Establishment: The University of Cambridge

Country of Study: United Kingdom

Application Procedure: Applicants must apply directly to the British Embassy in Indonesia

Contributor: Offered in collaboration with the Malaysian Commonwealth Studies Centre and the Foreign and Commonwealth Office (FCO) 
Additional Information: Further information is available on request

\section{For further information contact:}

Email: cambridge.trust@admin.cam.ac.uk

\section{British Chevening Malaysia Cambridge Scholarship for PhD Study}

Subjects: All subjects

Purpose: To financially support study towards a $\mathrm{PhD}$

Eligibility: Open to students from Malaysia. Applicants must apply to the University of Cambridge and be offered a place at Cambridge in the normal way. All applicants must have a First Class or High Second Class (Honours) Degree or equivalent and normally be under 26 . They must be successfully nominated for an Overseas Research Student (ORS) award

Level of Study: Doctorate

Type: Scholarship

Value: The University Composition Fee at the appropriate rate, approved college fees, a maintenance allowance sufficient for a single student and a contribution towards return economy airfare

Length of Study: Up to 3 years

Frequency: Annual

Study Establishment: The University of Cambridge

Country of Study: United Kingdom

Application Procedure: Applicants must complete a preliminary application form, which can be obtained from local universities, offices of the British Council or the Trust. Completed forms must be returned to the main address. Shortlisted candidates will be sent forms for admission to the University of Cambridge. The preliminary application form can also be downloaded from www.admin.cam.ac.uk/ offices/gradstud/admissions/forms/

Contributor: Offered in collaboration with the Foreign and Commonwealth Office (FCO)

\section{For further information contact:}

Email: cambridge.trust@admin.cam.ac.uk

\section{British Petroleum Research Bursaries for PhD Study}

Subjects: All subjects

Purpose: To celebrate the Centenary for BP and New Hall College
Eligibility: For citizens of Russia, Ukraine, Countries of the former Soviet Union, China, The Middle East (particularly Egypt), Southern Africa, or South Asia

Level of Study: Doctorate

Type: Bursary

Value: $£ 2,000$ annually

Frequency: Annual

Study Establishment: BP and New Hall College, The University of Cambridge

Country of Study: United Kingdom

Application Procedure: Applicants for a place to do a $\mathrm{PhD}$ should apply for an ORS award and should normally be successfully nominated for an ORS award or an ORS equivalent award, which meets the difference between the higher overseas rate and the lower domestic rate of the University Composition Fee

\section{For further information contact:}

Email: enquiry@bpgraduates.co.uk

\section{British Petroleum Research Bursaries for Postgraduate Study}

Subjects: All subjects

Purpose: To celebrate the Centenary for BP and New Hall College

Eligibility: For citizens of Russia, Ukraine, Countries of the former Soviet Union, China, The Middle East (particularly Egypt), Southern Africa, or South Asia

Level of Study: Doctorate

Type: Bursary

Value: $£ 2,000$ annually

Length of Study: 1 year

Frequency: Annual

Study Establishment: BP and New Hall College, The University of Cambridge

Country of Study: United Kingdom

For further information contact:

Email: enquiry@bpgraduates.co.uk

\section{Charles Wallace India Trust}

Subjects: Arts, Humanities, and Heritage Conservation Purpose: To financially assist postgraduate study for applicants who are not successful in winning a scholarship Eligibility: This scholarship is only available for citizens of India. Applicants for a place to do a PhD should apply for an ORS award and should be successfully nominated for an ORS award or an ORS equivalent award, which meets the 
difference between the higher overseas rate and the lower domestic rate of the University Composition Fee

Type: Bursary

Value: Varies

Frequency: Annual

Study Establishment: The University of Cambridge

Country of Study: Any country

Closing Date: See website for details

Contributor: Charles Wallace India Trust

For further information contact:

Email: cwit@in.britishcouncil.org

\section{China Scholarship Council Cambridge Scholarships}

Subjects: A range of priority subjects set each year by the China Scholarship Council

Purpose: To financially assist study towards a $\mathrm{PhD}$

Eligibility: Applicants must be from China, and have a firstclass honours degree, and preferably, a Masters degree or its equivalent from a recognised university in China

Level of Study: Doctorate

Type: Scholarship

Value: The University Composition Fee at the appropriate rate, approved College fees, a maintenance allowance sufficient for a single student, contribution towards an economy return airfare

Frequency: Annual

Study Establishment: The University of Cambridge

Country of Study: United Kingdom

Application Procedure: Applicants for a place to do a $\mathrm{PhD}$ should apply for an ORS award and should normally be successfully nominated for an ORS award or an ORS equivalent award, which meets the difference between the higher overseas rate and the lower domestic rate of the University Composition Fee

Contributor: In collaboration with the China Scholarship Council

\section{For further information contact:}

Email: cambridge.trust@admin.cam.ac.uk

\section{Corpus Christi Research Scholarship}

Subjects: Any subjects

Purpose: To financially assist study towards a PhD

Eligibility: Applicants must be from India, and already hold a degree equivalent to a first-class or a high upper second from a United Kingdom university
Level of Study: Doctorate

Type: Scholarship

Value: Varies

Study Establishment: Corpus Christi College, The University of Cambridge

Country of Study: United Kingdom

Application Procedure: Applicants for a place to do a $\mathrm{PhD}$ should apply for an ORS award and should normally be successfully nominated for an ORS award or an ORS equivalent award, which meets the difference between the higher overseas rate and the lower domestic rate of the university composition fee

Closing Date: See website for details

Contributor: In collaboration with the Corpus Christi College

\section{For further information contact:}

Email: research-fellowships@corpus.cam.ac.uk

\section{David M. Livingstone (Australia) Scholarship}

Subjects: All subjects

Purpose: To support students to undertake 1-year postgraduate degree course at the University of Cambridge

Eligibility: The scholarship is only available for citizens of Australia. Scholars must specify Jesus College as their first choice college

Level of Study: Postgraduate

Type: Scholarship

Value: University composition fee and college fee

Length of Study: 1 year

Frequency: Annual

Closing Date: 31 March

Contributor: Jesus College

\section{For further information contact:}

Tel: (44) 1223760606

Fax: (44) 1223338723

Email: admissions@gradstudies.cam.ac.uk

\section{Developing World Education Fund Scholarships for PhD Study}

Subjects: All subjects

Purpose: To financially support study towards a $\mathrm{PhD}$

Eligibility: For citizens from Bangladesh, China, India, Pakistan, Sri Lanka or Zambia. Applicants must apply to the University of Cambridge and be offered a place at Cambridge in the normal way. All applicants must have a degree 
equivalent to a First Class from a United Kingdom university, and normally be under 26

Level of Study: Doctorate

Type: Scholarships and fellowships

Value: The University Composition Fee at the appropriate rate, approve College fees, a maintenance allowance sufficient for a single student, contribution towards an economy return airfare

Study Establishment: The University of Cambridge

Country of Study: United Kingdom

Application Procedure: Applicants for a place to do a $\mathrm{PhD}$ should apply for an ORS award and should normally be successfully nominated for an ORS award or an ORS equivalent award, which meets the difference between the higher overseas rate and the lower domestic rate of the University Composition Fee

Closing Date: See website for details

\section{For further information contact:}

Email: joe@advance-africa.com

\section{International Club of Boston College Cambridge Scholarship}

\section{Subjects: Education}

Purpose: To financially support those undertaking postgraduate study

Eligibility: Open to students from Chile

Level of Study: Postgraduate

Type: Scholarships and fellowships

Value: The University composition fee at the overseas rate, approved college fees, a maintenance allowance sufficient for a single student, contribution towards an economy return airfare

Length of Study: 1 year

Frequency: Annual

Study Establishment: The University of Cambridge

Country of Study: United Kingdom

Application Procedure: Apply directly to the British Council in Chile. Applicants are reminded that they will also need to apply to the Cambridge Trusts on the Scholarship Application Form (SAF) in the usual way

Closing Date: See website for details

Contributor: Offered in collaboration with the Instituto Chileno Britanico de Cultura, the British Council, Chile and Cambridge Assessment (formerly the Local Examinations Syndicate), University of Cambridge

\section{For further information contact:}

Email: internationalstudents@admin.cam.ac.uk

\section{Jawaharlal Nehru Memorial Trust Commonwealth Shared Scholarships}

Subjects: All subjects

Purpose: To offer financial support

Eligibility: Open to citizens from India. All applicants must be under the age of 35 on October 1st with priority given to those candidates under the age of 30 . They must not be employed by a national or local government department or by a parastatal organization, nor at present be living or studying in a developed country and not have undertaken studies lasting a year or more in a developed country. Priority will be given to candidates wishing to pursue a study related to the economic and social development of their country

Level of Study: Postgraduate

Type: Scholarship

Value: The University Composition Fee, approved college fees, annual stipend sufficient for a single student and contribution towards travel costs

Length of Study: 1 year

Frequency: Annual

Study Establishment: The University of Cambridge, Trinity College

Country of Study: United Kingdom

Application Procedure: Applicants may obtain further details and a preliminary application form by writing before August 16th of the year before entry to the Joint Secretary of the Nehru Trust for Cambridge University, giving details of their academic qualifications

Closing Date: 28 February

Contributor: Offered in collaboration with the Jawaharlal Nehru Memorial Trust and the Commonwealth Scholarship Commission

\section{For further information contact:}

The Nehru Trust for Cambridge University, Teen Murti House, Teen Murti Marg 53 - 54 Sidney Street, CB2 3HX, Cambridge, United Kingdom

Email: cambridge.trust@admin.cam.ac.uk Contact: The Joint Secretary

\section{Ministry of Education (Malaysia) Scholarships for Postgraduate Study}

\section{Subjects: All subjects}

Purpose: To financially support those undertaking postgraduate study

Eligibility: Applicants must be from Malaysia, and must be nominated by the Ministry of Education. Applicants must apply to the University of Cambridge and be offered a place 
at Cambridge in the normal way. They must have a First Class or High Second Class (Honours) Degree or equivalent and normally be under 26

Level of Study: Postgraduate

Type: Scholarship

Value: The University Composition Fee at the overseas rate, approved college fees, a maintenance allowance sufficient for a single student and a contribution to return economy airfare Length of Study: 1 year

Frequency: Annual

Study Establishment: The University of Cambridge

Country of Study: United Kingdom

Application Procedure: Applicants must complete a preliminary application form, which can be obtained from local universities, offices of the British Council or the Trust. Completed forms must be returned to the main address. Shortlisted candidates will be sent forms for admission to the University of Cambridge. The preliminary application form can also be downloaded from www.admin.cam.ac.uk/ offices/gradstud/admissions/forms/

Closing Date: 28 February

Contributor: Offered in collaboration with the Malaysian Commonwealth Studies Centre and the Ministry of Education, Government of Malaysia

\section{For further information contact:}

Email: education.intoday@gmail.com

\section{Ministry of Science, Technology and the Environment Scholarships for Postgraduate Study (Malaysia)}

Subjects: All subjects

Purpose: To financially support those undertaking postgraduate study

Eligibility: Applicants must be from Malaysia, and must be nominated by the Ministry of Science, Technology and the Environment. Applicants must apply to the University of Cambridge and be offered a place at Cambridge in the normal way. They must have a First Class or High Second Class (Honours) Degree or equivalent and normally be under 26

Level of Study: Postgraduate

Type: Scholarship

Value: The University Composition Fee at the overseas rate, approved college fees, a maintenance allowance sufficient for a single student and a contribution to return economy airfare Length of Study: 1 year

Frequency: Annual

Study Establishment: The University of Cambridge

Country of Study: United Kingdom
Application Procedure: Applicants must complete a preliminary application form, which can be obtained from local universities, offices of the British Council or the Trust. Completed forms must be returned to the main address. Shortlisted candidates will be sent forms for admission to the University of Cambridge. The preliminary application form can also be downloaded from www.admin.cam.ac.uk/ offices/gradstud/admissions/forms/

Closing Date: 28 February

Contributor: Offered in collaboration with the Malaysian Commonwealth Studies Centre and the Ministry of Science, Technology and the Environment, Government of Malaysia

\section{For further information contact:}

Email: international_scholar@mohe.gov.my

\section{Nehru Trust for the Indian Collections V\&A Cambridge DFID Scholarship}

Subjects: Archaeology, focusing on archaeological heritage and museums or social anthropology, with special reference to the work of a museum

Purpose: To financially support those undertaking postgraduate study

Eligibility: Applicants must be from India, and must be under the age of 35 on October 1st with priority given to those candidates under the age of 30 . Applicants must not be employed by a national or local government department or by a parastatal organization, nor at present be living or studying in a developed country. Priority will be given to candidates wishing to pursue a course of study related to the economic and social development of their country

Level of Study: Postgraduate

Type: Scholarship

Value: The University Composition Fee at the overseas rate, approved college fees, a maintenance allowance sufficient for a single student and a contribution to return economy airfare. In addition a supplementary allowance to cover a short period of practical training at the Victoria and Albert Museum, or other approved institution, will be given

Length of Study: 1 year

Frequency: Annual

Study Establishment: The University of Cambridge

Country of Study: United Kingdom

Application Procedure: Applicants may obtain further details and a preliminary application form by writing before August 16th of the year before entry to the Joint Secretary at the address given below with details of academic qualifications

Closing Date: 28 February 
Contributor: Offered in collaboration with the Nehru Trust for the Indian Collections at the Victoria and Albert (V\&A) Museum and the Department for International Development (DFID)

\section{Oxford and Cambridge Society of Bombay Cambridge DFID Scholarship}

\section{Subjects: All subjects}

Purpose: To financially support those undertaking postgraduate study

Eligibility: Open to a resident of Bombay City or the State of Maharashtra whose application is supported by the Oxford and Cambridge Society of Bombay. All applicants must be under the age of 35 on October 1st with priority given to those candidates under the age of 30 . They must not be employed by a national or local government department or by a parastatal organization, nor at present be living or studying in a developed country. Priority will be given to candidates wishing to pursue a study related to the economic and social development of their country

Level of Study: Postgraduate

Type: Scholarship

Value: The University Composition Fee at the overseas rate, approved college fees, a maintenance allowance sufficient for a single student and a contribution to return economy airfare

Length of Study: 1 year

Frequency: Annual

Study Establishment: The University of Cambridge

Country of Study: United Kingdom

Application Procedure: Applicants may obtain further details and a preliminary application form by writing before August 16th of the year before entry to the Joint Secretary at address given below with details of academic qualifications

Closing Date: 28 February

Contributor: Offered in collaboration with the Department for International Development (DFID)

\section{Pok Rafeah Cambridge Scholarship}

Subjects: All subjects

Purpose: To financially support study towards a $\mathrm{PhD}$

Eligibility: Applicants must be from Malaysia. The Trusts cannot admit students to the University or any of its colleges. Applicants for awards from the Trusts must therefore also apply to the University of Cambridge and be offered a place at Cambridge in the normal way. All applicants must have a First Class or High Second Class (Honours) Degree or equivalent and normally be under 26. Applicants for scholarships for study towards the degree of $\mathrm{PhD}$ must be successfully nominated for an Overseas
Research Student (ORS) award, which covers the difference between the home and overseas rate of the University Composition Fee

Level of Study: Doctorate, Postgraduate, Predoctorate

Type: Scholarship

Value: The University Composition Fee at the approved rate, approved college fees, a maintenance allowance sufficient for a single student and a contribution to a return economy airfare

Length of Study: Up to 3 years for PhD study, and 1 year for postgraduate study

Frequency: Annual

Study Establishment: The University of Cambridge

Country of Study: United Kingdom

Application Procedure: Applicants must complete a preliminary application form, which can be obtained from local universities, offices of the British Council or the Trust. The preliminary application form can be downloaded from www. admin.cam.ac.uk/univ/gsprospectus/c7/overseas/schemes.html. Completed forms must be returned to the main address. Shortlisted candidates will be sent forms for admission to the University of Cambridge

Contributor: Offered in collaboration with the Pok Rafeah Foundation

Additional Information: Further information is available on request

\section{For further information contact:}

Email: cambridge.trust@admin.cam.ac.uk

Contact: The Secretary

\section{University of Cambridge, Judge Business School}

Trumpington Street, CB2 1AG, Cambridge, United Kingdom

Tel: $\quad$ (44) 1223339700

Fax: (44) 1223339701

Email: enquiries@jbs.cam.ac.uk

Website: www.jims.cam.ac.uk

Contact: Mrs Natacha Wilson

The Judge Business School is the University of Cambridge's business school. Founded in 1990, it offers a portfolio of management programmes, including the Cambridge MBA. Accredited by AMBA and EQUIS, the business school now hosts one of the largest concentrations of interdisciplinary business and management research activity in Europe. 


\section{Browns Restaurant Scholarships}

\section{Subjects: MBA}

Purpose: To provide funds for United Kingdom citizens with a strong interest in the hospitality and tourism industries to study for an MBA

Eligibility: Open to candidates with at least three years of experience in the hospitality or tourism industries. Candidates must show evidence of a career plan showing how they would use the skills and knowledge gained on the MBA course to develop their career within the hospitality or tourism industries. Where an applicant opts for the two year integrated version of the MBA course, arrangements should be in place for the placement year to be in an organisation in the hospitality or tourism industries. Applicants must be United Kingdom citizens

Level of Study: MBA

Type: Scholarship

Value: One scholarship of $£ 20,000$ to cover fees and two scholarships of $£ 10,000$ to cover roughly half the fees

Length of Study: 1 year

Frequency: Annual

Study Establishment: Judge Institute of Management, University of Cambridge

Country of Study: United Kingdom

Application Procedure: Applicants must complete and submit an application form, together with a covering letter indicating that they would like to apply for a Browns Restaurant Scholarship, to the Judge Institute of Management

Closing Date: The end of March

Funding: Commercial

Contributor: Browns Restaurants Limited

For further information contact:

Email:_financial_aid@brown.edu

\section{University of Canberra}

The scholarship is funded under the Australian government Research Training Program (RTP) scheme and is available for future and current international students in all research disciplines. The University of Canberra is proudly the university of Australia's capital. UC is one of Australia's top universities for getting a job.

\section{Australian Government Research Training Program (AGRTP) Stipend Scholarship}

Subjects: Scholarships are available in Research programme Purpose: Scholarships are offered in diverse fields to help students in upgrading their education
Eligibility: To be eligible to apply for this scholarship you must: 1. Be an international student. 2. Be seeking to enrol, or enrolled, as a full-time Doctor of Philosophy $(\mathrm{PhD})$ candidate. 3. Have a minimum first-class honours (H1) or be regarded by the University as having an equivalent level of attainment. 4. Not have previously held an Australian Governmentfunded research scholarship for more than 6 months

Level of Study: Postgraduate

Type: Scholarship

Value: A $\$ 26,682$ for 2017, tax-free

Length of Study: 3 years

Frequency: Annual

Country of Study: Australia

Application Procedure: The mode of applying is online

Closing Date: 31 October

\section{For further information contact:}

The Australian National University, Canberra, ACT 0200, Australia

Tel: (61) 261255111

Email: student@anu.edu.au

\section{University of Canterbury}

College of Arts, University of Canterbury, Private Bag 4800, Christchurch 8140, New Zealand

Tel: $\quad$ (64) 33642426 (ext: 6426)

Fax: (64) 33642683

Email: erin.hird@canterbury.ac.nz

Website: www.canterbury.ac.nz

Contact: Ms Erin Hird, Human Resource Administrator

The University of Canterbury offers a variety of subjects in a few flexible degree structures, namely, first and postgraduate degrees in arts, commerce, education, engineering, fine arts, forestry, law, music and science. At Canterbury, research and teaching are closely related, and while this feature shapes all courses, it is very marked at the postgraduate level.

\section{Dow Agrosciences Bursary in Chemical Engineering}

Subjects: Chemical and Process Engineering Purpose: In 1990, DowElanco (NZ) Limited took over the bursary, formerly offered by Ivon Watkins-Dow Limited, for tenure in the Department of Chemical Engineering. In 
January 1998, DowElanco (NZ) Limited changed its name to Dow AgroSciences (NZ) Limited

Eligibility: Must be a full time student who is enrolled for a BE(Hons) in Chemical \& Process Engineering. The applicant must have completed, or been exempted from, the First Professional examination

Level of Study: Graduate, Undergraduate

Type: Bursary

Value: NZ\$2,500

Frequency: Annual

Country of Study: Any country

Application Procedure: You may apply through this webpage approximately 8 weeks before applications close. If it's possible to apply on-line for this scholarship there will be a link above to the on-line system. If the link is not provided, please download and complete the application form located below. However, if the scholarship is managed by Universities NZ or another department of the University an External Website link will appear below and application instructions will be available through that link

Closing Date: 31 March

Funding: Private

\section{For further information contact:}

0800 Varsity, New Zealand

Tel: $\quad$ (64) 800827748

Email: enrol@canterbury.ac.nz

\section{Freyberg Scholarship}

Purpose: Freyberg Scholarships are awarded to encourage graduate study into areas relevant to national security. Study should be undertaken at a recognised institution in New Zealand or an Asia-Pacific country, including Canada and the United States

Eligibility: Applicants must be New Zealand citizens or permanent residents who meet the following academic requirements: they should normally have obtained at least second class honours, division $\mathrm{A}$, or equivalent in their qualifying degree and have completed academic studies in political science, history, economics or some other discipline that may be considered an appropriate foundation for such study

Level of Study: Graduate

Type: Scholarship

Value: NZ\$70,000 will be made annuallyfor the award of one or more scholarship

Frequency: Annual

Country of Study: New Zealand
Application Procedure: Apply online. check the below link for further information. www.universitiesnz.ac.nz/scholar ships/freyberg-scholarship

Closing Date: 1 October

Funding: Private

For further information contact:

Email: scholarships-cf@universitiesnz.ac.nz

\section{Gordon Watson Scholarship}

Purpose: The general purpose of the scholarship is to enable New Zealanders to study international relationships or social and economic conditions at a university overseas. Candidates will be planning to study at Masters or $\mathrm{PhD}$ level

Eligibility: 1. Graduated with or be graduating with an Honours or Masters degree in arts, science, commerce, law or divinity from a New Zealand university. 2. New Zealand citizens or permanent residents

Level of Study: Postgraduate

Type: Scholarship

Value: NZ\$12,000

Length of Study: Up to two years for Masters and up to three years for a $\mathrm{PhD}$

Country of Study: New Zealand

Application Procedure: Apply online. universitiesnz. communityforce.com

Closing Date: 1 March

Funding: Private

Additional Information: Please note that to be eligible a planned Masters degree must have a substantial research component, i.e. at least half

\section{For further information contact:}

Level 9, 142 Lambton Quay, Wellington PO Box 11915, Wellington 6142, New Zealand

Tel: $\quad$ (64) 43818500

Email: scholarships-cf@universitiesnz.ac.nz

\section{Kitchener Memorial Scholarship}

Purpose: The Kitchener Memorial Scholarship Fund offers scholarships to past or present members of the Armed Forces or their children, who are undertaking an agricultural course of study at a New Zealand university

Eligibility: Applicants must be either; 1. Past or present members of the Armed Forces or children of past or 
present members of the Armed Forces who have seen active service and who, at the time of enlistment, were domiciled in New Zealand, whether actually resident there or not, or. 2. Past or present members of the Armed Forces or their children to whom the above does not apply, or. 3. People resident in New Zealand for a period of not less than three years immediately before the award of the scholarship

Level of Study: Graduate

Type: Scholarship

Value: NZ $\$ 500$

Frequency: Annual

Country of Study: Any country

Closing Date: 1 December

Funding: Private

\section{Lighthouse Vision Trust Scholarship}

Purpose: The scholarships support students with a vision impairment in undertaking study at the University of Canterbury. It was established in 2016 by the Lighthouse Vision Trust

Eligibility: 1 Applicants must have a vision impairment that qualifies them to register with the Blind Foundation. 2 By the closing date for applications, an applicant must have registered with the University's Disability Resource Service as a student with a vision impairment. 3 Applicants must be citizens of New Zealand or holders of New Zealand residence class visas. 4 Applicants must be enrolled, full-time or parttime, at the University at either undergraduate or postgraduate level

Level of Study: Postgraduate, Undergraduate

Type: Scholarship

Value: Up to NZ\$10,000 can be received as total value

Length of Study: 1 year

Frequency: Annual

Country of Study: Any country

Application Procedure: 1 Applications must be made online at the Scholarships website 3 by 31 March. 2 Applicants will be considered for both scholarships, and the decision on which of the top candidates will be offered which of the two scholarships will be made randomly. 3 A previous recipient of Lighthouse Vision Trust Scholarship or a Susan Barnes Memorial Scholarship may re-apply for the scholarship that they held, and a previous recipient of one of the scholarships may apply for the other scholarship in another year. However, no student may hold one of the scholarships or a combination of the two scholarships over a total period of more than three years

Closing Date: 31 March

Funding: Private

\section{For further information contact:}

Email: enrol@canterbury.ac.nz

\section{Marian D Eve Memorial Scholarship}

Purpose: This scholarship supports students studying, researching, or developing, resources for early-childhood special-needs education at the University of Canterbury

Eligibility: Recipients must be undergraduate or postgraduate students who are enrolled full-time at the University and studying, researching, or developing, in any discipline, resources for early-childhood special-needs education

Level of Study: Graduate, Postgraduate

Type: Scholarship

Value: NZ\$2,000

Frequency: Annual

Country of Study: Any country

Application Procedure: You may apply through this webpage approximately 8 weeks before applications close. If it's possible to apply on-line for this scholarship there will be a link above to the on-line system. Apply through online link. www.studyinnewzealand.govt.nz/how-to-apply/scholar ship/details? scholarshipid $=25668$ \&institutionid $=142318$

Closing Date: 1 April

Funding: Private

\section{McKelvey Award}

Purpose: This award supports master's and $\mathrm{PhD}$ students in the New Zealand School of Forestry at the University of Canterbury. Normally, the award is available to assist students to present a paper at a relevant conference. However, in the absence of suitable applications, the applications may be opened to eligible students seeking support to meet other costs associated with their study

Eligibility: Forestry

Level of Study: Postgraduate

Type: Scholarship

Value: $\$ 1,000$

Frequency: Annual

Country of Study: Any country

Application Procedure: Apply online

Closing Date: 1 April

Funding: Foundation

\section{For further information contact:}

Email: scholarships-cf@universitiesnz.ac.nz 


\section{Park and Paulay Scholarship}

Purpose: This scholarship acknowledges and rewards a top performer in the first two Professional years of the programme for a Bachelor of Engineering (Honours) degree in Civil Engineering at the University of Canterbury

Eligibility: Full-time students in the Third Professional Year of the programme for the Bachelor of Engineering (Honours) degree in Civil Engineering (BE(Hons)(Civil)) at the University of Canterbury, who are enrolled in at least four courses related to Structural or Geotechnical or Earthquake Engineering

Level of Study: Graduate

Type: Scholarship

Value: NZ\$2,000

Frequency: Annual

Country of Study: Any country

Application Procedure: You may apply through this webpage approximately 8 weeks before applications close. If it's possible to apply on-line for this scholarship there will be a link above to the on-line system. If the link is not provided, please download and complete the application form located below. Closing dates are yet to be released for the same

Closing Date: 31 March

Funding: Private

For further information contact:

Email: info@canterbury.ac.nz

\section{Wood Technology Research Centre - Postgraduate Scholarships}

Subjects: Chemical engineering

Purpose: To develop a computer model to simulate energy flow and energy efficiency in wood and wood product processing industry

Level of Study: Postgraduate

Type: Scholarship

Value: $\mathrm{NZ} \$ 24,000$ per year for $\mathrm{PhD}$ and $\$ 18,000$ per year for ME

Length of Study: 3 years for $\mathrm{PhD}$ and one and half year for ME

Application Procedure: To apply or for further information on the above scholarships, please contact Dr Shusheng Pang Closing Date: See website for details

Contributor: University of Canterbury

Additional Information: Case studies will be conducted for manufacturing of Laminated Veneer Lumber (LVL) and Medium Density Fibreboard (MDF). The project will be conduced in collaboration with the University of Otago and a wood processing company

\section{For further information contact:}

Wood Technology Centre, Department of Chemical and Process Engineering, University of Canterbury, Christchurch, New Zealand
Tel:
(64) 33642538
Fax:
(64) 33642063
Email:
shusheng.pang@canterbury.ac.nz
Contact:
Dr Shush
Director

\section{University of Canterbury, Department of Management}

Private Bag 4800, Christchurch, New Zealand

Tel: $\quad$ (64) 33642808

Fax: (64) 33642325

Email: s.worrall@mang.canterbury.ac.nz

Website: www.regy.canterbury.ac.nz.home.html

Contact: Mrs Suzanne Worrall, MBA Programme Director

\section{Auckland Council Chief Economist's Research Scholarship in Economics}

Subjects: Economics

Purpose: The purpose of this scholarship is to encourage and support postgraduate research into urban economics that has particular relevance to local government in New Zealand

Eligibility: 1. At the time of application candidates must be enrolled or planning to enrol in a postgraduate programme at a New Zealand university. 2. The postgraduate programme must be in the area of urban economics. Universities NZ and Auckland Council reserve the right to determine the eligibility of a particular area of study. 3. A thesis, dissertation, or research report must be a requirement of the postgraduate programme Level of Study: Postgraduate

Type: Scholarship

Value: NZ\$3,000

Length of Study: 1 year

Frequency: Varies

Country of Study: Any country

Application Procedure: Apply online: universitiesnz. communityforce.com/

Closing Date: 5 March

Funding: Foundation 
Additional Information: For candidates who are enrolled on a part time basis the value of the award will be NZ\$1,500. The award is intended to help with tuition fees and research costs (e.g. data costs), and to contribute towards living costs

\section{For further information contact:}

Level 9, Pacific Radiology Building, 142 Lambton Quay, PO Box 11915, Wellington 6142, New Zealand

Tel: $\quad$ (64) 43818500

Email: scholarships-cf@universitiesnz.ac.nz

\section{Barbara Mito Reed Award}

Subjects: Japanese

Purpose: The award was established in memory of $\mathrm{Dr}$ Barbara Mito Reed (1955-1990), a graduate in Japanese of the University of Canterbury, by her husband, Mr T. Mito, her family and her friends. It was established to help outstanding graduate students of Japanese, whose native language is not Japanese, to further their studies towards a higher degree in a field of Japanese language and/or culture

Eligibility: The scholarship is open to graduates of the University of Canterbury enrolled, or intending to enrol, in a postgraduate programme in a field of Japanese studies at the University of Canterbury or at a university in Japan. Normally, the programme will be for a BA(Hons), master's or doctoral degree. The scholarship is open to citizens or Permanent Residents of New Zealand, excluding native speakers of Japanese Level of Study: Postgraduate

Type: Scholarship

Value: NZ\$1,000

Length of Study: 1 year

Frequency: Annual

Country of Study: Any country

Application Procedure: Apply online universitiesnz. communityforce.com/

Closing Date: 31 March

Funding: Foundation

\section{For further information contact:}

Email: scholarships@canterbury.ac.nz

\section{BayTrust Bruce Cronin Scholarship}

Subjects: All subjects

Purpose: This scholarship has been established to recognise his service to the people of the Bay of Plenty

Eligibility: Applicants will be eligible if they were born in, or attended school in, or have whakapapa back to the area
Level of Study: Postgraduate

Type: Scholarship

Value: NZ\$5,000

Length of Study: 1 year

Frequency: Annual

Country of Study: Any country

Application Procedure: Apply online

Closing Date: 1 February

Funding: Foundation

\section{For further information contact:}

73 Spring Street, Tauranga 3141, New Zealand

Email: info@baytrust.org.nz

\section{Christchurch City Council Antarctic Scholarship}

Subjects: Antarctic Studies

Purpose: The Christchurch City Council offers a $\$ 10,000$ one-year scholarship for a University of Canterbury student to carry out Antarctic or Southern Ocean research at master's or $\mathrm{PhD}$ level. The scholarship includes one season of logistical support provided by Antarctica New Zealand

Eligibility: A candidate who, during the tenure of the scholarship, is studying for a $\mathrm{PhD}$ or is in the thesis year of a master's degree at the University of Canterbury in an Antarctic-related topic

Level of Study: Postgraduate

Type: Scholarship

Value: NZ\$10,000

Length of Study: 1 year

Frequency: Varies

Country of Study: Any country

Application Procedure: Apply online through link www. antarcticanz.govt.nz/scholarships-and-fellowships

Closing Date: 12 March

Funding: Foundation

For further information contact:

International Antarctic Centre, 38 Orchard Road, Christchurch 8053, New Zealand

Email: adrian.mcdonald@canterbury.ac.nz

\section{Deutscher Akademischer Austauschdienst (German Academic Exchange Service) Scholarships}

Subjects: All subjects 
Purpose: The DAAD supports over 100,000 German and international students and researchers around the globe each year making it the world's largest funding organisation of its kind Eligibility: Graduates of all disciplines can apply for a scholarship to complete a postgraduate or Master's degree course at a German higher education institution and to gain a degree in Germany (Master's/Diploma)

Level of Study: Postgraduate

Type: Scholarship

Value: NZ€750

Length of Study: 10-24 Months

Frequency: Annual

Country of Study: Any country

Application Procedure: Apply online

Closing Date: 15 October

Funding: Trusts

\section{For further information contact:}

Embassy of the Federal Republic of Germany, PO Box 1687, Wellington, New Zealand

Email: daad@auckland.ac.nz

\section{Ernest William File Scholarship}

Purpose: The purpose of the scholarship is to support the sons and daughters of members of the Rail and Maritime Transport Union (RMTU) in their first year of degree study at a New Zealand university

Eligibility: 1. Sons or daughters of financial members of the RMTU. 2. Enrolled or planning on enrolling in their first year of full time study for an undergraduate degree at a New Zealand university. Applications will not be accepted from anyone who already has a qualification from a tertiary institution in New Zealand or overseas

Level of Study: Graduate

Type: Scholarship

Value: NZ\$2,000

Frequency: Annual

Country of Study: New Zealand

Closing Date: 1 April

Funding: Private

\section{Francis Martin Baillie Reynolds Scholarship in Law to Oxford}

\section{Subjects: All Subjects}

Purpose: The purpose of the scholarship is to assist New Zealand Law graduates to commence postgraduate study in Law at the University of Oxford. It has been established to recognise the support that Emeritus Professor
Francis Reynolds, Worcester College, Oxford, has provided to New Zealand Law students at the University of Oxford for over 40 years

Eligibility: 1. A New Zealand citizen or permanent resident. 2. Has completed the requirements for a LLB degree from a New Zealand University. 3. The date of application has applied for a place in a postgraduate programme in Law at the University of Oxford

Level of Study: Postgraduate

Type: Scholarship

Value: NZ $\$ 10,000$

Length of Study: 1 year

Frequency: Annual

Country of Study: Any country

Application Procedure: Apply online through link universitiesnz.communityforce.com

Closing Date: 28 February

Funding: Trusts

\section{Frank Knox Memorial Fellowships at Harvard University}

Subjects: All subjects

Purpose: Annie Reid Knox set up these scholarships to honour her late husband and asked that future scholars be selected on the basis of future promise of leadership, strength of character, keen mind, a balanced judgement and a devotion to the democratic ideal

Eligibility: 1 . New Zealand citizens at the time of application, normally resident in New Zealand. 2. Have completed or will complete a first or higher degree at a New Zealand university. 3. Studying for a first or higher degree; or have completed a first or higher degree and graduated no earlier than 2014

Level of Study: Postgraduate

Type: Fellowship

Length of Study: 2 year

Frequency: Annual

Country of Study: Any country

Application Procedure: Apply online through the link universitiesnz.communityforce.com

Closing Date: 1 November

Funding: Trusts

For further information contact:

Email: rbauerlock@fas.harvard.edu

\section{G B Battersby-Trimble Scholarship in Computer Science}

Subjects: Computer Science 
Purpose: The income from the trust fund is added to an annual grant from Trimble Navigation N Z Ltd. The Trimble grant has been given in recognition of the long service provided by the late Dr Battersby to the University and to the computing profession

Eligibility: Enrolled in final-year Honours, Master's or $\mathrm{PhD}$ level study at Canterbury, for advancing study in Computer Science that will be of benefit to NZ

Level of Study: Postgraduate

Type: Scholarship

Value: NZ\$4,000

Length of Study: 1 year

Frequency: Annual

Country of Study: Any country

Application Procedure: Apply online: universitiesnz. communityforce.com

Closing Date: 31 March

Funding: Trusts

\section{For further information contact:}

Email: scholarships@canterbury.ac.nz

\section{Gateway Antarctica's Ministry of Foreign Affairs and Trade Scholarship in Antarctic and Southern Ocean Studies}

Subjects: Antarctic

Purpose: The Ministry of Foreign Affairs and Trade (MFAT) Scholarship was founded in 2001 in support of research and teaching in Antarctic Studies in recognition of Antarctica as a continent devoted to peace and research

Eligibility: $\mathrm{PhD}$ or master's thesis students are eligible. The scholar is required to undertake research concerning a matter of importance to the understanding of Antarctica or the Southern Ocean

Level of Study: Postgraduate

Type: Scholarship

Value: NZ\$5,000

Length of Study: 1 year

Frequency: Varies

Country of Study: Any country

Application Procedure: Apply online

Closing Date: 28 February

Funding: Foundation

\section{Geography Students Conference Fund}

Subjects: Geography

Purpose: The fund was raised by Geography graduates, associates and the Canterbury Branch of the New Zealand
Geographical Society to commemorate the golden jubilee of the Department of Geography in 1987

Eligibility: The fund provides grants-in-aid to research students in the Department of Geography to assist with expenses involved in attending conferences. Priority will be given to conferences of the New Zealand Geographical Society

Level of Study: Postgraduate

Type: Scholarship

Value: NZ\$500

Length of Study: 1 year

Frequency: Varies

Country of Study: Any country

Application Procedure: Apply online: universitiesnz. communityforce.com

Closing Date: 31 March

Funding: Trusts

\section{Gertrude Ardagh Holmes Bursary Fund}

Subjects: All subjects

Purpose: The bursaries shall be for the purpose of assisting students of ability and good character to commence or to continue their studies at the University of Canterbury, who would otherwise by reason of their financial circumstances be unable to do so or be seriously handicapped in doing so. Preference shall be given to students who desire to undertake a medical course. Assistance may be continued to such students after they have proceeded to a medical or dental school in another New Zealand university

Eligibility: Grants are for students to commence or continue study at the University of Canterbury and who face financial hardship. Preference will be given to those who wish to pursue a medical course

Level of Study: Postgraduate

Type: Scholarship

Value: NZ\$600

Frequency: Varies

Country of Study: Any country

Application Procedure: Apply online: universitiesnz. communityforce.com

Closing Date: 31 March

Funding: Foundation

For further information contact:

Email: scholarships@canterbury.ac.nz

\section{Grant Lingard Scholarship}

Subjects: A scholarship in his name is offered at the University of Canterbury, Christchurch, New Zealand 
Purpose: These scholarships were established by the estate of Peter Lanini in memory of Grant Lingard (1961-1995), a graduate of the School of Fine Arts:-

Level of Study: Graduate

Type: Scholarship

Frequency: Annual

Country of Study: New Zealand

Application Procedure: You may apply through this webpage approximately 8 weeks before applications close. If it's possible to apply on-line for this scholarship there will be a link above to the on-line system. If the link is not provided, please download and complete the application form located below. Please check the website with the following link. scholarshipscanterbury.communityforce.com

Closing Date: 31 October

Funding: Private

For further information contact:

0800 Varsity, New Zealand

Tel: $\quad$ (64) 800827748

Tel: (64) 33694900

Email: scholarships@canterbury.ac.nz

\section{Henry Kelsey Scholarship}

\section{Subjects: All subjects}

Purpose: The purpose of the scholarship is to provide funds for individuals to undertake research towards a $\mathrm{PhD}$ at a New Zealand university or research institution, studying muscular function, including the causes and treatment of muscular dysfunction

Eligibility: Applicants will be New Zealand citizens or permanent residents, and will have a Bachelor degree or equivalent, with honours where they are awarded, in a field appropriate to their intended doctoral study at a New Zealand university

Level of Study: Postgraduate

Type: Scholarship

Value: NZ\$10,000

Length of Study: 3 year

Frequency: Varies

Country of Study: Any country

Application Procedure: Apply online: universitiesnz. communityforce.com

Closing Date: 1 October

Funding: Trusts

\section{Joan Burns Memorial Scholarship in History}

Subjects: History

Purpose: This scholarship recognises and supports academic excellence by honours and master's students in History at the
University of Canterbury. It was established from a 1995 bequest from Joan Mary Burns

Eligibility: Applicants must be enrolled full-time or part-time in a Bachelor of Arts with Honours degree programme or in Part 1 of a Master of Arts degree programme

Level of Study: Postgraduate

Type: Scholarship

Value: Stipend equivalent to domestic tuition fees

Length of Study: 1 year

Frequency: Annual

Country of Study: Any country

Application Procedure: Apply online: universitiesnz. communityforce.com

Closing Date: 31 March

Funding: Private

\section{Kia Ora Foundation Patricia Pratt Scholarship}

Subjects: Overseas

Purpose: The purpose of the Kia Ora Foundation Patricia Pratt Music Scholarship is to assist outstanding New Zealand musical performers, who have completed the equivalent of an honours degree in musical performance in New Zealand, to continue their musical development at a renowned international music school or conservatorium

Eligibility: Applicants will be New Zealand citizens. Applicants may apply from outside New Zealand but must have resided in New Zealand for at least three of the last five years immediately preceding the year of selection. Applicants will have recently completed the requirements for an honours degree in musical performance at a New Zealand university (or an equivalent musical qualification)

Level of Study: Postgraduate

Type: Scholarship

Value: NZ\$70,000

Length of Study: 1 year

Frequency: Annual

Country of Study: Any country

Application Procedure: Apply online: universitiesnz. communityforce.com

Closing Date: 1 March

Funding: Foundation

\section{Kiwi Music Scholarship}

Subjects: All subjects

Purpose: The purpose of the scholarship is to assist outstanding New Zealand musical performers or conductors who have completed or are completing an honours or master's degree in musical performance in New Zealand to continue their musical development either overseas or in New Zealand

Eligibility: Applicants will have completed or are completing an honours or masters degree in musical performance 
(including vocal performance) or conducting at a New Zealand university, or an equivalent musical qualification

Level of Study: Postgraduate

Type: Scholarship

Value: NZ\$50,000-\$60,000

Length of Study: 3 year

Frequency: Varies

Country of Study: Any country

Application Procedure: Apply online universitiesnz. communityforce.com

Closing Date: 1 March

Funding: Trusts

\section{B Wood Travelling Scholarship}

Subjects: Overseas

Purpose: The LB Wood Traveling Scholarship is awarded to supplement some other postgraduate scholarship held by the scholar supporting their studies in Britain. The scholarship can only be awarded for postgraduate study at a university or institution of university rank in Britain

Eligibility: Applicants must be graduates of a New Zealand university. No distinction is made regarding subject, disciple or faculty

Level of Study: Postgraduate

Type: Scholarship

Value: NZ\$3,000

Length of Study: 3 years

Frequency: Annual

Country of Study: Any country

Application Procedure: Apply online universitiesnz. communityforce.com/Login.aspx

Closing Date: 1 March

Funding: Foundation

\section{LB Wood Scholarship}

Subjects: All subjects

Purpose: 1. The LB Wood Traveling Scholarship is awarded to supplement some other postgraduate scholarship held by the scholar supporting their studies in Britain. 2. The scholarship can only be awarded for postgraduate study at a university or institution of university rank in Britain

Eligibility: Applicants must be graduates of a New Zealand university. No distinction is made regarding subject, disciple or faculty

Level of Study: Postgraduate

Type: Scholarship

Value: NZ\$3,000

Length of Study: 3 year

Frequency: Varies

Country of Study: Any country
Application Procedure: Apply online: universitiesnz. communityforce.com

Closing Date: 1 March

Funding: Trusts

\section{Master of Business Administration Programme}

Length of Study: 1 to 5 years

Application Procedure: Applicants must complete an application form, a self-evaluation essay, supply an original transcript or a certified copy of grades and provide two references Closing Date: Please contact the Organisation

For further information contact:

Tel: $\quad$ (64) 33642657

Fax: (64) 33642925

Email: international@regy.canterbury.ac.nz

Contact: International Manager

\section{New Zealand Law Foundation Ethel Benjamin Scholarship (for women)}

Subjects: Law

Purpose: To support postgraduate research in Law that encompasses the wider objectives of the NZ Law Foundation, in particular research that will protect and promote the interests of the public in relation to legal matters in New Zealand Eligibility: 1. A New Zealand citizen or permanent resident. 2. The holder of a New Zealand university law degree. 3. Accepted into a postgraduate course in law at either a New Zealand or an overseas university acceptable to the Selection Committee

Level of Study: Postgraduate

Type: Scholarship

Value: NZ\$20,000- $\$ 50,000$

Length of Study: 1 year

Frequency: Annual

Country of Study: Any country

Application Procedure: Apply online universitiesnz. communityforce.com

Closing Date: 1 March

Funding: Trusts

\section{Prince of Wales' Cambridge International Scholarship}

Subjects: All subjects

Purpose: Each year the Cambridge Commonwealth, European \& International Trust www.cambridgetrust.org/ offers several prestigious awards to enable graduates of high academic ability to study at Cambridge University 
Eligibility: These scholarships are open to graduates who are New Zealand citizens and who wish to pursue a course of research leading to the degree of $\mathrm{PhD}$ at Cambridge University

Level of Study: Postgraduate

Type: Scholarship

Length of Study: 3 years

Frequency: Varies

Country of Study: Any country

Application Procedure: Apply online: universitiesnz. communityforce.com

Closing Date: 1 October

Funding: Trusts

For further information contact:

Email: cambridge.trust@admin.cam.ac.uk

\section{Pukehou Poutu Scholarship}

Subjects: Pukehou Poutu Scholarship. The money for this scholarship has been made available by a bequest from the estate of Edith Fraser who wished that it be used for an award in agricultural or silvicultural sciences

Purpose: The money for this scholarship has been made available by a bequest from the estate of Edith Fraser who wished that it be used for an award in agricultural or silvicultural sciences

Eligibility: Applicants must be graduates of a New Zealand university and be New Zealand citizens

Level of Study: Postgraduate

Type: Scholarship

Value: NZ\$10,000

Length of Study: 1 year

Frequency: Annual

Country of Study: New Zealand

Application Procedure: Apply online universitiesnz. communityforce.com

Closing Date: 1 October

Funding: Foundation

\section{Roland Stead Postgraduate Scholarship in Biology}

Subjects: Biological Sciences

Purpose: This scholarship supports Master's research students of biology with an interest in ecology, freshwater fisheries and the Canterbury region

Eligibility: The scholarship will be available to full-time students in the School of Biological Sciences who are engaged in research in Part II of the Master of Science degree programme
Level of Study: Postgraduate

Type: Scholarship

Value: NZ\$5,000

Length of Study: 1 year

Frequency: Annual

Country of Study: Any country

Application Procedure: Apply online: myuc.canterbury.ac. nz/sso

Closing Date: 10 March

Funding: Foundation

For further information contact:

Email: scholarships@canterbury.ac.nz

\section{Sir Douglas Myers Scholarship}

Purpose: The Scholarship provides an opportunity for students who have already distinguished themselves academically to attend one of the most prestigious universities in the world Eligibility: Candidates for the Scholarship must: $1 . \mathrm{Be}$ entered for the Year 13 senior school examination (for example, NCEA Level 3, Cambridge exams, etc.) or equivalent senior school exam in the year of application. 2. Have a record of achievement sufficient to satisfy the academic criteria for entry to Cambridge University and Gonville and Caius College. 3. Be New Zealand citizens or permanent residents. 4. Normally have completed their five years of secondary schooling in New Zealand

Level of Study: Graduate

Type: Scholarship

Value: One scholarship is awarded each year and provides tuition fees and a living allowance

Frequency: Annual

Country of Study: Any country

Application Procedure: Check your eligibility. Read the Regulations. Applications must be done online. A link to the application website is here. www.universitiesnz.ac.nz/ scholarships/sir-douglas-myers-scholarship

Closing Date: 1 December

Funding: Private

\section{The Claude McCarthy Fellowships}

Subjects: All subjects

Purpose: Claude McCarthy Fellowships (Category A) are available to candidates who are graduates of a New Zealand university and who are enrolled in a $\mathrm{PhD}$ programme at a New Zealand university

Eligibility: 1. A graduate of a New Zealand university. 2. Registered for a doctoral degree at a New Zealand university. 
3. Have been registered for their doctoral degree for at least one year at the closing date for applications

Level of Study: Postgraduate

Type: Scholarship

Value: NZ\$5,000

Length of Study: 1 year

Frequency: Annual

Country of Study: Any country

Application Procedure: Apply online: universitiesnz. communityforce.com/

Closing Date: 1 April; 1 October

Funding: Trusts

\section{The Dick and Mary Earle Scholarship in Technology}

\section{Subjects: All subjects}

Purpose: The purpose of the scholarship is to provide funds for individuals to undertake research towards a masterate or doctorate degree at a New Zealand university or research institution in one or both of these fields: 1. Innovation and product development. 2. Bioprocess technology

Eligibility: 1. Applicants will be New Zealand citizens or permanent residents who have resided in New Zealand for at least three years immediately preceding the year of selection.

2. Applicants will have completed the requirements for a BTech, BEng, BE degree or equivalent, with honours where they are awarded, at a New Zealand university and in a field appropriate to their intended postgraduate study

Level of Study: Postgraduate

Type: Scholarship

Value: Up to NZ $\$ 17,000$ per annum at Masters level and $\mathrm{NZ} \$ 25,000$ per annum at PhD level

Length of Study: 3 year

Frequency: Varies

Country of Study: Any country

Application Procedure: Apply online: universitiesnz. communityforce.com

Closing Date: 1 September

Funding: Trusts

\section{The Edward \& Isabel Kidson Scholarship}

Subjects: All subjects

Purpose: The purpose of the scholarships is to enable a graduate of a New Zealand university, who is of good character and who has shown an ability in physics or a combination of physics and mathematics, to undertake further advanced study or research in meteorology, either in New Zealand or elsewhere

Eligibility: Applicants should be graduates of a New Zealand university, be of good character and have shown ability in physics or a combination of physics and mathematics. 1. Past pupils of Nelson Boys' College. 2. Graduates of the University of Canterbury

Level of Study: Postgraduate

Type: Scholarship

Value: NZ\$6,000

Length of Study: 3 year

Frequency: Annual

Country of Study: Any country

Application Procedure: Apply online

Closing Date: 1 October

Funding: Trusts

\section{The Judith Clark Memorial Fellowships}

Subjects: The Judith Clark Memorial Fellowships have been established to assist recent music graduates undertake a special sort-term project that will have long-term benefits for their future professional careers as musicians. Projects that will be considered by the selection committee include attendance at a reputable summer school or summer academy, or auditions for a longer-term postgraduate study programme Purpose: The Judith Clark Memorial Fellowships have been established to assist music graduates undertake a special short-term project that will have long term benefits for their future professional careers as musicians

Eligibility: Applicants must hold New Zealand citizenship or permanent residency and must have recently graduated, or expect to graduate in the year of application, with an Honours degree, or equivalent, in music from a New Zealand university

Level of Study: Postgraduate

Type: Fellowship/Scholarship

Value: NZ\$15,000

Length of Study: 1 year

Frequency: Varies

Country of Study: Any country

Application Procedure: Apply online universitiesnz. communityforce.com

Closing Date: 15 August and 15 February

Funding: Foundation

Additional Information: There are two application rounds available Round 1 : Principally to the support the cost of attending auditions in the November to February period. Round 2: Principally to support attendance at a summer school or summer academy in the May to August period

\section{The Kia Ora Foundation Patricia Pratt Music Scholarship}

Subjects: Overseas 
Purpose: The purpose of the Kia Ora Foundation Patricia Pratt Music Scholarship is to assist outstanding New Zealand musical performers, who have completed the equivalent of an honours degree in musical performance in New Zealand, to continue their musical development at a renowned international music school or conservatorium

Eligibility: Applicants will be New Zealand citizens. Applicants may apply from outside New Zealand but must have resided in New Zealand for at least three of the last five years immediately preceding the year of selection. Applicants will have recently completed the requirements for an honours degree in musical performance at a New Zealand university (or an equivalent musical qualification)

Level of Study: Postgraduate

Type: Scholarship

Value: NZ\$70,000

Length of Study: 2 years

Frequency: Varies

Country of Study: Any country

Application Procedure: Apply online: universitiesnz. communityforce.com

Closing Date: 1 March

Funding: Trusts

\section{University of Canterbury Doctoral Scholarship}

Purpose: These scholarships support students for study towards a research doctoral degree at the University of Canterbury. Approximately 60 scholarships are available each year, over two annual application rounds

Eligibility: The scholarships are tenable by full-time and part-time students engaged in study for a research doctoral degree at UC. An applicant must have completed an appropriate qualification at a level judged to be equivalent to a bachelor's or master's degree with first-class honours at UC (equivalent to a UC GPA of at least 7.0)

Level of Study: Postgraduate

Type: Scholarship

Value: NZ $\$ 21,000$ per 120 points of thesis enrolment

Frequency: Every 3 years

Country of Study: Any country

Application Procedure: Apply online thro below link. www. canterbury.ac.nz/scholarships/

Closing Date: 15 May

Funding: Private

\section{For further information contact:}

Tel: $\quad$ (64) 33694900

Email: scholarships@canterbury.ac.nz

\section{Woolf Fischer Scholarship}

Purpose: The Woolf Fisher Trust offers up to three Scholarships each year tenable at the University of Cambridge for three or four years of postgraduate research leading to a doctoral degree or equivalent

Eligibility: The Scholarships are open to New Zealand citizens who: a. are under the age of 30 in the year of application. b. attended a secondary school in New Zealand. c. have graduated or are expected to graduate with a first-class honours degree from a university in New Zealand. No application will be considered from a student already living outside of New Zealand and no award will be made for post-doctoral study

Level of Study: Graduate

Type: Scholarship

Value: maintenance allowance of NZ£15,000 sterling per annum,

Frequency: Every 3 years

Country of Study: New Zealand

Application Procedure: You may apply through this webpage approximately 8 weeks before applications close. If it's possible to apply on-line for this scholarship there will be a link above to the on-line system. For further details, visit the website. www.universitiesnz.ac.nz/scholarships/woolffisher-scholarship

Closing Date: 1 August

Funding: Private

\section{University of Cape Town}

University of Cape Town, Private Bag X3, Rondebosch, 7701, South Africa

Tel: (27) 216503622

Fax: (27) 216504352

Email: pgfunding@uct.ac.za

University of Cape Town (UCT) is very similar to the city of Cape Town: it has a vibrant, cosmopolitan community. It is a cultural melting pot where each person contributes their unique blend of knowledge and thinking. Our staff and students come from over 100 countries in Africa and the rest of the world. The university has also built links, partnerships and exchange agreements with leading African and international institutions that further enrich the academic, social and cultural diversity of our campus. 


\section{University of Cape Town Masters Scholarships in Public Health}

Purpose: To support the training of eye health professionals with strong public health skills, the Consortium offers scholarships for candidates from low- and middleincome African Commonwealth countries who have been accepted to study for a Masters Public Health, Community Eye Health at the University of Cape Town, South Africa

Eligibility: Applicants must come from a low- or middleincome African Commonwealth country to apply. Funding is available for postgraduate studies only. The bursaries are awarded on a yearly basis

Level of Study: Postgraduate

Country of Study: South Africa

Application Procedure: Check website for more details Closing Date: 31 July

Funding: Trusts

\section{University of Delaware}

Department of History, Newark, DE 19716, United States of America

Tel: $\quad$ (1) 3028318226

Fax: (1) 3028311538

Email:_dianec@udel.edu

Website: www.udel.edu

Contact: Ms Diane Clark, Administrative Assistant

The Department of History offers MA and $\mathrm{PhD}$ programmes in American and European history and more limited graduate study Ancient, African, Asian, Latin American, and Middle Eastern history. In conjunction with these, it offers special programmes in the history of industrialization, material culture studies, American Civilization, and museum studies.

\section{Executive MBA Programme}

Length of Study: 1 year;3 years

Application Procedure: Applicants must complete an application form supplying US\$45 fee, transcripts, Graduate Management Admission Test score, TOEFL score and two letters of recommendation

Closing Date: Varies
For further information contact:

Tel: $\quad$ (1) 3028312221

Fax: (1) 3028313329

Email: E-MBA@strauss.udel.edu

Contact: MBA Admissions Officer

\section{University of Derby}

Kedleston Rd, Derby DE22 1GB, United Kingdom

Tel: $\quad$ (44) 1332590500

Website: www.derby.ac.uk

Contact: University of Derby

The University of Derby is a public university in the city of Derby, United Kingdom. It traces its history back to the establishment of the Derby Diocesan Institution for the Training of Schoolmistresses in 1851 and gained university status in 1992 as one of the new universities.

\section{International Scholarships at University of Derby}

Subjects: Scholarships are awarded to study the subjects offered by the university

Purpose: The University of Derby is offering international scholarships for the academic year. These scholarships are available to apply for once you have received an offer on a course from the University

Eligibility: These scholarships are available to apply for once you have received an offer on a course from the University. International students are eligible to apply

Type: Postgraduate scholarships

Value: Varies

Study Establishment: Scholarships are awarded to study the subjects offered by the university

Country of Study: United Kingdom

Application Procedure: The mode of applying is online Closing Date: 14 January

Additional Information: For more details please visit the website scholarship-positions.com/international-scholarshipsuniversity-derby-uk/2017/09/29/

\section{For further information contact:}

Email: iadmissions@derby.ac.uk 


\section{University of Dundee}

Nethergate, Dundee DD1 4HN, United Kingdom

Tel:

(44) 1382345028

Fax: (44) 1382345343

Email: j.e.nicholson@dundee.ac.uk

Website: www.dundee.ac.uk

Contact: Postgraduate Office

The University of Dundee is one of United Kingdom's leading universities, named Scottish University of the Year 2004/ 2005 (Sunday Times) and ranked top for teaching quality in 2005 (THES). It is internationally recognised for its expertise across a range of disciplines including science, medicine, engineering and art and graduates more people into the professions than any other university in Scotland.

\section{Master of Business Administration Programme}

Length of Study: 2 years; 5 years

Application Procedure: Applicants must complete an application form supplying UK£25 fee, two academic references, official transcripts and evidence of English Language proficiency if applicable

Closing Date: Varies

For further information contact:

Tel: (44) 1382344300

Fax: (44) 1382228578

Email: cepmlp@dundee.ac.uk

Contact: MBA Admissions Officer

\section{University of East Anglia (UEA)}

Faculty of Arts and Humanities, School of Literature and Creative Writing, Norwich NR4 7TJ, United Kingdom

Tel:

(44) 1603456161

Fax: (44) 1603507728

Website: www.uea.ac.uk/lit/fellowships

Contact: Fellowship Administrator

The University of East Anglia (UEA) is organized into 23 schools of study encompassing arts and humanities, health, sciences and social sciences. These are supported by central service and administration departments.

\section{University of East Anglia International Development Scholarships}

Subjects: Masters degree courses offered by the School of International Development

Purpose: The University of East Anglia is offering one full fee scholarship for international students towards Masters Degree courses offered by the School of International Development

Eligibility: The scholarships are awarded on the basis of academic excellence (e.g. first class degree) and their personal statement. All applicants are expected to have met the School's English language requirements and been offered and accepted a place on the course by the deadline

Level of Study: Postgraduate

Type: Scholarship

Value: Full fees for masters degree programme

Frequency: Annual

Study Establishment: University of East Anglia

Country of Study: United Kingdom

Application Procedure: It is important to visit the official website for detailed information on how to apply for this scholarship

Closing Date: 31 March

Funding: Corporation

For further information contact:

Email: admissions@uea.ac.uk

\section{University of Edinburgh}

Old College South Bridge, Edinburgh EH8 9YL, United Kingdom

Tel: $\quad$ (44) 1316502159

Fax: (44) 1316508009

Email:_postgrad@ed.ac.uk

Contact: Grants Management Officer

\section{Alice Brown PhD Scholarships}

Purpose: The Alice Brown Scholarship is a new 6-year $\mathrm{PhD}$ scholarship offering a programme of advanced study, ongoing research, professional training and development 
Eligibility: Citizens of United Kingdom, European Economic Area and Switzerland are eligible to apply. A first class honours degree (or equivalent) in a subject relevant to the studentship OR a taught MSc degree at distinction level in a subject relevant to the studentship. Conditional offers can be made to applicants currently enrolled in a degree programme on the basis of anticipated results. 1. As comprehensive research training is integrated into the programme of this $\mathrm{PhD}$, there will be no automatic preference given to those holding MSc qualifications covering research training. 2. Applications are encouraged from those nearing the end of an undergraduate degree in a subject relevant to the scholarship. 3. Due to constraints on part-time study for international students on visas, this award is only open to nationals of the United Kingdom, countries of the European Economic Area, or Switzerland

Level of Study: Graduate

Type: Scholarship

Value: The scholarship covers full payment of $\mathrm{PhD}$ tuition fees and provides an annual stipend of $£ 10,000$ each year

Length of Study: 6-year PhD programme

Country of Study: United Kingdom

Application Procedure: Applicants are invited to submit a current $\mathrm{CV}$, a short research proposal/idea (max. 1,000 words) and a personal statement of up to 500 words explaining their suitability for the scholarship in the field to which they are applying

Contributor: University of Edinburgh

Additional Information: For more details, please visit scholarship-positions.com/alice-brown-phd-scholarships-uni versity-edinburgh-uk/2018/02/27/. All PhD students in the School of Social and Political Science can apply to the $\mathrm{PhD}$ Research Support Fund for help with fieldwork and other research-related costs throughout their period of study

For further information contact:

Email: pgresearch.sps@ed.ac.uk

\section{Clinical Management of Pain Scholarship}

Value: Each scholarship provides a one-off payment of $£ 700$ towards tuition fees

Country of Study: Any country

Application Procedure: In order to gain access to the scholarship application system applicants must have applied for admission to the University of Edinburgh. Please note that, following the submission of an application for admission, it can take up to five working days for all system checks to be completed and for access to be granted. The online scholarship application form is located in EUCLID and can be accessed via MyEd our web based information portal at www.myed.ed.ac.uk
Closing Date: 27 July

Additional Information: htttp://www.ed.ac.uk/studentsystems/support-guidance

\section{For further information contact:}

Email: studentfunding@ed.ac.uk

\section{Commonwealth Online Global Health Scholarships at University of Edinburgh}

Purpose: The University's Global Health Academy has been awarded 10 fully funded studentships across five online Masters programmes within the domain of Global Health

Eligibility: The scholarships will be awarded to a candidate who is accepted for admission on to an eligible programme (see above) and who is a citizen of and resident in one of the following developing Commonwealth countries

Level of Study: Postdoctorate

Type: Scholarship

Frequency: Annual

Country of Study: Any country

Closing Date: 22 March

Funding: Foundation

\section{Edinburgh Global Online Distance Learning Masters Scholarship}

Value: Each scholarship will cover full tuition fees and will be tenable for 3 years

Length of Study: Three years

Country of Study: Any country

Application Procedure: The online scholarship application form is located in EUCLID and can be accessed via MyEd our web based information portal at www.myed.ed.ac.uk

Closing Date: 1 June

For further information contact:

Email: studentfunding@ed.ac.uk

\section{Edinburgh Global Online Distance Learning Scholarships}

Purpose: The University of Edinburgh will offer a number of scholarships for distance learning Master's programmes offered by the University

Eligibility: 1. Scholarships will be available for students commencing in session current year in any distance learning Masters programme offered by the University. 2. Applicants must be nationals of the eligible countries 
Level of Study: Postdoctorate

Type: Scholarship

Length of Study: 3 years

Frequency: Annual

Country of Study: Any country

Application Procedure: Please submit your CV, and a $500-$ 800 word summary of your reason for applying for the masters programme and how you envision family medicine transforming healthcare

Closing Date: 1 June

Funding: Private

\section{For further information contact:}

Email: family.medicine@ed.ac.uk

Contact: Mr Jane Dumayne

\section{Edinburgh Global Research Scholarship}

Purpose: These awards are designed to attract high quality overseas research students to the University of Edinburgh

Eligibility: The awards are open to overseas nationals commencing a $\mathrm{PhD}$ in any field of study

Value: Each scholarship will cover the difference between the tuition fee for a United Kingdom/European Union postgraduate student and that chargeable to an overseas postgraduate student. The awards do not cover maintenance expenses

Length of Study: Three years

Country of Study: United Kingdom

Closing Date: April

Additional Information: For more details on this award please contact Scholarships and Student Funding Services. Work: +44 (0)131 651 4070; Email: studentfunding@ed. ac.uk

\section{For further information contact:}

Email: studentfunding@ed.ac.uk

\section{Glenmore Medical Postgraduate Scholarship}

Subjects: Medical science

Purpose: Two scholarships are available for postgraduate full-time one year Masters study for eligible Human Medical programmes offered by the University in the upcoming academic session

Eligibility: The scholarship will be awarded on the basis of academic merit. Candidates must have, or expect to obtain, the overseas equivalent of a United Kingdom first-class honours degree

Level of Study: Postgraduate

Type: Scholarship
Value: The scholarship will have a value of $£ 21,200$ and will be tenable for one academic year. The scholarship will cover tuition fees of up to $£ 21,200$ with any surplus paid as a stipend Length of Study: The scholarship is tenable for one academic year

Frequency: Annual

Country of Study: United Kingdom

Application Procedure: Please check website for more details: www.ed.ac.uk/student-funding/pgt-application. Eligible applicants should complete an online application form. The closing date for applications is 25 June

Closing Date: 25 June

\section{Haywood Doctoral Scholarship}

Subjects: Scholarships are available to pursue Doctoral research programs and are awarded within the College of Arts and Law in History of Art

Purpose: To offer Haywood Doctoral Scholarship to an outstanding doctoral research candidate in History of Art

Type: Scholarship

Value: As an international student, you will receive a reduction in tuition fees equivalent to the Home/European Union rate if successful

Country of Study: United Kingdom

Closing Date: 2 March

For further information contact:

Tel: (44) 1214143344

Email: calpg-research@contacts.bham.ac.uk

\section{Institute for Advanced Studies in the Humanities- School of Social and Political Science Visiting Fellowships}

Purpose: The IASH-SSPS Visiting Fellowships are intended to encourage outstanding interdisciplinary research, international scholarly collaboration, and networking activities of Visiting Research Fellows together with SSPS academics

Eligibility: Kindly check the below steps for further instructions. 1. Fellows are expected to be resident in Edinburgh throughout the tenure of their Fellowship and to play a full part in the activities of the Institute. The Institute will be pleased to help with finding suitable accommodation in Edinburgh but is unable to pay accommodation costs. 2. The minimum tenure for a Fellowship is two months; applications for less than two months will not be considered. 3. Only fully completed applications will be considered. It is the responsibility of each applicant to ensure that all documentation 
is complete, and that referees submit their reports to the Institute by the closing date. Applications may include a copy of any one article or publication that is thought to be specially relevant to the research proposal and Fellowship submission

Level of Study: Graduate

Type: Fellowship

Frequency: Annual

Country of Study: Any country

Application Procedure: The next closing date for the receipt of applications will be Thursday 28 February. Applications received after that date will not be considered. Successful candidates will be notified by email with a formal letter of confirmation to follow; please ensure that you supply a valid email address so that you can be contacted quickly after decisions are made. The application form can be completed online. Check with the below link. www.sps.ed.ac.uk/ research/academic visitors/iash-ssps visiting fellowships

Closing Date: 28 February

Funding: Commercial, Private

For further information contact:

Email: iash@ed.ac.uk

\section{National Health Service Education for Scotland Primary Care Ophthalmology Scholarship}

Eligibility: The scholarships will be awarded to students who are accepted for admission on to the online distance learning MSc in Primary Care Ophthalmology at the University of Edinburgh. Applicants should already have been offered a place at the University of Edinburgh and should have firmly accepted that offer or be intending to do so

Type: Scholarship

Value: The scholarship will have a total value of $50 \%$ of the course fees

Country of Study: United Kingdom

Closing Date: 27 July

Additional Information: For further information, please contact Scholarships and Financial Support Team. Work: +44 (0)131 651 4070; Email: studentfunding@ed.ac.uk

\section{For further information contact:}

Email: studentfunding@ed.ac.uk

\section{Perfect Storms: Leverhulme Doctoral Scholarships}

Subjects: Interdisciplinary research on perfect storms - the most profound problems facing contemporary and future societies
Level of Study: Doctorate

Value: Full fees, living and research costs

Length of Study: 3 years

Frequency: Annual

Study Establishment: University of Edinburgh

Country of Study: Scotland

Contributor: The Leverhulme Trusts

No. of awards given last year: 5

\section{For further information contact:}

Email: studentfunding@ed.ac.uk

\section{PhD Social Work Scholarship at University of Edinburgh in United Kingdom}

Subjects: Scholarship is awarded to study Social Work

Purpose: This award is available to students intending to commence PhD Social Work study in September on either a full-time or part-time basis

Eligibility: Citizens of all nationalities are eligible to apply. If English is not your first language then you will need to show that your English language skills are at a high enough level to succeed in your studies

Value: One award covering tuition fees at the Home/European Union fee rate, a maintenance stipend of $£ 14,000$ and a research grant of $£ 500$ is on offer to applicants for PhD Social Work in the School of Social and Political Science

Study Establishment: Social Work study

Country of Study: Any country

Application Procedure: The online scholarship application form is located in EUCLID and can be accessed via MyEd our web-based information portal. www.myed.ed.ac.uk/

Closing Date: 1 March

For further information contact:

Email: GradSchool.HCA@ed.ac.uk

\section{Polish School of Medicine Memorial Fund Scholarships}

Purpose: The scholarship enables medical scientists at the outset of their careers to undertake a period of further study or research at the University's Medical School and return to Poland

Eligibility: Eligible applicants should complete an online scholarship application. The online scholarship application form is located in EUCLID and can be accessed via MyEd our web based information portal at www.myed.ed.ac.uk Value: Allowance for a period of up to 1 year 
Length of Study: One year

Country of Study: Any country

Closing Date: 17 May

For further information contact:

Email: maria.graham@ed.ac.uk

\section{Principal Career Development PhD Scholarship}

Purpose: To attract the best and brightest $\mathrm{PhD}$ students, the University seeks to offer not only unparalleled research facilities and superb supervision, but also to provide development opportunities which will support our research students as they progress beyond their $\mathrm{PhD}$, through an innovative programme of integrated research, training, and career development Type: Scholarship

Value: Each scholarship covers the United Kingdom/European Union rate of tuition fee as well as a stipend of $£ 15,000$

Country of Study: United Kingdom

Closing Date: 1 February

Additional Information: For further information, please contact Scholarships and Financial Support Team, phone :0131 651 4070, email: studentfunding@ed.ac.uk

\section{For further information contact:}

Email: studentfunding@ed.ac.uk

\section{Shell Centenary Scholarships and Shell Centenary Chevening Scholarships at Edinburgh}

Subjects: Applied sciences and technology, including environmental sciences

Eligibility: Students from countries that are not present or applicant members of the Organization for Economic Co-operation and Development (OECD). Candidates should normally be aged $20-35$, be resident in one of the non-OECD countries and be intending to return to the country concerned at the end of the period of study. They should normally already hold a degree equivalent to a United Kingdom First Class (Honours) Degree or be expecting to obtain such a degree before the start of their proposed course

Level of Study: Postgraduate

Type: Scholarship

Value: The scholarships covers tuition fees, accommodation, maintenance costs and a return airfare for the scholarship holder

Length of Study: 1 year

Frequency: Annual
Study Establishment: University of Edinburgh

Country of Study: Scotland

Application Procedure: Applicants must apply separately for admission to the University of Edinburgh making a clear statement that they wish to be considered for a Shell Scholarship

Closing Date: 1 March

No. of awards given last year: 6

\section{For further information contact:}

Email: scholarships@ed.ac.uk

\section{The Anne Rowling Clinic Regenerative Neurology Scholarships}

Subjects: The scholarships will be awarded to applicants who are accepted for admission on to the online distance learning postgraduate Certificate, Diploma, or Masters Stem Cell and Translational Neurology programme at the University of Edinburgh for the academic session. Field of study is Neurology

Purpose: Masters scholarships for applicants commencing Stem Cells and Translational Neurology programmes in the academic year

Type: Scholarship

Value: One International Anne Rowling Clinic Regenerative Neurology Scholarship will cover 60 credits towards your module fees. Two Anne Rowling Clinic Regenerative Neurology Scholarships will cover 30 credits worth of course fees Country of Study: United Kingdom Application Procedure: Eligible applicants should complete an online scholarship application. Website link is www.ed. ac.uk/student-funding/postgraduate/e-learning/regenerativeneurology

Closing Date: 20 August

Funding: Private

Additional Information: For further information, please visit www.ed.ac.uk/student-funding/postgraduate/e-learning/ regenerative-neurology

\section{For further information contact:}

Email: studentfunding@ed.ac.uk

\section{The Edinburgh Online Family Medicine Scholarships Fund}

Purpose: Through the generous donations of a benefactor in India who is committed to improving healthcare in rural 
regions this full scholarship award will allow a student from

South Asia to study the online Masters of Family Medicine

Type: Scholarship

Frequency: Annual

Country of Study: Any country

Application Procedure: Applications should be made to

Michelle Hart at family.medicine@ed.ac.uk

Closing Date: 1 July

For further information contact:

Email: family.medicine@ed.ac.uk

\section{The Garden Scholarship in Surgical Sciences}

Type: Scholarship (grant-in-aid)

Value: $£ 1,000$

Country of Study: Any country

For further information contact:

Email: studentfunding@ed.ac.uk

\section{The Kirby Laing International Scholarships}

Value: The scholarships will cover tuition fees and provide a maintenance allowance of $£ 12,000$

Length of Study: 1 year

Country of Study: United Kingdom

Closing Date: 2 April

Additional Information: For further information, please contact School of Divinity, Work: 0441316508 900, Email:

Divinity.PG@ed.ac.uk

\section{For further information contact:}

Email: Divinity.PG@ed.ac.uk

\section{The Lt.Col Jack Wishart Scholarship}

Value: $£ 500$ per year toward tuition fees

Length of Study: Two academic years

Country of Study: Any country

Application Procedure: The online scholarship application form is located in EUCLID and can be accessed via MyEd our web based information portal at www.myed.ed.ac.uk

Closing Date: 30 September

\section{For further information contact:}

Email: studentfunding@ed.ac.uk

\section{The Rev Dr Norma P Robertson Scholarship}

Type: Scholarship

Value: The scholarship will have a maximum value of $£ 7,500$ Country of Study: Any country

\section{For further information contact:}

Email: studentfunding@ed.ac.uk

\section{The Sanders Scholarship in Clinical Ophthalmology}

Purpose: University of Edinburgh is offering twenty four scholarships for online distance learning. Scholarships are available for pursuing online distance learning masters degree programmes

Eligibility: The scholarships will be awarded to students who are accepted for admission on to the online distance learning MSc in Primary Care Ophthalmology and the ChM in Clinical Ophthalmology at the University of Edinburgh. Applicants must be medical or surgical trainees registered with the General Medical Council and working in a recognised training programme in the Scottish NHS, and be resident in Scotland. Applications from other health professionals involved in delivering eye care (except optometrists) in the Scottish NHS may be considered on an individual basis

Level of Study: Graduate

Type: Scholarship

Value: $£ 1,000$

Country of Study: United Kingdom

Application Procedure: Complete an online EUCLID application for the MSc in Primary Care Ophthalmology or the ChM (Master of Surgery) in Clinical Ophthalmology instructions on full application process can be found on the University's degree finder pages for the MSc PCO and the ChM CO. Wait for decision on application via EUCLID. If eligible to join the course, you will be given a conditional or unconditional offer, which you must accept prior to applying for a scholarship. Email a personal statement to declare your wish to apply for a scholarship to: chm.info@ed.ac.uk by 31 August

Closing Date: 27 July

Funding: Private

Additional Information: For further details, please contact Scholarships and Financial Support Team, Work:0131 651 4070, Email: studentfunding@ed.ac.uk

\section{For further information contact:}

Email: sarah.jones@ed.ac.uk 


\section{Wellcome Trust 4-Year PhD Programme Studentships}

Subjects: Cell biology

Eligibility: Students should be from a life sciences background and should hold, or expect to obtain, at least an Upper Second Class (Honours) Degree

Level of Study: Doctorate

Type: Studentship

Value: Tuition fees, research costs and maintenance allowance

Frequency: Annual

Study Establishment: The University of Edinburgh

Country of Study: Scotland

Application Procedure: Please see the website www.wcb. ed.ac.uk/phd

Closing Date: 10 December

No. of awards given last year: 5

For further information contact:

Email: karen.traill@ed.ac.uk

Contact: Karen Traill

\section{University of Essex}

Graduate Admissions Office, University of Essex, Wivenhoe Park, Colchester C04 3SQ, United Kingdom

Tel: $\quad$ (44) 1206872719

Fax: (44) 1206872808

Email:_pgadmit@essex.ac.uk

Website: www.essex.ac.uk

Contact: V Bartholomew, CRM Operations Manager

The University of Essex is one of the United Kingdom's leading academic institutions, ranked 10th nationally for research and 7th for teaching. It offers degrees and research opportunities across 19 academic departments (including government and sociology, which both have 6-star research ratings) and numerous research centres of world renown.

\section{Academic Excellence International Masters Scholarship}

Subjects: Scholarships are available for pursuing master's degree level at University of Essex in United Kingdom Purpose: University of Essex is inviting applications for academic excellence international masters scholarship
Eligibility: Applicants must meet the necessary language proficiency requirements of the host institution

Value: The scholarship worth up to $£ 5,000$, paid as a discount on tuition fee

Frequency: Annual

Study Establishment: Scholarships are awarded in the fields offered by the university

Country of Study: United Kingdom

Application Procedure: If applicants meet all the eligibility criteria and firmly accept the offer of your place by 30 September then you will automatically be awarded this scholarship. Applicants will be notified of your award by the end of October. You don't need to complete an application form

Closing Date: 30 September

Additional Information: For more details please visit the website scholarship-positions.com/academic-excellenceinternational-masters-scholarship-uk-2017/2015/11/16/

For further information contact:

Email: enquiries@essex.ac.uk

\section{Arts and Humanities Research Council Department of Sociology Studentships}

Subjects: Communication, culture and media studies

Purpose: To support students on a research programme

Eligibility: Open to United Kingdom or European Union applicants

Level of Study: Postgraduate

Type: Scholarship

Value: UK students - fees plus maintenance; European Union students - fees

Frequency: Annual

Study Establishment: University of Essex

Country of Study: United Kingdom

Contributor: AHRC

For further information contact:

Email: pgeduc@leeds.ac.uk

\section{Arts and Humanities Research Council Research Preparations Masters Award for Literature, Film, and Theatre Studies}

Subjects: Literature, film and theatre studies

Purpose: To support students undertaking a research preparations in the department

Eligibility: Open to postgraduates offered a place to study in the department 
Level of Study: Postgraduate

Type: Award

Value: $£ 10,600$ per year maintenance grant

Length of Study: 1 year

Frequency: Annual

Study Establishment: University of Essex

Country of Study: United Kingdom

Application Procedure: Applicants must contact the department concerned

\section{For further information contact:}

Email: graduateschool@gold.ac.uk

\section{Dowden Scholarship}

Subjects: Mathematical sciences

Purpose: To help highly able students who otherwise would not be able to study at postgraduate level

Eligibility: Applicant must have settled status in the United Kingdom; been 'ordinarily resident' in the United Kingdom for the 3 years before the start of their studentship; not been residing in the United Kingdom wholly or mainly for the purpose of full-time education (United Kingdom and European Union nationals are exempt from this requirement). The Vera Dowden Baldwin Scholarship awards financial assistance to a resident of Dowden Hall who demonstrates financial need. The fund is named in honor of the late Vera Dowden Baldwin '34, whose connection with the University spanned more than seventy years

Level of Study: Postgraduate

Type: Scholarship

Value: Up to $£ 5,000$

Frequency: Annual

Study Establishment: University of Essex

Country of Study: United Kingdom

Application Procedure: Indicate on application for doctoral course

Additional Information: Please contact the university for more information

\section{Drake Lewis Graduate Scholarship for Art History}

Subjects: Art history

Purpose: To support new MA students in art history

Eligibility: Open to postgraduate applicants

Level of Study: Postgraduate

Type: Scholarship

Value: $£ 5,000$

Frequency: Annual
Study Establishment: University of Essex

Country of Study: United Kingdom

Funding: Private

Contributor: Drake Lewis

Additional Information: Please check website for further information

\section{For further information contact:}

Email: scholarships@essex.ac.uk

\section{Drake Lewis Graduate Scholarship for Health and Human Sciences}

Subjects: Public health and health studies

Purpose: To support students on full-time masters in public health or health studies

Eligibility: Open to postgraduate applicants

Level of Study: Postgraduate

Type: Scholarship

Value: $£ 5,000$

Frequency: Annual

Study Establishment: University of Essex

Country of Study: United Kingdom

Application Procedure: Applicants must contact the department concerned

Funding: Private

Contributor: Drake-Lewis

Additional Information: Please check website for further information

For further information contact:

Email: scholarships@essex.ac.uk

\section{Economic and Social Research Council 1+3 Department of Sociology Studentships}

Subjects: Sociology

Purpose: To support students on a 1 year research training programme

Eligibility: Open to United Kingdom or European Union applicants who have not completed a programme of research training

Level of Study: Postgraduate

Type: Scholarship

Value: UK students - fees plus maintenance; European Union students - fees

Frequency: Annual

Study Establishment: University of Essex

Country of Study: United Kingdom

Application Procedure: See website 
Closing Date: March

Contributor: ESRC

For further information contact:

Email: fass-pg@lancaster.ac.uk

\section{Santander Masters Scholarship}

Subjects: All subjects

Purpose: To support students from Santander network countries to undertake further study

Eligibility: Open to graduates residing in one of the Santander network countries who have an offer to study at Masters level

Level of Study: Postgraduate

Type: Scholarships

Value: $£ 5,000$

Frequency: Annual

Study Establishment: University of Essex

Country of Study: United Kingdom

Application Procedure: Please check website

Funding: Corporation

Contributor: Santander

For further information contact:

Email: pgtaught@lboro.ac.uk

\section{Tinson Fund Scholarship for Law}

Subjects: Law

Purpose: To support students from the former Soviet Bloc interested in studying postgraduate law

Eligibility: Open to students from former Soviet Bloc countries, who have an offer on an LLM programme

Level of Study: Postgraduate

Type: Scholarship

Value: Tuition fees

Frequency: Annual

Study Establishment: University of Essex

Country of Study: United Kingdom

Application Procedure: See website for details

Closing Date: Mid-May

No. of awards given last year: 1

\section{For further information contact:}

Email: scholarships@essex.ac.uk

\section{University of Essex Centre for Psychoanalytic Studies Scholarship}

Subjects: Psychoanalytic studies

Purpose: To support postgraduate study within the centre

Eligibility: Open to postgraduates within the centre for psy-

choanalytic studies

Level of Study: Postgraduate

Type: Scholarship

Value: Depends on funds available

Length of Study: 1 year

Frequency: Annual

Study Establishment: University of Essex

Country of Study: United Kingdom

Application Procedure: Applicants must contact the centre concerned

Contributor: University of Essex

For further information contact:

Email: pgadmit@essex.ac.uk

\section{University of Essex Silberrad Scholarship}

Subjects: All subjects

Purpose: To support graduates to pursue PhD study

Eligibility: Open to applicants holding a degree from or about graduate from University of Essex who have an offer place at the University of Essex and are eligible to pay Home/European Union tuition fees

Level of Study: Postgraduate, Research

Type: Scholarship

Value: Home/European Union tuition fee and bursary element towards living costs

Length of Study: Up to 1 year

Frequency: Annual

Study Establishment: University of Essex

Country of Study: United Kingdom

Application Procedure: Please check website

Funding: Trusts

Contributor: Silberrad Estate

For further information contact:

Email: pgadmit@essex.ac.uk

\section{University of Exeter}

Postgraduate Administration Office, Northcote House, The Queen's Drive, Exeter EX4 4QJ, United Kingdom 
Tel: $\quad$ (44) 1392723044

Email: pg-ad@exeter.ac.uk

Website: www.exeter.ac.uk/postgraduate/money/funding/

Contact: Mrs Julie Gay, Scholarships Secretary

The University of Exeter is consistently regarded as one of the best universities in the United Kingdom and has an increasingly excellent reputation internationally. A member of the Russell Group, we attract funding from all major research councils, and are collaborators in 10 prestigious Doctoral Training Partnerships.

\section{Full-Fee Master's Scholarships}

Subjects: Selected taught Masters in the arts, business, education, humanities and social sciences and science

Purpose: Full fee waiver offered to students who best demonstrate the potential to progress to doctoral study

Eligibility: Applicants who demonstrate exceptional academic ability such as a first class honours or direct equivalent, and the potential to progress to doctoral study based on a submitted research proposal and personal statement will be considered

Level of Study: Graduate, Postgraduate

Type: Scholarship

Value: Full fee waiver of the taught Master's programme irrespective of fee status

Length of Study: 1 year

Frequency: Annual

Study Establishment: The University of Exeter

Country of Study: United Kingdom

No. of awards offered: 185

Application Procedure: Application forms can be downloaded from the website www.exeter.ac.uk/scholarships/post graduate/fullmasters

Closing Date: 31 March

Funding: Corporation

No. of awards given last year: 15

No. of applicants last year: 185

Additional Information: Applications will only be considered from students who have received an offer of a place on a taught Master's programme at the University

\section{For further information contact:}

Scholarship Administrator, Admissions Office, Laver Building, North Park Road, Exeter EX4 4QE

Email: admissions-scholarships@exeter.ac.uk

\section{University of Exeter Chapel Choir Choral and Organ Scholarship}

Purpose: Annual scholarships offered to choral and organ practitioners to aid in recitals on behalf of the chapel choir Eligibility: Based on audition. The Director of Chapel Music will invite for competitive audition on the basis of applications demonstrating a high level of competence and experience plus details of two referees familiar with the applicant's ability

Level of Study: Doctorate, Graduate, Postgraduate, Research, MBA

Type: Scholarship

Value: $£ 400$ per year for choral scholars, $£ 700$ per year for senior organ scholars, $£ 300$ per year for junior organ scholars Length of Study: 1 year initially but may be renewed for the duration of study, where appropriate

Frequency: Annual

Study Establishment: The University of Exeter

Country of Study: United Kingdom

No. of awards offered: 60

Application Procedure: Applicants can contact the Director for more information and request an application form

Closing Date: 13 February

Funding: Corporation, Trusts, Individuals

No. of awards given last year: 10

No. of applicants last year: 60

Additional Information: From the 10 choral scholarships available, 4 are offered to sopranos, 2 each for other voice parts of alto (male and female), tenor and bass. The award for senior organ scholarship status will require recipients to direct the choir when required

\section{For further information contact:}

Email: a.j.musson@exeter.ac.uk

Contact: Professor Anthony Musson, Director of Chapel Music

\section{World Class Business School International Scholarship}

Eligibility: A scholarship will be awarded to the most talented international students who have had an application accepted to one of The Business School MSc programmes. Applicants must be resident in one of the following: Africa, Asia, and the Commonwealth of Independent States including students resident in Azerbaijan, Kazakhstan, Norway, Russia, Ukraine and Turkey

Type: Scholarship

Value: $£ 10,000$

Length of Study: 1 year 
Frequency: Annual

Country of Study: United Kingdom

Application Procedure: Please apply at www.exeter.ac.uk/ studying/funding/apply/step1/?award=1039

Closing Date: 30 March

Contributor: University of Exeter

For further information contact:

Email: business-school-admissions@ex.ac.uk

Contact: Jane Knox

\section{University of Geneva}

University of Geneva, Geneva, Switzerland

Email: Excellence-Master-Sciences@unige.ch

Contact: Dean of the Faculty of Science

The University of Geneva is a public research university located in Geneva, Switzerland. It was founded in 1559 by John Calvin as a theological seminary and law school.

\section{University of Geneva Excellence Masters Fellowships}

Subjects: Astronomy, biology, chemistry and biochemistry, earth Sciences, environmental sciences, computer sciences, mathematics, pharmaceutical sciences and physics offered by the Faculty of Science

Purpose: The Faculty of Science of the University of Geneva, in collaboration with several sponsors, has established an Excellence Fellowship Program to support outstanding and highly motivated candidates who intend to pursue a Master of Science in any of the disciplines covered by the Faculty

Eligibility: The fellowships are open to students from any university with very good performance in their studies (belonging to the best $10 \%$ of their bachelor's programme) and that have completed the Bachelor degree or expect to complete it within 6 months. Selection of the applicants will be based on excellence

Level of Study: Doctorate, Postgraduate

Type: Fellowship

Value: CHF 10,000 to CHF 15,000 per year

Country of Study: Switzerland

Application Procedure: You must submit the application form and supporting documents as a unique PDF file by e-mail to the Dean of the Faculty of Science

Closing Date: 15 March
Additional Information: Please visit official website for more details: www.unige.ch/sciences/Enseignements/Forma tions/Masters/ExcellenceMasterFellowships_en.html

\section{For further information contact:}

24 rue du Général-Dufour, 1211 Genève 4, Switzerland

Tel: (41) 223797111

Email: Sciences@unige.ch

\section{University of Glasgow}

Postgraduate Research Office, Research and Enterprise, University of Glasgow, Glasgow G12 8QQ, United Kingdom

Tel: $\quad$ (44) 1413301989

Fax: (44) 1413303218

Email: s.rait@enterprise.gla.ac.uk

Website: www.gla.ac.uk

Contact: Shirley Rait

The University of Glasgow is a major research led university operating in an international context, which aims to provide education through the development of learning in a research environment, to undertake fundamental, strategic and applied research and to sustain and add value to Scottish culture, to the natural environment and to the national economy.

\section{Alexander and Dixon Scholarship (Bryce Bequest)}

Subjects: English literature

Eligibility: Open to the citizens of United Kingdom or a European Union national

Level of Study: Doctorate

Type: Scholarship

Value: $£ 3,500$ fees only

Length of Study: 3 years

Application Procedure: The application should consist of a 500-word case for support and a brief covering letter, including the proposed title of the thesis, the name(s) of the proposed supervisor(s), and give the applicant's email and other contact details

Closing Date: 21 June

\section{For further information contact:}

Department Office, Department of English Literature, University of Glasgow, United Kingdom 
Email: critstudies-pgscholarships@glasgow.ac.uk

Contact: Meg MacDonald

\section{Alexander and Margaret Johnstone Postgraduate Research Scholarships}

Subjects: Arts

Eligibility: Open to students intending a research degree in the faculty of arts in a department rated 5 or $5^{*}$ in the research assessment exercise

Level of Study: Doctorate

Type: Research scholarship

Value: Tuition fees at the Home/European Union student rate, plus stipend of between $£ 6,000$ and $£ 7,000$

Length of Study: 3 years

Application Procedure: Check website for further details

Funding: Government

\section{For further information contact:}

Tel: $\quad$ (44) 1413306828

Email: e.queune@admin.gla.ac.uk

Contact: Emily Queune

\section{Bellahouston Bequest Fund}

Subjects: Arts and science

Eligibility: Open to postgraduate students undertaking a Masters Degree course in the faculty of Arts

Level of Study: Postgraduate

Type: Scholarship

Value: $£ 1,000$

Length of Study: 1 year

Frequency: Annual

Application Procedure: The candidate must contact the clerk of the faculty of arts. Check website for further information

Closing Date: 31 July

Additional Information: Preference will be given to the Glaswegians

For further information contact:

Tel: $\quad$ (44) 1413302000

Email: ugs@archives.gla.ac.uk

Contact: Clerk of the Faculty of Arts

\section{British Federation of Women Graduates (BFWG)}

Subjects: All subjects
Purpose: To encourage applicants to become members of the Federation to help promote better links between female graduates throughout the world

Eligibility: Open to female graduate with academic excellence. Doctoral students of all nationalities who will be studying in the United Kingdom are eligible for the scholarship

Level of Study: Postgraduate

Type: Scholarship and award

Value: $£ 1,000-6,000$

Length of Study: Four years

Frequency: Annual

Country of Study: United Kingdom

Application Procedure: Check website for further details

Closing Date: March (date differs annually)

Funding: Private

No. of awards given last year: 6

Additional Information: Male graduates and female undergraduates are not eligible

\section{For further information contact:}

Tel: $\quad$ (44) 2074988037

Fax: (44) 2074985213

Email: info@bfwg.org.uk

\section{Clark Graduate Bursary Fund for International Students at University of Glasgow}

Subjects: Bursary is awarded in the field offered by the university

Purpose: The aim of the bursary is to support graduates of the University of Glasgow or Strathclyde studying for, or applying to study for, a subsequent degree at a university in the United Kingdom or abroad

Eligibility: Applicants can either be graduates of the University of Glasgow or Strathclyde studying for, or applying to study for, a subsequent degree at a university in the United Kingdom or abroad. Applicants must be fluent in English Type: Postgraduate scholarships

Value: The value of the bursary normally between $£ 500$ and $£ 1,500$

Study Establishment: Bursary is awarded in the field offered by the university

Country of Study: United Kingdom

Application Procedure: There is an annual application process. Applications can be submitted between 1st March and 1st October each year. Applications must be submitted online. Interviews of candidates selected for consideration are held in Glasgow at a Governors' meeting during November. Interviewees will usually be notified within a week of the interviews whether they will receive an award. Awards are normally paid to successful applicants before the end of the year 
Closing Date: 1 March and 1 October each year

Additional Information: For more details please visit the website scholarship-positions.com/clark-raduate-bursaryfund-international-students-university-of-glasgow-uk/2017/ $12 / 20 /$

\section{For further information contact:}

Email: clarkmileendfund@gmail.com

\section{Glasgow Educational \& Marshall Trust Award}

Subjects: All subjects

Purpose: To offer financial support to those who have lived, or are currently living within the Glasgow Municipal Boundary

Eligibility: Open to the candidates who are above 18 years of age and a resident of Glasgow within one of the following post code areas: G1-5, G11/12, G14/15, G20, G22/23, G31, G34, G40-42, G45, 51

Level of Study: Doctorate, Graduate, Postdoctorate, Postgraduate, Predoctorate, Research, MBA

Type: Studentships and bursaries

Value: $£ 50-1,000$

Length of Study: 1 year

Study Establishment: Glasgow Educational and Marshall

Trust

Country of Study: United Kingdom

Application Procedure: Check website for further details

Closing Date: 30 April

Contributor: Glasgow Educational and Marshall Trust

For further information contact:

Tel: $\quad$ (44) 1414334449

Fax: (44) 1414241731

Email: sloanea@hutchesons.org

Contact: Mrs Avril Sloane, Secretary and Treasurers

\section{Henry Dryerre Scholarship in Medical and Veterinary Physiology}

Subjects: Animal care and veterinary science; biology and life sciences; health sciences; medicine and surgery

Eligibility: Open to candidates holding a degree of a Scottish University with first class honours or, if in their final year, to be expected to achieve first class honours

Level of Study: Postgraduate

Type: Scholarships and fellowships

Value: Varies

Frequency: Every 3 years

Country of Study: Any country
Application Procedure: The candidate must submit the application form through a member of staff on the appropriate Henry Dryerre Nomination Form

\section{For further information contact:}

Email: scholarships@glasgow.ac.uk

Contact: Assistant Secretary

\section{Lord Kelvin/Adam Smith Postgraduate Scholarships}

Subjects: All subjects

Purpose: To enable the University to recruit outstanding postgraduate research students to a range of innovative, boundary-crossing research developments

Eligibility: Open to postgraduate students

Level of Study: Postgraduate

Type: Scholarship

Value: Stipend of $£ 13,590$. The project will benefit from $£ 5,300$ per year research costs

Length of Study: 4 years

Frequency: Annual

Application Procedure: Check website for further details

Funding: Trusts

For further information contact:

Email: lauren-currie@enterprise.gla.ac.uk

Contact: Lauren Currie, Postgraduate Research Secretary,

\section{R. Harper Brown Memorial Scholarship}

Subjects: All subjects

Purpose: To honour the late R. Harper Brown and to assist in defraying the cost of an American (United States) college student's study at a university in Scotland

Eligibility: Open to the candidates who are graduating seniors in high school with an acceptance and intention to attend university in Scotland or a student in an accredited American (United States) college or university looking for a study-abroad experience

Level of Study: Graduate

Type: Scholarship

Application Procedure: Check website for further details

Closing Date: Between 1 January and 31 March

Funding: Private

Contributor: The Illinois Saint Andrew Society

For further information contact:

Tel: $\quad$ (44) 8479672725

Email: dforlow@yahoo.com

Contact: David Forlow 


\section{Royal Historical Society: Postgraduate Research Support Grants}

Subjects: History

Purpose: To assist postgraduate students in the pursuit of advanced historical research

Eligibility: The candidate must be a postgraduate student registered for a research degree at United Kingdom Institute of Higher Education

Level of Study: Graduate, Research

Type: Award/Grant

Country of Study: United States of America

Application Procedure: Check website for further details

Closing Date: 14 January, 18 February, 6 May, 18 June,

9 September and 12 November

Contributor: Royal Historical Society

For further information contact:

Email: m.ransom@royalhistsoc.org

\section{Saint Andrew's Society of the State of New York Scholarship Fund}

Subjects: All subjects

Eligibility: Open to candidates who are either graduates of a Scottish university or of Oxford or Cambridge and have completed their first Degree course

Level of Study: Graduate

Type: Scholarship

Value: Up to US $\$ 20,000$ each to cover university tuition fees, room and board and transportation expenses

Length of Study: 1 academic year

Frequency: Annual

Country of Study: United States of America

Application Procedure: The candidate must arrange for references from two academic referees to be submitted in the appropriate referee forms

Closing Date: 25 January

Funding: Trusts

Contributor: Saint Andrew's Society of the State of New York

For further information contact:

Tel: (44) 1413306063

Email: c.omand@admin.gla.ac.uk

Contact: Catherine Omand

\section{Stevenson Exchange Scholarships}

Subjects: All subjects
Purpose: To promote friendly relations between the students of Scotland, Germany, France and Spain

Eligibility: Open to current or recent students of French, German or Spanish universities who intend to study at any university in Scotland

Level of Study: Postdoctorate

Type: Scholarship

Value: $£ 250-2,000$

Application Procedure: Check website for further details

Closing Date: 31 January

For further information contact:

1 The Square, University of Glasgow, Glasgow, United Kingdom

Tel: $\quad$ (44) 1413304241

Fax: (44) 1413304045

Email: 1.buchan@admin.gla.ac.uk

Contact: Linda Buchan, Exchange Co-ordinator

\section{The Catherine Mackichan Trust}

Subjects: Scottish history

Eligibility: Open to applications from academic centres worldwide, schools, colleges and individuals or groups

Level of Study: Research

Type: Award

Value: $£ 500$

Length of Study: 1 year

Frequency: Annual

Country of Study: Any country

Application Procedure: Check website for further details

Closing Date: 15 April

Funding: Trusts

Contributor: The Catherine Mackichan Trust

For further information contact:

Email: peter.mcghee@vaslan.org.uk

Contact: I Fraser, Vice Chairman

\section{William and Margaret Kesson Award for Postgraduate Study}

Subjects: Arts

Purpose: To enable a student to undertake study leading to a postgraduate degree in the faculty of arts

Eligibility: Open to candidates of Scottish or English nationality possessing a graduate degree

Level of Study: Graduate

Type: Scholarship

Length of Study: 3 years 
Country of Study: Any country

Application Procedure: Check website for further details

Closing Date: 1 May

For further information contact:

Email: e.queune@admin.gla.ac.uk

Contact: Clerk of the Faculty

\section{William Ross Scholarship}

Subjects: History

Purpose: To encourage the extraction of Scottish material from archives outside Scotland relating to all aspects of the history of Scotland, the Scottish people and Scottish influence abroad

Eligibility: Open to candidates possessing a degree in MLitt Level of Study: Research

Type: Scholarships and fellowships

Value: $£ 1,000$

Length of Study: 1 year

Frequency: Annual

Application Procedure: The candidate must submit a letter outlining a dissertation research proposal including the planned topic and archival research plans

Closing Date: 1 July

Contributor: Trustees of the Ross Fund

\section{For further information contact:}

Email: c.leriguer@arts.gla.ac.uk

Contact: Christelle LeRiguer

\section{Wingate Scholarships}

Subjects: All subjects

Purpose: To support creative or original work of intellectual, scientific, artistic, social or environmental value

Eligibility: Open for mature candidates and those from nontraditional academic backgrounds without any upper age limit Level of Study: Unrestricted

Type: Scholarship

Value: $£ 6,500-10,000$ in any 1 year

Length of Study: 1 year

Frequency: Annual

Country of Study: Any country

Application Procedure: Check website for further details

Closing Date: 1 February

\section{For further information contact:}

Email: emma@shrimsley.com

\section{University of Göttingen}

Project management, Equal Opportunities Office, Gosslerstrasse 9, DEU-37073, Göttingen, Germany

Tel: $\quad$ (49) $551 / 3933959$

Email: nina.guelcher@zvw.uni-goettingen.de

Contact: Mrs Nina Gülcher

The University of Göttingen is a public research university in the city of Göttingen, Germany.

\section{Dorothea Schlozer Postdoctoral Scholarships for Female Students}

Subjects: Faculty of Humanities, Faculty of Theology, Faculty of Law, Faculty of Economic Sciences, Faculty of Social Sciences and Medical Center (UMG)

Purpose: The University of Göttingen is inviting female postdocs from Germany to apply for Dorothea Schlozer Postdoctoral Scholarships. These scholarships are available to conduct a research project at the Georg-August-University Eligibility: Female postdocs from Germany are eligible to apply. The candidate should have a very good command of English language. Therefore, the application should be written in English

Value: There will be 3 positions (TV-L 13, 100\%, term of 2 years), one of which at the University Medical Center (UMG)

Length of Study: 2 years

Country of Study: Germany

Application Procedure: Applications will only be accepted through the online portal. After submitting your application you will receive an automatic confirmation of receipt via e-mail

Closing Date: 8 April

Additional Information: For more details, please visit the website www.uni-goettingen.de/de/122481.html

For further information contact:

Email: admin@scholarship-positions.com

\section{University of Graz}

Universitätsplatz 3, AUT 8010 Graz, Austria

Contact: University of Graz 
The University of Graz (German: Karl-Franzens-Universität Graz), located in Graz, Austria, is the largest and oldest university in Styria, as well as the second-largest and second-oldest university in Austria.

\section{Ida Pfeiffer Scholarships}

Purpose: This program is designed to give applicants the opportunity to submit an application for a waiver of tuition fees

Eligibility: For details, visit website www.european-fundingguide.eu/other-financial-assistance/14286-ida-pfeiffer-schol arships. Successful completion of at least two semesters at the University of Graz. Minimum age of 19 years and maximum age of 35 years, in exceptional cases (late start of studies, concurrent employment

Type: Scholarship

Length of Study: 1 year

Country of Study: Austria

Application Procedure: Eligibility requirements are as follows: 1. Successful completion of at least 2 semesters at the University of Graz. 2. Minimum age of 19

Closing Date: 13 April

Funding: Private

Additional Information: Please visit website international.unigraz.at/de/stud/outgoing/s-out-mprog/ida-pfeiffer-stipendium/ for more details

\section{For further information contact:}

Email: maren.leykauf@uni-graz.at

Contact: Mr Maren Leykauf

\section{Marie Sklodowska-Curie Actions Postdoctoral Fellowships}

Subjects: Fellowship is awarded to learn any of the courses offered by the university

Purpose: Fellowship is available to pursue Postdoctoral programme

Eligibility: Please visit www.scholarshipsupdates.com/universi ty-of-graz-marie-curie-individual-postdoctoral-fellowship-in -austria-2018/ for eligibility criteria

Value: Receive up to $€ 400$ for your travel costs to Austria

Country of Study: Austria

Closing Date: 12 September

Contributor: University of Graz

Additional Information: Please visit www.unica.it/unica/ it/news_avvisi_s1.page?contentId=AVS93045 for more details

\section{University of Guelph}

University Centre, Room 437, 50 Stone Road East, Guelph, ON N1G 2W1, Canada

Tel: $\quad$ (1) 5198244120

Fax: (1) 5197671693

Email: immccorki@uoguelph.ca

Website: www.uoguelph.ca

Contact: Linda McCorkindale, Associate Registrar

The University of Guelph is renowned in Canada and around the world as a research-intensive and learner-centred institution and for its commitment to open learning, internationalism and collaboration. Their vision is to be Canada's leader in creating, transmitting and applying knowledge to improve the social, cultural and economic quality of life of people in Canada and around the world.

\section{The Brock Doctoral Scholarship}

Subjects: All subjects

Purpose: To financially support Doctoral students to attain a high level of academic achievement and to make significant teaching and research contributions

Eligibility: Open to students with sustained outstanding academic performance, evidence of strong teaching and research skills, demonstrated outstanding communication skills and excellent potential for research and teaching as assessed by the College Dean

Level of Study: Doctorate

Type: Scholarship

Value: Up to $\mathrm{C} \$ 1,20,000(\mathrm{C} \$ 10,000$ per semester for up to 12 semesters)

Length of Study: 6 years

Frequency: Annual

Study Establishment: University of Guelph

Country of Study: Canada

Application Procedure: Students entering a Doctoral programme should apply to their College Dean by February 1st with a curriculum vitae, which must then be forwarded to Graduate Program Services by February 15th, with the Dean's written assessment of the candidate's research and teaching potential attached

Closing Date: 15 February

Additional Information: The Brock Doctoral Scholarship is one of the most prestigious Doctoral awards available at the University. It is hoped that award holders will be mentors for future Brock Doctoral Scholarship winners 


\section{For further information contact:}

Office of Registrarial Services, University of Guelph

Email: sinclair@registrar.uoguelph.ca

\section{University of Hertfordshire}

College Lane, Hatfield, Hertfordshire AL10 9AB, United Kingdom

Tel: (44) 1707284800

Fax: (44) 1707284115

\section{Yaasa Scholarship}

Purpose: The Yaasa Scholarships are available to all high school juniors and seniors as well as all students currently registered in any accredited post-secondary institution

Level of Study: Graduate, Postgraduate

Type: Scholarship

Value: $\mathrm{C} \$ 1,000$

Frequency: Annual

Country of Study: Any country

Application Procedure: The winner(s) of this annual scholarship will receive their award within 2 weeks of the listed deadline. All applicants should include their full name and mailing address with their submissions as well as the school they are currently attending

Closing Date: 14 June

Additional Information: Students who are successfully awarded the UH Graduate Scholarship are still eligible for the $£ 500$ tuition fee discount if they pay in full at registration. Please check at www.herts.ac.uk/international/fees/scholar ships-for-international-students/uh-family-scholarships for more information

For further information contact:

Email: scholarships@yaasa.com

\section{University of Illinois}

225 DKH, 1407 West Gregory, Urbana, IL 61801, United States of America
Tel:
(1) 2173338153
Fax:
(1) 2173331398

Website: www.uiuc.edu

Contact: Ms Diane Carson, Graduate Advising Office

The University of Illinois at Urbana-Champaign is a comprehensive, major public university. As a land grant institution chartered in 1867 , it provides undergraduate and graduate education in more than 150 fields of study, conducts both theoretical and applied research, and provides public service to the state and the nation.

\section{Master of Business Administration Programme}

Length of Study: 2 years

Application Procedure: Applicants must complete an application form supplying US\$50 fee, official transcripts, TOEFL score, statement of financial support and a personal statement

\section{For further information contact:}

Tel: $\quad$ (1) 2172448019

Email: mba@uiuc.edu

Contact: Mr Scott Beuchler, Assistant Dean

\section{University of Kent}

Admissions and Partnership Services, The Registry, Canterbury, Kent CT2 7NZ, United Kingdom

Tel: $\quad$ (44) 1227764000

Fax: (44) 1227827077

Email: scholarships@kent.ac.uk

Website: www.kent.ac.uk

The University of Kent is a United Kingdom higher education institution funded by the Higher Education Funding Council for United Kingdom (HEFCE). The university provides education of excellent quality characterized by flexibility and inter disciplinarily and informed by research and scholarship, meeting the lifelong needs of diversity students.

\section{lan Gregor Scholarship}

Subjects: Postcolonial studies, Dickens and Victorian culture, 18th-century studies, English and American literature, creative writing, critical theory, medieval and early modern studies 
Purpose: To support a candidate registered for a taught MA programme in English

Eligibility: Candidates are expected to hold at least an Upper Second Class (Honours) Degree or equivalent. Candidates should also have applied for an external scholarship, such as AHRC

Level of Study: Graduate, Postgraduate

Type: Scholarship

Value: Home fees and a $£ 500$ bursary for 1 year's full-time study

Length of Study: 1 year

Frequency: Annual

Study Establishment: The University of Kent

Country of Study: United Kingdom

Application Procedure: See webpages at www.kent.ac.uk/ english/postgraduate/fund.htm

Closing Date: 28 June

Funding: Trusts

No. of awards given last year: 1

\section{For further information contact:}

Email: englishpg@kent.ac.uk

Contact: Claire Lyons, Administrative Assistant

\section{Kent Law School Studentships and Bursaries}

Subjects: Banking law, carriage of goods, company law, comparative law, computers and the law, criminal law and penology, critical legal studies, environmental law, emergency powers, European comparative and human rights law, family law, gender, sexuality and law, immigration law, intellectual property law, international law and human rights, international economic and trade law, labor law, law and multiculturalism, legal services, legal theory, modern legal history, multinationals and the law, and private law

Purpose: To provide funding for 1 year in the first instance, extended to a maximum of 3 years (for registered students only) based on satisfactory progress (including upgrading to a $\mathrm{PhD}$ ). The retention of the posts will be subject to a review of progress and performance in both research and teaching after the 1st year

Eligibility: Candidates should hold an Upper Second Class (Honours) Degree or a good postgraduate taught degree in law Level of Study: Doctorate, Postgraduate, Research

Type: Studentship

Value: $£ 13,863$ and tuition fees paid at the Home/European

Union rate (up to $£ 3,900$ last year)

Length of Study: 1-3 years

Frequency: Annual

Study Establishment: The University of Kent

Country of Study: United Kingdom
No. of awards offered: $20-30$

Application Procedure: Applicants must submit to the University's recruitment and admissions office a research proposal, curriculum vitae and covering letter with an application for their chosen research degree. They should also ensure that the recruitment and admissions office receives two referees' reports by the closing date for applications. Applications are available at records.kent.ac.uk/external/ admissions/pg-application.php

Closing Date: 31 January

Funding: Private

Contributor: Kent Law School

No. of awards given last year: 2

No. of applicants last year: $20-30$

Additional Information: Holders of the studentships will be expected to teach for a maximum of 4 hours per week in term time on an undergraduate law module, at the direction of the head of department. For further information contact the Kent Law school at kls-pgoffice@kent.ac.uk

\section{For further information contact:}

Tel: $\quad$ (44) 1227827949

Email: m.drakopoulou@kent.ac.uk

Contact: Ms Maria Drakopoulou, Director of Postgraduate Research

\section{Language Lector Scholarships}

Subjects: European and Latin American literary, linguistic and cultural studies (French, German, Hispanic studies, Italian and comparative literary studies), philosophy (with special expertise in moral and political philosophy, aesthetics, philosophy of mind, philosophical logic and paradoxes, Bayesian epistemology and artificial intelligence), religious studies (modern theology, Christian ethics, mysticism and religious experience, religion and film, psychology of religion and cultural study of cosmology and divination) and the literature, history and archaeology of classical World (including Britain and Gaul)

Purpose: To support research

Eligibility: The scholarship is open to candidates who have made an application for any one of the taught MA programmes (except programmes taught in Paris or Athens) in SECL in an area related to the language they will be teaching. Candidates must hold a First Class or Upper Second Class Undergraduate Degree in a relevant subject (or have reached an appropriate point in their University education to be accepted onto a United Kingdom Master's degree). Candidates must be a native speaker of French, German, Spanish, Catalan or Portuguese. Candidates must have excellent communication skills, both written and oral and ideally some experience of language 
teaching. This scholarship is open to United Kingdom, European Union and overseas fee-paying students

Level of Study: Postgraduate, Research

Type: Studentship

Value: $100 \%$ of tuition fees at the Home/European Union rate for a postgraduate programme within the School of European Culture and Languages (SECL) and combined maintenance grant and salary

Length of Study: 3 years

Frequency: Annual

Study Establishment: The University of Kent

Country of Study: United Kingdom

Application Procedure: Application is via School of European Culture and Language website www.kent.ac.uk/ secl/postgraduate/funding.html?tab=language-lector-scholar ships

Closing Date: May (the precise date is to be confirmed)

Funding: Government

Additional Information: Candidates may be interviewed over the telephone as appropriate. Language Lectors teach for at least 20 of these 24 weeks and will be expected to teach 10 hours a week

\section{For further information contact:}

Email: seclpgadmin@kent.ac.uk

\section{Postgrad Solutions Study Bursaries}

Purpose: Kent University- Kent offers well-structured and ambitious. It provides a comprehensive package of skills development training programs, careers advice, and volunteering and paid work opportunities to enhance your career prospects in a global workplace.

Eligibility: Scholarship is available for pursuing Postgraduate degree program

Level of Study: Postgraduate

Type: Bursary

Value: $£ 500$

Frequency: Annual

Country of Study: Any country

Closing Date: 13 September

Funding: International office

\section{School of Economics funding}

Subjects: Labour economics, money and development, international finance and trade, migration, defence and energy economics, macro economics, ganne theory and econometrics Purpose: To support research
Eligibility: All applicants for a scholarship should have completed a Master's degree in Economics or a closely-related subject. In order to be eligible for this scholarship, you must have applied for and accepted a place to study at the University Level of Study: Doctorate, Postgraduate, Research

Type: Bursary

Value: Tuition fees at the Home/European Union rate and a maintenance grant, usually up to a similar rate to an ESRC grant (£13,590 for last year)

Length of Study: 1 year in the 1st instance, renewable for a maximum of 3 years subject to satisfactory academic performance

Frequency: Dependent on funds available

Study Establishment: The University of Kent

Country of Study: United Kingdom

Application Procedure: To apply for a scholarship, please send a curriculum vitae, including the names of two referees, a brief research proposal, transcripts of your previous degrees and a covering letter to the Postgraduate Co-ordinator, Katie Marshall at econpg@kent.ac.uk

Closing Date: 15 April

Funding: Government

Additional Information: Candidates should note that 4-6 hours of teaching per week and acceptable progress in the programme of study will be expected of the student. The bursary will be subject to review each year

\section{For further information contact:}

Email: Y.Zhu-5@kent.ac.uk

Contact: Dr Yu Zhu

\section{School of English MA Scholarships for International Students at University of Kent in United Kingdom}

Subjects: English

Purpose: The purpose of the scholarships is to award candidates with the strongest academic records. The School of English reserves the right to distribute the scholarships amongst candidates in a way that will honour that commitment Eligibility: Please check details at www.kent.ac.uk/english/ postgraduate/feesandfunding

Level of Study: Doctorate, Postgraduate

Type: Scholarship

Value: $£ 5,000$, For Master Degree

Length of Study: Up to 3 years

Frequency: Annual

Study Establishment: The University of Kent

Country of Study: United Kingdom

Application Procedure: All students who have made an application to study on an MA programme in the School of 
English by the deadline will automatically be considered for a scholarship

Closing Date: 22 March

Funding: Government, Commercial

No. of awards given last year: 5

For further information contact:

Email: englishpg@kent.ac.uk

\section{South East ESRC DTC Funding}

Subjects: Social psychology, cognitive psychology, neuropsychology, health psychology, developmental psychology, and forensic psychology

Purpose: To support research studies

Level of Study: Postgraduate, Research

Type: Studentship

Value: The funding will typically cover yearly maintenance ( $£ 13,863$ for last year) and fees for one of the following: +3 programme or $1+3$

Length of Study: 3 years

Frequency: Annual

Study Establishment: The University of Kent

Country of Study: United Kingdom

No. of awards offered: $30-40$

Application Procedure: Applicants must complete an application form

Closing Date: 2 February

Funding: Private

Contributor: South-East ESRC DTC

No. of awards given last year: 2

No. of applicants last year: $30-40$

Additional Information: Studentships will be awarded on the basis of the academic excellence of both the candidate and the research proposal

\section{For further information contact:}

Tel: (44) 1227823085

Email: rsg@kent.ac.uk

Contact: Dr Roger Giner-Sorolla, CSGP

\section{University of Kent Anthropology Bursaries}

Subjects: Anthropology

Purpose: To support both research and taught programmes Eligibility: Candidates are expected to hold an Upper Second Class (Honours) Degree

Level of Study: Doctorate, Postgraduate, Research

Type: Bursary

Value: Home fees only
Length of Study: 3 years

Frequency: Dependent on funds available

Study Establishment: The University of Kent

Country of Study: United Kingdom

Closing Date: Please write for details

No. of awards given last year: 2

For further information contact:

Email: n.a.kerry-yoxall@ukc.ac.uk

Contact: Ms Nicola Kerry Yoxall

\section{University of Kent at Canterbury Second English Scholarship}

Subjects: English

Purpose: To support research

Eligibility: Candidates are expected to hold at least an Upper Second Class (Honours) Degree or equivalent. Candidates should also have applied for an external scholarship, such as AHRB

Level of Study: Postgraduate

Type: Research grant

Value: Home tuition fees up to $£ 3,500$ bursary per year for up to three years full-time study. Some undergraduate teaching or research assistance will be expected from the successful candidate

Frequency: Annual

Study Establishment: The University of Kent

Country of Study: United Kingdom

Application Procedure: Candidates must complete the postgraduate application form, indicating in the appropriate section that they are interested in being considered for departmental scholarships. A covering letter supporting the scholarship application should be attached

Closing Date: 30 May

For further information contact:

Email: scholarships@kent.ac.uk

\section{University of Kent Department of Electronics Studentships}

Subjects: Electronics, including image processing and vision, embedded systems, broadband and wireless communications and electronic instrumentation

Purpose: To enable well-qualified students to undertake research programmes within the department

Eligibility: Candidates are expected to hold an Upper Second Class (Honours) Degree or equivalent in an appropriate subject, and be nationals of one of the European Union countries 
Level of Study: Doctorate, Postgraduate, Research

Type: Studentship

Value: Research Council studentships are at a fixed rate determined annually by EPSRC. Departmental bursaries depend on individual circumstances

Length of Study: 3 years

Frequency: Annual

Study Establishment: The University of Kent

Country of Study: United Kingdom

No. of awards offered: 10

Application Procedure: Applicants should contact the Department of Electronics

Closing Date: June

Funding: Government

Contributor: EPSRC

No. of awards given last year: 5

No. of applicants last year: 10

For further information contact:

Email: ee-admissions-pg@kent.ac.uk

Contact: Professor J Z Wang

\section{University of Kent Law School Studentship}

Subjects: Critical commercial law, business law and regulation, criminal justice, environmental law, European and comparative law, gender and sexuality, health care law and ethics, law politics and culture, law and political economy, legal theories and philosophy, property law

Purpose: To support research

Eligibility: Applicants should normally have obtained, or be about to obtain an undergraduate degree of at least Upper Second Class Honours level (2:1 or equivalent from other countries), or a postgraduate degree

Level of Study: Doctorate, Postgraduate

Type: Scholarships

Value: Maintenance grant equivalent to that offered by ESRC $(£ 13,863$ in last year) and tuition fees paid at the Home/European Union rate ( $£ 3,900$ in last year)

Length of Study: Up to 3 years

Frequency: Annual

Study Establishment: University of Kent

Country of Study: United Kingdom

Application Procedure: Applications to be filled electronically at www.kent.ac.uk/law/postgraduate/research/entryreqresearch.html. Along with their application, candidates must supply a research proposal of no more than 1,500 words (including bibliography), along with a sample of their written work (not exceeding 4,000 words - longer texts will not be read)

Closing Date: 31 January
Funding: Government, Commercial

No. of awards given last year: 8

Additional Information: See website for further details: www.kent.ac.uk/law/postgraduate/research/KLS_research_ funding.html

\section{For further information contact:}

Tel: $\quad$ (44) 1227827949

Email: mailto:m.drakopoulou@kent.ac.uk

Contact: Ms Maria Drakopoulou, Director of Postgraduate Research, Kent Law School

\section{University of Kent School of Drama, Film and Visual Arts Scholarships}

Subjects: Drama, including performance-making process and theory, theatre history and practice as research film studies, including varied aspects of film aesthetics, film theory and film history as well as research by practice. History and philosophy of art, including contemporary aesthetics and the history of art theory, the photograph, and the historical interplay of image, theory and institutions from the renaissance to the present

Purpose: To support research

Eligibility: Candidates are expected to hold an Upper Second Class (Honours) Degree and be a citizen of one of the European Union countries

Level of Study: Postgraduate, Research

Value: To cover home fees only

Length of Study: The bursary is 1 year

Frequency: Annual

Study Establishment: The University of Kent

Country of Study: United Kingdom

Application Procedure: Applicants must indicate their interest on the postgraduate application form

Closing Date: 31 July

Additional Information: Some teaching or research assistant work may be required

For further information contact:

Email: k.j.goddard@kent.ac.uk

\section{University of Kent School of Mathematics, Statistics and Actuarial Science Scholarships}

Subjects: Mathematics, statistics or actuarial science

Purpose: To support research

Eligibility: Candidates should hold a good (first or upper second) Honours degree, or a Master's degree in a relevant subject

Level of Study: Doctorate, Postgraduate 
Type: Scholarship

Value: Home fees and maintenance stipend

Length of Study: Up to 3 years

Frequency: Annual

Study Establishment: University of Kent

Country of Study: United Kingdom

Application Procedure: See webpages at www.kent.ac.uk/

Closing Date: 20 April

Funding: Government, Commercial

No. of awards given last year: 5

For further information contact:

Email: scholarships@kent.ac.uk

\section{University of Kent School of Politics and International Relations Scholarships}

Subjects: Politics and government, international relations, international conflict analysis

Purpose: To support research

Eligibility: These scholarships are available to Home/ European Union/Overseas students who have been made an offer by Kent for MPhil/PhD study

Level of Study: Doctorate, Postgraduate

Type: Scholarship

Value: Home fees and maintenance stipend

Length of Study: Up to 3 years

Frequency: Annual

Study Establishment: University of Kent

Country of Study: United Kingdom

Application Procedure: See webpages at www.kent ac.uk/scholarships/postgraduate/departmental/politicsandir. html

Closing Date: April

Funding: Government, Commercial

No. of awards given last year: 2

For further information contact:

Email: scholarships@kent.ac.uk

\section{University of Kent School of Psychology Scholarships}

Subjects: Cognitive psychology, developmental psychology, forensic psychology, group processes and intergroup relations, and social psychology

Purpose: To support research

Eligibility: Candidates must hold a good Honours degree (first class or 2i) or a Master's degree at merit or distinction in Psychology. Non-British qualifications will be judged individually; we will generally require an overall result in the top two grading categories

Level of Study: Doctorate, Postgraduate

Type: Scholarship

Value: Home fees and maintenance stipend

Length of Study: Up to 3 years

Study Establishment: University of Kent

Country of Study: United Kingdom

Application Procedure: Please check at www.kent.ac.uk/ scholarships/postgraduate/departmental/psychology.html

Closing Date: April

Funding: Government, Commercial

No. of awards given last year: 5

For further information contact:

Email: scholarships@kent.ac.uk

\section{University of Kent School of Social Policy, Sociology and Social Research Scholarships}

Subjects: Social Policy, sociology, criminology

Purpose: To support research

Eligibility: Candidates should hold a good (First or Upper Second Class) Honours degree or equivalent, in a relevant discipline

Level of Study: Doctorate, Postgraduate

Type: Scholarship

Value: Home fees and maintenance stipend

Length of Study: Up to 3 years

Frequency: Annual

Study Establishment: University of Kent

Country of Study: United Kingdom

Application Procedure: See webpages at www.kent.ac.uk/ sspssr/studying/scholarships-and-bursaries/index.html

Closing Date: 10 February

Funding: Government, Commercial

No. of awards given last year: 3

Additional Information: This scholarship will be in addition to any Kent scholarships and discounts (such as the $£ 1,000$ Graduate School Scholarship, 10\% Loyalty Discount and the School $£ 500$ discount for high performing students)

For further information contact:

Email: scholarships@kent.ac.uk

\section{University of KwaZulu-Natal}

Westville Campus, Private Bag X54001, Durban, South Africa 
Fax: (27) 312602587

Email: heard@ukzn.ac.za

Website: www.heard.org.za/

HEARD is a leading applied research centre with a global reputation for its research, education programmes, technical services, partnerships and networks, devoted to addressing the broad health challenges of Africa. HEARD was established in 1998 and is based at the University of KwaZulu-Natal, South Africa.

\section{Health Economics and HIV/AIDS Research Division PhD Scholarships}

Purpose: Under the supervision of Professor Nana Poku and with the generous support of Sida/NORAD, HEARD is offering up to four full-time PhD Research Scholarships in any of the following key areas of strategic focus: Sexual and Reproductive Health; Health Systems Strengthening and Economics of Critical Enablers in HIV Programming

Eligibility: Applicant must have the below criteria. 1. Hold a Master's Degree in a pertinent subject or a first or upper second class degree together with a track record of professional experience in a health o health-related field. 2. Have demonstrable research experience. 3 . Undertake to register for a $\mathrm{PhD}$ dissertation (full time) at the University of KwaZulu-Natal (UKZN). 4. Make a commitment to remain on the African continent for at least TWO years after graduation

Value: The value of each scholarship is ZAR 540,000 paid over three years

Length of Study: Scholarships will be paid in tranches over 3 years. Tranche payments will be conditional on research progress

Country of Study: South Africa

Application Procedure: 1. A letter of motivation and CV. 2. An eight to ten page concept note on one of HEARD's key thematic research areas: Sexual \& Reproductive Health \& Rights; Gender, Equality \& Health; Health Governance \& Finance; and Health Systems Strengthening. 3. Certified copies of both your academic qualifications and your full academic records. If qualifications were obtained from non-English speaking countries please ensure that an official English translation is included. 4. A certified copy of your ID/passport. 5. Two letters of reference, at least one of which must be academic. The second can be from an individual of professional standing

Closing Date: 1 March

Funding: Private

\section{For further information contact:}

Email: Hedderwick@ukzn.ac.za

\section{University of Leeds}

Postgraduate Scholarships, Research Student Administration, Leeds LS2 9JT, United Kingdom
Tel:
(44) 1133434077 ext 34077
Fax:
(44) 1133433941
Email: pg_scholarships@leeds.ac.uk
Website: www.scholarships.leeds.ac.uk
Contact: Erika Smith, Senior Clerk

The University of Leeds aims to promote excellence and to achieve and sustain international standing in higher education teaching, learning and research, and to serve a wide range of student constituencies, social and professional communities and industrial, commercial and government agencies, locally, nationally and internationally.

\section{Beit Trust Postgraduate Scholarships}

Subjects: Any subject that will contribute materially to the development of your country of origin

Purpose: To support Postgraduate Study or research at Masters' level (MSc/MA)

Eligibility: Open to persons under 30 years of age, or 35 years for medical doctors, who are university graduates domiciled in Zambia, Zimbabwe or Malawi. Applicants must be nationals of those countries, and have an Honours degree at undergraduate level

Level of Study: Postgraduate

Type: Scholarship

Value: Academic fees, living expenses, other allowances, economy return airfares and allowance toward laptops

Length of Study: a maximum of 2 years at a South African University or 1 year at a United Kingdom University

Frequency: Annual

Study Establishment: The University of Leeds

Country of Study: United Kingdom

No. of awards offered: 720

Application Procedure: Please see the Beit Trust website on 1 April for the new Scholarship application process. Applicants from Zimbabwe and Malawi should contact the Harare office at: africa@beittrust.org.uk

Closing Date: 1 April

Funding: Private

No. of awards given last year: 19

No. of applicants last year: 720

Additional Information: Zambian applicants should contact the Beit Trust United Kingdom office at: scholarships@ beittrust.org.uk 


\section{For further information contact:}

Tel: (263) 1483772575

Email: scholarships@beittrust.org.uk

Contact: Sir Andrew Pocock, Secretary

\section{Canon Collins Trust-FCO Chevening-University of Leeds Scholarships}

Subjects: Majority of subjects

Purpose: To provide awards to students of high academic calibre, who demonstrate both academic excellence and the potential to become leaders, decision makers and opinion formers in their own countries

Eligibility: Open to candidates from Angola, Botswana, Lesotho, Malawi Mozambique, Namibia, South Africa, Swaziland, Zambia or Zimbabwe. Applicants must already hold a degree of equivalent standard to a United Kingdom upper second class honours degree. An adequate standard of English is required

Level of Study: Postgraduate

Type: Scholarship

Value: Academic fees, living expenses, other allowances, economy return airfares

Length of Study: 1 year

Frequency: Annual

Study Establishment: The University of Leeds

Country of Study: United Kingdom

No. of awards offered: Not known

Application Procedure: Applicants must complete an application form available on request from the Canon Collins Trust

Closing Date: 28 February

Funding: Government, Private

No. of awards given last year: 10

No. of applicants last year: Not known

\section{For further information contact:}

Email: info@canoncollins.org.uk

\section{Derek Fatchett Memorial Scholarships (Palestine)}

Subjects: Politics or international studies

Purpose: To provide awards to students of high academic calibre

Eligibility: Open to candidates who have obtained or are about to obtain the equivalent of a United Kingdom First or Second Class (Honours) Degree. Candidates must be nationals of Palestine

Level of Study: Postgraduate

Type: Scholarship
Value: Academic fees, living expenses, books, equipment, arrival and departure allowance, economy return airfares and the production of a dissertation

Length of Study: 1 year

Frequency: Annual

Study Establishment: The University of Leeds

Country of Study: United Kingdom

No. of awards offered: Not known

Application Procedure: Application procedures are now handled by the British Council offices in Ramallah and East Jerusalem

Closing Date: 31 May

Funding: Private

No. of applicants last year: Not known

\section{For further information contact:}

Email: Lmec@Lmec.org.uk

\section{Frank Parkinson Scholarship}

Subjects: Any subject

Purpose: To provide postgraduate scholarships for United Kingdom research students of high calibre

Eligibility: Candidates must be commencing PhD study for the first time and hold at least a United Kingdom upper second class honours degree or equivalent. Candidates must have British parents who have been domiciled in Yorkshire for a period of not less than 10 years

Level of Study: Doctorate

Type: Scholarship

Value: Fees at the United Kingdom rate plus a maintenance allowance

Length of Study: Up to 3 years, subject to satisfactory progress

Frequency: Annual

Study Establishment: University of Leeds

Country of Study: United Kingdom

No. of awards offered: 39

Application Procedure: An application form must be completed and returned to the Postgraduate Scholarships Office by the relevant date

Closing Date: 1 June

Funding: Private

No. of awards given last year: 2

No. of applicants last year: 39

\section{For further information contact:}

Email: fbsgrad@leeds.ac.uk 


\section{Frank Stell Scholarship}

Subjects: Biology, Agricultural Science, or Social and Political Science

Purpose: To provide postgraduate scholarships for United Kingdom research students of high calibre

Eligibility: Candidates must be commencing PhD study for the first time and hold at least a United Kingdom Upper Second Class Honours degree or equivalent. Candidates should be resident, or have parents resident within the former administrative area of the County Council of the West Riding of Yorkshire

Level of Study: Doctorate

Type: Scholarship

Value: Fees at the University of Leeds standard United Kingdom/European Union rate plus a maintenance allowance Length of Study: Up to 3 years, subject to satisfactory progress

Frequency: Dependent on funds available

Study Establishment: University of Leeds

Country of Study: United Kingdom

Application Procedure: Details provided on website www. scholarships.leeds.ac.uk

Closing Date: See website for closing date www.scholar ships.leeds.ac.uk

Additional Information: The scholarship is subject to funding and will only be advertised on www.scholarships. leeds.ac.uk if there are available funds

\section{For further information contact:}

Email: fbsgrad@leeds.ac.uk

\section{Henry Ellison Scholarship}

Subjects: Pure and Applied Chemistry and Physics

Purpose: To provide postgraduate scholarships for United Kingdom and European Union research students of high calibre Eligibility: Candidates must be from the United Kingdom or an European Union country (or eligible to pay fees at the United Kingdom rate) and be commencing PhD study for the first time. Candidates must hold at least a United Kingdom Upper Second Class Honours degree or equivalent and be a University of Leeds graduate

Level of Study: Doctorate

Type: Scholarship

Value: Fees at the University of Leeds standard United Kingdom/European Union rate plus a maintenance allowance Length of Study: Up to 3 years, subject to satisfactory progress

Frequency: Dependent on funds available

Study Establishment: University of Leeds
Country of Study: United Kingdom

Application Procedure: Details provided on website www. scholaships.leeds.ac.uk

Closing Date: See website for closing date www.scholar ships.leeds.ac.uk

Additional Information: The award is available within the School of Physics and Astronomy. The scholarship is subject to funding and will only be advertised on scholarships.leeds. ac.uk if there are available funds

\section{For further information contact:}

Email: maps.pgr.admissions@leeds.ac.uk

\section{John Henry Garner Scholarship}

Subjects: Research on matters relating to chemical and biological surveys of rivers and streams, pollution prevention and purification of sewage and trade effluents in the area previously known as the West Riding of Yorkshire

Purpose: To provide postgraduate scholarships for United Kingdom and European Union research students of high calibre Eligibility: Candidates must be from the United Kingdom or an European Union country (or eligible to pay fees at the United Kingdom rate) and be commencing $\mathrm{PhD}$ study for the first time. Candidates must hold at least a United Kingdom Upper Second Class Honours degree or equivalent

Level of Study: Doctorate

Type: Scholarship

Value: Fees at the University of Leeds standard United Kingdom/European Union rate plus a maintenance allowance Length of Study: Up to 3 years, subject to satisfactory progress

Frequency: Dependent on funds available

Study Establishment: University of Leeds

Country of Study: United Kingdom

Application Procedure: Details provided on website www. scholarships.leed.ac.uk

Closing Date: See website for closing date www.scholar ships.leeds.ac.uk

Additional Information: The scholarship is subject to funding and will only be advertised on www.scholarships. leeds.ac.uk if there are available funds

\section{For further information contact:}

Email: fbsgrad@leeds.ac.uk

\section{Marks and Spencer - Leeds University- FCO Chevening Scholarships}

Subjects: Preference is given to Management Studies 
Purpose: To provide postgraduate scholarships to students of high academic calibre

Eligibility: Open to candidates from Hong Kong who have obtained, or are about to obtain, a first degree of a similar standard to a United Kingdom good Upper Second Class (Honours) Degree. An adequate standard of English language is required

Level of Study: Postgraduate

Type: Scholarship

Value: Full tuition fees, maintenance allowance, books, equipment and production of dissertation

Length of Study: 1 year

Frequency: Annual

Study Establishment: The University of Leeds

Country of Study: United Kingdom

Application Procedure: By application form and acceptance onto taught course. Both application forms are available from the University and British Council (Hong Kong)

Closing Date: Usually December

Funding: Government, Commercial

No. of awards given last year: 1

Additional Information: The address for the British Council in Hong Kong is: The Education Exchange Unit, 255 Hennessey Road, Wanchai, Hong Kong

\section{For further information contact:}

Email: scholarships@gcu.ac.uk

\section{Mary and Alice Smith Memorial Scholarship}

Subjects: Research into the prevention or cure of cancer or heart disease

Purpose: To provide postgraduate scholarships for United Kingdom research students of high calibre

Eligibility: Candidates must be British and be commencing $\mathrm{PhD}$ study for the first time. Candidates must hold at least a United Kingdom Upper Second Class Honours degree or equivalent

Level of Study: Doctorate

Type: Scholarship

Value: Fees at the University of Leeds standard United Kingdom/European Union rate plus a maintenance allowance Length of Study: Up to 3 years, subject to satisfactory progress

Frequency: Dependent on funds available

Study Establishment: University of Leeds

Country of Study: United Kingdom

Application Procedure: Details provided on www.scholar ships.leeds.ac.uk

Closing Date: See website for closing date www.scholar ships.leeds.ac.uk
Additional Information: The scholarship is subject to funding and will only be advertised on www.scholarships. leeds.ac.uk if there are available funds

\section{For further information contact:}

Email: fbsgrad@leeds.ac.uk

\section{Stanley Burton Research Scholarship}

Subjects: Music

Purpose: To provide postgraduate scholarships for United Kingdom/European Union research students of high calibre Eligibility: Candidates must be from United Kingdom or an European Union country and be commencing PhD study for the first time. Candidates must hold at least a United Kingdom upper second class honours degree or equivalent

Level of Study: Doctorate

Type: Scholarship

Value: Fees at the University of Leeds standard United Kingdom/European Union rate plus a maintenance allowance Length of Study: Up to 3 years, subject to satisfactory progress

Frequency: Dependent on funds available

Study Establishment: University of Leeds

Country of Study: United Kingdom

Application Procedure: Details provided on www.scholar ships.leeds.ac.uk

Closing Date: See website for closing date www.scholar ships.leeds.ac.uk

Additional Information: The award is available within the School of Music. This scholarship is subject to funding and will only be advertised on scholarships.leeds.ac.uk if there are available funds

\section{For further information contact:}

Email: pg_scholarships@leeds.ac.uk

\section{University of Leeds International Fee Bursary (Vietnam) - for subject areas listed below Leeds}

Subjects: Economics, economics and finance, accounting and finance, human resource management, development studies, international political economy, international studies, politics of international resources and development, cognitive systems, international finance, banking \& finance, company management

Purpose: To provide scholarships to students of high academic calibre in the School of Computing, Politics and International Studies and Leeds University Business School 
Eligibility: Open to nationals of Vietnam who have obtained a degree equivalent to a good Second Class (Honours) Degree. An adequate standard of English is required

Level of Study: Postgraduate

Type: Scholarship

Value: Academic fees

Length of Study: 1 year

Frequency: Annual

Study Establishment: The University of Leeds

Country of Study: United Kingdom

No. of awards offered: Not known

Application Procedure: Applicants must make an application in letter format to the Taught Postgraduate Secretary in the school they intend to study

Closing Date: 29 May

Funding: Private

No. of awards given last year: 4

No. of applicants last year: Not known

For further information contact:

Email: info@lubs.leeds.ac.uk

\section{University of Leeds International Fee Bursary (Vietnam) - Information Systems/Multimedia Systems}

Subjects: Information systems or multimedia systems Purpose: To provide scholarships to students of high academic calibre who wish to study in the school of computing Eligibility: Applicants must be nationals of Vietnam and must already have obtained a good Second Class (Honours) Degree. An adequate standard of English is also required

Level of Study: Postgraduate

Type: Scholarship

Value: Academic fees

Length of Study: 1 year

Frequency: Annual

Study Establishment: The University of Leeds

Country of Study: United Kingdom

Application Procedure: Applicants must make an application in letter form to the Taught Postgraduate Secretary in the School of Computing

Closing Date: 11 June

Funding: Private

No. of awards given last year: 1

For further information contact:

International office, University of Leeds, Leeds LS2 9JT, United Kingdom

Email: info@lubs.leeds.ac.uk

\section{University of Leeds International Fee Bursary (Vietnam)}

Subjects: Information systems, distributed multimedia systems, multidisciplinary informatics

Purpose: To provide scholarships to students of high academic calibre

Eligibility: Open to nationals of Vietnam who have obtained a degree equivalent to a good Second Class (Honours) Degree. An adequate standard of English is required

Level of Study: Postgraduate

Type: Scholarship

Value: Academic fees

Length of Study: 1 year

Frequency: Annual

Study Establishment: The University of Leeds

Country of Study: United Kingdom

Application Procedure: Applicants must address a letter of application to the School of Computing

Closing Date: 10 June

Funding: Private

No. of awards given last year: 1

\section{University of Leicester}

University Road, Leicester LE1 7RH, United Kingdom

Tel: $\quad$ (44) 162522522

Fax: (44) 1162522200

Email: upim@admin.le.ac.uk

Website: www.le.ac.uk

Contact: Mr K J Julian, Registrar and Secretary

\section{Central United Kingdom NERC Training Alliance (CENTA) PhD Studentships for European Union Students}

Purpose: Studentships are available to pursue $\mathrm{PhD}$ research programme

Type: Award

Value: CENTA has been awarded $£ 4.9$ million from the Natural Environment Research Council (NERC)

Length of Study: 5 years

Country of Study: United Kingdom

Closing Date: 22 January

For further information contact:

Email: communications@ukri.org 


\section{College of Science and Engineering Postgraduate Scholarship Scheme}

Subjects: Scholarships are awarded in the field of Chemistry, Engineering, Geography, Informatics, Mathematics and Physics and Astronomy

Purpose: University of Leicester's aim is to be a world-class research-intensive university and deliver teaching and facilitate learning of the highest quality

Eligibility: Applicants must be classified as an international (non-European Union) student for fee purposes. The fee discount will be calculated on the basis of the standard tuition fee, excluding components for 'with industry' degrees. In accordance with scholarship guidelines, students are allowed to hold only one University of Leicester scholarship, awarded either centrally or by a department. If you are awarded more than one scholarship, you will therefore receive only the higher value award. The scholarship is only valid for entry in September. If you currently have a conditional offer of a place at the University, you will still need to fulfil any conditions stated on your offer letter. The scholarship is only available for campus-based courses

Type: Postgraduate scholarships

Value: Successful applicant will receive tuition fee discount of $22 \%$ - or $28 \%$

Study Establishment: Scholarships are awarded in the field of Chemistry, Engineering, Geography, Informatics, Mathematics and Physics and Astronomy

Country of Study: United Kingdom

Application Procedure: Academic qualifications and transcripts Personal statement/research proposal Two completed references (one must be academic) OR names and contact details of two people from whom we can request references (one must be an academic referee). Proof of English language competency (if your first language is not English)

Closing Date: Open

Additional Information: please browse the website for more details scholarship-positions.com/college-of-science-enginee ring-postgraduate-scholarship-scheme-uk/2017/12/18/

\section{For further information contact:}

Email: scholarships@le.ac.uk

\section{PhD Studentships in Computer Science}

Subjects: Computer science

Purpose: To support research organizations attract the best people into postgraduate research and training and to provide doctoral training grant support

Eligibility: Please check at EPSRC website at www2.le.ac. uk/study/research/funding/epsrc-computing
Level of Study: Doctorate

Type: Studentship

Value: The successful applicants will receive an annual stipend of at least $£ 13,863$ together with a conference allowance and training support grant worth $£ 600$ each year

Length of Study: 3 years

Frequency: Dependent on funds available

Study Establishment: University of Leicester, Computer Science Department

Country of Study: United Kingdom

Application Procedure: Please refer to the University of Leicester website at www2.le.ac.uk/study/research/funding/ epsrc-computing. Our $\mathrm{PhD}$ superiors have a range of interests and the aim is to align you with someone with expertise in your field. Details of our research themes are on the website

Closing Date: Open Until Filled

Funding: Government

Contributor: EPSRC (DTG)

Additional Information: Applications are considered throughout the year. Refer to advertisement on website

\section{For further information contact:}

Email: fdv1@mcs.le.ac.uk

Contact: Dr Fer-Jan de Vries, PhD Admissions Tutor

\section{PhD Studentships in Mathematics}

Subjects: Pure and applied mathematics, financial mathematics and actuarial science are considered

Eligibility: United Kingdom and European Union PhD students, who have been residents in the United Kingdom for 3 years prior to application, and fees-only funding for other European Union students

Level of Study: Doctorate, Research

Type: Studentship

Value: $£ 14,057$ in the first year, rising in successive years, and full tuition fees

Length of Study: 3.5 years

Country of Study: United Kingdom

Application Procedure: Applications can be made online and submitted to admissions office. Information on how to apply and what supporting documents needed can be found at www2.le.ac.uk/research/degrees/phd/maths/supervision

Closing Date: For further information, please visit www2.le. ac.uk/departments/mathematics/postgraduate-study/phd/phdstudy

\section{For further information contact:}

Email: pgresearch@maths.ed.ac.uk 


\section{President's Postgraduate Scholarship Scheme}

Purpose: This is a postgraduate scholarship that enables international students to get a chance to study in University of Leicester, United Kingdom

Value: President's Postgraduate Scholarship Scheme at the University of Leicester provides $£ 3,500$ in the form of a reduction in tuition fee

Length of Study: 1 to 2 years

Country of Study: Any country

Application Procedure: Send your completed application by email to scholarships@le.ac.uk

Closing Date: 31 July

\section{For further information contact:}

Tel: (44) 1413313000

Email: ukroenquiries@gcu.ac.uk

\section{University of Limerick}

Kemmy Business School, Limerick, Ireland

Tel: $\quad$ (353) 61202116

Fax: (353) 61330316

Email:_elaine.kirwan@ul.ie

Website: www.ul.ie

Contact: Elaine Kirwan

\section{Kemmy Business School: PhD Scholarship}

Subjects: The scholarship is awarded in Organization Science and Public Policy

Purpose: The competition is open to prospective students, as well as those who have registered in the current calendar year, and will cover fees and a stipend of $€ 1,000$ per month for years one to four of a full time traditional or structured $\mathrm{PhD}$ programme

Eligibility: Applicants should have first or upper second class degree (Level 8 - National Qualifications Authority of Ireland or equivalent) or a Master's degree in economics, statistics, demography, mathematics, computer science or cognate discipline. They should have strong econometric skills, computer programming skills and demonstrated experience in at least one high-level language, such as R or Matheamatica. Applicants should have strong verbal and written communication skills and should have the ability to write concise and accessible reports for both specialist and non-specialist audiences. Non-European Union citizens are eligible for this international $\mathrm{PhD}$ scholarship
Level of Study: Doctorate

Type: PhD scholarship

Value: The value of the scholarship is $€ 14,000$ per year plus European Union fees for a maximum of 3 years (the final year fee will have to be paid by the student)

Frequency: Every 3 years

Country of Study: Ireland

Application Procedure: The mode of applying is electronically. Completed application forms should be submitted electronically to michelle.cunningham@ul.ie, stating the research theme under which candidates are applying, along with a copy of official academic results, curriculum vitae, research proposal and letter of application. For further information, refer the below link. www.ul.ie/business/sites/default/files/ file /Dean\%20Scholarship\%20Detail\%202019\%20.pdf

Closing Date: 10 May

Contributor: Kemmy Business School at the University of Limerick

Additional Information: The duration is of maximum 3 years

\section{For further information contact:}

Email: rebecca.gachet@ul.ie

\section{University of Lincoln}

Brayford Pool, Lincoln LN6 7TS, United Kingdom

Tel: $\quad$ (44) 1522882000

Website: www.lincoln.ac.uk

Contact: University of Lincoln

Lincoln is ranked 11th in the United Kingdom for student satisfaction in the National Student Survey (NSS) 2016. The University is committed to developing enterprising graduates, with Lincoln students enjoying good graduate prospects and many going on to start their own successful businesses. The University of Lincoln is producing world-leading research across many subject areas.

\section{Academic Excellence Scholarship}

Subjects: Scholarships are awarded any of subjects offered by the university

Purpose: For programmes commencing in January / February and September, the university invites applications for Academic Excellence Scholarships from students from around the world. Students from China, India, Malaysia, 
Norway, Nigeria, Saudi Arabia, Thailand, Vietnam and the United States are eligible to apply for these scholarships

Eligibility: The University invites applications from students in the following countries: China, India, Malaysia, Norway, Nigeria, Saudi Arabia, Thailand, Vietnam and the United States. Applicants must have their previous degree. Applicants must meet the programmes general English language requirements

Type: Postgraduate scholarships

Value: $£ 5,000$ which will be deducted from your tuition fees during the first year of enrolment

Study Establishment: Scholarships are awarded to learn in any of subjects offered by the university

Country of Study: United Kingdom

Application Procedure: To apply for an Academic Excellence Scholarship, you will need to complete an Academic Excellence Scholarship Application Form and submit to intscholarships-at-lincoln.ac.uk

Closing Date: The Application deadlines are 24 November and 22 June

Additional Information: For more details please visit the website scholarship-positions.com/academic-excellencescholarship-university-lincoln-uk/2017/01/05/

\section{Egypt Scholarship}

Purpose: To offer Egypt Scholarships to high achieving postgraduate applicants

Eligibility: Be an Egyptian citizen

Type: Scholarship

Value: $£ 5,000$

Country of Study: United Kingdom

Application Procedure: Submit application to intscholarships@lincoln.ac.uk

Closing Date: 22 June

For further information contact:

Email: intscholarships@lincoln.ac.uk

\section{Ghana Scholarship}

Purpose: The University of Lincoln are delighted to offer Ghana Scholarships to high achieving applicants

Type: Scholarship

Value: $£ 5,000$

Country of Study: Any country Application Procedure: Submit the application to intscholarships@lincoln.ac.uk

Closing Date: 22 June

\section{For further information contact:}

Email: international@lincoln.ac.uk

\section{Global Postgraduate Scholarship}

Subjects: Overseas

Purpose: To be eligible for the scholarship, students must hold a recognised Bachelor degree with a minimum grade of $2: 2$ or equivalent. Please note that this scholarship is not available for $\mathrm{MPhil} / \mathrm{PhD}$ programmes.

Eligibility: 1. University of Lincoln International Scholarships take the form of a tuition fee reduction upon enrolment. 2. University of Lincoln International Scholarships are non-transferable and are not valid in conjunction with each other; only one Scholarship per student per course will be applied. 3. The University of Lincoln reserves the right to withdraw any University of Lincoln International Scholarship at any point and without notice. 4 . Students who are sponsored by an organisation such as an external funding body. Government, or employer are not eligible to receive a University of Lincoln International Scholarship.

Level of Study: Postgraduate

Type: Scholarship

Value: $£ 2,000$

Frequency: Varies

Country of Study: Any country

Application Procedure: Apply online

Closing Date: 19 February, 19 September

Funding: Trusts

For further information contact:

Email: international@lincoln.ac.uk

\section{India Scholarship}

Subjects: Overseas

Purpose: The Lincoln India Scholarship is aimed at supporting high-achieving postgraduate students from across India.

Eligibility: 1. University of Lincoln International Scholarships take the form of a tuition fee reduction upon enrolment. 2. University of Lincoln International Scholarships are non-transferable and are not valid in conjunction with each other; only one Scholarship per student per course will be applied. 3. The University of Lincoln reserves the right to withdraw any University of Lincoln International Scholarship at any point and without notice. 4. Students who are sponsored by an organisation such as an external funding body. Government, or employer are not eligible to receive a University of Lincoln International Scholarship.

Level of Study: Postgraduate 
Type: Scholarship

Value: $£ 5,000$

Length of Study: 1 Year

Frequency: Varies

Country of Study: Any country

Application Procedure: Apply online

Closing Date: 19 February, 19 September

Funding: Trusts

For further information contact:

Email: intscholarships@lincoln.ac.uk

\section{Indonesia Scholarship}

Subjects: Overseas

Purpose: The University of Lincoln Indonesia Scholarship is aimed at supporting high-achieving postgraduate students from across Indonesia

Eligibility: 1. University of Lincoln International Scholarships take the form of a tuition fee reduction upon enrolment. 2. University of Lincoln International Scholarships are non-transferable and are not valid in conjunction with each other; only one Scholarship per student per course will be applied. 3. The University of Lincoln reserves the right to withdraw any University of Lincoln International Scholarship at any point and without notice. 4 . Students who are sponsored by an organisation such as an external funding body. Government, or employer are not eligible to receive a University of Lincoln International Scholarship

Level of Study: Postgraduate

Type: Scholarship

Value: $£ 5,000$

Frequency: Varies

Country of Study: Any country

Application Procedure: Apply online

Closing Date: 19 February, 19 September

Funding: Trusts

For further information contact:

Email: intscholarships@lincoln.ac.uk

\section{Lincoln Alumni Master of Architecture Scholarship}

Subjects: This Scholarship applies to students enrolling on the Master of Architecture (Part two) programme in academic year

Purpose: This scholarship is available to Home/European Union students holding a University of Lincoln degree when enrolling on the Master of Architecture programme (MArch)
Type: Scholarship

Value: $£ 1,000$ will be paid directly to the student for each year of study for each completed academic year of study, with parttime students eligible for a pro-rata payment

Country of Study: United Kingdom

Application Procedure: No procedure is required. Eligible students will receive this scholarship upon enrolling for the Master of Architecture programme

Funding: Private

Additional Information: You are subject to tuition fees of $£ 9,250$

For further information contact:

Email: intscholarships@lincoln.ac.uk

\section{Master of Science Sport Science: Applied Sport Science Bursary}

Subjects: Overseas

Purpose: Up to three Applied Sport Science Bursaries will be offered to exceptional students enrolling on MSc Sport Science program

Level of Study: Postgraduate

Type: Bursary

Value: NZ£1,500

Frequency: Varies

Country of Study: Any country

Application Procedure: Apply online

Closing Date: 19 September

Funding: Trusts

For further information contact:

Tel: (44) 1522886651

Email: swillmott@lincoln.ac.uk

\section{Nigeria Scholarship}

Purpose: The University of Lincoln Nigeria Scholarship is aimed at supporting high-achieving postgraduate students from across Nigeria

Eligibility: Be a Nigerian citizen. Already hold a conditional or unconditional offer from the University of Lincoln for a full-time postgraduate taught or Master's by Research programme commencing in September

Type: Scholarship

Value: The scholarship is valued at $£ 5,000$

Country of Study: United Kingdom

Application Procedure: Submit applications to intscholarships@lincoln.ac.uk

Funding: Private 
Additional Information: For further information, please contact the International Office

\section{For further information contact:}

Email: intscholarships@lincoln.ac.uk

\section{Thai Scholarship}

\section{Subjects: Overseas}

Purpose: For programmes commencing in 2019, the University of Lincoln are delighted to offer Thai Scholarships to high achieving postgraduate applicants.

Eligibility: 1. University of Lincoln International Scholarships take the form of a tuition fee reduction upon enrolment. 2. University of Lincoln International Scholarships are non-transferable and are not valid in conjunction with each other; only one Scholarship per student per course will be applied. 3. The University of Lincoln reserves the right to withdraw any University of Lincoln International Scholarship at any point and without notice. 4. Students who are sponsored by an organisation such as an external funding body. Government, or employer are not eligible to receive a University of Lincoln International Scholarship

Level of Study: Postgraduate

Type: Scholarship

Value: $£ 5,000$

Frequency: Varies

Country of Study: Any country

Application Procedure: Apply online

Closing Date: 19 February, 19 September

Funding: Trusts

\section{For further information contact:}

Email: intscholarships@lincoln.ac.uk

\section{Thailand Scholarship}

Purpose: The University of Lincoln Thai Scholarship is aimed at supporting high-achieving postgraduate students from across Thailand

Eligibility: Be a Thai citizen. Already hold a conditional or unconditional offer from the University of Lincoln for a fulltime postgraduate taught or Master's by Research programme commencing in September

Type: Scholarship

Value: $£ 5,000$

Application Procedure: For details, please visit intscholarships@lincoln.ac.uk

\section{For further information contact:}

Email: intscholarships@lincoln.ac.uk

\section{The Lincoln $\mathbf{5 0 \%}$ Global Scholarship}

Subjects: Overseas

Purpose: The University of Lincoln are delighted to offer $50 \%$ Global Scholarships to international applicants who demonstrate the highest levels of excellence in academia, extracurricular and personal endeavour.

Eligibility: 1. University of Lincoln International Scholarships take the form of a tuition fee reduction upon enrolment. 2. University of Lincoln International Scholarships are non-transferable and are not valid in conjunction with each other; only one Scholarship per student per course will be applied. 3. The University of Lincoln reserves the right to withdraw any University of Lincoln International Scholarship at any point and without notice. 4 . Students who are sponsored by an organisation such as an external funding body. Government, or employer are not eligible to receive a University of Lincoln International Scholarship.

Level of Study: Postgraduate

Type: Scholarship

Frequency: Varies

Country of Study: Any country

Application Procedure: Apply online

Closing Date: 19 February, 19 September

Funding: Trusts

For further information contact:

Email: intscholarships@lincoln.ac.uk

\section{University of Lincoln India Scholarships}

Value: $£ 5,000$

Country of Study: Any country

Application Procedure: The mode of applying is online

Closing Date: September

\section{For further information contact:}

Email: intscholarships@lincoln.ac.uk

\section{Uruguay PhD Scholarship}

Subjects: Life Sciences

Purpose: To conduct $\mathrm{PhD}$ studies in Life Sciences has recently been agreed between the University of Lincoln and 
the Uruguay National Agency for Research and Innovation (ANII - Agencia Nacional de Investigaciön e Innovaciön)

Type: Scholarship

Value: The scholarship covers university fees and a subsistence bursary

Country of Study: United Kingdom

Closing Date: 15 March

Additional Information: For additional information regarding this scholarship please contact: Dr Daniel PincheiraDonoso, Email: DPincheiraDonoso@lincoln.ac.uk, Telephone $+44(0) 1522835025$

\section{For further information contact:}

Email: fmontealegrez@lincoln.ac.uk

\section{Vietnam Merit Scholarship}

Purpose: The University of Lincoln Vietnam Merit Scholarship is aimed at supporting high achieving postgraduate students from across Vietnam

Value: $£ 5,000$

Country of Study: Any country

Application Procedure: Submit applications to intscholar ships@lincoln.ac.uk

\section{For further information contact:}

Email: intscholarships@lincoln.ac.uk

\section{University of Liverpool}

Liverpool L69 3BX, United Kingdom

The University of Liverpool is a public university based in the city of Liverpool, United Kingdom. Founded as a college in 1881, it gained its royal charter in 1903 with the ability to award degrees and is also known to be one of the six original "red brick" civic universities. It comprises three faculties organized into 35 departments and schools. It is a founding member of the Russell Group, the N8 Group for research collaboration and the University Management school is AACSB accredited.

\section{Commonwealth Shared Scholarship Scheme}

Purpose: Commonwealth Shared Scholarships, offered in partnership with United Kingdom universities, are for developing country students who would not otherwise be able to undertake master's level study in the United Kingdom Type: Scholarship
Value: Covers tuition fees, living costs and return flights to the United Kingdom

Country of Study: United Kingdom

Closing Date: 7 March

Additional Information: Please email seschol@liverpool. ac.uk to confirm you are applying for the scheme and quoting that number

\section{For further information contact:}

Email: seschol@liverpool.ac.uk

\section{FIDERH Award}

Eligibility: You must be a Mexican national Type: Award

Value: $20 \%$ reduction in tuition fees for postgraduate taught and research programmes

Country of Study: United Kingdom

Closing Date: 28 February

Additional Information: Please apply for funding through FIDERH. Students who are awarded a FIDERH Graduate Loan and register at the University of Liverpool will automatically receive the award

\section{For further information contact:}

Website: https://www.fiderh.org.mx/

\section{Hodgson Law Scholarship}

Purpose: The Trustees wish Hodgson Law Scholars to benefit from education in Liverpool with a view to encouraging the intellectual growth of promising law students and the nurturing of close links with the City of Liverpool and the Liverpool City Region

Eligibility: 1. Procedure 2: Application for an LLM place at University Applicants should apply for, and hold an offer of place, for a full-time postgraduate taught degree in law (LLM) at the University of Liverpool or Liverpool John Moores University to be eligible for the Hodgson Law Scholarship Value: The Scholarship includes full tuition fees for a fulltime postgraduate taught degree in law (LLM), and a stipend of $£ 9,135$

Country of Study: United Kingdom

Application Procedure: You will need to complete and submit the Hodgson Law Scholarship application form electronically to the Hodgson Selection Committee by email to hodgscho@liverpool.ac.uk

Closing Date: 1 May

Additional Information: For enquiries please contact Dr Gregory Messenger, Hodgson Scholarship Liaison. www.liverpool. 
ac.uk/law/study/masters/; www.ljmu.ac.uk/study/courses/post graduates/international-business-corporate-and-finance-law

\section{For further information contact:}

Email: hodgscho@liverpool.ac.uk

\section{John Lennon Memorial Scholarships}

Purpose: The award is intended to support students from Merseyside who might be in financial need and enhance, among other things, awareness of global problems and environmental issues. The John Lennon Memorial Scholarships were set up by a trust fund endowed in the University for the provision of scholarships in the memory of John Lennon

Type: Scholarship

Length of Study: Three years

Country of Study: Any country

Application Procedure: You will need to complete and submit the form by email to the Secretary to the Scholarships Sub-Committee by email to seschol@liverpool.ac.uk

Closing Date: 30 March

\section{For further information contact:}

Email: seschol@liverpool.ac.uk

\section{Liverpool International College (LIC) Excellence Award}

Eligibility: Students who achieve an average of $75 \%$ or above in their LIC Pre-Master's programme

Type: Award

Value: $£ 2,500$ tuition fee reduction

Country of Study: United Kingdom

Additional Information: No application necessary. The award will automatically be awarded to those who meet criteria

\section{For further information contact:}

Email: irro@liverpool.ac.uk

\section{Liverpool Law School LLM Bursaries}

Purpose: Awards will help students with their tuition fees. They are offered to encourage the best students, from the United Kingdom, Europe and internationally, to join the expanding LLM programme

Eligibility: Home, European Union and international students studying a LLM programme. Liverpool Law School
LLM Bursaries will be awarded on the basis of merit. Academic performance in earlier degrees they have taken, as well as any other practical or intellectual achievements, will be taken into account

Type: Bursary

Value: There are two bursaries worth $£ 500$ each available to two students classified as home/European Union and two bursaries of $£ 1,000$ each available to two international students

Country of Study: United Kingdom

Application Procedure: Students do NOT need to make an extra application for the Liverpool Law School LLM Bursaries. All students who have registered for the LLM will be considered automatically. The decision of Liverpool Law School on the award of the bursaries is final

\section{For further information contact:}

Email: irro@liverpool.ac.uk

\section{Marshall Scholarships}

Purpose: To enable intellectually distinguished young Americans, their country's future leaders, to study in the United Kingdom. 1. To help Scholars gain an understanding and appreciation of contemporary Britain

Eligibility: To qualify, candidates should: 1 . Be citizens of the United States of America normally resident in the United States of America. 2. Hold a doctorate in a science or engineering subject by the time they take up their Fellowship

Type: Scholarship

Value: Full tuition fee waiver for a master

Country of Study: United Kingdom

Closing Date: 10 October

Additional Information: Apply via: www.marshallscholar ship.org/applications/apply

\section{For further information contact:}

Email: apps@marshallscholarship.org

\section{Santander Awards}

Purpose: Santander International Postgraduate Scholarships reward international students who demonstrate academic excellence. The awards are available to international students entering onto postgraduate taught programmes at the University of Liverpool in September Value: $£ 5,000$ tuition fee reduction for 1 year only

Country of Study: United Kingdom

Closing Date: 15 June 


\section{For further information contact:}

Email: santander.universities@santander.co.uk

\section{University of Liverpool Commonwealth Postgraduate Bursary}

Purpose: The University of Liverpool Commonwealth Postgraduate Bursary fee reduction for students from Commonwealth countries new to studying at the University of Liverpool on master's programmes

Type: Bursary

Value: $£ 2,500$ fee reduction for Commonwealth students studying Engineering, Electrical Engineering and Electronics, and Computer Science programmes; $£ 1,500$ fee reduction for Commonwealth students studying all other subjects

Country of Study: Any country

Additional Information: No application necessary, automatically awarded to those who meet criteria

\section{For further information contact:}

Email: irro@liverpool.ac.uk

\section{University of Liverpool Management School Academic Award}

Purpose: The University of Liverpool Management School is delighted to offer range of generous scholarships and study awards to help cover the cost of MBA tuition fees

Eligibility: HEU/OSI applicants on the Liverpool MBA and the Football Industries MBA* programmes with an excellent academic profile and excellent work experience, or combination of very high standards in both of the above. It is an on-campus programme

Type: Award

Value: $£ 2,000$

Country of Study: United Kingdom

For further information contact:

Email: ulmsmba@liverpool.ac.uk

\section{University of Manchester}

Oxford Road, Manchester M13 9PL, United Kingdom

Tel: (44) 1613066000

Email: hr@manchester.ac.uk

Website: www.manchester.ac.uk
The University of Manchester is Britain's largest single site university with a proud history of achievement and an ambitious agenda for the future. The University has an exceptional record of generating and sharing new ideas, and the quality, breadth and volume of its research activity is unparalleled in Britain.

\section{Indian Excellence Scholarship Award}

Subjects: Scholarships are awarded within the Faculty of Science and Engineering at the University of Manchester Purpose: Scholarships are available for pursuing undergraduate degree programme

Eligibility: This scheme applies to any undergraduate degree programme within the Faculty of Science and Engineering at The University of Manchester. Each scholarship will be awarded on the basis of a student demonstrating high performance in their International Baccalaureate or Standard XII examinations and the academic reference on their UCAS form. Applicants must be Indian nationals or permanently domiciled in India. Applicants must have applied through UCAS for a place on an undergraduate degree programme in FSE for entry in September. Applicants must have accepted a programme in FSE as their firm choice by the end of June

Type: Scholarship

Value: $£ 3,000$ per annum

Country of Study: Any country

Closing Date: End of June

Additional Information: Application for courses in this School should be made online through the Universities and Colleges Admissions Service (UCAS)

\section{For further information contact:}

Email: app.req@ucas.ac.uk

\section{Institute for Development Policy and Management Taught Postgraduate Scholarship Scheme}

Subjects: Development studies

Eligibility: Bachelors degree with Second Class Honours, Upper Division or above, or Overseas equivalent (please contact School for details of equivalencies). Applicants whose first language is a language other than English must achieve 7.0 or above in IELTS or an equivalent test (TOEFL) Level of Study: Postgraduate

Type: Scholarship

Value: $£ 2,000$

Frequency: Annual 
Application Procedure: Check website for further details www.manchester.ac.uk/postgraduate/funding/search/display/? $\mathrm{id}=00000177$

Closing Date: 30 June

\section{For further information contact:}

Email: paul.arrowsmith@manchester.ac.uk

Contact: Paul Arrowsmith, School of Environment \& Development, Admissions Office

\section{Manchester-China Scholarship Council Joint Postgraduate Scholarship Programme}

Subjects: Telecommunication and information technology, life science and public health, material science and new material, energy sources and environment, engineering science and applied social sciences and WTO-related areas

Purpose: To provide scholarships to the nationals of PR China who wish to pursue their $\mathrm{PhD}$ at the University of Manchester

Eligibility: Open to students who are citizens and permanent residents of PR China and who hold a Master's degree from one of the 38 Chinese universities under 985 Programme

Level of Study: Doctorate, Postgraduate

Type: Scholarships

Value: Tuition fees and annual stipend of approx. $£ 4,800$

Length of Study: 3 years

Frequency: Annual

Study Establishment: University of Manchester

Country of Study: United Kingdom

Application Procedure: Applicants must complete the standard postgraduate application form and return it together with: Academic transcripts, English language qualification, 2 reference letters and a research proposal

Closing Date: 20 April

Additional Information: For further details, please see the website: www.manchester.ac.uk/postgraduate/funding/search/ display $/$ id $=00000066 \& p g=2 \&$ offset $=\&$ sort $=$ name $\&$ sortdir $=$ ascending\&subjectArea $=\&$ studyLevel $=$ ALL\&nationality $=\&$ income $=\&$ submit $=$

\section{President's Doctoral Scholar Award}

Type: Scholarship

Value: $£ 1,000$

Country of Study: United Kingdom

Application Procedure: For further information, please visit the PDS website
For further information contact:

Email: EPSGradEd@manchester.ac.uk

\section{University of Melbourne}

Scholarships Office, Melbourne, Melbourne, VIC 3010, Australia

Tel: $\quad$ (61) 383444000

Fax: (61) 383445104

Email: pg-schools@unimelb.edu.au

Website: www.unimelb.edu.au

The University of Melbourne has a long and distinguished tradition of excellence in teaching and research. It is the leading research institution in Australia and enjoys a reputation for the high quality of its research programmes, consistently winning the largest share of national competitive research funding.

\section{Dairy Postgraduate Scholarships and Awards}

Subjects: Dairy farming and dairy manufacturing

Purpose: To enable students for research contributing to the technical areas relevant to dairy farming and dairy manufacturing operations

Eligibility: Open to citizens or permanent residents of Australia

Level of Study: Postgraduate

Type: Scholarship

Value: A $\$ 25,000$ stipend plus A $\$ 3,000$ per year

Frequency: Annual

Country of Study: Australia

Application Procedure: To apply for this scholarship one must apply direct to the faculty

Closing Date: 20 October

\section{For further information contact:}

Tel: $\quad$ (61) 396943810

Fax: (61) 396943701

Email: research@dairyaustralia.com.au

\section{PhDs in Bio Nanotechnology}

Subjects: Bio nanotechnology

Eligibility: Open to those who have achieved Honours 2a or equivalent 
Level of Study: Postgraduate, Research

Type: Scholarship

Value: A\$19,616 per year

Length of Study: 2 years (Masters) and 3 years (PhD)

Frequency: Annual

Study Establishment: University of Melbourne

Country of Study: Australia

Application Procedure: Applicants must apply directly to the scholarship provider. Check website for further details

Closing Date: 21 July

Contributor: University of Melbourne

For further information contact:

Email: fcaruso@unimelb.edu.au

Contact: Professor Frank Caruso, Federation Fellow

\section{Rae and Edith Bennett Travelling Scholarship}

Subjects: All subjects

Purpose: To enable students and graduates of the University of Melbourne to undertake postgraduate study or research in the United Kingdom

Eligibility: Open to students and graduates of the University of Melbourne who can demonstrate outstanding academic merit and promise

Level of Study: Postgraduate

Type: Scholarship

Value: A\$40,000-60,000 per year

Frequency: Annual

Country of Study: Australia

Application Procedure: Please see the website www. services.unimelb.edu.au/scholarships/research/local/available/ travelling/rae for more details

Closing Date: 30 June

Funding: Private

Contributor: Rae and Edith Bennett Travelling Scholarship

Fund

For further information contact:

Email: gsa@gsa.unimelb.edu.au

\section{Sir Arthur Sims Travelling Scholarship}

Subjects: All subjects

Purpose: To enable graduates of Australian universities to undertake postgraduate study or research in United Kingdom Eligibility: Open to graduates of Australian universities who can demonstrate outstanding academic merit and promise. Applicants must be born in Australia or have parents who have been Australian residents for 7 years or more
Level of Study: Postgraduate, Research

Type: Scholarship

Value: Living allowance, tuition fees (approx. $\$ 20,000$ per year)

Length of Study: $1-3$ years

Country of Study: United Kingdom

Application Procedure: Check website www.services. unimelb.edu.au/scholarships/research/local/available/travel ling/sims for further the details

Closing Date: 30 June

Funding: Private

Contributor: Sir Arthur Sims Traveling Scholarship Fund

\section{For further information contact:}

Email:13melb@unimelb.edu.au

\section{Sir Thomas Naghten Fitzgerald Scholarship}

Subjects: Surgery

Purpose: This scholarship is to support further surgical training in Australia or Overseas

Eligibility: Open to candidates studied or currently studying at The University of Melbourne

Level of Study: Postgraduate

Type: Scholarship

Value: Approx. A $\$ 12,000$

Length of Study: 1 year

Frequency: Annual

Study Establishment: University of Melbourne

Country of Study: Australia

Application Procedure: Check website www.research. mdhs.unimelb.edu.au/fitzgerald-scholarship for further details

Closing Date: 31 October

Funding: Government

For further information contact:

Email: jyv@unimelb.edu.au

Contact: Joan Vosen, Medicine Faculty

\section{The Helen Macpherson Smith Scholarships}

Subjects: Science, humanities and social sciences

Purpose: To establish special scholarships for outstanding women who are entering graduate study

Eligibility: Open to outstanding women who are entering postgraduate study. Only citizens of Australia may apply

Level of Study: Postgraduate

Type: Scholarship 
Value: A $\$ 8,000$ (Current rate) top-up payment (payable over 1 year) in addition to an APA or MRS

Frequency: Annual

Country of Study: Australia

Application Procedure: Check website for further details services.unimelb.edu.au/scholarships/research/local/available/ prestigious\#Macpherson

Closing Date: 31 October

Funding: Trusts

Contributor: Helen Macpherson Smith Trust

\section{For further information contact:}

Email: gsa@gsa.unimelb.edu.au

\section{Viola Edith Reid Bequest Scholarship}

Subjects: Medicine

Purpose: This scholarship is to support postgraduate study in any discipline of Medicine

Eligibility: Open for study in Australia. There are no restrictions on citizenship

Level of Study: Postgraduate, Research

Type: Scholarship

Value: A $\$ 21,174$ maximum per award

Length of Study: 1 year

Frequency: Annual

Study Establishment: University of Melbourne

Country of Study: Australia

Application Procedure: Check website www.research.mdhs. unimelb.edu.au/viola-edith-reid-bequest for further details

Closing Date: 31 October

Funding: Government

For further information contact:

Tel: $\quad$ (61) 83444019

Fax: (61) 93477854

Email: jyv@unimelb.edu.au

Contact: Joan Vosen, Medicine Faculty

\section{University of Nevada, Las Vegas (UNLV)}

Graduate College, 4505 Maryland Parkway, Box 451010, Las Vegas, NV 89154-1017, United States of America

Tel: $\quad$ (1) 7028953011

Fax: (1) 7028954180

Email:_gradcollege@unlv.edu

Website: www.unlv.edu

Contact: Administrative Officer

\section{University of Nevada, Las Vegas Alumni Association Graduate Scholarships}

Subjects: All subjects

Purpose: To reward outstanding graduate students

Eligibility: Students must have completed any degree at UNLV, with a 3.5 GPA or better and be a member of the UNLV Alumni Association. Students must enrol in a graduate program at least half-time ( 6 credits/semester), and must maintain a cumulative and semester GPA of 3.5

Level of Study: Graduate, MBA

Type: Scholarship

Value: US\$1,500

Length of Study: 1 year

Frequency: Annual

Study Establishment: UNLV

Country of Study: United States of America

Application Procedure: Please check the website www. financialaid.unlv.edu/apps/ScholarshipSearch/index.asp?action $=$ detail $\& s=466$

Closing Date: 3 March

Additional Information: Student may receive the scholarship for a maximum of two (2) years, or four (4) semesters

\section{For further information contact:}

Email: unlvscholarships@unlv.edu

Contact: UNLV Financial Aid \& Scholarships

\section{University of Nevada, Las Vegas James F Adams/ GPSA Scholarship}

Subjects: All subjects

Purpose: To recognize the academic achievements of graduate students

Eligibility: Applicant must be a master's-level or specialist student. He/she must have completed at least 12 credits of graduate study at UNLV (by the end of the current spring semester). Have a minimum graduate GPA of 3.5. Enroll in six or more credits in each semester of the scholarship year

Level of Study: Graduate, MBA

Type: Scholarship

Value: US $\$ 1,000$

Length of Study: Varies

Frequency: Annual

Study Establishment: UNLV

Country of Study: United States of America

Application Procedure: Please see the website www.finan cialaid.unlv.edu/apps/ScholarshipSearch/index.asp?action= detail\&s $=419$

Closing Date: 3 March 
For further information contact:

Email:_eric.lee@unlv.edu

Contact: Eric Lee

\section{University of New South Wales (UNSW)}

Scholarships and Financial Support, Sydney, NSW 2052, Australia

Tel: $\quad$ (61) 293851000

Fax: (61) 2938500706

Email:_scholarships@unsw.edu.au

Website: www.unsw.edu.au

University of New South Wales (UNSW) is one of Australia's leading research and teaching universities. UNSW takes great pride in the broad range and high quality of teaching programmes. UNSW's teaching gains strength, vitality and currency both from their research activities and from their international nature.

\section{Association of Professional Academic Institutions Scholarship in Metallurgy/Materials}

Subjects: Metallurgy, materials engineering

Purpose: To undertake blast furnace research in collaboration with industry

Eligibility: This scholarship requires candidates to have achieved Honours 1 or equivalent, or Honours 2a or equivalent

Level of Study: Doctorate, Postgraduate

Type: Scholarship

Value: Stipend of A $\$ 25,000$ per year

Length of Study: $3-3.5$ years

Frequency: Annual

Study Establishment: School of Materials Science and Engineering

Application Procedure: Check website for further details

Closing Date: 31 October

\section{For further information contact:}

Email: a.yu@unsw.edu.au

Contact: Professor Aibing Yu, Scientia Professor \& Federation Fellow

\section{College of Fine Arts Research Scholarship}

Subjects: Fine arts

Purpose: To support students with outstanding research potential who are ineligible for an APA/UPA

Eligibility: Students with an offer to commence a full-time $\mathrm{PhD}$ at COFA, or students currently enroled full-time in a $\mathrm{PhD}$ at COFA

Level of Study: Doctorate

Type: Scholarship

Value: A $\$ 22,500$ per year

Length of Study: Up to 3 years

Frequency: Annual

Study Establishment: University of New South Wales

Country of Study: Australia

Application Procedure: Application forms are available at the COFA Student Centre on the UNSW Scholarships website www.cofa.unsw.edu.au/about-us/scholarships/cofa-researchscholarship/

Closing Date: 31 January

\section{For further information contact:}

COFA Students Centre

Tel: $\quad$ (61) 293850684

Email: chad.roberts@unsw.edu.au

Contact: Chad Roberts, Scholarships Officer

\section{PhD Scholarship - Metal Dusting}

Subjects: Materials science and engineering

Purpose: To support research on metal dusting

Eligibility: Open to citizens of Australia or permanent residents holding high Honours Degree in science

Level of Study: Postgraduate, Research

Type: Scholarship

Value: A $\$ 25,000-30,000$ per year (tax free)

Length of Study: $3-3.5$ years

Frequency: Annual

Study Establishment: University of New South Wales

Country of Study: Australia

Application Procedure: Check website for further details Closing Date: 28 February

\section{For further information contact:}

Tel: $\quad$ (61) 93854322

Fax: (61) 93855956 
Email: d.young@unsw.edu.au

Contact: David Young, (Professor) Science/Materials

\section{PhD Scholarships in Environmental Microbiology}

Subjects: Environmental microbiology, microbial genomics

Purpose: To attract the nation's strongest candidates capable of pursuing $\mathrm{PhD}$ studies in the genomics of environmental microorganisms

Eligibility: This scholarship is for study in Australia for those who have achieved Honours 1 or equivalent, or Masters or equivalent. There are no restrictions on citizenship

Level of Study: Doctorate, Postgraduate, Research

Type: Scholarship

Value: A $\$ 35,000$

Application Procedure: Check website www.emi.science. unsw.edu.au/recruitment.html for further details

Closing Date: 31 March

\section{For further information contact:}

Email: r.cavicchioli@unsw.edu.au

Contact: Rick Cavicchioli

\section{Postdoctoral Fellow Positions in Computational Mathematics}

Subjects: Positions are awarded in Computational Mathematics in the School of Mathematics and Statistics, UNSW Sydney.

Purpose: Applications are sought for two Postdoctoral Fellow positions in Computational Mathematics in the School of Mathematics and Statistics, UNSW Sydney.

Eligibility: Australian citizens are eligible to apply.

Type: Postdoctoral fellowship

Value: Australian $\$ 89 \mathrm{~K}$ - Australian $\$ 96 \mathrm{~K}$ per year (plus up to $17 \%$ superannuation and leave loading)

Frequency: Annual

Study Establishment: Positions are awarded in Computational Mathematics in the School of Mathematics and Statistics, UNSW Sydney

Country of Study: Australia

Application Procedure: Applicants should submit the following documents toims@shanghaitech.edu.cn: CV, including a list of publications, a research statement of up to 5 pages, describing their main achievements to date, as well as outlining the program of research they intend to follow for the next few years. A teaching statement Four letters of recommendation, at least one of which should address teaching, to be submitted directly to the hiring committee by the letter writers.

Closing Date: 1 February

Additional Information: For more details please visit the website scholarship-positions.com/postdoctoral-fellowpositions-computational-mathematics-unsw-australia/2018/ 03/06/. www.jobs.ac.uk/job/BOY792/postdoctoral-fellowin-computational-mathematics

\section{For further information contact:}

Email: ims@shanghaitech.edu.cn

\section{Vida Rees Scholarship in Pediatrics}

Subjects: Medicine (Paediatrics)

Purpose: To support Australian students to undertake research in paediatrics

Eligibility: To be eligible for a Scholarship an applicant must be an Australian citizen or permanent resident undertaking an Honours project or Postgraduate Research in Paediatrics. Recipients may not concurrently hold any other scholarship or award (except for Youth Allowance) except with the permission of the UNSW Selection Committee

Level of Study: Postgraduate, Research

Type: Scholarship

Value: AU $\$ 3,000$

Length of Study: 1 year

Frequency: Annual

Study Establishment: University of New South Wales

Country of Study: Australia

Application Procedure: Completed application forms and any supporting documentation should be scanned and emailed (preferably as a single pdf document) to the Graduate Research School. For more details please see the website

Closing Date: 1 December to 18 February

For further information contact:

Email: domestic.grs@unsw.edu.au

Contact: Sean Goodwin

\section{Viktoria Marinov Award in Art}

Subjects: Creative arts 
Purpose: To financially assist female artists under the age of 35 years who are proposing to undertake the Master of Art or Master of Fine Arts course

Eligibility: Female students who are under 35 years old completing the Master of Fine Arts (by research). Must be Australian citizens or permanent residents

Level of Study: Postgraduate

Type: Award

Value: $A \$ 7,500$

Length of Study: 1 year

Frequency: Annual

Study Establishment: New South Wales, Sydney City Central and Eastern Suburbs

Country of Study: Australia

Application Procedure: Applicants need to provide at least 6 images of their work, including information on the dimensions and materials of each work. These images can be supplied either electronically on DVD/CD or as attached printed images (no larger than A4). Applicants must include a personal statement addressing the selection criteria as part of their application. Please see the website for more applications related details: www.cofa.unsw.edu.au/about-us/scholar ships/the-viktoria-marinov-award-in-art/

Closing Date: 30 July

\section{For further information contact:}

Tel: $\quad$ (61) 293850684

Email: chad.roberts@unsw.edu.au

Contact: Chad Roberts, Scholarships Officer

\section{University of New United Kingdom (UNE)}

Research Grants Office, Armidale, NSW 2351, Australia

Tel: $\quad$ (61) 267733333

Fax: (61) 267733100

Email: research@une.edu.au

Website: www.une.edu.au

UNE is internationally recognized as one of the best teaching and research universities. Yearly, the university offers students more than AU $\$ 2,500,000$ in scholarships, prizes, and bursaries and more than $\mathrm{AU} \$ 18,000,000$ for staff and students involved in research. It provides distance education for the students. Its scholars and scientists have established international reputations through their contributions in areas such as rural science, agricultural economics, educational administration, linguistics and archaeology.

\section{A S Nivison Memorial Scholarship}

Subjects: Pasture improvement, animal husbandry, farm management, wool research or promotion, water conservation, and environmental protection

Eligibility: Applicants must be a citizen or a permanent resident of Australia undertaking PhD or Research Masters at the University of United Kingdom in one of the listed areas

Level of Study: Doctorate, Postgraduate

Type: Scholarship

Value: AU\$5,000

Length of Study: 1 year

Frequency: Annual

Country of Study: Australia

Application Procedure: Check website for further details

Closing Date: 30 April

Funding: Private

Contributor: Nivison family

For further information contact:

Tel: $\quad$ (61) 267733745

Email: pgscholarships@une.edu.au

Contact: Belinda Keogh

\section{Cooperative Research Centre Programme Spatial Information PhD Scholarship}

Subjects: Agriculture

Purpose: To produce long-lasting outcomes relating to understanding how complex decision-making processes can be improved using spatial and other data

Eligibility: Applicants must hold a Class 1 or 2A Honours (or equivalent) Degree in a suitable discipline, and be a citizen or permanent resident of Australia. A valid driver's licence is also a necessary requirement

Level of Study: Doctorate

Type: Scholarship

Value: Please check website

Frequency: Annual

Study Establishment: University of New England

Country of Study: Australia

Application Procedure: Applicants should send a letter outlining suitability for the position, accompanied by a brief curriculum vitae (including contact details of two referees) and a copy of academic transcripts

Closing Date: Please check with the website

Funding: Government

\section{For further information contact:}

Tel: $\quad$ (61) 267732436

Email: jim.scott@une.edu.au

Contact: Professor Jim Scott 


\section{Cotton Research and Development Corporation Postgraduate Scholarship}

Subjects: Cotton research

Purpose: To enhance the environmental, economic and social performance of the Australian cotton industry

Eligibility: These scholarships are open to anyone who is an Australian resident, studying at an Australian university and interested in working in the Australian cotton industry to pursue postgraduate studies relating to the cotton industry or its related activities

Level of Study: Postgraduate

Type: Scholarship

Value: AU $\$ 30,000$

Length of Study: 3 years

Frequency: Annual

Study Establishment: University of New England

Country of Study: Australia, New Zealand or

South Africa

Application Procedure: Check with the website for further details

Closing Date: End of January

Funding: Government

Contributor: Cotton Research and Development Corporation (CRDC)

Additional Information: Projects may relate to any field of cotton-related research

\section{For further information contact:}

Cotton Research and Development Corporation, 2 Lloyd Street, Narrabri, NSW 2390, Australia

Tel: $\quad$ (61) 267924088

Fax: (61) 267924400

Email:rresearch@crdc.com.au

\section{PhD Scholarship in Animal Breeding}

Subjects: Animal breeding

Purpose: To investigate aspects of sow feed intake and its impact on reproductive performance and longevity

Eligibility: Applicants should be well versed in statistics and/or animal breeding units at a tertiary level and computing and data analysis skills is highly desirable

Level of Study: Doctorate

Type: Scholarship

Value: A $\$ 28,000$ per year

Length of Study: 3 years

Frequency: Annual

Study Establishment: University of New England

Country of Study: Australia

Application Procedure: Please check with the website
Closing Date: 30 June

Contributor: Australian Pork CRC

For further information contact:

Tel: $\quad$ (61) 267733788

Email: kbunter2@une.edu.au

Contact: Dr Kim Bunter

\section{PhD Scholarship: Molecular Factors in Plant- Microbe Associations}

Subjects: Molecular biology

Purpose: To study the molecular aspect of the interaction between the fungal pathogen and the plant

Eligibility: Applicants must hold a Class 1 or 2A Honours (or equivalent) Degree in a suitable discipline, and be a citizen or permanent resident of Australia

Level of Study: Doctorate

Type: Scholarship

Value: AU $\$ 26,000$ per year (tax free)

Length of Study: 3 years

Frequency: Annual

Study Establishment: University of New England

Country of Study: Australia

Application Procedure: Applicants should send a letter outlining their suitability for the position, accompanied by a brief curriculum vitae (including contact details of two referees) and a copy of their academic transcripts

Funding: Government

For further information contact:

Tel: $\quad$ (61) 267732708

Fax: (61) 267733267

Email: lperegge@une.edu.au

Contact: Dr Lily Pereg-Grek

\section{PhD Scholarship: Weed Ecology}

Subjects: Ecology

Purpose: To manage the species through a series of field and controlled environment experiments on emergence, growth, reproduction and spread of environment experiments on emergence, growth, reproduction and spread of fleabane species

Eligibility: Applicants must hold a Class 1 or 2A Honours (or equivalent) Degree in a suitable discipline, and be an citizen or permanent resident of Australia

Level of Study: Doctorate

Type: Scholarship

Value: AU $\$ 26,000$ per year (tax free)

Length of Study: 3 years 
Study Establishment: University of New England Country of Study: Australia

Application Procedure: Applicants should send a letter outlining their suitability for the position accompanied by a brief curriculum vitae (including contact details of two referees) and a copy of their academic transcripts

Closing Date: 27 April

Funding: Government

\section{For further information contact:}

School of Rural Science and Agriculture, University of New England, Armidale, NSW 2351, Australia

Tel: $\quad$ (61) 267733238

Email: bsindel@une.edu.au

Contact: Brian Sindel, Associate Professor

\section{University of New England Research Scholarship}

Subjects: All subjects

Eligibility: Applicants must have achieved Honours 1 or equivalent, or Masters or equivalent

Level of Study: Doctorate, Postgraduate

Type: Scholarship

Value: $A \$ 19,231$

Length of Study: 3 years $(\mathrm{PhD})$ and 2 years (Masters)

Frequency: Annual

Study Establishment: University of New England

Country of Study: Australia

Application Procedure: Contact the university for details

Closing Date: End of September or December

Funding: Government

\section{For further information contact:}

Tel:

$$
\text { (61) } 67733571
$$

Fax: (61) 67733543

Email: aharris@une.edu.au

Contact: Thea Harris, Scholarships Administrative Assistant

\section{University of New United Kingdom Equity Scholarship for Environmental and Rural Science}

\section{Subjects: Science}

Eligibility: Applicants must be citizens of Australia or New Zealand and be an Aboriginal or Torres Strait Islander, non-English speaking background person, student with a disability or woman from non-traditional area

Level of Study: Postgraduate, Research

Type: Scholarship

Length of Study: 2 years (Masters) or 3 years $(\mathrm{PhD})$
Frequency: Annual

Study Establishment: University of New England

Country of Study: Australia, New Zealand or South Africa

Application Procedure: Check website for further details

Funding: Government

\section{For further information contact:}

University of New England, Armidale, NSW 2351, Australia

Email: aharris@une.edu.au

Contact: Thea Harris, Scholarships Administrative Assistant

\section{University of Newcastle}

Research Division, University of Newcastle, Callaghan, NSW 2308, Australia

Tel: $\quad$ (61) 249215000

Fax: (61) 249854200

Email: research@newcastle.edu.au

Website: www.newcastle.edu.au/research/rhd/

Contact: Office of Graduate Studies

The University of Newcastle is one of Australia's top ten research universities. The University has over 1,200 research degree candidates enroled in five faculties, incorporating a wide range of disciplines including architecture, building, humanities, social sciences, education, economics, management, engineering, computer science, law, medicine, nursing, health sciences, music, drama and creative arts, physical and natural sciences, mathematics and information technology. Scholarships are available to support research degree candidates in most disciplines. About 90 new scholarships are awarded each year.

\section{Chemical Engineering Scholarship}

Subjects: Chemical Engineering

Purpose: To develop models capable of simulating temporal and spatial characteristics of rainfall fields over large river basins using novel approaches to hierarchical modelling, storm clustering, advection and calibration. The models will provide continuous simulation support for the design and assessment of water-related infrastructure

Eligibility: Open only to the postgraduates who are the citizens of Australia or the permanent residents of Australia

Level of Study: Postgraduate

Type: Scholarship

Value: A living allowance of AU\$24,653 per year 
Length of Study: 2 years (Masters) and 3 years (PhD)

Frequency: Annual

Country of Study: Australia

Application Procedure: Application form and the Research Higher Degree prospectus from can be downloaded from the website

Closing Date: 31 August, $4 \mathrm{pm}$ each year (International applicants); 31 October, 4 pm each year (Domestic applicants)

\section{For further information contact:}

Tel: $\quad$ (61) 249216038

Email: George.Kuczera@newcastle.edu.au

Contact: Professor George Kuczera

\section{PhD Scholarship in Coal Utilization in Thermal and Coking Applications}

Subjects: Chemical engineering, mechanical engineering, and chemistry

Purpose: To undertake research on particular coal properties which determine its utilization potential

Eligibility: Open to the engineering and the science graduates who have an Honours Degree in chemical or mechanical engineering or chemistry

Level of Study: Doctorate, Postgraduate

Type: Scholarship

Value: A $\$ 19,616$ per year

Length of Study: 3 years

Application Procedure: Check website for further details

Closing Date: 1 March

For further information contact:

Tel: $\quad$ (61) 249216179

Email: Terry.Wall@newcastle.edu.au

Contact: Professor Terry Wall

\section{PhD Scholarship in Immunology of Kidney Stone Diseases}

Subjects: Scholarships are awarded to work on the project titled, "Immunology of kidney stone diseases"

Purpose: This project aims to improve our understanding of how our immune system protects against stone recurrence and its role in preventing long-term consequences such as impaired kidney function

Eligibility: This scholarship is for domestic and international students. If English is not your first language then you will need to show that your English language skills are at a high enough level to succeed in your studies

Type: Scholarship
Value: Scholarship Value: AU\$26,682 p.a., indexed in January each year. The scholarship is for a period of three years and a half years. This Scholarship is linked to the Dr Starkey ARC DECRA fellowship

Frequency: Annual

Study Establishment: Scholarships are awarded to work on the project titled, "Immunology of kidney stone diseases"

Country of Study: Australia

Application Procedure: To enable us to assess your application, candidates will be expected to submit an email expressing their interest including: 1 . Academic transcripts. 2. A brief statement of research interests. 3. Full CV including previous degrees, grades, research experience, employment, papers published, and any grants obtained. Applicants are automatically considered for the scholarship on acceptance to University College

Closing Date: 1 April

Additional Information: For more details please visit the website scholarship-positions.com/phd-scholarshipimmunology-kidney-stone-diseases-australia/2018/02/01/

\section{Postgraduate Research Scholarship in Physics}

Subjects: Physics

Eligibility: Open to the residents of Australia and New Zealand or the permanent residents of Australia who have an Honours 1 or 2A or a Masters Degree

Level of Study: Postgraduate, Research

Type: Scholarship

Value: AU\$17,071 per year

Length of Study: 3 years

Frequency: Annual

Application Procedure: Check website for more details

Closing Date: 1 July

Contributor: ARC Discovery-projects

For further information contact:

School of Mathematical and Physical Sciences

Tel: $\quad$ (61) 249216653

Fax: (61) 249216907

Email: vicki.keast@newcastle.edu.au

Contact: Dr Vicki Keast

\section{University of Newcastle Postgraduate Research Scholarship (UNRS Central)}

Subjects: All subjects

Eligibility: Open to the residents of Australia and New Zealand or permanent residents who have achieved 
Honours 1 or equivalent and have completed at least 4 years of undergraduate study

Level of Study: Postgraduate, Research

Type: Scholarship

Value: AU $\$ 23,728$ per year full-time stipend, AU $\$ 12,898$ part time stipend

Length of Study: 2 years (Masters) and 3 years $(\mathrm{PhD})$

Frequency: Annual

Country of Study: Australia

Application Procedure: Check website for further details

Closing Date: 31 October

\section{For further information contact:}

Research Higher Degrees, The Chancellery Eastern Wing, University Drive

Tel: (61) 249216537

Fax: (61) 249216908

Email: research@newcastle.edu.au

\section{University of Newcastle, Australia MBA Programme}

Application Procedure: Applicants must return a completed application form, with original or certified copies of official academic transcripts (not to be returned), Graduate Management Admission Test and TOEFL (if applicable) scores, the names of two referees

\section{For further information contact:}

Business Administration International Students Office University Drive

Tel: $\quad$ (61) 49216595

Fax: (61) 49601766

Email: io@newcastle.edu.au

Contact: MBA Admissions Officer

\section{University of Notre Dame}

1124 Flanner Hall, Notre Dame, IN 46556, United States of America

Tel: $\quad$ (1) 5746311305

Fax: $\quad$ (1) 5746318997

Email: ndias@nd.edu, bgregor3@nd.edu

Website: www.nd.edu

Contact: Brad S Gregory, Director of the Notre Dame Institute for Advanced Study
The University of Notre Dame provides a distinctive voice in higher education that is at once rigorously intellectual, unapologetically moral in orientation, and firmly embracing of a service ethos.

\section{Break Travel and Research Grants for Sophomores and Juniors}

Purpose: The Break Travel and Research Grant provides seed funding for educational and research projects in European studies. The grant is intended to support wellfocused, short-term exploratory trips conducted over fall, winter, or spring break

Eligibility: Applicants must be enrolled as a sophomore or junior at the University of Notre Dame and scheduled to return the following semester

Level of Study: Postgraduate

Type: Grant

Value: US $\$ 2,500$. Funds are typically paid at one-time sum

Frequency: Annual

Country of Study: Any country

Closing Date: 4 February

Funding: Private

\section{For further information contact:}

Tel: $\quad$ (1) 5746318326

Email: cstump@nd.edu

\section{Templeton Fellowships for United States of America and International Scholars at NDIAS}

Subjects: Philosophy, theology, sciences, etc

Purpose: With grant support from the John Templeton Foundation, the NDIAS will help chart a new course for future scholarship by offering Templeton Fellowships that encourage scholars to return to reflection on the broad questions that link multiple areas of inquiry and to do so in a manner that embraces a value-oriented interpretation of the world

Eligibility: Distinguished senior scholars with extensive records of academic accomplishment and who have had a considerable impact on their discipline are encouraged to apply. Outstanding junior scholars with academic records of exceptional promise and whose research agendas align with the purpose and parameters of the program are also invited to apply

Type: Fellowship

Value: These distinctive fellowships offer an extraordinary measure of scholarly support, including: a stipend of up to US $\$ 1,00,000$; fully furnished faculty housing (for those who reside outside of the Michiana area); up to US $\$ 3,000$ in research expenditures; a private office at the NDIAS, with 
a personal desktop computer and printer; etc. Check detailed information on the website

Frequency: Annual

Country of Study: United States of America

Application Procedure: Please see ndias.nd.edu/fellow ships/templeton/application-instructions/ for details on how to apply. Please direct any questions you may have on the application process or fellowship program to Carolyn Sherman at csherman@nd.edu

Closing Date: 15 October

Additional Information: For more information, please check at ndias.nd.edu/fellowships/templeton/

For further information contact:

Email: csherman@nd.edu

Contact: Carolyn Sherman

\section{University of Notre Dame: College of Arts and Letters}

Office of the Dean, 100 O'Shaughnessy Hall, Notre Dame, IN 46556, United States of America
Tel:
(1) 5746317085
Fax: (1) 5746317743
Email:_aldean@nd.edu
Website: al.nd.edu

University of Notre Dame: College of Arts and Letters offers one of the finest liberal arts educations in the nation. Its Division of the Humanities was recently ranked 12th among private universities, while the social sciences continue their ascent in the national rankings. College of Arts and Letters is the largest and oldest of the University's 4 colleges.

\section{The Erskine A. Peters Dissertation Year Fellowship at Notre Dame}

Subjects: Arts, humanities, social sciences and theological disciplines

Purpose: To provide an opportunity for African American scholars at the beginning of their academic careers to experience life at a major Catholic research university

Eligibility: Open to African American Doctoral candidates who have completed all degree requirements with the exception of the dissertation

Level of Study: Postgraduate, Research
Type: Fellowship

Value: US $\$ 30,000$ stipend and US $\$ 2,000$ research budget

Length of Study: 10 months

Frequency: Annual

Country of Study: United States of America

Application Procedure: Applicants may apply online

Closing Date: Early December

No. of awards given last year: 3

For further information contact:

Tel: $\quad$ (1) 5746315628

Fax: (1) 5746313587

Email: astudies@nd.edu

\section{University of Nottingham}

University of Nottingham, University Park, Nottingham NG7 2RD, United Kingdom

Tel: $\quad$ (44) 1158468400

Fax: (44) 1158467799

Email: graduate-school@nottingham.ac.uk

Website: www.nottingham.ac.uk/gradschool

Contact: Ms Nicola Pickering, Process Manager

Funding

The University of Nottingham is a community of students and staff dedicated to bringing out the best in all of its members. It aims to provide the finest possible environment for teaching, learning and research and has a world class record of success.

\section{Developing Solutions Masters Scholarship}

Subjects: Faculty of Engineering, Faculty of Medicine and Health Sciences, Faculty of Science and Faculty of Social Science

Purpose: The aim of the Developing Solutions Masters Scholarship is to enable and encourage academically able students from Africa, India or one of the countries of the Commonwealth

Eligibility: Students who are a national of (or permanently domiciled in) Africa, India, or one of the countries of the Commonwealth countries. You can apply for this scholarship if you: are a national of (or permanently domiciled in) Africa, India, OR one of the other Commonwealth countries AND are classed as an overseas student for fee purposes AND have not already studied outside of your home country 
Value: $30 \times 100 \%$ tuition fee; $75 \times 50 \%$ of tuition fees

Country of Study: Any country

Application Procedure: Apply online

Closing Date: 22 March

Additional Information: For more details, visit www.not tingham.ac.uk/studywithus/international-applicants/scholar ships-fees-and-finance/scholarships/masters-scholarships/ dev-sol-masters.aspx. scholarship-assistant@nottingham. ac.uk

\section{For further information contact:}

Tel: (61) 1159515247

Email: scholarship-assistant@nottingham.ac.uk

\section{High Achiever Foundation Prize for Africans}

Subjects: The foundation courses provide an entry route to selected degrees in arts, business, engineering, science and social sciences

Purpose: Prizes are available for pursuing foundation courses at University of Nottingham

Eligibility: Candidates can apply if they are a national of (or permanently domiciled in) Africa, they are classed as an overseas student for fee purposes, already hold an offer to start a full-time foundation program at Nottingham in September

Type: Prize

Value: 3 undergraduate high achiever prizes of $£ 2,000$ towards tuition fees

Country of Study: United Kingdom

Application Procedure: The mode of applying is online

Closing Date: 15 April

Additional Information: Successful applicants will be notified of the outcome within 6 weeks of the closing date

\section{For further information contact:}

Email: scholarship-assistant@nottingham.ac.uk

\section{Japan Masters Scholarships at University of Nottingham in United Kingdom}

Purpose: The aim of the scholarship is strengthen the bond of Japan and United Kingdom

Eligibility: 1. National of (or permanently domiciled in) Japan. 2. Classed as an overseas student for fee purposes. 3. Already have, or expect to receive, a final CGPA of no less than 3.2 grade B or $70 \%$. 4. Already hold an offer to start a full-time master degree programme, including MRes, at Nottingham in September, any subject area

Level of Study: Postgraduate

Type: Scholarship

Value: These scholarships will cover 25\% each towards tuition fees for students from Japan

Country of Study: Any country

Application Procedure: Applications must complete online application form to apply for scholarships. www. nottingham.ac.uk/international/_online_forms/scholarships/_ sships_appform_p1.php

Closing Date: 18 May

\section{For further information contact:}

Email: scholarship-assistant@nottingham.ac.uk

\section{Nottingham Developing Solutions Scholarships}

Purpose: The Developing Solutions Scholarships are designed for international students who want to pursue a Master's Degree in the University of Nottingham and make a difference to the development of their home country Eligibility: 1 . Are a national of (or permanently domiciled in) Africa, India or one of the countries of the Commonwealth. 2. Are classed as an overseas student for fee purposes. 3. Have not already studied outside of your home country. 4. Are not currently studying at a University of Nottingham campus or are not a University of Nottingham graduate

Level of Study: Postdoctorate

Type: Scholarship

Frequency: Annual

Country of Study: Any country

Closing Date: 22 March

Funding: Foundation

\section{Nottingham University Business School MBA Programme}

Length of Study: 1 year full-time or 2;4 years part-time Country of Study: Any country

Application Procedure: Applicants must complete an application form, and provide transcripts or copies of professional qualifications together with two references (ideally, one should be from an academic source, the other from an employer or business contact). All language test scores must be submitted for International students. Note that the school may ask for further individual details to support an application

Closing Date: Varies, please contact the organisation for further details 


\section{For further information contact:}

Tel: $\quad$ (44) 1155515500

Fax: (44) 1155515503

Email: business-enquiries@nottingham.ac.uk

Contact: MBA Admissions Officer

\section{University of Oklahoma}

College of Business Administration, Adams Hall Room 105K, Norman, OK 73019, United States of America

Tel: $\quad$ (1) 4053254107

Fax: (1) 4053251957

Email: awatkins@ou.edu

Contact: MBA Admissions Officer

\section{Ben Barnett Scholarship}

Subjects: Fine arts

Purpose: Any full-time Art majors admitted to either the MA or MFA degree program

Eligibility: Applicant must be a full-time student in the School of Art and have a minimum 3.0 GPA and an outstanding portfolio

Level of Study: Postgraduate

Type: Scholarship

Value: Maximum of US $\$ 1,000$ will be given as scholarship amount

Frequency: Annual

Country of Study: Any country

Application Procedure: Contact Director, School of Art University of Oklahoma 520 Parrington Room 202 Normak, OK 73019 United States Phone: (405) 325-2691

Closing Date: 1 March

Funding: Private

Additional Information: Visit the official website for further info: www.ou.edu

For further information contact:

Email: art@ou.edu

\section{University of Ontario}

Graduate Finance and Administration, 2000 Simcoe Street North, London, ON L1H 7K4, Canada

Email:_pmenzies@uwo.ca

Contact: Office of Graduate Studies Manager,
The University of Ontario Institute of Technology is a public research university located in Oshawa, Ontario, Canada.

\section{The Ontario Trillium Scholarships (OTS)}

Purpose: To attract top international students to Ontario for PhD studies

Eligibility: An eligible applicant must have achieved a minimum of $80 \%$ in each of the last 2 most recently completed years of full-time university study, or equivalent to fulltime study. Eligibility averages for competitive scholarship are rounded ONLY to the nearest decimal place

Type: Scholarship

Value: CA $\$ 40,000$ annually

Length of Study: 4 years

Frequency: Annual

Country of Study: Any country

Application Procedure: Submit a complete UOIT application with supporting documentation to the Office of Graduate Studies

Closing Date: 1 April

Additional Information: Submit the PDF nomination to SGPS (pmenzies@uwo.ca) any time after January 1st

For further information contact:

Email: pmenzies@uwo.ca

\section{University of Oregon}

1585E, 13th Ave, Eugene, OR 97403, United States of America

Tel: (1) 5413461000

Fax: (1) 5413461000

Website: www.uoregon.edu

\section{Center for AIDS Prevention Studies, Small Professional Grants for Graduate Students}

Purpose: Awards will be made for the following purposes: travel to conferences to present papers, travel to library, museum, and archival collections; and expenses related to book and article production and publication

Eligibility: The Center for Asian and Pacific Studies is offering awards of up to US\$500 in support of the professional activities of UO graduate students studying Asia. Awards will be made for the following purposes: travel to conferences to present papers, travel to library, museum, and archival 
collections; and expenses related to book and article production and publication

Level of Study: Postgraduate

Type: Grant

Frequency: Annual

Country of Study: Any country

Application Procedure: 1. To submit a proposal, please click here to complete the online application form. 2. A brief letter of support from your advisor explaining how this activity is central to your research interests is also required. This letter can be emailed directly to Holly Lakey at lakey@uoregon.edu Closing Date: 5 April

Funding: Private

\section{For further information contact:}

1246 University of Oregon, Eugene, OR 97403, United States of America

Tel: (1) 5413465068

Email:1lakey@uoregon.edu

\section{Jeremiah Lecture Series Support}

Purpose: The Center for Asian and Pacific Studies is accepting proposals from UO faculty for speakers to visit the UO and deliver a public lecture on campus

Level of Study: Postgraduate

Type: Award

Frequency: Annual

Country of Study: Any country

Application Procedure: For a hardcopy version of the application form, please contact Holly Lakey at lakey@uoregon. edu. To submit a proposal, please click here to complete the online application form. oregon.qualtrics.com $/ \mathrm{jfe} /$ form $/ \mathrm{SV}$ cu6IXYJ5vItOZ7v. It will provide complete information for the application process

Closing Date: 5 April

Funding: Private

\section{For further information contact:}

Email: Lakey@uoregon.edu

\section{University of Oslo}

Problemveien 7, 0315 Oslo, Norway

Contact: University of Oslo
The University of Oslo, until 1939 named the Royal Frederick University, is the oldest university in Norway, located in the Norwegian capital of Oslo.

\section{PhD Research Fellowship in Ecotoxicology}

\section{Subjects: Ecotoxicology}

Purpose: The purpose of the PhD Fellowship is research training leading to the successful completion of a $\mathrm{PhD}$ degree Eligibility: International students are eligible to apply for the fellowship. Applicants must have a Master's degree or equivalent in toxicology or marine ecology, relevant to this $\mathrm{PhD}$ project. A good command of English is required of all students attending the University of Oslo

Type: Fellowship

Value: NOK 436,900-490,900 per year

Country of Study: Norway

Application Procedure: Please visit www.scholarshipsads. com/norway-university-oslo-phd-fellowship-exotoxicology2018/\#gs.wOqf5y0 for application procedure

Closing Date: 1 February

Additional Information: The project combines knowledge from ecotoxicology, ecology, and environmental chemistry. The successful candidate will design and conduct extensive field studies, analyze contaminants and dietary descriptors, and deal with large datasets

\section{For further information contact:}

Email: nina.holtan@mn.uio.no

\section{PhD Research Fellowships in Energy Informatics}

Subjects: Energy Informatics

Purpose: Fellowships are available to pursue PhD Research programme. The aim of providing the scholarship is to achieve a balanced gender composition in the organisation and to recruit people with ethnic minority backgrounds

Eligibility: For eligibility details, please visit www.scholar shipsads.com/university-oslo-phd-research-fellowships-ener gy-informatics-2018/\#gs.sYt9HtQ

Type: Research fellowship

Value: NOK 436,900-490,900 per year. Attractive welfare benefits and a generous pension agreement, in addition to Oslo's family-friendly environment with its rich opportunities for culture and outdoor activities

Length of Study: 3 years

Country of Study: Norway

Application Procedure: The mode of applying is online

Closing Date: 15 November

Contributor: University of Oslo 


\section{For further information contact:}

Email: yanzhang@ifi.uio.no

\section{Postdoctoral fellowships in Educational Assessment and Measurement}

Subjects: Fellowships are awarded in Educational Assessment and Measurement

Purpose: The main purpose of the fellowships is to qualify researchers for work in higher academic positions within their disciplines

Eligibility: For eligibility, please visit www.scholarship supdates.com/university-of-oslo-four-year-postdoctoral-fello wships-for-international-students-in-norway-2018/

Level of Study: Professional development

Type: Fellowship

Value: Salary NOK 499,600-569,000

Length of Study: 4 years

Frequency: Annual

Country of Study: Norway

Application Procedure: For online application, visit website www.jobbnorge.no/en/available-jobs/job/149727/1-2-fouryear-postdoctoral-fellowships-in-educational-assessment-andmeasurement

Closing Date: 15 May

For further information contact:

Email:rolfvo@cemo.uio.no

\section{Postdoctoral Fellowships in Political Philosophy or Legal Theory}

Subjects: Political philosophy or legal theory, studying international courts and tribunals (ICs)

Purpose: Fellowships are available to pursue postdoctoral programme

Eligibility: For eligibility, please visit www.scholarshipsads. com/postdoctoral-fellowships-political-philosophy-legal-the ory-norway-2018/

Type: Postdoctoral fellowship

Value: NOK 490,900-569,000

Country of Study: Any country

Closing Date: 1 November

\section{For further information contact:}

Email: siri.johnsen@jus.uio.no

\section{University of Otago}

Advanced Business Programme, PO Box 56, Dunedin, New Zealand

$\begin{array}{ll}\text { Tel: } & \text { (64) } 34798046 \\ \text { Fax: } & \text { (64) } 34798045 \\ \text { Email: } & \text { mbainfo@commerce.otago.ac.nz } \\ \text { Website: } & \text { www.otago.ac.nz } \\ \text { Contact: } & \text { MBA Admissions Officer }\end{array}$

\section{Aarhus University PhD Fellowships Program}

Purpose: Aarhus University PhD Fellowships Program, Denmark are fully funded fellowships offered to the students of Denmark to pursue $\mathrm{PhD}$ fellowships and research training supplements, both research and $\mathrm{PhD}$ fellowships are funded by the Faculty of Health Science at Aarhus University, the scholarships are developed with an aim to develop international cooperation in the areas of teaching and research, university is a modern, academically diverse and researchintensive university with a strong commitment to high-quality research and education and the development of society existed around the world

Eligibility: The candidates who are interested to apply for the Aarhus University scholar apply for a 3-year PhD study programme students must have completed a relevant Master's degree, the Master's study has to be equivalent to a Danish Master's degree of 120 ECTS, all applications will be evaluated based on the submitted material using the following criteria, the time for research experience after the qualifying exam is taken into consideration, all applicants must document English language qualifications comparable to an 'English B level' in the Danish upper secondary school, if the candidate has any doubt about the criteria they can submit your diplomas for an assessment via graduateschoolhealth-at-au.dk

Level of Study: Postgraduate

Type: Fellowship

Length of Study: 3 year

Frequency: Annual

Country of Study: New Zealand

Closing Date: February

Funding: Foundation

\section{For further information contact:}

Tel: (44) 87150000

Email: housing@au.dk 


\section{Angus Ross Travel Scholarship in History}

Purpose: Established by the family of Angus Ross in 2010, the Angus Ross Travel Scholarship in History is intended to assist $\mathrm{PhD}$ candidates studying history with the costs associated with off-campus field and archival research

Eligibility: 1. Are conducting historically-focused research. 2 . Will be conducting off-campus field or archival research in the year for which the scholarship is awarded

Level of Study: Postgraduate

Type: Scholarship

Value: NZ \$1,000

Frequency: Annual

Country of Study: New Zealand

Closing Date: 1 November

Funding: Foundation

\section{Brenda Shore Award for Women}

Purpose: Brenda Shore was an enthusiastic, enterprising person famous for her energy and passion. Over the course of 35 years Brenda became a prominent figure in the University of Otago Botany Department, both as a researcher and teacher, until her retirement in 1983. Leading by example Brenda Shore established this fund to help support women who have that same passion and energy for the natural sciences, particularly where their research relates to the Otago, Southland or Antarctic region

Eligibility: 1. University of Otago women graduates. 2. Women graduates carrying out research related to the Otago, Southland and Antarctic area. 3. Women graduates carrying out research for a postgraduate degree at the University of Otago

Level of Study: Postgraduate

Type: Award

Value: Up to NZ $\$ 15,000$

Length of Study: 1 year

Frequency: Annual

Country of Study: New Zealand

Closing Date: 28 February

Funding: Foundation

\section{China Scholarship Council and Griffith University PhD Scholarships}

Purpose: China Scholarship Council and Griffith University $\mathrm{PhD}$ Scholarships are offering scholarships to the students of China who are interested to pursue $\mathrm{PhD}$ degree programme at the Griffith university which is based in the United Kingdom, through this scholarship the students develops the research opportunities with an environment that collaborates the students
Eligibility: The participants should meet all the necessary requirements, polices and the rules that are offered by the China Scholarship Council and Griffith University, this scholarship program is extended to all research programs where, The applicants of the China Scholarship Council and Griffith University $\mathrm{PhD}$ scholarships should meet the academic entry requirements which also include the level of English language Proficiency with good communication skills and the student must be certified or held with a bachelor degree with a first class or second-class honors which come under the Division A or the Master's degree or its equivalent incorporating a significant research component, from a recognised institution or its equivalent, Candidates are selected based on the criteria that was instructed by China Scholarship Council

Level of Study: Postgraduate

Type: Scholarship

Length of Study: 4 year

Frequency: Annual

Country of Study: New Zealand

Closing Date: January

Funding: Foundation

\section{Demand Response in the Agricultural Sector PhD Scholarship}

Purpose: The Centre for Sustainability calls for expressions of interest in a PhD scholarship focusing on "Demand response in the agricultural sector - a socio-technical study". The research will examine farmer interest in electricity demand response, examine the barriers that farmers face in engaging in demand response, and identify solutions to improve adoption of demand response strategies. Candidates with a background in socio-technical studies would be ideal, although those with a background in social or physical sciences will be considered if they have an interest in extending their theoretical and methodological scope. The scholarship is funded by Science for Technological Innovation, a National Science Challenge and the successful candidate will be based at the Centre for Sustainability, University of Otago

Level of Study: Postgraduate

Type: Scholarship

Value: $\$ 27,500$

Length of Study: 3 year

Frequency: Annual

Country of Study: New Zealand

Closing Date: 22 February

Funding: Foundation, International office

\section{For further information contact:}

Email: janet.stephenson@otago.ac.nz 


\section{Diane Campbell-Hunt Memorial Award}

Purpose: Diane Campbell-Hunt was a $\mathrm{PhD}$ candidate in the Department of Geography, funded by a Tertiary Education Commission Top Achiever Doctoral scholarship. She had completed two-thirds of her $\mathrm{PhD}$ programme at the time of her death. Her project looked at the long-term sustainability of fenced sanctuaries in New Zealand in a multi-disciplinary analysis: ecological, economic, social, and governmental

Eligibility: 1. Be enrolled and confirmed in a $\mathrm{PhD}$ programme in any Department or School at the University of Otago. 2. Have had accepted a peer-reviewed academic paper (conference or journal) that contributes to New Zealand conservation (as defined above), and in which they are the lead author. 3. Not have previously been awarded the award

Level of Study: Postgraduate

Type: Award

Value: NZ $\$ 1,000$

Frequency: Annual

Country of Study: New Zealand

Closing Date: 30 June

Funding: Foundation

\section{Douglass D Crombie Award in Physics}

Purpose: Established by the University of Otago Council in memory of Mr Douglass D Crombie. This award has been made possible by a generous bequest from the late $\mathrm{Mr}$ Crombie for the purpose of encouraging postgraduate research in Physics. This award will be offered to an outstanding University of Otago Physics graduate intending to undertake a $\mathrm{PhD}$ in Physics at an overseas university

Eligibility: 1. Were born in New Zealand. 2. Graduated or will soon graduate from the University of Otago with a degree in Physics. 3. Are intending to pursue doctoral-level studies in Physics. 4. Are intending to undertake their studies at an English speaking University in an English speaking country (excluding New Zealand). 5. Have displayed outstanding academic ability

Level of Study: Postgraduate

Type: Award

Value: NZ \$7,000

Frequency: Annual

Country of Study: New Zealand

Closing Date: Apply anytime

Funding: Foundation

\section{For further information contact:}

Scholarships Office, Graduate Research School, PO Box 56, Dunedin 9054, New Zealand

Email: scholarships@otago.ac.nz

\section{Dr Sulaiman Daud 125th Jubilee Postgraduate Scholarship}

Purpose: This scholarship was established in 1994 to mark the 125th Anniversary of the foundation of the University of Otago, New Zealand's oldest university. The purpose of the scholarship is to assist an exceptional postgraduate research student from Malaysia to attend the University

Eligibility: 1. Unless otherwise stated in these conditions or within the schedule, doctoral and Masters' scholarships are open only to Domestic Fee Paying Students. International candidates studying for professional doctorates are eligible to apply but if awarded a scholarship the tuition fee waiver will be capped at the domestic rate. 2 . In the case of applicants for a doctoral scholarship, confirmation of the scholarship is dependent on approval of their application for admission to the relevant doctoral programme and completion of the enrolment procedure. 3. In the case of applicants for a Master's scholarship, confirmation of the scholarship is dependent on approval of their application to register as a Master's candidate and completion of the enrolment procedure

Level of Study: Postgraduate

Type: Scholarship

Value: NZ\$27,000

Length of Study: 1 year

Frequency: Annual

Country of Study: New Zealand

Closing Date: Applicants can apply at any time

Funding: Foundation

\section{For further information contact:}

P.O. Box 514070, Milwaukee, WI 53203-3470, United States of America

Email: scholarships@otago.ac.nz

\section{Elizabeth Jean Trotter Postgraduate Research Travelling Scholarship in Biomedical Sciences}

Subjects: The Elizabeth Jean Trotter Postgraduate Research Travelling Scholarship in Biomedical Sciences was established to support travel to a conference, workshop, or laboratory for postgraduate students undertaking research in Biomedical Sciences

Purpose: Established by the University of Otago Council from a generous donation in memory of Elizabeth Jean Trotter Eligibility: 1 . Be enrolled for a $\mathrm{PhD}$ or in the research year of a Master's programme with primary supervision in the Otago School of Medical Sciences (OSMS). 2. Be undertaking research in a Biomedical Sciences field

Level of Study: Postgraduate 
Type: Fellowships

Value: Up to NZ $\$ 5,000$

Length of Study: 1 year

Frequency: Annual

Country of Study: New Zealand

Application Procedure: Every application for the scholarship must be submitted to the University of Otago Scholarships Office by the closing date. Every applicant must submit: 1. A completed application form detailing the purpose of, and benefits expected to result from, the proposed travel. 2. A letter of support from the candidate's primary supervisor, addressing the candidate's work to date and the value of the chosen conference, workshop, or laboratory visit, to the candidate. 3. A brief Curriculum Vitae. 4. Title of proposed oral presentation or poster at the chosen conference (if applicable)

Closing Date: 1 November

Funding: Foundation

\section{Elman Poole Travelling Scholarship}

Purpose: Dr Elman Poole and the University of Otago are pleased to be able to offer this award to promote, encourage and facilitate research by providing grants to $\mathrm{PhD}$ students of the University of Otago to study overseas during their $\mathrm{PhD}$, for a period normally not less than three months and not more than six months to gain experience or to use facilities not normally available at Otago and to further their subsequent work or career at Otago

Eligibility: 1. Enrolled full-time for a Doctor of Philosophy (PhD) at the University of Otago. 2. Majoring in one of following areas: Physical or Biological Sciences, Health Sciences or music. 3. Intending to engage in study in the second or third year of his/her PhD outside of New Zealand. 4. New Zealand citizen or New Zealand permanent resident. 5 . under 35 years of age on the first day of February in the year of application

Level of Study: Postgraduate

Type: Scholarship

Value: NZ \$20,000

Length of Study: 2 year

Frequency: Annual

Country of Study: New Zealand

Closing Date: 1 June

Funding: Foundation

\section{For further information contact:}

St David II Building, University of Otago, PO Box 56, Dunedin 9054, New Zealand

\section{Freemasons Scholarships}

Purpose: The Freemasons Scholarships are provided annually by Freemasons New Zealand and are administered by the Freemasons Charity

Eligibility: 1. Have a good academic report. 2. Be a New Zealand citizen or permanent resident. 3. Demonstrate good citizenship. 4. Show leadership potential. 5. Have proven community commitment

Level of Study: Postgraduate

Type: Scholarship

Value: NZ\$10,000

Frequency: Annual

Country of Study: New Zealand

Closing Date: 1 October

Funding: Foundation

\section{For further information contact:}

Email: info@lincoln.ac.nz

\section{Fully Funded PhD Scholarships}

Purpose: Fully Funded PhD Scholarships, University of Sheffield, United Kingdom are offered to the international students who attract the administration panel with their academic performance to pursue $\mathrm{PhD}$ programme, the University of Sheffield is a public research university in Sheffield, South Yorkshire, United Kingdom, by merging the Sheffield Medical School and Sheffield Technical School, the candidates should have the knowledge in the English language and the candidate from the non-English countries should have meet the abilities of the university by attaining the IELTS and other related tests, annually the university offers five scholarships

Eligibility: In order to apply for the Fully Funded $\mathrm{PhD}$ scholarships at the university of Sheffield the candidates should meet the requirements, the applicant should be a citizen of United Kingdom and the applicants should be the holder or about to obtain the upper second class degree from the United Kingdom university or equivalent to the qualification of the degree from an recognised European Union or overseas institutions in masters or relevant degree as per the English Language requirements for the entry of the college the students must have show the evidence such as IELTS, TOEFL that the candidate have met the abilities to of English language skills and communication internationally as requirement of the University of the Sheffield

Level of Study: Postgraduate

Type: Scholarship

Frequency: Annual

Country of Study: New Zealand 
Closing Date: January

Funding: Foundation

\section{Future Global Leaders Fellowship Program}

Purpose: Future Global Leaders Fellowship Program is an international program designed for Freshmen students who are interested to pursue research and fellowship training, where the fellowship program is an internationally competitive program which is intended for granting first generation and low-income students entry into the Fortis Society, which is the world's first private network for diverse leaders, The main objective of the program is to gather students from world's top most universities which includes-Harvard University, the University of Oxford, Sciences Po, and Peking University

Eligibility: Applicants must be first-year university students and must fit the following eligibility criteria: 1. FirstGeneration or Low-Income University Student - students who do not have a family history of higher education, or who come from a low-income background. 2. Track Record of Academic Excellence - throughout high school and during the first months of the current school year. 3. Proven Leadership Abilities - through self-started initiatives and ventures, or leadership in their schools or communities

Level of Study: Postgraduate

Type: Fellowship

Frequency: Annual

Country of Study: New Zealand

Closing Date: 31 January

Funding: Foundation

\section{Gilbert M Tothill Scholarship in Psychological Medicine}

Purpose: Doctoral scholarships are awarded by the University Council, on the recommendation of the Senate, to candidates proceeding to a course of supervised doctoral study at this University. These scholarships are normally available only to students seeking to obtain their first doctoral qualification

Eligibility: In the case of an applicant for a doctoral scholarship who has completed a Master's degree by papers and thesis (at least 0.75 EFTS), the grades of all relevant2 advanced level papers counting towards the award of the degree and the thesis will be taken into account. An explanation of the time taken for completion of the thesis may be requested and considered by the Scholarships and Prizes Committee if the thesis has taken more than 2 EFTS (2 fulltime years) to complete

Level of Study: Postgraduate
Type: Scholarship

Value: NZ \$10,000

Length of Study: 3 year

Frequency: Annual

Country of Study: New Zealand

Closing Date: Applicants can apply anytime

Funding: Foundation

\section{For further information contact:}

Email: scholarships@otago.ac.nz

\section{Helen Rosa Thacker Scholarship in Neurological Research}

Purpose: The Helen Rosa Thacker Scholarship in Neurological Research was established by Helen Rosa Thacker in 2012 to support research and teaching in the field of neurology at the University of Otago. The scholarship aims to recognise, reward and inspire a particularly good $\mathrm{PhD}$ student. This scholarship can be held alongside an existing scholarship. This scholarship will be awarded for one year, with a chance of extension to a second year due to outstanding progress Eligibility: 1. A full time $\mathrm{PhD}$ student in neurological research at the University of Otago. 2. A male scholar holding a New Zealand birth certificate. 3. Available to receive the scholarship in person and provide updates on the progress of their research

Level of Study: Postgraduate

Type: Scholarship

Value: NZ \$5,000

Length of Study: 1 year

Frequency: Annual

Country of Study: New Zealand

Closing Date: 26 October

Funding: Foundation

\section{For further information contact:}

Jane Reynolds, Administrative Assistant, Brain Health Research Centre, C/- Department of Anatomy, PO Box 56, Dunedin 9054, New Zealand

Email: bhrc@otago.ac.nz

\section{James Park Scholarship in Geology}

Purpose: Masters' scholarships are awarded by the University Council, on the recommendation of the Senate, to candidates in the first year of their thesis research for a Master's degree which constitutes entry to the $\mathrm{PhD}$ course at this University. These scholarships are available only to students 
seeking to obtain their first research-based Master's qualification

Eligibility: 1. Unless otherwise stated in these conditions or within the schedule, doctoral and Masters' scholarships are open only to Domestic Fee Paying Students. International candidates studying for professional doctorates are eligible to apply but if awarded a scholarship the tuition fee waiver will be capped at the domestic rate. 2 . In the case of applicants for a doctoral scholarship, confirmation of the scholarship is dependent on approval of their application for admission to the relevant doctoral programme and completion of the enrolment procedure. 3. In the case of applicants for a Master's scholarship, confirmation of the scholarship is dependent on approval of their application to register as a Master's candidate and completion of the enrolment procedure

Level of Study: Postgraduate

Type: Scholarship

Value: NZ \$27,000

Frequency: Annual

Country of Study: New Zealand

Closing Date: Applicants can apply anytime

Funding: Foundation

\section{For further information contact:}

Email: scholarships@otago.ac.nz

\section{Macandrew-Stout Postgraduate Scholarship in Economics}

Purpose: Established from funds made available by public subscription in memory of the late James Macandrew, member of the Council and one of the founders of the University and in 1920 by Sir Robert Stout, KCMG, Chief Justice of New Zealand

Eligibility: 1. Unless otherwise stated in these conditions or within the schedule, doctoral and Masters' scholarships are open only to Domestic Fee Paying Students. International candidates studying for professional doctorates are eligible to apply but if awarded a scholarship the tuition fee waiver will be capped at the domestic rate. 2 . In the case of applicants for a doctoral scholarship, confirmation of the scholarship is dependent on approval of their application for admission to the relevant doctoral programme and completion of the enrolment procedure. 3. In the case of applicants for a Master's scholarship, confirmation of the scholarship is dependent on approval of their application to register as a Master's candidate and completion of the enrolment procedure

Level of Study: Postgraduate

Type: Scholarship
Value: NZ \$27,000

Frequency: Annual

Country of Study: New Zealand

Closing Date: Applicants can apply anytime

Funding: Foundation

\section{For further information contact:}

Email: scholarships@otago.ac.nz

\section{Neuropsychology Scholarships}

Subjects: Neuropsychology

Purpose: To investigate how visual information is used by humans in the learning of new skills

Eligibility: Open to applicants with an undergraduate qualification and a background or interest in cognitive science or neuropsychology. The project would suit a self-motivated person who is able to work well with participants and patients and other members on the study team. A working knowledge of the software package MATLAB and experience in programming with its language, is highly desirable

Level of Study: Postgraduate

Type: Scholarship

Value: NZ \$12,000 per year for 2 years maximum, plus a maximum of NZ $\$ 4,000$ per year towards tuition fees

Application Procedure: Applicants must enquire in the first instance to the director of the Cognitive Science programme Contributor: Marsden Fund of the Royal Society of New Zealand

\section{For further information contact:}

Tel:

(64) 34795269

Fax: (64) 34798335

Email:1franz@psy.otago.ac.nz

Contact: Dr Elizabeth Franz

\section{Nga Pae O Te Maramatanga Doctoral Scholarships}

Purpose: Fostering Te Pa Harakeke - understanding, achieving and maintaining 'healthy and prosperous families of mana' and the lessons this may hold for New Zealand families overall. Understanding what ' $\mathrm{Te} \mathrm{Pa}$ Harakeke' is, enabling it to be achieved and addressing the barriers

Eligibility: For Maori or indigenous students who are currently enrolled or in the process of enrolling in a recognised doctoral programme of study and research at a tertiary institution. Applicants must not work more than 10 hours per week in paid employment while in receipt of this scholarship Level of Study: Postgraduate

Type: Scholarship 
Value: $\$ 25,000$

Length of Study: 3 year

Frequency: Annual

Country of Study: New Zealand

Closing Date: 30 September

Funding: Foundation

\section{Noni Wright Scholarship}

Purpose: Established by the University Council in association with the Guardian Trust in 2011 to provide support for Theatre Studies students to pursue postgraduate study. The scholarship was made possible by a generous endowment from the late Mrs Eleanor Wright, to honour the memory of her daughter Noni Wright, who was well known in drama circles, and had appeared on programmes for the BBC

Eligibility: The scholarship is open to both domestic and international students. Applicants must be currently enrolled or intending to enrol for full-time study at the University of Otago in the year following the closing date, for the degree of MA or MFA in Theatre Studies, or for a PhD researching a topic in Theatre Studies

Level of Study: Postgraduate

Type: Scholarship

Value: NZ \$5,000

Length of Study: 1 year

Frequency: Annual

Country of Study: New Zealand

Closing Date: 1 November

Funding: Foundation

\section{For further information contact:}

Email: scholarships@otago.ac.nz

\section{Patricia Pratt Scholarships in Musical Performance}

Purpose: The purpose of the scholarship is to assist outstanding New Zealand musical performers who have completed an honours degree in musical performance in New Zealand to continue their musical development at a renowned international music school or conservatorium. The scholarship will be awarded for classical music performance including vocal or instrumental performance or conducting

Eligibility: 1. Be New Zealand citizens with preference given to students who have resided in New Zealand for at least three years immediately preceding the year of selection. 2 . Hold an honours degree in music performance from a New Zealand University

Level of Study: Postgraduate

Type: Scholarship
Value: Up to US $\$ 45,000$

Frequency: Annual

Country of Study: New Zealand

Closing Date: 1 March

Funding: Foundation

\section{Postgraduate Tassell Scholarship in Cancer Research}

Purpose: Doctoral scholarships are awarded by the University Council, on the recommendation of the Senate, to candidates proceeding to a course of supervised doctoral study at this University. These scholarships are normally available only to students seeking to obtain their first doctoral qualification

Eligibility: 1. Unless otherwise stated in these conditions or within the schedule, doctoral and Masters' scholarships are open only to Domestic Fee Paying Students. International candidates studying for professional doctorates are eligible to apply but if awarded a scholarship the tuition fee waiver will be capped at the domestic rate. 2 . In the case of applicants for a doctoral scholarship, confirmation of the scholarship is dependent on approval of their application for admission to the relevant doctoral programme and completion of the enrolment procedure. 3. In the case of applicants for a Master's scholarship, confirmation of the scholarship is dependent on approval of their application to register as a Master's candidate and completion of the enrolment procedure

Level of Study: Postgraduate

Type: Scholarship

Value: NZ \$27,000

Frequency: Annual

Country of Study: New Zealand

Closing Date: Applicants can apply anytime

Funding: Foundation

For further information contact:

Email: scholarships@otago.ac.nz

\section{Ramboll Masters Scholarship for International Students}

Purpose: Ramboll Masters Scholarship for International Students provides scholarships to the students all over the world who are pursuing masters degree and diploma in engineering in all related fields of Engineering, Natural Science, Political Science, Economics or Architecture, the candidates are selected based on the academic merit considering their projects and profile, the Ramboll offers opportunities to the 
students by providing inspirational and longstanding solutions that strengthen the ideas of candidate and enhance the nature and future

Eligibility: To be eligible to be granted a Ramboll Scholarship the applicant should meet necessary criteria such as the candidate is currently studying Engineering, Natural Science, Political Science, Economics or Architecture subjects as one of their course studies, and are going to study abroad outside of Denmark, to be eligible to apply the applicant should be a Diploma Engineer on semester $4-7$ or studying on a Master's level, and must agree to send Ramboll two travel updates during their stay abroad

Level of Study: Postgraduate

Type: Scholarship

Value: NZ\$25,000

Frequency: Annual

Country of Study: New Zealand

Closing Date: 8 May

Funding: Foundation

\section{Senior Smeaton Scholarship in Experimental Science}

Purpose: Masters' scholarships are awarded by the University Council, on the recommendation of the Senate, tocandidates in the first year of their thesis research for a Master's degree which constitutes entry to the $\mathrm{PhD}$ course at this University. These scholarships are available only to students seeking to obtain their first research-based Master's qualification

Eligibility: 1. Unless otherwise stated in these conditions or within the schedule, doctoral and Masters' scholarships are open only to Domestic Fee Paying Students. 3 International candidates studying for professional doctorates are eligible to apply but if awarded a scholarship the tuition fee waiver will be capped at the domestic rate. 2. In the case of applicants for a doctoral scholarship, confirmation of the scholarship is dependent on approval of their application for admission to the relevant doctoral programme and completion of the enrolment procedure. 3 . In the case of applicants for a Master's scholarship, confirmation of the scholarship is dependent on approval of their application to register as a Master's candidate and completion of the enrolment procedure

Level of Study: Postgraduate

Type: Scholarship

Value: NZ \$27,000

Frequency: Annual

Country of Study: New Zealand

Closing Date: Applicants can apply anytime

Funding: Foundation

\section{For further information contact:}

Email: scholarships@otago.ac.nz

\section{The Dr Stella Cullington Postgraduate Scholarship in Ophthalmology}

Purpose: Established in 2014 by the Faculty of Medicine, from a generous donation from Dr Stella Cullington. Dr Cullington is a medical graduate and practised as a GP in United Kingdom and New Zealand. The Dr Stella Cullington Postgraduate Scholarship in Ophthalmology was created to support the sustainability and development of Ophthalmology Research within the academic discipline

Eligibility: 1. Be a NZ citizen or NZ permanent resident. 2. Hold a Bachelor of Medicine and Bachelor of Surgery degrees $(\mathrm{MBChB})$ or an equivalent medical degree. 3. Demonstrate proof of potential academic research ability through (i) successful completion of a research Master's degree, or (ii) appropriate and equivalent prior research experience. 4. Be enrolled or intending to enrol for a MOphth or PhD at the University of Otago

Level of Study: Postgraduate

Type: Scholarship

Value: up to $\$ 5,000$

Length of Study: 1 year

Frequency: Annual

Country of Study: New Zealand

Closing Date: Applicants can apply anytime

Funding: Foundation

\section{The Eamon Cleary Trust Postgraduate Study Scholarship}

Purpose: Established in 2016 by the University of Otago Council from a generous donation by the Eamon Cleary Trust. The Eamon Cleary Trust Postgraduate Study Scholarship was created to support University of Otago students undertaking postgraduate research in Irish Studies. The scholarship may be used for expenses associated with postgraduate study, such as tuition fees, research expenses or travel associated with their research programme

Eligibility: 1 . Be intending to enrol in a Doctoral or Research Masters programme in Irish Studies or a Coursework Masters programme in Irish Studies with a research component greater than or equal to 60 points at the University of Otago for the year of the award. 2. Have made contact to discuss satisfactory supervisory arrangements with the Eamon Cleary Professor of Irish Studies prior to submission of the application

Level of Study: Postgraduate 
Type: Scholarship

Value: Between NZ \$15,000 to $\$ 25,000$

Frequency: Annual

Country of Study: New Zealand

Closing Date: 1 November

Funding: Foundation

\section{The Joan, Arthur \& Helen Thacker Aboriginal and/or Torres Strait Islander Postgraduate Scholarship}

Purpose: Established by the University of Otago Council in 2014, through the provision of funding from Helen $\mathrm{R}$ Thacker, this scholarship aims to support students of Aboriginal and/or Torres Strait Islander descent to undertake postgraduate studies in the field of Health Sciences at the University of Otago. The purpose of the fund is to support research and training in health sciences subjects that may have a future benefit to Aboriginal and/or Torres Strait Islander communities

Eligibility: 1. Aboriginal and/or Torres Strait Islander descent 2. Australian citizens and residing in Australia at the time of application. 3. Planning to enrol in a postgraduate course of study in either Dental Technology, Dentistry, Oral Health, Medicine, Neuroscience, Pharmacy or Radiation Therapy at the University of Otago. 4. Planning to undertake study/ research that is likely to be of future benefit to their Aboriginal and/or Torres Strait Islander community. 5. Intending to return to work in Australia after their course of study

Level of Study: Postgraduate

Type: Scholarship

Value: NZ \$30,000

Frequency: Annual

Country of Study: New Zealand

Closing Date: 1 October

Funding: Foundation

\section{The Robinson Dorsey Postgraduate Scholarship}

Purpose: The Robinson Dorsey Postgraduate Scholarship was created to support postgraduate students who are returning to university study after a break, and/or who through their personal circumstances, are not eligible for usual scholarships

Eligibility: 1. A NZ citizen or NZ permanent resident. 2. Enrolled or intending to enrol in a postgraduate diploma, honours degree, Master of Science or $\mathrm{PhD}$ degree in Physiology or Human Nutrition at the University of Otago. 3. Returning to university study after a break, and/or who through their personal circumstances are not eligible for usual scholarships

Level of Study: Postgraduate
Type: Scholarship

Value: NZ \$25,000 full time PhD study or NZ \$13,000 full time Masters', Postgraduate Diploma or Honours Study

Frequency: Annual

Country of Study: New Zealand

Closing Date: 28 February

Funding: Foundation

\section{For further information contact:}

Post to Student Administration (Scholarships), St David II Building, University of Otago, PO Box 56, Dunedin 9054, New Zealand

Email: scholarships@otago.ac.nz

\section{University of Helsinki Masters Scholarships}

Purpose: University of Helsinki Masters Scholarships are offered to the students of international arena who are interested to pursue masters degree from the university, the scholarships offered are fully funded which includes full tuition fees, eligible candidates are selected by the committee not only based on academic criteria the committee will also consider the variety and diversity of the applicants and grant the scholarships to those coming from different backgrounds and fields of studies, the main aim hidden under the scholarship program is to create a rich and diverse learning environment at the University of Helsinki, candidates should receive an offer from the university to apply for the scholarship

Eligibility: 1. You are eligible for the Master's programme at the University of Helsinki. 2. The country of your nationality is outside the European Union/EEA and you meet the requirements for obtaining an entry visa and residence permit for Finland. More information at the Studyinfo. 3. You have obtained excellent results in your previous studies and can prove this in your application

Level of Study: Postgraduate

Type: Scholarship

Value: Fully funded grant (Tuition fee $+10,000$ EUR), study grant

Length of Study: 2 years

Frequency: Annual

Country of Study: New Zealand

Application Procedure: The Master's Programme will make the academic assessment of your degree application simultaneously with your scholarship application. At this stage the scholarship criteria is the same as the programme specific selection criteria. Advantages of having this scholarships are free or highly affordable health care services by the Finnish Student Health Service (FSHS) student meal discounts in Unicafe restaurants reductions in public transport 
Closing Date: 11 January

Funding: Private

Additional Information: Tuition fee will range from 13,000 to 18,000 euros. For further information on the scholarship, refer the below link. www.helsinki.fi/en/admissions/ scholarship-programme

\section{University of Otago Academic General Practitioner Registrar PhD Scholarship}

Purpose: Established in 2013 by the Faculty of Medicine, the University of Otago Academic General Practitioner Registrar PhD Scholarship was created to support the sustainability and development of the Primary Health Care and General Practice academic discipline. The scholarship aims to help establish research capability among a new generation of General Practitioners by supporting the achievement of a Doctoral degree $(\mathrm{PhD})$ at the University of Otago as well as vocational registration as a Fellow of the Royal New Zealand College of General Practitioners (RNZCGP)

Eligibility: 1. A NZ citizen or NZ permanent resident. 2. Hold a Bachelor of Medicine and Bachelor of Surgery degrees $(\mathrm{MBChB})$ or an equivalent medical degree. 3. Demonstrate a formal commitment to a General Practice career by having successfully completed either (i) the General Practice Education Programme first year (GPEP1) with an above average pass in the Primary Membership Examination (PRIMEX) or (ii) a RNZCGP Fellowship. 4. Have successfully completed either the 'Health Sciences Research Methods' paper (HASX417) or the 'Research Methods in General Practice' paper (GENX821), or an alternative 30 point postgraduate research methods paper with a minimum $\mathrm{B}+$ grade. 5. Demonstrate proof of potential academic research ability through (i) successful completion of a research Master's degree, or (ii) appropriate and equivalent prior research experience

Level of Study: Postgraduate

Type: Scholarship

Value: NZ \$25,000 per year for full-time study or NZ $\$ 12,500$ per year for part-time study plus a tuition fee waiver for the $\mathrm{PhD}$ thesis paper for the period of tenure

Frequency: Annual

Country of Study: New Zealand

Closing Date: 15 September

Funding: Foundation

\section{University of Otago China Scholarship Council Doctoral Scholarship}

Purpose: Masters' scholarships are awarded by the University Council, on the recommendation of the Senate, to candidates in the first year of their thesis research for a Master's degree which constitutes entry to the $\mathrm{PhD}$ course at this University. These scholarships are available only to students seeking to obtain their first research-based Master's qualification

Eligibility: 1. Unless otherwise stated in these conditions or within the schedule, doctoral and Masters' scholarships are open only to Domestic Fee Paying Students. International candidates studying for professional doctorates are eligible to apply but if awarded a scholarship the tuition fee waiver will be capped at the domestic rate. 2 . In the case of applicants for a doctoral scholarship, confirmation of the scholarship is dependent on approval of their application for admission to the relevant doctoral programme and completion of the enrolment procedure. 3. In the case of applicants for a Master's scholarship, confirmation of the scholarship is dependent on approval of their application to register as a Master's candidate and completion of the enrolment procedure

Level of Study: Postgraduate

Type: Scholarship

Frequency: Annual

Country of Study: New Zealand

Closing Date: Applicants can apply anytime

Funding: Foundation

\section{For further information contact:}

Email: scholarships@otago.ac.nz

\section{University of Otago City of Literature PhD Scholarship}

Purpose: Masters' scholarships are awarded by the University Council, on the recommendation of the Senate, to candidates in the first year of their thesis research for a Master's degree which constitutes entry to the $\mathrm{PhD}$ course at this University. These scholarships are available only to students seeking to obtain their first research-based Master's qualification

Eligibility: 1. Unless otherwise stated in these conditions or within the schedule, doctoral and Masters' scholarships are open only to Domestic Fee Paying Students.3 International candidates studying for professional doctorates are eligible to apply but if awarded a scholarship the tuition fee waiver will be capped at the domestic rate. 2 . In the case of applicants for a doctoral scholarship, confirmation of the scholarship is dependent on approval of their application for admission to the relevant doctoral programme and completion of the enrolment procedure. 3. In the case of applicants for a Master's scholarship, confirmation of the scholarship is dependent on approval of their application to register as a Master's candidate and completion of the enrolment procedure

Level of Study: Postgraduate

Type: Scholarship 
Value: NZ \$27,000

Frequency: Annual

Country of Study: New Zealand

Closing Date: 30 September

Funding: Foundation

For further information contact:

Email: scholarships@otago.ac.nz

\section{University of Otago Doctoral Scholarships}

Subjects: All subjects

Purpose: To fund research towards a $\mathrm{PhD}$ degree at the University of Otago

Eligibility: Open to applicants of any country but must be primarily resident in New Zealand during study

Level of Study: Doctorate, Research

Type: Scholarship

Value: NZ \$25,000 plus fees (excluding insurance and student services fees)

Length of Study: 3 years

Frequency: Annual

Study Establishment: The University of Otago

Country of Study: New Zealand

Application Procedure: Please visit www.otago.ac.nz/ applynow for further details

Closing Date: Applicant can apply anytime

No. of awards given last year: 180

For further information contact:

Email: scholarships@otago.ac.nz

\section{University of Otago Doctorate in Medical Education Scholarship}

Purpose: Established with funding from the Otago Medical School, this scholarship is intended to provide support for clinically qualified health care professionals with an interest in medical education to undertake research at $\mathrm{PhD}$ level. The research must be applicable to the enhancement of the Otago MB ChB programme. The scholarship will be awarded for a three-year period; parttime PhDs will be considered. The participants will perform medical educational research in their own educational setting at University of Otago campuses in Dunedin, Christchurch or Wellington, but associated sites e.g. Invercargill, Nelson, Palmerston North, Hawkes Bay will be considered provided satisfactory supervisory arrangements can be made
Eligibility: 1 . Normally be a NZ citizen or NZ permanent resident. 2. Hold a clinical health care discipline degree. Non-clinically qualified people with a strong background in Education may be considered but priority will be given to applicants from the first category. 3. Provide confirmation that this is their first doctoral qualification. 4. Be enrolled or intending to enrol for a $\mathrm{PhD}$

Level of Study: Postgraduate

Type: Scholarship

Value: NZ $\$ 25,000$ stipend per annum plus a domestic tuition fees waiver

Frequency: Annual

Country of Study: New Zealand

Closing Date: 20 February

Funding: Foundation

\section{University of Otago International Master's Scholarship}

Purpose: To assist international students in their master's thesis year of studies at the University of Otago

Eligibility: Open to all international applicants intending to study at the University of Otago who would normally be charged international fees

Level of Study: Postdoctorate, Research

Type: Scholarship

Value: NZ $\$ 13,000$, International tuition fees (excluding insurance and student services fees

Frequency: Annual

Country of Study: Any country

Closing Date: Applications can be applied anytime

Funding: Private

\section{For further information contact:}

Doctoral and Scholarships Office, PO Box 56, Dunedin, New Zealand

Email: university@otago.ac.uk

\section{University of Otago Maori Doctoral Scholarship}

Purpose: Doctoral scholarships are awarded by the University Council, on the recommendation of the Senate, tocandidates proceeding to a course of supervised doctoral study at this University. These scholarships are normally available only to students seeking to obtain their first doctoral qualification

Eligibility: 1. Unless otherwise stated in these conditions or within the schedule, doctoral and Masters' scholarships are open only to Domestic Fee Paying Students.3 International 
candidates studying for professional doctorates are eligible to apply but if awarded a scholarship the tuition fee waiver will be capped at the domestic rate. 2 . In the case of applicants for a doctoral scholarship, confirmation of the scholarship is dependent on approval of their application for admission to the relevant doctoral programme and completion of the enrolment procedure

Level of Study: Postgraduate

Type: Scholarship

Value: NZ \$27,000

Frequency: Annual

Country of Study: New Zealand

Closing Date: Applicants can apply anytime

Funding: Foundation

\section{For further information contact:}

Email: scholarships@otago.ac.nz

\section{University of Otago Postgraduate Scholarship in Obstetrics and Gynaecology}

Purpose: The Scholarship is intended to provide support for Obstetrics and Gynaecology trainees to carry out research in Obstetrics, Gynaecology and Women's Health whilst enrolled at the University of Otago for a graduate research degree, such as a Master of Medical Science (MMedSc) or Doctor of Philosophy ( $\mathrm{PhD})$. It is desirable, but not compulsory, that the research be carried out at the University of Otago

Eligibility: 1. Medical graduates (normally Registrars enrolled in the Royal Australian and New Zealand College of Obstetrics and Gynaecology Integrated Training Programme, or Members or Fellows of the College). 2. Enrolled in, or intending to enrol in a research Master's degree or $\mathrm{PhD}$, normally towards a topic in the field of Obstetrics and Gynaecology or Women's Health

Level of Study: Postgraduate

Type: Scholarship

Value: \$25,000

Frequency: Annual

Country of Study: New Zealand

Closing Date: 17 November

Funding: Foundation

\section{Waddell Smith Postgraduate Scholarship}

Purpose: Masters' scholarships are awarded by the University Council, on the recommendation of the Senate, tocandidates in the first year of their thesis research for a Master's degree which constitutes entry to the $\mathrm{PhD}$ course at this University. These scholarships are available only to students seeking to obtain their first research-based Master's qualification

Eligibility: 1. Unless otherwise stated in these conditions or within the schedule, doctoral and Masters' scholarships are open only to Domestic Fee Paying Students. International candidates studying for professional doctorates are eligible to apply but if awarded a scholarship the tuition fee waiver will be capped at the domestic rate. 2 . In the case of applicants for a doctoral scholarship, confirmation of the scholarship is dependent on approval of their application for admission to the relevant doctoral programme and completion of the enrolment procedure. 3. In the case of applicants for a Master's scholarship, confirmation of the scholarship is dependent on approval of their application to register as a Master's candidate and completion of the enrolment procedure

Level of Study: Postgraduate

Type: Scholarship

Value: NZ \$2,000

Frequency: Annual

Country of Study: New Zealand

Closing Date: Applicants can apply anytime

Funding: Foundation

\section{For further information contact:}

Educational Credential Evaluators, Inc., P.O. Box 514070, Milwaukee, WI 53212, United States of America

Email: scholarships@otago.ac.nz

\section{Williamson Medical Research PhD Scholarship}

Purpose: The scholarship may be held by $\mathrm{PhD}$ candidates studying towards a $\mathrm{PhD}$ in the field of medical research. Applicants must have previously completed a medical degree and be New Zealand citizens (preference will be given to New Zealand-born applicants). The scholarship shall be awarded by the University of Council on the recommendation of the Faculty of Medicine

Eligibility: 1. Unless otherwise stated in these conditions or within the schedule, doctoral and Masters' scholarships are open only to Domestic Fee Paying Students. 3 International candidates studying for professional doctorates are eligible to apply but if awarded a scholarship the tuition fee waiver will be capped at the domestic rate. 2 . In the case of applicants for a doctoral scholarship, confirmation of the scholarship is dependent on approval of their application for admission to the relevant doctoral programme and completion of the enrolment procedure. 3. In the case of applicants for a Master's scholarship, confirmation of the scholarship is dependent on 
approval of their application to register as a Master's candidate and completion of the enrolment procedure

Level of Study: Postgraduate

Type: Scholarship

Value: NZ \$25,000

Length of Study: 3 year

Frequency: Annual

Country of Study: New Zealand

Closing Date: Applicants can apply anytime

Funding: Foundation

For further information contact:

Email: scholarships@otago.ac.nz

\section{University of Oxford}

University Offices, Wellington Square, Oxford OX1 2JD, United Kingdom

Tel: $\quad$ (44) 1865270000

Fax: (44) 1865270708

Email: $\quad$ karen.walker@admin.ox.ac.uk

Website: www.ox.ac.uk

Contact: Mrs Ben Nicholas, Graduate Funding

Administrator

\section{Alan Turing Doctoral Studentships}

Eligibility: Open to all graduate applicants for a variety of doctoral graduate courses related to data science. Please see website for further details and eligible subjects, including how to apply

Level of Study: Doctorate

Type: Studentship

Value: Studentships include a generous tax-free stipend of $£ 20,500$ per annum, a travel allowance and tuition fees (home/European Union rate) for a period of 3.5 years. A limited number of studentships include fully funded international tuition fees or a partial contribution towards international tuition fees

Length of Study: 3.5 years

Country of Study: Any country

Additional Information: Please visit the website: www. turing.ac.uk/opportunities/studentships/ for more information

\section{For further information contact:}

Email: hr@turing.ac.uk

\section{Archaeology: AHRC}

Purpose: Archaeology

Eligibility: Open to United Kingdom applicants for DPhils in Archaeology and Classical Archaeology. Other European Union nationals are eligible for a fees-only award. All eligible applicants will be automatically considered

Level of Study: Doctorate

Type: Scholarship

Value: University fee, college fee and full living expenses. Fees-only awards for non-United Kingdom, European Union students

Length of Study: Up to 3 years

Country of Study: Any country

Closing Date: 20 January

Additional Information: Please visit the website: www. humanities.ox.ac.uk/prospective students/graduates/ahrc for more information

\section{For further information contact:}

Email: hca-research@ed.ac.uk

\section{Archaeology: Edward Hall Awards}

Purpose: Archaeological Science

Eligibility: Open to all applicants for the MSc/MSt in Archaeological Science. All applicants to course will be automatically considered

Level of Study: Postgraduate

Type: Award

Value: $£ 8,120$

Length of Study: 1 year

Country of Study: Any country

Closing Date: 20 January

Additional Information: Please visit the website: www. arch.ox.ac.uk/graduate-archaeological-science.html for more information

\section{For further information contact:}

Email: webofficer@arch.ox.ac.uk

\section{Area Studies: FirstRand Laurie Dippenaar Scholarship}

Purpose: African Studies

Eligibility: Open to South African graduate applicants for the MSc African Studies

Level of Study: Postgraduate

Type: Scholarship 
Value: University fee, college fee and full living expenses Length of Study: Period of fee liability

Frequency: Annual

Study Establishment: Wadham College

Country of Study: South Africa

Application Procedure: Please see website for further details, including how to apply

Closing Date: 20 January

Additional Information: Please visit the website: www. firstrand.co.za/csi/Pages/laurie-dippenaar-scholarship.aspx for more information

\section{Atmospheric, Oceanic \& Planetary Physics: STFC Studentships}

Eligibility: Open to Home and European Union graduate applicants to the DPhil Atmospheric, Oceanic and Planetary Physics. To be eligible for consideration for these scholarships, applicants must be successful in being offered a place on their course after consideration of applications received by the relevant January deadline for the course

Level of Study: Doctorate

Type: Studentship

Value: Tuition and college fees, and a tax free stipend. Feesonly award for European Union students who have not been resident in the United Kingdom for the previous 3 years

Length of Study: 3 years

Frequency: Annual

Country of Study: Any country

Closing Date: 20 January

Additional Information: Please visit the website: www2.phys ics.ox.ac.uk/study-here/postgraduates/atmospheric-oceanicand-planetary-physics/funding for more information

\section{For further information contact:}

Email: F.Y.Ogrin@exeter.ac.uk

\section{Balliol College: Balliol Economics Scholarship}

Subjects: Economics

Eligibility: Open to all graduate applicants to MPhil or MPhil +DPhil 2+2 in Economics. Students of any nationality applying to read for the MPhil in economics

Type: Scholarship

Value: Up to $£ 6,500$. When offered in conjunction with Clarendon funding this will create a combined award covering university and college fee and full living expenses

Length of Study: Up to 3 years
Application Procedure: Please see website for how to apply and more details

Closing Date: 22 January

\section{For further information contact:}

Email: graduate.admissions@balliol.ox.ac.uk

Contact: Tutor for Graduate Admissions

\section{Balliol College: Brassey Italian Scholarship}

Eligibility: Open to all applicants to postgraduate degrees in Modern Languages where Italian is the principal subject of study. Please see website for more details

Level of Study: Postgraduate, Research

Type: Scholarship

Value: College fee

Length of Study: Duration of fee liability

Application Procedure: Please see website for how to apply and more details

Closing Date: 22 January

\section{For further information contact:}

Email: graduate.admissions@balliol.ox.ac.uk

Contact: Tutor for Graduate Admissions

\section{Balliol College: Eddie Dinshaw Scholarship}

Subjects: Engineering, mathematics, economics, history, law, and the physical and biological sciences. (This includes biochemistry but excludes integrated immunology and the DPhil in psychiatry)

Eligibility: Open to all graduate applicants from India for relevant areas of study

Level of Study: Postgraduate, Research

Type: Scholarship

Value: Full living expenses

Length of Study: Up to 3 years

Frequency: Annual

Application Procedure: Please see website for more details and how to apply

Closing Date: 18 January

Additional Information: Eligible to nationals of India. Please check at www.balliol.ox.ac.uk/graduate-admissions/ scholarships for more information

\section{For further information contact:}

Email: graduate.admissions@balliol.ox.ac.uk

Contact: Tutor for Graduate Admissions 


\section{Balliol College: Foley-Bejar Scholarships}

Eligibility: Open to all graduate applicants who a) were born in or who have one parent born in Mexico, Spain, or the Republic of Ireland, or who have a strong connection with Northern Ireland; and b) are ordinarily resident in Mexico, Spain or the Republic of Ireland. Please see website for more details

Type: Scholarship

Value: Stipend

Length of Study: Period of fee liability up to 4 years

Country of Study: Any country

Application Procedure: Please see website for more details and how to apply

Closing Date: 23 January

Additional Information: Please check at www.balliol.ox.ac. $\mathrm{uk} /$ graduate-admissions/scholarships for more information

\section{For further information contact:}

Email: graduate@balliol.ox.ac.uk

\section{Balliol College: IKOS Half Bursary}

Eligibility: Open to candidates of any nationality who have expressed an intention to pursue an academic, vocational or public-service oriented career following their degrees

Level of Study: Postgraduate, Research

Type: Bursary

Value: Up to $£ 6,000$ per year

Length of Study: Up to 3 years

Application Procedure: Applicants must apply to the University of Oxford for admission by the University's second deadline in January, and must apply for any University scholarship, including the Clarendon, for which they are eligible Additional Information: Please check at www.balliol.ox.ac. $\mathrm{uk} /$ graduate-admissions/scholarships for more information

\section{For further information contact:}

Email: graduate.admissions@balliol.ox.ac.uk

Contact: Tutor for Graduate Admissions

\section{Balliol College: Jason Hu Scholarship}

Eligibility: Open to all graduate applicants from Asia with preference for candidates from Taiwan and China

Level of Study: Postgraduate, Research

Type: Scholarship

Value: $£ 10,000$ per year

Length of Study: Up to 3 years

Frequency: Annual
Application Procedure: Please see website for more details and how to apply

Closing Date: 18 January

Additional Information: It is awarded in conjunction with Clarendon Fund or other award or scholarship. Four scholarships can only be offered to students from Taiwan and China as a whole, one can be offered to candidates from any Asian country

\section{For further information contact:}

Email: graduate.admissions@balliol.ox.ac.uk

Contact: Tutor for Graduate Admissions

\section{Balliol College: McDougall Scholarship}

Subjects: Law

Eligibility: Open to graduate applicants to Law

Level of Study: Graduate, Postgraduate

Type: Scholarship

Value: Combined with Research Council award will cover university fee, college fee and full living expenses

Length of Study: Up to 3 years

Frequency: Annual

Application Procedure: Please see website for how to apply and more details

Closing Date: 22 January

\section{For further information contact:}

Email: graduate.admissions@balliol.ox.ac.uk

Contact: Tutor for Graduate Admissions

\section{Balliol College: Peter Storey Scholarship}

Subjects: History

Eligibility: Open to all applicants to Master's degrees in History. May be awarded as a fully-funded scholarship in partnership with an AHRC award or as a standalone award of $£ 10,000$ per year. Please see website for more details

Level of Study: Postgraduate, Research

Type: Scholarship

Value: A minimum of $£ 10,000$ per year

Length of Study: Period of fee liability

Application Procedure: Please see website for more details and how to apply

Closing Date: 22 January

Additional Information: Scholarship will be awarded to a candidate with AHRC Funding 


\section{For further information contact:}

Email: graduate.admissions@balliol.ox.ac.uk

Contact: Tutor for Graduate Admissions

\section{Balliol College: Snell Scholarship}

Subjects: All subjects

Purpose: The College seeks to elect one Scholar who have gained an offer of admission to read for a higher degree at Balliol College from October after completing a degree at the University of Glasgow

Eligibility: Honours graduates or in their final Honours year, applicants must have a connection with Scotland by birth (either themselves or one parent), domicile (at least three years) or education at a school in Scotland (at least three years) before admission to the University of Glasgow. Graduates of the University of Glasgow. Please see website for more details including how to apply

Type: Scholarship

Value: Up to $£ 10,000$. When offered in conjunction with RCUK funding this will create a combined award covering university and college fee, and full living expenses

Length of Study: Up to 3 years

Country of Study: Any country

Closing Date: 22 January

Additional Information: Please check at www.balliol.ox.ac. $\mathrm{uk} /$ graduate-admissions/scholarships for more information

For further information contact:

Email: outreach@balliol.ox.ac.uk

\section{Blavatnik School of Government: Africa Governance Initiative Scholarship}

Subjects: Public Policy

Eligibility: Open to all Master of Public Policy applicants who are ordinarily resident in Africa. Scholarships are awarded on the basis of outstanding academic ability, commitment to public service, a capacity to lead, an interest in and experience of improving governance in Africa, a commitment to completing their summer project on some aspect of governance in Africa, and a commitment to return to Africa after their time at the School to continue their work on governance there

Level of Study: Postgraduate

Type: Scholarship

Value: University fee, college fee and full living expenses

Length of Study: Period of fee liability

Frequency: Annual

Country of Study: Any country
Application Procedure: To apply, applicants must provide a supporting statement. Please see website for more details Closing Date: 20 January

For further information contact:

Email: inquiries@aigafrica.org

\section{Blavatnik School of Government: African Initiative for Governance Scholarships}

\section{Purpose: Public Policy}

Eligibility: Open to all Master of Public Policy applicants who are ordinarily resident in Nigeria and Ghana (and other West African nations). Scholarships are awarded on the basis of exceptional academic and leadership merit and/or potential. Applicants will usually hold an undergraduate degree from an African university. They should also intend to return to work in public service in Qualifying country for at least three years after completing their studies

Level of Study: Postgraduate

Type: Scholarship

Value: University fee, college fee and full living expenses

Length of Study: Period of fee liability

Frequency: Annual

Country of Study: Any country

Application Procedure: To apply, applicants must provide a supporting statement. Please see website for more details

Closing Date: 20 January

Additional Information: Please visit the website: www. bsg.ox.ac.uk/study/mpp/bsg-funding-options for more information

\section{For further information contact:}

Email: enquiries@bsg.ox.ac.uk

\section{Blavatnik School of Government: Public Service Scholarship}

Purpose: Public Policy

Eligibility: Open to all Master of Public Policy applicants. Scholarships are awarded on the basis of unwavering dedication to public service, shown through an exceptional academic and professional record

Level of Study: Postgraduate

Type: Scholarship

Value: University fee, college fee and full living expenses

Length of Study: Period of fee liability

Frequency: Annual

Country of Study: Any country 
Application Procedure: To apply, applicants must provide a supporting statement. Please see website for more details Closing Date: 20 January

Additional Information: Please visit the website: www.bsg. ox.ac.uk/study/mpp/bsg-funding-options for more information

\section{For further information contact:}

Email: enquiries@bsg.ox.ac.uk

\section{Blavatnik School of Government: The Lemann Fellows Scholarships}

Subjects: Public policy

Eligibility: Open to all Master of Public Policy applicants that are ordinarily resident in Brazil. Scholarships are awarded on the basis of exceptional academic merit and a commitment to social change in Brazil. To apply applicants must provide a supporting statement

Level of Study: Postgraduate

Type: Scholarship

Value: University fee, college fee and full living expenses

Length of Study: Period of fee liability

Country of Study: Any country

Application Procedure: Please see the website for full details, including how to apply

Closing Date: 20 January

Additional Information: Please check at www.bsg.ox.ac.uk/ study/mpp/bsg-funding-options for more information

\section{For further information contact:}

Email: enquiries@bsg.ox.ac.uk

\section{Blavatnik School of Government: The Walter Kwok Scholarships}

Subjects: Public policy

Eligibility: Open to all Master of Public Policy applicants that are ordinarily resident in Hong Kong or China. Scholarships are awarded on the basis of exceptional academic merit and a commitment to change in the HKSAR region. Interviews may be held as part of the selection process

Type: Scholarship

Value: University fee, college fee and full living expenses

Length of Study: Period of fee liability

Country of Study: Any country

Application Procedure: Please see website for more details and how to apply

Closing Date: 20 January
Additional Information: Please check at www.bsg.ox.ac.uk/ study/mpp/bsg-funding-options for more information

For further information contact:

Email: enquiries@bsg.ox.ac.uk

\section{Brasenose College: Senior Fiddian}

Eligibility: Open to graduates who are former members of Monmouth School or Haberdashers Monmouth School for Girls

Level of Study: Graduate, Postgraduate

Type: Grant

Value: $£ 3,000$

Length of Study: Period of fee liability

Study Establishment: Brasenose College

Country of Study: Any country

Application Procedure: Please see website for more details Closing Date: Relevant January deadline for your course Additional Information: For more information, please check at www.bnc.ox.ac.uk/prospective-students/graduateadmissions/fees-funding

\section{For further information contact:}

Brasenose College Radcliffe Square Oxford, OX1 4AJ, United Kingdom

Email: college.office@bnc.ox.ac.uk

\section{Brasenose Hector Pilling Scholarship}

Subjects: Arts or science

Purpose: For graduates of Commonwealth countries Eligibility: Open to graduates of any Commonwealth university, excluding the United Kingdom

Level of Study: Postgraduate

Type: Scholarship

Value: Fees and maintenance to be determined by the administrators of the Clarendon Fund Scholarships

Frequency: Annual

Study Establishment: Brasenose College, University of Oxford Country of Study: United Kingdom

No. of awards offered: 1

Application Procedure: Applicants must write for details Funding: Private

Contributor: In conjunction with the Clarendon Fund Studentship Scheme

No. of awards given last year: 1

No. of applicants last year: 1 
Additional Information: This scholarship is offered in conjunction with the Clarendon Fund Studentship Scheme

\section{For further information contact:}

Email: international.office@admin.ox.ac.uk

Contact: International Office

\section{Brasenose Joint Commonwealth Studentship}

Eligibility: Open to all applicants from Commonwealth countries. Please see website for more details

Level of Study: Graduate, Postgraduate

Value: University fee, college fee, and living expenses (of which $£ 13 \mathrm{~K}$ funded by BNC)

Length of Study: One year

Study Establishment: Brasenose

Country of Study: United Kingdom

Application Procedure: For more information, please check website: www.bnc.ox.ac.uk/prospective-students/graduateadmissions/fees-funding

Closing Date: 22 January

For further information contact:

Email:1lawfac@law.ox.ac.uk

\section{Business School (Saïd): Registrar's University of Oxford Scholarship}

Subjects: EMBA

Purpose: To assist graduate students with fees and a living allowance

Eligibility: Open to all

Level of Study: Postgraduate, MBA

Type: Scholarship

Value: Programme cost

Length of Study: 2 years

For further information contact:

Email: Diana.Hulin@admin.ox.ac.uk

Contact: Diana Hulin

\section{Chevening Scholarships}

Eligibility: Eligibility varies by country

Level of Study: Graduate

Type: Scholarship

Value: University fee, college fee, and full living expenses

Length of Study: 1 year
Country of Study: Any country

Application Procedure: Please see website for more details and how to apply

Additional Information: Please check at www.fco.gov.uk/ en/about-us/what-we-do/scholarships/chevening/how-to-apply/ for more information

For further information contact:

Email: international@lincoln.ac.uk

\section{Christ Church Senior Scholarship}

Subjects: All subjects

Purpose: To enable graduate scholars to undertake training or a definite course of literary, educational, scientific or professional study

Eligibility: Open to candidates who will have been reading for a higher degree at the University of Oxford for at least 1 year, but not more than 2 years, by October 1 st of the year in which the award is sought

Level of Study: Postgraduate

Type: Scholarship

Value: Varies

Length of Study: 2 years, with a possibility of renewal for a further year

Frequency: Annual

Study Establishment: Christ Church, University of Oxford Country of Study: United Kingdom

No. of awards offered: 102

Application Procedure: Applicants must write for details. Applications should be made in February

Closing Date: 1 April

No. of awards given last year: 2

No. of applicants last year: 102

Additional Information: Normally, the scholarship is held in conjunction with an award from a government agency that pays the university fees

\section{Commonwealth Shared Scholarship Scheme (CSSS)}

Subjects: All subjects

Purpose: To support students from developing Commonwealth countries who would not otherwise be able to study in the United Kingdom

Eligibility: Open to new students from developing Commonwealth countries. Candidates should normally be under 35 at the time the award begins. This scholarship is not available to those living or studying in a developed country, employees of government departments or parastatal organisations 
Level of Study: Postgraduate

Value: University and college fees; full grant for living costs; return air travel to the United Kingdom

Length of Study: 1 year

Country of Study: Any country

Application Procedure: Candidates must apply to Oxford by completing the Graduate Application Form by Application Deadline 2. They must complete the CSSS application form and submit this to Student Funding Services by email or post by March 13th

Closing Date: 13 March

\section{Comparative Philology: Joint Christ Church Linguistics Graduate Scholarship}

Subjects: Linguistics, philology, phonetics

Purpose: To assist graduate students with fees and maintenance

Eligibility: Open to all

Level of Study: Postgraduate, Research

Type: Scholarship

Value: College fees and maintenance allowance of $£ 2,000$

Length of Study: Up to 3 years

Closing Date: 16 January

For further information contact:

Email: kate.dobson@ling-phil.ox.ac.uk

\section{Computer Science: Department Studentships}

Subjects: Computer Science

Purpose: To develop practical methods, algorithms, and tools for a use-case driven approach to system-level hardware/ software formal co-verification. A key objective, and the foundation for the methodology, will be the invention of a systematic abstraction framework that closes the gap, currently unaddressed, between a system and implementation levels in co-verification

Eligibility: Open to all applicants applying for a DPhil in Computer Science

Level of Study: Doctorate

Type: Studentship

Value: Course fee, college fee and stipend

Length of Study: 3 years

Country of Study: Any country

Closing Date: 10 March

Additional Information: Please visit the website: www.cs. ox.ac.uk/aboutus/vacancies/studentship.html for more information
For further information contact:

Email: enquiries@cs.ox.ac.uk

\section{Computer Science: Engineering and Physical Sciences Research Council (EPSRC) Doctoral Training Partnership Studentships}

\section{Purpose: Computer Science}

Eligibility: Open to applicants applying for a DPhil in Computer Science. Home students and European Union students who have studied in the United Kingdom for the previous 3 years are eligible for full studentship. European Union students who have studied elsewhere in the European Union are eligible for fees only award

Level of Study: Doctorate

Type: Studentship

Value: Course fee, college fee and stipend (if eligible). Home students and European students who have studied in the United Kingdom for the previous 3 years are eligible for full studentship. European Union students who have studied elsewhere in the European Union are eligible for fees only award

Length of Study: Up to 3.5 years

Country of Study: Any country

Closing Date: 30 March

Additional Information: Please visit the website: www.cs. ox.ac.uk/aboutus/vacancies/studentship.html for more information.

\section{Continuing Education: MSc Programme Scholarship}

Subjects: Continuing Education

Eligibility: Open to all applicants for the MSc in Sustainable Urban Development

Level of Study: Postgraduate

Type: Scholarship

Value: Tuition and college fee

Length of Study: Duration of programme

Frequency: Annual

Country of Study: Switzerland

Closing Date: 20 January

Additional Information: Please visit the website: www. conted.ox.ac.uk/about/msud-programme-scholarship for more information

\section{For further information contact:}

Email: sud@conted.ox.ac.uk 


\section{Corpus Christi College: A E Haigh English Studentship}

Eligibility: Open to all graduate applicants in English

Level of Study: Postgraduate, Research

Type: Studentship

Value: $£ 7,500$ per year towards college fee and contribution towards living expenses

Length of Study: Period of fee liability

Country of Study: Any country

Application Procedure: Please see website for details of how to apply

Additional Information: Please check at www.ccc.ox.ac.uk/ for more information

\section{For further information contact:}

Email: jane.sherwood@admin.ox.ac.uk

\section{Crystal Clinical Scholarships}

Type: Scholarship

Value: Scholarship funds will be used for travel and associated expenses

Length of Study: 1 year

Country of Study: Any country

\section{For further information contact:}

Email: info@onfgivesback.org

\section{Department of Education: Talbot Scholarship}

Subjects: Education

Eligibility: Open to all applicants for DPhil in Education. Please visit website for more details

Level of Study: Doctorate

Type: Partial scholarship

Value: $£ 15,000$ per annum contribution towards fees and living expenses $35 \%$ reduction of tuition fee

Length of Study: 3 years

Frequency: Every 3 years

Country of Study: Any country

Closing Date: 20 January

Additional Information: Please visit the website: www.edu cation.ox.ac.uk/courses/d-phil/funding-opportunities/ for more information

\section{Donald Tovey Memorial Prize}

Subjects: The philosophy, history or understanding of music Purpose: To assist in the furtherance of research or in the publication of work already done, in the fields of philosophy, history or understanding of music

Eligibility: Open to men or women, without regard to nationality, age or membership of a university

Level of Study: Postdoctorate

Type: Prize

Value: UK£1,000

Frequency: Dependent on funds available

Study Establishment: Unrestricted

Country of Study: Any country

Application Procedure: Applications should be addressed to the Heather Professor of Music at the address shown

Closing Date: June in the year offered

Funding: Private

Contributor: Donal Tovey Memorial Fund

Additional Information: If for furtherance of research, applicants need to demonstrate that the programme falls within the scope of the award, and produce testimonials or other written evidence of previous attainment which demonstrate the researcher's fitness to undertake it. If to assist in publication of work already completed, the applicant must submit one copy of work with an explanation of why the Prize is needed to ensure publication. The Prize is generally awarded for postdoctoral or advanced research

\section{For further information contact:}

Faculty of Music, St Aldate's, Oxford OX1 1DB UK, United Kingdom

Tel: $\quad$ (44) 1865276125

Fax: (44) 1865276128

Email: musicfac@sable.ox.ac.uk

Contact: Heather Professor of Music

\section{Duke of Cambridge Scholarship at University of Oxford}

Purpose: Public Policy

Eligibility: Open to applicants who are ordinarily resident in the United Kingdom and who are applying to the Master of Public Policy (MPP). Please see website for more details Level of Study: Postgraduate

Type: Scholarship

Value: University fee, college fee, and full living expenses of about $€ 14,553$ 
Length of Study: Period of fee liability

Country of Study: Any country

Closing Date: 20 January

Additional Information: The scholarship is only tenable at University College. Please visit the website: www.ox. ac.uk/admissions/graduate/fees-and-funding/fees-funding-andscholarship-search/scholarships-1\#duke for more information

\section{For further information contact:}

Tel: $\quad$ (44) 1865614343

Email: admin@scholarship-position.com

\section{Economic and Social Research Council: Interdisciplinary Area Studies}

Subjects: Interdisciplinary Area Studies

Eligibility: Candidates need to apply by the January admissions deadline to their postgraduate programme at the University of Oxford, using the statement of purpose form, which requires candidates to write an indicative research proposal for DPhil level study

Level of Study: Graduate

Value: University fee, college fee, and living expenses. Feesonly award for European Union applicants

Length of Study: Period of fee liability

Country of Study: Any country

Application Procedure: Please visit website for more details and how to apply

Closing Date: 20 January

Additional Information: Please check at www.area-studies. ox.ac.uk/scholarships-sias for more information

For further information contact:

Email: f.ciuta@ucl.ac.uk

\section{Economic and Social Research Council (ESRC): Social Policy \& Intervention}

Subjects: Comparative social policy, evidence based social intervention and policy evaluation, and social policy/social intervention

Eligibility: Open to applicants to MSc/MPhil comparative social policy, MSc/MPhil evidence based social intervention and policy evaluation and DPhil social policy/social intervention. Candidates apply at the same time as they apply for admission to their postgraduate programme at the University of Oxford, using the same application form

Level of Study: Postgraduate
Value: University fee, college fee and living expenses. Feesonly award for European Union applicants

Length of Study: Period of fee liability

Country of Study: Any country

Application Procedure: Please apply using the standard graduate application form, and confirm with the Department that you wish to be considered for an ESRC studentship

Closing Date: 22 January

Additional Information: Please check at www.spi.ox.ac.uk/ study-with-us/funding.html for more information

\section{For further information contact:}

Email: erzsebet.bukodi@spi.ox.ac.uk

\section{Economic and Social Research Council: Socio- Legal Studies}

Subjects: Law

Eligibility: Open to all prospective students applying for the 1+3 MSt Socio-Legal Studies and DPhil Socio-Legal Studies, or just for the latter

Level of Study: Postgraduate

Type: Scholarship

Value: University fee, college fee, and living expenses. Feesonly award for European Union applicants

Length of Study: Period of fee liability

Frequency: Annual

Country of Study: United Kingdom

Closing Date: 20 January

Funding: Trusts

Additional Information: Please see website: www.law.ox. ac.uk/postgraduate/scholarships.php for more details

For further information contact:

Email: r.sparks@ed.ac.uk

\section{Economics -Economic and Social Research Council (ESRC) Quota Award}

Subjects: MPhil and DPhil economics

Purpose: To assist graduate students with fees and maintenance

Eligibility: Open to all graduate applicants in Economics Level of Study: Doctorate, Research

Type: Award

Value: University fee, college fee, and full living expenses

Length of Study: Up to 4 years 
Application Procedure: Applicants are strongly advised to submit their application for consideration at the first application deadline of January 18th. Places on the second application deadline will be limited

Closing Date: 18 January

Additional Information: Please visit website for more details and how to apply www.economics.ox.ac.uk/index. php/graduate

\section{For further information contact:}

Tel: $\quad$ (44) 1865281162

Email: econgrad@economics.ox.ac.uk

Contact: Julie Minns

\section{Economics: Doctoral Studentship}

Subjects: To support some of the finest aspiring economists from around the world

Purpose: Economics

Eligibility: Open to Home/Eu/Overseas. DPhil in economics. Please note this is only available to those who will have DPhil status in MT 2012

Type: Studentship

Value: $£ 11,126$

Length of Study: 2 years

Application Procedure: Applicants are strongly advised to submit their application for consideration at the first application deadline of January 20th. Places on the second application deadline will be limited

Closing Date: 20 January and 9 March

Additional Information: All applicants accepted by the Department will be offered a place at a college. You may indicate on your application form which college you would like to be considered for; if you have no preference Graduate Admissions will make a selection for you. Students do not necessarily get accepted by their first choice. Please check at www.economics.ox.ac.uk/index.php/graduate for more information

\section{For further information contact:}

Tel: (44) 1865281162

Email: econgrad@economics.ox.ac.uk

Contact: Julie Minns

\section{Education: Economic and Social Research Council (ESRC)}

Subjects: Education

Eligibility: Open to all Home/European Union applicants for both DPhil in Education and MSc Education (Research
Design and Methodology). Please visit website for more details

Level of Study: Doctorate, Postgraduate

Type: Studentship

Value: University fee, college fee and full living expenses

Length of Study: Period of fee liability

Country of Study: Any country

Closing Date: 20 January

Additional Information: Please visit the website: www.edu cation.ox.ac.uk/courses/d-phil/funding-opportunities/ for more information. Kindly contact Mr. Peter Henley for further funding information

For further information contact:

Email: eddev@esrc.ukri.org

\section{Engineering and Physical Sciences Research Council (EPSRC) Centre for Doctoral Training in Autonomous Intelligent Machines and Systems}

Subjects: Engineering

Purpose: To develop in-depth knowledge, understanding and expertise in autonomous intelligent systems

Eligibility: Open to United Kingdom and European Union applicants for DPhil in Engineering. European Union applicants may only be eligible for a fees-only award, depending on residency requirements. Please visit website for more details

Level of Study: Doctorate

Type: Scholarship

Value: University fee, college fee and full living expenses

Length of Study: 4 years

Country of Study: Any country

Closing Date: 20 January

Additional Information: Please visit the website: www.ox. ac.uk/admissions/graduate/courses/autonomous-intelligentmachines-and-systems for more information

For further information contact:

Tel: (44) 1865270000

Email: aims-cdt@robots.ox.ac.uk

\section{Engineering and Physical Sciences Research Council (EPSRC) Doctoral Training Programme Studentships}

Subjects: Statistics

Eligibility: Open to United Kingdom and European Union applicants for DPhil in Statistics. European Union applicants 
may only be eligible for a fees-only award, depending on residency requirements

Level of Study: Postgraduate

Value: University fee, college fee and full living expenses

Length of Study: Three and a half years maximum

Frequency: Annual

Country of Study: United Kingdom

Closing Date: 20 January

Funding: Trusts

Additional Information: For more information, please visit website: www.stats.ox.ac.uk/study_here/research_degrees

\section{For further information contact:}

Email: phdfunding-salc@manchester.ac.uk

\section{Engineering and Physical Sciences Research Council CDT in Industrially Focussed Mathematical Modelling}

Subjects: Mathematical Modelling

Eligibility: Four studentships will be available to applicants regardless of nationality. The remaining studentships are restricted to United Kingdom/European Union nationals Level of Study: Postgraduate

Type: Scholarship

Value: University fee, college fee and full living expenses (minimum $£ 14,296$ per year for 4 years)

Length of Study: 4 years

Frequency: Annual

Country of Study: Any country

Application Procedure: We will automatically assign students to funding and no separate application for funding is required

Closing Date: 10 March

Funding: Trusts

Additional Information: For more information, please visit the website: www.maths.ox.ac.uk/study-here/postgraduatestudy/industrially-focused-mathematical-modelling-epsrc-cdt. This course is still accepting applications for current and upcoming entry

\section{For further information contact:}

Email: infomm@maths.ox.ac.uk

\section{English Faculty: AHRC Doctoral Training Partnership Studentships}

Subjects: English
Eligibility: Open to all Home/European Union's graduates applying to undertake research degrees in the Faculty of English. Please see website for more details

Level of Study: Postgraduate

Type: Studentship

Value: University fee, college fee, and full living expenses. Fees-only awards for non-United Kingdom, European Union students

Length of Study: Period of fee liability

Frequency: Annual

Country of Study: United Kingdom

Closing Date: 20 January

Additional Information: For more information, please check website: www.humanities.ox.ac.uk/prospective_stu dents/graduates/funding/ahrc

For further information contact:

Email: FASS-PhD-Applications@open.ac.uk

\section{English Faculty: Asian Human Rights Commission (AHRC) Doctoral Training Partnership Studentship (Master}

Subjects: English

Eligibility: Open to all Home/European Union applicants to MSt and MPhil degrees offered by the Faculty of English. Please see website for more details

Level of Study: Postgraduate

Type: Studentship

Value: University fee, college fee, and living expenses (pro-rata for courses less than 1 year). Fees-only awards for non-United Kingdom, European Union students

Length of Study: Period of fee liability

Frequency: Annual

Country of Study: United Kingdom

Closing Date: 20 January

Funding: Trusts

Additional Information: For more information, please visit: www.humanities.ox.ac.uk/prospective students/graduates/ funding/ahrc

For further information contact:

Email: ahrcdtp@admin.ox.ac.uk

\section{English Faculty: Cecily Clarke Studentship}

Subjects: English literature

Eligibility: Open to all applicants to English Medieval Studies, with preference to Middle English Philology. All students 
applying for English graduate courses will automatically be considered

Level of Study: Postgraduate

Type: Studentship

Value: $£ 12,000$ per year

Length of Study: Up to 2 years

Country of Study: Any country

Closing Date: 18 January

Additional Information: All students applying for English graduate courses will automatically be considered. Candidates apply at the same time as they apply for admission to their postgraduate programme at the University of Oxford, using the same application form. To be considered candidates must apply by the January deadline. Please check at www. english.ox.ac.uk for more information

For further information contact:

Tel: (44) 1865270000

\section{Exeter College Usher-Cunningham Senior Studentship}

Subjects: Awarded for medical science and medieval or modern history

Purpose: To support graduate study

Eligibility: History is open to graduates of Irish universities only. Medicine is open to all

Level of Study: Postgraduate

Type: Studentship

Value: Home level fees plus maintenance up to the equivalent of a Research Council Award

Length of Study: Usually awarded for up to 3 years

Frequency: Every 3 years

Study Establishment: Exeter College, University of

Oxford

Country of Study: United Kingdom

Application Procedure: Applicants must address enquiries to the Academic Administrator

Funding: Private

Contributor: An endowment

For further information contact:

Email: admissions@exeter.ox.ac.uk

\section{Exeter College: Exonian Graduate Scholarship}

Eligibility: Exeter College is pleased to offer a studentship covering college fees to two DPhil students, linked to a United Kingdom Research Council award covering university fees
Level of Study: Postdoctorate

Type: Fellowship

Value: College fee only

Length of Study: Up to 3 years

Country of Study: United Kingdom

Application Procedure: Applicants must address enquiries to the Academic Administrator

Closing Date: 22 January

Funding: Private

For further information contact:

Exeter College, Turl St, Oxford OX1 3DP, United Kingdom

Email: academic.administrator@exeter.ox.ac.uk

Contact: Academic Administrator

\section{Exeter College: Nicholas Frangiscatos Scholarship in Byzantine Studies}

Eligibility: For a DPhil student in the field of Byzantine studies

Level of Study: Doctorate, Postdoctorate

Type: Fellowship

Value: Up to $£ 10,000$ per year

Length of Study: Up to 3 years

Frequency: Every 3 years

Country of Study: United Kingdom

Application Procedure: Please see website for how to apply

Closing Date: 12 March

Funding: Private

Additional Information: Please check at www.exeter.ox.ac. uk/currentstudents/finance/scholarships for more information

For further information contact:

Email: admissions@exeter.ox.ac.uk

\section{Exeter College: Senior Scholarship in Theology}

Subjects: Theology or philosophy and theology

Purpose: To support a graduate who wishes to read for the Final Honour School of Theology or Philosophy and Theology

Eligibility: Applicants must hold at least a Second Class (Honours) Degree by the time of admission in a subject other than theology

Level of Study: Postgraduate

Type: Scholarship

Value: University and college fees at Home/European Union rate, maintenance grant $£ 5,000$ per year 
Length of Study: 3 years

Frequency: Every 3 years

Study Establishment: Exeter College, the University of Oxford

Country of Study: United Kingdom

Application Procedure: Applicants must apply in writing to the Academic Administrator or see the website www.exeter. ox.ac.uk for details

Closing Date: 1 May

Funding: Private

Contributor: Endowment

No. of awards given last year: 1

Additional Information: The College proposes to elect a graduate to a Senior Scholarship in Theology from October 1st. The Scholar is to study for the Final Honour School of either Theology or Philosophy \& Theology (2nd BA)

\section{Faculty of Medieval and Modern Languages: Heath Harrison DPhil Award}

Subjects: Medieval \& Modern Languages

Eligibility: Open to graduate students accepted to read for a DPhil in Medieval and Modern Languages. Please visit the website for more details

Level of Study: Postgraduate

Type: Scholarship

Value: University fee, college fee, and full living expenses

Length of Study: Three years

Frequency: Annual

Country of Study: United Kingdom

Application Procedure: For more information, please check the website: grad.mml.ox.ac.uk/funding fees

Closing Date: 22 January

Funding: Trusts

\section{For further information contact:}

Email:_office@mod-langs.ox.ac.uk

\section{Freshfields Bruckhaus Deringer Scholarships (Law)}

Subjects: Legal studies

Purpose: To assist graduate students with fees and a living allowance

Eligibility: Varies

Level of Study: Doctorate, Postgraduate, Research

Type: Scholarships

Value: To be confirmed

Length of Study: 1 year
Country of Study: Any country

Closing Date: 22 January

For further information contact:

Email: ContactFSLScheme@freshfields.com

\section{Frost Scholarship Programme (Israel)}

Subjects: Science, technology, engineering and mathematics

Purpose: The Frost Scholarship Programme (Israel) funds current students of Israeli universities to study one-year, full-time master's courses in science, technology, engineering and mathematics ('STEM' subjects) at the University of Oxford

Eligibility: Open to Israeli residents currently studying at an Israeli university, who have not previously been enrolled on a full degree programme at an institution outside of Israel. You must be applying for a one-year, full-time Master's course in a STEM subject (Science, Technology, Engineering and Mathematics). Four awards will be made each year. Closing date varies according to course

Level of Study: Postgraduate

Type: Scholarship

Value: University fee, college fee, and full living expenses

Length of Study: Period of fee liability

Frequency: Annual

Country of Study: Any country

Closing Date: Relevant January deadline for your course

Funding: Trusts

Additional Information: Please see website: www.graduate. ox.ac.uk/frostisrael for more details, including the course list

\section{Geography and the Environment: Andrew Goudie Bursary}

Eligibility: Open to all applicants for MSc in Environmental Change and Management

Level of Study: Postgraduate

Type: Scholarship

Value: Up to $£ 5,000$

Length of Study: 1 year

Country of Study: Any country

Closing Date: 20 January

Additional Information: Please visit the website: www.eci. ox.ac.uk/msc/funding.html for more information

\section{For further information contact:}

Email: support@linacre.ox.ac.uk 


\section{Geography and the Environment: Boardman Scholarship}

Eligibility: Open to all applicants for MSc in Environmental Change and Management

Level of Study: Postgraduate

Type: Scholarship

Value: Up to $£ 5,000$

Length of Study: 1 year

Country of Study: Any country

Closing Date: 20 January

Additional Information: Please visit the website: www.eci. ox.ac.uk/msc/funding.html for more information

\section{For further information contact:}

Email: socialsciences@devoff.ox.ac.uk

Contact: Rachel Kirwan, Head of Development

\section{Geography: Sir Walter Raleigh Postgraduate Scholarship}

Subjects: Environmental change

Eligibility: Open to all applicants for MSc Environmental Change and Management. The award is tenable only at Oriel College

Level of Study: Postgraduate

Type: Scholarship

Value: $£ 3,500$

Length of Study: 1 year

Frequency: Annual

Application Procedure: Any person wishing to be considered for this award should follow the application procedure for admission to the degree of Master of Science in Environmental Change and Management at Oxford University, nominating Colleges of preference as detailed in the application procedure. They must, additionally, download (from website) and complete the application form and return it to the address given below

Additional Information: Please note that Oriel College only offers a small number of places per year to applicants for the MSc in Environmental Change and Management, and one of these places will be reserved for the applicant who has been awarded the Sir Walter Raleigh Scholarship

\section{For further information contact:}

Tel: $\quad$ (44) 1865276520

Fax: (44) 1865286548

Email: admissions@oriel.ox.ac.uk

Contact: The Admissions Officer

\section{Goodger and Schorstein Research Scholarships in Medical Sciences}

Eligibility: Open to postdoctoral researchers from any department/institute of the Medical Sciences Division. Applicants must have completed their DPhil (at any Higher Education Institution) at the time of application and are required to work primarily in units run by the University of Oxford Type: Scholarship

Value: Typically in the range between $£ 2,000$ and $£ 25,000$

Length of Study: Up to 1 year

Country of Study: Any country

Application Procedure: Please see the website for more details. Enquires may be sent by email to Aga.Bush@ medsci.ox.ac.uk

Closing Date: 30 January

Additional Information: Please visit the website: www. medsci.ox.ac.uk/research/internal/funding-directory/goodgerand-schorstein-scholarship for more information

\section{For further information contact:}

Email:Aga.Bush@medsci.ox.ac.uk

\section{Graduate Scholarship in Medieval and Modern Languages with Keble College}

Subjects: Medieval and modern languages

Purpose: To assist graduate students with fees, maintenance and accommodation

Eligibility: All eligible doctoral applicants submitting applications before the third gathered field will automatically be considered, irrespective of choice of college, provided that they have applied for other funded awards (if eligible)

Level of Study: Research

Type: Scholarship

Value: University fee at United Kingdom/European Union rate; maintenance grant of $£ 5,000$. Additional benefits include some dining rights and guaranteed accommodation in 1 st year Length of Study: Up to 3 years

Country of Study: Any country

Closing Date: 22 January

For further information contact:

Email: trish.long@keble.ox.ac.uk

\section{Graduate Scholarship in Medieval and Modern Languages with Merton College}

Subjects: Medieval and modern languages 
Purpose: To assist graduate students with fees and a living allowance

Eligibility: All eligible doctoral applicants submitting applications before the third gathered field will automatically be considered, irrespective of choice of college, provided that they have applied for other funded awards (if eligible)

Level of Study: Research

Type: Scholarship

Value: University fee at United Kingdom/European Union rate; allowance of $£ 5,000$ to assist with college fees and/or maintenance

Length of Study: Up to 3 years

Country of Study: Any country

Closing Date: 22 January

For further information contact:

Email: trish.long@keble.ox.ac.uk

\section{Graduate Scholarship in Medieval and Modern Languages with Somerville College}

Subjects: Medieval and modern languages

Purpose: To assist graduate students with fees, maintenance and accommodation

Eligibility: All eligible doctoral applicants submitting applications before the third gathered field will automatically be considered, irrespective of choice of college, provided that they have applied for other funded awards (if eligible)

Level of Study: Research

Type: Scholarship

Value: University fee at United Kingdom/European Union rate; maintenance grant of $£ 6,000$. Additional benefits include some dining rights and guaranteed accommodation in 1st year Length of Study: Up to 3 years

Country of Study: Any country

Closing Date: 22 January

\section{For further information contact:}

Email: trish.long@keble.ox.ac.uk

\section{Green Moral Philosophy Scholarship}

Eligibility: Open to all graduate applicants for DPhil courses in the Faculty of Philosophy. All applicants who receive a place on any graduate course automatically considered

Type: Scholarship

Value: The value of the scholarship is to be determined by the Board of Graduate Admissions. The scholarship may not be offered on a yearly basis
Length of Study: 1 year

Country of Study: Any country

Closing Date: 4 January

Additional Information: Please check website for more information

\section{For further information contact:}

Email: jane.sherwood@admin.ox.ac.uk

\section{Green Templeton College: GTC-Medical Sciences Doctoral Training Centre Scholarship}

Purpose: Green Templeton College is pleased to be able to offer a top-up award for overseas students who have been awarded a Studentship for study at the Medical Sciences Doctoral Training Centre beginning in October month Eligibility: Open to all applicants to the Medical Sciences Doctoral Training Centre with Overseas fee status

Level of Study: Doctorate

Type: Scholarship

Value: GTC will fund the difference between Home/European Union fees and Overseas fees, for up to four years. All other expenses are covered by a Studentship at the Medical Sciences Doctoral Training Centre

Length of Study: Up to 4 years

Country of Study: Any country

Closing Date: 11 January

Additional Information: Please visit the website: www.gtc. ox.ac.uk/admissions/scholarships-and-awards for more information

\section{For further information contact:}

Email: enquiries@msdtc.ox.ac.uk

Contact: Professor Robert Gilbert, Director

\section{Green Templeton College: GTC-SBS DPhil Scholarship}

Subjects: Management studies

Eligibility: Open to all applicants to the DPhil in Management Studies

Level of Study: Doctorate, Graduate

Type: Scholarship

Value: Full fees and living costs (at the Research Council United Kingdom minimum stipend rate) for 3 years, with possibility of stipend and payment of university continuation charge in year 4 , if required

Length of Study: Period of fee liability; possibility of one further year 
Study Establishment: Green Templeton College

Country of Study: Any country

Application Procedure: Please see website: www.gtc.ox.ac. uk/admissions/scholarships-and-awards for more details and how to apply

Closing Date: 11 January

Additional Information: Restrictions: New DPhil students in Management Studies only (includes both Management Research and Financial Economics routes)

\section{Green Templeton College: Rosemary Stewart Scholarship}

Eligibility: DPhil students with research interests in the area of health care organization and management

Level of Study: Doctorate

Type: Scholarship

Value: $£ 6,000$ per year

Length of Study: Up to 3 years

Study Establishment: Green Templeton College

Country of Study: Any country

Application Procedure: Please see website for more details and how to apply

Closing Date: 13 March

Additional Information: Please visit the website: www.gtc. ox.ac.uk/admissions/scholarships-and-awards for more information

\section{For further information contact:}

Tel: $\quad$ (44) 1865274770

Email: lodge@gtc.ox.ac.uk

\section{Hertford - English Graduate Scholarship in Irish Literature}

Subjects: English

Eligibility: Open to Home/European Union students applying to undertake a DPhil in Irish Literature. Applicants are automatically considered for the scholarship by the English Faculty. Please visit the website for more details

Level of Study: Postgraduate

Type: Scholarship

Value: University fee, college fee and full living expenses

Length of Study: Period of fee liability

Frequency: Annual

Country of Study: United Kingdom

Application Procedure: For more information, please visit the website: www.english.ox.ac.uk
Closing Date: 8 January

Funding: Trusts

For further information contact:

Email: college.office@hertford.ox.ac.uk

\section{Hertford College Archaeology Award}

Eligibility: Open to all graduate students pursuing the MSt in Archaeology. Please see the website for more details

Level of Study: Postgraduate

Type: Scholarship

Value: $£ 10,000$ towards course fees, college fees and living costs where appropriate

Length of Study: One year

Frequency: Annual

Study Establishment: Hertford

Country of Study: United Kingdom

Application Procedure: For more information, please check the website: www.hertford.ox.ac.uk/discover-hertford/gradu ates/graduate-scholarships

Closing Date: 11 March

Funding: Trusts

For further information contact:

Email: communications@hertford.ox.ac.uk

\section{Hertford College Law Award}

Eligibility: Open to all graduate students pursuing the BCL or Mjur. Please see the website for more details

Level of Study: Postgraduate

Type: Scholarship

Value: $£ 10,000$ towards course fees, college fees and living costs where appropriate

Length of Study: One year

Frequency: Annual

Study Establishment: Hertford

Country of Study: United Kingdom

Application Procedure: For more information, please check the website: www.hertford.ox.ac.uk/discover-hertford/gradu ates/graduate-scholarships

Closing Date: 11 March

Funding: Trusts

\section{For further information contact:}

Email: graduate.admissions@hertford.ox.ac.uk 


\section{Hertford College Pharmacology Award}

Eligibility: Open to all graduate students pursuing a DPhil in Pharmacology. Please see the website for more details, including how to apply

Level of Study: Postgraduate

Type: Scholarship

Value: $£ 6,500$ towards course fees, college fees and living costs where appropriate

Length of Study: Three years

Frequency: Annual

Study Establishment: Hertford

Country of Study: United Kingdom

Application Procedure: For more information, please visit the website: www.pharm.ox.ac.uk/gso/dphil-in-pharmacology

Closing Date: 8 January

Funding: Trusts

For further information contact:

Email: communications@hertford.ox.ac.uk

\section{Hertford College Senior Scholarships}

Subjects: All subjects

Eligibility: Restricted to students who are about to commence a new research degree course or those about to upgrade their current course

Level of Study: Postgraduate

Type: Scholarship

Value: UK£1,000 per year, plus priority for housing and some dining rights

Length of Study: 2 years

Frequency: Annual

Study Establishment: Hertford College, University of Oxford

Country of Study: United Kingdom

Application Procedure: Applicants must write to the College for further details

\section{For further information contact:}

Email: graduate.admissions@hertford.ox.ac.uk

\section{Hertford College: Baring Senior Scholarship}

Eligibility: Open to all graduate students pursuing research in any area of study

Level of Study: Postgraduate

Type: Scholarship
Value: $£ 5,000$ per year with certain associated dining rights Length of Study: Two years

Frequency: Annual

Study Establishment: Hertford

Country of Study: United Kingdom

Application Procedure: For more information, please visit the website: www.hertford.ox.ac.uk/discover-hertford/gradu ates/graduate-scholarships

Closing Date: 11 March

Funding: Trusts

For further information contact:

Email: graduate.admissions@hertford.ox.ac.uk

\section{Hertford College: Vaughan Williams Senior Scholarship}

Purpose: The Vaughan Williams Fund supports medical students with a $£ 300$ award per student towards stethoscopes and 'on the ward' textbooks

Eligibility: Open to all graduate students pursuing research in any area of study. Please see website for more details, including how to apply

Level of Study: Postgraduate

Type: Scholarship

Value: $£ 5,000$ per year with certain associated dining rights

Length of Study: Two years

Frequency: Annual

Study Establishment: Hertford

Country of Study: United Kingdom

Application Procedure: For more information, please visit : www.hertford.ox.ac.uk/discover-hertford/graduates/graduatescholarships

Closing Date: 11 March

Funding: Trusts

For further information contact:

Email: communications@hertford.ox.ac.uk

\section{Hertford College: Worshipful Company of Scientific Instrument Makers Senior Scholarship}

Eligibility: Open to DPhil applicants in all subjects. Please note: applicants are expected to be involved in the design of instrumentation

Level of Study: Doctorate, Graduate

Type: Scholarship

Value: $£ 4,000$ per year with certain associated dining rights

Length of Study: 2 years 
Country of Study: Any country

Application Procedure: Please see website for details of how to apply

Additional Information: Please check at www.hertford.ox. ac.uk/advertised-posts for more information

\section{For further information contact:}

Email: college.office@hertford.ox.ac.uk

\section{Hong Kong Jockey Club Graduate Scholarships}

Purpose: To students who combine outstanding academic performance with a strong commitment to serving the community

Eligibility: Open to applicants who are ordinarily resident in Hong Kong and who are applying to a full-time master's or full-time DPhil course at Oxford. Please note that DPhil courses with four years of fee liability are not eligible. Please see website for more details

Level of Study: Doctorate, Postgraduate

Type: Scholarship

Value: University fee, college fee, and full living expenses

Length of Study: Period of fee liability

Country of Study: Any country

Closing Date: Relevant January deadline for your course

Funding: Trusts

Additional Information: Please visit the website: www.ox. ac.uk/admissions/graduate/fees-and-funding/fees-funding-andscholarship-search/scholarships-1\#hkjc for more information

For further information contact:

Email: hkjcscholarships@hkjc.org.hk

\section{International Development: QEH Scholarship}

Eligibility: Open to all graduate applicants for MPhil in Development Studies with a preference for those from Sub-Saharan Africa. Please visit departmental website for more details

Level of Study: Predoctorate

Type: Scholarship

Value: University fee, college fee, and $£ 13,000$ towards living expenses

Length of Study: 21 months

Country of Study: Any country

Closing Date: 20 January

Additional Information: Please visit the website: www.qeh. ox.ac.uk/content/fees-funding for more details
For further information contact:

Email: jane.sherwood@admin.ox.ac.uk

\section{James Fairfax - Oxford-Australia Fund Scholarships}

Subjects: All

Eligibility: Applicants should normally be under 30 on January 1st in the year in which the scholarship is to be taken up, and must have a bachelor's degree with first or upper second class honours or equivalent from a recognized university

Level of Study: Graduate, Postgraduate

Type: Scholarship

Value: University fees at the home and European Union rate, college fees and a living allowance of the order of A $\$ 12,000$ per year

Length of Study: Oxford-Australia Fund scholarships are for 2 years, or in the case of DPhil for 3 years, and James Fairfax scholarships are generally of 2 years duration

Frequency: Annual

Study Establishment: University of Oxford

Country of Study: United Kingdom

Application Procedure: Applicants must write for details or visit the website at www.admin.ox.edu.au/io

Closing Date: 21 February

Funding: Private, Individuals

Contributor: Australian scholars who have studied at Oxford and, in particular, Mr James Fairfax

For further information contact:

Tel: $\quad$ (61) $261253578 / 3761$

Email: jww@rsc.anu.edu.au

Contact: Professor J W White

\section{Jesus College: Joint Law Faculty-Jesus College BCL} Scholarship

Eligibility: Open to all graduate applicants to the BCL (Bachelor of Civil Law). Please see website for further details Level of Study: Graduate

Type: Scholarship

Value: $£ 10,000$

Length of Study: Period of fee liability

Frequency: Annual

Study Establishment: Jesus College

Country of Study: Any country

Closing Date: 20 January

Additional Information: Please visit the website: www. jesus.ox.ac.uk/current-students/scholarships-prizes-awards? 
field_subject_target_id=20\&field_type_value=Graduate for more information

\section{For further information contact:}

Email: lodge@jesus.ox.ac.uk

\section{Kalisher Trust-Wadham Student Scholarship}

Purpose: The scholarships are intended to encourage and assist those intending to practise at the Criminal Bar who demonstrate 'exceptional promise but modest means'

Eligibility: Applications are invited from United Kingdom residents who can demonstrate: 1 . Intellectual ability - demonstrated by academic performance, past work, activities and other experience. 2. Motivation to succeed at the Criminal Bar - including steps taken to acquire the personal skills required of a Barrister, and a demonstration of the will to succeed. 3. Potential as an advocate - both in oral and written skills. 4. Personal qualities - including self-reliance, independence, integrity, reliability and humanity. 5. Financial need - candidates will be asked to supply to the interview panel, in confidence, information demonstrating financial need

Level of Study: Graduate

Type: Scholarship

Frequency: Annual

Country of Study: Any country

Application Procedure: In particularly to discuss their motivation to succeed at the Criminal Bar. This statement should be no more than 800 words

Closing Date: 27 November

Funding: Private

\section{For further information contact:}

The Faculty of Law, University of Oxford, St Cross Building, St Cross Road, Oxford OX1 3UL, United Kingdom

Email: tracy.kaye@crim.ox.ac.uk

\section{Keble College Gosden Graduate Scholarship}

Subjects: Theology

Eligibility: Open to students intending to seek ordination in a church in communion with the Church of United Kingdom. Candidates must be either ordained or be able to show clear evidence of desire for ordination in the Church of United Kingdom or a church in communion therewith, and be already at or intending to be registered for a postgraduate degree at Keble College, University of Oxford

Level of Study: Postgraduate

Type: Scholarship
Value: Up to UK£5,000 per year

Length of Study: Up to 3 years

Frequency: Dependent on funds available

Study Establishment: Keble College, University of Oxford Country of Study: United Kingdom

No. of awards offered: 4

Application Procedure: Applicants must contact the Deputy Academic Administrator at Keble College in the first instance Closing Date: March/April

No. of awards given last year: 2

No. of applicants last year: 4

\section{For further information contact:}

Keble College, Oxford, OX1 3PG UK, United Kingdom

Email: college.office@keb.ox.ac.uk

Contact: Deputy Academic Administrator

\section{Keble College Gwynne-Jones Scholarship}

Subjects: All subjects

Eligibility: Open to nationals of Sierra Leone or the Yorubaspeaking people of Nigeria

Level of Study: Postgraduate

Type: Scholarship

Value: Up to UK£4,000 per year

Length of Study: Up to 3 years

Frequency: Varies

Study Establishment: Keble College, University of Oxford Country of Study: United Kingdom

Application Procedure: Applicants must write for details

Closing Date: May

Funding: Private

\section{Keble College lan Palmer Graduate Scholarship in Information Technology}

Subjects: Computer science and related fields concerning the practical uses of computer systems

Eligibility: Applicants must write for details

Level of Study: Postgraduate

Type: Scholarship

Value: Up to the value of college fees

Length of Study: Up to 3 years

Frequency: Dependent on funds available

Study Establishment: Keble College, University of Oxford Country of Study: United Kingdom

Application Procedure: Applicants must write for details Closing Date: May

Funding: Private 


\section{Keble College Ian Tucker Memorial Bursary}

Subjects: All subjects

Eligibility: Candidates must demonstrate sporting prowess principally in the field of rugby football, together with qualities that will make a contribution to both the College and University

Level of Study: Graduate

Type: Bursary

Value: Up to UK£8,000 per year

Length of Study: 1 year

Frequency: Annual

Study Establishment: Keble College, University of

Oxford

Country of Study: United Kingdom

No. of awards offered: 6

Application Procedure: Applicants must contact the Tutor for Graduates at Keble College for an application form

Closing Date: May each year

No. of awards given last year: 2

No. of applicants last year: 6

\section{Keble College Keble Association Open Graduate Scholarship}

Subjects: All subjects

Eligibility: Open to research students and 2nd BM applicants

Level of Study: Postgraduate, Research

Type: Scholarship

Value: UK£2,000

Length of Study: Up to 3 years

Frequency: Annual

Study Establishment: Keble College, University of Oxford Country of Study: United Kingdom

No. of awards offered: 19

Application Procedure: Applicants must write to request an application form

Closing Date: May

Funding: Private

No. of awards given last year: 2

No. of applicants last year: 19

\section{Keble College Paul Hayes Graduate Scholarship}

Subjects: All subjects

Eligibility: Candidates must demonstrate sporting excellence Level of Study: Doctorate, Graduate

Type: Scholarship

Value: $U p$ to the value of college fees
Length of Study: Up to 3 years

Study Establishment: Keble College, the University of Oxford

Country of Study: United Kingdom

Application Procedure: Applicants must contact the Deputy Academic Administrator at Keble College

Closing Date: May

\section{Keble College Water Newton Scholarship}

Subjects: Theology

Eligibility: Open to students intending to seek ordination in a church in communication with the Church of United Kingdom

Level of Study: Postdoctorate, Research

Type: Scholarship

Value: Up to UK£5,000 per year

Length of Study: Up to 3 years

Frequency: Dependent on funds available

Study Establishment: Keble College, University of Oxford

Country of Study: United Kingdom

Application Procedure: Applicants must contact the Deputy Academic Administrator

Closing Date: April

Funding: Private

\section{Keble College: Delia Bushell Graduate Scholarship}

Subjects: History

Eligibility: Open to graduate applicants to study for a postgraduate degree in the History Faculty in the University of Oxford, or be presently registered for a postgraduate degree in the History Faculty in the University of Oxford

Level of Study: Postgraduate

Type: Scholarship

Value: Up to $£ 6,250$ per year towards living expenses

Length of Study: 1 year

Study Establishment: Keble College

Country of Study: Any country

Application Procedure: Please see website for more details, including how to apply

Closing Date: 11 March

Additional Information: Please visit the website: www. keble.ox.ac.uk/admissions/graduate/graduate-scholarships for more information

For further information contact:

Email: college.office@keble.ox.ac.uk 


\section{Keble College: James Martin Graduate Scholarship}

Eligibility: Open to Home/European Union students, who can demonstrate that they are in financial need. Applicants must be intending to study for a MSc in the MPLS (Mathematical, Physical and Life Sciences) Division, Medical Sciences Division or Geography and the Environment department

Level of Study: Postgraduate

Type: Scholarship

Value: Up to $£ 9,000$ per year towards living expenses

Length of Study: 1 year

Study Establishment: Keble College

Country of Study: Any country

Application Procedure: Please see website for further details, including how to apply

Closing Date: 11 March

Additional Information: Please visit the website: www. keble.ox.ac.uk/admissions/graduate/graduate-scholarships for more information

For further information contact:

Email: college.office@keble.ox.ac.uk

\section{Kellogg College: Naji DPhil Scholarship in the Public Understanding of Evidence-Based Medicine}

Eligibility: Open to applicants for the DPhil in Primary Health Care whose research directly addresses public understanding of evidence for health claims

Level of Study: Doctorate

Type: Scholarship

Value: University fee, college fee, and full living expenses

Length of Study: Period of fee liability

Study Establishment: Kellogg College

Country of Study: Any country

Application Procedure: Please see website for more details, including how to apply

Closing Date: 6 January

Additional Information: Please visit the website: www.kel logg.ox.ac.uk/study/scholarships-2017/naji-dphil-scholarshipin-the-public-understanding-of-evidence-based-medicine/ for more information

\section{For further information contact:}

Tel: (44) 1865612000

\section{Kellogg College: Oxford-McCall MacBain Graduate Scholarship}

Purpose: The scholarship is only tenable at Kellogg College. All eligible applicants will be considered for the scholarship Eligibility: All eligible applicants will be considered for the scholarship, regardless of which college (if any) you state as your preference on the graduate application form. However, successful applicants will be transferred to Kellogg College in order to take up the scholarship

Level of Study: Graduate

Type: Scholarship

Value: The scholarship covers course fees and provides a study support grant

Frequency: Annual

Country of Study: Any country

Closing Date: 1 March

Funding: Private

Additional Information: Initially the MMF operated on a regional-based approach, with a strategy to develop and encourage best practices and policies in multiple areas related to improving the human condition

\section{For further information contact:}

Kellogg College, 60-62 Banbury Road, Oxford OX2 6PN, United Kingdom

Email: enquiries@kellogg.ox.ac.uk

\section{Lady Margaret Hall Talbot Research Fellowship}

Subjects: Various arts subjects, as advertised

Purpose: To provide an opportunity for academic postdoctoral research

Eligibility: Open to qualified persons who hold or will have obtained a postdoctoral or equivalent degree by the start of tenure

Level of Study: Postgraduate

Type: Fellowship

Value: Please contact the college for details

Length of Study: 3 years, not renewable

Frequency: Every 3 years

Study Establishment: Lady Margaret Hall, the University of Oxford

Country of Study: United Kingdom

Closing Date: As advertised

\section{For further information contact:}

Lady Margaret Hall Norham Gardens 
Tel: (44) 1865274300

Fax: (44) 1865511069

Email: college.office@ college.office@lmh.ox.ac.uk

\section{Lady Margaret Hall: Ann Kennedy Graduate Scholarship in Law}

Eligibility: Open to graduate applicants for the BCL, MJur, MSt in Legal Research or MPhil in Law at Lady Margaret Hall. The award will be made on the basis of academic excellence

Level of Study: Graduate, Postgraduate, Predoctorate

Type: Scholarship

Value: The award covers college fees and a contribution to the university fees. It is awarded for one year for an amount of up to $£ 14,000$. It is not intended to contribute to living expenses

Length of Study: 1 year

Study Establishment: Lady Margaret Hall

Country of Study: Any country

Closing Date: 20 January

Additional Information: Please visit the website: www. law.ox.ac.uk/admissions/scholarships-index/college-awardsspecific-law-postgraduates-index for more information

For further information contact:

Email: enquiries@1mh.ox.ac.uk

\section{Lady Margaret Hall: Gavin Cameron Graduate Scholarship in Economics}

Level of Study: Graduate

Type: Scholarship

Value: Free accommodation in new Graduate accommodation

Length of Study: Three years

Study Establishment: Lady Margaret Hall

Country of Study: Any country

Application Procedure: Open to all graduate applicants in Economics with a preference for, but not restricted to, applicants who put LMH as their first choice College

Closing Date: Relevant January deadline for your course Additional Information: Please visit the website: www. lmh.ox.ac.uk/prospective-students/Graduates/Scholarshipopportunities.aspx for more information

\section{For further information contact:}

Email: stassistant@lmh.ox.ac.uk

\section{Lady Margaret Hall: Open Residential Scholarships}

Eligibility: Open to all graduate applicants with a preference for, but not restricted to, applicants who put LMH as their first choice college. Please see website for details of how to apply Level of Study: Postgraduate

Type: Scholarship

Value: $£ 5,000$ plus additional benefits including an option on accommodation and limited dining rights

Length of Study: 1 year

Frequency: Annual

Study Establishment: Lady Margaret Hall

Country of Study: Any country

Closing Date: Relevant January deadline for your course Additional Information: Please check the website: www. lmh.ox.ac.uk for more information

\section{For further information contact:}

Email: graduate.admissions@lmh.ox.ac.uk

\section{Latin American Centre-Latin American Centre Scholarship}

Subjects: MSc in Latin American Studies

Eligibility: Open to all graduate applicants to the MSc in Latin American Studies from one of the CAF shareholder countries. Applicants must send an email to the Admissions Secretary requesting to be considered

Level of Study: Postgraduate

Type: Scholarship

Value: University and college fees (not living expenses)

Length of Study: 1 year (Non-renewable)

Country of Study: Any country

Application Procedure: Please visit website for more details and how to apply

Closing Date: 10 March

Additional Information: For more information, please check the websites: www.lac.ox.ac.uk/funding; www.lac.ox. ac.uk/scholarships-latin-american-centre

\section{For further information contact:}

Email:1aclib@bodleian.ox.ac.uk

\section{Law Faculty: David and Helen Elvin Scholarship}

Eligibility: Open to all graduate applicants for the BCL and MJur. Award holders will become members of Hertford College. Please see website for more information Level of Study: Graduate, Postgraduate 
Type: Scholarship

Value: $£ 10,000$ towards course fees, college fees and living costs where appropriate

Length of Study: 1 year

Study Establishment: Hertford College

Country of Study: Any country

Closing Date: 20 January

Additional Information: Please visit the website: www.law. ox.ac.uk/postgraduate/scholarships.php for more information

\section{For further information contact:}

Email: lawfac@law.ox.ac.uk

\section{Law Faculty: Des Voeux Chambers}

Subjects: Law

Eligibility: Open to all graduate applicants to the BC-

L. Preference may be shown for candidates with an interest in pursuing a career at the Hong Kong Bar. Please see website for more information

Level of Study: Postgraduate

Type: Scholarship

Value: $£ 10,000$

Length of Study: 1 year

Frequency: Annual

Country of Study: United Kingdom

Closing Date: 20 January

Funding: Trusts

Additional Information: Please check the website: www.law.ox.ac.uk/postgraduate/scholarships.php for more information

For further information contact:

Email: pupillage@dvc.com.hk

\section{Law Faculty: James Bullock Scholarship}

Purpose: The James Bullock Scholarship is restricted to students taking the MSc in Taxation and provides an award of $£ 5,000$ which will be paid in two instalments

Eligibility: Open to all applicants for the MSc in Taxation

Level of Study: Postgraduate

Type: Scholarship

Value: $£ 2,500$ per year

Length of Study: 2 years

Country of Study: Any country

Closing Date: 10 March

Additional Information: Please visit the website: www.law. ox.ac.uk/postgraduate/scholarships.php for more information
For further information contact:

Email: lawfac@law.ox.ac.uk

\section{Law Faculty: The Peter Birks Memorial Scholarship}

Subjects: Law

Purpose: To assist graduate students with fees

Eligibility: Open to all graduate applicants to BCL/MJur, MSc in Law and Finance, MSt Legal Research, MPhil Or DPhil Law. Please see website for further information

Level of Study: Graduate, Postgraduate

Type: Scholarship

Value: $£ 7,500$ per year

Length of Study: 1 year

Frequency: Annual

Country of Study: Any country

Closing Date: 20 January

Additional Information: Please check the website: www.law. ox.ac.uk/postgraduate/scholarships.php for more information

For further information contact:

Email:1lawfac@law.ox.ac.uk

\section{Linacre College: Applied Materials MSc Scholarship}

Subjects: Environmental change and management

Purpose: To assist graduate students with fees and a living allowance

Eligibility: Open to all

Level of Study: Postgraduate

Type: Scholarship

Length of Study: 1 year

For further information contact:

School of Geography and the Environment, University of Oxford, South Parks Road, Oxford OX1 3QY, United Kingdom

Tel: $\quad$ (44) 1865285070

Email:_enquiries@ouce.ox.ac.uk

Contact: Director of Graduate Studies

\section{Linacre College: David Daube Scholarship}

Purpose: The David Daube Law Scholarship is available to a student reading or intending to read for a DPhil in law, and who is liable to pay fees

Eligibility: Open to all graduate applicants for the BCL and MJur 
Level of Study: Postgraduate

Type: Scholarship

Value: College fee

Length of Study: Period of fee liability

Country of Study: Any country

Closing Date: 12 March

Additional Information: Applicants should first secure a place on the Oxford BCL or MJur course and mark Linacre College as their chosen College. Please check at www.linacre. ox.ac.uk/Admissions/Scholarships for more information

\section{For further information contact:}

Email: ben.nicholson@admin.ox.ac.uk

\section{Linacre College: EPA Cephalosporin Scholarship}

Subjects: Biological, medical and chemical sciences

Purpose: To assist graduate students with fees

Eligibility: Open to all graduate students

Level of Study: Postgraduate, Research

Type: Scholarship

Value: College fees

Length of Study: Up to 2 years depending on fee liability

\section{For further information contact:}

Sir William Dunn School of Pathology

Email: administration@path.ox.ac.uk

Contact: Director of Graduate Studies

\section{Linacre College: Hicks Scholarship}

Subjects: Economics

Purpose: With the initial support of several Old Members, a fund is being established to provide a College fee scholarship to a Linacre student studying for a degree in Economics Eligibility: Open to students reading, or intending to read for a DPhil in Economics who are liable to pay fees

Level of Study: Doctorate, Postgraduate

Type: Scholarship

Value: $£ 80,000$. 1st 3 years scholarship paid out $=£ 6,486$

Length of Study: Period of fee liability

Study Establishment: Linacre College

Country of Study: Any country

Closing Date: 21 April

Funding: Private

Additional Information: Please visit the website: www.linacre. ox.ac.uk/prospective-students/scholarships for more information
For further information contact:

Linacre College, St. Cross Road, Oxford OX1 3JA, United Kingdom

Tel: (44) 1865271650

Email: development@linacre.ox.ac.uk

\section{Linacre College: Hitachi Chemical Europe Scholarship}

Subjects: Environmental change and management

Eligibility: Preference given to applicant from China or Central/South America

Level of Study: Postgraduate

Type: Scholarship

Value: College fee plus $£ 1,000$

Length of Study: 1 year

Application Procedure: No separate application required. Please contact to Director of Graduate Studies

Additional Information: Please check at www.linacre.ox.ac. uk/extras/scholarships for more information

\section{For further information contact:}

Director of Graduate Studies

\section{Linacre College: John Bamborough MSc Scholarship}

Subjects: Humanities

Eligibility: Open to all graduate applicants for MSc courses in the Humanities division

Level of Study: Postgraduate

Type: Scholarship

Value: $100 \%$ university and college fees. $£ 3,205$

Length of Study: One year

Study Establishment: Linacre College

Country of Study: Any country

Application Procedure: Please see website for more details, including how to apply

Closing Date: 19 April

Additional Information: Please visit the website: www. linacre.ox.ac.uk/prospective-students/scholarships for more information

\section{For further information contact:}

Email: scholarships@linacre.ox.ac.uk 


\section{Linacre College: Linacre Rausing Scholarship (English)}

Subjects: English Literature

Eligibility: Open to all

Level of Study: Research

Type: Scholarship

Value: $£ 4,000$

Length of Study: Up to 3 years

Country of Study: Any country

Application Procedure: No separate application required. Please contact: Director of Graduate Studies, English Faculty, Oxford OX1 3UQ, United Kingdom

For further information contact:

Email: english.office@ell.ox.ac.uk

\section{Linacre College: Mary Blaschko Graduate Scholarship}

Subjects: Humanities

Purpose: To enable European students to carry out research for 1 year in the department of pharmacology or the MRC anatomical neuropharmacology unit

Eligibility: Open to all graduate applicants for research degrees in the Humanities division

Level of Study: Postgraduate, Research

Type: Scholarship

Value: College fee

Length of Study: Period of fee liability

Study Establishment: Linacre College

Country of Study: Any country

Application Procedure: Please see website for more details, including how to apply

Closing Date: 21 April

Additional Information: Please visit the website: www. linacre.ox.ac.uk/prospective-students/scholarships for more information

\section{For further information contact:}

Email: scholarships@linacre.ox.ac.uk

\section{Linacre College: Rausing Scholarship in Anthropology}

Subjects: Anthropology

Eligibility: Open to all graduate applicants in Anthropology

Level of Study: Research

Type: Scholarship
Value: College fee plus $£ 2,000$ towards living expenses Length of Study: Period of fee liability Country of Study: Any country

Application Procedure: There is no application form. Applications should consist of a detailed doctoral proposal of 3-4 pages, a curriculum vitae and two letters of reference, one of which should be provided by the student's current or prospective supervisor for the doctorate. Applications should be sent to the Director of Graduate Studies. Please see website for details of how to apply

Additional Information: Please check at www.linacre.ox.ac. uk/Admissions/Scholarships for more information

For further information contact:

Email: ben.nicholson@admin.ox.ac.uk

Contact: Director of Graduate Studies

\section{Linacre College: Rausing Scholarship in English}

Subjects: English

Eligibility: Open to all graduate applicants for any course in the English Faculty

Level of Study: Doctorate

Type: Scholarship

Value: College fee

Length of Study: Period of fee liability (up to 3 years)

Study Establishment: Linacre College

Country of Study: Any country

Application Procedure: Please see website for more details, including how to apply

Closing Date: Relevant January deadline for your course Additional Information: Please visit the website: www.lina cre.ox.ac.uk/prospective-students/scholarships for more information

For further information contact:

Email: support@linacre.ox.ac.uk

\section{Linacre College: Raymond and Vera Asquith Scholarship}

Subjects: Humanities

Eligibility: Open to suitably qualified students who were born in the United Kingdom, reading or intending to read for a DPhil in Humanities who are liable to pay fees and have AHRC funding

Level of Study: Doctorate, Postgraduate

Type: Scholarship

Value: College fee 
Length of Study: Period of fee liability

Country of Study: Any country

Application Procedure: Please see website for details of how to apply

Additional Information: Please check at www.linacre.ox.ac. uk/Admissions/Scholarships for more information

\section{For further information contact:}

Email: ben.nicholson@admin.ox.ac.uk

\section{Linacre College: Ronald and Jane Olson Scholarship}

Subjects: Refugee studies

Eligibility: Open to all graduate applicants for the MSc in Refugee and Forced Migration Studies

Level of Study: Postgraduate

Type: Scholarship

Value: College fee, plus a maintenance grant of $£ 2,500$

Length of Study: 1 year

Study Establishment: Linacre College

Country of Study: Any country

Closing Date: 20 January

Additional Information: Please visit the website: www.lina cre.ox.ac.uk/prospective-students/scholarships for more information

\section{For further information contact:}

Email: rsc-msc@qeh.ox.ac.uk

\section{Linacre College: Women in Science Scholarship}

Subjects: Materials

Eligibility: Open to all graduate applicants for the DPhil in Materials who are liable to pay fees

Level of Study: Doctorate

Type: Scholarship

Value: College fee

Length of Study: Period of fee liability

Study Establishment: Linacre College

Country of Study: Any country

Closing Date: 21 April

Additional Information: Please visit the website: www. linacre.ox.ac.uk/prospective-students/scholarships for more information

\section{For further information contact:}

Email: support@linacre.ox.ac.uk

\section{Lincoln College: Berrow Foundation Lord Florey Scholarships}

Subjects: Medical, chemical or biochemical sciences

Eligibility: Open to all graduate applicants for courses in Medical, Chemical or Biochemical Sciences of Swiss or Lichtenstein nationality who are students at, or have recently graduated from, any Swiss university, including ETHZ and EPFL, and who must not be more than five years beyond graduation from their first degree at one of these institutions (except for candidates in medicine, for whom the five years limit dates from obtaining the Federal Diploma in Medicine). Up to two awards available. Please see website for full details and application form

Level of Study: Postgraduate, Research

Type: Scholarship

Value: University fee (at the United Kingdom level), college fee, and living expenses equivalent to Rhodes Scholarship stipend

Length of Study: Up to 3 years

Frequency: Annual

Study Establishment: Lincoln

Country of Study: Any country

Application Procedure: Please see website for details of how to apply

Closing Date: 18 January

Funding: Foundation

Additional Information: Please check the website: www. lincoln.ox.ac.uk/funding-and-awards-for-graduates for more information

\section{For further information contact:}

Email: info@lincoln.ox.ac.uk

\section{Lincoln College: Berrow Foundation Scholarships}

Eligibility: Open to all graduate applicants of Swiss or Lichtenstein nationality who are students at, or have recently graduated from, selected Swiss universities. Up to four awards available. Please see website for full details and application form

Level of Study: Postgraduate, Research

Type: Scholarship

Value: University fee (at the United Kingdom level), college fee, and living expenses equivalent to Rhodes Scholarship stipend

Length of Study: Up to 3 years

Frequency: Annual

Study Establishment: Lincoln

Country of Study: Any country 
Closing Date: 20 January

Funding: Foundation

Additional Information: Please check the website: www. lincoln.ox.ac.uk/funding-and-awards-for-graduates for more information

For further information contact:

Email: info@lincoln.ox.ac.uk

\section{Lincoln College: Crewe Graduate Scholarships}

Subjects: All subjects

Eligibility: Open to all

Level of Study: Graduate, Postgraduate, MBA

Type: Scholarship

Value: $£ 3,000$

Length of Study: One year, with the possibility of renewal on applying

Frequency: Annual

Study Establishment: Lincoln College, University of Oxford

Country of Study: United Kingdom

Application Procedure: Information will be made available when the college makes a conditional offer to candidates. For other details please see the website www.lincoln.ox.ac.uk

Closing Date: 1 August

Funding: Trusts

No. of awards given last year: 6

For further information contact:

Email: info@lincoln.ox.ac.uk

Contact: Admissions Office, Lincoln College

\section{Lincoln College: Hartley Bursary}

Eligibility: Open to all graduate students normally resident in the United Kingdom beginning, or continuing, on a course of study in the Humanities, who show evidence of financial need

Level of Study: Graduate

Type: Scholarship

Value: $£ 1,000$ per year

Length of Study: Up to 3 years

Study Establishment: Lincoln College

Country of Study: Any country

Application Procedure: Applicants must hold a place, or an offer of a place, at Lincoln College before making an application. Please see website for full details and application form

Closing Date: 1 June
Additional Information: Please visit the website: www.lin coln.ox.ac.uk/funding-and-awards-for-graduates for more information

For further information contact:

Email: info@lincoln.ox.ac.uk

\section{Lincoln College: Jermyn Brooks Graduate Award}

Subjects: Humanities, with a preference for modern languages

Eligibility: Open to graduate students of the college (other new or continuing) who are studying in the humanities, with a preference for modern languages

Level of Study: Postgraduate

Type: Scholarship

Value: UK£1,000

Length of Study: One year

Frequency: Annual

Study Establishment: Lincoln college, University of Oxford Country of Study: United Kingdom

Application Procedure: Application form available from Admissions Office at Lincoln College

Closing Date: First week of August

Funding: Private

For further information contact:

The Admissions Office Lincoln College

Email: info@lincoln.ox.ac.uk

\section{Lincoln College: Kenneth Seward-Shaw Scholarship}

Subjects: Law, history, politics, English

Eligibility: Open to graduates in Law, history, English or politics who have already been offered a place at Lincoln College

Level of Study: Postgraduate

Type: Scholarship

Value: UK£1,500

Length of Study: 1 year

Frequency: Annual

Study Establishment: Lincoln College, University of Oxford

Country of Study: United Kingdom

Application Procedure: Applicants must contact the Admissions Office

Funding: Private 


\section{For further information contact:}

Admissions Office, Lincoln College, 300 Keokuk St, Lincoln, Illinois 62656, United Kingdom

Email: info@lincoln.ox.ac.uk

\section{Lincoln College: Lord Crewe Graduate Scholarship in Medical Sciences (Clarendon-Linked)}

Subjects: All graduate courses within the Medical Sciences Division

Eligibility: Applicants must nominate Lincoln as their College of Preference and be considered for a Clarendon Fund Scholarship

Level of Study: Postgraduate, Research

Type: Scholarship

Value: All university and college fees and a generous living allowance (Clarendon-linked)

Length of Study: Period of fee liability

Country of Study: Any country

Closing Date: 20 January

Additional Information: Please check at www.clarendon. ox.ac.uk/partnership/ for more information

\section{For further information contact:}

Email: info@lincoln.ox.ac.uk

\section{Lincoln College: Lord Crewe Graduate Scholarship in Social Sciences (Clarendon-Linked)}

Subjects: All graduate courses within the Social Sciences Division

Eligibility: Applicants must nominate Lincoln as their College of Preference and be considered for a Clarendon Fund Scholarship

Level of Study: Postgraduate, Research

Type: Scholarship

Value: All university and college fees and a generous living allowance (Clarendon-linked)

Length of Study: Period of Fee liability

Frequency: Annual

Country of Study: Any country

Closing Date: 20 January

Additional Information: Please check at www.clarendon. ox.ac.uk/partnership/ for more information

\section{For further information contact:}

Email: info@lincoln.ox.ac.uk

\section{Lincoln College: Lord Crewe Graduate Scholarships in the Humanities}

Subjects: All graduate courses within the Humanities division

Eligibility: Open to graduates of any United Kingdom university for all courses within the Humanities

Level of Study: Postgraduate, Research

Type: Scholarship

Value: $£ 18,000$ per year

Length of Study: Period of fee liability

Country of Study: Any country

Application Procedure: Please see website for details of how to apply

Closing Date: 18 January

Additional Information: Please check at www.lincoln.ox. ac.uk/ for more information

\section{For further information contact:}

Email: info@lincoln.ox.ac.uk

\section{Lincoln College: Lord Crewe Graduate Scholarships in the Social Sciences}

Subjects: All graduate courses within the Social Sciences Division

Eligibility: Open to graduates of any United Kingdom university for all courses within the Social Sciences

Level of Study: Postgraduate, Research

Type: Scholarship

Value: $£ 18,000$ per year

Length of Study: Period of fee liability

Country of Study: Any country

Application Procedure: Please see website for details of how to apply

Closing Date: 18 January

Additional Information: Please check at www.lincoln.ox. ac.uk/ for more information

For further information contact:

Email: info@lincoln.ox.ac.uk

\section{Lincoln College: Menasseh Ben Israel Room}

Eligibility: Open to all graduate applicants who have graduated from an Israeli university. Preference will be shown to graduates of the Hebrew University, Jerusalem. Applicants must hold a place, or an offer of a place, at Lincoln College before making an application. Please see website for full details and application form 
Level of Study: Graduate, Postgraduate

Type: Scholarship

Value: Free accommodation for one academic year (37 weeks) as occupant of the Menasseh Ben Israel Room in college

Length of Study: 1 year

Country of Study: Any country

Application Procedure: Please see website for full details and application form

Closing Date: 1 June

Additional Information: Please check at www.lincoln.ox.ac. uk/funding-and-awards-for-graduates for more information

\section{For further information contact:}

Email: info@lincoln.ox.ac.uk

\section{Lincoln College: Overseas Graduate Entrance Scholarship}

Subjects: All subjects

Eligibility: All non-European Union nationals

Type: Scholarship

Value: $£ 2,300$

Length of Study: 1 year

Country of Study: Any country

Closing Date: 1 June

Additional Information: Successful candidates will show evidence of both academic merit and financial need. Applicants must hold a place, or an offer of a place, at Lincoln College before applying. Eligible to the nationals of Overseas

\section{For further information contact:}

Email: info@lincoln.ox.ac.uk

\section{Lincoln College: Polonsky Foundation Grants}

Eligibility: Open to all overseas graduate applicants who show evidence of financial need, academic merit and potential for good college citizenship

Type: Grant

Value: Approx. $£ 5,300$ per year

Length of Study: Up to 3 years

Study Establishment: Lincoln

Country of Study: Any country

Application Procedure: Applicants must hold a place, or an offer of a place, at Lincoln College before making an application. Please see website for full details and application form Closing Date: 3 June

Additional Information: Candidates may be new or current students and must be citizens of countries not in the European
Union. Please check the website: www.lincoln.ox.ac.uk/ funding-and-awards-for-graduates for more information

\section{For further information contact:}

Email: info@lincoln.ox.ac.uk

\section{Lincoln College: Sloane Robinson Foundation Graduate Awards}

Subjects: All subjects

Purpose: To fund those intending to pursue research programmes at Oxford

Eligibility: Open to all

Level of Study: Graduate, Postgraduate, Research, MBA

Type: Award

Value: $£ 5,000$ per year

Length of Study: 1 year, with the possibility of renewal on applying

Frequency: Annual

Study Establishment: Lincoln College, University of Oxford

Country of Study: United Kingdom

Application Procedure: Information will be made available when the college makes a conditional offer to candidates. Please see website www.lincoln.ox.ac.uk for further details

Closing Date: 1 June

Funding: Foundation

Additional Information: Successful candidates will show evidence of both academic merit and financial need. Applicants must hold a place, or an offer of a place, at Lincoln College before applying

For further information contact:

Email: info@lincoln.ox.ac.uk

Contact: Admissions Office, Lincoln College

\section{Lincoln College: Supperstone Law Scholarship}

Subjects: Law

Eligibility: Open to candidates reading for the BCL or the MJuris, with an emphasis or special interest in European or public law. Applicants must have an offer of a college place at Lincoln College

Level of Study: Postgraduate

Type: Scholarship

Value: UK£650

Length of Study: 1 year

Frequency: Annual

Study Establishment: Lincoln College, University of Oxford 
Country of Study: United Kingdom

Application Procedure: Applicants must contact the Admissions Office at Lincoln College

Funding: Trusts

\section{Lingyin Graduate Scholarship in Buddhist Studies}

Purpose: Oriental Studies

Eligibility: Open to current and incoming Master's or DPhil students whose study or research focuses on Buddhist Studies (including all areas, historical periods, and aspects of this field). Eligible incoming students will be considered automatically, but current students need to submit a Lingyin application form. Three scholarships available. Please see website for more details

Level of Study: Postgraduate

Type: Scholarship

Value: $£ 8,000$ tenable only for one year at a time. Students holding the scholarship who would wish to reapply for it for the following year would be required to submit a new application for that year, which would be considered competitively alongside other applications for that year

Length of Study: One year

Frequency: Annual

Country of Study: United Kingdom

Application Procedure: For more information, please visit the website: www.orinst.ox.ac.uk/administration/grants/ index.html

Closing Date: 22 January

Funding: Trusts

\section{For further information contact:}

Email: Buddhist-studies@email.arizona.edu

\section{Magdalen College: Perkin Research Studentship}

Subjects: All subjects

Eligibility: Open to all graduate applicants from Commonwealth countries for Chemistry

Level of Study: Research

Type: Studentship

Value: $£ 7,000$ per year

Length of Study: Period of fee liability

Country of Study: Any country

Application Procedure: Please see website for details of how to apply

Additional Information: Please check at www.magd.ox.ac.uk/ admissions_graduate/scholarships.shtml for more information
For further information contact:

Email: jane.sherwood@admin.ox.ac.uk

\section{Magdalen College: Student Support Fund Graduate Grants}

Subjects: All subjects

Eligibility: Graduate students already studying at Magdalen

Level of Study: Postgraduate, Research

Type: Grant

Value: According to individual circumstances

Length of Study: 1 year, renewable after review

Country of Study: Any country

For further information contact:

Email: senior.tutor@magd.ox.ac.uk

\section{Magdalen Hong Kong Scholarship}

Eligibility: Open to students who are ordinarily resident in Hong Kong and are citizens of the People's Republic of China (PRC). Candidates should be intending to return to Hong Kong or the PRC on completion of their studies

Level of Study: Postgraduate

Type: Scholarship

Value: Maximum of $£ 26,250$ per year as a contribution towards college and university tuition fees and living expenses

Length of Study: Up to 4 years

Application Procedure: Please see the website for further details

Closing Date: 22 January

Additional Information: Please visit www.magd.ox.ac.uk/ studying-here/as-a-graduate/scholarships-and-awards- 2 for more details and to register your interest

\section{For further information contact:}

Email: admissions@magd.ox.ac.uk

\section{Mansfield College: Adam von Trott Scholarship}

Subjects: MPhil politics

Eligibility: Open to German nationals applying to the two year MPhil in Politics. Please see website for more details Level of Study: Postgraduate, Research Type: Scholarship 
Value: University fee, college fee, living expenses up to $€ 20,000$ per annum

Length of Study: Duration of fee liability

Country of Study: Any country

Closing Date: 6 January

Additional Information: Please check the website: www. mansfield.ox.ac.uk/prospective/postgrad/scholarships.html for more information

For further information contact:

Email: avt.committee@outlook.com

\section{Mansfield College: Elfan Rees Scholarship}

Subjects: Theology

Purpose: To commencing studies towards a higher degree in the field of theology

Eligibility: Open to students on the MSt, MPhil, MLitt or DPhil in any branch of theology

Level of Study: Postdoctorate, Postgraduate, Research

Type: Scholarship

Value: $£ 3,000$ maintenance, college fee waiver, matching Faculty award up to $£ 5,000$

Length of Study: Up to 2 years

Country of Study: Any country

Closing Date: October

Additional Information: Please check at www.mansfield.ox. ac.uk/current/prizes-scholarships.html for more information

For further information contact:

Email: lodge@mansfield.ox.ac.uk

\section{Medical Sciences Doctoral Training Centre: British Heart Foundation Studentship in Cardiovascular Science}

Subjects: Cardiovascular science

Eligibility: Open to all applicants to the DPhil in Cardiovascular Science. All applicants are automatically considered for these awards

Level of Study: Doctorate

Type: Studentship

Value: Course fee, college fee, living expenses

Length of Study: 4 years

Country of Study: Any country

Closing Date: 6 January

Funding: Foundation
Additional Information: Please visit the website: www. medsci.ox.ac.uk/study/graduateschool/courses/dtc-structuredresearch-degrees/cardiovascular-science for more information

For further information contact:

Email: Graduate.School@medsci.ox.ac.uk

\section{Medical Sciences Doctoral Training Centre: Wellcome Trust Fellowship in Biomedical and Clinical Sciences}

Subjects: Biomedical and clinical sciences

Eligibility: Open to all applicants to the DPhil in Biomedical and Clinical Sciences. All applicants are automatically considered for these awards

Level of Study: Doctorate

Type: Fellowship

Value: Course fee, college fee, living expenses

Length of Study: 3 years

Country of Study: Any country

Closing Date: 6 January

Funding: Trusts

Additional Information: Please visit the website: www. medsci.ox.ac.uk/study/graduateschool/courses/dtc-structuredresearch-degrees/doctoral-training-fellowship-scheme-forclinicians for more information

For further information contact:

Email: christopher.buckley@kennedy.ox.ac.uk

\section{Medical Sciences Doctoral Training Centre: Wellcome Trust Studentship in Chromosome and Developmental Biology}

Subjects: Chromosome and developmental biology

Purpose: To provide students with training and supporting infrastructure to apply advanced biological imaging/super resolution microscopy, high-throughput sequencing method (and computational genomics for data analysis), advanced proteomics, and state of the art genome engineering

Eligibility: Open to all applicants to the DPhil in Chromosome and Developmental Biology. All applicants are automatically considered for these awards

Level of Study: Doctorate

Type: Studentship

Value: Course fee, college fee, living expenses

Length of Study: 4 years

Country of Study: Any country

Closing Date: 6 January 
Funding: Trusts

Additional Information: Please visit the website: www. medsci.ox.ac.uk/study/graduateschool/courses/dtc-structuredresearch-degrees/chromosome-and-developmental-biology for more information

For further information contact:

Email: enquiries@msdtc.ox.ac.uk

\section{Medical Sciences Doctoral Training Centre: Wellcome Trust Studentship in Genomic Medicine and Statistics}

Subjects: Genomics, statistics, bioinformatics and epidemiology

Purpose: Trains future scientific leaders who will work at the cutting edge of genomics in biomedical research and enable effective delivery into the clinic

Eligibility: Open to all applicants to the DPhil in Genomic Medicine and Statistics. All applicants are automatically considered for these awards

Level of Study: Doctorate

Type: Studentship

Value: Course fee, college fee, living expenses

Length of Study: 4 years

Country of Study: Any country

Closing Date: 6 January

Funding: Trusts

Additional Information: Please visit the website: www. medsci.ox.ac.uk/study/graduateschool/courses/dtc-structuredresearch-degrees/genomic-medicine-and-statistics for more information

\section{For further information contact:}

Email: enquiries@msdtc.ox.ac.uk

\section{Medical Sciences Doctoral Training Centre: Wellcome Trust Studentship in Infection, Immunology and Translational Medicine}

Subjects: Infection, immunology and translational medicine Purpose: Provides integrated training in infection and immunology, and how fundamental research can be translated into benefits for human health

Eligibility: Open to all applicants to the DPhil in Infection, Immunology and Translational Medicine. All applicants are automatically considered for these awards

Level of Study: Doctorate

Type: Studentship

Value: Course fee, college fee, living expenses

Length of Study: 4 years
Country of Study: Any country

Application Procedure: Applicants are suggested to select St Edmund Hall as their college choice. Please see the website for more details

Closing Date: 6 January

Funding: Trusts

Additional Information: Please visit the website: www medsci.ox.ac.uk/study/graduateschool/courses/dtc-structuredresearch-degrees/infection-immunology-and-translationalmedicine for more information

For further information contact:

Email: Graduate.School@medsci.ox.ac.uk

\section{Medical Sciences Doctoral Training Centre: Wellcome Trust Studentship in Ion Channels and Disease}

Purpose: Trains the student in a range of multidisciplinary approaches and embraces all aspects of ion channel and membrane transport research from protein structure, genetics and cell physiology to animal behaviour and human disease Eligibility: Open to all applicants to the DPhil in Ion Channels and Disease. All applicants are automatically considered for these awards

Level of Study: Doctorate

Type: Studentship

Value: Course fee, college fee, living expenses

Length of Study: 4 years

Country of Study: Any country

Application Procedure: Applicants who have no strong preference for a college are suggested to consider Green Templeton College or The Queen's College as their choice

Closing Date: 6 January

Funding: Trusts

Additional Information: Please visit the website: www. medsci.ox.ac.uk/study/graduateschool/courses/dtc-structuredresearch-degrees/ion-channels-and-membrane-transport-inhealth-and-disease-oxion for more information

For further information contact:

Email: enquiries@msdtc.ox.ac.uk

\section{Medical Sciences Doctoral Training Centre: Wellcome Trust Studentship in Neuroscience}

Subjects: Neuroscience

Purpose: Provides a wide range of skills training in experimental and theoretical methods that is intended to enable you to ask questions and tackle problems that transcend the traditional disciplines from which this field has evolved 
Eligibility: Open to all applicants to the Wellcome Trust combined MSc and DPhil in Neuroscience. All applicants are automatically considered for these awards

Level of Study: Doctorate

Type: Studentship

Value: Course fee, college fee, living expenses

Length of Study: 4 years

Country of Study: Any country

Closing Date: 6 January

Funding: Trusts

Additional Information: Please visit the website: www. medsci.ox.ac.uk/study/graduateschool/courses/dtc-structuredresearch-degrees/neuroscience for more information

\section{For further information contact:}

University of Oxford, Wellington Square, Oxford OX1 2JD, United Kingdom

Tel: (44) 1865270000

Email: enquiries@msdtc.ox.ac.uk

\section{Medical Sciences Doctoral Training Centre: Wellcome Trust Studentship in Structural Biology}

Subjects: Structural biology

Purpose: Provides training in structural biology and related biochemical, genetic and cell biological approaches to understand molecular and cellular function

Eligibility: Open to all applicants to the DPhil in Structural Biology. All applicants are automatically considered for these awards

Level of Study: Doctorate

Type: Studentship

Value: Course fee, college fee, living expenses

Length of Study: 4 years

Country of Study: Any country

Closing Date: 6 January

Funding: Trusts

Additional Information: Please visit the website: www. medsci.ox.ac.uk/study/graduateschool/courses/dtc-structuredresearch-degrees/cellular-structural-biology for more information

\section{For further information contact:}

Email: enquiries@msdtc.ox.ac.uk

\section{Merton College Leventis Scholarship}

Subjects: Greek studies from the Bronze Age to $1453 \mathrm{AD}$ Eligibility: Open to citizens of Greece or the Republic of Cyprus only
Level of Study: Graduate

Type: Scholarship

Value: Fees and maintenance

Length of Study: Up to 4 years depending on programme of study

Frequency: Every 2 years

Study Establishment: Merton College, University of Oxford Country of Study: United Kingdom

No. of awards offered: 10

Application Procedure: Further particulars and application forms are available from the Merton College website www. merton.ox.ac.uk/vacancies

Closing Date: End of January

Funding: Private

No. of applicants last year: 10

Additional Information: Prospective applicants should refer to the college website www.merton.ox.ac.uk for up-to-date information

\section{For further information contact:}

Merton College Merton Street, Oxford, OX1 4JD, United Kingdom

Email: julie.gerhardi@merton.ox.ac.uk

Contact: Admissions Office

\section{Merton College: Barton Scholarship}

Subjects: Law

Eligibility: Open to British graduate applicants for the BCL. Awarded with the Law Faculty. No separate application required

Level of Study: Graduate, Postgraduate

Type: Scholarship

Value: $£ 5,000$ per year

Length of Study: 1 year

Country of Study: Any country

Application Procedure: No separate application required

Closing Date: 22 January

Additional Information: Please check at www.merton.ox.ac. uk/graduate/graduate-scholarships-2015 for more information

\section{For further information contact:}

Email: jane.sherwood@admin.ox.ac.uk

\section{Merton College: Chemistry Scholarship}

\section{Subjects: Chemistry}

Eligibility: Open to Home/European Union applicants for any graduate Chemistry programme of study normally considered by the College. Please see website for more details 
Level of Study: Graduate

Type: Scholarship

Value: Course fees, college fees, full maintenance award (at RCUK rate)

Length of Study: Duration of fee liability

Study Establishment: Merton College

Country of Study: Any country

Closing Date: Relevant January deadline for your course

Additional Information: Please visit the website: www. merton.ox.ac.uk/graduate/graduate-scholarships for more information

\section{For further information contact:}

Tel: (44) 1865276310

\section{Merton College: Merton Lawyers}

\section{Subjects: BCL/MJur}

Eligibility: Open to graduate applicants for the BCL/MJur. No separate application required. Please see website for more details

Level of Study: Graduate, Postgraduate

Type: Scholarship

Value: $£ 5,000$ from each of the Faculty and College

Length of Study: 1 year

Frequency: Annual

Study Establishment: Merton

Country of Study: Any country

Closing Date: 20 January

Additional Information: Please check the website: www. merton.ox.ac.uk/graduate/graduate-scholarships for more information

\section{Merton College: Peter J Braam Global Wellbeing Graduate Scholarship}

Subjects: Biochemistry

Eligibility: Open to Home/European Union applicants for any graduate Biochemistry programme of study normally considered by the College. Please see website for more details

Level of Study: Doctorate

Type: Scholarship

Value: Course fees, college fees, full maintenance award (at RCUK rate)

Length of Study: Duration of fee liability

Country of Study: Any country

Application Procedure: Applicants wishing to be considered for this scholarship should apply for the DPhil in Biochemistry and state how their research addresses a problem related to global wellbeing
Closing Date: Relevant January deadline for your course Additional Information: Please visit the website: www. merton.ox.ac.uk/graduate/graduate-scholarships for more information

\section{For further information contact:}

Email: graduate.admissions@admin.ox.ac.uk

\section{Merton College: Two Merton Domus B Scholarships}

Subjects: All subjects for which the College normally considers

Purpose: To enable United Kingdom/European Union students pursue studies at Merton College

Eligibility: Home/European Union applicants

Level of Study: Graduate, Postgraduate, Research

Type: Scholarship

Value: All fees plus maintenance award of $£ 11,500$

Length of Study: Up to 4 years

Frequency: Annual

Study Establishment: Merton College, University of Oxford

Country of Study: United Kingdom

Application Procedure: Further particulars and application forms are available from the Merton College website www. merton.ox.ac.uk/vacancies/index.htm or from the Secretary for Graduates

Closing Date: 20 January

For further information contact:

Email: julie.gerhardig@merton.ox.ac.uk

Contact: Admissions Office

\section{New College: The Yeotown Scholarship in Science}

Eligibility: Open to all Home/European Union applicants to a research degree in Computer Science. The scholarship covers living costs and will be offered in conjunction with a departmental scholarship covering University and college fees. Please see website for more details

Level of Study: Postgraduate

Type: Scholarship

Value: Tuition and college fee plus maintenance stipend

Length of Study: Period of fee liability

Frequency: Annual

Study Establishment: New College

Country of Study: United Kingdom

Application Procedure: For more information, please check the website: www.new.ox.ac.uk/scholarships-0 
Closing Date: 8 January

Funding: Trusts

For further information contact:

Email: thenewcollege600014@gmail.com

\section{North American Electric Reliability Corporation (NERC) Studentships in Earth Sciences}

Subjects: Earth sciences

Purpose: To assist graduate students with fees and maintenance

Eligibility: Open to Home or European Union candidates usually with a 2.1 degree or higher

Level of Study: Research

Type: Studentship

Value: $£ 5,000$ per year

Length of Study: Duration of fee liability

Frequency: Annual

Country of Study: Any country

Application Procedure: 1. Upload a transcript from your current or previous study, a CV and any other documents that you feel would support your application (within 24 hours of submitting your online application you will receive a link allowing you to upload additional supporting documents). 2. Ask your referees to submit a reference for you by 29 April at the very latest. Note: when you submit your application, an email will automatically be sent to your referees requesting a reference for you. This email will contain a secure link for your referee to upload a reference for you. 3 . View the available projects. 4. Make an initial project enquiry by contacting supervisors directly

Closing Date: January

Additional Information: The Department will have a number of NERC studentships, to be confirmed. An European Union national who has studied for an undergraduate degree at a United Kingdom university during the 3 years leading up to the application may be classed as a United Kingdom resident

\section{For further information contact:}

Email: researchcareers@nerc.ac.uk

\section{Nuffield College Funded Studentships}

Subjects: Social sciences

Purpose: To assist students in a postgraduate degree course Eligibility: Open to persons with at least an Upper Second Class (Honours) Degree or equivalent

Level of Study: Postgraduate

Type: Studentship
Value: Maximum UK£14,500 (home and European Union students) UK£19,500 (overseas students), usually partial awards only

Length of Study: For the length of the course, subject to satisfactory progress up to 4 years

Frequency: Annual

Study Establishment: Nuffield College, University of Oxford Country of Study: United Kingdom

Application Procedure: All students offered a place at Nuffield College will automatically be considered for a studentship without the need for further application, other than the University of Oxford Graduate Admissions application form

Additional Information: Requests for information should be addressed to the Academic Administrator

\section{For further information contact:}

Nuffield College, New Rd, Oxford OX1 1NF UK, United Kingdom

Email: academic.administrator@nuffield.ox.ac.uk

Contact: Academic Administrator

\section{Nuffield College Guardian Research Fellowship}

Subjects: Media and broadcasting

Purpose: To support research on projects directly related to the media

Eligibility: Open to journalists or management staff members from fields of newspaper press, periodicals and broadcasting Level of Study: Professional development

Type: Fellowship

Value: Varies according to the fellow's financial circumstances and proposed research

Length of Study: 1 academic year

Frequency: Every 2 years

Study Establishment: Nuffield College, the University of Oxford

Country of Study: United Kingdom

Application Procedure: Applicants are required to submit $\mathrm{CV}$, research proposal, and names and addresses of three referees when the post is advertised

Closing Date: Mid-January

Funding: Commercial

Contributor: The Scott Trust

Additional Information: Preference will be given to proposals directly related to the applicant's experience of working in the media. The fellow will be asked to give the annual Guardian Lecture to members of the university and the public at some time during tenure. Requests for information should be addressed to the Warden's Secretary 


\section{For further information contact:}

Tel: (44) 1865278520

Fax: (44) 1865278676

Email: marion.rogers@nuf.ox.ac.uk

Contact: Warden's Secretary

\section{Nuffield College Gwilym Gibbon Research Fellowships}

Subjects: Problems of government, the subject having been approved by the college

Purpose: To support the study of problems of government, especially by co-operation between academic and non academic persons

Eligibility: Preference will be given to candidates with experience in some form of public service

Level of Study: Postdoctorate, Postgraduate, Professional development

Type: Fellowship

Value: To cover accommodation, necessary travel costs and some secretarial and other assistance

Length of Study: 1 year

Frequency: Annual

Study Establishment: Nuffield College, the University of Oxford

Country of Study: United Kingdom

Application Procedure: Write for application form

Closing Date: Mid-April

No. of awards given last year: 1

Additional Information: It is hoped that the results of the research will be published or made available in some way to interested persons. Requests for information should be addressed to the Student Administrator. Please note that the 1998-9 competition was suspended and that it is possible that it may not run in subsequent years. For further information please consult the Warden of the College

For further information contact:

Tel: $\quad$ (44) 1865278515

Fax: (44) 1865278621

Email: glynis.baleham@nuf.ox.ac.uk

Contact: Student Administrator

\section{Nuffield College ODA Shared Scholarship}

Subjects: Social sciences in taught postgraduate courses Eligibility: Graduates from developing countries of the Commonwealth are eligible to apply

Level of Study: Postdoctorate

Type: Studentship
Value: Fees and maintenance

Length of Study: Up to 3 years

Frequency: Annual

Study Establishment: Nuffield College, the University of Oxford

Country of Study: United Kingdom

Application Procedure: Applicants must submit a list of publications, a curriculum vitae, a synopsis of the proposed research and the names and addresses of three referees when the post is advertised

\section{For further information contact:}

Email: marion.rogers@nuf.ox.ac.uk

\section{Nuffield College Postdoctoral Prize Research Fellowship}

Subjects: Economics, politics, sociology, broadly constructed to include, for example, social science approaches to history, social and medical statistics, international relations and public policy

Purpose: To allow scholars who have recently completed, or who are close to the completion of, a doctoral dissertation, to engage in independent scholarly research in the social sciences Eligibility: Open to men and women who at the date of taking up the fellowship will not have spent more than eight years in postgraduate study, teaching or reseach in the social sciences Level of Study: Postdoctorate, Postgraduate

Type: Fellowship

Value: UK£21,044 plus single accommodation or a housing allowance, children's allowance and research expenses

Length of Study: 3 years

Frequency: Annual

Study Establishment: Nuffield College, University of Oxford Country of Study: United Kingdom

Closing Date: Beginning of November

No. of awards given last year: 4

For further information contact:

Email: justine.crump@nuffield.ox.ac.uk

Contact: Justine Crump, Administrative Officer

\section{Nuffield Department of Clinical Medicine: LICR Studentship (Ludwig Institute for Cancer Research)}

Eligibility: Minimum 2:1 or above, Higher level English language test. Open to United Kingdom, European Union and Overseas Students

Type: Studentship 
Value: All University and College fees plus stipend $£ 16,500$ per year

Length of Study: 3-4 years

Country of Study: Any country

Additional Information: Please check at www.ludwig.ox. ac.uk/ for more information

For further information contact:

Email: webmaster@ox.ac.uk

\section{Nuffield Department of Orthopaedics, Rheumatology and Musculoskeletal Sciences: Kennedy Trust Prize Studentships}

Subjects: Immunity and microbiome, inflammation, and tissue remodelling and regeneration

Purpose: To provide world-class scientific training in a supportive and collaborative environment

Eligibility: Both European Union and Overseas applicants for the DPhil in Molecular and Cellular Medicine are eligible for this award. Interested applicants should have or expect to obtain a first or upper second class BSc degree or equivalent, and will also need to provide evidence of English language competence at time of application

Level of Study: Doctorate

Type: Studentship

Value: A bursary of $£ 22,189$ per annum (for up to 4 years).

Fees at the Home/European Union rate. Consumables of $£ 11,000$ per annum (up to a value of $£ 44,000$ ). Travel costs of $£ 2,500$ over the duration of the award

Length of Study: 4 years

Frequency: Annual

Country of Study: Any country

Closing Date: 6 January

Additional Information: Please visit the website: www. ndorms.ox.ac.uk/graduate-courses/kennedy-trust-prize-stu dentships for more information

For further information contact:

Email: reception@kennedy.ox.ac.uk

\section{Nuffield Department of Population Health: NDPH Scholarship}

Eligibility: The department aims to provide up to two fully funded scholarships for the MSc each year. All applicants for the MSc in Global Health Science are eligible for this; the highest ranked applicants in the department are shortlisted for funding

Level of Study: Postgraduate
Type: Scholarship

Value: Course fee, College fee, living expenses at RCUK rate Length of Study: 1 year

Frequency: Annual

Country of Study: Any country

Closing Date: 6 January

Additional Information: Please visit the website: www. ndph.ox.ac.uk/study/for-postgraduates/fees-and-funding for more information

\section{For further information contact:}

Email: enquiries@ndph.ox.ac.uk

\section{Nuffield Department of Primary Care Health Science: NIHR School for Primary Care Research DPhil Studentship}

Purpose: The Health Sciences Research Group invites applications for 2011 NIHR School for Primary Care Research (NSPCR) PhD studentships

Eligibility: The award can only be taken up by a student enrolled on the DPhil in Primary Health Care programme in a non-clinical area

Level of Study: Doctorate

Type: Studentship

Value: Course fee up to Home/European Union level, college fee, stipend. Annual tax-free stipend of $£ 18,000$

Length of Study: 3 years

Frequency: Annual

Country of Study: Any country

Closing Date: 11 January

Additional Information: Please visit the website: www. phc.ox.ac.uk/study/dphil-and-msc-by-research/availablestudentships-are-listed-below for more information

For further information contact:

Radcliffe Observatory Quarter, Woodstock Road, Oxford OX2 6GG, United Kingdom

Tel: (44) 1865289300

\section{Ooni Adeyeye Enitan Ogunwusi Scholarships}

Purpose: The scholarship is funded by the Imperial Majesty Oba Adéyeyè Enitan Ògúnwùsì and aims to provide funding to exceptional candidates pursuing postgraduate study of Africa

Eligibility: Open to graduate applicants who are ordinarily resident in Nigeria and applying to a full- time one-year master's course within the African Studies Centre at Oxford 
Level of Study: Postgraduate

Type: Scholarship

Value: Course fee and a grant for living expenses of at least $£$ 14,777 per year

Frequency: Annual

Country of Study: Any country

Application Procedure: For further information, check the below link. www.ox.ac.uk/admissions/graduate/fees-andfunding/fees-funding-and-scholarship-search/scholarships2\#ooni

Closing Date: Relevant January deadline for your course Funding: Private

\section{For further information contact:}

University of Oxford, University Offices, Wellington Square, Oxford OX1 2JD, United Kingdom

Tel: $\quad$ (44) 1865270000

Email: joe@advance-africa.com

\section{Oriel College: Oriel Graduate Scholarships}

Subjects: All subjects

Eligibility: Open to all current graduate students at the college.

Please see website for more details, including how to apply

Level of Study: Postgraduate, Research

Type: Scholarship

Value: Approximately $£ 2,500$ per year and accommodation rights

Length of Study: Period of fee liability

Country of Study: Any country

Closing Date: 29 January

Additional Information: Scholars are entitled to dine free of charge at High Table once per week during term time. Please contact to Academic Assistant at academic.office@oriel.ox. ac.uk. Please check the website for further details www.oriel. ox.ac.uk/content/financial-support-postgraduates

\section{For further information contact:}

Email: jane.sherwood@admin.ox.ac.uk

\section{Oriel College: Paul Ries Collin Graduate Scholarship}

Subjects: Humanities

Eligibility: Open to current graduate students at Oriel

Level of Study: Postgraduate, Research

Type: Scholarship

Value: Annual stipend equivalent to college fee; guaranteed college room at usual charge
Length of Study: 1 year, renewable for second or third

Frequency: Annual

Country of Study: Any country

Closing Date: 27 January

Additional Information: Scholars are entitled to dine free of charge at High Table once a week during term-time

\section{For further information contact:}

Oriel College, Oriel Square, Oxford OX1 4EW, United Kingdom

Email: academic.office@oriel.ox.ac.uk

\section{Oriel College: Sir Walter Raleigh Scholarship}

Subjects: Environmental change and management

Purpose: To assist a student studying at the Environmental Change Institute for an MSc degree in Environmental Change and Management

Eligibility: Open to all applicants to the MSc in Environmental Change and Management. Please see website for more details, including how to apply

Level of Study: Postgraduate

Type: Scholarship

Value: $£ 4,000$

Length of Study: 1 year

Frequency: Annual

Country of Study: Any country

Application Procedure: Applicants can download an application form from the website www.ox.ac.uk/admissions/ index.html or obtain one from the Academic Office or the Environmental Change Institute

Closing Date: 30 April

Additional Information: The successful applicant will be expected to transfer their application to Oriel College if they have already been accepted by another college. Please check the website for further details www.oriel.ox.ac.uk/content/ financial-support-postgraduates

For further information contact:

Email: admissions@oriel.ox.ac.uk

Contact: Admissions Officer

\section{Oriental Studies: H.H. Sheikh Hamad bin Khalifa AI Thani Graduate Studentship in Contemporary Islamic Studies}

Purpose: Contemporary Islamic Studies

Eligibility: Open to applicants to the DPhil in Oriental Studies. The award is intended for any postgraduate student pursuing doctoral research in any field of 
Contemporary Islamic Studies. Please see website for more information

Level of Study: Doctorate

Type: Studentship

Value: University fee, college fee, and maintenance grant. The award is tenable from October for 1 year in the first instance, renewable for up to a maximum of 3 years subject to receipt of a satisfactory report from the supervisor(s)

Length of Study: Up to 4 years

Country of Study: Any country

Closing Date: 31 March

Additional Information: Please visit the website: www. orinst.ox.ac.uk/administration/grants/index.html for more information

\section{For further information contact:}

62 Woodstock Road, Oxford OX2 6JF, United Kingdom

\section{Oriental Studies: KS Scholarship in Chinese Art}

Subjects: Oriental Studies

Eligibility: Open to applicants to graduate degrees at the University in any field of Chinese Art History, with a preference for Chinese painting. Please see website for more details and how to apply

Level of Study: Postgraduate

Type: Scholarship

Value: University fee, college fee and living expenses

Length of Study: Period of fee liability

Frequency: Annual

Country of Study: United Kingdom

Application Procedure: For more information, please check the website: www.orinst.ox.ac.uk/administration/trust_funds/ ks_scholarship_in_chinese_art.html

Closing Date: 22 January

Funding: Trusts

For further information contact:

Email: orient@orinst.ox.ac.uk

\section{Oriental Studies: Sasakawa Fund}

Subjects: Japanese

Eligibility: Open to all graduate applicants in Oriental Studies, or United Kingdom applicants whose work will require some time spent in Japan

Level of Study: Postgraduate, Research

Type: Award

Value: $£ 5,000$ per year

Length of Study: Period of fee liability
Application Procedure: An application form is available at www.orinst.ox.ac.uk/general/grants/sasakawa_fund.html

Closing Date: 18 January

\section{For further information contact:}

Tel: (44) 1865278225

Fax: (44) 1865278190

Email: chris.williams@orinst.ox.ac.uk

\section{Other studentships in Earth Sciences}

Subjects: Earth sciences

Eligibility: Applicants must have 2.1 degree or higher. United Kingdom students are eligible for full support, and a range of support is available for European Union and international students

Level of Study: Research

Type: Studentship

Value: University and college fees and maintenance allowance Length of Study: Normally 3 years, which can be extended in some cases

Frequency: Dependent on funds available

Application Procedure: Candidates are advised to apply directly to the department as advertised on the website

Closing Date: 20 January

Additional Information: The department occasionally has studentship funding associated with grants or industrial funding

For further information contact:

Email: emmab@earth.ox.ac.uk

Contact: Emma Brown

\section{Oxford Research in the Scholarship and Humanities of Africa Studentships}

Subjects: Social and cultural anthropology, archaeology, history, human geography, African literature, politics and international relations, development studies; religious studies and sociology, subject to appropriate supervision being available Purpose: To support postgraduate study of Africa in the humanities

Eligibility: Open to candidates for admission, or those already registered as graduate students. The successful applicant, if not already a member of an Oxford College, may be offered a place at St Antony's College or St Cross College

Level of Study: Postgraduate

Type: Studentship

Value: Varies, however it will cover college and University fees plus maintenance allowance. University fees will normally be covered at the home rate, although in exceptional circumstances supplemental grants may be made in order to 
meet, or to go some way towards meeting, the difference between the home and overseas fee

Length of Study: 2 years with the possibility of extension for 3 and occasionally 4 years

Frequency: Annual

Study Establishment: University of Oxford

Country of Study: United Kingdom

Application Procedure: Refer to the website www. africanstudies.ox.ac.uk/orisha for details

\section{For further information contact:}

Email: african.studies@africa.ox.ac.uk

Contact: African Studies Administrator

\section{Oxford University Theological Scholarships (Eastern and Central Europe)}

\section{Subjects: Theology}

Purpose: To enable students to pursue further studies in the University's Faculty of Theology

Eligibility: Open to candidates aged 22-40, who already have, or expect to obtain, a theological degree from a recognized university or theological college. Applications are invited from citizens of Russia, the Ukraine and any other countries of the former Soviet Union (apart from the Baltic States), Croatia, Serbia, Montenegro, Bosnia, Macedonia, Bulgaria, Albania and Romania

Level of Study: Graduate

Type: Scholarship

Value: Fees, a maintenance allowance and, where necessary, a return airfare

Length of Study: Up to 1 year

Frequency: Annual

Study Establishment: The Faculty of Theology, University of Oxford

Country of Study: United Kingdom

Application Procedure: Applicants must contact Mrs Elizabeth Macallister for further information

Funding: Government, Private

Contributor: Member churches of the Council of Churches for Britain and Ireland, the Foreign and Commonwealth Office and Oxford University

Additional Information: Scholarships are open to members of any Christian denomination. Applicants must be sponsored by a recognised church authority in their home country

\section{For further information contact:}

Email: elizabeth.macallister@admin.ox.ac.uk

Contact: Mrs Elizabeth Macallister, Theology Faculty

\section{Oxford-A G Leventis Graduate Scholarship}

Subjects: History

Eligibility: Open to all applicants applying for a DPhil in history, specialising in Byzantine studies

Type: Scholarship

Value: University fee, college fee and full living expenses

Length of Study: Period of fee liability

Country of Study: Any country

Application Procedure: Please visit the website for application details

Closing Date: 22 January

Additional Information: Please check at www.graduate.ox. ac.uk/ogs for more information

\section{For further information contact:}

Email: peter.frankopan@worc.ox.ac.uk

\section{Oxford-Aidan Jenkins Graduate Scholarship}

Eligibility: Open to applicants who are applying to any fulltime course in the Faculty of English Language and Literature. Tenable at Merton College only. Please see website for more details

Type: Scholarship

Value: University fee, college fee, and full living expenses

Length of Study: Duration of fee liability

Study Establishment: Merton College

Country of Study: Any country

Closing Date: 20 January

Additional Information: Please visit the website: www.ox. ac.uk/admissions/graduate/fees-and-funding/fees-funding-andscholarship-search/scholarships-2\#aidanjenkins for more information

\section{Oxford-Bellhouse Graduate Scholarship}

Eligibility: Open to applicants who are ordinarily resident in the EEA or Switzerland and who are applying to the full-time DPhil in Engineering Sciences, specialising in Biomedical Engineering. The scholarship is only tenable at Magdalen College. Please see website for more details

Level of Study: Doctorate

Type: Scholarship

Value: University fee, college fee, and full living expenses

Length of Study: Period of fee liability

Study Establishment: Magdalen College

Country of Study: Any country

Closing Date: 20 January 
Additional Information: Please visit the website: www. ox.ac.uk/admissions/graduate/fees-and-funding/fees-fundingand-scholarship-search/scholarships-2\#bellhouse for more information

\section{For further information contact:}

Email: accommodation@linacre.ox.ac.uk

\section{Oxford-Brunsfield Association of Southeast Asian Nations (ASEAN) Human Rights Graduate Scholarships}

Eligibility: Open to applicants who are nationals of and ordinarily resident in Brunei Darussalam, Cambodia, Indonesia, Laos, Malaysia, Myanmar (Burma), Philippines, Singapore, Thailand or Vietnam and who are applying to the parttime MSt in International Human Rights Law. Please see website for more details

Level of Study: Postgraduate

Type: Scholarship

Value: University fee, college fee, and study support grant

Length of Study: Period of fee liability

Country of Study: Any country

Closing Date: 31 March

Additional Information: Please visit the website: www. ox.ac.uk/admissions/graduate/fees-and-funding/fees-fundingand-scholarship-search/scholarships-2\#brunsfield for more information

\section{For further information contact:}

Email: iphumrts@conted.ox.ac.uk

\section{Oxford-Calleva Scholarship}

Subjects: The project aims to investigate the network structure and dynamics of intra- and inter-group interactions in humans, with a focus on cooperation and competition

Purpose: It is intended to make available three scholarships for entry in October to applicants ordinarily resident in the European Union applying to the DPhil History (including History of Science and Medicine, and Economic and Social History), the DPhil Experimental Psychology, or the DPhil Anthropology

Eligibility: Each DPhil student will develop their own project within their respective discipline that explores childhood experiences and the impact of adversity and inequalities, using either psychological or modern British historical evidence

Level of Study: Doctorate

Type: Scholarship
Frequency: Annual

Country of Study: Switzerland

Application Procedure: The scholarship is only tenable at Linacre College. All eligible applicants will be considered for this scholarship, regardless of which college (if any) you state as your preference on the graduate application form

Closing Date: 1 January

Funding: Private

For further information contact:

Email:1ucy.bowes@psy.ox.ac.uk

\section{Oxford-Hoffmann Graduate Scholarships}

Subjects: The Oxford-Weidenfeld and Hoffmann Scholarships and Leadership Programme was established in 2015 thanks to generous donations from multiple donors to mark the 95th birthday of Lord Weidenfeld

Purpose: Fondation Hoffmann is a Swiss-based grant making institution supporting the emergence and expansion of concrete projects which address global problems in today's societies Eligibility: Open to applicants who are applying to any full or part-time course within the Medical Science Division. Tenable at Jesus College only

Level of Study: Graduate

Type: Scholarship

Value: $100 \%$ of course fees and a grant for living costs (at least $£ 14,777$ )

Length of Study: Duration of fee liability

Frequency: Annual

Study Establishment: Jesus College

Country of Study: Any country

Closing Date: 11 January

Additional Information: Please visit the website: www.ox.ac. uk/admissions/graduate/fees-and-funding/fees-funding-and-sch olarship-search/scholarships-2\#hoffmann for more information

\section{Oxford-Jerry Hausman Graduate Scholarship}

Subjects: The scholarship is only tenable at Nuffield College Eligibility: Open to all applicants applying for any graduate course in the departments of Economics, Politics, and Sociology. Tenable at Nuffield College only. Please see website for more details

Level of Study: Postgraduate

Type: Scholarship

Value: University fee, college fee, and full living expenses

Length of Study: Period of fee liability

Frequency: Annual

Study Establishment: Nuffield College 
Country of Study: United Kingdom

Application Procedure: For more information, please check the website: www.ox.ac.uk/admissions/graduate/feesand-funding/fees-funding-and-scholarship-search/scholarships2\#jerryhausman

Closing Date: 22 January

Funding: Trusts

Additional Information: One full scholarship is available for applicants who are applying to any full-time or part-time graduate course in the departments of Economics, Politics and International Relations and Sociology; preference will be given to applicants for Economics courses under OxfordJerry Hausman Graduate Scholarship

\section{For further information contact:}

Email: information@anthro.ox.ac.uk

\section{Oxford-John and Pat Cuckney Graduate Scholarship}

Eligibility: Open to applicants who are ordinarily resident in EEA or Switzerland and who are applying to the full-time DPhil in Particle Physics. Tenable at Lincoln College only

Level of Study: Doctorate

Type: Scholarship

Value: University fee, college fee, and a grant for living costs of $£ 14,553$ towards the tenable year

Length of Study: Duration of fee liability

Study Establishment: Lincoln College

Country of Study: Any country

Closing Date: 20 January

Additional Information: Please visit the website: www. ox.ac.uk/admissions/graduate/fees-and-funding/fees-fundingand-scholarship-search/scholarships-2\#cuckney for more information

\section{For further information contact:}

Email: dtcenquiries@dtc.ox.ac.uk

\section{Oxford-Keith Lloyd Graduate Scholarship}

Eligibility: Open to applicants ordinarily resident in sub-Saharan Africa (excluding South Africa), and who is studying for an MSc course in the School of Geography and the Environment. The scholarship is only tenable at Linacre College

Level of Study: Postgraduate

Type: Scholarship

Value: University fee, college fee, and a grant for living costs
Length of Study: 1 year

Study Establishment: Linacre College

Country of Study: Any country

Closing Date: 20 January

Additional Information: Please visit the website: www. ox.ac.uk/admissions/graduate/fees-and-funding/fees-fundingand-scholarship-search/scholarships-3\#keithlloyd for more information

\section{For further information contact:}

Email: shared.scholarships@cscuk.org.uk

\section{Oxford-Mary Jane Grefenstette Graduate Scholarship}

Eligibility: Open to all applicants applying for a DPhil in Computer Science or Philosophy, specialising in the crossover between the subjects. Tenable at Hertford College only. Please see website for more details

Level of Study: Postgraduate

Type: Scholarship

Value: University fee, college fee, and full living expenses

Length of Study: Period of fee liability

Frequency: Annual

Study Establishment: Hertford

Country of Study: United Kingdom

Application Procedure: For more information, please check the website: www.ox.ac.uk/admissions/graduate/fees-andfunding/fees-funding-and-scholarship-search/scholarships3 \#grefenstette

Closing Date: 22 January

Funding: Trusts

\section{For further information contact:}

Email: enquiries@cs.ox.ac.uk

\section{Oxford-Mitsui \& Co. Europe PLC Graduate Scholarships}

Purpose: Two full scholarships are available for applicants ordinarily resident in Africa, and who are applying for the full-time MSc in African Studies

Eligibility: Open to applicants ordinarily resident in Africa, applying for the full-time MSc in African Studies. You are applying to start a new graduate course; Y You submit your course application by the relevant January admissions deadline;; You are subsequently offered a place after consideration of applications received by the deadline;; Your application is not placed on a waiting list or held back after the January admissions deadline to be re-evaluated against applications 
received by the March admissions deadline; and You meet the eligibility criteria. This content was originally published on After School Africa from www.afterschoolafrica.com/17003/ oxford-mitsui-scholarships/

Level of Study: Postgraduate

Type: Scholarship

Value: covers Course fees, college fees and a grant for living costs of at least $£ 14,553$

Length of Study: Period of fee liability

Frequency: Annual

Study Establishment: University of Oxford

Country of Study: Any country

Closing Date: May

Funding: Trusts

Additional Information: For more information, please check the website: www.ox.ac.uk/admissions/graduate/feesand-funding/fees-funding-and-scholarship-search/scholarships3\#mitsui

\section{For further information contact:}

Email: webmaster@ox.ac.uk

\section{Oxford-Nizami Ganjavi Graduate Scholarships}

Purpose: The University of Oxford will soon be home to a dedicated centre for the study of Azerbaijan, the Caucasus and Central Asia, thanks to generous philanthropic support from the British Foundation for the Study of Azerbaijan and the Caucasus (BFSAC)

Eligibility: Open to applicants applying for any full or parttime DPhil or Master's course offered by the Humanities or Social Sciences Division where the course content relates to the study of the history, languages and cultures of Azerbaijan, the Caucasus and Central Asia. Please see the website for further details, including how to apply

Level of Study: Graduate

Type: Scholarship

Frequency: Annual

Country of Study: Any country

Closing Date: Relevant January deadline for your course

Funding: Private

\section{For further information contact:}

Tel: (44) 1865270000

Fax: (44) 1865270708

\section{Oxford-Oak Foundation Clinical Medicine}

Eligibility: Open to applicants who are applying to the fulltime DPhil in Clinical Medicine, specializing in Tropical
Medicine and Global Health, with a preferences for the candidates to be ordinarily resident in Nepal, Zimbabwe, Kenya and Vietnam

Level of Study: Doctorate

Type: Scholarship

Value: University fee, college fee, and full living expenses

Length of Study: Duration of fee liability

Country of Study: United Kingdom

Closing Date: 6 January

Additional Information: Please visit the website: www.ox.ac. uk/admissions/graduate/fees-and-funding/fees-funding-andscholarship-search/scholarships-3\#oak for more information

\section{Oxford-Particle Physics Graduate Scholarship}

Eligibility: Open to applicants who are applying to the fulltime DPhil Particle Physics course

Level of Study: Doctorate

Type: Scholarship

Value: University fee, college fee, and full living expenses

Length of Study: Duration of fee liability

Country of Study: Any country

Closing Date: 20 January

Additional Information: Please visit the website: www.ox.ac. uk/admissions/graduate/fees-and-funding/fees-funding-andscholarship-search/scholarships-3\#particlephysics for more information

\section{For further information contact:}

Email: contact@physics.ox.ac.uk

\section{Oxford-Percival Stanion Graduate Scholarship in Biochemistry}

Eligibility: Open to applicants who are applying to the DPhil Biochemistry or MSc by Research Biochemistry. Tenable at Pembroke College only. Please see the website for more details

Level of Study: Doctorate, Postgraduate

Type: Scholarship

Value: University fee, college fee, and a grant for living costs

Length of Study: Period of fee liability

Study Establishment: Pembroke College

Country of Study: Any country

Closing Date: 6 January

Additional Information: Please visit the website: www.ox. ac.uk/admissions/graduate/fees-and-funding/fees-funding-andscholarship-search/scholarships-3\#percivalstanion for more information 


\section{For further information contact:}

Email: ioannis.vakonakis@bioch.ox.ac.uk

\section{Oxford-Qatar-Thatcher Graduate Scholarships}

Eligibility: Candidates who have been accepted to study at the University of Oxford on a graduate course offered by the Faculty of English Language and Literature, Department of Engineering Science or Faculty of Law. There is a preference for students ordinarily resident in Algeria, Bahrain, Egypt, Iraq, Jordan, Kuwait, Lebanon, Libya, Morocco, Oman, Palestine, Qatar, Saudi Arabia, Sudan, Syria, Tunisia, United Arab Emirates or Yemen

Level of Study: Postgraduate

Type: Scholarship

Value: Tuition fees, college fees and a grant for living costs

Length of Study: Period of fee liability

Frequency: Annual

Study Establishment: Somerville College

Country of Study: Any country

Closing Date: 20 January

Funding: Trusts

Additional Information: Please visit the website: www some.ox.ac.uk/studying-here/fees-funding/thatcher-scholar ships/ for more information

For further information contact:

Email: academic.office@some.ox.ac.uk

\section{Oxford-Robert and Soulla Kyprianou Graduate Scholarship}

Purpose: The University of Oxford is currently accepting applications for the Oxford-Robert and Soulla Kyprianou Program. This fully-funded scholarship is exclusively open to students from Republic of Cyprus

Eligibility: Open to applicants ordinarily resident in the Republic of Cyprus, applying for any full- or part-time master's or DPhil course offered by Brasenose College. This scholarship is open to applicants who are ordinarily resident in the Republic of Cyprus and who are applying for a full- or part-time master's or DPhil course, within the range accepted by Brasenose College

Level of Study: Doctorate, Postgraduate

Type: Scholarship

Value: University fee, college fee, and full living expenses

Length of Study: Period of fee liability

Study Establishment: Brasenose College

Country of Study: United Kingdom

Closing Date: 6 or 20 January, depending on your course
Additional Information: The scholarship is only tenable at Brasenose College. Please check the website: www.ox.ac.uk/ admissions/graduate/fees-and-funding/fees-funding-and-scholar ship-search/scholarships-3\#kyprianou for more information

\section{For further information contact:}

Email: contact@scholarshipdesk.com

\section{Oxford-Rothermere American Institute Graduate Scholarship}

\section{Subjects: History}

Eligibility: Open to applicants who are ordinarily resident in the EEA and who are applying to a full- or part-time DPhil in History, specialising in American History. The scholarship is ordinarily tenable at University College. Please see website for more details

Level of Study: Doctorate

Type: Scholarship

Value: University fee, college fee, and full living expenses

Length of Study: Period of fee liability

Study Establishment: University College

Country of Study: Any country

Closing Date: 20 January

Additional Information: Please visit the website: www.ox. ac.uk/admissions/graduate/fees-and-funding/fees-fundingand-scholarship-search/scholarships-3\#rothermere for more information

For further information contact:

Email: enquiries@rai.ox.ac.uk

\section{Oxford-Sir Anwar Pervez Graduate Scholarships}

Purpose: The scholarship is funded by the Imperial Majesty Oba Adéyeyè Enitan Ògúnwùsì and aims to provide funding to exceptional candidates pursuing postgraduate study of Africa

Eligibility: 1. Open to applicants ordinarily resident in Pakistan, who have not previously studied for an HE qualification outside of Pakistan. 2. Candidates can be applying for any graduate course. Scholars to be selected on the basis of academic merit and financial need. Please see the website for further details

Level of Study: Postgraduate

Type: Scholarship

Value: University fee, college fee, and full living expenses of at least $€ 14,777$

Length of Study: Period of fee liability

Frequency: Annual 
Country of Study: United Kingdom

Application Procedure: For more information, please check the website: www.ox.ac.uk/admissions/graduate/fees-andfunding/fees-funding-and-scholarship-search/scholarships3\#pervez

Closing Date: Relevant January deadline for your course Funding: Trusts

\section{For further information contact:}

Tel: $\quad$ (44) 1865611530

Email: enquiries@devoff.ox.ac.uk

\section{Oxford-Sir David Weatherall Graduate Scholarship}

Eligibility: Open to applicants who are applying to a full-time DPhil in Medical Sciences, based at the Weatherall Institute of Molecular Medicine. The scholarship is only tenable at Green Templeton College

Level of Study: Doctorate

Type: Scholarship

Value: University fee, college fee, and full living expenses

Length of Study: Duration of fee liability

Study Establishment: Green Templeton College

Country of Study: Any country

Closing Date: 6 January

Additional Information: Please visit the website: www. ox.ac.uk/admissions/graduate/fees-and-funding/fees-fundingand-scholarship-search/scholarships-3\#weatherall for more information

\section{For further information contact:}

Email: development@gtc.ox.ac.uk

\section{Oxford-Swire Graduate Scholarship}

Eligibility: Open to all applicants for any full- or part-time master's and DPhil courses in the Faculty of History, within the range accepted by University College

Level of Study: Doctorate, Postgraduate

Type: Scholarship

Value: University fee, college fee, and full living expenses

Length of Study: Period of fee liability

Country of Study: Any country

Closing Date: 20 January

Additional Information: The scholarship is only tenable at University College. Please check the website: www.ox.ac.uk/ admissions/graduate/fees-and-funding/fees-funding-and-scho larship-search/scholarships-3\#swire for more information

\section{For further information contact:}

Email: scholarships@jsshk.com

\section{Oxford-TrygFonden Graduate Scholarship}

Purpose: One full scholarship is available for applicants who are ordinarily resident in Denmark and who are applying for one of the following courses (preference will be given to courses in the order listed): MSc Evidence-Based Social Intervention and Policy Evaluation; MSc Education, with a speciality in Research Training

Eligibility: Open to applicants ordinarily resident in Denmark who are applying to various master's courses. One full scholarship is available for applicants who are ordinarily resident in Denmark and who are applying for one of the following courses (preference will be given to courses in the order listed): MSc Evidence-Based Social Intervention and Policy Evaluation; MSc Education, with a speciality in Research Training

Level of Study: Postgraduate

Type: Scholarship

Value: It covers the expenditure of about $£ 14,777$ (students on part-time courses will receive a study support grant instead)

Length of Study: Period of fee liability

Frequency: Annual

Country of Study: Any country

Application Procedure: 1. The eligibility criteria will be applied automatically, using the details you provide in the relevant sections of the graduate application form (for example, your country of ordinary residence and your previous education institutions), to determine whether you are eligible. 2. Selection is based on academic merit, unless specified otherwise. Some of the scholarships are only tenable at specific colleges. Unless specified otherwise, you do not need to select that college as your preference on the graduate application form. All eligible applicants will be considered, regardless of which college (if any) you state as your preference. However, successful applicants will be transferred to the relevant college in order to take up the scholarship

Closing Date: Relevant January deadlines

Funding: Private

Additional Information: Please check the website: www. ox.ac.uk/admissions/graduate/fees-and-funding/fees-fundingand-scholarship-search/scholarships-3\#trygfonden for more information. Selection process is expected to take place on April

\section{For further information contact:}

Tel: (44) 1865270000

Fax: (44) 1865270708 


\section{Oxford-Urquhart-RAI Graduate Scholarship}

Eligibility: Open to applicants who are ordinarily resident in the EEA or Switzerland and who are applying to a DPhil in Politics, specializing in American Politics

Value: University fee, college fee and full living expenses

Length of Study: Period of fee liability

Country of Study: Any country

Closing Date: 6 January

Additional Information: For more details, please visit www. ox.ac.uk/admissions/graduate/fees-and-funding/fees-fundingand-scholarship-search/scholarships-3\#urquhart

\section{For further information contact:}

Email: enquiries@rai.ox.ac.uk

\section{Oxford-Wadham Graduate Scholarships for Disabled Students}

Purpose: Scholarships are awarded to applicants who have demonstrated excellent academic ability, who will contribute to the University's ground-breaking research, and who will go on to contribute to the world as leaders in their field, pushing the frontiers of knowledge

Eligibility: Open to all applicants applying to any full- and part-time master's courses offered by Wadham College, who have a disability as defined by the Equality Act and determined by the University's Disability Advisory Service

Level of Study: Postgraduate

Type: Scholarship

Value: University fee, college fee, and a grant for living costs Length of Study: Period of fee liability

Frequency: Annual

Study Establishment: Wadham College

Country of Study: Any country

Closing Date: Relevant January deadline for your course

Funding: Trusts

Additional Information: The scholarship is only tenable at Wadham College. For more information, please check the website: www.ox.ac.uk/admissions/graduate/fees-and-funding/ fees-funding-and-scholarship-search/scholarships-3\#wadham

For further information contact:

Email: graduate.admissions@wadham.ox.ac.uk

\section{Oxford-Weidenfeld and Hoffmann Scholarships and Leadership Programme}

Purpose: The Oxford-Weidenfeld and Hoffman Scholarship and Leadership Programme supports outstanding students from transition and emerging economies throughout Africa,
Eligibility: Open to applicants from selected countries to selected courses. Please see website for more details and how to apply, including closing dates

Level of Study: Postgraduate

Type: Scholarship

Value: $100 \%$ of University fee, college fee, and full living expenses. Average cost of at least $£ 14,777$ being covered

Length of Study: Period of fee liability

Frequency: Annual

Country of Study: Any country

Closing Date: 11/ 25 January (annual)

Funding: Trusts

Additional Information: For more information, please check the website: www.graduate.ox.ac.uk/weidenfeld-oxford

\section{For further information contact:}

Weidenfeld-Hoffmann Trust, Saïd Business School, Park End Street, Oxford OX1 1HP, United Kingdom

Email: info@whtrust.org

\section{Oxford-Wolfson-Ancient History Graduate Scholarship}

Eligibility: Open to applicants ordinarily resident in the EEA or Switzerland, applying for any graduate course in Ancient History, preferably with a focus on economics and banking. Tenable at Wolfson College only. Please see website for more details

Level of Study: Postgraduate

Type: Scholarship

Value: University fee, college fee, and full living expenses

Length of Study: Period of fee liability

Frequency: Annual

Study Establishment: Wolfson

Country of Study: United Kingdom

Application Procedure: For more information, please check the website: www.ox.ac.uk/admissions/graduate/fees-andfunding/fees-funding-and-scholarship-search/scholarships$3 \#$ wolfsonancienthistory

Closing Date: 22 January

Funding: Trusts

For further information contact:

Wolfson College, Linton Road, Oxford OX2 6UD, United Kingdom

\section{Oxford-Wolfson-Min Sunshik Graduate Scholarship in Modern Korean Literature}

Eligibility: Open to applicants who are ordinarily resident in the EEA or Switzerland and who are applying to the full-time 
MSt Korean Studies. Preference will be given to applicants focussing on Modern Korean Literature and Translation Studies

Level of Study: Postgraduate

Type: Scholarship

Value: University fee, college fee, and a grant for living expenses

Length of Study: Period of fee liability

Frequency: Annual

Study Establishment: Wolfson College

Country of Study: Any country

Closing Date: 20 January

Funding: Trusts

Additional Information: he scholarship is only tenable at Wolfson College. For more information, please check the website: www.ox.ac.uk/admissions/graduate/fees-andfunding/fees-funding-and-scholarship-search/scholarships3\#minsunshik

\section{Pembroke College Jose Gregorio Hernandez Award of the Venezuelan National Academy of Medicine}

Subjects: Medicine or the biological sciences

Eligibility: Open to nationals of Venezuela. Students must be nominated by the Venezuelan National Academy of Medicine and then accepted by the General Medical Council

Level of Study: Postgraduate

Type: Stipendiary

Value: Full fees and maintenance

Length of Study: 1 year, renewable for a further year

Frequency: Dependent on funds available

Study Establishment: Pembroke College, University of Oxford

Country of Study: United Kingdom

Application Procedure: Applicants must write or email the Admissions Secretary for details

Funding: Private

\section{For further information contact:}

Pembroke College, CB2 1RF, Cambridge, United Kingdom

Email: admissions@pmb.ox.ac.uk

Contact: Admissions Secretary

\section{Pembroke College: Gordon Aldrick Scholarship}

Subjects: Chinese cultural studies

Purpose: To assist scholars in Chinese cultural studies

Eligibility: Open to candidates beginning a two or three-year research degree at Oxford
Level of Study: Research

Type: Scholarship

Value: $£ 5,000$ per year towards college fee and contribution towards living expenses

Length of Study: Tenable for up to three years whilst the recipient is liable to pay University and College fees. Automatically renewed each year if satisfactory academic progress is made

Frequency: Annual

Country of Study: Any country

Application Procedure: Intending candidates should apply in Section L of the Oxford University graduate application form or notify the Admissions \& Access Officer at Pembroke Closing Date: 1 May

\section{For further information contact:}

Email: jane.sherwood@admin.ox.ac.uk

\section{Pembroke College: Tokyo Electric Power Company (TEPCO) Scholarship}

Subjects: Japanese studies

Eligibility: Open to all graduate applicants specialising in studies of Japanese literature, art or history. Please see website for details of how to apply at www.pmb.ox.ac.uk/Students/ Graduate_Students/Scholarships_Awards/Graduate_Scholar ships.php

Level of Study: Research

Value: $£ 5,000$ per year towards college fee and contribution towards living expenses

Length of Study: Period of fee liability

Country of Study: Any country

Closing Date: 3 May

For further information contact:

Email: ben.nicholson@admin.ox.ac.uk

\section{Philosophy Faculty-Wolfson College Joint Scholarship}

Subjects: Philosophy

Eligibility: Open to Home/European Union graduate applicants to DPhil courses in the Faculty of Philosophy. Eligible applicants for these courses are automatically considered. Please see website for more information

Level of Study: Postgraduate

Type: Scholarship

Value: University fee, college fee, and living expenses

Length of Study: Period of fee liability

Frequency: Annual

Study Establishment: Wolfson 
Country of Study: United Kingdom

Application Procedure: For more information, please check the website: www.philosophy.ox.ac.uk/admissions/graduate/ graduate_funding

Closing Date: 8 January

Funding: Trusts

\section{For further information contact:}

Email: graduatestudies@mml.cam.ac.uk

\section{Physics: Engineering and Physical Sciences Research Council (EPSRC) and Doctoral Training Grant Studentships}

Eligibility: United Kingdom residents are eligible for full awards, including fees and maintenance; European Union residents are eligible for awards covering fees only. European Union Students who have studied in the United Kingdom for the previous 3 years are eligible for a full award. The Department automatically considers all eligible applicants who have been offered places and who have applied by the January deadline

Type: Studentship

Value: University fee, college fee, and living expenses (European Union fee-only awards)

Length of Study: Period of fee liability

Country of Study: Any country

Application Procedure: Please visit the website for application details

Closing Date: 22 January

Additional Information: Please check at www2.physics.ox. ac.uk/study-here/postgraduates/fees-and-funding for more information

\section{Pirie-Reid Scholarships}

Subjects: All subjects

Purpose: To enable persons who would otherwise be prevented by lack of funds to begin a course of study at Oxford Eligibility: Preference will be given to candidate's who have lived in or been educated in Scotland, who are applying from other universities (i.e. not already studying at Oxford)

Level of Study: Doctorate, Postgraduate

Type: Scholarship

Value: University and college fees normally at the home rate plus maintenance grant, subject to assessment of income from other sources

Length of Study: Renewable from year to year, subject to satisfactory progress and continuance of approved full-time study
Frequency: Annual

Study Establishment: University of Oxford

Country of Study: United Kingdom

Application Procedure: Candidates must apply for admission to the University through the Graduate Admissions Office (www.admin.ox.ac.uk/gsp). Scholarship application forms are available at www.admin.ox.ac.uk/io

Closing Date: 1 May

Funding: Private

Additional Information: Preference will be given to candidates domiciled or educated in Scotland. Candidates not fulfilling these criteria are unlikely to be successful

\section{For further information contact:}

Email: student.funding@admin.ox.ac.uk

\section{Politics and International Relations: ESRC DTC +3 Studentships (Doctoral Awards)}

Subjects: DPhil in Politics and International Relations Eligibility: Open to all United Kingdom applicants for DPhil Politics and DPhil International Relations. Other European Union nationals are eligible for a fees-only award

Level of Study: Graduate, Postdoctorate

Type: Studentship

Value: University fee, college fee and full living expenses

Length of Study: Period of fee liability

Country of Study: Any country

Application Procedure: Please visit website for more details and how to apply

Closing Date: 9 January

Additional Information: Please check at www.politics. ox.ac.uk/index.php/student-funding/student-funding.html for more information

\section{For further information contact:}

Email: r.llewellyn@bbk.ac.uk

\section{Radcliffe Department of Medicine: RDM Scholars Programme}

Eligibility: Open to basic science applicants of any nationality applying for projects based within the Radcliffe Department of Medicine. Please see additional information on personal statement on the RDM webpage

Value: All fees and living expenses of $£ 18,000$ per annum

Length of Study: 4 years

Country of Study: Any country

Closing Date: 6 January 
Additional Information: For more details, please visit www. rdm.ox.ac.uk/rdm-scholars-programme

\section{For further information contact:}

Email: graduate.enquiries@rdm.ox.ac.uk

\section{Radiation Oncology \& Biology: Departmental Studentships}

Purpose: To provide comprehensive preparation for a career in research or industry, whether in radiobiology, protection or the advancement of cancer treatments

Eligibility: Open to home/European Union and overseas students

Level of Study: Postgraduate, Research

Type: Studentship

Value: University and college fees at the home/European Union rate, stipend, research expenses and support with travel to conferences

Length of Study: Up to 4 years

Frequency: Annual

Closing Date: March

Contributor: Cancer Research United Kingdom(United Kingdom) or Medical Research Council(MRC)

Additional Information: The Medical Research Council (MRC) awards have residency requirements

\section{For further information contact:}

Tel: $\quad$ (44) 1865617373

Email: sarah.norman@oncology.ox.ac.uk

Contact: Dr Sarah Norman, Course Coordinator

\section{Regent's Park College: Eastern European Scholarship}

Subjects: Theology

Eligibility: Open to new or continuing graduate in theology from Central and Eastern Europe. Preference is shown for members of the Baptist denomination

Level of Study: Postgraduate, Research

Type: Scholarship

Value: Up to the amount of the College Fee each year

Length of Study: Up to 3 years

Frequency: Annual

Application Procedure: Please visit website for more details and how to apply

Closing Date: 1 February

Additional Information: Please check at www.rpc.ox.ac.uk/ index.php?pageid $=272 \&$ tln $=$ Courses for further details
For further information contact:

Regent's Park College, Pusey Street, Oxford OX1 2LB UK, United Kingdom

Tel: (44) 1865288120

Fax: (44) 1865288121

Email: enquiries@regents.ox.ac.uk

\section{Regent's Park College: Ernest Payne Scholarship}

\section{Subjects: Theology}

Eligibility: Open to all new and continuing United Kingdom graduate students of theology. Preference is shown for those preparing for the Baptist ministry

Level of Study: Postgraduate, Research

Type: Scholarship

Value: Up to the amount of the College Fee each year

Length of Study: 2 years initially

Application Procedure: Please visit website for more details and how to apply

Closing Date: 1 May

Additional Information: Scholarship is awarded over 2 years, extendable in proportion for a 3 rd year. Please check at www.rpc.ox.ac.uk/index.php?pageid $=272 \&$ tln $=$ Courses for further details

\section{Regent's Park College: Henman Scholarship}

Subjects: Theology

Eligibility: Open to all graduate applicants in Theology

Level of Study: Postgraduate, Research

Type: Scholarship

Value: Up to the amount of the College Fee each year

Length of Study: Period of fee liability

Application Procedure: Please see website for details of how to apply

Closing Date: 1 May

Additional Information: Eligible to overseas nationals. Please check the website www.rpc.ox.ac.uk for further details

For further information contact:

Email: larry.kreitzer@regents.ox.ac.uk

Contact: Dr Larry Kreitzer, Graduate Studies Tutor

\section{Regent's Park College: J W Lord Scholarship}

Subjects: Theology

Eligibility: Open to all graduate applicants in Theology that are preparing to serve Christian churches in India, Hong Kong 
or China, or otherwise in Asia, Africa, Central and South America and the Caribbean

Type: Scholarship

Value: Up to the value of the College Fee each year

Length of Study: Up to 3 years

Frequency: Annual

Application Procedure: Please see website for details of how to apply

Closing Date: 1 May

Additional Information: Eligible to overseas countries. Please check the website www.rpc.ox.ac.uk/index.php? pageid $=272 \&$ tln $=$ Courses for further details

\section{Roche-Law Faculty Scholarship}

Subjects: Law

Eligibility: Open to all graduate applicants to BCL/MJur, MSc in Law and Finance, MSt Legal Research, MPhil or DPhil Law. Award holders will become members of New College. Please see website for more information

Level of Study: Doctorate, Graduate, Postgraduate, Research Type: Scholarship

Value: $£ 10,000$

Length of Study: Dependent on fee liability

Study Establishment: New College

Country of Study: Any country

Closing Date: 20 January

Additional Information: Please visit the website: www.law. ox.ac.uk/postgraduate/scholarships.php for more information

\section{For further information contact:}

Email: student.finance@new.ox.ac.uk

\section{Sasakawa Fund Scholarships}

Subjects: All subjects that require some period of study in Japan

Eligibility: Candidates must be Japanese nationals or students from countries other than Japan whose course at the University of Oxford requires some period of study in Japan Level of Study: Doctorate, Graduate, Postgraduate

Type: Scholarship

Value: Up to UK£5,000

Length of Study: 1 year in the first instance, with the possibility of renewal for a maximum of 3 years, subject to satisfactory progress

Frequency: Annual

Study Establishment: University of Oxford

Country of Study: United Kingdom

Application Procedure: Applicants must complete the relevant section of the graduate admission form available at www. admin.ox.ac.uk/gsp Applicants from the United Kingdom should contact the Secretary of the Sasakawa Fund

Closing Date: 1 March

Additional Information: Applicants must either have been accepted by the University of Oxford to undertake a research degree as a probationer research or DPhil student, or be currently undertaking such a course

\section{For further information contact:}

Tel: $\quad$ (44) 1865278225

Fax: (44) 1865278190

Email: sasakawa@massey.ac.nz

Contact: Secretary

\section{Sasakawa Postgraduate Studentship in Japanese Studies}

Subjects: Japanese studies

Eligibility: The Nissan Institute of Japanese Studies, University of Oxford invites applications for up to three Sasakawa Postgraduate Studentships in Japanese Studies, with the generous support by the Nippon Foundation and the Great Britain Sasakawa Foundation. The studentship consists of $£ 10,000$ for either MSc or MPhil course in Japanese studies or DPhil research which focuses on any aspect of Japan

Level of Study: Doctorate, Postgraduate, Research

Type: Studentship

Value: $£ 10,000$

Length of Study: 1 year

Country of Study: Any country

Application Procedure: Please see website for more details, including how to apply

Closing Date: 20 January

Additional Information: Please check the website: www. nissan.ox.ac.uk/sasakawa-japanese-studies-postgraduate-stud entships-0 for more information

For further information contact:

Email: trustfunds@orinst.ox.ac.uk

\section{School of Anthropology and Museum Ethnography: Peter Lienhardt/Philip Bagby Travel Awards}

\section{Subjects: Anthropology}

Eligibility: Open to new and current Anthropology students who are hoping to fund research/travel. Please see website for more details, including closing dates and how to apply

Level of Study: Postgraduate

Type: Scholarship 
Value: Up to $£ 1,000$ for travel/small research projects only Length of Study: Ad hoc

Frequency: Annual

Country of Study: United Kingdom

Application Procedure: For more information, please check the website: www.anthro.ox.ac.uk/prospective-students/ funding/travel-grants/

Closing Date: 22 January

Funding: Trusts

For further information contact:

Email: information@anthro.ox.ac.uk

\section{Sir William Dunn School of Pathology: Departmental PhD Prize Studentships}

Eligibility: Open to applicants for the DPhil in Molecular Cell Biology in Health and Disease with a minimum 2.1 degree in relevant area. Relevant research experience required and must apply for one of the advertised projects. Please see website for more details

Value: Full fees, a stipend of $£ 16,000 \mathrm{pa}$, and research and travel costs of $£ 5,300$ pa

Length of Study: 4 years

Frequency: Annual

Country of Study: Any country

Closing Date: 6 January

Additional Information: For more details, please visit www. path.ox.ac.uk/

For further information contact:

Tel: (44) 1865275500

Email: finance@path.ox.ac.uk

\section{Social \& Cultural Anthropology: Economic and Social Research Council}

Subjects: Social anthropology

Eligibility: Open to United Kingdom applicants for Social Anthropology. Other European Union nationals are eligible for a fees-only award

Level of Study: Graduate

Type: Grant

Value: University fee, college fee and full living expenses

Length of Study: Period of fee liability

Country of Study: Any country

Application Procedure: Please visit website for more details and how to apply

Closing Date: 23 January

Additional Information: Please check at www.isca.ox.ac. uk/prospective-students/funding/ for more information
For further information contact:

Email: enquiries@sociology.ox.ac.uk

\section{Social Policy and Intervention: Barnett House- Nuffield Joint Scholarship}

Eligibility: Open to all applicants applying for the DPhil Social Policy at the Department of Social Policy and Intervention and Nuffield College

Value: Course fee, college fee, maintenance

Length of Study: 3 years

Country of Study: Any country

Closing Date: 20 January

Additional Information: For more details, please visit www. spi.ox.ac.uk/study-with-us/funding.html

For further information contact:

Tel: (44) 1865270325

Email: info@spi.ox.ac.uk

\section{Social Policy and Intervention: Barnett Scholarship}

Eligibility: Open to all applicants applying for a DPhil at the Department of Social Policy and Intervention

Value: $£ 25,000$

Length of Study: 3 years or 2 years for MPhil applicants applying for 2 year DPhil study

Country of Study: Any country

Closing Date: 20 January

Additional Information: For more details, please visit www. spi.ox.ac.uk/study-with-us/funding.html

For further information contact:

Email: scholarships@spi.ox.ac.uk

\section{Social Policy and Intervention: Centenary Scholarship}

Eligibility: Open to all applicants applying for a DPhil at the Department of Social Policy and Intervention

Level of Study: Graduate

Type: Scholarship

Value: $£ 25,000$

Length of Study: 3 years or 2 years for MPhil applicants applying for 2 year DPhil study

Country of Study: Any country

Closing Date: 20 January 
Additional Information: For more details, visit website www.spi.ox.ac.uk/study-with-us/funding.html

\section{For further information contact:}

Tel: (44) 1865270325

Email: scholarships@spi.ox.ac.uk

\section{Somerville College Janet Watson Bursary}

Subjects: All subjects

Eligibility: Open to graduates from the United States of America who are in need of financial assistance

Level of Study: Postgraduate

Type: Bursary

Value: UK£2, $000, £ 3,500$ p.a

Length of Study: 1 year, with possibility of renewal for second year

Study Establishment: Somerville College, the University of Oxford

Country of Study: United Kingdom

Application Procedure: Applicants must contact the Assistant College Secretary

Funding: Private

For further information contact:

Email: sara.kalim@some.ox.ac.uk

Contact: Assistant College Secretary

\section{Soudavar Fund}

Subjects: All subjects

Purpose: The Soudavar Fund provides small grants to assist students from Iran who are studying for a degree at the University of Oxford and who are facing financial difficulty Eligibility: The Soudavar Fund provides small grants of up to $£ 2,500$ to assist students from Iran at the University of Oxford and who are facing genuine financial difficulty. The award is open to students who have started their degree at Oxford

Type: Funding support

Value: Up to $£ 2,500$

Length of Study: 1 year

Frequency: Annual

Application Procedure: Application forms can be obtained from the International Office

Additional Information: Eligible to nationals of Iran. The Soudavar Fund assists students from Iran who are facing genuine financial difficulty. Applicants must be able to show how they are connected to Iran, e.g. through citizenship, residence etc. Soudavar Fund scholarships are made in conjunction with the Clarendon Fund to support Iranian graduate students
For further information contact:

Email: international.office@admin.ox.ac.uk

\section{St Antony's College - Swire Scholarship}

Subjects: Social Sciences and Humanities Divisions

Purpose: The Swire Scholarships at St Antony's are generously funded by the Swire Charitable Trust, founded by John Swire \& Sons. These scholarships are available to graduate students demonstrating exceptional academic merit

Eligibility: The scholarships are open to applicants who are permanent residents of Japan, China or Hong Kong and have completed the majority of their formal education in their country of permanent residency. The Scholarships will be awarded primarily on academic merit, although financial need may be taken into account. Applicants must apply for admission to a full-time graduate course of study that is offered by St Antony's College to start in current and upcoming year

Level of Study: Graduate

Type: Scholarship

Value: $100 \%$ of the university fees, a grant for living costs of $£ 17,442$ per year

Frequency: Annual

Country of Study: Japan

Closing Date: 15 March

Funding: Private

For further information contact:

Email: scholarships@jsshk.com

\section{St Antony's College Ali Pachachi Scholarship}

Subjects: Modern Middle Eastern studies

Purpose: To assist candidates pursue doctoral study in any discipline in the humanities or social sciences with a primary focus on the social and political issues confronting the modern Middle East

Eligibility: St Antony's doctoral students

Level of Study: Doctorate, Research

Value: $£ 7,500$ towards fees and maintenance

Length of Study: One year

Application Procedure: Please check the website for further details

\section{For further information contact:}

Email: mec@sant.ox.ac.uk

Contact: The Director 


\section{St Antony's College Wai Seng Senior Research Scholarship}

Subjects: Subjects concerning the Asia Pacific region

Level of Study: Doctorate

Type: Scholarship

Value: Fees and maintenance

Length of Study: 2 years

Frequency: Every 2 years

Study Establishment: St Antony's College, University of Oxford

Country of Study: United Kingdom

Application Procedure: See www.sant.ox.ac.uk for details

Funding: Individuals

Additional Information: Available in even-numbered years only

\section{For further information contact:}

Email: asian@sant.ox.ac.uk

Contact: The Director

\section{St Catherine's College Glaxo Scholarship}

Subjects: Medicine

Purpose: To assist graduates who are, or will be registered for the Oxford University 2nd BM or the accelerated graduate entry medicine course

Eligibility: Open to graduates who have a confirmed place in the Oxford University 2nd BM or the accelerated graduate entry medicine course

Level of Study: Graduate

Type: Scholarship

Value: UK£1,500 per year

Length of Study: Up to 2 years whilst the recipient is liable for university and college fees

Frequency: Annual

Study Establishment: St Catherine's College, University of Oxford

Country of Study: United Kingdom

Application Procedure: See www.stcatz.ox.ac.uk for details

\section{For further information contact:}

St Catherine's College, Manor Rd, Oxford OX1 3UJ, United Kingdom

Tel: $\quad$ (44) 1865271768

Email: academic.registrar@stxatz.ox.ac.uk

Contact: Academic Registrar

\section{St Catherine's College: College Scholarship (Arts)}

Subjects: Humanities and social sciences

Eligibility: Open to DPhil, MLitt, and MSc by Research applicants and students in the Humanities and Social Sciences Divisions

Level of Study: Doctorate, Postgraduate, Research

Type: Scholarship

Value: $£ 3,021$ per annum

Length of Study: Period of fee liability (up to 3 years)

Frequency: Annual

Study Establishment: St Catherine's College, University of Oxford

Country of Study: United Kingdom

Application Procedure: Please see website for full details including how to apply

Closing Date: 10 March

Funding: Private

Additional Information: Please check the website: www. stcatz.ox.ac.uk/Scholarships-and-bursaries/Postgraduate for more information

For further information contact:

Fax: (44) 1865271700

Contact: Academic Office

\section{St Catherine's College: College Scholarship (Sciences)}

Eligibility: Open to DPhil and MSc by research applicants and students in the Mathematical, Physical and Life Sciences Division and Medical Sciences Division

Level of Study: Doctorate, Postgraduate, Research

Type: Scholarship

Value: $£ 3,021$ per annum

Length of Study: Period of fee liability (up to 3 years)

Frequency: Annual

Study Establishment: St Catherine's College, University of Oxford

Country of Study: United Kingdom

Application Procedure: Please see website for full details including how to apply

Closing Date: 10 March

Funding: Private

Additional Information: Please check the website: www. stcatz.ox.ac.uk/Scholarships-and-bursaries/Postgraduate for more information

For further information contact:

Contact: Academic Office 


\section{St Catherine's College: Ghosh Graduate Scholarship}

Subjects: Humanities

Eligibility: Open to BPhil, MFA, MSt, MSc by Coursework or MPhil in the Humanities Division. Please see website for full details including how to apply

Level of Study: Postgraduate, Predoctorate

Type: Scholarship

Value: $£ 5,000$ per annum

Length of Study: Period of fee liability (up to 2 years)

Study Establishment: St Catherine's College, University of Oxford

Country of Study: United Kingdom

Closing Date: 10 March

Funding: Private

Additional Information: Please see check the website: www.stcatz.ox.ac.uk/Scholarships-and-bursaries/Postgradu ate for details

For further information contact:

Contact: Academic Office

\section{St Catherine's College: Leathersellers' Company Scholarship}

Eligibility: Open to DPhil and MSc by Research applicants and students in the MPLS Division and Department of Biochemistry who have studied at a European (including United Kingdom) university

Level of Study: Doctorate, Postgraduate, Research

Type: Scholarship

Value: $£ 3,000$ per annum

Length of Study: Period of fee liability (up to 3 years)

Frequency: Annual

Study Establishment: St Catherine's College, University of

Oxford

Country of Study: United Kingdom

Closing Date: 10 March

Funding: Private

Additional Information: Please check the website: www. stcatz.ox.ac.uk/Scholarships-and-bursaries/Postgraduate for details

For further information contact:

Contact: Academic Office

\section{St Catherine's College: Overseas Scholarship}

Subjects: All subjects
Purpose: To assist students who are, or will be reading for an Oxford University DPhil, MLitt or MSc by research degree Eligibility: Open to overseas DPhil, MLitt and MSc by research applicants and students

Level of Study: Doctorate, Postgraduate, Research

Type: Scholarship

Value: $£ 2,765$ per year plus additional benefits including guaranteed accommodation at the current room charge rate and dining rights

Length of Study: Up to 3 years while student is liable for fees Frequency: Annual

Study Establishment: St Catherine's College, University of Oxford

Country of Study: United Kingdom

Application Procedure: Please refer to the website www. stcatz.ox.ac.uk for details

Closing Date: 12 March

Funding: Private

Additional Information: Eligible to the overseas countries

For further information contact:

Email: academic.registrar@stcatz.ox.ac.uk

Contact: Academic Registrar

\section{St Catherine's College: Poole Scholarship}

Subjects: Mathematical, physical, and life sciences

Purpose: To assist students who are or will be reading for an Oxford University DPhil, MLitt or MSc by research degree

Eligibility: British nationals of good character studying for a DPhil. Limited SCR dining rights and guaranteed 2 years' single accommodation at current room rate

Level of Study: Graduate, Research

Type: Scholarship

Value: $£ 2,500$ per annum

Length of Study: Up to 3 years while student is liable for fees Frequency: Dependent on funds available

Study Establishment: St Catherine's College, University of Oxford

Country of Study: United Kingdom

Application Procedure: See www.stcatz.ox.ac.uk for details

For further information contact:

Fax: (44) 1865271768

Email: academic.registrar@stcat2.ox.ac.uk

Contact: Academic Registrar, St Catherine's college

\section{St Cross College: E.P. Abraham Scholarships}

Purpose: St Cross College is a graduate college of the University of Oxford. It offers an outstanding academic 
environment dedicated to the pursuit of excellence within the Collegiate University

Eligibility: Open to all graduate applicants for research degrees in the chemical, biological/life and medical sciences. Please visit website for more details, including how to apply Level of Study: Postgraduate

Type: Scholarship

Value: $£ 10,000$ per year towards college fee with the remainder towards living expenses

Length of Study: Up to three years

Frequency: Annual

Study Establishment: St Cross College

Country of Study: United Kingdom

Application Procedure: For more information, please check the website: www.stx.ox.ac.uk/prospective-students/fundingsupport/ep-abraham-scholarships-chemical-biologicallife-andmedical

Closing Date: 18 May

Funding: Trusts

\section{For further information contact:}

Email: master.pa@stx.ox.ac.uk

\section{St Cross College: Graduate Scholarship in Environmental Research}

Eligibility: St Cross College, jointly with the Oxford NERC Doctoral Training Program in Environmental Research, offers this scholarship for Home/European Union students who will be studying for a DPhil in this Doctoral Training Programme (DTP). Please visit website for more details including how to apply

Value: University fee, college fee and living expenses. Feesonly awards for European Union residents

Length of Study: Up to 3 years

Country of Study: Any country

Closing Date: 18 January

Additional Information: For more details, please visit website www.stx.ox.ac.uk/prospective-students/fundingsupport/graduate-scholarship-environmental-research

For further information contact:

Email: bursar@stx.ox.ac.uk

\section{St Cross College: HAPP MPhil Scholarship in the History of Science}

Eligibility: Open to applicants for the MPhil in History of Science, Medicine and Technology. Preference will be given to candidates with an interest in the history of physics for their
MPhil dissertation topic. Please see website for further details, including how to apply

Value: $£ 10,000$ per annum to cover the annual college fee and an annual stipend

Length of Study: Tenable for 2 years coterminous with college fee liability

Country of Study: Any country

Closing Date: 20 January

Additional Information: For more details, please visit www. stx.ox.ac.uk/prospective-students/funding-support/happ-mphilscholarship-history-science

\section{For further information contact:}

Email: admissions-academic@stx.ox.ac.uk

\section{St Cross College: MPhil Scholarships in the Humanities and Social Sciences}

Eligibility: Open to all applicants for MPhil degrees in the Humanities and the Social Sciences or for the BPhil degree in Philosophy. The scholarships are tenable at St Cross College only

Level of Study: Predoctorate

Type: Scholarship

Value: $£ 4,000$

Length of Study: 2 years

Study Establishment: St Cross College

Country of Study: United Kingdom

Application Procedure: Please visit website for more details, including how to apply

Closing Date: 10 March

Additional Information: Please check the website: www.stx. ox.ac.uk/prospective-students/funding-support/mphil-scholar ships-humanities-and-social-sciences for more information

For further information contact:

St Cross College, St Giles, Oxford OX1 3LZ, United Kingdom

Tel: $\quad$ (44) 1865278458

Fax: (44) 1865278484

Email: admissions-academic@stx.ox.ac.uk

Contact: Admissions and Academic Assistant

\section{St Cross College: ORISHA DPhil Scholarship in Area Studies}

Eligibility: Applicants applying to study for the DPhil in Area Studies

Level of Study: Doctorate

Type: Scholarship 
Value: University fee, college fee, maintenance stipend of $£ 12,910$

Length of Study: 3 years

Study Establishment: St Cross College

Country of Study: Any country

Closing Date: 25 January

Additional Information: Please visit the website: www.stx. ox.ac.uk/prospective-students/funding-support/orisha-dphilscholarship-area-studies for more information

\section{For further information contact:}

Email: master@stx.ox.ac.uk

\section{St Cross College: Oxford-Ko Cheuk Hung Graduate Scholarship}

Eligibility: Open to applicants who are ordinarily resident in the EEA or Switzerland and who are applying for the full-time MSt Chinese Studies

Level of Study: Postgraduate

Type: Residency

Value: Tuition fees, college fees and a grant towards living expenses

Length of Study: Period of fee liability

Frequency: Annual

Study Establishment: St Cross

Country of Study: United Kingdom

Application Procedure: For more information, please check the website: www.ox.ac.uk/admissions/graduate/feesand-funding/fees-funding-and-scholarship-search/scholarships3 \#kocheukhung

Closing Date: 22 January

Funding: Trusts

\section{For further information contact:}

Tel: (44) 1865278490

Email: master@stx.ox.ac.uk

\section{St Cross College: SBFT Scholarship in the Humanities}

Eligibility: Open to applicants who will be studying for a doctoral degree in the Humanities Division at the University of Oxford in the academic year. The scholarship is open to applicants who are students or academic staff members at a university, other higher education institution or vocational training institution in China. Please see website for further details, including how to apply
Value: $£ 15,000$ per annum. The successful scholar will also be guaranteed to have a room in College accommodation (at the standard rent) for the first year of their course

Length of Study: Three fee-liability years of the doctoral course

Country of Study: Any country

Closing Date: 20 January

Additional Information: For more details, visit website www.stx.ox.ac.uk/prospective-students/funding-support/stcross-sbft-scholarship-humanities

For further information contact:

Email: master@stx.ox.ac.uk

\section{St Cross College: The Harun Ur Rashid Memorial Scholarship}

Eligibility: Open to applicants (who are normally resident in Bangladesh) for MPhil degrees in the Humanities and the Social Sciences or for the BPhil degree in Philosophy. Please visit website for more details including how to apply

Value: $£ 3,000$

Length of Study: 2 years

Country of Study: Any country

Closing Date: 9 June

Additional Information: For more details, visit website www.stx.ox.ac.uk/prospective-students/funding-support/harunur-rashid-memorial-scholarship

For further information contact:

Email: master@stx.ox.ac.uk

\section{St Cross College: The Robin \& Nadine Wells Scholarship}

Subjects: All subjects

Purpose: To provide financial assistance to an academically meritorious graduate student who has been accepted into both an accredited one year's Masters programme at the University of Oxford and St Cross College and are unable to secure funding elsewhere

Eligibility: Open to all applicants for one-year Master's courses who are unable to secure funding from elsewhere

Level of Study: Postgraduate

Type: Scholarship

Value: $£ 10,000$

Length of Study: 1 year

Frequency: Annual

Study Establishment: St Cross College

Country of Study: United Kingdom 
Application Procedure: Please visit website for more details, including how to apply

Closing Date: 16 June

Additional Information: Please note that this scholarship is not open to students who have already been accepted by another Oxford college. Please check the website: www.stx. ox.ac.uk/prospective-students/funding-support/robin-nadinewells-scholarship for more information

\section{For further information contact:}

Contact: The Academic and Admissions Assistant

\section{St Cross College: Unilever Graduate Scholarship in Sciences}

Subjects: Engineering or biochemistry

Purpose: To assist graduate students with fees

Eligibility: Open to graduate students

Level of Study: Postgraduate, Research

Type: Scholarship

Value: $£ 2,208$ per year

Length of Study: Up to 3 years of study, depending on college fee liability

Country of Study: Any country

Closing Date: 13 March

\section{For further information contact:}

Email: jane.sherwood@admin.ox.ac.uk

\section{St Edmund Hall William R Miller Graduate Awards}

Subjects: All subjects

Level of Study: Postgraduate

Type: Scholarship

Value: Free accommodation

Length of Study: 1 year with possible extension for a further year

Frequency: Annual

Study Establishment: St Edmund Hall, University of Oxford

Country of Study: United Kingdom

No. of awards offered: 50

Application Procedure: Application forms are available from the website www.seh.ox.ac.uk or from the Registrar at the address below. Forms are available from around the beginning of February

Closing Date: 1 May

Funding: Private

Contributor: William R Miller
No. of awards given last year: 4 (1 new award, 3 extended for a further year)

No. of applicants last year: 50

For further information contact:

Email: admissions@seh.ox.ac.uk

Contact: Registrar

\section{St Edmund Hall: Graduate Scholarships}

Subjects: All subjects

Purpose: To assist graduate students with fees and a living allowance

Eligibility: Open to all

Level of Study: Postgraduate, Research

Type: Scholarship

Country of Study: Any country

For further information contact:

Email: lodge@seh.ox.ac.uk

Contact: The Registrar, St Edmund Hall

\section{St Edmund Hall: Peel Award}

Eligibility: Open to all students applying for Master of Fine Art at the Ruskin School

Level of Study: Postgraduate

Type: Scholarship

Value: $£ 5,000$

Length of Study: 1 year

Frequency: Annual

Study Establishment: St Edmund Hall

Country of Study: Any country

Closing Date: 20 January

Additional Information: Please visit the website: www.seh. ox.ac.uk/admissions/scholarships for more information

For further information contact:

Email:1awfac@law.ox.ac.uk

\section{St Edmund Hall: William Asbrey BCL Studentship}

Purpose: The William Asbrey scholarship is worth $£ 10,000$, is jointly funded by St Edmund Hall and the Law Faculty, and is available to all BCL applicants. There is no separate application procedure:

Eligibility: Open to all graduate applicants to the BCL Value: $£ 10,000$ 
Length of Study: 1 year

Country of Study: Any country

Closing Date: 20 January

Additional Information: For more details, visit website www.law.ox.ac.uk/admissions/graduate-scholarships

For further information contact:

Email: lodge@seh.ox.ac.uk

\section{St Edmund Hall: William R. Miller Postgraduate Award}

Purpose: To assist graduate students with fees and accommodation

Eligibility: A rent-free college room for one academic year offered to a student entering the first or second year of a research degree (DPhil or MRes)

Level of Study: Postgraduate, Research

Type: Award

Value: Free accommodation in college

Length of Study: 1 year

Frequency: Annual

Country of Study: Any country

Application Procedure: Please see website for more details, including how to apply

Closing Date: 20 January

Additional Information: Please check the website: www. seh.ox.ac.uk/admissions/scholarships for more information

For further information contact:

Email: jane.sherwood@admin.ox.ac.uk

\section{St Hilda's College: New Zealand Bursaries}

Subjects: MSt in English (650-1550)

Eligibility: Open to all graduate applicants from New Zealand Level of Study: Postgraduate

Type: Scholarship

Value: Up to $£ 2,000$ per year

Length of Study: 1 year with the possibility of renewal

Frequency: Annual

Application Procedure: Please see website for details of how to apply

For further information contact:

Tel: $\quad$ (44) 1865276884

Fax: (44) 1865276816

Email: college.office@st-hildas.ox.ac.uk

Contact: Admissions Secretary

\section{St John: loan \& Rosemary James Undergraduate Scholarships}

Eligibility: The scholarship is available to any graduate student embarking upon a DPhil in Mathematics or joining a CDT in the Mathematical Institute. Please see website for further details

Value: University fees (at either the Home/European Union or Overseas student rate as applicable), College fees and a maintenance stipend at the United Kingdom research council rate Length of Study: Duration of full-fee liability; 3 years for DPhil and 4 years for CDT

Country of Study: Any country

Closing Date: Relevant January deadline for your course Additional Information: For more details, please visit www. sjc.ox.ac.uk

For further information contact:

Email: sarah.jones@sjc.ox.ac.uk

\section{St John's College North Senior Scholarships}

Subjects: All subjects

Eligibility: Open to graduates normally with United Kingdom degrees, who have already begun research and who are aged under 25

Level of Study: Postgraduate

Type: Scholarship

Value: Free accommodation

Length of Study: Usually 2 years

Study Establishment: St John's College, the University of Oxford

Country of Study: United Kingdom

Application Procedure: Applicants must contact the Secretary to the Tutor for Graduates in the first instance

Closing Date: Mid January. Advertised in November and December, tenable from the following October

For further information contact:

Tel: $\quad$ (44) 1865277428

Fax: (44) 1865277640

Email: graduate.admissions@sjc.ox.ac.uk

\section{St Peter's College Bodossaki Graduate Scholarship in Science}

Subjects: Any field of science

Purpose: To assist Greek or Cypriot citizens under the age of 30 , based on merit and financial need 
Eligibility: Applicants should be Greek or Cypriot citizens under the age of 30. Award made on the basis of academic merit and financial need

Level of Study: Research

Type: Scholarship

Value: Up to $£ 13,000$ per annum; may be used for university \& college fees, and maintenance

Length of Study: Up to 3 years, subject to satisfactory academic progress

Frequency: Annual

Study Establishment: St Peter's College, the University of Oxford

Country of Study: United Kingdom

Application Procedure: Applicants must contact the College Secretary at St Peter's College in the first instance, or see www.spc.ox.ac.uk

Closing Date: 30 January

Funding: Foundation

Contributor: The Bodossaki Foundation

For further information contact:

Email: college.secretary@spc.ox.ac.uk

\section{St. John}

Eligibility: Open to applicants for the DPhil in Mathematics, or CDT in Mathematical Institute only

Value: University fees (at either the Home/European Union or Overseas student rate as applicable), College fees and a maintenance stipend at the United Kingdom research council rate

Country of Study: Any country

Application Procedure: Duration of full-fee liability; 3 years for DPhil and 4 years for CDT. For non-CDT students, the Mathematical Institute will provide an additional 6 months of funding from its own funds for maintenance

Closing Date: Relevant January deadline for your course

Additional Information: For more details, please visit website www.sjc.ox.ac.uk

\section{For further information contact:}

Email: sarah.jones@sjc.ox.ac

\section{Standard Bank Derek Cooper Africa Scholarship}

Eligibility: Open to applicants who are ordinarily resident in one of the following countries: Angola, Botswana, Cote d'Ivoire, Democratic Republic of the Congo, Ghana, Kenya, Lesotho, Malawi, Mauritius, Mozambique, Namibia, Nigeria, South Africa, South Sudan, Swaziland, Tanzania, Uganda,
Zambia or Zimbabwe. Preference will be given to nationals of Angola, Ghana, Kenya, Mozambique, Nigeria, South Africa and South Sudan. You must also be applying to start any full-time, 1 year taught master's course within the Mathematical, Physical and Life Sciences, Social Sciences, or Humanities Divisions

Level of Study: Postgraduate

Type: Scholarship

Value: University fee, college fee and a grant for living costs

Length of Study: Period of fee liability

Frequency: Annual

Country of Study: United Kingdom

Closing Date: Relevant January deadline for your course

Funding: Trusts

Additional Information: For more information, please check the website: www.ox.ac.uk/admissions/graduate/fees-andfunding/fees-funding-and-scholarship-search/scholarships-4

\section{For further information contact:}

Tel: (44) 2074057686

Email: graduates@standardbank.co.za

\section{Statistical Science (EPSRC and MRC Centre for Doctoral Training) Studentships}

Subjects: Statistical science

Eligibility: Open to United Kingdom and European Union applicants for Statistical Science (EPSRC and MRC CDT)

Level of Study: Doctorate, Research

Type: Studentship

Value: University fee, college fee and full living expenses

Length of Study: 4 years

Frequency: Annual

Country of Study: Any country

Closing Date: 20 January

Funding: Trusts

Additional Information: For more information, please check the website: www.stats.ox.ac.uk/study_here/research degrees

For further information contact:

Email: ri@fgv.br

\section{Synthetic Biology Doctorate Training Centre EPSRC/ BBSRC Studentships}

\section{Subjects: Doctoral Training Centre - MPLS}

Eligibility: Open to United Kingdom applicants for all MPLS subjects. Other European Union nationals are eligible for 
a fees-only award. It is recommended that students submit a CV directly to us prior to making a full application. Please visit website for more information

Level of Study: Postgraduate

Type: Scholarship

Value: University fee, college fee and full living expenses for home students. University and college fees only for European Union

Length of Study: Four years

Frequency: Annual

Country of Study: United Kingdom

Application Procedure: For more information, please check the website: www.dtc.ox.ac.uk/

Funding: Trusts

\section{For further information contact:}

Email: dtcenquiries@dtc.ox.ac.uk

\section{Templeton College Barclay DPhil Scholarship}

Subjects: Management studies

Level of Study: Doctorate

Type: Scholarship

Value: UK£5,000

Length of Study: Up to 3 year

Frequency: Annual

Study Establishment: Templeton College, University of Oxford

Country of Study: United Kingdom

Application Procedure: Applicants must apply to the Graduate Services Manager, Templeton College and should visit the website www.templeton.ox.ac.uk for further information Funding: Private

\section{For further information contact:}

Templeton College, Wellington Square, Oxford OX1 2JD, United Kingdom

Email: admissions@templeton.ox.ac.uk

Contact: Graduate Services Manager

\section{Templeton College Leyland Scholarships}

Subjects: Management studies

Level of Study: Postgraduate

Type: Scholarship

Value: Up to UK£1,500

Length of Study: 1 year

Frequency: Annual
Study Establishment: Templeton College, University of Oxford

Country of Study: United Kingdom

Application Procedure: Applicants must contact the Academic Administrator for further information

For further information contact:

Email: thc@eastern.edu

Contact: Graduate Services Manager

\section{Templeton College MBA Scholarship}

Subjects: MBA

Level of Study: MBA

Type: Scholarship

Value: Up to UK£5,000

Length of Study: 1 year

Frequency: Annual

Study Establishment: Templeton College, the University of Oxford

Country of Study: United Kingdom

Application Procedure: Applicants must contact the Academic Administrator

\section{For further information contact:}

Email: admissions@templeton.ox.ac.uk

Contact: Academic Administrator

\section{The Christopher Welch Scholarship in Biological Sciences}

Subjects: Medical

Eligibility: Open to all DPhil applicants applying for a project falling within the broad topic of Biological Sciences in Departments in the Medical Science, the Department of Plant Sciences and the Department of Zoology. Enquires may be sent by email to ga.Bush@medsci.ox.ac.uk. Christopher Welch Scholarships were established to promote the study of biology therefore to be eligible for the award candidates must have applied to the University for admission for postgraduate study normally in one of the following departments:

Level of Study: Graduate

Value: University fee (Home/European Union level), college fee, full living expenses and a research support and training grant

Length of Study: 3 years

Country of Study: Any country

Closing Date: Early January deadline for Medical Sciences and late January deadline for Zoology and Plant Sciences 
Additional Information: Check on the following weblink for application www.medsci.ox.ac.uk/study/medicine

For further information contact:

Email: ga.Bush@medsci.ox.ac.uk

\section{The John Brookman Scholarship}

Purpose: The Brookman Fund may also be able to help with certain expenses such as instrumental tuition or hire of a piano Eligibility: The Scholarship is open to those reading for, and those who have applied to read for, a graduate degree at the University of Oxford in any subject, and who as John Brookman Scholar will participate in the musical life of the College

Level of Study: Graduate

Type: Scholarship

Value: $£ 3,206$

Frequency: Annual

Country of Study: Any country

Application Procedure: 1. Please email graduate. admissions@wadham.ox.ac.uk a full CV detailing: your academic and musical qualifications and experience; the graduate course that you are following or to which you have applied; and the names of two referees. 2. Applicants should also ask their referees to email their references to the Graduate Administrator (on the email above) by this same date. 3 . The successful candidate will take up their scholarship from 1 October. For further information on selection process, kindly check the following link. www.wadham.ox.ac.uk/stu dents/graduate-students/graduate-finance/graduate-scholarships Closing Date: 22 March

Funding: Private

\section{The Khazanah Asia Scholarship in Collaboration with Ancora Foundation}

Purpose: Initiated through a generous benefaction from Mr. Gita Irawan Wirjawan, this scholarship provides one year's tuition, fees, and expenses,

Eligibility: Applicants should have; (a) a confirmed acceptance at the Environmental Change Institute, Oxford University; (b) an excellent academic record with a first degree equivalent to a good Second Class (Upper) Honors or a GPA of at least $3.5 ;$; (c) a very good command of the English language; (d) a commercial or industrial background and a deep interest in the environment; (e) assessed to have outstanding potential for leadership in government, business, or civil society after graduation

Level of Study: Graduate
Type: Scholarship

Value: Up to $£ 28,500$

Frequency: Varies

Country of Study: Any country

Application Procedure: Each fellowship is tenable for one-year only for full-time students on the Master of Science in Environmental Change and Management program. The successful candidate is expected to complete his/her studies within the tenable period. Each scholarship will cover the following: Tuition and other compulsory fees (as specified by Oxford University); Monthly stipend; and Return air-ticket (economy class)

Closing Date: 6 December

Funding: Private

\section{For further information contact:}

Equity Tower, 41st Floor Sudirman Central Business District (SCBD), Jl. Jend. Sudirman Kav.52-53, Lot 9, Jakarta 12190, Indonesia

Email: inquiry@ancorafoundation.com

\section{Theology and Religion: AHRC Doctoral Training Partnership studentships}

Level of Study: Graduate

Value: University fee, college fee and full living expenses. Fees-only awards for non-United Kingdom, European Union students

Length of Study: Period of fee liability

Country of Study: Any country

Application Procedure: Open to all graduate applicants for the DPhil degree offered by the Faculty of Theology and Religion. Please see website for more details

Closing Date: 20 January

Additional Information: For more details, please visit www. humanities.ox.ac.uk/prospective_students/graduates/funding/ ahrc

\section{For further information contact:}

Email: theo.pgresearchadmissions@durham.ac.uk

\section{Theology and Religion: Faculty Graduate Studentships}

Level of Study: Graduate

Value: At least $£ 1,000$

Length of Study: Period of fee liability

Country of Study: Any country 
Application Procedure: Open to all graduate applicants and continuing graduate students in Theology and Religion. Please see website for more details, including how to apply

Closing Date: 20 January

Additional Information: For more details, please visit website www.theology.ox.ac.uk/

\section{For further information contact:}

Email: theo.pgresearchadmissions@durham.ac.uk

\section{Trinity College Birkett Scholarship in Environmental Studies}

Subjects: Environmental change and management Eligibility: Open to any graduate accepted for the MSc Level of Study: Postgraduate

Type: Scholarship

Value: UK£2,400

Length of Study: 1 year

Frequency: Annual

Study Establishment: Trinity College, University of Oxford Country of Study: United Kingdom

Application Procedure: Applicants must contact the Academic Administrator for details

\section{For further information contact:}

Trinity College, Broad St, Oxford OX1 3BH, United Kingdom

Email: jane.sherwood@admin.ox.ac.uk

Contact: Academic Administrator

\section{Trinity College Junior Research Fellowship}

Subjects: Biological sciences, history, geography, theology, law, philosophy, economics, politics, physical sciences, English, classics, modern languages, mathematics. Subjects rotate

Purpose: To promote and encourage research among those at the start of an academic career

Eligibility: Open to suitably qualified candidates having some research experience (e.g. a completed doctoral thesis)

Level of Study: Doctorate, Postdoctorate

Value: Approx. UK£20,000 p.a

Length of Study: 3 years, non renewable

Frequency: Annual

Study Establishment: Trinity College, University of Oxford Country of Study: United Kingdom

Application Procedure: Please see application form on Trinity College website www.trinity.ox.ac.uk

\section{Trinity College: Michael and Judith Beloff Scholarship}

Subjects: Civil law

Purpose: To assist graduate students with fees

Eligibility: Open to all graduate applicants for the BCL. Preference given those intending to practise at the Bar of United Kingdom and Wales

Level of Study: Postgraduate

Type: Scholarship

Value: $£ 6,500$

Length of Study: 1 year

Frequency: Annual

Country of Study: Any country

Application Procedure: Please note interest on application form. Please see website for details of how to apply

Closing Date: 30 August

Additional Information: Please check at www.trinity.ox.ac. uk/pages/admissions/loans-grants-and-bursaries.php for more information

\section{University College: Chellgren}

Subjects: Economics

Purpose: Applicants must have a place on a postgraduate programme at University College, Oxford. Scholarships can be awarded to students embarking on any postgraduate programme. However, prospective economics students are given preference

Eligibility: Open to all graduate applicants in Economics. Applicants must have a place on a postgraduate programme at University College, Oxford

Level of Study: Postgraduate

Type: Scholarship

Value: $£ 4,000$ per year

Length of Study: Up to 3 years

Frequency: Annual

Study Establishment: University

Country of Study: United Kingdom

Application Procedure: Please see website for more details, including how to apply

Closing Date: Relevant January deadline for your course Funding: Trusts

Additional Information: For more information, please check the website: www.univ.ox.ac.uk/postgraduate/finan cial_1/scholarships_and_studentships/

\section{University College: Henni-Mester Scholarship}

Eligibility: Open to all graduate applicants to the Nuffield Department of Orthopaedics, Rheumatology and Musculoskeletal Sciences. Please see website for more details 
Level of Study: Postgraduate

Type: Scholarship

Value: University fee, college fee and full living expenses

Length of Study: Period of fee liability

Frequency: Annual

Study Establishment: University

Country of Study: United Kingdom

Application Procedure: For more information, please check the website: www.univ.ox.ac.uk/postgraduate/financial_1/ scholarships_and_studentships/

Closing Date: 8 January

Funding: Trusts

\section{For further information contact:}

Email:1 lodge@univ.ox.ac.uk

\section{University College: Loughman}

Eligibility: Open to graduates who have been offered a place at University College, who are outstanding in their academic field and who, in addition, can demonstrate that they will make significant contributions to College life through the quality of their extra-academic pursuits (sports, arts, community service, etc.)

Level of Study: Postgraduate

Type: Scholarship

Value: $£ 4,000$ per year

Length of Study: Up to 3 years

Frequency: Annual

Study Establishment: University

Country of Study: United Kingdom

Closing Date: Relevant January deadline for your course

Funding: Trusts

Additional Information: For more information, please check the website: www.univ.ox.ac.uk/postgraduate/finan cial_1/scholarships_and_studentships/

\section{For further information contact:}

Email: john.loughman@ucd.ie

\section{University Hardship Fund}

Purpose: The University Hardship Fund aims to assist students who experience unexpected financial difficulties due to circumstances which could not have been predicted at the start of their course

Eligibility: Students can apply to the University Hardship Fund (UHF) if they are experiencing unexpected and unforeseeable financial difficulties

Level of Study: Graduate

Type: Funding support
Frequency: Annual

Country of Study: Any country

Application Procedure: Students should contact their college hardship officer to request an application form and discuss their application. The hardship officer varies across colleges but could be your Senior Tutor, Bursar or Academic Administrator. Complete application forms should be submitted by the student or their college to Student Fees and Funding as soon as possible and by the appropriate deadline listed below. The form includes sections for the student, tutor or supervisor and college hardship officer to complete, and applications will only be considered when all sections and evidence have been received

Closing Date: 17 March

Funding: Trusts

\section{For further information contact:}

Email: graduatefunding@admin.cam.ac.uk

\section{Wadham College - David Richards Scholarship in Chemistry}

Purpose: Applicants for postgraduate research courses offered by the Department of Chemistry. The scholarship is open to home,

Eligibility: To be eligible for consideration for this scholarship, applicants must be successful in being offered a place on their course after consideration of applications received by the relevant January deadline for the course. Course applications which are held over after the January deadline to be re-evaluated against applications received by the March deadline or course applications which have been put on a waiting list are not eligible for scholarship consideration

Level of Study: Graduate

Type: Scholarship

Value: $100 \%$ of course fees and a grant for living costs (at least $£ 14,777$ ) for the duration of the course

Frequency: Annual

Country of Study: Any country

Application Procedure: Scholarships are awarded to applicants who have demonstrated excellent academic ability, who will contribute to the University's ground-breaking research, and who will go on to contribute to the world as leaders in their field, pushing the frontiers of knowledge. The Richards family bequest contributes $60 \%$ of the funds for these scholarships, with the remaining $40 \%$ being contributed by the University of Oxford

Closing Date: January will be the deadline

Funding: Private

\section{For further information contact:}

Email: graduate.admissions@wadham.ox.ac.uk 


\section{Wadham College: Beit Scholarship}

Value: University fee, college fee, and full living expenses Length of Study: 1 year

Country of Study: Any country

Application Procedure: Open to graduate applicants for 1-year Masters courses who are ordinarily resident in Malawi, Zambia or Zimbabwe. Please see website for further details, including how to apply

Closing Date: Relevant January deadline for your course Additional Information: For more details, please visit website www.wadham.ox.ac.uk/students/graduate-students/ graduate-finance/graduate-scholarships

\section{For further information contact:}

Email: graduate.admissions@wadham.ox.ac.uk

\section{Wadham College: Donner Canadian Foundation Law Scholarship}

Purpose: The Donner Canadian Scholarship is awarded to Canadian graduates intending to undertake the BCL or MJur at the University of Oxford as a member of Wadham College. This prize is available on an annual basis and is awarded on the basis of academic excellence and aptitude

Eligibility: Open to any graduate applicant to the BCL or MJur who is ordinarily resident in Canada. Please see website for more details

Level of Study: Postgraduate

Type: Scholarship

Value: $£ 20,000$ towards University and college fees or living expenses

Length of Study: One year

Frequency: Annual

Country of Study: Any country

Application Procedure: For more information, please check the website: www.wadham.ox.ac.uk/students/graduatestudents/graduate-finance/graduate-scholarships

Closing Date: 22 January

Funding: Trusts

\section{For further information contact:}

Tutor for Graduates, Wadham College, Parks Road, Oxford OX1 3PN, United Kingdom

Email: senior.tutor@wadh.ox.ac.uk

\section{Wadham College: Hackney BCL Scholarship}

Value: University fee, college fee, and full living expenses Length of Study: 1 year
Country of Study: Any country

Application Procedure: Open to all graduate applicants for the BCL

Closing Date: 20 January

Additional Information: For more details, please visit website www.wadham.ox.ac.uk/students/graduate-students/ graduate-finance/graduate-scholarships

\section{For further information contact:}

Email: graduate.admissions@wadham.ox.ac.uk

\section{Wadham College: John Brookman Scholarship}

\section{Subjects: All subjects}

Purpose: To assist an organisation scholar who has been given admission to read for a higher degree in the university Eligibility: Open to any graduate student who wishes to play a role in the musical life of the college

Level of Study: Postgraduate, Research

Type: Scholarship

Value: Equivalent to college fee

Length of Study: Duration of fee liability

Frequency: Annual

Study Establishment: Wadham College, University of Oxford Country of Study: United Kingdom

Application Procedure: Applicants should send a full curriculum vitae detailing: their academic and musical qualifications and experience; the graduate course that they are following, or to which they have applied; and the names of two referees, either by post to the Tutor for Graduates. Applicants should also request referees to submit their references (using the same contact details as listed above) by the same date. A successful candidate will take up his/her scholarship from October 1st

Closing Date: 23 April

Funding: Trusts

Contributor: Endowed by late E.W.M. Brookman, an old member of the college, in memory of his son, John M. Brookman (1926-1980)

For further information contact:

Email: admissions@wadh.ox.ac.uk

Contact: Tutor for Graduates

\section{Wadham College: Oxford-Richards Scholarship in Chemistry}

Eligibility: Open to a graduate applying for one of the DPhil courses offered by the Chemistry Department. Please see website for details

Level of Study: Postgraduate 
Type: Scholarship

Value: University fee, college fee, and full living expenses

Length of Study: Duration of fee liability

Frequency: Annual

Study Establishment: Wadham

Country of Study: United Kingdom

Application Procedure: For more information, please check the website: www.ox.ac.uk/admissions/graduate/fees-andfunding/fees-funding-and-scholarship-search/scholarships-

3\#richards

Closing Date: 22 January

Funding: Trusts

\section{For further information contact:}

Email: graduate.admissions@wadham.ox.ac.uk

\section{Wadham College: Oxford-Richards Scholarship in Economics}

Eligibility: Open to a graduate applying for the DPhil in Economics. Please see website for details

Level of Study: Postgraduate

Type: Scholarship

Value: University fee, college fee, and full living expenses

Length of Study: Duration of fee liability

Frequency: Annual

Study Establishment: Wadham

Country of Study: United Kingdom

Application Procedure: For more information, please check the website: www.ox.ac.uk/admissions/graduate/fees-andfunding/fees-funding-and-scholarship-search/scholarships3 \#richards

Closing Date: 22 January

Funding: Trusts

For further information contact:

Email: graduate.admissions@wadham.ox.ac.uk

\section{Wadham College: Oxford-Richards Scholarships in Climate Science}

Eligibility: Open to a graduate applying for a DPhil in Atmospheric, Oceanic and Planetary Physics. Please see website for more details

Level of Study: Postgraduate

Type: Scholarship

Value: University fee, college fee, and full living expenses

Length of Study: Duration of fee liability

Frequency: Annual

Study Establishment: Wadham

Country of Study: United Kingdom
Application Procedure: For more information, please check the website: www.ox.ac.uk/admissions/graduate/fees-andfunding/fees-funding-and-scholarship-search/scholarships-

3\#richards

Closing Date: 8 January

Funding: Trusts

\section{For further information contact:}

Email: domestic.bursar@wadham.ox.ac.uk

\section{Wadham College: Oxford-Richards Scholarships in History}

Eligibility: Open to a graduate applying for one of the DPhil courses offered by the History Faculty. Please see website for more details

Level of Study: Postgraduate

Type: Scholarship

Value: University fee, college fee, and full living expenses

Length of Study: Duration of fee liability

Frequency: Annual

Study Establishment: Wadham

Country of Study: United Kingdom

Application Procedure: For more information, please check the website: www.ox.ac.uk/admissions/graduate/fees-andfunding/fees-funding-and-scholarship-search/scholarships3\#richards

Closing Date: 22 January

Funding: Trusts

For further information contact:

Email: graduate.admissions@wadham.ox.ac.uk

\section{Wadham College: Peter Carter Graduate Scholarship in Law}

Level of Study: Graduate

Value: $£ 10,000$ towards course and college fees or living expenses

Length of Study: Duration of fee liability

Country of Study: Any country

Application Procedure: Open to all graduate applicants for the BCL, MJur, MPhil in Law or DPhil in Law

Closing Date: 20 January

Additional Information: For more details, please visit website www.wadham.ox.ac.uk/students/graduate-students/ graduate-finance/graduate-scholarships

For further information contact:

Email: study@ox.ac.uk 


\section{Wadham College: Peter Carter Taught Graduate Scholarship in Law}

Purpose: The Taught Graduate Scholarship in Law is available to graduate students of exceptional academic merit embarking on the BCL or MJur at Wadham College and is available to law graduates of any university

Eligibility: Open to all graduate applicants for the BCL or MJur. Please see website for details

Level of Study: Graduate, Postgraduate

Type: Scholarship

Value: $£ 12,500$ towards course and college fees or living expenses

Length of Study: 1 year

Study Establishment: Wadham College

Country of Study: Any country

Application Procedure: Please visit the website: www. wadham.ox.ac.uk/students/graduate-students/graduate-finance/ graduate-scholarships for more information

Closing Date: 20 January

Additional Information: Please visit the website: www wadham.ox.ac.uk/students/graduate-students/graduate-finance/ graduate-scholarships for more information. The scholarship can be used to defray in part University fees, College fees and/or maintenance of the Scholar during their period of study. It does not cover all fees so you will have to demonstrate sufficient funds for additional costs

\section{For further information contact:}

Email: admissions@wadh.ox.ac.uk

\section{Wadham College: Philip Wright Scholarship}

Subjects: All subjects

Eligibility: Open to any graduate student who is a former student of Manchester Grammar School

Level of Study: Postgraduate, Research

Type: Scholarship

Value: University and college fee (to a maximum of $£ 10,000$ ) plus $£ 8,000$ per year stipend or, where recipient receives financial support from another source (i.e. RCUK), payment of the college fee

Length of Study: 1 year, possible renewal

Application Procedure: Application forms are available at www.wadham.ox.ac.uk/student-life/scholarships/the-philipwright-scholarship.html either in Word or PDF format. Please send the completed form, a full Curriculum Vitae and (for graduates applying for research work) a one page summary of your research proposal, either by post to the Tutor for Graduates

Closing Date: 23 April
Funding: Trusts

Contributor: Philip Wright Fund

\section{Wakeham Humanities Scholarship (History or Literature)}

Purpose: All of these scholarships, apart from the Light Senior Scholarships, are open to new graduate students commencing graduate study at Oxford in October

Eligibility: Students at other colleges are eligible to apply for all of these scholarships apart from the Light Senior Scholarships, but would need to migrate to St Catherine's to take up the scholarship if their application was successful

Level of Study: Graduate

Type: Scholarship

Value: Check the website for further details

Frequency: Every 2 years

Country of Study: Any country

Application Procedure: Applications for Graduate Scholarships should be sent by email to college.office@stcatz.ox.ac. uk, in a single PDF file if possible, and should be singlespaced and in at least a 12 point font. For further details, check the website link. www.stcatz.ox.ac.uk/prospective-students/ postgraduate-admissions/student-finance-and-scholarships/

Closing Date: 26 April, 3 May and 10 May

Funding: Private

Additional Information: www.ox.ac.uk/admissions/gradu ate/colleges/st-catherines-college

For further information contact:

Manor Road, Oxford, OX1 3UJ, United Kingdom

\section{Weatherall Institute of Molecular Medicine: WIMM Prize Studentship}

Level of Study: Graduate

Value: All fees and living expenses of $£ 18,000$ per annum

Length of Study: 4 years

Country of Study: United Kingdom

Application Procedure: Open to applicants of any nationality applying for projects advertised on the WIMM website. Applicants must quote scholarship reference code H816027

Closing Date: 1 June

Additional Information: For more details, visit website www.imm.ox.ac.uk/wimm-prize-studentship-2017

\section{For further information contact:}

University of Oxford Level 6, West Wing John Radcliffe Hospital Headington Oxford, OX3 9DU, United Kingdom

Email: graduate.enquiries@rdm.ox.ac.uk 


\section{Weidenfeld-Hoffmann Scholarships and Leadership Programme}

Eligibility: You must be applying to start a new graduate course at Oxford. Please visit the website to see the complete list of eligible courses and country of residence

Level of Study: Postgraduate

Type: Scholarship

Value: University fee, college fee, and full living expenses

Length of Study: Period of fee liability

Frequency: Annual

Country of Study: United Kingdom

Application Procedure: Please see website for more details, including how to apply

Closing Date: Relevant January deadline for your course (11 January)

Funding: Trusts

Additional Information: For more information, please check the website: www.graduate.ox.ac.uk/weidenfeldhoffmann

For further information contact:

Email: info@whtrust.org

\section{Wolfson College: Lorne Thyssen Scholarship}

Level of Study: Graduate

Value: University fee, college fee, and living expenses

Length of Study: Period of fee liability

Country of Study: Any country

Application Procedure: Open to new Home/European Union applicants to DPhil courses within the range accepted by Wolfson College, and who are specializing in Ancient World Studies. Please see website for more details

Closing Date: Relevant January deadline for your course Additional Information: For more details, please visit www. wolfson.ox.ac.uk/scholarships/lorne-thyssen

For further information contact:

Email: ancient.world@wolfson.ox.ac.uk

\section{Wolfson College: Mougins Museum Ashmolean Scholarship}

Subjects: Classical archaeology (specifically Greek material culture from 700 to $30 \mathrm{BC}$ )

Eligibility: Open to Home/European Union and Overseas. The applicant's thesis should fall within the field of 'Greek material culture from 700 to $30 \mathrm{BC}$ ' and will ideally focus on the archaeological and/or numismatic collections within the
Ashmolean. The Mougins Museum itself holds important collections which can be made available for study

Level of Study: Research

Type: Scholarship

Value: $£ 20,000$ per year for 3 years towards university fees, college fees and maintenance

Length of Study: Up to 3 years

Frequency: Annual

Application Procedure: Select the 'Mougins Scholarship's box in the University of Oxford Scholarships section of the Application Form for Graduate Study. Applicants are encouraged to include a statement explaining how their proposed research relates to the Scholarship. Preference may be given to those who list Wolfson as their first choice college

Closing Date: 22 January

Additional Information: Graduate scholarship in Greek material culture of the archaic, classical or Hellenistic periods. Please check at www.wolfson.ox.ac.uk/mougins-museumashmolean-scholarship-2015-16 for more information

\section{For further information contact:}

Email: $\quad$ susan.walker@ashmus.ox.ac.uk

Contact: Dr Susan Walker

\section{Worcester College: C. Douglas Dillon Scholarship}

Eligibility: Open to graduate applicants for 1 year or 2-year courses in the fields of Politics, Diplomacy, Governance and International Relations. Please see website for more details, including eligible courses and how to apply

Level of Study: Graduate

Value: $£ 10,000$

Length of Study: 1 or 2 years

Country of Study: Any country

Closing Date: 3 March

Additional Information: For more details, visit website www. worc.ox.ac.uk/applying/graduates/graduate-scholarships

For further information contact:

Email: graduate.enquiries@worc.ox.ac.uk

\section{Worcester College: Drue Heinz Scholarship}

Level of Study: Graduate

Value: $£ 10,000$

Length of Study: 1 year

Country of Study: Any country

Application Procedure: Open to graduate applicants in the Humanities. Preference given to international applicants. Please see website for more details, including how to apply 
Closing Date: 3 March

Contributor: Worcester

Additional Information: For more details, please visit website: www.worc.ox.ac.uk/applying/graduates/graduatescholarships

\section{For further information contact:}

Email: graduate.enquiries@worc.ox.ac.uk

\section{Worcester College: Law Faculty Graduate Scholarship}

Eligibility: Open to applicants who are applying for the Bachelor of Civil Law or Magister Juris. Award holders will become members of Worcester College. Please see website for more information

Level of Study: Graduate, Postgraduate

Type: Scholarship

Value: $£ 10,000$

Length of Study: 1 year

Study Establishment: Worcester College

Country of Study: Any country

Closing Date: Relevant January deadline for your course

Additional Information: Please visit the website: www. worc.ox.ac.uk/applying/graduates/graduate-scholarships for more information

\section{For further information contact:}

Tel: $\quad$ (44) 1865278300

Email: lodge@worc.ox.ac.uk

\section{Worcester College: Martin Senior Scholarship}

Subjects: All subjects

Eligibility: Open to graduate applicants to research degrees from the United Kingdom or European Union who are current or previous members of Worcester College

Level of Study: Postgraduate, Research

Type: Scholarship

Value: $£ 4,000$

Length of Study: Duration of student's fee liability

Frequency: Annual

Study Establishment: Worcester College

Application Procedure: Please see college website for details of how to apply

Closing Date: 1 March

Additional Information: Please check the website: www. worc.ox.ac.uk/applying/graduates/graduate-scholarships for further details
For further information contact:

Email: graduate.enquiries@worc.ox.ac.uk

Contact: Graduate Officer

\section{Worcester College: Ogilvie Thompson Scholarships}

Subjects: All subjects

Purpose: To assist graduate students with fees

Eligibility: Open to incoming graduates who have been undergraduates at Worcester within the last two years and have not undertaken any graduate work at Oxford or elsewhere

Type: Scholarships

Value: Up to $£ 6,000$

Length of Study: 1 year

Country of Study: Any country

For further information contact:

Email: graduate.enquiries@worc.ox.ac.uk

\section{University of Paris-Saclay}

Website: www.universite-paris-saclay.fr/en/universiteparis-saclay-international-masters-scholarship

The University of Paris-Saclay is a French federal research university which is currently under development with the aim to become a world top-10 university.

\section{Université Paris-Saclay International Master's Scholarships}

Purpose: The Université Paris-Saclay would like to promote access to its master's (nationally-certified degree) programs to international students, taught in its member establishments, and to make it easier for highly-qualified foreign students to attend its university especially those wishing to develop an academic project through research up to the doctoral level Eligibility: Newly arrived international students, aged 30 and under during the course of the selection year. - International students living in France for less than a year, taking language classes (type FFL or the like). - Students enrolled in a Université Paris-Saclay Master's programme and whose institution of administrative enrolment is one of the following: AgroParisTech, CentraleSupelec, ENS Paris-Saclay, INSTN-CEA, IOGS, UVSQ, UEVE, UPSud

Level of Study: Postgraduate 
Value: $€ 10,000$ per year

Frequency: Annual

Study Establishment: Université Paris-Saclay, France

Country of Study: France

Application Procedure: To be considered for the scholarships, students must first be admitted to a Master's Programme offered at Université Paris-Saclay

Closing Date: 13 May

Funding: Government

Additional Information: For more details visit official scholarship website: www.universite-paris-saclay.fr/en/universiteparis-saclay-international-masters-scholarship-programmeacademic-year-2017-2018

\section{University of Pretoria}

Private Bag X20, Hatfield 0028, South Africa

Tel: (27) 124203111

Website: www.up.ac.za/

\section{Commonwealth PhD scholarships}

Subjects: The scholarships are provided to learn any of the courses offered by the University of Pretoria in South Africa Purpose: Commonwealth PhD Scholarships are for candidates from low and middle income Commonwealth countries, for full-time doctoral study at a United Kingdom university. Commonwealth $\mathrm{PhD}$ Scholarships are for candidates from low and middle income Commonwealth countries, for fulltime doctoral study at a United Kingdom university

Eligibility: 1. Applicants should be citizens of Commonwealth countries (excluding South African students). 2. Applicants must conduct their studies at the University of Pretoria. 3. They must have completed the degree that will give them admission to a doctoral programme a maximum of 3 years prior to their application for the University of Pretoria Commonwealth Doctoral Scholarship. 4. They must not be older than 35 years of age at the time of application. Masters students currently registered at the University of Pretoria are not eligible for the Doctoral Scholarship

Level of Study: Doctorate

Type: Scholarship

Value: The value of the Doctoral Scholarships will be ZAR 120,000. This amount must be used to cover accommodation and living cost, medical aid and books/stationery. For detailed information, please visit website

Country of Study: South Africa

Application Procedure: The mode of applying is electronically or by post
Closing Date: 30 August

Contributor: University of Pretoria

Additional Information: For further information, kindly check the following pdf link. cscuk.dfid.gov.uk/wp-content/ uploads/2019/02/terms-conditions-phd-scholarships-low-mi ddle-income-countries-2019-FINAL._pdf

\section{For further information contact:}

Email: eas@cscuk.org.uk

\section{University of Pune}

Institute of Bioinformatics \& Biotechnology (IBB), Ganeshkhind, Pune, Maharashtra 411007, India

Tel: $\quad$ (91) 2025692039

Fax: (91) 2025690087

Email:_director@bioinfo.ernet.in

Website: www.unipune.ernet.in

Contact: Director

The University stands for humanism and tolerance, for reason for adventure of ideas and for the search of truth. It stands for the forward march of the human race towards even higher objectives. If the universities discharge their duties adequately then it is well with the nation and the people-Jawaharlal Nehru.

\section{Department of Biotechnology (DBT) Junior Research Fellowship}

Subjects: Biotechnology and applied biology

Purpose: To support candidates pursuing research in areas of biotechnology and applied biology

Eligibility: Open to candidates from the centres supported by the DBT, New Delhi

Level of Study: Research

Type: Fellowship

Value: INR 30,000 per fellow per year

Length of Study: $3-5$ years

Frequency: Annual

Study Establishment: University of Pune

Country of Study: India

Application Procedure: A written application along with application fee of INR 500 in the form of a DD in favour of Registrar, University of Pune

Contributor: Government of India 


\section{For further information contact:}

Department of Biotechnology, University of Pune, Pune, Maharashtra 411007, India

Tel: $\quad$ (91) 2025694952,25692248

Email:_jkpal@unipune.ernet.in,jkpal@hotmail.com

Contact: Professor Jayanta Kumar Pal, Co-ordinator, DBJ-JRF Programme

\section{University of Queensland}

Research and Postgraduate Studies, Cumbrae-Stewart Building, Brisbane, St Lucia, QLD 4072, Australia

Tel: (61) 733651111

Fax: (61) $733654455 / 6941$

Email: scholarships@research.uq.edu.au

Website: www.uq.edu.au

The University of Queensland has an outstanding profile in the Australian and international research community. It maintains a world-class, comprehensive programme of research and research training, underpinned by state-of-the-art infrastructure and a commitment to rewarding excellence. As one of Australia's premier universities, UQ attracts researchers and students of outstanding calibre.

\section{Dr Rosamond Siemon Postgraduate Renal Research Scholarship}

Subjects: Medical sciences

Purpose: To support a research higher degree candidate to undertake multidisciplinary, collaborative research into renal disease, repair and regeneration

Eligibility: Open to candidates who are enroled or intend to enrol in a research higher degree at the University of Queensland and who demonstrate a high level of academic achievement and ability

Level of Study: Postgraduate

Type: Scholarship

Value: $A \$ 30,000$ per year (a stipend of $A \$ 25,000$ and a direct research cost allowance of $A \$ 5,000$ )

Length of Study: 3 years and 6 months

Frequency: Annual

Country of Study: Australia

Application Procedure: Applicants must send a proposed research project description, certified copies of academic transcripts, academic curriculum vitae, including publications and 3 letters of recommendation
Closing Date: 31 August

Funding: Individuals

Contributor: Dr Rosamond Siemon

Additional Information: Research Scholarships Referee Report Form can be used. This can be accessed from www. uq.edu.au/grad-school/scholarship-forms

\section{For further information contact:}

Research Scholarships, Office of Research and Postgraduate Studies, The University of Queensland, St Lucia, QLD 4072, Australia

Email: postgrad-office@imb.uq.edu.au

Contact: Professor Melissa Little

\section{Global Archaeological Science Scholarships}

Subjects: Scholarships are awarded for archaeological science projects in Africa, Europe and Australia.

Purpose: The University of Queensland Archaeology Program is offering four $\mathrm{PhD}$ studentships for international and domestic students to start for archaeological science projects in Africa, Europe and Australia.

Eligibility: Australian and international students are eligible to apply. Students whose first language is not English must demonstrate proficiency in English by submitting satisfactory scores from the Test of English as a Foreign Language (TOEFL).

Type: Postgraduate scholarships

Value: A $\$ 27,082$ (old rate) indexed annually, tuition fees, Overseas Student Health Cover (OSHC)

Study Establishment: Scholarships are awarded for archaeological science projects in Africa, Europe and Australia

Country of Study: Australia

Application Procedure: See the website

Closing Date: 17 January

Additional Information: For more details please visit the website scholarship-positions.com/global-archaeologicalscience-scholarships-university-queensland-2018/2017/12/29/

\section{For further information contact:}

Email: a.crowther@uq.edu.au; t.manne@uq.edu.au; c.clarkson@uq.edu.au

\section{Herdsman Fellowship in Medical Science}

Subjects: Medicine, related health sciences

Purpose: The fellowship is open to graduates in medicine or related health sciences enroled full-time for a $\mathrm{PhD}$ on a topic related to the medical problems of the aged 
Eligibility: Applicants must be graduates in medicine or related health sciences, enrol full-time for a $\mathrm{PhD}$, and be undertaking a research topic related to the medical problems of the aged

Level of Study: Postgraduate

Type: Fellowship

Value: A $\$ 22,860$ per year

Length of Study: Fellowship shall initially be for 1 year but may be extended by the committee for further terms of 1 year up to a total of 3 years

Country of Study: Australia

No. of awards offered: 1

Application Procedure: Applications must consist of: covering letter addressing the Herdsman Fellowship Rules, in particular point 2, academic curriculum vitae, 2 referee reports. No strict format is required; however the Research Scholarships generic Referee Report may be used

Closing Date: 31 August

Contributor: Maintained by the income from a bequest of \$2,60,000 from Mrs Rose Herdsman

No. of awards given last year: 1

No. of applicants last year: 1

\section{For further information contact:}

Faculty of Health Sciences, University of Queensland, Australia

Email: s.tett@pharmacy.uq.edu.au

Contact: Professor Susan Tett, Deputy Executive Dean and Director of Research

\section{PhD Scholarship in Immunology and Immunogenetics}

Subjects: Immunology

Purpose: To provide the foundations for the development of treatments based on the genetic findings

Eligibility: Open to a dynamic, intelligent and diligent $\mathrm{PhD}$ candidate (Australian or international) with either a clinical or a relevant basic science background to take forward the project

Level of Study: Doctorate

Type: Scholarship

Value: $A \$ 25,000$ per year

Length of Study: 3 years

Frequency: Annual

Study Establishment: The University of Queensland

Country of Study: Australia

Application Procedure: Candidates must contact Prof. Brown for more information

Closing Date: 3 September

Additional Information: International applicants must cover tuition fees (A $\$ 27,000$ per year)

\section{For further information contact:}

Tel: $\quad$ (61) 732402870

Email: matt.brown@qut.edu.au

Contact: Professor Matt Brown

\section{R.N. Hammon Scholarship}

Subjects: Science, engineering, medicine, dentistry, architecture, agriculture and veterinary science, and other fields of study

Purpose: To assist Australian Aboriginal and/or Torres Strait Island students for further studies

Eligibility: Open to Australian Aboriginal and/or Torres Strait Island students who have successfully completed at least 1 year of an undergraduate or postgraduate program and are enroling on a full-time basis for a subsequent year of that program, or for a further program

Level of Study: Postgraduate

Type: Scholarship

Value: A $\$ 3,500$

Frequency: Annual

Study Establishment: The University of Queensland, Queensland University of Technology, University of Southern Queensland, Central Queensland University, or Queensland Colleges of TAFE

Country of Study: Australia

Application Procedure: Candidates can download the application form and referee report form from the website

Closing Date: 15 March

Additional Information: The Selection Committee shall take into account the academic merit or technical excellence, any other scholarship, bursary, award or benefit, whether governmental or otherwise, to which the applicant is entitled; and social and economic need

\section{For further information contact:}

Tel: $\quad$ (61) 733651984

Email: ugscholarships@uq.edu.au

\section{Sustainable Tourism CRC Climate Change PhD}

Subjects: Commerce, management, tourism and services Purpose: To develop a tourism consumer decision-making model that focuses on climate change as a driver of consumer choice and apply it to Australian tourism market Eligibility: Open to candidates who have achieved First Class (Honours) Degree or equivalent

Level of Study: Postgraduate, Research

Type: Scholarship

Value: A $\$ 19,930$ per year

Length of Study: 3 years 
Frequency: Annual

Study Establishment: The University of Queensland

Country of Study: Australia

Application Procedure: Candidates must contact Jane Malady for application forms

Contributor: Sustainable Tourism CRC and University of Queensland

Additional Information: For further information on topic and research proposal contact Prof. Ballantyne at r.ballantyne@uq.edu.au

\section{For further information contact:}

Tel: $\quad$ (61) 755529063

Email: Jane@crctourism.com.au

Contact: Jane Malady

\section{The Constantine Aspromourgos Memorial Scholarship for Greek Studies}

Subjects: Greek studies

Purpose: To assist a research higher degree student studying at least 1 area of Greek studies

Eligibility: Open to candidates who have obtained their Bachelors or Masters degrees and are undertaking a postgraduate programme involving studies which pertain to at least one area of Greek studies

Level of Study: Postgraduate

Type: Scholarship

Value: Approx. A $\$ 4,000$

Length of Study: 1 year

Frequency: Annual

Country of Study: Australia

Application Procedure: Applicants must send a completed application form

Closing Date: 22 March

Funding: Individuals

Additional Information: The Scholarship is also open to candidates who are undertaking the programme as a student of another university acceptable to the committee, or this university, provided that some part of the programme involves studies at another university

\section{For further information contact:}

Faculty of Arts, Forgan Smith Building, The University of Queensland, St Lucia, QLD 4072, Australia

Tel: $\quad$ (61) 733651333

Email: arts@uq.edu.au

Contact: Executive Dean

\section{University of Queensland PhD Scholarships for International Students}

Subjects: View projects by area Agribusiness, Agriculture, Environment, and Science Engineering, Architecture and Planning, and Information Technology Health Humanities, Education, Psychology, and Music Business, economics, and law (coming soon).

Purpose: Students must have achieved an entry level OP minimum of 11 or the equivalent if originating from another Australian state or territory or for continuing students has a GPA of at least 4.0.

Eligibility: Australian and Permanent Residents or NZ citizens and International students are eligible to apply. Applicants must meet the university's English language proficiency requirements apply. A postgraduate degree of at least one year full-time equivalent with an overall GPA (grade point average) equivalent to 5.0 on the 7-point UQ scale, together with demonstrated research experience equivalent to honors IIA will be considered for PhD entry on a case by case basis.

Value: A Base stipend of A $\$ 27,082$ per annum (old rate), indexed annually, tuition fees, Overseas Student Health Cover (OSHC)

Study Establishment: View projects by area Agribusiness, Agriculture, Environment, and Science Engineering, Architecture and Planning, and Information Technology Health Humanities, Education, Psychology, and Music Business, economics, and law (coming soon)

Country of Study: Australia

Application Procedure: See the website.

Closing Date: 31 December

Additional Information: For more details please visit the website scholarship-positions.com/uq-phd-scholarshipsinternational-students-australia/2018/03/06/

\section{For further information contact:}

Tel: (61) 733651111

Email: graduateschool@uq.edu.au

\section{Walter and Eliza Hall Scholarship Trust Opportunity Scholarship for Nursing}

Purpose: Awarded to a financially disadvantaged student studying the Bachelor of Nursing or Bachelor of Nursing/ Bachelor of Midwifery program

Eligibility: The scholarship is open to students who: 1. Are domestic students in accordance with The University's Fee Policy; and; 2. Are enrolled full-time in the Bachelor of Nursing program or the dual Bachelor of Nursing/Bachelor of Midwifery program; and; 3. Have completed at least 16 units towards their program; and do not hold another similar scholarship 
Level of Study: Graduate

Type: Scholarship

Value: $A \$ 10,000$

Length of Study: 2nd - 4th year

Frequency: Annual

Country of Study: Any country

Application Procedure: The Scholarship will be awarded on the basis of: I. academic merit. II. financial disadvantage. III. a personal statement. The Scholarship will be awarded by a selection committee consisting of members nominated by the Deputy Vice Chancellor (Registrar) or their nominated delegate Closing Date: 4 March

Funding: Private

Additional Information: The recipient must demonstrate financial need, and also have performed satisfactorily in the program to date. Grade point averages will be considered; however, the grade point average will not be the sole determinant in satisfactory progress - the applicants' behaviour, class attendance, dedication to the program and career aspirations are also a part of the selection process

\section{For further information contact:}

Brisbane, St Lucia, QLD 4072, Australia

Tel: $\quad$ (61) 733651111

Email: nmsw.scholarship@uq.edu.au

\section{University of Reading}

Whiteknights, PO Box 217, Reading RG6 6AH, United Kingdom

Tel: $\quad$ (44) 1189875123

Fax: (44) 1189314404

Email: student.recruitment@reading.ac.uk

Website: www.rdg.ac.uk

Contact: Student Financial Support Office

The University of Reading offers postgraduate taught and research degree courses in all the traditional subject areas except medical sciences. Vocational courses are also offered. Research work in many areas is of international renown.

\section{British Property Federation Lord Samuel of Wych Cross Memorial Award}

Subjects: Land management

Purpose: To assist students who would otherwise be unable financially to follow the MSc course
Eligibility: Open to candidates who hold a 1st degree and are, at the time of the award, ordinarily resident in the United Kingdom

Level of Study: Postgraduate

Type: Scholarship

Value: $£ 1,000-£ 2,000$

Length of Study: 1 year

Frequency: Annual

Study Establishment: The University of Reading

Country of Study: United Kingdom

Application Procedure: Applicants must submit a curriculum vitae by invitation to the Director of the FullTime Postgraduate Real Estate Programme

Closing Date: Applications will be invited in May of the intended year of entry

Funding: Private

No. of awards given last year: 3

Additional Information: Scholars must intend to remain resident in the United Kingdom after the term of the scholarship has ended

\section{For further information contact:}

Tel: $\quad$ (44) 1183786336

Email: n.s.french@reading.ac.uk

Contact: Mr Nick French

\section{Otway Cave Scholarship}

Subjects: Land management

Purpose: To assist students who would otherwise be unable financially to follow the MSc course in Land Management

Eligibility: Open to candidates who hold a first degree and are, at the time of the award, ordinarily resident in the United Kingdom

Level of Study: Postgraduate

Type: Scholarship

Value: $£ 1,000$ (but may be higher)

Length of Study: 1 year

Frequency: Annual

Study Establishment: The University of Reading

Country of Study: United Kingdom

No. of awards offered: 20

Application Procedure: Applicants must submit curriculum vitaes by invitation

Funding: Private

No. of awards given last year: 1

No. of applicants last year: 20

Additional Information: Scholars must intend to remain resident in the United Kingdom after the term of the scholarship has ended. Awarded only to students accepted to study MSc Land Management 
For further information contact:
Tel: $\quad$ (44) 1734318182
Fax: (44) 1734316658
Email: n.samman@reading.ac.uk
Contact: Mr J Samman-Lloyd

\section{University International Research Studentships}

Subjects: All areas within the faculties of science, life sciences and arts, humanities and social science

Eligibility: Funding is only open to international (non-European Union) candidates. You will be required to meet the language requirements specified by your department upon entry

Type: Studentship

Value: Full prize: a subsistence grant (stipend) to match the current United Kingdom Research Council rate (the last year's rate is $£ 13,863)$. Fees-only: tuition fees at the international rate, a $£ 1,000$ per year training and development allowance

Length of Study: Up to 3 years

Frequency: Annual

Closing Date: January

Contributor: University of Reading

\section{For further information contact:}

Email: j.john@reading.ac.uk

Contact: Joanna John

\section{University of Reading Dorothy Hodgkin Postgraduate Award}

Subjects: Science, engineering, medicine, social science and technology

Eligibility: Open to nationals of either India, Mainland China, Hong Kong, Russia or a country in the developing world only

Level of Study: Postgraduate

Type: Scholarship

Value: All tuition fees and a grant for living costs

Length of Study: 1 year; 3 years

Frequency: Annual

Study Establishment: University of Reading

Country of Study: United Kingdom

Application Procedure: Contact the Jonathan Lloyd at the faculties of science and life science

Closing Date: 6 May
For further information contact:

Tel: (44) 1183788341

Email: j.d.lloyd@reading.ac.uk

\section{University of Reading MSc Intelligent Buildings Scholarship}

Subjects: Construction management and engineering Eligibility: In order to be considered for this Scholarship you must hold the offer of a place on the MSc Intelligent Buildings course

Level of Study: Postgraduate

Type: Scholarship

Value: $£ 3,000$

Length of Study: 1 year

Frequency: Annual

Study Establishment: University of Reading

Country of Study: United Kingdom

No. of awards offered: 1

Application Procedure: Contact Gulay Ozkan, Programme Coordinator at the School of Construction Management and Engineering

Closing Date: 30 August

Contributor: The Happold Trust

No. of awards given last year: 1

No. of applicants last year: 1

For further information contact:

Tel: $\quad$ (44) 1183786254

Email: g.ozkan@rdg.ac.uk

Contact: Gulay Ozkan, Programme Coordinator

\section{University of Reading Music Scholarship}

Subjects: Music

Purpose: To support excellence in music

Eligibility: In order to be considered for this scholarship you must already hold an offer of a place at the university

Level of Study: Postgraduate

Type: Scholarship

Value: All tuition fees

Length of Study: 1 year

Frequency: Annual

Study Establishment: University of Reading

Country of Study: United Kingdom

Application Procedure: Apply online

Closing Date: 1 March

Additional Information: Students must be available for audition on 21 March 


\section{For further information contact:}

Email: music@rdg.ac.uk

\section{University of Regina}

\section{Master of Indigenous Education}

Purpose: The Master of Indigenous Education degree aims to: 1. Prepare students as leaders in pedagogical practice in Indigenous Education. 2. Provide students with the required skills, knowledge, and competencies needed to become effective Indigenous educators. 3. Prepare students to conduct research with Indigenous peoples

Eligibility: Below details should be mandatorily available to process the application for the grant. 1. Personal information. 2. Proxy or Third-Party information (if you want to designate a proxy or third party to act on your behalf). 3. Educational history of all higher post-secondary institutions attended, and dates attended. This includes institutions that you attended but no degree was awarded, and degrees that are in progress and have not yet been awarded. 4. English Proficiency test scores (if applicable). 5. Names and e-mail addresses of your references. 6. Personal statement of interest. Please review "Most Common Mistake Applicants Make" before submitting your personal statement. 7. Resumé or CV. 8. Valid credit card (MasterCard, VISA, or American Express). Pre-paid credit cards and MasterCard Debit, VISA Debit or American Express Debit are not acceptable methods of payment. 9. Valid e-mail address

Level of Study: Postgraduate

Type: Funding support

Frequency: Annual

Country of Study: Any country

Application Procedure: 1. The online application takes about 30 minutes to complete. 2 . The first time you access the online application, you will be asked to create a Login ID and PIN. For security reasons, it is important that you choose a unique (hard-to-guess) PIN number. Please make a note of your login information, as you will need it later. 3 . Once you have started your application, you may choose to Finish Later. You can return to the application at any time by re-entering your Login ID and PIN number. However, you must complete it prior to the application deadline for your program

Closing Date: 15 February and 15 October

Funding: Private

\section{For further information contact:}

Tel: $\quad$ (44) 3065854502

Email: Grad.Studies@uregina.ca

\section{University of Sheffield}

85 Wilkinson Street, Sheffield S10 2GJ, United Kingdom

Tel: (44) 1142221404

Fax: (44) 1142221420

Website: www.shef.ac.uk

Contact: Graduate Office

The University of Sheffield is a research led university offering research supervision, taught courses and professional training in engineering and physical sciences, biologies, environmental sciences, humanities, social sciences, medical and health sciences. Many departments have funding council accreditation and scholarships and bursaries may be available.

\section{Allan \& Nesta Ferguson Charitable Trust}

Purpose: The Allan \& Nesta Ferguson Charitable Trust was set up to promote their particular interests in education, international friendship and understanding, and the promotion of world peace and development

Eligibility: Applications for either a gap year or $\mathrm{PhD}$ grant should be made as soon as possible, either before the beginning of the proposed gap year or at least three months before the start of the final year of a $\mathrm{PhD}$ course

Level of Study: Graduate

Type: Varies

Frequency: Annual

Country of Study: Any country

Application Procedure: 1. The Trust prefer where possible that you complete and submit the on-line application form on this website and email it to us. Alternatively you may download and print out the application form, complete it and send it by letter post. 2. Please do not extend the length of the forms, or add any attachments. Applications MUST NOT exceed 3 pages. Please use text size 12. 3. If you are applying for more than one project, please use a separate form for each project. All applications by email will be acknowledged and a decision will usually be given within three months of the application

Closing Date: 24 May

Funding: Private

\section{For further information contact:}

John St, Royston, SG8 9BG, United Kingdom

Email: internationalscholarships@sheffield.ac.uk 


\section{Allan \& Nesta Ferguson Charitable Trust Masters Scholarships at University of Sheffield}

Purpose: The University of Sheffield, in collaboration with the Allan and Nesta Ferguson Charitable Trust and the Sheffield Institute for International Development, is now able to offer 10 scholarships (over 3 years) targeted at international students from developing countries for a number of courses that are affiliated with the Sheffield Institute for International Development

Eligibility: 1 . Must be between the ages of 23-32 at the time of submitting his/her application. 2. Must have obtained or be on the verge of completing their undergraduate degree with a Baccalaureate from an accredited college/university, or its equivalent. 3. Must have a minimum cumulative GPA of 3.0 or higher on a 4.0 rating system, or its equivalent. 4 . Must be matriculated at an accredited university for the upcoming academic year starting August/September, and must maintain full-time status for the duration of the Master's Degree

Level of Study: Postgraduate

Type: Scholarship

Frequency: Annual

Study Establishment: University of Sheffield

Country of Study: Any country

Application Procedure: You will be automatically considered for the scholarship if you receive an offer to study one of the eligible courses and you are a national of, or permanently domiciled in, one of the eligible countries or territories. Your course application will be assessed by a panel of academic judges to decide whether you will progress to the final stage of the application process. Please use our postgraduate online application system to submit your application for an eligible course. For further information, check the website link. www. sheffield.ac.uk/international/money/fergusonscholarship

Closing Date: 30 April

Funding: Private

Contributor: University of Sheffield

\section{For further information contact:}

The University of Sheffield, Western Bank, Sheffield S10 2TN, United Kingdom

Email: internationalscholarships@sheffield.ac.uk

\section{Edward Bramley Excellence Postgraduate Scholarship}

Purpose: The University of Sheffield is pleased to offer the Edward Bramley Excellence Postgraduate Scholarship to support an outstanding United Kingdom or European Union law student, based on academic excellence
Type: Scholarship

Value: University has one full fee waiver with $£ 7,000$ towards living costs for the outstanding student

Country of Study: United Kingdom

Closing Date: 15 June

Contributor: Edward Bramley Excellence

\section{For further information contact:}

Email:1law@sheffield.ac.uk

\section{Economic and Social Research Council(ESRC) White Rose Doctoral Training Partnership (DTP) and Faculty Scholarships}

Purpose: The University is part of the ESRC White Rose Doctoral Training Partnership - a collaboration between the Universities of Leeds, Sheffield, York, Sheffield Hallam, Hull, Bradford and Manchester Metropolitan University - and offers a range of ESRC Postgraduate Scholarships

Eligibility: Our Faculty scholarships are open to applicants of any nationality and in any discipline within the Faculty of Social Sciences. Most ESRC White Rose DTP scholarships are open to United Kingdom and European Union applicants; there may be limited opportunities for overseas students, and all applicants should check ESRC White Rose DTP guidance before making an application

Level of Study: Graduate, Postgraduate

Type: Scholarship

Value: Tuition Fees, an annual stipend and research training support grant

Frequency: Annual

Study Establishment: University of Sheffield

Country of Study: Any country

Closing Date: Not available

Funding: Private

For further information contact:

Email: pgr-scholarships@sheffield.ac.uk

\section{Hossein Farmy Scholarship}

Subjects: Mining, including, but not limited to the geological, engineering, scientific and technological aspects of mining, and the archaeological, economic, historical, legal and social aspects of mining and the mining industry

Value: The Hossein Farmy Scholarship covers the cost of the United Kingdom tuition fees and provides an annual, tax-free maintenance stipend at the standard United Kingdom Research rate $(£ 14,553)$ 
Country of Study: United Kingdom

Closing Date: End of April

Funding: Private

Additional Information: If you have any questions about the Hossein Farmy Scholarship please email pgr-scholarships@ sheffield.ac.uk

\section{For further information contact:}

Email: pgr-scholarships@sheffield.ac.uk

\section{International Merit Postgraduate Scholarship}

Value: $50 \%$ of the annual postgraduate tuition fee

Country of Study: Any country

Application Procedure: Please visit website www.sheffield. ac.uk/international/enquiry/money/pgtmerit for more details

Closing Date: 15 June

\section{For further information contact:}

Email:1.a.tarrant@sheffield.ac.uk

\section{Postgraduate Taught Sheffield Scholarship}

Purpose: To offer the Postgraduate Taught Sheffield Scholarship to international students starting a taught masters programme in September

Type: Scholarship

Value: $£ 2,000$ if your tuition fees are between $£ 16,800$ and $£ 18,900$ and $£ 2,500$ if your tuition fees are $£ 18,901$ and upwards

Country of Study: United Kingdom

Application Procedure: Subject to meeting the eligibility and award criteria the Postgraduate Taught Sheffield Scholarship will be awarded automatically - no application is required

Closing Date: 21 February

\section{For further information contact:}

Email: eurec@sheffield.ac.uk

\section{Sheffield Postgraduate Scholarships}

Purpose: The scholarships are for students who meet at least one of our widening participation criteria and/or students who achieve a first in their undergraduate degree. If your application is successful you can use the scholarship towards fees or living expenses, the choice is yours
Eligibility: You can apply for a scholarship if you meet the following four criteria: Studying a taught postgraduate course full-time or part-time for a maximum of four years. Domiciled in the United Kingdom (United Kingdom) or European Union (European Union) and not charged international rate fees. Not already qualified at masters level, or higher. Must be self funding - courses fully funded by the NHS or the Initial Teacher Training bursary, or courses that are eligible for undergraduate funding such as integrated masters are not eligible

Type: Scholarship

Value: $£ 10,000$ each

Country of Study: United Kingdom

Application Procedure: A selection panel consisting of senior academic and professional services staff, will consider your scholarship application. The panel will look at personal circumstances of those who meet widening participation criteria and take into account achievements of the academic merit applicants. All applications are anonymised and the decision of the panel is discretionary and final

Closing Date: 14 May

Additional Information: If you have any questions or would like to talk to someone about the awards, please contact the Financial Support Team on 01142221319 or sheffieldscho lars@sheffield.ac.uk

\section{For further information contact:}

Email: sheffieldscholars@sheffield.ac.uk

\section{University Prize Scholarships}

Subjects: These scholarships are open to applicants in all subjects

Purpose: Each year the University offers a small number of University Prize Scholarships to the very best $\mathrm{PhD}$ applicants

Type: Scholarship

Value: Full tuition fees (United Kingdom, European Union or overseas), an annual, tax-free maintenance stipend of $£ 20,000$,a Research Training Support Grant of $£ 2,500$ per year for study visits, conferences, books, consumables and equipment

Country of Study: United Kingdom

Closing Date: 23 January

Additional Information: If you have any questions about University Prize Scholarships please email pgrscholarships@sheffield.ac.uk

\section{For further information contact:}

Email: pgr-funding@sheffield.ac.uk 


\section{White Rose Studentships}

Subjects: Plant biology

Purpose: Collaborative research networks within the three White Rose Universities

Eligibility: Open to United Kingdom, European Union, and international applicants who will register with the University for a $\mathrm{PhD}$ degree

Level of Study: Postgraduate, Research

Type: Studentship

Value: Home/European Union tuition fees, an annual maintenance grant of $£ 14,057$

Length of Study: 3 years

Frequency: Annual

Study Establishment: One of the three White Rose Universities Application Procedure: Candidates can check the website for further details

Closing Date: Check with the website www.sheffield.ac.uk/ postgraduate/research/scholarships/whiterose

Additional Information: International applicants are only eligible if they can show sufficient funds to cover the difference between the United Kingdom and international students tuition fee

For further information contact:

Email: s.beecroft@shef.ac.uk

Contact: Simon Beecroft

\section{University of South Australia}

GPO Box 2471, Adelaide, SA 5001, Australia

Tel: $\quad$ (61) $883026611 / 3615$

Fax: (61) $883022466 / 3997$

Email: research.international@unisa.edu.au

Website: www.unisa.edu.au

The University of South Australia is an innovative and successful institution with a distinctive profile. It is committed to educating professionals, creating and applying knowledge and serving the community.

\section{Division of Business Student Mobility Scholarships}

Subjects: Business programme

Purpose: To assist business students undertaking an international exchange (via the UniSA International Student Exchange Program) at a partner university
Eligibility: Open to both undergraduate and postgraduate coursework students enroled in a Division of Business program and are participating in exchange for the first time

Level of Study: Postgraduate

Type: Scholarship

Value: A $\$ 5,000$ for Institutional Partner Scholarships; $\$ 2,500$ for Student Mobility Scholarships

Frequency: Annual

Application Procedure: For extended criteria and application details, please contact: Ms Sarah Oolyer-Braham

Closing Date: 30 January

\section{For further information contact:}

Tel: $\quad$ (44) 883020880

Email: sarah.collyer-braham@unisa.edu.au

Contact: Ms Sarah Collyer-Braham, Administrative Officer

\section{Donald Dyer Scholarship - Public Relations \& Communication Management}

Subjects: Public relations and communication management Purpose: To encourage research of an original nature leading to the advancement of knowledge in public relations and communication

Eligibility: Open to candidates who have achieved First Class (Honours) or equivalent. Candidates from discipline areas such as public relations, communication, marketing or advertising are encouraged to apply

Level of Study: Postgraduate, Research

Type: Scholarship

Value: A $\$ 22,000$ per year (tax-free) plus one return travel airfare between the candidate's home location and Adelaide, and organized by the University

Frequency: Annual

Study Establishment: University of South Australia

Country of Study: Australia

Application Procedure: Check website for further details Closing Date: 29 October

Contributor: Bequest from the estate of the Late Sylvia Dyer

\section{For further information contact:}

Tel: $\quad$ (61) 883024493

Fax: (61) 883024745

Email: david.brittan@unisa.edu.au

Contact: David Brittan, (Postgraduate Research)

Education Administrator

\section{Ferry Scholarship}

Subjects: Physics and chemistry 
Purpose: Promoting study and research in physics and chemistry

Eligibility: Open to Australian citizens under the age of 25 years on January 1 st of the year of the award, who have completed at least 4 years of tertiary education studies, have a First Class (Honours) (or equivalent undergraduate degree), and have enroled as full-time students for a Master's Degree or Doctorate by research in chemistry or physics

Level of Study: Postgraduate

Type: Scholarship

Value: A \$7,500 per year

Length of Study: Up to 3 years (Doctorate) and 2 years (Masters Degree)

Frequency: Annual

Application Procedure: Applications can be filled online

Closing Date: 31 January

Contributor: Bequest from the late Cedric Arnold Seth Ferry

For further information contact:

Tel: $\quad$ (44) 83023967

Email: jenni.critcher@unisa.edu.au

Contact: Jenni Critcher

\section{Lewis O'Brien Scholarship}

Subjects: Education, arts, and social sciences

Purpose: To assist and encourage Aboriginal and Torres Strait Islander people in postgraduate study in a field of particular relevance and potential benefit to the Indigenous Australian community

Eligibility: Open to Aboriginal and Torres Strait Islander people eligible to undertake a postgraduate program in the division of education, arts and social sciences

Level of Study: Postgraduate

Type: Scholarship

Value: Maximum A $\$ 10,000$ per year $(A \$ 2,500$ will be paid on commencement and the remainder will be paid in instalments during the year subject to certification by the supervisor of satisfactory progress)

Frequency: Annual

Country of Study: Australia

Application Procedure: Candidates must contact Ms Jillian

Mille for further information

Closing Date: 11 February

Contributor: Division of Education, Arts and Social Sciences

\section{For further information contact:}

Tel: $\quad$ (61) 883029151

Fax: (61) 883027034

Email: jillian.miller@unisa.edu.au

Contact: Jillian Miller, Coordinator Indigenous Support Services

\section{Margaret George Award}

Subjects: Archival research, history

Purpose: To encourage and facilitate use of National Archives collection by promoting archival research in Australia and encouraging scholarly use of its holdings

Eligibility: Open to postgraduate degree holders, historians, academics, independent researchers, or journalists with a talent for research

Level of Study: Postgraduate

Type: Award

Value: A $\$ 10,000$

Frequency: Annual

Country of Study: Australia

Application Procedure: Check website for further details

Closing Date: 30 June

Additional Information: Successful applicants may undertake their award at any time from the date of the announcement of the award until June 30th the following year

\section{For further information contact:}

Tel: $\quad$ (61) 262123986

Fax: (61) 262123699

Email: derina.mclaughlin@naa.gov.au

Contact: Derina McLaughlin

\section{Research Training Program International Scholarships in Australia (RTPI)}

Subjects: Scholarships are awarded to study the subjects offered by the university

Purpose: To offer Research Training Program international (RTPi) Scholarships

Eligibility: Generally, an applicant must have first-class Honours or equivalent to gain a scholarship at the University of South Australia. An awardee must be enrolled on a full-time basis as a candidate for a Masters by Research or $\mathrm{PhD}$ at the University of South Australia. An awardee shall be enrolled as an internal candidate at the University of South Australia Level of Study: Research

Type: Scholarship

Value: At least $A \$ 26,682$ per annum for 3 years, with the possibility of one 6-month extension

Length of Study: 3 years

Country of Study: Any country

Closing Date: 31 August

Funding: Government

Additional Information: An RTPi scholarship will cover your tuition fees and your Overseas Student Health Cover (OSHC), and provide a stipend (living allowance), but will not pay for travel expenses. A thesis allowance is funded to cover the cost of printing and binding the thesis 
For further information contact:

Email: research.degrees@unisa.edu.au

\section{Synchrotron Microprobe Analysis of Nickel Laterites Scholarship}

Subjects: Synchrotron Microprobe Analysis of Nickel Laterites

Purpose: To enable deserving students to pursue a career in the related fields

Eligibility: Open to citizens or permanent residents of Australia or New Zealand who have achieved an Honours Degree or equivalent

Level of Study: Postgraduate

Type: Scholarship

Value: $\mathrm{A} \$ 4,000$ per year

Frequency: Annual

Study Establishment: University of South Australia

Country of Study: Australia

Application Procedure: Applicants must write to the faculty

Closing Date: 30 September

Contributor: South Australian Premier's Science and Research Fund grant with matching funding from Rio Tinto and BHP-Billiton

For further information contact:

Email: andrea.gerson@unisa.edu.au

Contact: Andrea Gerson

\section{Trevor Prescott Memorial Scholarship}

Subjects: All subjects

Purpose: To help youth in the South Australian community to advance their careers through further postgraduate studies Eligibility: Open to students between 20 and 30 years of age who desire to do further postgraduate studies or equivalent

Level of Study: Unrestricted

Type: Scholarship

Value: Up to A $\$ 25,000$ and may be divided between more than 1 recipient

Frequency: Annual

Application Procedure: Check website for further details

Closing Date: 30 June

Funding: Foundation

Contributor: The Masonic Foundation Inc

Additional Information: Preference is not given to a Freemason or to a member of the family for the scholarship
For further information contact:

Tel: $\quad$ (61) 884439909

Fax: (61) 884439928

Email: masfound@senet.com.au

\section{University of South Wales}

Pontypridd, Wales NP18 3YG, United Kingdom

Tel: $\quad$ (44) 8455767778

Fax: (44) 1443654050

Email:_enquiries@southwales.ac.uk

Website: www.southwales.ac.uk

The University of Wales, Newport, has been involved in higher education for more than 80 years, and its roots go back even further to the first Mechanics Institute in the town, which opened in 1841 .

\section{University of Wales Postgraduate Studentship}

Subjects: All subjects approved by the University

Purpose: To support a student with a First Class (Honours) Degree at the university to progress to postgraduate research Level of Study: Doctorate, Doctorate

Type: Scholarship

Frequency: Annual

Study Establishment: University of Wales

Country of Study: Wales

Application Procedure: Applicants must check with the website or the University

Funding: Private, Private

Contributor: Private benefactions

For further information contact:

Email: shelley.doolan@uwtsd.ac.uk

\section{University of Southampton}

University of Southampton, University Road, Southampton SO17 1BJ, United kingdom

Tel: $\quad$ (44) 2380595000

Fax: (44) 2380593131

Email:_admissns@soton.ac.uk

Website: www.soton.ac.uk

Contact: Student Marketing Office 
The University of Southampton was granted its Royal Charter. Today, the University is one of the United Kingdom's top ten research universities, offering a wide range of postgraduate taught and research courses in engineering, science, mathematics, law, arts, social sciences, medicine and health and life sciences.

\section{Honor Frost Foundation Masters and/or Doctoral Awards in Maritime Archaeology}

Subjects: The Foundation's mission is to promote the advancement and research, including publication, of maritime archaeology with particular focus on the eastern Mediterranean Purpose: The Foundation's mission is to promote the advancement and research, including publication, of maritime archaeology with particular focus on the eastern Mediterranean

Eligibility: 1. The successful candidate must demonstrate a genuine interest in maritime archaeology and would be expected to develop the subject in their home country upon their return. 2 . The successful candidate will also be required to submit annual reports on their progress to the Honor Frost Foundation and contribute towards the Foundation's activities during the duration of their studies, including supporting the annual lecture. 3. The MA Scholarship requires: a good 2:1 honours degree (or equivalent) in either archaeology or a related discipline. You must be a citizen of Cyprus, Lebanon, Egypt or Syria

Level of Study: Postgraduate

Type: Award

Value: an annual stipend of $£ 15,000$ with an additional travel fund of $£ 1,000$

Frequency: Annual

Country of Study: Any country

Application Procedure: The MA Scholarship requires: a good 2:1 honours degree (or equivalent) in either archaeology or a related discipline. You must be a citizen of Cyprus, Lebanon, Egypt or Syria. The MA scholarship is tenable for one year, commencing September, at an annual stipend of $£ 15,000$ with an additional travel fund of $£ 1,000$, which can be drawn as required during your study. Tuition fees will also be paid directly to the University at the appropriate fee rate. There may also be the opportunity to continue to $\mathrm{PhD}$, fully funded, for a further 3 years on completion of the MA/MSc. Application for this studentship is by CV; a sample of written work (4,000 words, max); and a personal statement of up to 800 words explaining why you feel you are suitable for the MA or PhD scholarship. Please also arrange for two academic references to be sent independently by the deadline

Closing Date: 15 May

Funding: Private

\section{For further information contact:}

Email:11kb@soton.ac.uk

Contact: Dr Lucy Blue

\section{University of Southern California (USC)}

College of Letters, Arts and Sciences, University Park, Mail Code 4012, Los Angeles, CA 90089, United States of America

Tel: $\quad$ (1) 2137402531

Fax: $\quad$ (1) 2137408607

Website: www.usc.edu/schools/college

Contact: Mr Richard Tithecott, Assistant Administrative Director

Located near the heart of Los Angeles, the University of Southern California (USC) is a private research university. It maintains a tradition of academic strength at all levels, from the earliest explorations of the undergraduate to the advanced scholarly research of the postdoctoral Fellow.

\section{Master of Business Administration/Master of Science in Industrial and Systems Engineering (MSISE) Programme}

Application Procedure: Please contact the organisation for details

For further information contact:

Tel: $\quad$ (1) 2137404893

Fax: (1) 2137401120

Email: gradapp@enroll1.usc.edu

Contact: MBA Admissions Officer

\section{University of Stirling}

University of Stirling, Stirling FK9 4LA, United Kingdom

Email: international@stir.ac.uk

Website: www.stir.ac.uk

The University of Stirling is a United Kingdom research intensive campus university founded by Royal charter in 1967 in Stirling, Scotland. It is ranked among the top 
60 universities in the world that are under 50 years old by the Times Higher Education World University Rankings.

\section{Postgraduate Awards for International Students at University of Stirling in United Kingdom}

Purpose: University aims to be at the forefront of research and learning that helps to improve lives

Level of Study: Postgraduate

Type: Award

Value: Each award has a value of $£ 3,000$

Country of Study: Scotland

Application Procedure: Students from eligible countries will automatically be assessed for an International Postgraduate Award as part of the admissions process; there is no separate application required for this award. Students who qualify for award will be notified by admissions, once academic offer conditions have been met

Closing Date: 31 August

Additional Information: For details, contact international@stir.ac.uk

For further information contact:

Email: graduate.admissions@stir.ac.uk

\section{University of Strasbourg}

Email: admin-at-icfrc.fr

Contact: Dr Stéphanie Loison, Scientific coordinator

Strasbourg has a long tradition of scientific excellence, in particularly in chemistry, built through the ages by renowned scientists such as Louis Pasteur, Charles Gerhardt and Nobel Laureates Adolf von Baeyer, Emil Fischer, Hermann Staudinger, Jean-Marie Lehn and more recently Martin Karplus (2013) and now Jean-Pierre Sauvage (2016). The result is that Strasbourg has always been a center of excellence in molecular science, with its top 20 worldwide ranking.

\section{PhD Fellowships in Chemistry}

Subjects: Chemistry

Purpose: To pursue $\mathrm{PhD}$

Eligibility: Foreign students can apply for these $\mathrm{PhD}$ fellowships, as well as French national students, who wish to pursue their $\mathrm{PhD}$ research study in Strasbourg from September or October
Length of Study: 3 years

Country of Study: France

Closing Date: 15 November

Funding: Foundation

Contributor: Ernest Solvay Fund and the FRC Foundation

For further information contact:

Email: admin@scholarship-positions.com

\section{University of Strathclyde}

McCance Building, 16 Richmond Street, Glasgow G1 1XQ, United Kingdom

Tel: $\quad$ (44) 1415482387

Fax: (44) 1415520775

Email: r.livingston@mis.strath.ac.uk

Website: www.strath.ac.uk

\section{Department of Chemical and Process Engineering PhD Studentship}

Subjects: Chemical and process engineering

Eligibility: Candidates should be highly motivated and have a First Class Honours degree in chemical engineering, physics or chemistry. An MSc/MEng in science or engineering and previous experience in the field of chemistry of materials would be an advantage. Students will engage in the Department's research seminar programme, and will have opportunities to attend national and international conferences. Other generic skills and courses are open to students, including scientific writing, presentation and careers workshops. International students must be proficient in English language (the University's entry requirements are IELTS 6.5, TOEFL 600 including the test of written English, TOEFL 250 computer based test or TOEFL 90-95 internet based test)

Level of Study: Doctorate

Type: Studentship

Value: The award will cover United Kingdom/European Union tuition fees and will pay a stipend of $£ 13,863$ per year (for 3 years). International students would have to pay the difference between the Home/European Union and international fee

Length of Study: 3 years

Frequency: Annual

Study Establishment: University of Strathclyde

Country of Study: Scotland 
Application Procedure: Please send your curriculum vitae and a covering letter, indicating your previous experience and fields of interest and include the details of at least two academic referees to Dr S. V. Patwardhan

Closing Date: 30 May

\section{For further information contact:}

Tel: (44) 1415485786

Email: Siddharth.Patwardhan@strath.ac.uk

\section{Fraser of Allander Institute Scholarships for MSc Applied Economics}

Subjects: Applied Economics

Purpose: Scholarships are available to join the MSc Applied Economics programme

Value: Each scholarship worth $£ 6,000$

Country of Study: United Kingdom

Application Procedure: Candidates interested in applying should provide a maximum 1,000 word statement demonstrating, through their ideas, experience and future career plans (including their reasoning for joining the MSc Applied Economics) why they should be awarded this scholarship. Candidates will also be considered on the overall quality of their application and financial need. The mode of applying is online. Please visit website www.sbs.strath.ac.uk/apps/schol arships/economics/applied-economics.asp for online application

Closing Date: 1 June

Additional Information: For more details, please visit the website www.strath.ac.uk/studywithus/scholarships/strathcly debusinessschoolscholarships/economicsscholarships/frasero fallanderinstitutefaihomeeuscholarshipsformscappliedecono mics/

\section{For further information contact:}

Email: sbs.admissions@strath.ac.uk

\section{International Marketing Bursaries}

Subjects: MSc in international marketing

Purpose: To assist applicants who are seeking sources of financial assistance to pursue full-time postgraduate study in international marketing

Eligibility: A limited number of departmental bursaries are available to well qualified candidates

Level of Study: Postgraduate

Type: Departmental bursaries

Value: $£ 3,000$

Length of Study: 1 year
Frequency: Annual

Study Establishment: University of Strathclyde

Country of Study: United Kingdom

Application Procedure: Applicants must contact the Department of Marketing

Contributor: Department of Marketing, Strathclyde University

\section{For further information contact:}

Tel: (44) 1415483451

Email: mscim.helpdesk@strath.ac.uk

\section{International Strathclyde Prestige Award for Excellence in Business Translation and Interpreting in United Kingdom}

Subjects: Strathclyde University is a major international technical university situated in Glasgow, Scotland. The mission of the University is socially progressive and brings positive change in the life of its students for society and the world

Purpose: Scholarship is available for pursuing Postgraduate degree program

Eligibility: To be eligible, the applicants must meet all the following criteria: 1 . To apply for this scholarship, the applicants must be available to commence their academic studies in the United Kingdom. By the start of the academic year in September. 2. The candidates must hold a first degree at first class or upper second class honors, or equivalent

Level of Study: Postgraduate

Type: Award

Value: $£ 5,000$ with tuition fees

Frequency: Annual

Country of Study: United Kingdom

Application Procedure: 1. Applications must be processed with the below link. r1.dotmailer-surveys.com/432p4736ae3nzoab. 2. Supporting Documents: As part of the application, the applicants must provide a 300 -word essay demonstrating your ability to contribute to the field of study which you are applying for. 3. Admission Requirements: To apply for this scholarship you need to take admission onto the full-time Postgraduate Study program at the university

Closing Date: 31 May

Funding: Private

Additional Information: For further information, check the following link: r1.dotmailer-surveys.com/432p4736ae3nzoab

\section{For further information contact:}

Email: hass-pg-enquiries@strath.ac.uk 


\section{John Mather Scholarship}

Subjects: Postgraduate instructional courses in business administration and management, economics, hospitality management and tourism

Purpose: To encourage potential rising stars in the business world, selected on the basis of academic merit

Eligibility: Open to students from the vicinity of the former Strathclyde Region area enrolled in postgraduate instructional courses

Level of Study: Postgraduate

Type: Scholarship

Value: UK£5,000

Length of Study: 1 year

Frequency: Annual

Study Establishment: Strathclyde Business School

Country of Study: United Kingdom

No. of awards offered: 10

Application Procedure: Applicants must be nominated by their Head of Department on forms available from the Faculty Officer

Closing Date: 23 July

Funding: Trusts

Contributor: John Mather Charitable Trust

No. of awards given last year: 4

No. of applicants last year: 10

For further information contact:

Email: e.leiper@mis.strath.ac.uk

\section{Mac Robertson Travelling Scholarship}

Subjects: All subjects

Purpose: To provide funding that will enrich and further the award holder's academic experience and research achievements

Eligibility: Applicants should be postgraduate research students currently registered at Strathclyde or Glasgow Universities

Level of Study: Postgraduate, Research

Type: Scholarship

Value: $£ 2,000-3,000$

Length of Study: 1 year

Frequency: Annual

Study Establishment: University of Strathclyde

Country of Study: United Kingdom

No. of awards offered: 20

Application Procedure: Application forms can be downloaded from the website www.strath.ac.uk

Closing Date: 4 May

Funding: Individuals
Contributor: Mac Robertson

No. of awards given last year: 11

No. of applicants last year: 20

Additional Information: The aim of the scheme is to provide funding which will enrich and further the award holder's experience and research achievements

\section{For further information contact:}

Email: cathy.bonner@mis.strath.ac.uk

\section{University of Strathclyde and Glasgow Synergy Scholarships}

Subjects: All subjects, but the project must be jointly supervised between Glasgow and Strathclyde universities

Purpose: To assist applicants and students who are seeking sources of financial assistance to pursue full-time postgraduate research study at the University of Strathclyde

Eligibility: Applicants should be $\mathrm{PhD}$ candidates of outstanding academic merit

Level of Study: Doctorate

Type: Scholarship

Value: $£ 12,600$ per year

Length of Study: Up to 3 years

Frequency: Annual

Study Establishment: University of Strathclyde

Country of Study: United Kingdom

Application Procedure: Applicants seeking nomination for the awards should contact the department they wish to join. Existing research students should contact their head of department or supervisor

Closing Date: Check the website

Funding: International office

Contributor: University

Additional Information: For more information, visit the website www.strath.gla.ac.uk/synergy

For further information contact:

Email: synergy@gla.ac.uk

\section{University of Surrey}

University of Surrey, Guildford GU2 7XH, United Kingdom

Tel: $\quad$ (44) 148386050

Fax: (44) 148386071

Email: maphdinfo@surrey.ac.uk

Website: www.maths.surrey.ac.uk 


\section{Studentship in Physical Sciences}

Purpose: The aim of this project is to determine the microscopic length scales that control the macroscopic rheology using novel magnetic resonance imaging and optical light scattering techniques in combination with conventional tools Eligibility: To be eligible for this studentship, you are required to have a First, 2:1 or merit in a masters degree in a physical sciences subject. If English is not your first language you are required to have an IELTS of 6.5 or above. United Kingdom and European Union candidates are eligible to apply. Activities at the Cambridge centre focus on the development of new science and technology for well construction, with an emphasis on drilling and automation

Level of Study: Graduate

Type: Studentship

Frequency: Annual

Country of Study: Any country

Application Procedure: In order to apply for this studentship, kindly contact Noelle Hartley, Centre Manager for the EPSRC CDT in MiNMaT Greater understanding of the hierarchy of relevant structural lengths from the nanoscale to the macroscale will enable the design of improved complex fluid formulations with predictable rheological properties. N.Hartley@surrey.ac.uk

Closing Date: 30 April

Funding: Private

\section{For further information contact:}

Tel: $\quad$ (44) 1483683467

Email: N.Hartley@surrey.ac.uk

\section{University of Sussex}

Postgraduate Office, Sussex House, Falmer, Brighton BN1 9RH, United Kingdom

Tel: $\quad$ (44) 1273606755

Fax: (44) 1273678335

Email: information@sussex.ac.uk

Website: www.sussex.ac.uk

Contact: Mr Terry O’Donnell

The University of Sussex is one of the United Kingdom's foremost research institutions. The University boasts a distinguished faculty that includes 17 Fellows of the Royal Society and four Fellows of the British Academy. The University has around 12,000 students, $25 \%$ of whom are postgraduates.

\section{Chancellor's International Scholarship}

Purpose: Applications are invited for University of Sussex to international postgraduate students who can demonstrate academic excellence

Value: $50 \%$ tuition fee reduction

Length of Study: 2 years

Country of Study: Any country

Application Procedure: Apply online. For application procedures, please visit website www.sussex.ac.uk/study/ money/apply-chancellors-international-scholarship

Closing Date: May

Contributor: University of Sussex

\section{For further information contact:}

Email: information@sussex.ac.uk

\section{PhD Studentships in Mathematics}

Subjects: PhD studentships are provided in the field of Mathematics. Supervision is available in diverse topics

Eligibility: Applicants must hold, or expect to hold, a Bachelor degree at first or upper second class, and/or a Masters degree, in Mathematics, or equivalent non United Kingdom qualifications. United Kingdom and European Union residents are eligible. Overseas (ex-European Union) students may also apply, but applicants should note that the awards waive the fees at United Kingdom/European Union rates only, of $£ 3,900$ per year. Ex-European Union students must state in their application how they would fund the remaining fees. (Overseas fees will be $£ 13,000$ per year in total, so additional funding of $£ 9,100$ will be needed)

Level of Study: Doctorate

Type: Studentship

Value: Each PhD studentship includes a tax free maintenance bursary of $£ 13,863$ per year, plus a waiver of United Kingdom/European Union fees for 3.5 years

Length of Study: Scholarships will be offered for 3.5 years

Country of Study: United Kingdom

Application Procedure: The mode of applying is online

Closing Date: 31 August

Contributor: University of Sussex, United Kingdom

\section{For further information contact:}

Email: pgresearch@maths.ed.ac.uk

\section{Sussex Malaysia Scholarship}

Subjects: Scholarship is awarded in the fields offered by the university 
Purpose: The aim of the Sussex Master Scholarship is to enable and encourage academically able students from Malaysia

Eligibility: Listed are the eligibility requirements. $1 . \mathrm{Be}$ a Malaysian national. 2. Be classified as overseas for fee purposes. 3. Be self-financing. 4. Have accepted an offer to study an eligible Masters course at Sussex

Type: Scholarship

Value: $£ 3,500$ towards your tuition fee when you register on your Masters at Sussex

Length of Study: 2 years

Country of Study: United Kingdom

Application Procedure: Register your interest in the scholarship through the postgraduate application system when you accept our offer of a place on an eligible Masters course. To submit the registration, use the below link. www.sussex.ac. uk/study/masters/apply/log-into-account

Closing Date: 1 August

Contributor: University of Sussex

For further information contact:

Email: scholarships@sussex.ac.uk

\section{University of Sydney}

Scholarships and Financial Support Service, Jane Foss Russell Building, G02, Sydney, NSW 2006, Australia

Tel: $\quad$ (61) 286278112

Fax: (61) 286278485

Email: scholarships.officer@sydney.edu.au

Website: www.sydney.edu.au

Contact: Manager

The role of the University of Sydney is to create, preserve, transmit, extend and apply knowledge through teaching, research, creative works and other forms of scholarship. In carrying out its role, the University affirms its commitment to the values and goals of institutional autonomy, recognizes the importance of ideas and intellectual freedom to pursue critical and open enquiry, as well as social responsibility, tolerance, honesty and respect, as the hallmarks of relationships throughout the University community. It also understands the needs and expectations of those whom it serves and constantly improves the quality and delivery of its services.

\section{Alexander Hugh Thurland Scholarship}

Subjects: Agriculture

Eligibility: Open to the graduates from other universities with relevant degree
Level of Study: Doctorate, Postgraduate, Research

Type: Scholarship

Value: A \$24,653 per year

Length of Study: 2 years for Masters by research candidates and 3 years with a possible 6-month extension for research doctoral candidates

Frequency: Dependent on funds available

Study Establishment: The University of Sydney

Country of Study: Australia

Application Procedure: Check website www.sydney.edu. au/agriculture for further details

Funding: Trusts

\section{For further information contact:}

Tel: (61) 286271002

Fax: (61) 286271099

Email: pg@agric.usyd.edu.au

\section{Dean's International Postgraduate Research Scholarships}

Subjects: Scholarships are awarded in any of the courses within in faculty of science at University of Sydney

Purpose: Scholarships are available to undertake a research doctorate degree $(\mathrm{PhD})$ programme

Level of Study: Postgraduate

Value: The scholarship consists of the full cost of academic tuition fees plus a stipend equivalent to an Australian Postgraduate Award indexed annually (RTP stipend rates for 2016 are $\mathrm{A} \$ 26,288$ for full-time students)

Length of Study: 3 years

Study Establishment: Faculty of Science

Country of Study: Australia

Application Procedure: International students (except Australia or New Zealand) can apply for these postgraduate research scholarships. An annual stipend allowance equivalent to the Research Training Program (RTP) stipend rate indexed annually

Closing Date: 30 April

Additional Information: For more details, visit website scholarship-positions.com/deans-international-postgraduateresearch-scholarships-in-australia-2015-2016/2015/03/03/

\section{Dr Abdul Kalam International Postgraduate Scholarships}

Eligibility: International students with an offer of admission for a Masters program in the Faculty of Engineering \& Information Technologies in Semester II. Open to all international applicants with an offer of admission for a Master of Information Technology, Master of Information Technology 
Management or combined Master of Information Technology/Master of Information Technology Management program in the Faculty of Engineering and IT at the time of submitting a scholarship application. Students who have already commenced their postgraduate studies, or students transferring from other postgraduate programs are not eligible Level of Study: Postgraduate

Type: Scholarship

Value: 50\% tuition fees for a maximum of 1 year

Frequency: Annual

Country of Study: United States of America

Application Procedure: Applicants must complete an online scholarship application (sydney.edu.au/engineering/scholar ships/postgraduate/dr-kalam.shtml), and submit their academic transcripts and admission letter of offer to the Scholarships Officer by the scholarship closing date. Successful candidates will be informed by June

Closing Date: May

Additional Information: Please check at sydney.edu.au/engi neering/scholarships/postgraduate/future-coursework.shtml for more information

\section{For further information contact:}

Tel: $\quad$ (61) 293518155

Fax: (61) 293517082

Email: engineering.scholarships@sydney.edu.au

\section{International Postgraduate Research Scholarships (IPRS) Australian Postgraduate Awards (APA)}

Subjects: All subjects

Purpose: To support candidates with exceptional research potential

Eligibility: Open to suitably qualified graduates eligible to commence a higher degree by research. Australia and New Zealand citizens and Australian permanent residents are not eligible to apply

Level of Study: Doctorate, Postgraduate, Research

Type: Scholarship

Value: Tuition fees for IPRS, and an Australian Postgraduate

Award for A $\$ 24,653$ per year

Length of Study: 2 years for the Master's by research candidates, and 3 years with a possible 6-month extension for $\mathrm{PhD}$ candidates

Frequency: Annual

Study Establishment: The University of Sydney

Country of Study: Australia

Application Procedure: Applicants must complete an application form for admission available from the International Office

Closing Date: 31 July for Semester 1 and 15 December for Semester 2

Funding: Government
Contributor: Australian Government and University of Sydney

No. of awards given last year: 34

For further information contact:

Tel: $\quad$ (61) 286278358

Fax: (61) 286278387

Email: infoschol@io.usyd.edu.au

\section{Master of Business Administration Programme}

Length of Study: 1 year

Application Procedure: Applicants must complete an application form supplying official transcripts and a Graduate Management Admission Test score

Closing Date: 31 October

\section{For further information contact:}

Tel: $\quad$ (61) 293510038

Fax: (61) 293510099

Email: gsbinfo@gsb.usyd.edu

Contact: MBA Admissions Officer

\section{PhD Scholarship Healthcare Services for Older People}

Subjects: Medical and health sciences, allied health (therapies), health services research

Purpose: To investigate the effectiveness of transition care services for older people

Eligibility: Open only to permanent residents and the citizens of Australia or New Zealand who have Honours Degree, or equivalent, in health-related discipline to undertake research studies

Level of Study: Postgraduate

Type: Scholarship

Value: A $\$ 22,000$ per year

Length of Study: 3 years

Frequency: Annual

Study Establishment: University of Sydney

Application Procedure: Applicants must send their curriculum vitae, copy of academic transcript, names and contact details of at least 2 referees to Prof Cameron (preferably by email)

Closing Date: 14 August

\section{For further information contact:}

Tel: $\quad$ (61) 298089236

Fax: (61) 298099037

Email: ianc@mail.usyd.edu.au

Contact: Professor Ian Cameron 


\section{PhD Scholarship to Advance Aquaculture in Australasia}

Subjects: Agricultural, veterinary and environmental sciences, biological sciences or fisheries sciences

Purpose: To improve the productivity and profitability of smallholder shrimp farms in Indonesia

Eligibility: Open only to the citizens of Australia or permanent residents

Level of Study: Postgraduate, Research

Type: Scholarship

Value: A $\$ 25,000$ per year

Length of Study: 3 years

Frequency: Annual

Application Procedure: Applicants must mail their curriculum vitae, copy of academic transcript, proof of citizenship or permanent residency, names and contact details of at least 2 referees to Dr Toribio

Closing Date: 17 August

For further information contact:

Tel: $\quad$ (61) 61293511609

Fax: (61) 61293511618

Email: jennyt@camden.usyd.edu.au

Contact: Dr Jenny Ann Toribio

\section{University of Tasmania}

Private Bag 45, Hobart, TAS 7001, Australia

Tel: $\quad$ (61) 362262999

Fax: (61) 362262018

Email: scholarships@research.utas.edu.au

Website: www.utas.edu.au

Contact: Graduate Research Unit

The University of Tasmania was officially founded on January 1st 1890, by an Act of the Colony's Parliament and was only the fourth university to be established in 19th century Australia. The university represents areas of significant research strengths and substantial teaching endeavours.

\section{Across PhD - Bio analytical Research - Pharmacokinetics and Drug Metabolism Scholarship}

Subjects: Chemical sciences, medical biochemistry, clinical chemistry, pharmacology, or pharmaceutical sciences
Purpose: To promote research on retention mechanisms, breakthrough, and recovery for the model analytes together with appropriate characterization of the monolithic phase

Eligibility: Open to applicants who have achieved Honours 2a or equivalent

Level of Study: Postgraduate, Research

Type: Scholarship

Value: A $\$ 20,000$ for living expenses

Length of Study: 3 and a half years

Frequency: Annual

Application Procedure: Applicants should send a curriculum vitae directly to Prof Paul Haddad. Check website for further details

Contributor: Pfizer Analytical Research Centre (PARC)

For further information contact:

Tel: $\quad$ (61) 362262179

Email: paul.haddad@utas.edu.au

Contact: Professor Paul Haddad, Director of ACROSS

\section{Across PhD Scholarship; Analytical Chemistry; Rock Lobster Aquaculture}

Subjects: Animal production, chemical sciences or soil and water sciences

Eligibility: Open to applicants who have achieved Honours 2a or equivalent

Level of Study: Postgraduate, Research

Type: Scholarship

Value: $A \$ 25,118$ for living expenses

Length of Study: 3 and a half years

Frequency: Annual

Application Procedure: Applicants should send a curriculum vitae directly to Prof Paul Haddad. Check website for further details

\section{For further information contact:}

Tel:

$$
\text { (61) } 362262179
$$

Email: paul.haddad@utas.edu.au

Contact: Professor Paul Haddad, Director of ACROSS

\section{Across PhD, High Performance lon Exchange Chromatography Scholarship}

Subjects: Chemical sciences

Purpose: To investigate the feasibility of using HP-IEC for the separation and detection of small to medium MW organic acids and bases

Eligibility: Open to applicants who have achieved Honours 2a or equivalent 
Level of Study: Postgraduate, Research

Type: Scholarship

Value: A $\$ 20,000$ for living expenses

Length of Study: 3 and a half years

Frequency: Annual

Country of Study: Australia

Application Procedure: Applicants should send a curriculum vitae directly to Prof Paul Haddad. Check website for further details

Contributor: Pfizer Analytical Research Centre (PARC)

\section{Cancer Council Honours Scholarship}

Subjects: Cancer control

Purpose: To fund honours student to undertake research on cancer

Eligibility: Open to a full-time student undertaking honours in any area that focuses on cancer control

Level of Study: Research

Type: Scholarship

Value: A $\$ 10,000$ (A $\$ 7,000$ for living allowance and $A \$ 3,000$

for research costs)

Length of Study: 1 year

Frequency: Annual

Application Procedure: Check website for further details

Closing Date: 31 October

\section{For further information contact:}

Tel: $\quad$ (61) 362264832

Email: g.m.woods@utas.edu.au

Contact: Greg Woods, Associate Professor

\section{Cardiac Rehabilitation UTAS Exercise Physiology Graduate Research Scholarship}

Subjects: Exercise physiology, medical and health sciences or medical physiology

Purpose: To investigate the effectiveness of provision of an exercise physiology service as part of a cardiac rehabilitation program, as well as identifying the optimal modality and intensity of exercise undertaken by patients as part of the program

Eligibility: Open to applicants who have achieved Honours $2 \mathrm{a}$ or equivalent. Only citizens of Australia or permanent residents can apply

Level of Study: Postgraduate, Research

Type: Scholarship

Value: $A \$ 19,616$

Length of Study: 3 years
Frequency: Annual

Study Establishment: University of Tasmania

Country of Study: Australia

Application Procedure: Check website for further details

Closing Date: 30 June

\section{For further information contact:}

Tel: $\quad$ (61) 363245487

Email: Andrew.Williams@utas.edu.au

Contact: Dr Andrew Williams

\section{Centre of Excellence in Ore Deposits PhD Scholarships}

Subjects: Geology, geophysics or geochemistry with relevance to the location, formation, discovery or recovery of ore deposits

Purpose: For students to study within one of the five major programs of the centre: location, formation, discovery, recovery or technology

Eligibility: Open to students undertaking $\mathrm{PhD}$ research in the specified fields. Applicants require either an MSc in geology/ geophysics or a first or upper second-class honours degree. Some experience in the minerals industry is preferred but not essential

Level of Study: Postgraduate

Value: $\mathrm{A} \$ 20,000$ - $\mathrm{A} \$ 30,000$ depending on qualifications and experience

Length of Study: 3 and a half years

For further information contact:

Tel: $\quad$ (61) 362262892

Email: j.mcphie@utas.edu.au

Contact: Jocelyn McPhie

\section{Master of Business Administration Programme}

Length of Study: Varies

Application Procedure: Applicants must contact The University of Tasmania Graduate School of Management for an application form

For further information contact:

Tel: $\quad$ (61) 2207837

Fax: (61) 2207862

Email: International.Office@admin.utas.edu.au

Contact: Graduate Administrator 


\section{Menzies Research Institute Honours Scholarship}

Subjects: Epidemiology and communal diseases

Purpose: To support vital work in epidemiology, and diseases which affect the community

Eligibility: Open to a student eligible to undertake an honours research program in any area of research undertaken by the Institute

Level of Study: Research

Type: Scholarship

Value: $A \$ 5,000$

Length of Study: 1 year

Frequency: Annual

Country of Study: Any country

Application Procedure: Applicants can apply through the Tasmania Honours Scholarship application form downloaded from the website. All potential honours students should contact the Honours Co-ordinator in their discipline to discuss interests and options

Closing Date: 31 October

For further information contact:

Email: enquiries@menzies.utas.edu.au

\section{North Hobart Football Club Peter Wells Scholarships}

Subjects: Sports

Purpose: To support North Hobart players while at UTAS Eligibility: One scholarship available to a north-western/ northern student and one to a southern student with good academic records and who are available to play for the NHFC while studying at UTAS

Type: Scholarship

Value: $A \$ 3,000$ and $A \$ 2,000$

Length of Study: 1 year

Frequency: Annual

Country of Study: Any country

Contributor: The late Peter Wells

For further information contact:

Email: International.Scholarships@utas.edu.au, Scholarships.Office@utas.edu.au

\section{Qantas Tasmanian Devil Research Scholarship}

Subjects: Facial tumour disease

Purpose: To assist research into the facial tumour disease affecting devil populations

Eligibility: Open to researchers in facial tumour diseases

Level of Study: Research
Type: Scholarship

Value: Up to APA level, additional research funding may be available

Length of Study: 3 and a half years

Frequency: Annual

Country of Study: Any country

Application Procedure: Check website for further details

Contributor: Qantas

For further information contact:

Email: devil.appeal@utas.edu.au

\section{Quantitative Marine Science PhD Scholarships}

Subjects: Quantitative Marine Science

Purpose: To offer specialized graduate-level coursework in quantitative marine science (QMS)

Eligibility: Open to students who hold at least an upper second-class honours degree, or equivalent, and have a major in mathematics, physical sciences, life sciences, geomatics or Engineering

Level of Study: Doctorate

Type: Scholarship

Value: $\mathrm{A} \$ 32,000$ per annum. and production costs will also be provided

Length of Study: Up to 3 years

Frequency: Annual

Country of Study: Any country

Application Procedure: Application forms, conditions of awards and program information on Graduate Research Scholarships can be downloaded from the website

Funding: Private

Contributor: Commonwealth Scientific and Industrial Research Organisation (CSIRO) in partnership with the University of Tasmania

Additional Information: For further information on all Graduate Research Scholarships please contact the Graduate Research Office on (3) 62262766

\section{For further information contact:}

CSIRO-UTAS Joint PhD Program in Quantitative Marine Science, Private Bag 129, Hobart, TAS 7001, Australia

Tel: $\quad$ (61) 362262108

Email: Peter.Strutton@utas.edu.au

Contact: Professor Pete Strutton, Program Coordinator

\section{Riawunna Postgraduate Scholarship}

Purpose: To encourage an Aboriginal or Torres Strait Islander student to undertake honours or postgraduate 
coursework study at the University and committed to the advancement of knowledge about Aboriginal and Torres Strait Islander cultures and societies

Eligibility: Open to an Aboriginal or Torres Strait Islander student who undertake honours or postgraduate coursework study at the University

Level of Study: Postgraduate

Type: Scholarship

Value: $A \$ 3,000$

Length of Study: 1 year

Frequency: Annual

Country of Study: Any country

Contributor: Riawunna

\section{For further information contact:}

Email: scholarships.referee@utas.edu.au

\section{Sir Victor Burley Scholarship in Music}

Subjects: Music

Purpose: The family of Victor Burley has endowed this scholarship to encourage the development of advanced music skills, especially in the classical music area

Eligibility: Open to student eligible to enter a postgraduate music course at the Conservatorium of Music preferably studying in a classical area of music

Level of Study: Postgraduate

Type: Scholarship

Value: A $\$ 1,000$

Length of Study: 1 year

Frequency: Annual

Country of Study: Australia

Contributor: The family of the late Sir Victor Burley

\section{For further information contact:}

Email: Scholarships.Referee@utas.edu.au

\section{Tasmania Honours Scholarships}

Subjects: All subjects

Purpose: To encourage excellent students to continue their study at honours level

Eligibility: Open to students with excellent academic achievement in their undergraduate courses who wish to study at honours level. Additional benefits may be available to students who obtain a first-class honours degree and continue on to a research program at UTAS

Level of Study: Postgraduate

Type: Scholarship
Value: A \$4,500; A \$9,000 include a living allowance, course fees, support with accommodation and establishment fees and a return airfare to Tasmania if you live interstate

Length of Study: 1 year (full-time study)

Frequency: Annual

Country of Study: Any country

Application Procedure: Applicants can apply through the Tasmania Honours Scholarship application form from the website. All potential honours students should contact the Honours Co-ordinator in their discipline to discuss interests and options

Closing Date: 31 October

Additional Information: Six of the 10 awards will target students commencing study at the University of Tasmania

\section{For further information contact:}

Email: Scholarships.Referee@utas.edu.au

\section{Tasmania University Cricket Club Scholarship}

\section{Subjects: Sports}

Purpose: To support cricketers at UTAS

Eligibility: Available to a commencing or current student who can demonstrate a talent and commitment to cricket. Selection will based on the following five criteria: 1. Cricket skill i.e. representative levels and success at those levels. 2. Academic achievement and potential to succeed at university. 3. Leadership skills and experiences. 4. Cricket involvement e.g. coaching. 5. Community involvement. The selected student must be playing for, or be able to play for, the TUCC in the coming season. Potential applicants may also wish to visit the Cricket website (www.tucc. org.au/) to gain a better understanding about the club and its goals

Type: Scholarship

Value: $A \$ 3,000$

Length of Study: 1 year

Frequency: Annual

Country of Study: Any country

Application Procedure: Apply online prior to closing date. Applications cannot be submitted after closing date. As applicants will be assessed on the quality of application, all questions should be answered in full. Please ensure care is taken with spelling and grammar. info.scholarships.utas.edu.au/ AwardDetails.aspx? AwardId $=281$

Closing Date: 31 October

Contributor: Supporters and past players of the Tasmania University Cricket Club

\section{For further information contact:}

Email: chas.rose@gmail.com 


\section{Tasmanian Government Mining Honours Scholarships}

Subjects: Geological research

Purpose: To encourage geological research at CODES on topics that are relevant to the Tasmanian minerals industry

Eligibility: Open to students undertaking research in the field of geology, with relevance to the Tasmanian minerals industry. Specialization in one or more of: ore deposit geology, igneous petrology, volcanology, structure, sedimentology, geochemistry or geophysics. Applicants require at least a credit average in geology units at the second or third year levels

Level of Study: Research

Type: Scholarship

Value: $\mathrm{A} \$ 5,000 ; \mathrm{A} \$ 8,000$ depending on qualifications and experience

Length of Study: 1 year

Frequency: Annual

Application Procedure: Applicants can apply through the Tasmania Honours Scholarship application form downloaded from the website

Closing Date: 31 October

Contributor: Mineral Resources Tasmania

\section{For further information contact:}

Tel: $\quad$ (61) 362262815

Email: garry.davidson@utas.edu.au

Contact: Dr Garry Davidson

\section{Tasmanian Government Mining PhD Scholarship}

Subjects: Geological research

Purpose: To encourage geological research undertaken at the ARC Centre of Excellence in Ore Deposits (CODES) on topics relevant to the Tasmanian minerals industry

Eligibility: The following eligibility criteria apply to this scholarship: 1. The scholarship is open to domestic (Australian and New Zealand) and international candidates. 2. The Research Higher Degree must be undertaken on a fulltime basis. 3. Applicants must already have been awarded a First Class Honours degree or hold equivalent qualifications or relevant and substantial research experience in an appropriate sector. 4. Applicants must be able to demonstrate strong research and analytical skills

Level of Study: Doctorate, Research

Type: Scholarship

Value: A $\$ 18,000-25,000$ depending on qualifications and experience

Length of Study: 3 and a half years

Frequency: Annual
Country of Study: Any country

Contributor: Mineral Resources Tasmania

For further information contact:

Tel: $\quad$ (61) 362262819

Email: anita.parbhakar@utas.edu.au

Contact: Professor Rose Large

\section{University of Technology Sydney (UTS)}

PO Box 123 Broadway, Ultimo, NSW 2007, Australia

Tel: $\quad$ (61) 295141659

Email: clg.postgraduate@uts.edu.au

Website: ippg.uts.edu.au

Contact: UTS Institute for Public Policy and Governance

The University of Technology Sydney (UTS) is a thriving university located in the centre of Sydney, one of the world's most desirable and multicultural cities.

\section{University of Technology Sydney Institute for Public Policy and Governance Postgraduate Scholarship in Australia, 2017}

Subjects: Scholarships are awarded by the Institute for Public Policy and Governance.

Purpose: To support commencing University of Technology Sydney (UTS) Master of Local Government students by assisting them financially.

Eligibility: Australian or New Zealand citizen, or the holder of an Australian permanent resident visa or permanent humanitarian visa; and must have submitted an application and met the entry requirements for admission to the UTS Institute for Public Policy and Governance Master of Local Government degree by coursework degree; and must be commencing the UTS Institute for Public Policy and Governance Master of Local Government program; and must not have completed any study under any other postgraduate courses within the UTS Institute for Public Policy and Governance; and intend to enroll in a minimum of 12 credit points/session in the session immediately following the Scholarship selection; and all candidates must apply using the online UTS online Scholarship Application form to be eligible.

Level of Study: Postgraduate

Type: Scholarship

Value: The maximum value of this scholarship is A $\$ 5,000$ for each recipient 
Length of Study: 1 year

Frequency: Annual

Country of Study: Any country

Application Procedure: Please note that Scholarship applicants must first submit an application for the UTS Master of Local Government to be considered for the Scholarship. To apply for the Master course, please request an application form from the Institute at postgraduate-at-uts.edu.au or on +61295141659.

Closing Date: 6 March

Funding: Government

Additional Information: The UTS Institute for Public Policy and Governance (UTS:IPPG) Postgraduate Scholarship was designed to support local government professionals seeking to broaden their knowledge and skills through postgraduate study and to recognize the diverse pathways to a local government career

\section{For further information contact:}

Email: Alan.Morris@uts.edu.au

\section{University of Texas}

School of Public Health Health, Science Center, PO Box 20186, Houston, TX 77225, United States of America

Contact: Mr Robert E Roberts

\section{Harry Ransom Center: Research Fellowships}

Subjects: The fellowships support research in all areas of the humanities

Purpose: The fellowships are awarded for projects that require substantial on-site use of its collections

Eligibility: All applicants, with the exception of dissertation fellowship applicants, must have a $\mathrm{PhD}$ or be an independent scholar with a substantial record of achievement; if the $\mathrm{PhD}$ is in-progress, the proposal and letters of recommendation must clearly indicate a June 1st, completion in order to be eligible for fellowships. Dissertation fellowship applicants must be doctoral candidates engaged in dissertation research by the time of application. United States of America citizens and foreign nationals are eligible to apply. Previous recipients of Ransom Center fellowships are eligible to reapply after two full academic years have passed. All things being equal, however, preference is given to applicants who have not previously held a Ransom Center fellowship

Type: Research fellowship
Value: Stipends of US $\$ 3,000$ per month. Also available are US\$1,200-US\$1,700 travel stipends and dissertation fellowships with a US\$1,500 stipend

Frequency: Annual

Country of Study: United States of America

Application Procedure: Fellowships must be submitted electronically through an online fellowship account on the Ransom Center's website

Closing Date: 31 March

Additional Information: Please visit at www.hrc.utexas. edu/research/fellowships/

\section{For further information contact:}

Email: ransomfellowships@utexas.edu

\section{Mobility Scooters Direct Scholarship Program}

Purpose: Mobility Scooters Direct provides a $\$ 1,500$ scholarship each year to selected students who apply to the program Eligibility: 1. Must be enrolled in a minimum of 6 hours undergraduate or 3 hours graduate at an accredited University or College. 2. Must have taken at least 40 undergraduate credit hours or 10 graduate credit hours. 3. Must have proof of a declared major. 4. Must demonstrate involvement on campus or in the community of attended University or College. 5. Must attach one letter of recommendation on official letterhead. 6. You must be at least 18 years of age to apply. 7. You must be currently enrolled at your college or university during the time of submission. 8. You must have a 3.0 GPA or higher

Level of Study: Graduate

Type: Programme grant

Value: US $\$ 1,500$

Frequency: Annual

Country of Study: Any country

Application Procedure: The below details have to be included in the application. 1. Your first \& last name, ph. number \& email address(s). 2. Statement or transcript of your Grade Point Average (GPA). Letter of recommendation should have the below entities. 1. All applicants must meet certain criteria outlined below and submit an application via email or United States mail. 2. Applicants are also required to provide a letter of recommendation from a teacher, professor or counselor from the school being attended by the applicant Closing Date: 10 December each year

Funding: Private

\section{For further information contact:}

4135 Dr. M.L. King Jr Blvd. Store D21, Ft. Myers, FL 33916, United States of America

Email: orders@mobilityscootersdirect.com 


\section{University of Tokyo}

9-7-3, Akasaka TK 107-0052, Japan

Tel: $\quad$ (81) 362714368

Contact: Fujixerox Co., Ltd., Kobayashi Fund, c/o Fuji Xerox

The University of Tokyo aims to be a world-class platform for research and education, contributing to human knowledge in partnership with other leading global universities. The University of Tokyo aims to nurture global leaders with a strong sense of public responsibility and a pioneering spirit, possessing both deep specialism and broad knowledge.

\section{Kobayashi Research Grants}

Subjects: Humanities and social sciences

Purpose: Grants are available to pursue research programme Eligibility: International students from Asia, Oceania countries/regions. 1. Note the Asia-Pacific countries and regions as referred to here, it shows the following countries and regions Type: Grant

Value: Maximum of $¥ 1,200,000$ /person

Country of Study: Japan

Application Procedure: Please download the application documents and instructions for sending at the following link: www.fujixerox.com/eng/company/social/pdf/1.pdf

Closing Date: 28 February

No. of awards given last year: 39

\section{For further information contact:}

International Liaison Office Room 120, Environmental Studies Building 5-1-5 Kashiwanoha, Kashiwa, Chiba 277-8563, Japan

\section{Kobayashi Research Grants in Humanities and Social Sciences}

Subjects: Grants shall be conferred for individual research (not group research) in the field of Humanities (Cultural Science) or Social Sciences, with special emphasis on themes that help deepen the researcher's understanding and awareness of Japanese or Asian/Oceanian society and culture and enhance international interchanges among them in the future Eligibility: Scholarships are offered in diverse fields to help students in upgrading their education
Type: Research

Value: Maximum $¥ 1,200,000$ per grantee will be available to approximately 30 grantees. An amount from $¥ 3,20,000$ to $¥ 1,200,000$ per grantee was provided to 32 grantees for the program. (Depending upon the results of the Grantee Screening Committee's assessment, the actual amount for some grantees could be less than the originally requested amount.)

Study Establishment: Grants shall be conferred for individual research (not group research) in the field of Humanities (Cultural Science) or Social Sciences, with special emphasis on themes that help deepen the researcher's understanding and awareness of Japanese or Asian/Oceanian society and culture and enhance international interchanges among them in the future

Country of Study: Japan

Application Procedure: The mode of applying is online Closing Date: 28 February

Additional Information: For more details please visit to the website scholarship-positions.com/kobayashi-researchgrant-humanities-social-sciences-university-tokyo-japan/2017/ $01 / 24 /$

\section{University of Twente}

Universiteit Twente, Drienerlolaan 5, Enschede 7522 NB, Netherlands

Tel: (31) 534899111

Email: info@utwente.nl

Website: www.utwente.nl/en

\section{ASML Henk Bodt Scholarship}

Subjects: MSc applied mathematics, applied physics, computer science, electrical engineering, embedded systems, mechanical engineering, systems and control

Purpose: The ASML Henk Bodt Scholarship supports a talented technical student who has completed (or is about to complete) the Bachelor of Science programme, and who is further motivated to pursue a 2 years full-time Master of Science degree in technical and scientific disciplines at the University of Twente

Eligibility: To qualify for a ASML Henk Bodt Scholarship, candidates must at least fulfill the following basic requirements: Bachelor of Science diploma, academic transcripts of each academic year from the BSc programme, cumulative Grade Point Average of at least $80 \%$ of the scale maximum of all courses of the BSc program, MSc programme admission 
letter from the University of Twente, up-to-date curriculum vitae

Type: Scholarship

Value: The scholarship will provide financial support for the entire duration of the Master's degree (2-year period) which covers the full tuition fee and living expenses, approx. $€ 22,000$ per year

Length of Study: 2 years

Frequency: Annual

Country of Study: Any country

Closing Date: 1 March

Additional Information: Check details at www.utwente.nl/ internationalstudents/scholarshipsandgrants/all/asml henk bodt_scholarship/

\section{For further information contact:}

Tel: $\quad$ (81) 402686572

Email: scholarships@asml.com

\section{Holland Scholarship}

Purpose: The Holland Scholarship is a scholarship for excellent students from non-European Union/EEA countries, applying for a Bachelor or Masters programme at the University of Twente

Eligibility: Open to non-European Union/EEA countries. In order to be eligible for a Holland Scholarship, you should meet all the requirements as follows: your programme starts in the current academic year; you have not studied in the Netherlands before for a full degree (e.g. a Bachelor's or Master's degree); you are from a non-European Union/EEA country; you are an excellent student (i.e. CGPA of 7.5 (out of $10)$ ); etc. Please check complete eligibility criteria at www. utwente.nl/internationalstudents/scholarshipsandgrants/all/ holland-scholarship/

Type: Scholarship

Value: $€ 5,000$

Country of Study: Any country

Application Procedure: In order to apply for this scholarship, you already need to be (provisionally) admitted to one of the qualifying Bachelor or Master programmes

Closing Date: 1 April

Additional Information: Outcomes will be communicated by 15 May. Please note: if you apply for a Holland Scholarship without meeting all the requirements, your application will not be considered. www.studyinholland.nl/scholarships/ holland-scholarship

\section{For further information contact:}

Email: info@utwente.nl

\section{Orange Tulip Scholarship (OTS) China}

Subjects: All subjects

Purpose: The Orange Tulip Scholarship (OTS) offers talented students from China the opportunity to obtain a Masters degree at the University of Twente. The scholarship programme is highly selective, offering two scholarships for the current academic year

Level of Study: Graduate

Type: Scholarship

Value: $€ 24,000$. The scholarship consists of a reduction of the institutional tuition fee for non-EEA students (to $€ 2,083$

Country of Study: Any country

Application Procedure: Applications should be submitted to the Netherlands Education Support Office (NESO) China. Visit their website for more information about the requirements for the Orange Tulip Scholarship (OTS), or send an email to ots@nesochina.org. Visit the website of NESO China

Closing Date: 1 March

\section{Orange Tulip Scholarship (OTS) Indonesia}

Subjects: All subjects

Purpose: The Orange Tulip Scholarship (OTS) offers talented students from Indonesia the opportunity to obtain a Master degree at the University of Twente

Level of Study: Graduate

Type: Scholarship

Value: $€ 24,000$ per year

Country of Study: Any country

Application Procedure: Applications should be submitted to the Netherlands Education Support Office (NESO) Indonesia. Visit their website for more information about the requirements for the Orange Tulip Scholarship (OTS), or send an email to ots@nesoindonesia.or.id

Closing Date: 15 April

Additional Information: Please visit www.utwente.nl/ internationalstudents/scholarshipsandgrants/all/ots-indonesia/ for more information

For further information contact:

Email: info@utwente.nl

\section{Orange Tulip Scholarship (OTS) Mexico}

Subjects: All subjects

Purpose: The Orange Tulip Scholarship (OTS) offers talented students from Mexico the opportunity to obtain 
a Master degree at the University of Twente. The scholarship programme is highly selective, offering one scholarship for the current academic year

Level of Study: Graduate

Type: Scholarship

Value: $€ 24,000$

Frequency: Annual

Country of Study: Any country

Application Procedure: Visit the website of NESO Mexico. Applications should be submitted to the Netherlands Education Support Office (NESO) Mexico. Visit their website for more information about the requirements for the Orange Tulip Scholarship (OTS), or send an email to ots@nesomexico.org Closing Date: 1 April

Additional Information: Check information at www. utwente.n1/internationalstudents/scholarshipsandgrants/all/otsmexico/

\section{University of Ulster}

Research Office, Cromore Road, Coleraine, Co. Londonderry BT52 1SA, Northern Ireland

Tel:

(44) 2870324729

Fax: (44) 2870324905

Email: hj.campbell@ulster.ac.uk

Website: www.ulster.ac.uk

Contact: Mrs H Campbell, Administrative Officer

The University of Ulster is a dynamic and innovative institution, which is very proud of its excellent track record in the education and training of researchers. Our doctoral graduates can demonstrate outstanding achievements in advancing knowledge and making breakthroughs of relevance to the economic, social and cultural development of society.

\section{University Studentships/Vice-Chancellor's Research Studentships (VCRS)}

Subjects: Arts, Humanities and Social Sciences Computing, engineering and Built Environment Life and Health Sciences Business

Purpose: From time to time the University makes funding available to support University Studentships. The awards for United Kingdom, European Union and overseas students. Applicants should indicate in the appropriate area on their University application form that they wish to apply for a University Studentship/VCRS award
Eligibility: These awards are open to applicants who hold or, expect to obtain, a first or upper second class honours degree and provide for payment of fees and maintenance allowance

Level of Study: Doctorate

Type: Scholarships

Value: $£ 14,777$

Length of Study: up to 3 years subject to satisfactory progress

Frequency: Annual

Country of Study: United Kingdom

No. of awards offered: 700

Application Procedure: www.ulster.ac.uk/doctoralcollege/ postgraduate-research/apply

Closing Date: February each year

Funding: Government

No. of awards given last year: 30

No. of applicants last year: 700

\section{For further information contact:}

Email: hj.campbell@ulster.ac.uk

\section{Vice Chancellor}

Subjects: All subjects

Purpose: To assist candidates of a high academic standard to complete research degrees $(\mathrm{PhD})$

Eligibility: Applicants must have or expect to obtain the minimum of an upper second class Honours degree in a specific research area (as advertised). Applications are invited from United Kingdom, European Union and overseas students. Only candidates who are new applicants to $\mathrm{PhD}$ will be eligible

Level of Study: Doctorate, Postgraduate

Type: Scholarship

Value: Fees and maintenance grant

Length of Study: Up to 3 years

Frequency: Annual

Study Establishment: Ulster University

Country of Study: United Kingdom

Application Procedure: Applicants must apply online research.ulster.ac.uk/info/prospective/funding.html

Closing Date: Check website

Funding: Private

No. of awards given last year: 30

No. of applicants last year: 800

Additional Information: Applications are invited from United Kingdom, European Union and Overseas students. Further information is available on the website www.ulster. ac.uk/research study 


\section{For further information contact:}

Email: research.support@sydney.edu.au

\section{University of Verona}

Via S. Francesco, 22, VR 37129 Verona, Italy

Tel: $\quad$ (39) 458028588

Contact: University of Verona

The University of Verona is a university located in Verona, Italy. It was founded in 1982 and is organized in 12 Departments.

\section{Invite doctoral programme}

Subjects: Arts and humanities, legal and economic sciences, health and life sciences, natural and engineering sciences

Purpose: The INVITE doctoral programme aims to encourage each student's intellectual curiosity and support the acquisition of critical thinking skills by training them in the use of innovative theoretical tools and practical methods

Value: Living allowance: $€ 2,000 /$ month for 36 months, mobility allowance: $€ 600 /$ month for 36 months, family allowance: $€ 150 /$ month for 36 months

Country of Study: Italy

Closing Date: 16 April

For further information contact:

Email: invite@ateneo.univr.it

\section{University of Waikato}

Private Bag 3105, Hamilton, New Zealand

Tel: $\quad$ (64) 78562889 ext. 6723

Fax: (64) 78384600

Email: scholarships@waikato.ac.nz

Website: www.waikato.ac.nz/asd/groups/scholarships. shtml

Contact: Ms Maureen Phillips, Assistant Manager, Scholarships

The Mission of the University of Waikato is to be the New Zealand leader in the business of knowledge. The business of knowledge includes the development of new knowledge, the transmission and dissemination of knowledge, and the assembling and structuring of knowledge.

\section{Acorn Foundation Eva Trowbridge Scholarship}

Subjects: All subjects

Purpose: To support the people of Tauranga and the Western Bay of Plenty community

Eligibility: Adult students (25 years and over) studying at the University of Waikato's Tauranga campus and residing in the areas administered by Tauranga City Council or Western Bay of Plenty District Council are eligible for the award

Type: Scholarship

Value: NZ\$3,000 per year

Length of Study: 1 year

Frequency: Annual

Country of Study: New Zealand

Closing Date: 31 August

Contributor: Acorn Foundation

Additional Information: The Scholarship will be paid in one lump sum to the successful applicant

\section{For further information contact:}

Tel: $\quad$ (64) 78384964 or 78585195

Email: scholarships@waikato.ac.nz

\section{Alan Turing Prize}

Subjects: Computer science and mathematics

Purpose: To encourage students to develop strong joint interests in Computer Science and Mathematics

Eligibility: Open to students who have strong interest in computer science and mathematics

Level of Study: Research

Type: Prize

Length of Study: 3 years

Frequency: Annual

Country of Study: Any country

Application Procedure: Check website for further details

Contributor: Council of the University of Waikato

For further information contact:

Email: info@waikato.ac.nz

\section{Alumini Master's Scholarship}

Subjects: All subjects 
Purpose: To support a student who has graduated with a degree of the University of Waikato and is enroled for a Masters Degree at this University in the year of tenure Eligibility: Open to New Zealand citizens or permanent residents who have qualified for a First Degree from the University of Waikato and be enroled full-time for a Masters Degree at the University of Waikato in the year of tenure. The candidate must be in their final year of study for the degree

Level of Study: Postgraduate

Type: Scholarship

Value: NZ\$5,500 plus actual tuition fees up to a maximum of $\mathrm{NZ} \$ 4,000$

Length of Study: 1 year

Frequency: Annual

Application Procedure: Check website for further details

Closing Date: 31 October

Additional Information: The Scholarship will be awarded to a student who demonstrates academic merit; who is active in University affairs and who contributes to the activities of the School or Faculty in which they are enroled; who demonstrates willingness to maintain an active relationship with the Alumni programme; who demonstrates willingness to attend Alumni functions and promotional activities; who is considered to be a good ambassador for the University of Waikato and the Alumni Association

\section{For further information contact:}

Email: scholarships@waikato.ac.nz

\section{Chamber of Commerce Tauranga Business Scholarship}

Subjects: Management Studies

Purpose: For the benefit of members of the Tauranga Chamber of Commerce to assist the recipient to undertake study at postgraduate level

Eligibility: Open to citizens or permanent residents of New Zealand having a tertiary or relevant professional qualification; must have a minimum of 5 years' relevant work experience; must own or be employed by a business or organization which is a member of the Tauranga, Chamber of Commerce; must have the support of his/her employer and currently not enroled in a Postgraduate Diploma in Management Studies with the Waikato, Management School, University of Waikato. Check website for further details

Level of Study: Postgraduate

Type: Scholarship

Value: The value of the scholarship is usually equivalent to

1 year's fees (a total of four papers)

Length of Study: Above 2 years

Frequency: Annual
Application Procedure: Check website for further details Closing Date: 30 November

\section{For further information contact:}

Email: scholarships@waikato.ac.nz

\section{Evelyn Stokes Memorial Doctoral Scholarship}

Subjects: Geography, tourism and environmental planning Eligibility: Open to candidates enroled or intending to enrol in an approved full-time programme of study at the University of Waikato in the years of tenure of the scholarship. Applicants who have undertaken study outside the University of Waikato must supply a full verified copy of their academic transcript(s) from their previous institution(s)

Level of Study: Doctorate

Type: Scholarship

Value: NZ\$5,000 per year

Length of Study: 3 years

Frequency: Annual

Study Establishment: University of Waikato

Country of Study: New Zealand

Application Procedure: Check website for further details Closing Date: 31 October in the year prior to that in which the award will be taken up

Funding: Private

Additional Information: The Scholarship will end on the completion of doctoral study, or after 3 years, whichever is the earlier date, provided that the candidate is enroled during this time in an appropriate programme of studies. Completion takes place when the postgraduate studies committee has accepted the report of the examiners and recommends the awarding of the degree

\section{For further information contact:}

Email: scholarships@waikato.ac.nz

\section{Lee Foundation Grants}

Subjects: All subjects

Eligibility: Open to citizens and residents of Singapore or Malaysia, must have completed at least 1 year of study or are studying at the University of Waikato in Hamilton

Type: Grant

Value: NZ\$500

Application Procedure: Check website for further details Closing Date: 30 April

Additional Information: Grants are awarded on the basis of above average academic performance 
For further information contact:

Email: scholarships@waikato.ac.nz

\section{Priority One Management Scholarship}

Subjects: Management studies

Eligibility: Open to citizens or permanent residents of New Zealand who have a tertiary or relevant professional qualification with a minimum of 5 years relevant work experience, own or be employed by a business or organization which is a member of Priority One, have the support of his/her employer, must not already be enroled in a Postgraduate Diploma in Management Studies with the Waikato, Management School, University of Waikato, not have been a previous recipient of any Waikato Management School, University of Waikato

Level of Study: Postgraduate

Type: Scholarship

Value: Equivalent to 1 year's fees

Length of Study: 2 years

Frequency: Annual

Application Procedure: Check website for further details

Closing Date: 30 November

\section{For further information contact:}

Email: scholarships@waikato.ac.nz

\section{Tauranga Campus Research Masters Scholarship}

Purpose: At this university, candidates can study a broad range of subjects to shape a qualification that matches to their strengths and career interests. It helps the candidate with career planning, developing a CV and cover letters, interview skills, enhancing their employability skills.

Eligibility: For students who have applied to enrol full-time in a thesis of 90-points or more as part of their first master's degree at the University of Waikato and will be based at the Tauranga campus.

Level of Study: Postgraduate

Type: Scholarship

Value: Up to NZ $\$ 23,000$

Frequency: Annual

Country of Study: Any country

Closing Date: 30 April

Funding: International office

\section{For further information contact:}

Te Mata Kairangi School of Graduate Research, The University of Waikato, Private Bag 3105, Hamilton 3240, New Zealand
Tel: (64) 78585096

Email: scholarships@waikato.ac.nz

\section{Ted Zorn Waikato Alumni Award For Management Communication}

Subjects: Management studies

Purpose: To provide an opportunity for peer recognition of graduates of the department who have, since their graduation, distinguished themselves in a field of management communication

Eligibility: Open to candidates holding a responsible position in an organization or in a project, sustainability and/or workplace well being; must know the use of creativity and initiative in performing the responsibilities of the position. Check website for further details

Level of Study: Postgraduate

Type: Award

Value: NZ\$1,000

Frequency: Annual

Application Procedure: Check website for further details

Closing Date: 31 December

For further information contact:

Email: jbeaton@waikato.ac.nz

Contact: Jean Beaton

\section{University of Waikato Masters Research Scholarships}

Subjects: All subjects

Purpose: To encourage research at the University, principally by assisting with course-related costs

Eligibility: Open to citizens and permanent residents of New Zealand who have qualified for a first degree and be enroled full-time for a first Masters or Master of Philosophy degree at the University of Waikato in the year of tenure

Level of Study: Postgraduate

Type: Research grant

Value: NZ $\$ 12,000$, of which up to NZ $\$ 3,500$ is to be applied to tuition fees for the masters degree. The remainder (NZ\$8,500 in the case of a full Scholarship) will normally be paid out in two instalments

Length of Study: 1 year

Frequency: Annual

Application Procedure: Check website for further details

Closing Date: 31 October and 30 April annually

No. of awards given last year: 65 
Additional Information: Should a student also hold another fees scholarship, the University of Waikato Masters Research Scholarship will pay the balance of any fees (up to NZ\$3,500)

\section{For further information contact:}

Tel: (64) 78585136 or 78585195

Email: scholarships@waikato.ac.nz

\section{University of Waikato MBA Programme}

Length of Study: 1 year; 2 years

Application Procedure: All applicants must return a complete application form. Candidates may be required to sit a Graduate Management Admission Test or TOEFL exam

\section{For further information contact:}

Tel:

(64) 78384439

Fax:

(64) 78384269

Email: international@waikato.ac.nz

Contact: MBA Admissions Officer

\section{University of Wales, Bangor (UWB)}

Bangor North Wales, Bangor, Wales, Gwynedd LL57 2DG, United Kingdom

Tel: (44) $1248382025 / 18$

Fax: (44) 1248370451

Email:_admissions@bangor.ac.uk

Website: www.bangor.ac.uk

Contact: The Student Recruitment Unit

The University of Wales, Bangor (UWB) is the principal seat of learning, scholarship and research in North Wales. It was established in 1884 and is a constituent institution of the Federal University of Wales. The University attaches considerable importance to research training in all disciplines and offers research studentships of a value similar to those of other United Kingdom public funding bodies.

\section{Bangor University Merit Scholarships for International Students}

Eligibility: All international students will be automatically considered for these scholarships. These scholarships are not open to United Kingdom/European Union applicants
Type: Scholarship

Value: $£ 2,500$ (Bangor campus); $£ 2,000$ (London centre). Candidates who are fully sponsored by a third party will not be entitled to these Scholarships

Frequency: Annual

Country of Study: Any country

Application Procedure: All applicants will be automatically considered for these scholarships. No additional scholarship application needed

Additional Information: Please check at www.bangor.ac.uk/ international/future/merit scholarships.php\#ug for detailed information. These scholarships are available for both January intake and September intake courses

\section{For further information contact:}

Email: international@bangor.ac.uk

\section{Gold and Silver Scholarships}

Subjects: Banking, Management, Business and Finance, and Law

Purpose: To provide financial support to full-time students on all MSc, MBA and MA programmes

Eligibility: Open to applicants who wish to apply for a postgraduate MBA or MA degree programme included in the scholarship scheme

Level of Study: Postgraduate, MBA

Type: Scholarship

Value: Gold Scholarship $£ 5,000$ per year. Silver Scholarship $£ 2,000$ per year

Length of Study: 1 year

Frequency: Annual

Study Establishment: Bangor University

Country of Study: United Kingdom

Application Procedure: There is no application form for scholarships. Candidates who wish to be considered for the awards should include a letter listing their main academic and personal achievements together with a short essay on why they have chosen to study at Bangor and a curriculum vitae. For further information contact at law.pg@bangor.ac.uk Closing Date: 1 March (Interim deadline); 1 July (Final deadline)

Funding: Government

\section{For further information contact:}

Tel: $\quad$ (44) 1248382644

Fax: (44) 1248383228

Email: b.hamilton@bangor.ac.uk

Contact: Bethan Hamilton-Hine Scholarships (Gold and Silver) 


\section{MSc Bursaries}

Subjects: Sports and exercise psychology, sports and exercise physiology, sports science and exercise rehabilitation Eligibility: Open to applicants with good second class honours degree in sports science or health and to students with a 2:2 degree or a degree from a different academic area will also be considered

Level of Study: Postgraduate

Type: Bursary

Value: $£ 2,500$ (United Kingdom/European Union students); $£ 3,500$ (non-European Union international students)

Length of Study: 1 year (full-time); 2 years (part-time); 30 weeks full-time (diploma)

Frequency: Dependent on funds available

Study Establishment: Bangor University

Country of Study: United Kingdom

Application Procedure: Complete a Postgraduate Application Form with a four page (maximum) curriculum vitae or resumé. Refer to the website for further details or mail to postgraduate@bangor.ac.uk

Closing Date: 30 June

Contributor: Bangor University

Additional Information: $£ 1,000$ internal bursaries to former SHES (or related disciplines) students (who have 1st class undergraduate degree). $£ 1,000$ internal assistantships in addition to the other bursaries aimed at the very best students

\section{For further information contact:}

Tel: (44) 1248383493

Email: mscsport@bangor.ac.uk

Contact: James Hardy

\section{Open PhD Studentships}

Subjects: English, history, Welsh history and archaeology, linguistics and English language, modern languages, music, theology and religious studies, Welsh creative industries Eligibility: Open to candidates who have applied unsuccessfully to a United Kingdom funding council (e.g. the AHRC or the ESRC) to study at Bangor

Level of Study: Doctorate

Type: Studentship

Value: Fees plus maintenance grant

Frequency: Dependent on funds available

Application Procedure: Applicants must submit a scholarship application form along with a summary of your proposed research project in up to 500 words

Closing Date: Please check website
For further information contact:

Email: s.lee@bangor.ac.uk

\section{Santander Taught Postgraduate Scholarships}

Subjects: All subjects

Purpose: The Santander Group will be awarding a number of 1 year undergraduate and taught postgraduate scholarships to current Bangor University students

Eligibility: The scholarship fund aims to reward the most academically gifted students from countries that are supported by the Santander Universidades scheme. The award will be given to students from the following 11 countries: Argentina, Brazil, Chile, Colombia, Mexico, Portugal, Puerto Rico, Spain, Uruguay and Venezuela. To be eligible for the postgraduate scholarship you will have to have studied within a University which is part of the Santander Universidades Scheme

Type: Scholarship

Value: All studentships are for one year only and vary from $£ 3,000-£ 4,166$

Application Procedure: Application forms and guidance notes for the Santander Scholarship Scheme are available on the University website www.bangor.ac.uk/scholarships/san tander.php.en

Closing Date: 10 December

Additional Information: For further information or if you have any questions about the scheme, please contact Academic Registry

\section{For further information contact:}

Email: k.chidley@bangor.ac.uk

Contact: Mrs Karen Chidley, Academic Registry

\section{University of Wales (Bangor) MBA in Banking and Finance}

Length of Study: 1 year

Country of Study: Any country

Application Procedure: Applicants must submit an application form, together with two references and copies or transcripts of previous qualifications. Where necessary TOEFL and IELTS scores must be included

Closing Date: 31 August, for admission in October

\section{For further information contact:}

Tel: $\quad$ (44) 1248371408

Fax: (44) 1248370769

Email: international@bangor.ac.uk

Contact: MBA Admissions Officer 


\section{University of Warwick}

Tel: $\quad$ (44) 2476523523

Fax: (44) 2476461606

Website: www.warwick.ac.uk

Contact: Project Officer, Postgraduate Scholarships

The University of Warwick offers an exciting range of doctoral, research-based and taught Master's programmes in the humanities, sciences, social sciences and medicine. In the 2001 Research Assessment Exercise, Warwick was ranked 5 th in the United Kingdom for research quality. Postgraduate students make up around $35 \%$ of Warwick's 18,000 students. The University is located in the heart of United Kingdom, adjacent to the city of Coventry and on the border with Warwickshire.

\section{Argentina Chevening Scholarship}

Subjects: All subjects

Eligibility: Applicants should be nationals of Argentina not currently registered at the University

Level of Study: Postgraduate

Type: Scholarship

Value: UK cost of Academic fee and maintenance

Length of Study: 1 year

Study Establishment: University of Warwick

Country of Study: United Kingdom

Application Procedure: Applicants must complete an application form, available from the British Council

Contributor: University of Warwick, Foreign and Commonwealth office

\section{For further information contact:}

Email: info@britishcouncil.org

\section{College of Continuing Professional Studies Doctoral Scholarship}

Subjects: Projects in the area of culture and development the arts, creative industries and heritage in either international development, or other forms of development

Purpose: Scholarship is available for pursuing doctoral degree level at the University of Warwick

Eligibility: To be eligible for the scholarship, candidates must have received an unconditional offer for entry to CCPS MPhil/PhD programme by January 31st. The scholarship scheme is open to both European Union and Overseas candidates
Level of Study: Doctorate

Type: Scholarship

Value: The value of the scholarship will be around $£ 18,000$ per year. The precise amount will be confirmed at the time of the offer

Study Establishment: Drury University

Country of Study: United Kingdom

Application Procedure: The mode of applying is online

Closing Date: 31 January

Contributor: Centre for Cultural Policy Studies

Additional Information: The successful candidate will be notified before the end of February

\section{For further information contact:}

Email: drury@drury.edu

\section{Colombia Postgraduate Awards (Warwick Manufacturing Group/Colfuturo)}

Subjects: WMG (Warwick Manufacturing Group) taught masters courses

Purpose: To support Master's Columbian students at WMG Eligibility: Applicants should be nationals of Columbia, not currently registered on a postgraduate course at the University, and should have received an offer of a place from WMG. Only students who have been awarded a COLFUTURO scholarship-loan are eligible

Level of Study: Postgraduate

Type: Scholarship

Value: full tuition fees

Length of Study: 1 year

Frequency: Dependent on funds available

Study Establishment: University of Warwick United Kingdom Country of Study: United Kingdom

Application Procedure: Applicants must apply via COLFUTURO

Funding: Private

Contributor: WMG/COLFUTURO

Additional Information: Non-renewable, for taught masters only

\section{For further information contact:}

Email: yosoyfuturo@colfuturo.com

\section{Colombia Postgraduate Awards (Warwick/ Foundation for the Future of Colombia - Colfuturo)}

Subjects: Any except MBA or WMG courses

Purpose: To support Columbian students on postgraduate courses at Warwick 
Eligibility: Applicants should be nationals of Columbia and classed as an international fee-payer. Applicants can be registered on an Undergraduate course at the University of Warwick, but should have received a place on a Postgraduate Taught Master's course at Warwick. Only students who have been awarded a COLFUTURO scholarship-loan are eligible

Level of Study: Postgraduate

Type: Scholarship

Value: Tuition fees

Length of Study: 1 year

Frequency: Dependent on funds available

Study Establishment: University of Warwick

Country of Study: United Kingdom

Application Procedure: Application should be submitted via COLFUTURO

Funding: International office

Contributor: Foundation for the Future of Colombia Colfuturo (COLFUTURO)

Additional Information: Non-renewable, for taught masters only

For further information contact:

Email: yosoyfuturo@colfuturo.com.co

\section{Karim Rida Said Foundation Postgraduate Award (KRSF/Warwick)}

Subjects: All subjects

Purpose: To support students from the Middle Eastern region on Postgraduate courses at Warwick

Eligibility: Applicants should be Jordanian, Iraqi, Lebanese, Palestinian or Syrian nationals and be resident in the Middle East. Applicants should meet all other eligibility criteria as set by KRSF and awards will only be offered to applicants who already hold an offer of a place at Warwick

Level of Study: Postgraduate

Type: Scholarship

Length of Study: 1 year

Study Establishment: University of Warwick

Country of Study: United Kingdom

Application Procedure: Applications are submitted via KRSF website www.krsf.org/whatwedo/masters

Funding: International office

Contributor: KRSF

No. of awards given last year: 2

Additional Information: Non-renewable, for taught masters only

\section{For further information contact:}

Tel: (44) 2476522469

Email: j.c.inegbedion@warwick.ac.uk

Contact: Jon Inegbedion

\section{Mexico Postgraduate Award (Chevening/ Brockmann/Warwick)}

Subjects: All subjects

Purpose: To support Mexican students on a postgraduate course at Warwick

Eligibility: Applicants should be nationals of Mexico, not currently registered at the University of Warwick and should have received an offer of a place at Warwick

Level of Study: Postgraduate

Type: Scholarship

Value: Full tuition fees plus maintenance

Length of Study: 1 year

Study Establishment: University of Warwick

Country of Study: United Kingdom

Application Procedure: Applicants must complete an application

Closing Date: 9 May

Funding: Government

Contributor: The Foreign and Commonwealth Office and the Brockmann Foundation

No. of awards given last year: 1

Additional Information: Non-renewable

For further information contact:

Tel: $\quad$ (44) 2476572686

Email: ana_delcarmen@hotmail.com

Contact: Ana Gallegos, Adviser for Latin America International Office

\section{School of Law - Brazil Postgraduate Award}

Subjects: Law

Purpose: To support students from Brazil on LLM programme at Warwick

Eligibility: Open to prospective full-time postgraduate students in any postgraduate degree within the Law School. Applicants can be registered on Undergraduate courses at the University of Warwick, but should have received a place for taught master courses at Warwick Law School

Level of Study: Postgraduate

Type: Scholarship

Value: $50 \%$ towards tuition fees

Length of Study: 1 year

Frequency: Dependent on funds available

Study Establishment: University of Warwick

Country of Study: United Kingdom

Application Procedure: Applicants must complete an online application form

Closing Date: 31 May

Contributor: Warwick Law School 
Additional Information: Non-renewable, deducted from tuition fees, for taught masters only

\section{For further information contact:}

Email: paula.nascimento@britishcouncil.org.br

\section{Sociology Departmental MA Scholarship}

Subjects: Overseas

Purpose: We are delighted to confirm that 10 awards of $£ 5,000$ are available for students commencing MA study in the Sociology department in Autumn. The award will automatically be deducted from the winners' tuition fees.

Eligibility: 1. Open to applicants on all Sociology taught Masters programmes. 2 . Candidates must apply to the university and have paid their application fee no later no later than 26 April. You must submit your application to the MA programme before submitting your scholarship application. 3. Successful candidates must obtain an offer from the university before taking up the award. 4. Candidates may apply concurrently to other funding sources; however, successful candidates who receive major tuition funding elsewhere will be disqualified.

Level of Study: Postgraduate

Type: Scholarship

Value: $£ 2,500$

Length of Study: 2 year

Frequency: Annual

Country of Study: Any country

Closing Date: 26 April

Funding: Foundation

\section{For further information contact:}

Social Sciences Building, The University of Warwick, Coventry CV4 7AL, United Kingdom

Email: m.j.wolfe@warwick.ac.uk

\section{Warwick Postgraduate Research Scholarships}

Eligibility: Open to Home, European Union and Overseas students from all disciplines at Warwick. For more details, please refer to the website

Level of Study: Doctorate

Type: Scholarship

Value: $£ 3,390$ for full-time students for the payment of academic fees at the Home/European Union rate. A maintenance grant, in line with the United Kingdom Research Council stipend, of $£ 13,290$ for full-time award holders

Country of Study: United Kingdom
Application Procedure: Please refer to the website www2. warwick.ac.uk/services/academicoffice/gsp/scholarship/ apply/pgr_guidelines_2015-16.pdf

Closing Date: 12 January

Additional Information: Students and applicants who wish to apply for an AHRC doctoral award should apply to the WPRS competition and will automatically be considered for both competitions

\section{For further information contact:}

Email: aci@mrc.ac.za

\section{University of Washington}

School of Business Administration, 110 Mackenzie Hall Box 353200, Seattle, WA 98195, United States of America

Tel: $\quad$ (1) 2065434661

Fax: (1) 2066167351

Email: mba@u.washington.edu

Contact: MBA Admissions Officer

\section{African American Heritage Endowed MBA Scholarship}

Purpose: This scholarship is available for African-American MBA students who are attending the Foster Business school at the University of Washington in Seattle

Eligibility: 1. Must be an African American student. 2. Must be an MBA candidate at the time of application. 3. Must be enrolled at the Foster Business School at the University of Washington in Seattle. 4. This award is for United States of America students

Level of Study: Graduate

Type: Scholarship

Value: US $\$ 10,000$

Frequency: Annual

Country of Study: United States of America

Application Procedure: Applications and information about the African American Heritage Endowed MBA Scholarship are available online at the University of Washington Foster School of Business website. To apply for this award, students must first be accepted to the MBA program at the University of Washington in Seattle. Eligible students who are interested in this award should contact the Michael G. Foster School of Business for further information about the admissions and scholarship application process. All applications must be completed online by the deadline date 
Closing Date: 15 April

Funding: Foundation

\section{For further information contact:}

124 Mackenzie Hall Box 353200, Seattle, WA, 98195-3200, United States

Tel: (1) 2065434661

Email: scholarships@swe.org

\section{University of Waterloo}

200 University Avenue West, Waterloo, ON N2L 3G1, Canada

Email: rchild@uwaterloo.ca

\section{International Research Partnership Grants (IRPG)}

Purpose: The International Research Program Grants (IRPG) programs are internal seed grants aimed to provide Waterloo researchers with incentives to develop new or existing international research collaborations with leading institutions known for high quality research and global ranking

Eligibility: Projects should involve a group of Waterloo researchers and international partners. Preference will be given to projects with multiple Waterloo faculties/departments and a network of partner institutions;; 1. Preference will be given to projects that have not received IRPG funding for a previous project with the same international partners. 2. Preference is given to applications where matching cash contribution is from a new source or one that is outside of University of Waterloo, instead of existing research funds

Level of Study: Graduate

Type: Grants and fellowships

Value: Up to C $\$ 20,000,50 \%$ of the costs

Frequency: Annual

Country of Study: Any country

Application Procedure: You could refer to the following pdf for further instructions. uwaterloo.ca/research/sites/ca. research/files/uploads/files/irpg_program_guidelines-30-nov2018.pdf

Closing Date: 1 May and 1 November annually

Funding: Private

\section{For further information contact:}

200 University Avenue West, Waterloo, ON N2L 3G1, Canada

Email: rchild@uwaterloo.ca

\section{Mitacs Accelerate Fellowship}

Purpose: The Mitacs Accelerate Fellowship provides a longterm funding and internship option for master's and $\mathrm{PhD}$ students. Recipients can also access professional development training that helps them ensure project success and gain in-demand career skills

Level of Study: Graduate

Type: Fellowship

Value: $\mathrm{C} \$ 40,000$ per year

Length of Study: 18 months

Frequency: Annual

Country of Study: Any country

Application Procedure: Interested applicants can apply for the Accelerate Fellowship at any time. All other Accelerate program guidelines apply. 1. Review the following information when you begin writing your proposal. Eligible research and adjudication criteria 1. Writing Your Proposal guide Policies. 2. Submit Cover Sheet to Office of Research contact below, with a copy of the draft proposal. 3. Get feedback on the proposal from all participants and the Mitacs Program contact below. 4. Collect all required signatures: intern(s), professor(s), partner representative and the Office of Research contact below. 5. Email your proposal package to your Mitacs Program contact below Additional Information available on the Mitacs website Funding: Private

\section{For further information contact:}

Tel: (1) 5198884567

Email: accelerate@mitacs.ca

\section{University of West London}

\section{International Ambassador Scholarships at University of West London}

Purpose: The International Ambassador Scholarship recognises and provides financial support for outstanding students who wish to act as ambassadors for the University of West London

Eligibility: Applicants must be: 1. A self-funded overseas full fee-paying paying student (please note: European Union applicants are not eligible). 2. An offer holder for an undergraduate or postgraduate course at UWL. This means, you must have already applied for a course of study at this University and you must have already received an official offer from one of our Admissions Officers. 3. The International Ambassador Scholarship will be awarded on a competitive basis to candidates who demonstrate enthusiasm and the ability to be an excellent international student ambassador 
Level of Study: Graduate

Type: Scholarship

Frequency: Annual

Country of Study: Any country

Application Procedure: To be considered for the scholarship, you must have been offered a place to study on a fulltime undergraduate or postgraduate course at the University of West London. The deadline for the intakes are as follows:

1. For courses starting in January applications must be received by 30 November

Closing Date: 30 June

Funding: Private

For further information contact:

Tel: $\quad$ (44) 2082312914

Email: int.app@uwl.ac.uk

\section{University of Western Australia}

35 Stirling Highway, Crawley, WA 6009, Australia

Tel: $\quad$ (61) 893802490,864886000

Fax: $\quad$ (61) 893801919,864881380

Email: general.enquiries@uwa.edu.au

Website: www.uwa.edu.au

Since its establishment in 1911, the University of Western Australia has helped to shape the careers of more than 75,000 graduates. Their success reflects the UWA's balanced coverage of disciplines in the arts, sciences and professions.

\section{Advanced Consumer Research PhD Scholarship}

Subjects: Law

Purpose: To study the effectiveness of Commonwealth, State and Territory consumer protection laws in relation to information disclosure

Eligibility: Open to those who have completed an undergraduate degree in law with honours or equivalent research qualifications

Level of Study: Postgraduate

Type: Scholarship

Value: A $\$ 25,000$ per year

Length of Study: 3 years and 6 months

Frequency: Annual

Study Establishment: The University of Western Australia Application Procedure: Check website for further details

Closing Date: 3 August
For further information contact:

Tel: $\quad$ (61) 864882947

Email: eileen.webb@uwa.edu.au

Contact: Eileen Webb, Faculty of Law

\section{Health Effects of Air Pollution (Top-Up)}

Subjects: Biological sciences or medical and health sciences Purpose: To support various projects in the School of Population Health

Eligibility: Open to those doing research in Australia

Level of Study: Postgraduate

Type: Scholarship

Value: $A \$ 10,000$, plus Australian Dollar; 2,500 for relocation costs

Frequency: Annual

Study Establishment: University of Western Australia

Country of Study: Australia

Application Procedure: Candidates must apply direct to the faculty. Check website for further details

Closing Date: 1 December

For further information contact:

Tel: $\quad$ (61) 864887804

Email: Angus.Cook@uwa.edu.au

Contact: Dr Angus Cook, Research Fellow

\section{Master of Business Administration Programme}

For further information contact:

Tel: $\quad$ (61) 93803939

Fax: (61) 93824071

Email: icweb@acs.edu.au

Contact: MBA Admissions Officer

\section{Natural Gas/LNG Production Scholarships}

Subjects: Chemical engineering, chemical sciences, physical sciences or resources engineering

Purpose: To use the research outcomes to improve the design of LNG production trains and to treat contaminated gas reserves

Eligibility: Open to candidates who have achieved Second Class (Honours) or equivalent

Level of Study: Postgraduate

Type: Scholarship

Value: A $\$ 31,118$ per year

Length of Study: 3 years 
Frequency: Annual

Country of Study: Australia

Application Procedure: Check website for further details

Closing Date: 17 December

For further information contact:

Tel: $\quad$ (61) 64882954

Fax: (61) 64881964

Email: Eric.May@uwa.edu.au

Contact: Dr Eric F May

\section{The Science \& Innovation Studentship Award}

Subjects: Science

Purpose: To promote innovation in areas of key technologies Eligibility: Open to citizens of Australia or permanent residents who have completed 2 years, or more, full-time study in a science degree at a recognized Western Australian University Level of Study: Postgraduate

Type: Studentship

Value: A $\$ 7,000$ per year

Frequency: Annual

Study Establishment: Curtin University of Technology, Edith Cowan University, Murdoch University, The University of Notre Dame, The University of Western Australia

Country of Study: Any country

Application Procedure: Check website for further details

Closing Date: 14 September

For further information contact:

100 Plain Street, Perth, WA 6004, Australia

Tel: $\quad$ (61) 892223333

Fax: (61) 892223862

Email: rchapman@wellesley.edu

Contact: Krystle McCormick, Studentship Co-ordinator, The Office of Science, Technology and Innovation

\section{Water and Health Scholarships}

Subjects: Medical microbiology, earth sciences, or public health and health services

Purpose: To position graduates favourably with respect to future employment opportunities through research projects in the area of public health impacts of recycled water use

Eligibility: Open to Australian candidates with a broad range of backgrounds

Level of Study: Postgraduate

Type: Scholarship
Value: A \$30,000 per year

Length of Study: 3 years

Frequency: Annual

Study Establishment: The University of Western Australia Country of Study: Australia

Application Procedure: Check website for further details Closing Date: 6 July

Additional Information: Applications are open from 13 June

For further information contact:

Tel: $\quad$ (61) 864887804

Email: Angus.Cook@uwa.edu.au

Contact: Dr Angus Cook, Research Fellow, The

University of Western Australia

\section{Western Australian CSIR University Postgraduate Scholarships}

Subjects: Geology, geophysics, or metallurgy

Purpose: To enhance research into minerals and energy exploration, extraction and processing

Eligibility: Open to citizens of Australia enrolling for postgraduate research

Level of Study: Postgraduate

Type: Scholarship

Value: A $\$ 25,000$ per year

Length of Study: 3 years

Country of Study: Australia

Application Procedure: Check website for further details

For further information contact:

Tel: $\quad$ (61) 864883027

Email: campbell.thomson@uwa.edu.au

Contact: Dr Campbell Thomson, Director Research Services

\section{University of Western Sydney}

Office of Research Services, Hawkesbury Campus, Building H3, Locked Bag 1797, Penrith South DC, NSW 1797, Australia

Tel: $\quad$ (61) 245701463

Fax: (61) 245701686

Email: t.mills@uws.edu.au

Website: www.uws.edu.au

Contact: Ms Tracey Mills, Research Scholarships

Development Officer 


\section{Master of Business Administration Programme}

Length of Study: 1-5 years

Application Procedure: Applicants must complete an application form supplying a TOEFL score

Closing Date: Varies, please contact organisation

\section{For further information contact:}

Tel: $\quad$ (61) 296859297

Fax: $\quad$ (61) 296859298

Email: international@uws.edu.au

Contact: MBA Admissions Officer

\section{University of Westminster}

Scholarships Department, Cavendish House, 101 New Cavendish Street, London W1W 6XH, United Kingdom

Tel: $\quad$ (44) 2079115000 Exts 66257, 66258, 66259

Fax: (44) 2079115858

Email:_scholarships@westminster.ac.uk

Website: www.westminster.ac.uk

The University of Westminster is proud of its generous scholarship programme, which benefits both United Kingdom and international students. Full details are available on our website www.westminster.ac.uk/scholarships.

\section{Brian Large Bursary Fund}

Subjects: Bursaries are awarded in the sphere of delivery Purpose: To provide financial support to United Kingdom students that are studying full time on the Transport and Planning MSc

Eligibility: Financial need and you must be a United Kingdom citizen or have permanent United Kingdom residential status. Up to three Brain large Masters Bursaries are to be addressed

Type: Funding support

Value: $£ 7,000$ paid in three tranches of $£ 2,400$ over the year Country of Study: United Kingdom

Application Procedure: If you are interested in applying for one of these bursaries please contact Dr. Enrica Papa, the Course Leader of MSc Transport Planning at: papa@westminster.ac.uk

Closing Date: 2 July

Additional Information: For more information visit the Brian Large Bursary Fund website

\section{Fully funded Master scholarship}

Purpose: To study a full-time master degree in a subject within the School of Media, Arts and Design at the university

Type: Scholarship

Value: Full tuition fee award, accommodation, living expenses, flights to and from London

Country of Study: Any country

Application Procedure: For application, please visit website www.westminster.ac.uk/about-us/faculties/westminster-schoolof-media-arts-and-design/departments

Closing Date: 11 January

\section{For further information contact:}

Email: graduate.admissions@cs.ox.ac.uk

Contact: Scholarships Office

\section{Fully funded University of Westminster Master's Scholarship for Developing Countries}

Subjects: Master's degree in all subjects

Purpose: The Westminster Vice-Chancellor's Scholarships, is one of the University's most prestigious award, it is aimed at fully funding a student from a developing country to study a full-time Master's degree at the University

Eligibility: The main requirement of this scholarship is that the candidates must hold an offer for a full-time Master's degree at University of Westminster. In addition, the applicant should have First Class Honours degree, financial need and development potential

Level of Study: Postgraduate

Type: Award

Value: The winner of this scholarship may expect to receive full tuition fee waivers, accomodation and flights to and from London

Frequency: Annual

Country of Study: Any country

Application Procedure: 1. A copy of the letter/email from the University of Westminster confirming your conditional or unconditional offer of a place on your chosen course. 2. An official copy of your transcript from your chosen course. 3. A reference letter written specifically in support of your scholarship application. This should be written by a previous tutor, professor, academic or employer and cannot be the same reference provided as part of your admission application

Closing Date: 31 May

Funding: Private 


\section{For further information contact:}

Tel: (44) 2079115000

Email: course-enquiries@westminster.ac.uk

\section{Higher Education Scholarship Palestine (HESPAL) Scholarships}

Subjects: HESPAL aims to create the next generation of senior academics who can maintain international quality standards at Palestinian universities and develop renewed and sustainable links between Palestinian and United Kingdom universities

Purpose: The University of Westminster is working in partnership with the British Council to provide a Higher Education Scholarship for a Palestinian (HESPAL); that is, to support a junior academic at a Palestinian University wishing to study a one-year masters programme or a three-year $\mathrm{PhD}$ research programme in the United Kingdom

Eligibility: For eligibility and other details visit how to apply page www.westminster.ac.uk/study/fees-and-funding/scholar ships/before-you-apply

Value: Full tuition fee award, pre-departure briefing from the British Council, arrival allowances, thesis allowances and a monthly allowance to cover living expenses

Country of Study: Any country

Application Procedure: Applications are made through the British Council in the Palestinian Territories. Find out more on the British Council website

Closing Date: 23 January

\section{For further information contact:}

Email: tom.sperlinger@bristol.ac.uk

\section{Politics and International Relations PhD Scholarships}

Subjects: Politics and International Relations

Purpose: Scholarships are available for pursuing $\mathrm{PhD}$ programme

Eligibility: Candidates should normally have a minimum classification of a 2.1 in their BA, or equivalent, and preferably a Master's degree

Value: One fee waiver (Home/European Union rate applications are invited for the following awards which are tenable for up to 3 years for full-time study:) and $£ 16,000$ per year for 3 years. Up to two fee waivers (Home/European Union rate) and $£ 5,000$ per year for 3 years

Length of Study: 3 years

Country of Study: United Kingdom
Application Procedure: Apply online. Please visit the website www.westminster.ac.uk/study/postgraduate/researchdegrees/research-areas/social-sciences-and-humanities/howto-apply

Closing Date: 27 April

Contributor: University of Westminster

Additional Information: For more details, visit website www.westminster.ac.uk/news/2018/call-for-applications-poli tics-and-international-relations-2018-phd-scholarships

\section{For further information contact:}

Tel: (61) 2079115000

Email: robert.elgie@dcu.ie

\section{Rees Jeffrey Road Fund}

Purpose: To support financially for education, research and physical road transport-related projects in accordance with the founding Trust Deed

Type: Bursary

Value: This fund provides a bursary of up to $£ 10,000$ towards financial support for education, research and physical road transport-related projects

Country of Study: Any country

Application Procedure: Expressions of interest should in the first instance be directed to Dr. Enrica Papa, the Course Leader of Transport Planning MSc at: E.papa@westminster. ac.uk

Closing Date: May and June of each year

Additional Information: For more information visit the Rees Jeffreys website

For further information contact:

Email: brianmurrell@reesjeffreys.org

\section{Westminster Full-Fee Masters Scholarships for International Students}

Subjects: Any full-time master's degree Programme offered at the university except MBA

Purpose: The Westminster University offers full tuition fee scholarships to prospective postgraduate applicants from any country

Eligibility: You must hold an offer for a full-time Masters Program at the University of Westminster. The main scholarship criteria are: equivalent to a United Kingdom First Class Honours degree and financial need

Level of Study: Doctorate, Postgraduate

Type: Scholarship

Value: Full tuition fee award only 
Country of Study: United Kingdom

Application Procedure: You should only apply for a scholarship once you have applied for admission and successfully been offered a place (either conditional or unconditional) on the course you wish to study. To apply for a scholarship, you will need to download and complete the relevant scholarship application form and submit it together with supporting documents by post

Closing Date: 4 May and 13 October

Additional Information: For more details visit official scholarship Website: www.westminster.ac.uk/study/pro spective-students/fees-and-funding/scholarships/internationalpostgraduate-scholarships/westminster-full-fee-scholarship

\section{For further information contact:}

Email: course-enquiries@westminster.ac.uk

\section{Westminster School of Media, Arts and Design Scholarship}

Purpose: To pursue a full-time master degree in a subject within the School of Media, Arts and Design at the university Value: Full tuition fee award, accommodation, living expenses and flights to and from London

Frequency: Annual

Country of Study: Any country

Application Procedure: For application forms, please visit website www.westminster.ac.uk/study/fees-and-funding/ scholarships/westminster-school-of-media-arts-and-designscholarship

Closing Date: 31 May

Contributor: Westminster School of Media, Arts and Design

\section{For further information contact:}

Email: scholarships@westminster.ac.uk

\section{Westminster Vice-Chancellor's Scholarships}

Subjects: Any full-time master's degree programme offered at the university. Academic excellence, financial need and development potential. Academic excellence, financial need and development potential

Purpose: The Westminster Vice-Chancellor's Scholarships, the university's most prestigious award, is aimed at fully funding a student from a developing country to study a fulltime masters degree at the University

Eligibility: You must be an international student from a developing country and hold an offer for a full-time Undergraduate degree at University of Westminster. The main criteria are: United Kingdom First Class Honours degree, financial need and development potential

Level of Study: Postgraduate

Type: Scholarship

Value: Full tuition fee waivers, accommodation, living expenses and flights to and from London

Frequency: Annual

Study Establishment: University of Westminster

Country of Study: United Kingdom

Application Procedure: It is important to visit the official website to access the application form and for detailed information on how to apply for this scholarship

Closing Date: 31 May

Additional Information: For more details, please visit official scholarship website: www.westminster.ac.uk/study/pro spective-students/fees-and-funding/scholarships/internationalpostgraduate-scholarships/vice-chancellor-scholarship

\section{University of Winnipeg}

\section{The University of Winnipeg Manitoba Graduate Scholarships (MGS)}

Subjects: These scholarships will be awarded in the subjects offered by the university

Purpose: Applications are open for the University of Winnipeg Manitoba Graduate Scholarships (MGS) organized by the University of Winnipeg. These scholarships are open to the students who are enrolled or plan to enroll as a full-time student in a master's program at the University of Winnipeg Eligibility: 1. Have achieved a minimum GPA of 3.75 in the last 60 credits hours of study. 2. Be in a pre-master's program and/or entering the first or second year of an eligible master's program as of May or September of the current year or January of the upcoming year. 3. Be enrolled in or plan to enroll in as a full-time student in a master's program.

Level of Study: Postdoctorate

Type: Scholarship

Value: $\$ 15,000$

Length of Study: 1 year

Frequency: Annual

Country of Study: Any country

Application Procedure: Apply online: www.uwinnipeg. ca/graduate-studies/docs/uwmgs-application+checklist-revi sedjan2019-2.pdf

Closing Date: 1 March

Funding: Foundation

\section{For further information contact:}

Email: gradstudies@uwinnipeg.ca 


\section{University of Wisconsin-Milwaukee}

University of Wisconsin-Milwaukee, PO Box 413, Milwaukee, WI 53201, United States of America

Tel: (1) 4142291122

Email: fellowship@uwm.edu

Website: www.uwm.edu

The University of Wisconsin-Milwaukee (UWM) is located just a few blocks from Lake Michigan in one of Milwaukee's most attractive residential areas, and offers research and teaching programmes extending to 148 different degree programmes that serve nearly 26,000 students. UWM focuses on approaches to education that are inclusive, multidisciplinary and marked by excellent research and outstanding teaching.

\section{University of Wisconsin-Milwaukee Graduate School Dissertation Fellowships}

\section{Subjects: All subjects}

Purpose: To fund dissertation-level graduate students at the University of Wisconsin-Milwaukee

Eligibility: Applicants must have completed all coursework, passed preliminary examinations, completed $\mathrm{PhD}$ residency requirements and obtained dissertator status. No other award may be held concurrently (with the exception of the Chancellor's Graduate Student Award). Current or previous awardees are not eligible

Level of Study: Doctorate

Type: Fellowship

Value: US $\$ 14,000$, in addition to full coverage of resident instructional fees (approx. US\$1,740), a remission of the outof-state portion of the tuition, low-cost comprehensive health insurance and other benefits

Length of Study: 1 academic year

Frequency: Annual

Study Establishment: University of WisconsinMilwaukee

Country of Study: United States of America

Application Procedure: Applicants must check the website for details

Closing Date: 21 January

\section{For further information contact:}

Tel: $\quad$ (1) 4142296276

Email: fellowship@uwm.edu

\section{University of Wollongong (UOW)}

Northfields Ave, Wollongong, NSW 2522, Australia

Tel: $\quad$ (61) 242213555

Fax: (61) 242214322

Email: scholarships@uow.edu.au

Website: www.uow.edu.au

The University of Wollongong (UOW) is a university of international standing with an enviable record of achievement in teaching and research. It enjoys a significant international research profile, attracting more Australian Research Council funding per student that any other Australian university. Over 850 postgraduate students are enrolled of which $30 \%$ are overseas students.

\section{Marketing Research Innovation Centre PhD Scholarship}

Subjects: Commerce, management, tourism and services Purpose: To conduct research in the area of qualitative and quantitative methods, market segmentation, brand image studies and advertising experiments

Eligibility: Open to applicants who have an excellent tertiary track record, experience with conducting academic research

Level of Study: Postgraduate, Research

Type: Scholarship

Value: A $\$ 20,000$ per year

Length of Study: 3 years

Frequency: Annual

Country of Study: Australia

Application Procedure: Candidates can check the website for further details

For further information contact:

Tel: $\quad$ (61) 2070007000

Fax: (61) 242213862

Email: housing@london.ac.uk

Contact: Professor Sara Dolnicar, Professor

\section{University of Wollong (UOW) Work-Integrated Learning Scholarship}

Purpose: To reward outstanding academic achievements Eligibility: Open to students with outstanding academic achievements 
Level of Study: Postgraduate

Type: Scholarship

Value: $A \$ 3,000 ; A \$ 9,300$

Frequency: Annual

Study Establishment: University of Wollongong

Country of Study: Australia

Application Procedure: Apply online

Closing Date: October

Additional Information: Scholarship holders are required to undertake a period, usually 6-10 weeks of professional work experience each year with an appropriate sponsor organization

\section{For further information contact:}

Tel: $\quad$ (61) 1300367869

Fax: (61) 242213233

Email: uniadvice@uow.edu.au

\section{University of Wollongong Sydney Business School Bursary Scheme}

Subjects: Bursaries are awarded to study the subjects offered by the university

Purpose: The University of Wollongong (UOW) is offering Sydney Business School Bursary Scheme for students commencing master's courses. The bursaries offer a $15 \%$ reduction of the tuition fee per trimester of the study of applied

Eligibility: The bursary will apply to the following citizenships only: India, Nepal, Vietnam, Pakistan, Indonesia, Sri Lanka, Bangladesh, Thailand, Iran, Kenya, Mongolia, Nigeria, Cambodia, Zimbabwe, Myanmar and Ghana

Value: The bursaries offer a $15 \%$ reduction of the tuition fee per trimester of the study of applied

Study Establishment: Bursaries are awarded to study the subjects offered by the university

Country of Study: Australia

Application Procedure: You do not have to make a separate application for a bursary, as it will be awarded automatically when you receive an offer for an eligible course and meet scholarship requirements. Applicants will receive a bursary notification and Terms and Conditions of their bursary at the same time as their offer of admission into their course

Additional Information: For more details please visit the website scholarship-positions.com/uow-sydney-businessschool-bursary-scheme-australia/2017/07/27/

\section{For further information contact:}

Email: business-enquiries@uow.edu.au

\section{University of Wollongong In Dubai (UOWD)}

Blocks 5 \& 15, Knowledge Village, PO Box 20183, Dubai United Arab Emirates

Tel: $\quad$ (971) 43672400

Fax: (971) 43672760

Email: info@uowduabi.ac.ae

The UOWD in Dubai, established in 1993, is one UAE's oldest and most prestigious universities. The university strives to provide a fertile environment for bright young minds to flourish, and maintains a long and proud tradition of excellence in education.

\section{University of Wollongong In Dubai Postgraduate Scholarships}

Purpose: To reward the academically outstanding postgraduates

Eligibility: Open to all outstanding postgraduate students enrolled at the university

Level of Study: Postgraduate

Type: Scholarship

Value: Payment of tuition fees

Frequency: Annual

Study Establishment: University of Wollongong in Dubai Country of Study: United Kingdom

Application Procedure: Contact the University

Closing Date: September

No. of awards given last year: 1

For further information contact:

Fax: $\quad$ (971) 43678047

Email: info@uowdubai.ac.ae

\section{University of York}

Graduate Schools Office, Heslington, York Y010 5DD, United Kingdom

Tel: $\quad$ (44) 1904432143

Fax: (44) 1904432092

Email: graduate@york.ac.uk

Website: www.york.ac.uk/admin/gso/gsp

Contact: Mr Philip Simison 
The University of York offers postgraduate degree courses in archaeology, art history, biology, biochemistry, chemistry, communication studies, computer science, economics, educational studies, electronics, English, environment, health sciences, history, language and linguistics, management, mathematics, medieval studies, music, philosophy, physics, politics, psychology, social policy, social work, sociology and women's studies.

\section{China Scholarships Council joint research scholarships}

Purpose: The scholarships are open to Chinese nationals intending to begin a $\mathrm{PhD}$ in the current and upcoming academic year. They will be awarded on the basis of academic merit and CSC priorities

Eligibility: 1 . You must be a citizen and permanent resident of the People's Republic of China at the time of application. 2. You must hold an unconditional offer* for a full-time $\mathrm{PhD}$ degree programme at the University of York commencing in Autumn. 3. You must fulfil any English language requirements of your offer by 15 February. 4. You must satisfy the eligibility and selection criteria set out by the CSC

Level of Study: Postgraduate

Type: Scholarship

Value: $100 \%$ of tuition fees for the full duration of the CSC funding period, a grant and uk visa fees

Frequency: Annual

Country of Study: Any country

Application Procedure: Check the details online. www. york.ac.uk/study/postgraduate-research/funding/china-schol arships/

Closing Date: 1 March

Funding: Private

\section{For further information contact:}

Email: international@york.ac.uk

\section{Overseas Continuation Scholarship (OCS)}

Subjects: All subjects

Purpose: For current University of York Masters students who are progressing to $\mathrm{PhD}$ studies at the University of York Eligibility: Students must be outstanding academically and have the support of their chosen department at York. You must hold an offer for PhD study and be a current University of York Masters student to be eligible to apply

Level of Study: Doctorate

Type: Scholarship
Value: The scholarship is worth $£ 5,000$ in the first year of study as a deduction from tuition fees

Application Procedure: Please visit www.york.ac.uk/study/ international/fees-funding/scholarships/ to apply

Closing Date: 30 April

Additional Information: Please email international@york. ac.uk for further information

\section{For further information contact:}

Email: international@york.ac.uk

\section{Overseas Research Scholarship (ORS)}

Subjects: All subjects

Purpose: For applicants commencing PhD study at the University of York. Applicants must be liable to pay the overseas rate of tuition fee

Eligibility: Students must be outstanding academically and have the support of their chosen department at York. You must hold an offer for $\mathrm{PhD}$ study to be eligible to apply

Level of Study: Doctorate

Type: Scholarship

Value: The scholarship will pay the full overseas tuition fee and a stipend of $£ 5,000$ per year for each year of successful study

Application Procedure: Please visit www.york.ac.uk/study/ international/fees-funding/scholarships/ to apply

Closing Date: 30 April

Additional Information: Please email international@york. ac.uk for further information

\section{For further information contact:}

Email: international@york.ac.uk

\section{Scholarship for Overseas Students}

Subjects: All subjects except MBBS (Medicine)

Purpose: For applicants commencing study of any subject (excluding students applying to the Hull York Medical School) at any level as a full-time student at the University of York. Applicants must be liable to pay the overseas rate of tuition fee

Eligibility: This is a competitive scholarship based on academic merit and financial need. You must hold an offer for academic study to be eligible to apply

Level of Study: Postgraduate

Type: Scholarship

Value: The scholarship is worth one-quarter $(25 \%)$ of the overseas tuition fee for each year of successful study

Frequency: Annual 
Application Procedure: Please visit www.york.ac.uk/study/ international/fees-funding/scholarships/ to apply

Closing Date: 30 April

Additional Information: Please email international@york. ac.uk for further information

\section{For further information contact:}

Email: international@york.ac.uk

\section{White Rose University Consortium Studentships}

Subjects: Available across various schools and subjects, see website for further details

Purpose: Each year York collaborates with the Universities of Leeds and Sheffield to be able to offer a number of studentships in each of the three universities

Eligibility: In order to be eligible you must: have applied for a place on a full time $\mathrm{PhD}$ programme in the relevant Department. Have or expect to obtain a first or upper second class honours degree or equivalent prior to commencing the $\mathrm{PhD}$ degree

Level of Study: Doctorate

Type: Studentship

Value: A full Research Council equivalent stipend: $£ 14,057$. Rates for current year were not set at time of publication. A fee waiver at the Home/European Union rate (Overseas candidates are welcome to apply but would need to fund the difference between Home/European Union fee rate and international fee rate.). A Research Support Grant: $£ 900$

Frequency: Annual

Application Procedure: Please visit www.york.ac.uk/study/ postgraduate/fees-funding/research/white-rose-studentships/ for further details. Applications are submitted online

Closing Date: 30 April

Additional Information: Contact research-student-admin@ york.ac.uk for further information

\section{For further information contact:}

Email: research-student-admin@york.ac.uk

\section{Wolfson Foundation Scholarships}

Subjects: The Wolfson Postgraduate Scholarships will fund doctoral research in three disciplines that align closely with the Foundation's interests: history, literature and languages Purpose: The University is delighted to be offering Wolfson Scholarships in the Humanities for the second year as part of a national Arts funding scheme

Eligibility: The Wolfson Postgraduate Scholarships in the humanities will be awarded to outstanding students who demonstrate the potential to make an impact on their chosen field. Wolfson Scholarships will be awarded solely on academic merit. In order to be eligible you must: have applied for and be in receipt of an offer of a place on a full time $\mathrm{PhD}$ programme in the relevant department (some departments may be able to accept applications on the basis of a programme application without an offer, please speak to your prospective department to confirm). Expect to begin your $\mathrm{PhD}$ studies in October. Have or expect to obtain a first or upper second class honours degree or equivalent prior to commencing the $\mathrm{PhD}$. Have completed a masters level qualification before commencing the $\mathrm{PhD}$

Level of Study: Doctorate

Type: Scholarship

Value: The scholarships are worth $£ 26,000$ per year for up to 3 years of $\mathrm{PhD}$ study. Each scholarship offers a stipend of $£ 17,750$ per year for up to 3 years of $\mathrm{PhD}$ study. Each scholarship will contribute to fees (up to $£ 10,000$ ). Any funds remaining after payment of the stipend and fees will be kept as a Research Training and Support Grant to be accessed by the award holder on request to support the work of the $\mathrm{PhD}$

Country of Study: Any country

Application Procedure: Please visit www.york.ac.uk/study/ postgraduate/fees-funding/postgraduate/wolfson/ for further details. Applications are submitted online

Closing Date: 1 February

\section{For further information contact:}

Tel: (44) 1334462254

Email: admissions@st-andrews.ac.uk

\section{Uppsala University}

Website: www.uu.se/en/admissions/scholarships/uppsalauniversity/

Uppsala University is a research university in Uppsala, Sweden, and is the oldest university in Sweden and all of the Nordic countries, founded in 1477.

\section{Uppsala IPK Scholarships for International Students}

Purpose: Uppsala University awards several scholarships for fee-paying students applying for Master's programmes commencing in the autumn. One of these scholarship programs is the Uppsala IPK Scholarships 
Eligibility: 1. Citizens of a country outside the European Union/EEA and Switzerland. 2. Applicants must demonstrate academic talent and show interest in belonging to an educational milieu. 3. Students can only be awarded an IPK scholarship for their first priority programme at Uppsala University. 4. You must meet the entrance requirements for the programme you applied to and application fee and supporting documents must have been received before deadline to University Admissions

Type: Scholarship

Value: Scholarships will cover the cost of tuition but not living expenses

Country of Study: Any country

Application Procedure: You must then submit an online scholarship application form on which you will note your application ID from www.universityadmissions.se

Closing Date: 20 January

Contributor: The Uppsala University in Sweden

Additional Information: For more details, visit official scholarship website: www.uu.se/en/admissions/scholarships/ uppsala-university/

\section{For further information contact:}

Email: tuitiongrants@uadm.uu.se

\section{Utrecht University}

Domplein 29, NLD-3512 JE, Utrecht, Netherlands

Tel: $\quad$ (31) 302532670

Email: studievoorlichting@uu.nl

Website: www.uu.nl

Utrecht University stands for broad and interdisciplinary education. Students at Utrecht University learn to look beyond the boundaries of their fields of study and work together in interdisciplinary projects. The education programmes are modern and innovative. Students and high-ranking scientists work together on a better future.

\section{Utrecht Excellence Scholarships for International Students}

Subjects: The Utrecht Excellence Scholarship offers a number of outstanding prospective students the opportunity to pursue a Master's degree in a selected number of fields at Utrecht University

Purpose: none

Eligibility: To be eligible for an Utrecht Excellence Scholarship, you must: 1 . Belong to the top $10 \%$ of your graduating class. 2. Hold a non-European Union/EEA passport and not be eligible for support under the Dutch system of study grants and loans. 3. Have completed your secondary school and/or Bachelor degree outside the Netherlands. 4. Have applied for an eligible international master's programme with a start date of 1 September

Level of Study: Graduate, Postgraduate

Type: Scholarship

Frequency: Annual

Country of Study: Any country

Application Procedure: Your application for a scholarship will only be processed if you have submitted an application for a Master's programme as well. After submitting an application for the Master's programme, non-European Union/EEA students will have the option to submit an application for an Utrecht Excellence Scholarship. Prospective students who wish to be considered for the scholarship must apply before 1 February. Please note that in some cases you may need to apply before 1 December; check the 'When to apply' section under Admission and application of your master's programme. It is important to visit the official website (link found below) for detailed information on how to apply for this scholarship. Application has to be processed online. E-mail is not required Closing Date: 1 February

Funding: Private

Additional Information: Official Scholarship Website: www.uu.nl/masters/en/general-information/international-stu dents/financial-matters/grants-and-scholarships/utrecht-ex cellence-scholarships

\section{For further information contact:}

Email: study@uu.nl 